
Digitized by the Internet Archive in 2010 with funding from UNEP-WCMC, Cambridge 


$$
1516
$$





\section{THE IUCN}

\section{AMPHIBIA - REPTILIA \\ RED DATA BOOK}

\section{PART 1}

\section{Testudines Crocodylia Rhynchocephalia}

Compiled by BRIAN GROOMBRIDGE assisted by Lissie Wright

of the IUCN CONSERVATION MONITORING CENTRE

with the help and advice of the Species Survival Commission of IUCN and other experts throughout the world

Published by IUCN, Gland, Switzerland, 1982 (IUCN Conservation Monitoring Centre, 219(c) Huntingdon Road, Cambridge CB3 ODL, U.K.)

Prepared with the financial assistance of

THE WORLD WILDLIFE FUND

and

THE UNITED NATIONS ENVIRONMENT PROGRAMME A contribution to the Global Environment Monitoring System 


\section{IUCN}

IUCN (International Union for Conservation of Nature and Natural Resources) is a network of governments, nongovernmental organization (NGOs), scientists and other conservation experts, joined together to promote the protection and sustainable use of living resources.

Founded in 1948, IUCN has more than 450 member governments and NGOs in over 100 countries. Its six Commissions consist of more than 700 experts on threatened species, protected areas, ecology, environmental planning, environmental policy, law and administration, and environmental education.

\section{IUCN}

- monitors the status of ecosystems and species throughout the world;

- plans conservation action, both at the strategic level through the World Conservation Strategy and the programme level through its programme of conservation for sustainable development;

- promotes such action by governments, intergovernmental bodies and nongovernmental organizations;

- provides assistance and advice necessary for the achievement of such action.

(c) International Union for Conservation of Nature and Natural Resources

ISBN No. 2-88032-601-X

Cover drawing of a Nile Crocodile (Crocodylus niloticus) by Brian Groombridge

Printed by Unwin Brothers Limited,

The Gresham Press, Old Woking, Surrey, U.K. 


\title{
PREAMBLE
}

IUCN has always had as one of its principal functions the gathering of data on species and habitats under threat, so that action can be taken. It has, over the years, initiated and solicited information throughout the world. For species, this has been mainly through the Specialist Groups of the Species Survival Commission (SSC) or particular contracted indidivuals.

It was recognized some while ago that to handle and put to best advantage the amount of data being received, together with the requirement to present information in many different ways and to insure that action programmes be developed rapidly, there was a need for a full-time Monitoring Centre to be set up. This has now been possible with the moral and financial support of the United Nations Environment Programme (UNEP) and the World Wildlife Fund (WWF), for which I am most grateful.

It has been my pleasure and privilege to help create this Centre and watch it quickly grow. It is now coming to the production stage, having had to collate sufficiently all the previous scattered information. This, as all researchers know, is a most frustrating task; working hard but having little to show for one's efforts. We now see the beginnings of not just a whole new generation of the Red Data Books, but a computer-held data base with much wider information available. In time this will allow many different outputs for many different purposes as well as updated information on single or groups of sheets; either geographic or taxonomically arranged as needed.

The present work is the result of this activity, involving the sustained attention of the compiler, support from the Centre's administrative staff and guidance from the Species Survival Commission's Specialist Group members and consultants. As will be evident from the Introduction, we rely heavily on the assistance and support of our own expert associates to ensure that our data is of the highest quality. May I count on your help?

I would like to express my thanks and congratulations to all those who have contributed towards this work; in particular Brian Groombridge who has compiled it, Lissie Wright who assisted him, Carol Hovenden and Suzanne Vernon who were responsible for handling the text storage and processing equipment, and Tony Mence, the Centre's manager.

\author{
G.Ll. Lucas \\ Chairman \\ Species Survival Commission
}

July 1982 



\section{CONTENTS}

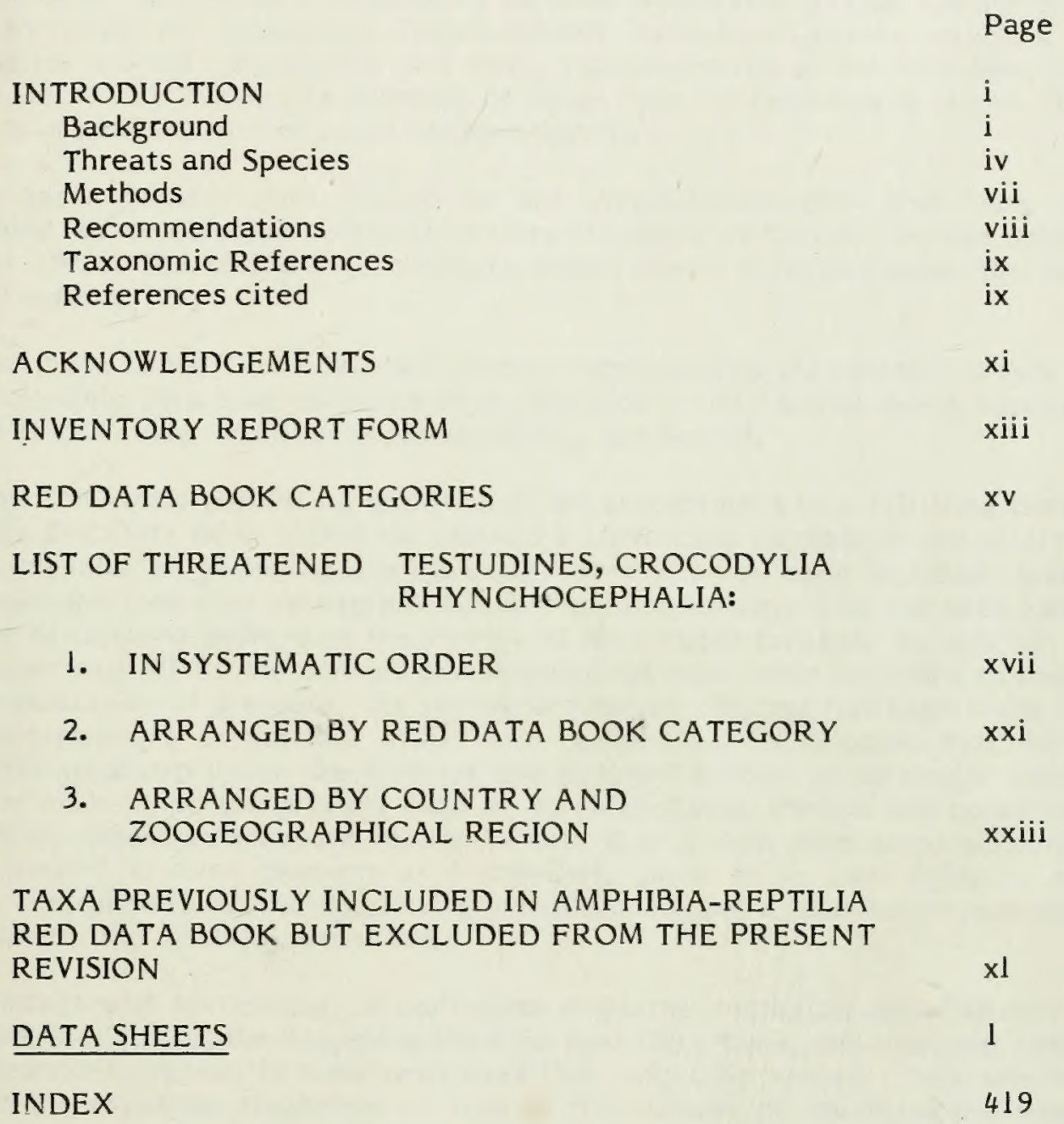



This volume, the first part of a new fully-revised and expanded edition of the IUCN Amphibia-Reptilia Red Data Book, comprises accounts of the species (or subspecies) of the reptile orders Testudines, Crocodylia and Rhynchocephalia, whose continued survival is known or strongly suspected to be actively threatened or otherwise at risk.

The order Testudines ('chelonians') includes freshwater turtles, sea turtles and land tortoises; the Crocodylia ('crocodilians') includes alligators, caimans, true crocodiles and the Gharial; the only living representative of the Rhynchocephalia is the lizard-like Tuatara (a diversity of fossil rhynchocephalians is known, dating back to around 200 million years before present).

A partly-revised third edition of the Amphibia-Reptilia Red Data Book, compiled (as were earlier editions) by René Honegger of Zürich Zoo, was published in late 1979. The majority of the data sheets were un-revised since the second (1975) edition.

This book is the first published product incorporating information drawn from the expanding data base on threatened amphibians and reptiles being established at the Conservation Monitoring Centre (CMC, see below).

The CMC word-processing facility and the appointment of a full-time compiler for this Red Data Book (RDB) has allowed a significant increase in the effort that can be devoted to gathering and updating information on each included taxon. It has been the intention to exploit this in providing a fairly full, but still concise, profile of relevant aspects of the biology of each taxon treated. In common with the other new RDBs the format and subheadings have been modified to improve the organization of the data. At the same time an attempt has been made to be as comprehensive as possible within each subheading. It is hoped that the new material presented under the 'Habitat and Ecology' section in particular will give greater meaning to the primary data on survival status, threats and conservation measures. Where an adequate volume of data is available, each taxon account has been treated in some respects as a scientific paper in its own right; all major facts, interpretations and opinions are referenced and a 'Summary' provides an overview of the material presented.

Contact with herpetological colleagues and other zoologists demonstrates that awareness of IUCN, the Amphibia-Reptilia Red Data Book, and concepts relating to threatened species, is more restricted than might be wished. Thus, one major aim of the expanded treatment of taxa in this volume of the Amphibia-Reptilia RDB is to reach and influence readers outside the conservationist and environmentalist world who may be attracted initially by the basic zoological data. Such data are difficult to find for many of the species, or not available from a single source.

This approach does, however, require that publication of material on threatened amphibians and reptiles is staggered, so that information remains adequately up-to-date at the time of publication. A taxonomic approach is followed by most workers who have provided data, and by the IUCN/SSC Specialist Groups themselves, and this has been adopted in partitioning the Amphibia-Reptilia RDB into manageable sections. It is recognized that a geographical breakdown might be more appropriate for some users, but information on a regional basis will be accessible through the CMC computer 
when fully operational, and (as in previous RDBs) there is a geographical index. It was decided to begin the revision with chelonians, crocodilians and the Tuatara because of the volume of data available, and to some extent because of the wider interest in these species. Taxon accounts for these groups are here published as Part 1 of the new Amphibia-Reptilia RDB. Further parts, dealing with snakes and lizards, and with amphibians, will follow. Although the volume of data available on most of these species is relatively small, the number of species to be treated is very large and relevant information is difficult to obtain. Thus it is not possible at this time to state when these further volumes will appear.

The following outline of the aims and establishment of the Conservation Monitoring Centre is taken from the recently-published Part 1 of the Mammal RDB (3).

"The World Conservation Strategy (1), published in 1980, succinctly articulated the rationale for species conservation and absorbed it into the concept of conservation for development.

Living resource conservation for sustainable development is seen to have three specific objectives:

to maintain essential ecological processes and life support systems (such as soil regeneration and protection, the recycling of nutrients, and the cleansing of waters), on which human survival and development depend;

to preserve genetic diversity (the range of genetic material found in the world's organisms), on which depend the breeding programmes necessary for the protection and improvement of cultivated plants and domesticated animals, as well as much scientific advance, technical innovation, and the security of the many industries that use living resources;

to ensure the sustainable utilization of species and ecosystems (notably fish and other wildlife, forests and grazing lands), which support millions of rural communities as well as major industries.

The increasing threats to species survival and the urgent need for conservation action thus made it essential that the updating of the Red Data Books be accelerated, that full-time staff be employed, and that modern methods of data collection, storage and processing be used. In response, IUCN in 1979 established the Species Conservation Monitoring Unit (SCMU) in Cambridge, England. This Unit, when joined at the end of 1980 by the International Council for Bird Preservation (ICBP) which compiles the Bird Red Data Book, brought together under one roof the compilation of all animal Red Data Books. At the same time IUCN's Wildlife Trade Monitoring Unit (WTMU) (formerly known as TRAFFIC) moved in to share the Cambridge premises. The enlarged operation demanded a new. name, thus the IUCN's Conservation Monitoring Centre (CMC) came into existence as an umbrella title. The Centre also embraces IUCN's Threatened Plants Committee (TPC) which compiles the Plant Red Data Book and is located at The Royal Botanic Gardens, Kew, England, and IUCN's Protected Areas Data Unit (PADU), established in 1981, also based at Kew. The latter is an instrument of IUCN's Commission on National Parks and Protected Areas (CNPPA) and 
compiles and maintains up-to-date lists of the world's protected areas. Some of this information is published in the United Nations List of National Parks and Equivalent Reserves and The World Directory of National Parks and other Protected Areas. PADU will assess the coverage by protected areas of each biogeographical province on land as identified by Udvardy, and biophysical province at sea. CNPPA will then be able to identify gaps in the world-wide system of reserves and thus focus its attention on the establishment of protected areas where they are most required. Initially PADU plans to produce volumes on each of the eight biogeographical realms.

All sections of the Centre have word-processing facilities which have greatly increased the efficiency of data compilation, and a computer has been installed at Kew to store and process the data base that is emerging.

The establishment of a data base incorporating animal and plant status, wildlife trade, and protected area data is now the principal aim of the Centre. Close collaboration will also be maintained with IUCN's Environmental Law Centre in Bonn, Germany, which provides legislative data, and with the Global Environment Monitoring System (GEMS) of the United Nations Environment Programme (UNEP).

Red Data Books are seen as but one output of this data base. Data will also be made available to, for instance, national and regional endangered species programmes, conservation funding agencies, and conventions such as the 1973 Convention on International Trade in Endangered Species of Wild Fauna and Flora (CITES), and the 1979 Convention on Conservation of Migratory Species of Wild Animals. Already the Centre has provided the European Economic Community (EEC) with draft lists, and detailed data sheets, of threatened mammals (excluding bats and cetacea), amphibians and reptiles, and plants, within its boundaries.

The information will, in addition, be used by the SSC to produce and update its programme of Action to Prevent Extinction (APX) and this will provide an input to the overall IUCN and World Wildlife Fund programmes and will assist them in their task of screening project proposals submitted for funding.

More importantly the availability of species, habitat and protected area information in the same data system will at last allow species conservation to take on a strategic aspect; reserves can be planned in areas where the maximum benefit to the maintenance of species diversity will accrue. Such information will be available to, for instance, development banks and technical assistance agencies so that the problems and needs of species conservation can be incorporated into land use and development planning at an early stage." 
The preservation of the genetic diversity represented by species and distinct subspecies of organisms may be seen partly as a matter of ethics, but, more directly, as a matter of necessity for human well-being.

The animals treated in this book are often spectacular, often of immense scientific interest, often of ritual or cultural significance to indigenous peoples; but most critically, of ten invaluable renewable resources providing food or other products and performing a variety of roles in natural ecosystems.

Crocodiles of essentially modern aspect lived alongside their archosaurian cousins, the dinosaurs, about 100 million years ago, while sea turtles cruised the Cretaceous seas; forms directly ancestral to each of these groups are known much further back in earth history. Freshwater turtles and land tortoises have provided a conveniently packaged ("they come with their own cooking pot") and readily accessible food source in many parts of the world. The regular seasonal appearance of nesting sea turtles on tropical beaches, with their abundance of nutritious eggs, must have seemed little short of miraculous to littoral peoples. Today these animals, most especially the crocodiles and sea turtles, are almost universally in decline.

The detailed distribution and the biology of most of the freshwater turtles and land tortoises included in this volume are very poorly known. In some cases this may be due to their small size and secretive behaviour, or perhaps to simple over-familiarity. For many taxa in these groups the prime conservation proposal is for a field survey to determine survival status, distribution and relevant aspects of biology. Habitat loss is cited as a threat to many of these animals, perhaps most often to the freshwater species that tend to be affected by wetland drainage or pollution as agricultural efforts expand. The Aquatic Box Turtle Terrapene coahuila, endemic to the marshes of the Cuatro Cienegas basin of north $\overline{M e x i c o,}$ is a prime example. Certain of the freshwater turtles, notably Podocnemis expansa and Batagur baska, resemble sea turtles in coming ashore seasonally to lay large clutches of small eggs. This strategy renders the species liable to excessive human predation on eggs, but adults of the former species in particular have been, and still are, heavily utilized for food (and formerly for oil). However, some of the freshwater species, such as Phrynops dahli and Pseudemydura umbrina, appear to be naturally extremely rare, while others are affected by a combination of small range, exploitation for food, and habitat loss. Similarly, most of the land tortoises are affected by a combination of factors. Some, such as Geochelone platynota are known to have been locally common in the nineteenth century but lack recent study and are suspected to be declining due to heavy food use. Exploitation for the pet trade has been a major threat to many of the taxa listed, Geochelone chilensis and Testudo graeca graeca for example. The most critically endangered tortoise, Geochelone yniphora from Madagascar, has in the past been exploited for food, occasionally for pets, and suitable habitat over much of the small range has been lost.

Sea turtles have been exploited on a local subsistence basis, for meat or eggs, through much of their range. Although extremely vulnerable to exploitation (due to the seasonal nesting congregations, the awkwardness of the female on land, and easily-discovered nests), it appears that, in general, the resource was able to withstand this level of utilization. However, some Green Turtle populations in the Caribbean were already under heavy pressure in the seventeenth century, as colonial mariners and settlers found them a bountiful food source, and the taste for turtle soup developed in Europe. By the middle of the present century, population increase, the introduction of cash economies and the products of 
western technology (such as aluminimum boats and dutboard motors), had led to a widespread increase in the intensity of utilization. Compounded by international trade demands - again for luxury items such as turtle soup, 'tortoiseshell' accessories, turtle oil and turtle-skin leather, in developed countries - intense exploitation in many parts of the world has caused severe depletion in sea turtle species. While being the target species of much fishing activity, sea turtles more recently face a major threat from incidental catch in shrimp and prawn trawls, squid nets and a variety of fish nets. This kind of mortality is particularly significant for the critically endangered Kemp's Ridley, whose mature adult female population is down to only a few hundred individuals. Habitat destruction and disturbance pose a further major threat as shorelines become increasingly developed for settlement and tourism. Sea turtles are typically highly sensitive to disturbance during initial stages of the nesting process, and in many parts of their range there are fewer undisturbed beaches available.

Conservation and rational utilization of the potential resource provided by sea turtles faces many problems inherent in the population biology of these species. The following outline is taken, slightly modified, from a recent report from the IUCN/SSC Marine Turtle Specialist Group (1).

1. "Sea turtle populations exposed to high levels of exploitation have, without exception, declined or become extinct. Thus, our present concern is real and immediate.

2. Each sea turtle nesting population is genetically isolated and distinct and cannot replenish other such populations. Details of the biology vary between species, and between different populations of the same species. Detailed knowledge of each population is necessary, and our knowledge of nearly all populations is insufficient. Only a small number of the discrete populations known are receiving adequate study and protection, or effective management.

3. Nesting aggregations draw turtles from large disperse feeding ranges and thus give falsely high indications of population size. These aggregations are not fortuitous but a necessary component of the life history strategy, enabling turtles to counter natural mortality which becomes insupportable if nesting density is reduced.

4. Numbers of turtles nesting in any one season are difficult to estimate because of our inadequate knowlege of their biology. Nesting numbers vary by factors of $2-50$ in different years so that the single season cannot be used to estimate total numbers.

5. Despite the large numbers of eggs laid by a female in a given clutch, the ability of a sea turtle population to replace individuals which die is actually very low, for the following reasons.

a. It takes a long time for them to reach sexual maturity in the wild - recent estimates include figures of from 15-50 years.

b. There is heavy mortality of hatchlings.

c. New data and re-examination of old data suggest that turtles nest less frequently than previously supposed, both re-nesting fewer times in a season and re-migrating in fewer seasons (often only nesting in one season). 
1. Each turtle population must be treated as a discrete entity for the purposes of conservation.

2. The estimation of turtle population sizes and hence sustainable yields cannot be done with certainty at this time.

3. Turtle populations exploited on the basis of nesting aggregation size are likely to decline rapidly.

4. Turtles have a very limited ability to replace individuals lost to the population."

The body of data incorporated in the revised accounts for threatened sea turtles in this volume could, by one interpretation, suggest that the status category formerly given to certain of the species might require modification. However, largely because of the factors just outlined above, the SSC has decided to maintain the previous category designations for all sea turtles, pending a planned discussion of the criteria defining each present category, and related aspects of sea turtle biology and conservation.

Many crocodilian species are magnificent, although deceptively sluggish, predators and are among the few animals that can prey on man with ease. This relationship is now reversed; often equipped with high-powered rifles, night-lights and motor-powered boats, hide-hunters have pushed some species to the edge of extinction. Unregulated trade in hides, for leather to be used in shoes, handbags and other items in fashion-conscious developed countries, has caused very severe depletion of the crocodile resource throughout the tropics and subtropics, while maximum profits have remained high up in the trade chain - rarely or never with local peoples.

The primary threat of over-exploitation is compounded in some cases by habitat destruction, notably drainage of wetlands. The focus of exploitation has tended to shift from one species to another, the more accessible and/or commercially preferable species being the major targets. In southeast Asia and Australia, for example, the Estuarine Crocodile could be readily hunted in one of its main habitats, mangrove-fringed river mouths, often when hauled out to bask on exposed mud banks. The hide of this species was simultaneously in great demand for fashion accessories, due to the lack of bony buttons (osteoderms) in the belly scales, and the small size of the scales (producing an attractively-patterned leather). In Africa, hides of the Nile Crocodile were in maximum demand, but with widespread depletion of this species hunting pressure appears to be switching to the two other African species.

Extensive crocodile management programmes have been operating in some areas. In India for example, a joint FAO-Government project appears to have brought the Gharial back from the brink of extinction. This project involves incubating eggs collected from natural nests, rearing the young until past the phase of suspected maximum mortality, and releasing them in specially established reserve areas. A similar project is also operating for the Mugger, with controlled commercial harvest as one potential objective. In Papua New Guinea a pioneering attempt has been made, again with FAO assistance, to control unrestricted hunting by promoting crocodile-rearing operations (originally mainly village-based), and permitting legal commerce in hides from a particular size class. A monitoring programme now being developed should provide information on the extent to which the rearing scheme is fulfilling its objective of bringing hunting pressure on the wild crocodile resource down to an acceptable level. In U.S.A., populations of American Alligator, apparently more resilient than many other crocodilian species, have responded to strict protection to the extent that 
While conservation of crocodilian species for aesthetic, ecological and scientific motives may be feasible in parts of the world, and is certainly desirable; commercial utilization is likely to be the prime justification in many countries. The critical challenge here will be to ensure, firstly, that international trade in crocodilian products is very strictly regulated to limit trade to managed populations, and secondly, that management is aimed at long term survival of the resource species.

\section{Methods}

The species (and subspecies) accounts forming the main text of this volume are based on compilation, selection and editing of published and unpublished written information, sometimes verbal information, from a variety of sources.

The Survival Service Commission (SSC) of IUCN now has Specialist Groups for all taxa treated herein (except the unique Tuatara Sphenodon punctatus); specifically, for Crocodiles, Marine Turtles, Freshwater Turtles and Tortoises. These last two Specialist Groups are relatively new, while those for Crocodiles and Marine Turtles are of much longer standing. One of the many functions of the Chairmen of Specialist Groups is to promote supply of data for RDB purposes regarding which taxa covered by the group are of particular concern, and on their conservation status, based on the research and experience of the group members and correspondents. Contact with the Chairmen and members of the relevant SSC Specialist Groups has provided probably the major part of the information presented. A large proportion has also come from a variety of other persons, not formally associated with IUCN, including field, museum and zoo herpetologists, various other field professionals associated with wildlife, parks, and aid organizations, and amateur naturalists. Data may be in the form of published literature, pre-publication manuscripts, unpublished research reports (eg. relating to WWF-funded projects), letters or verbal communications. Basic data on aspects of the biology, distribution and taxonomy of a group have come mainly from the herpetological literature.

A preliminary draft data account is compiled from the information gathered. In some cases workers contacted have provided outline drafts, which can than be amplified or refined as necessary, using data on file. The preliminary draft is typically then circulated for comment, correction, and additional current data. Drafts are sent to as many authorities as possible; although quite frequently only one or two persons may be known to be competent (by virtue of their field experience) to review the material, in some instances many persons are involved. This latter case may pose the problem of resolving apparently conflicting statements and opinions; this is not always possible, in which event both viewpoints are presented. There may be one or several review phases, depending variously on the geographical spread of the animal concerned, on the number of authorities involved and on the direct limitations of time. Although the cut-off point for the 'final' taxon account is determined largely by publication schedules, there is actually no final version since the aim is to continually expand and update the data base. It is to be hoped that publication of this volume will itself prompt comments and corrections on the information presented.

It must be recognized that the taxa treated in this volume are those known or strongly suspected to be threatened; it is a minimum treatment in that many taxa in these groups (especially among freshwater and land chelonians) remain largely unknown, and there are degrees of 'suspicion' - several more taxa suspected to be 
threatened could have been listed if time were unlimited. Information will continue to be sought on all taxa of concern.

While decisions regarding inclusion of a particular taxon and assignment of an appropriate status category have been made with the assistance of as extensive specialist advice as possible, the list is flexible and modifications will be made whenever new evidence demands re-assessment.

The Compiler will be grateful for any corrections, for additional information on the status of listed species, and for data on other species believed to be threatened throughout their range. An inventory report form follows this Introduction and data can usefully be set out in accordance with this form. A special plea is made for substantiating data, since opinion alone is difficult to interpret:

\section{Recommendations}

Each Red Data account includes a section on 'Conservation Measures Proposed', which comprises recommendations on the action required to improve the taxon's prospects of survival. The proposals are primarily concerned with the protection of the animal and its habitat, and the elimination of threats to its survival, and/or the collection of biological data on which to base more effective remedial measures.

Below is a general check-list of conservation measures for threatened species, the original of which was compiled by the Species Survival Commission in 1966/67.

\section{A. Fact Finding}

1. To conduct a survey to determine

(a) the status of the taxon;

(b) the current threats to its survival;

(c) the remaining habitat suitable to its needs;

(d) the legal and enforcement situation.

2. To launch a research project to ascertain its ecology, the factors limiting its population growth, and the relationship between it, its habitat and the local human population.

\section{B. Action Proposed}

\section{Legal}

(a) to promote or prompt new legislation, or make better use of powers under existing legislation;

(b) to promote a special international convention;

(c) to improve law enforcement:

(i) within national parks or reserves;

(ii) in the country generally;

(iii) with regard to international trade;

(d) to add a taxon to one of the Appendices of the 1973 - Convention on International Trade in Endangered Species of Wild Fauna and Flora (CITES), or to transfer it to a higher Appendix;

(e) to improve the legal situation in any other way. 
2. To promote the formation of a national park, nature reserve or wildlife refuge
(a) by an official body;
(b) by a voluntary organization.

3. To establish a continuing scientific presence

(a) through a scientific research programme;

(b) by establishing a research station;

(c) by establishing a research foundation.

4. To undertake educational or public relations measures.

5. To encourage existing conservation effort.

6. To promote a programme of captive propagation

(a) in a zoo;

(b) in an institution designed for propagating threatened taxa;

(c) on a site in the taxon's own habitat.

7. To re-establish a taxon in an area where it is either extinct or very rare

(a) by translocation direct from the wild;

(b) by release of captive-bred stock;

(c) by increasing the food supply or living space by habitat management.

8. To offer bounties for successful rearing of young (chiefly applicable to birds).

9. To control feral or introduced animals

(a) predators;

(b) competitors for the available forage.

\section{Taxonomic References}

The systematic arrangement and scientific nomenclature used herein in most cases follows Wermuth and Mertens (1977). Exceptions in chelonian nomenclature, especially in regard to generic names within the Testudinidae, follow current consensus usage outlined in Pritchard (1979). Where relevant, matters of taxonomic dispute are referred to and referenced in the data account for the taxon in question.

a. Pritchard, P.C.H. (1979). Encyclopedia of Turtles, T.F.H. Publications, New Jersey and Hong Kong.

b. Wermuth, H. and Mertens, R. (1977). Testudines, Crocodylia, Rhynchocephalia. Das Tierreich, 100: 1-174. Berlin, Walter de Gruyter.

\section{$\underline{\text { References cited }}$}

1. Anon. (Allen, R (Ed.)) (1980). World Conservation Strategy: Living Resource Conservation Strategy for Sustainable Development. Prepared by IUCN with advice, cooperation and financial assistance of the United Nations Environment Programme (UNEP) and the World Wildlife Fund (WWF) and in collaboration with the Food and Agriculture Organization of the United Nations (FAO) and the United Nations Educational, Scientific and Cultural 
Organisation (UNESCO). IUCN, Gland, Switzerland. (Also see Allen, R. (1980). How to save the world, Kogan Page, London - a longer text based on the above work).

2. Ross, J.P., and the SSC Marine Turtle Specialist Group (1979). Present status of sea turtles. A summary of recent information and conservation priorities. Unpublished report.

3. Thornback, J., and Jenkins, M. (1982). The IUCN Mammal Red Data Book, Part 1. IUCN, Gland, Switzerland. 


\section{ACKNOWLEDGEMENTS}

Very many persons have contributed materially to the preparation of this book. Such contributions range from a sight record of a particular animal in one country, to provision of draft data sheets for one or more taxa, or extensive review of several draft accounts. Those who have assisted with information, comments, corrections and other material during the review process are acknowledged in the 'Remarks' section of the relevant taxon account, and are noted overleaf.

The Compiler would like to express his sincere gratitude to everyone who has taken time, usually from an already over-full working life, to assist with this task.

Some individuals have been able to make particularly significant contributions. Anne Meylan (Agenda Officer of the Marine Turtle Specialist Group) has coordinated review of most of the draft sea turtle accounts, providing crucial comments from herself, Archie Carr (Chairman), Karen Bjorndal and others, also important literature. George Balazs (Vice-Chairman) and Perran Ross, among several other group members have been similarly helpful. Peter Pritchard (Vice-President, Science and Research, Florida Audubon Society) has responded rapidly and fully to every request regarding chelonians, providing incisive review comment and important literature. Ed Moll (Chairman of the Freshwater Chelonian Specialist Group) has likewise provided ready guidance on freshwater turtles; Russ Mittermeier and Anders Rhodin have been especially helpful among other group members. Ian Swingland (Chairman of the Tortoise Specialist Group) organized a highly productive first meeting of the group. Peter Brazaitis (Superintendent of Herpetology, Bronx Zoo) supplied valuable draft accounts for many of the South American crocodilians, also relevant reprints and other material. H.R. Bustard, (formerly with the crocodile breeding and management programme in India) and Jeff Lang provided abundant help with crocodiles in India and New Guinea respectively. Members of the SSC Crocodile Specialist Group have also been of assistance. Harry Messel (University of Sydney) supplied a steady flow of material on Australian Estuarine Crocodile populations. The late H.W. 'Duke' Campbell (former Chairman) was kindly able to provide much literature on New World crocodilians, and F. Wayne King (present Chairman) has supplied invaluable comments on some of the crocodile drafts. René Honegger (former Compiler) provided substantial advice and friendly guidance.

My gratitude is also extended to staff of the British Museum (Natural History), especially of the Amphibia-Reptilia section, in particular Miss A.G.C. Grandison (Curator) and E.N. Arnold, for readily providing advice, information and access to herpetological literature.

Within this office, Lissie Wright has assisted in the later stages of research and compilation, not only writing sections of some drafts and entire drafts for a few taxa, but also providing critical moral and practical support in final preparation of the manuscript. Sincere thanks are also due to Carol Hovenden and Suzanne Vernon for their almost unfailing enthusiasum in the often tiresome tasks of transferring barely legible handwriting into the word-processor, and to Kathy McVittie for her painstaking work in preparing the Index and the Taxonomic and Geographical lists. Finally, my wife Mary has helped in many ways and on very many occasions that she would probably rather forget. 
G. Aguirre, J. Andrianarivo, E.N. Arnold, S. Biswas, K. Bjorndal, C. Blanc, R. Bour, A.A. Burbidge, A. Carr, S.E. Cornelius, J.L. Dobie, A. Duff-MacKay, D. Ehrenfeld, M. Freiberg, J. Fretey, W.R. Garstka, J. Grieg, E. Gudynas, H. Hirth, T.W. Hoffman, R. Honegger, G.R. Hughes, J.B. Iverson, J.O. Juvik, Md.A.R. Khan, A. Laurie, J. MacKinnon, W.E. Magnusson, R. Marquez, C.J. McCoy, P.A. Medica, H. Medelssohn, T. Milliken, R. Mittermeier, N. Mrosovsky, D. Moll, E.O. Moll, D.J. Morafka, J. Mortimer, T.S.N. Murthy, C.E. Norris, S.N. Nuitja, L.F.M. de Padua, F. Parker, A. Paolillo, R. Petocz, R.S. Pillai, N. Polunin, P.C.H. Pritchard, K. Proud, A.G.J. Rhodin, J.P. Rische, M. Rose, J.P. Ross, R.V. Salm, N. Scott, J.S. de Silva, K.T. Siow, P. Soini, I.R. Swingland, W.H. Timmis, P.E. Vanzolini, D. Watling, R.G. Webb.

\section{Crocodylia}

C.L. Abercrombie, L.N. Acharjyo, Md.F. Ahmed, A.W. Akonda, A.C. Alcala, M. Alvarez del Toro, P. Andau, D.K. Blake, C. Blanc, M. Bolton, A.A. Burbidge, H.R. Bustard, H.W. Campbell, B.C. Choudhury, H. Chu-chien, D. Dickinson, M. Freiberg, S.J. Gorzula, E. Gudynas, R.W.G. Jenkins, S. Kar, A.A. Khan, Md. A.R. Khan, F.W. King, J.W. Lang, J. Lever, D. Mack, J. MacKinnon, W.E. Magnusson, T.M. Maskey, M. McCoy, H. Messel, R. Mittermeier, K. Miyata, J.J. Montague, M.R. Nadeau, J.C. Ogden, J.C. Pernetta, R. Petocz, M.J. Plotkin, T. Pooley, J.C. Reid, C.A. Ross, N. Scott, I.S. Suwelo, P.E. Vanzolini, L.S. Varona, M. Watanabe, G.J.W. Webb, R. Whitaker.

\section{Rhynchocephalia}

D.G. Newman. 
Report to be mailed to SCMU, 219(c) Huntingdon Rd, Cambridge, CB3 ODL, I.K.

1. Country

3. Reporter

Name:

4. Taxon

Scientific Name:

5. Distribution

Present:

Former:

If possible, please include a map. Is present range preferred or enforced habitat?

6. Population

Estimated numbers in the wild. Indicate date of estimate and describe method of estimation. Are numbers increasing, decreasing or stable?

7. Habitat and Ecology

Biome type. Elevation range. Brief notes about social structure, feeding habits and diet, reproduction (gestation, breeding season, number of young, age of sexual maturation), longevity etc.

8. Threats to Survival

Eg. habitat destruction, over-exploitation, hybridization, natural disasters, competition for food.

9. Conservation Measures Taken

Legal measures (international conventions, national laws); is law enforced? Protected areas - does it occur in national parks, reserves etc.? If so, please list. Management programmes or research programmes in progress.

10. Conservation Measures Proposed

Same as for 9 , but measures that are needed for the conservation of the taxon.

11. Captive Breeding

Numbers in captivity. Does it breed readily in captivity?

Where and when? 
12. Remarks

Reference citations for description of animal. Comments about related taxa. If the above information concerns a subspecies then brief information should be given about the distribution and status of the species as a whole. Special acknowledgements etc.

13. References

Can be published papers, unpublished manuscripts, or references to correspondence (cited as In litt.). 


\section{RED DATA BOOK CATEGORIES}

\section{EXTINCT (EX)}

Species not definitely located in the wild during the past 50 years (criterion as used by CITES).

\section{ENDANGERED (E)}

Taxa in danger of extinction and whose survival is unlikely if the causal factors continue operating.

Included are taxa whose numbers have been reduced to a critical level or whose habitats have been so drastically reduced that they are deemed to be in immediate danger of extinction. Also included are taxa that are possibly already extinct but have definitely been seen in the wild in the past 50 years.

\section{VULNERABLE (V)}

Taxa believed likely to move into the 'Endangered' category in the near future if the causal factors continue operating.

Included are taxa of which most or all the populations are decreasing because of over-exploitation, extensive destruction of habitat or other environmental disturbance; taxa with populations that have been seriously depleted and whose ultimate security has not yet been assured; and taxa with populations that are still abundant but are under threat from severe adverse factors throughout their range.

\section{RARE (R)}

Taxa with small world populations that are not at present 'Endangered' or 'Vulnerable', but are at risk.

These taxa are usually localised within restricted geographical areas or habitats or are thinly scattered over a more extensive range.

\section{INDETERMINATE (I)}

Taxa known to be 'Endangered', 'Vulnerable' or 'Rare' but where there is not enough information to say which of the three categories is appropriate.

\section{OUT OF DANGER (O)}

Taxa formerly included in one of the above categories, but which are now considered relatively secure because effective conservation measures have been taken or the previous threat to their survival has been removed.

\section{INSUFFICIENTLY KNOWN (K)}

Taxa that are suspected but not definitely known to belong to any of the above categories, because of lack of information.

N.B. In practice, 'Endangered' and 'Vulnerable' categories may include, temporarily, taxa whose populations are beginning to recover as a result of remedial action, but whose recovery is insufficient to justify their transfer to another category. 



\section{LIST OF THREATENED \\ TESTUDINES, CROCODYLIA AND RHYNCHOCEPHALIA}

\section{IN SYSTEMATIC ORDER}

The letter preceding each taxon refers to its Red Data Book category (see page xv). Also included are 14 taxa that are categorised as 'Insufficiently Known'.

\section{TESTUDINES}

\section{KINOSTERNIDAE}

$\mathrm{R} \quad$ Kinosternon angustipons

$\mathrm{R}$ Kinosternon creaseri

$\mathrm{R}$ Kinosternon dunni

E Kinosternon flavescens spooneri

I Sternotherus minor depressus

DERMATEMYDIDAE

Dermatemys mawii

EMYDIDAE

Batagur baska

Callagur borneoensis

Clemmys muhlenbergii

Heosemys silvatica

Pseudemys alabamensis
Pseudemys felis

Pseudemys malonei

Pseudemys rubriventris bangsi

Pseudemys scripta callirostris

Rhinoclemmys areolata

Rhinoclemmys rubida

Terrapene coahuila

\section{TESTUDINIDAE}

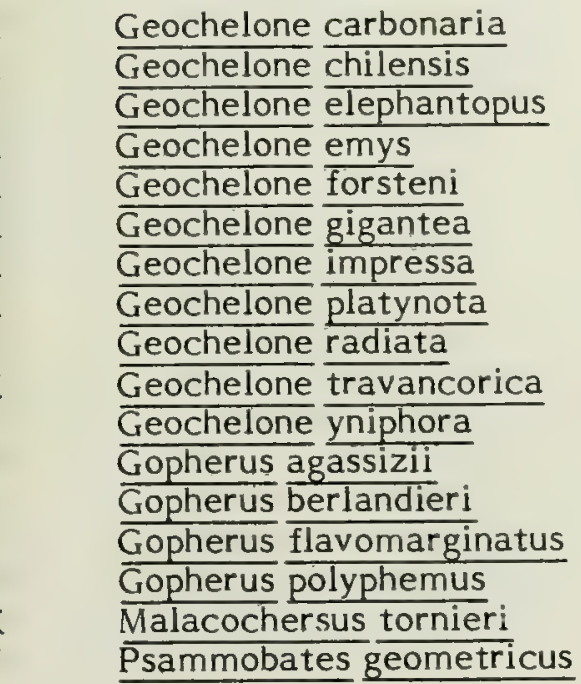

Narrow-bridged Mud Turtle

Creaser's Mud Turtle

Dunn's Mud Turtle

Illinois Mud Turtle

Flattened Musk Turtle

Central American River Turtle

River Terrapin

Painted Terrapin

Bog Turtle

Kavalai Forest Turtle

Alabama Red-bellied Turtle

Cat Island Turtle

Inagua Island Turtle

Plymouth Red-bellied Turtle

South American Red-lined Turtle

Furrowed Wood Turtle

Mexican Spotted Wood Turtle

Aquatic Box Turtle

Red-foot Tortoise

Chaco Tortoise

Galapagos Giant Tortoise

Burmese Brown Tortoise

Celebes Tortoise

Aldabra Giant Tortoise

Impressed Tortoise

Burmese Starred Tortoise

Radiated Tortoise

Travancore Tortoise

Angonoka

Desert Tortoise

Berlandier's Tortoise

Bolson Tortoise

Gopher Tortoise

Pancake Tortoise

Geometric Tortoise 
Pyxis arachnoides

Pyxis planicauda

Testudo graeca graeca

Testudo hermanni

Testudo kleinmanni

CHELONIIDAE

V Caretta caretta

E Chelonia mydas

E Eretmochelys imbricata

E Lepidochelys kempii

E Lepidochelys olivacea

DERMOCHELYIDAE

E

Dermochelys coriacea

CARETTOCHELYIDAE

K

Carettochelys insculpta

TRIONYCHIDAE

R

Trionyx nigricans

PELOMEDUSIDAE

Erymnochelys madagascariensis Podocnemis ery throcephala Podocnemis expansa Podocnemis lewyana Podocnemis sextuberculata Podocnemis unifilis

CHELIDAE

Phrynops dahli

Phrynops hogei

Phrynops rufipes

Platemys pallidipectoris

Platemys spixii

Pseudemydura umbrina

\section{CROCODYLIA}

\section{ALLIGATORIDAE}

E Alligator sinensis

I Caiman crocodilus apaporiensis

V Caiman crocodilus crocodilus

V Caiman crocodilus fuscus

I Caiman crocodilus yacare

E Caiman latirostris

E Melanosuchus niger
Madagascar Spider Tortoise Madagascar Flat-tailed Tortoise Spur-thighed Tortoise Hermann's Tortoise Egyptian Tortoise

\section{Loggerhead Turtle}

Green Turtle

Hawksbill Turtle

Kemp's Ridley

Olive Ridley

Leatherback

New Guinea Plateless Turtle

Dark Soft-shell Turtle

Madagascar Sideneck Turtle Red-headed Amazon Sideneck Turtle South American River Turtle Magdalena River Turtle Pitiu

Yellow-spotted Sideneck Turtle

Dahl's Toad-headed Turtle Hoge's Sideneck Turtle Red-headed Sideneck Turtle Chaco Sideneck Turtle Spix's Sideneck Turtle Western Swamp Tortoise

Chinese Alligator

Rio Apaporis Caiman

Spectacled Caiman

Brown Caiman

Yacare

Broad-nosed Caiman

Black Caiman 


\section{CROCODYLIDAE}

E Crocodylus acutus

I Crocodylus cataphractus

E Crocodylus intermedius

V Crocodylus johnsoni

E Crocodylus mindorensis

E Crocodylus moreletii

V Crocodylus niloticus

$\mathrm{V} \quad$ Crocodylus novaeguineae

V Crocodylus palustris

E Crocodylus porosus

E Crocodylus rhombifer

E Crocodylus siamensis

I Osteolaemus tetraspis

E Tomistoma schlegelii

GAVIALIDAE

E

Gavialis gangeticus

RHYNCHOCEPHALIA

SPHENODONTIDAE

R

Sphenodon punctatus
American Crocodile

African Slender-snouted Crocodile Orinoco Crocodile

Australian Freshwater Crocodile

Philippines Crocodile

Morelet's Crocodile

Nile Crocodile

New Guinea Crocodile

Mugger

Estuarine Crocodile

Cuban Crocodile

Siamese Crocodile

African Dwarf Crocodile

False Gharial

Gharial

Tuatara 



\section{LIST OF THREATENED \\ TESTUDINES, CROCODYLIA, AND RHY NCHOCEPHALIA}

\section{ARRANGED BY RED DATA BOOK CATEGORY}

Taxa are listed in systematic order under the category (see page xv) to which they are currently assigned.

\section{ENDANGERED}

E Kinosternon fl

E Geochelone elephantopus

E Geochelone yniphora

E Gopherus flavomarginatus

E Chelonia mydas

E Eretmochelys imbricata

E Lepidochelys kempii

E Lepidochelys olivacea

E Dermochelys coriacea

E Podocnemis expansa

E Pseudemydura umbrina

E Alligator sinensis

E Caiman Tatirostris

E Melanosuchus niger

E Crocodylus acutus

E Crocodylus intermedius

E Crocodylus mindorensis

E Crocodylus moreletii

E Crocodylus porosus

E Crocodylus rhombifer

E Crocodylus siamensis

E Tomistoma schlegelii

E Gavialis gangeticus

\section{VULNERABLE}

$\mathrm{V}$

V

V

V

V

V

V

V

V

V

V

V

V

V

V

V

V

V

V
Dermatemys mawii

Callagur borneoensis

Pseudemys scripta callirostris

Terrapene coahuila

Geochelone radiata

Gopherus agassizii

Gopherus polyphemus

Psammobates geometricus

Testudo graeca graeca

Testudo hermanni

Caretta caretta

Podocnemis unifilis

Caiman crocodilus crocodilus

Caiman crocodilus fuscus

Crocodylus johnsoni

Crocodylus niloticus

Crocodylus novaeguineae

Crocodylus palustris
Illinois Mud Turtle

River Terrapin

Galapagos Giant Tortoise

Angonoka

Bolson Tortoise

Green Turtle

Hawksbill Turtle

Kemp's Ridley

Olive Ridley

Leatherback

South American River Turtle

Western Swamp Tortoise

Chinese Alligator

Broad-nosed Caiman

Black Caiman

American Crocodile

Orinoco Crocodile

Philippines Crocodile

Morelet's Crocodile

Estuarine Crocodile

Cuban Crocodile

Siamese Crocodile

False Gharial

Gharial

Central American River Turtle

Painted Terrapin

South American Red-lined Turtle

Aquatic Box Turtle

Radiated Tortoise

Desert Tortoise

Gopher Tortoise

Geometric Tortoise

Spur-thighed Tortoise

Hermann's Tortoise

Loggerhead Turtle

Yellow-spotted Sideneck Turtle

Spectacled Caiman

Brown Caiman

Australian Freshwater Crocodile

Nile Crocodile

New Guinea Crocodile

Mugger 
R Kinosternon angustipons

$\mathrm{R}$ Kinosternon creaseri

$\mathrm{R}$ Kinosternon dunni

$\mathrm{R}$ Pseudemys felis

$\mathrm{R}$ Pseudemys malonei

$\mathrm{R} \quad$ Pseudemys rubriventris bangsi

$\mathrm{R}$ Geochelone forsteni

$\mathrm{R}$ Geochelone gigantea

$R$ Trionyx nigricans

$\mathrm{R}$ Platemys pallidipectoris

$\mathrm{R}$ Sphenodon punctatus

\section{INDETERMINATE}

I Sternotherus minor depressus

I Clemmys muhlenbergii

I Heosemys silvatica

I Pseudemys alabamensis

I Gopherus berlandieri

I Pyxis arachnoides

I Pyxis planicauda

I Testudo kleinmanni

I Erymnochelys madagascariensis

I Podocnemis lewyana

I Phrynops dahli

I Phrynops hogei

I Caiman crocodilus apaporiensis

I Caiman crocodilus yacare

I Crocodylus cataphractus

I Osteolaemus tetraspis

\section{INSUFFICIENTLY KNOWN}

\begin{tabular}{|c|c|}
\hline K & hinoclemmys areolata \\
\hline $\mathrm{K}$ & Rhinoclemmys rubida \\
\hline $\mathrm{K}$ & Geochelone carbonaria \\
\hline $\mathrm{K}$ & Geochelone chilensis \\
\hline $\mathrm{K}$ & Geochelone emys \\
\hline K & Geochelone impressa \\
\hline K & Geochelone platynota \\
\hline K & Geochelone travancorica \\
\hline $\mathrm{K}$ & Malacochersus tornieri \\
\hline K & Carettochelys insculpta \\
\hline K & Podocnemis erythrocephala \\
\hline & Podocnemis sextuberculata \\
\hline & Phrynops rufipes \\
\hline & Platemys spixii \\
\hline
\end{tabular}

Narrow-bridged Mud Turtle

Creaser's Mud Turtle

Dunn's Mud Turtle

Cat Island Turtle

Inagua Island Turtle

Plymouth Red-bellied Turtle

Celebes Tortoise

Aldabra Giant Tortoise

Dark Soft-shell Turtle

Chaco Sideneck Turtle

Tuatara

Flattened Musk Turtle

Bog Turtle

Kavalai Forest Turtle

Alabama Red-bellied Turtle

Berlandier's Tortoise

Madagascar Spider Tortoise

Madagascar Flat-tailed Tortoise

Egyptian Tortoise

Madagascar Sideneck Turtle

Magdalena River Turtle

Dahl's Toad-headed Turtle

Hoge's Sideneck Turtle

Rio Apaporis Caiman

Yacare

African Slender-snouted Crocodile

African Dwarf Crocodile

Furrowed Wood Turtle

Mexican Spotted Wood Turtle

Red-foot Tortoise

Chaco Tortoise

Burmese Brown Tortoise

Impressed Tortoise

Burmese Starred Tortoise

Travancore Tortoise

Pancake Tortoise

New Guinea Plateless Turtle

Red-headed Amazon Sideneck Turtle

Pitiu

Red-headed Sideneck Turtle

Spix's Sideneck Turtle

ENDANGERED 24

VULNERABLE 18

RARE II

INDETERMINATE 16

INSUFFICIENTLY KNOWN 14 


\section{LIST OF THREATENED \\ TESTUDINES, CROCODYLIA AND RHYNCHOCEPHALIA}

\section{ARRANGED BY COUNTRY AND ZOOGEOGRAPHICAL REGION}

The zoogeographical regions first described by Wallace in 1876 are used, slightly modified, as a basis for this index. Boundaries have been adjusted in some cases in order to avoid subdividing a particular political unit.

The Palearctic region is the northerly part of the Old World. It extends over the whole of Europe, U.S.S.R. and China, including the adjacent offshore islands, and includes the Mediterranean Coast of Africa. In the present list the entire Arabian Peninsula is assigned to this region.

The Ethiopian region covers central and southern Africa, and the islands of Madagascar with its smaller neighbours.

The Oriental region covers Asia south of China from the western border of Afghanistan and Pakistan east to the Pacific Ocean including the Philippines and Indonesia (with the exception of Irian Jaya and the Aru Islands, here included with New Guinea).

The Australasian region includes the islands of New Guinea, Australia, Tasmania and New Zealand.

The Nearctic region covers all of North America including Greenland the Aleutian Islands and northern Mexico (see Neotropical).

The Neotropical region includes southern Mexico, the Caribbean Islands, Central and South America. In the present list Mexico as a unit is assigned to this region.

Oceans and Oceanic Islands are treated separately.

'Ex' following a taxon denotes that it is regarded as extinct in that country and '?' denotes lack of confirmation of its presence.

For the circumtropical sea turtles only those countries with breeding colonies for which an entry appears in the 'Population' section of the data account are listed below. For further details see the 'Distribution' section of the relevant account.

PALEARCTIC REGION

ALBANIA

Testudo hermanni

Hermann's Tortoise

ALGERIA

$\underline{\text { Testudo graeca graeca }}$

Spur-thighed Tortoise

BULGARIA

Testudo hermanni

Hermann's Tortoise 
Alligator sinensis

Crocodylus porosus

\section{CYPRUS}

Caretta caretta

Chelonia mydas

EGYPT

Chelonia mydas

Crocodylus niloticus

Testudo kleinmanni

\section{FRANCE}

Caretta caretta

Testudo graeca graeca

Testudo hermanni

\section{GREECE}

Caretta caretta

Testudo hermanni

IRAN

Crocodylus palustris

Eretmochelys imbricata

ISRAEL

Caretta caretta

Chelonia mydas

Testudo kleinmanni

ITALY

Caretta caretta

Testudo graeca graeca

Testudo hermanni

JAPAN

Caretta caretta

Chelonia mydas

LIBYA

Testudo graeca graeca

Testudo kleinmanni

MOROCCO

Testudo graeca graeca
Chinese Alligator

Estuarine Crocodile (Ex?)

Loggerhead Turtle Green Turtle

Green Turtle Nile Crocodile

Egyptian Tortoise

Loggerhead Turtle Spur-thighed Tortoise Hermann's Tortoise

Loggerhead Turtle Hermann's Tortoise

Mugger

Hawksbill Turtle

Loggerhead Turtle

Green Turtle

Egyptian Tortoise

Loggerhead Turtle Spur-thighed Tortoise Hermann's Tortoise

Loggerhead Turtle Green Turtle

Spur-thighed Tortoise Egyptian Tortoise

Spur-thighed Tortoise 
Caretta caretta

Chelonia mydas

Eretmochelys imbricata

Lepidochelys olivacea
Loggerhead Turtle

Green Turtle

Hawksbill Turtle

Olive Ridley

PEOPLE'S DEMOCRATIC REPUBLIC OF YEMEN

Chelonia mydas

Eretmochelys imbricata

QATAR

Eretmochelys imbricata

ROMANIA

Testudo hermanni

SAUDI ARABIA

Chelonia mydas

Eretmochelys imbricata

SPAIN

Testudo graeca graeca

Testudo hermanni

TUNISIA

Testudo graeca graeca

TURKEY

Caretta caretta

Chelonia mydas

Testudo hermanni

YEMEN

Chelonia mydas

YUGOSLAVIA

Testudo hermanni
Green Turtle

Hawksbill Turtle

Hawksbill Turtle

Hermann's Tortoise

Green Turtle

Hawksbill Turtle

Spur-thighed Tortoise Hermann's Tortoise

Spur-thighed Tortoise

Loggerhead Turtle

Green Turtle

Hermann's Tortoise

Green Turtle

Hermann's Tortoise

ORIENTAL REGION

BANGLADESH

Batagur baska

Crocodylus palustris

River Terrapin

Mugger (?)

Crocodylus porosus

Estuarine Crocodile 
Gavialis gangeticus

Geochelone emys

Trionyx nigricans

BHUTAN

Gavialis gangeticus

BRUNEI

Crocodylus porosus

BURMA

Batagur baska

Caretta caretta

Chelonia mydas

Crocodylus porosus

Dermochelys coriacea

Eretmochelys imbricata

Gavialis gangeticus

Geochelone emys

Geochelone impressa

Geochelone platynota

Lepidochelys olivacea

INDIA

Batagur baska

Chelonia mydas

Crocodylus palustris

Crocodylus porosus

Dermochelys coriacea

Eretmochelys imbricata

Gavialis gangeticus

Geochelone emys

Geochelone travancorica

Heosemys silvatica

Lepidochelys olivacea

INDONESIA

Batagur baska

Callagur borneoensis

Chelonia mydas

Crocodylus porosus

Crocodylus siamensis

Dermochelys coriacea

Eretmochelys imbricata

Geochelone emys

Geochelone forsteni

Lepidochely olivacea

Tomistoma schlegelii

KAMPUCHEA

Batagur baska

$x \times v i$
Gharial

Gharia!

Burmese Brown Tortoise

Dark Soft-shell Turtle

Estuarine Crocodile

River Terrapin

Loggerhead Turtle

Green Turtle

Estuarine Crocodile

Leatherback

Hawksbill Turtle

Gharial (Ex)

Burmese Brown Tortoise

Impressed Tortoise

Burmese Starred Tortoise

Olive Ridley

River terrapin (?)

Green Turtle

Mugger

Estuarine Crocodile

Leatherback

Hawksbill Turtle

Gharial

Burmese Brown Tortoise

Travancore Tortoise

Kavalai Forest Turtle

Olive Ridley

River Terrapin

Painted Terrapin

Green Turtle

Estuarine Crocodile

Siamese Crocodile (Ex ?)

Leatherback

Hawksbill Turtle

Burmese Brown Tortoise

Celebes Tortoise

Olive Ridley

False Gharial

River Terrapin (?) 
Crocodylus porosus

Crocodylus siamensis

Geochelone impressa

\section{LAOS}

Crocodylus siamensis Geochelone impressa

\section{MALAYSIA}

Batagur baska

Callagur borneoensis

Chelonia mydas

Crocodylus porosus

Crocodylus siamensis

Dermochelys coriacea

Eretmochelys imbricata

Geochelone emys

Geochelone impressa

Lepidochelys olivacea

Tomistoma schlegelii

NEPAL

Crocodylus palustris

Gavialis gangeticus

\section{PAKISTAN}

Chelonia mydas

Crocodylus palustris

Gavialis gangeticus

Lepidochelys olivacea

\section{PHILIPPINES}

Chelonia mydas

Crocodylus mindorensis

Crocodylus porosus

Eretmochelys imbricata

\section{SINGAPORE}

Crocodylus porosus

SRI LANKA

Crocodylus palustris

Crocodylus porosus

Dermochelys coriacea

Eretmochelys imbricata

Lepidochelys olivacea

THAILAND

Batagur baska
Estuarine Crocodile (?)

Siamese Crocodile (Ex ?)

Impressed Tortoise (?)

Siamese Crocodile (Ex ?) Impressed Tortoise (?)

River Terrapin

Painted Terrapin

Green Turtle

Estuarine Crocodile

Siamese Crocodile (Ex ?)

Leatherback

Hawksbill Turtle

Burmese Brown Tortoise

Impressed Tortoise

Olive Ridley

False Gharial

Mugger

Gharial

Green Turtle

Mugger

Gharial

Olive Ridley

Green Turtle

Philippines Crocodile

Estuarine Crocodile

Hawksbill Turtle

Estuarine Crocodile (Ex)

Mugger

Estuarine Crocodile

Leatherback

Hawksbill Turtle

Olive Ridley

River Terrapin 
Callagur borneoensis

Chelonia mydas

Crocodylus porosus

Crocodylus siamensis

Dermochelys coriacea

Eretmochelys imbricata

Geochelone emys

Geochelone impressa

Lepidochelys olivacea

Tomistoma schlegelii

VIETNAM

Batagur baska

Crocodylus porosus

Crocodylus siamensis

Geochelone impressa
Painted Terrapin

Green Turtle

Estuarine Crocodile

Siamese Crocodile

Leatherback

Hawksbill Turtle

Burmese Brown Tortoise

Impressed Tortoise

Olive Ridley

False Gharial

River Terrapin (?)

Estuarine Crocodile

Siamese Crocodile (Ex ?)

Impressed Tortoise

\section{AUSTRALASIAN REGION}

\section{AUSTRALIA}

Caretta caretta

Carettochelys insculpta

Chelonia mydas

Crocodylus johnsoni

Crocodylus porosus

Dermochelys coriacea

Eretmochelys imbricata

Lepidochelys olivacea

Pseudemydura umbrina

Loggerhead Turtle

New Guinea Plateless Turtle

Green Turtle

Australian Freshwater Crocodile

Estuarine Crocodile

Leatherback

Hawksbill Turtle

Olive Ridley

Western Swamp Tortoise

ARU ISLANDS (INDONESIA)

Crocodylus novaeguineae

Crocodylus porosus

New Guinea Crocodile

Estuarine Crocodile

IRIAN JAYA (INDONESIA)

Carettochelys insculpta

Crocodylus novaeguineae

Crocodylus porosus

Dermochelys coriacea

NEW ZEALAND

Sphenodon punctatus

Tuatara

PAPUA NEW GUINEA

Carettochelys insculpta

Chelonia mydas

Crocodylus novaeguineae

New Guinea Plateless Turtle

New Guinea Crocodile

Estuarine Crocodile

Leatherback

Crocodylus porosus

Dermochelys coriacea

Eretmochelys imbricata

New Guinea Plateless Turtle

Green Turtle

New Guinea Crocodile

Estuarine Crocodile

Leatherback

Hawksbill Turtle

xxviii 


\section{ALDABRA (SEYCHELLES)}

Geochelone gigantea

Lepidochelys olivacea

ANGOLA

Caretta caretta

Chelonia mydas

Crocodylus cataphractus

Crocodylus niloticus

Dermochelys coriacea

Lepidochelys olivacea

Osteolaemus tetraspis

BENIN

Crocodylus cataphractus

Crocodylus niloticus

Osteolaemus tetraspis

BOTSWANA

Crocodylus niloticus

BURUNDI

Crocodylus niloticus

\section{CAMEROON}

Crocodylus cataphractus

Crocodylus niloticus

Osteolaemus tetraspis

CENTRAL AFRICAN REPURLIC

Crocodylus cataphractus

Crocodylus niloticus

Osteolaemus tetraspis

CHAD

Crocodylus cataphractus

Crocodylus niloticus

\section{CONGO}

Crocodylus cataphractus

Crocodylus niloticus

Osteolaemus tetraspis
Aldabra Giant Tortoise

Olive Ridley

Loggerhead Turtle

Green Turtle

African Slender-snouted Crocodile

Nile Crocodile

Leatherback

Olive Ridley

African Dwarf Crocodile

African Slender-snouted Crocodile Nile Crocodile

African Dwarf Crocodile

Nile Crocodile

Nile Crocodile

African Slender-snouted Crocodile Nile Crocodile

African Dwarf Crocodile

African Slender-snouted Crocodile Nile Crocodile

African Dwarf Crocodile

African Slender-snouted Crocodile Nile Crocodile

African Slender-snouted Crocodile Nile Crocodile

African Dwarf Crocodile 


\section{ETHIOPIA}

Chelonia mydas

Crocodylus niloticus

Eretmochelys imbricata

\section{GABON}

Crocodylus cataphractus

Crocodylus niloticus

Osteolaemus tetraspis

GAMBIA

Crocodylus cataphractus

Crocodylus niloticus

Osteolaemus tetraspis

GHANA

Crocodylus cataphractus

Crocodylus niloticus

Osteolaemus tetraspis

GUINEA

Crocodylus cataphractus

Crocodylus niloticus

Osteolaemus tetraspis

GUINEA BISSAU

Crocodylus cataphractus

Crocodylus niloticus

Osteolaemus tetraspis

IVORY COAST

Crocodylus cataphractus

Crocodylus niloticus

Osteolaemus tetraspis

KENYA

Chelonia mydas

Crocodylus niloticus

Eretmochelys imbricata

Malacochersus tornieri

LIBERIA

Crocodylus cataphractus

Crocodylus niloticus
Green Turtle

Nile Crocodile

Hawksbill Turtle

African Slender-snouted Crocodile Nile Crocodile

African Dwarf Crocodile

African Slender-snouted Crocodile Nile Crocodile

African Dwarf Crocodile

African Slender-snouted Crocodile Nile Crocodile

African Dwarf Crocodile

African Slender-snouted Crocodile Nile Crocodile (?)

African Dwarf Crocodile

African Slender-snouted Crocodile (?) Nile Crocodile (?)

African Dwarf Crocodile (?)

African Slender-snouted Crocodile Nile Crocodile

African Dwarf Crocodile

Green Turtle

Nile Crocodile

Hawksbill Turtle

Pancake Tortoise

African Slender-snouted Crocodile Nile Crocodile 
MADAGASCAR

Caretta caretta

Chelonia mydas

Crocodylus niloticus

Eretmochelys imbricata

Erymnochelys madagascariensis

Geochelone radiata

Geochelone yniphora

Lepidochelys olivacea

Pyxis arachnoides

Pyxis planicauda

MALAWI

Crocodylus niloticus

Crocodylus cataphractus

Crocodylus niloticus

MALI

Crocodylus cataphractus

Crocodylus niloticus

\section{MAURITANIA}

Crocodylus cataphractus

MOZAMBIQUE

Caretta caretta

Chelonia mydas

Crocodylus niloticus

Dermochelys coriacea

Eretmochelys imbricata

Lepidochelys olivacea

NAMIBIA

Crocodylus niloticus

Nile Crocodile

NIGER

Crocodylus niloticus

NIGERIA

Crocodylus cataphractus

Crocodylus niloticus

Osteolaemus tetraspis
Loggerhead Turtle

Green Turtle

Nile Crocodile

Hawksbill Turtle

Madagascar Sideneck Turtle

Radiated Tortoise

Angonoka

Olive Ridley

Madagascar Spider Tortoise

Madagascar Flat-tailed Tortoise

Nile Crocodile

African Slender-snouted Crocodile

Nile Crocodile

African Slender-snouted Crocodile Nile Crocodile

African Slender-snouted Crocodile

Loggerhead Turtle

Green Turtle

Nile Crocodile

Leatherback

Hawksbill Turtle

Olive Ridley

Nile Crocodile

African Slender-snouted Crocodile Nile Crocodile

African Dwarf Crocodile

REUNION AND DEPENDENCIES (FRANCE)

Chelonia mydas

Eretmochelys imbricata
Green Turtle

Hawksbill Turtle 
RWANDA

Crocodylus niloticus

Nile Crocodile (?)

SENEGAL

Caretta caretta

Chelonia mydas

Crocodylus cataphractus

Crocodylus niloticus

Lepidochelys olivacea

Osteolaemus tetraspis

Loggerhead Turtle

Green Turtle

African Slender-snouted Crocodile

Nile Crocodile

Olive Ridley

African Dwarf Crocodile

\section{SEYCHELLES}

Chelonia mydas

Eretmochelys imbricata

Green Turtle

Hawksbill Turtle

SIERRA LEONE

Crocodylus cataphractus

Crocodylus niloticus

Osteolaemus tetraspis

African Slender-snouted Crocodile Nile Crocodile

African Dwarf Crocodile

SOMALIA

Chelonia mydas

Crocodylus niloticus

Green Turtle

Nile Crocodile (?)

SOUTH AFRICA

Caretta caretta

Dermochelys coriacea

Crocodylus niloticus

Dermochelys coriacea

psammobates geometricus

Loggerhead Turtle

Leatherback

Nile Crocodile

Leatherback

Geometric Tortoise

SUDAN

Crocodylus niloticus

Eretmochelys imbricata

Nile Crocodile

Hawksbill Turtle

SWAZILAND

Crocodylus niloticus

Nile Crocodile

TANZANIA

Chelonia mydas

Crocodylus cataphractus

Crocodylus niloticus

Eretmochelys imbricata

Lepidochelys olivacea

Malacochersus tornieri

Green Turtle

African Slender-snouted Crocodile

Nile Crocodile

Hawksbill Turtle

Olive Ridley

Pancake Tortoise 
Crocodylus cataphractus

Crocodylus niloticus

Osteolaemus tetraspis

UGANDA

Crocodylus niloticus

Osteolaemus tetraspis

\section{UPPER VOLTA}

Crocodylus cataphractus

Crocodylus niloticus

Osteolaemus tetraspis

\section{ZAIRE}

Crocodylus cataphractus

Crocodylus niloticus

Osteolaemus tetraspis

ZAMBIA

Crocodylus cataphractus Crocodylus niloticus

ZIMBABWE

Crocodylus niloticus
African Slender-snouted Crocodile Nile Crocodile

African Dwarf Crocodile

Nile Crocodile

African Dwarf Crocodile (?)

African Slender-snouted Crocodile Nile Crocodile

African Dwarf Crocodile

African Slender-snouted Crocodile Nile Crocodile

African Dwarf Crocodile

African Slender-snouted Crocodile Nile Crocodile

Nile Crocodile
U.S.A.

Caretta caretta

Chelonia mydas

Clemmys muhlenbergii

Crocodylus acutus

Dermochelys coriacea

Eretmochelys imbricata

Gopherus agassizii

Gopherus berlandieri

Gopherus polyphemus

Kinosternon flavescens spooneri

Lepidochelys kempii

Pseudemys alabamensis

Pseudemys rubriventris bangsi

Sternotherus minor depressus
Loggerhead Turtle Green Turtle

Bog Turtle

American Crocodile

Leatherback

Hawksbill Turtle

Desert Tortoise

Berlandier's Tortoise

Gopher Tortoise

Illinois Mud Turtle

Kemp's Ridley

Alabama Red-bellied Turtle

Plymouth Red-bellied Turtle

Flattened Musk Turtle 


\section{ARGENTINA}

Caiman crocodilus yacare

Caiman latirostris

Geochelone chilensis

Platemys pallidipectoris

Platemys spixii

BAHAMA ISLANDS

Caretta caretta

Chelonia mydas

Eretmochelys imbricata

Pseudemys felis

Pseudemys malonei

\section{BELIZE}

Caretta caretta

Crocodylus acutus

Crocodylus moreletii

Dermatemys mawii

Eretmochelys imbricata

Rhinoclemmys areolata

BOLIVIA

Caiman crocodilus yacare

Caiman latirostris

Geochelone chilensis

Melanosuchus niger

Platemys pallidipectoris

Podocnemis expansa

Podocnemis unifilis

BRAZIL

Caiman crocodilus crocodilus

Caiman crocodilus yacare

Caiman latirostris

Chelonia mydas

Geochelone carbonaria

Lepidochelys olivacea

Melanosuchus niger

Phrynops hogei

Phrynops $\overline{\text { rufipes }}$

Platemys spixii

Podocnemis ery throcephala

Podocnemis expansa

Podocnemis sextuberculata

Podocnemis unifilis
Yacare

Broad-nosed Caiman

Chaco Tortoise

Chaco Sideneck Turtle

Spix's Sideneck Turtle

Loggerhead Turtle

Green Turtle

Hawksbill Turtle

Cat Island Turtle

Inagua Island Turtle

Loggerhead Turtle

American Crocodile

Morelet's Crocodile

Central American River Turtle

Hawksbill Turtle

Furrowed Wood Turtle

Yacare

Broad-nosed Caiman

Chaco Tortoise (?)

Black Caiman

Chaco Sideneck Turtle

South American River Turtle

Yellow-spotted Sideneck Turtle

Spectacled Caiman

Yacare

Broad-nosed Caiman

Green Turtle

Red-foot Tortoise

Olive Ridley

Black Caiman

Hoge's Sideneck Turtle

Red-headed Sideneck Turtle

Spix's Sideneck Turtle

Red-headed Amazon Sideneck Turtle

South American River Turtle

Pitiu

Yellow-spotted Sideneck Turtle 
Eretmochelys imbricata

CAYMAN ISLANDS

Chelonia mydas

\section{COLOMBIA}

Caiman crocodilus apaporiensis

Caiman crocodilus crocodilus

Caiman crocodilus fuscus

Caretta caretta

Chelonia mydas

Crocodylus acutus

Crocodylus intermedius

Dermochelys coriacea

Eretmochelys imbricata

Geochelone carbonaria

Kinosternon dunni

Melanosuchus niger

Phrynops dahli

Phrynops rufipes

Podocnemis expansa

Podocnemis lewyana

Podocnemis sextuberculata

Podocnemis unifilis

Pseudemys scripta callirostris

COSTA RICA

Caiman crocodilus fuscus

Chelonia mydas

Crocodylus acutus

Dermochelys coriacea

Eretmochelys imbricata

Kinosternon angustipons

Lepidochelys olivacea

CUBA

Caretta caretta

Crocodylus acutus

Crocodylus rhombifer

DOMINICAN REPUBLIC

Chelonia mydas

Crocodylus acutus

Dermochelys coriacea

Eretmochelys mbricata

ECUADOR

Caiman crocodilus crocodilus Caiman crocodilus fuscus
Hawksbill Turtle

Green Turtle

Rio Apaporis Caiman

Spectacled Caiman

Brown Caiman

Loggerhead Turtle

Green Turtle

American Crocodile

Orinoco Crocodile

Leatherback

Hawksbill Turtle

Red-foot Tortoise

Dunn's Mud Turtle

Black Caiman

Dahl's Toad-headed Turtle

Red-headed Sideneck Turtle

South American River Turtle

Magdalena River Turtle

Pitiu

Yellow-spotted Sideneck Turtle

South American Red-lined Turtle

Brown Caiman

Green Turtle

American Crocodile

Leatherback

Hawksbill Turtle

Narrow-bridged Mud Turtle

Olive Ridley

Loggerhead Turtle

American Crocodile

Cuban Crocodile

Green Turtle

American Crocodile

Leatherback

Hawksbill Turtle

Spectacled Caiman

Brown Caiman 
Chelonia mydas

Crocodylus acutus

Eretmochelys imbricata

Geochelone carbonaria

Melanosuchus niger

Podocnemis expansa

Podocnemis unifilis

\section{EL SALVADOR}

Caiman crocodilus fuscus

Chelonia mydas

Crocodylus acutus

Eretmochelys imbricata

Lepidochelys olivacea

\section{FRENCH GUIANA}

Caiman crocodilus crocodilus

Dermochelys coriacea

Geochelone carbonaria

Lepidochelys olivacea

Melanosuchus niger

Podocnemis expansa

Podocnemis unifilis

\section{GALAPAGOS ISLANDS (ECUADOR)}

Chelonia mydas

Eretmochelys imbricata

Geochelone elephantopus

\section{GUATEMALA}

Caiman crocodilus fuscus

Caretta caretta

Chelonia mydas

Crocodylus acutus

Crocodylus moreletii

Dermatemys mawii

Eretmochelys imbricata

Lepidochelys olivacea

Rhinoclemmys areolata

\section{GUYANA}

Caiman crocodilus crocodilus

Chelonia mydas

Dermochelys coriacea

Eretmochelys imbricata

Geochelone carbonaria

Lepidochelys olivacea

Melanosuchus niger

Podocnemis expansa

Podocnemis unifilis
Green Turtle

American Crocodile

Hawksbill Turtle

Red-foot Tortoise (?)

Black Caiman

South American River Turtle (?)

Yellow-spotted Sideneck Turtle

Brown Caiman

Green Turtle

American Crocodile

Hawksbill Turtle

Olive Ridley

Spectacled Caiman

Leatherback

Red-foot Tortoise

Olive Ridley

Black Caiman

South American River Turtle (?)

Yellow-spotted Sideneck Turtle

Green Turtle

Hawksbill Turtle

Galapagos Giant Tortoise

Brown Caiman

Loggerhead Turtle

Green Turtle

American Crocodile.

Morelet's Crocodile

Central American River Turtle

Hawksbill Turtle

Olive Ridley

Furrowed Wood Turtle

Spectacled Caiman

Green Turtle

Leatherback

Hawksbill Turtle

Red-foot Tortoise

Olive Ridley

Black Caiman

South American River Turtle

Yellow-spotted Sideneck Turtle 
Chelonia mydas

Crocodylus acutus

Eretmochelys imbricata

\section{HONDURAS}

Caiman crocodilus fuscus

Caretta caretta

Chelonia mydas

Crocodylus acutus

Crocodylus moreletii

Dermatemys mawii

Eretmochelys imbricata

Lepidochelys olivacea

Rhinoclemmys areolata

JAMAICA

Caretta caretta

Chelonia mydas

Crocodylus acutus

Eretmochelys imbricata

\section{'LESSER ANTILLES'}

Chelonia mydas

Eretmochelys imbricata

Geochelone carbonaria

\section{MEXICO}

Caiman crocodilus fuscus

Caretta caretta

Chelonia mydas

Crocodylus acutus

Crocodylus moreletii

Dermochelys coriacea

Dermatemys mawii

Eretmochelys imbricata

Gopherus agassizii

Gopherus berlandieri

Gopherus flavomarginatus

Kinosternon creaseri

Lepidochelys kempii

Lepidochelys olivacea

Rhinoclemmys areolata

Rhinoclemmys rubida

Terrapene coahuila

NICARAGUA

Caiman crocodilus fuscus

Caretta caretta

Chelonia mydas

Crocodylus acutus
Green Turtle

American Crocodile

Hawksbill Turtle

Brown Caiman

Loggerhead Turtle

Green Turtle

American Crocodile

Morelet's Crocodile (?)

Central American River Turtle (?)

Hawksbill Turtle

Olive Ridley

Furrowed Wood Turtle

Loggerhead Turtle

Green Turtle

American Crocodile

Hawksbill Turtle

Green Turtle

Hawksbill Turtle

Red-foot Tortoise

Brown Caiman

Loggerhead Turtle

Green Turtle

American Crocodile

Morelet's Crocodile

Leatherback

Central American River Turtle

Hawksbill Turtle

Desert Tortoise

Berlandier's Tortoise

Bolson Tortoise

Creaser's Mud Turtle

Kemp's Ridley

Olive Ridley

Furrowed Wood Turtle

Mexican Spotted Wood Turtle

Aquatic Box Turtle

\section{Brown Caiman}

Loggerhead Turtle

Green Turtle

American Crocodile 
Eretmochelys imbricata

Kinosternon angustipons

Lepidochelys olivacea

PANAMA

Caiman crocodilus fuscus

Caretta caretta

Chelonia mydas

Crocodylus acutus

Dermochelys coriacea

Eretmochelys imbricata

Geochelone carbonaria

Kinosternon angustipons

Lepidochelys olivacea

\section{PARAGUAY}

Caiman crocodilus yacare

Caiman latirostris

Geochelone carbonaria

Geochelone chilensis

Melanosuchus niger

Platemys pallidipectoris

\section{PERU}

Caiman crocodilus crocodilus

Chelonia mydas

Crocodylus acutus

Eretmochelys imbricata

Melanosuchus niger

Podocnemis expansa

Podocnemis sextuberculata

Podocnemis unifilis

\section{PUERTO RICO}

Dermochelys coriacea

Eretmochelys imbricata

\section{SURINAM}

Caiman crocodilus crocodilus

Chelonia mydas

Dermochelys coriacea

Eretmochelys imbricata

Geochelone carbonaria

Lepidochelys olivacea

Podocnemis expansa

Podocnemis unifilis

\section{TRINIDAD AND TOBAGO}

Caiman crocodilus crocodilus Dermochelys coriacea Eretmochelys imbricata
Hawksbill Turtle

Narrow-bridged Mud Turtle Olive Ridley

\section{Brown Caiman}

Loggerhead Turtle

Green Turtle

American Crocodile

Leatherback

Hawksbill Turtle

Red-foot Tortoise

Narrow-bridged Mud Turtle

Olive Ridley

\author{
Yacare \\ Broad-nosed Caiman \\ Red-foot Tortoise \\ Chaco Tortoise \\ Black Caiman \\ Chaco Sideneck Turtle
}

Spectacled Caiman
Green Turtle
American Crocodile
Hawksbill Turtle
Black Caiman
South American River Turtle
Pitiu
Yellow-spotted Sideneck Turtle

Leatherback

Hawksbill Turtle

Spectacled Caiman

Green Turtle

Leatherback

Hawksbill Turtle

Red-foot Tortoise

Olive Ridley

South American River Turtle (?)

Yellow-spotted Sideneck Turtle
Spectacled Caiman

Leatherback

Hawksbill Turtle 
Geochelone carbonaria

Lepidochelys olivacea

URUGUAY

Caiman latirostris

Platemys spixii

VENEZUELA

Caiman crocodilus crocodilus

Caiman crocodilus fuscus

Chelonia mydas

Crocodylus acutus

Crocodylus intermedius

Eretmochelys imbricata

Geochelone carbonaria

Podocnemis erythrocephala

Podocnemis expansa

Podocnemis unifilis

Pseudemys scripta callirostris

VIRGIN ISLANDS (U.S.)

Dermochelys coriacea

Eretmochelys imbricata
Red-foot Tortoise

Olive Ridley

Broad-nosed Caiman

Spix's Sideneck Turtle

Spectacled Caiman

Brown Caiman

Green Turtle

American Crocodile

Orinoco Crocodile

Hawksbill Turtle

Red-foot Tortoise

Red-headed Amazon Sideneck Turtle

South American River Turtle

Yellow-spotted Sideneck Turtle

South American Red-lined Turtle

Leatherback

Hawksbill Turtle

OCEANS AND OCEANIC ISLANDS

INDIAN OCEAN

ANDAMAN AND NICOBAR ISLANDS (INDIA)

Crocodylus porosus

Estuarine Crocodile

PACIFIC OCEAN

CAROLINE ISLANDS (U.S. TRUST TERR.)

Crocodylus porosus

Estuarine Crocodile

SOLOMON ISLANDS

Crocodylus porosus

Estuarine Crocodile

VANUATU

Crocodylus porosus

Estuarine Crocodile

Note It has been considered impractical to list here every island political unit in which breeding populations of sea turtles occur, or around which feeding or migrating populations regularly occur. Five of the species treated here are present in each of the major oceans (Green Turtle, Hawksbill, Leatherback, Loggerhead, Olive Ridley); the sixth, (Kemp's Ridley) breeds only in Mexico. See individual data accounts for further details. 

Chelonia depressa Garman 1880

Order TESTUDINES

Family CHELONIIDAE

Endemic to the Australian continental shelf; widespread and abundant in Queensland and Northern Territory, also occurs commonly in Western Australia. In Queensland low density nesting occurs throughout the coastal zones of the Gulf of Carpentaria, western Torres Strait, and central to south Queensland. There is a major rookery in the area of Wild Duck and Avoid Islands, while the most important site is Crab Island, with many thousands of Flatbacks nesting annually (almost all year-round). In Northern Territory, low density nesting is known throughout; Greenhill Island is a major rookery. Nests in Western Australia; few of the suspected nest sites are confirmed.

All sea turtle species are protected in Queensland and Western Australia, with the exception that indigenous peoples in these states can take turtles for subsistence purposes. However, $C$. depressa is not a favoured species, the flesh of the related Green Turtle C. mydas is much preferred. All sea turtles are protected in Australian territorial waters. Although a high incidental catch is reported, in prawn trawls and set nets, this does not (1979) appear to cause significant mortality. Present conservation measures must be maintained and both magnitude of incidental catch and the size of subsistence and illegal harvest of adults require monitoring.

Although this species was listed as 'Rare' in the previous edition of the Red Data Book, it is considered that on present information the Flatback does not fulfil the criteria for inclusion in any of the Red Data Book categories for threatened species.

a. Burbidge, A.A. (1981). In litt., 5 February.

b. Kowarsky, J. (in press, 1982). Subsistence hunting of sea turtles in Australia. In Bjorndal, K. (Ed.), The Biology and Conservation of Sea Turtles, Smithsonian Institute Press, Washington, D.C.

C. Limpus, C.J. (in press, 1982). The status of Australian sea turtle populations. In Bjorndal, K. (Ed.), The Biology and Conservation of Sea Turtles, Smithsonian Institute Press, Washington, D.C.

DWARF CAIMAN

or CUVIER'S SMOOTH-FRONTED CAIMAN

Paleosuchus palpebrosus (Cuvier 1807)
Formerly listed

'VULNERABLE'

Order CROCODYLIA

Family ALLIGATORIDAE

Widespread throughout tropical South America in the Orinoco and Amazon basins; 
extends from Venezuela and the Guianas south to Sao Paulo and the upper Rio Paraguay in southern Brazil, west to the Rio Pastaza in Ecuador. Occurs singly or in pairs, typically in clear clean fast-moving streams in forest regions, often associated with waterfalls and rapids. May prefer relatively cool water. Males reach $1.5 \mathrm{~m}$, females $1.2 \mathrm{~m}$. Feeds on a variety of vertebrates and invertebrates. Eighteen-25 eggs laid in mound nest, possibly breeds throughout year. Protected in Surinam, listed on CITES Appendix II. Has bred in captivity.

No population data available. The ventral skin is highly armoured, with broadly overlapping osteoderms, so preparation of fine tanned hides is impossible with present technology. Thus over-exploitation for hides, the single factior that has led to severe depletion of crocodilians worldwide, has not affected this species. Eggs and animals are eaten by local people, juveniles are sometimes sold to tourists as stuffed curios.

Although listed as 'Vulnerable' in the previous edition of the Amphibia-Reptilia Red Data Book, there appears to be no evidence that this species fulfils the criteria for inclusion in any of the Red Data Book categories for threatened species. However, population status and commercial exploitation levels should be monitored.

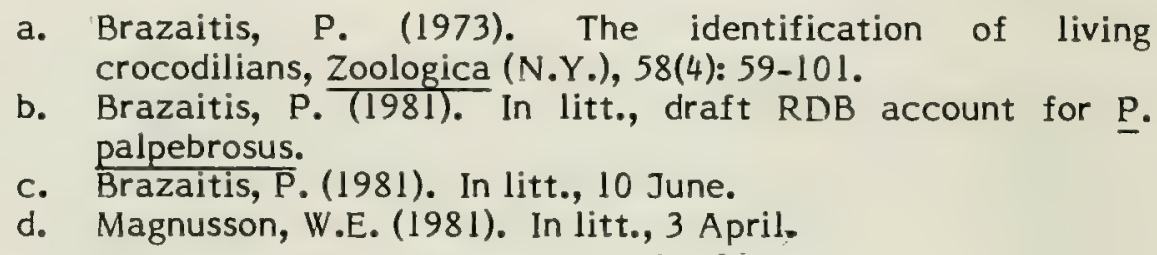

\section{SCHNEIDER'S SMOOTH-FRONTED CAIMAN Formerly listed}

'VULNERABLE'

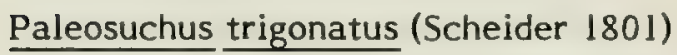

\section{Order CROCODYLIA Family ALLIGATORIDAE}

Widespread throughout tropical South America in the Orinoco and Amazon basins; extends from Venezuela and the Guianas south to Bahia in southern Brazil. Occurs singly or in pairs, typically in clear clean forest streams, often associated with waterfalls and rapids. Appears to prefer slightly quieter and less cool water than P. palpebrosus. To $1-1.3 \mathrm{~m}$, occasionally to over $2 \mathrm{~m}$. Feeds on a variety of small vertebrates and invertebrates. Around 17 eggs are laid in a mound nest. Protected in Surinam, listed on CITES Appendix II. Has bred in captivity.

No population data available. The ventral skin is highly armoured, with broadly overlapping osteoderms, so preparation of fine tanned hides is impossible with present technology. Thus over-exploitation for hides, the single factor that has led to severe depletion of crocodilians worldwide, has not affected this species. Eggs and animals are eaten by local people, juveniles are sometimes sold to tourists as stuffed curios. Adept at avoiding hunters.

Although listed as 'Vulnerable' in the previous edition of the Amphibia-Reptilia Red Data Book, there appears to be no evidence that this species fulfills the criteria for inclusion in any of the Red Data Book categories for threatened species. However, population status and commercial exploitation levels should be monitored. 
 a. Brazaitis, P. (1973). The identification of living
crocodilians, Zoologica (N.Y.), 58(4): 59-101.
b. Brazaitis, P. (1981). In litt., draft RDB account for $\underline{P}$. trigonatus.
c. Brazaitis, P. (1981). In litt., 10 June.
d. Magnusson, W.E. (1981). In litt., 3 April.

Alligator mississippiensis (Daudin 1802)

\section{Order CROCODYLIA}

Family ALLIGATORIDAE

Listed as 'Out of Danger' in previous edition of the Amphibia-Reptilia Red Data Book. Relatively widespread in various wetland habitats in southeast U.S.A., from coastal North Carolina westward through southern portions of South Carolina, Georgia and Alabama, through much of Mississippi, all of Louisiana (just into Arkansas and Oklahoma), eastern Texas, and extends throughout Florida. Present range similar to historical range. Optimum habitat includes large marsh-bordered lakes, freshwater and brackish coastal marshes, and savannas.

Severely depleted by the mid-twentieth century by hide-hunting, persecution and habitat loss. Strict state and Federal protective measures, including listing under the U.S. Endangered Species Act, have allowed a marked recovery, eg. from around 26,000 in Louisiana in 1957, to over 300,000 at present. Total population now around 800,000 . Louisana population recently reclassified under the Endangered Species Act as Threatened by Similarity of Appearance, permitting statewide regulated commercial harvest. Transferred from CITES A.ppendix I to II in 1979. Commerce in Alligator products is subject to strict regulation; effects on international trade in other crocodilian products must be closely monitored.

a. Bender, M. (1981). Service recognizes the recovery of Alligator in Louisiana. Endangered Species Technical Bulletin, 6(9):7.

b. Honegger, R. (1979). Red Data Book, Vol.3, Amphibia-Reptilia. IUCN, Gland, Switzerland. (Revised data sheet on American Alligator).

c. Fogarty, M.J. (1979). American Alligator account, pp.63-67 in McDairmid, R.W. (Ed.), Rare and Endangered Biota of Florida, Vol.3., Amphibians and Reptiles. University Presses of Florida. 

Kinosternon angustipons Legler 1965

Order TESTUDINES

SUMMARY An apparently extremely rare species, known from eight localities in Central America. Basic ecological data and population status information are needed. No conservation measures taken.

DISTRIBUTION Only known from eight localities on the Caribbean versant of Central America, in southwestern Nicaragua, Costa Rica, and northwestern Panama (1).

POPULATION No data. Apparently extremely rare. About 19 museum specimens are known.

HABITAT AND ECOLOGY Inhabits shallow swamps, slow streams and lagoons. An omnivorous feeder $(2,3)$. In captivity it prefers meat and fish (3). One to four eggs are laid per clutch (3), more than one clutch may be produced annually (5).

THREATS TO SURVIVAL No information.

CONSERVATION MEASURES TAKEN None.

CONSERVATION MEASURES PROPOSED The IUCN/SSC Freshwater Chelonian Specialist Group has listed a study of the distribution and population status of this species as a priority project.

CAPTIVE BREEDING None. Three specimens may exist in captivity (4).

REMARKS This account was prepared by J.B. Iverson (member, IUCN/SSC Freshwater Chelonian Specialist Group), with minor additions.

REFERENCES I. Iverson, J. (1980). Kinosternon angustipons. Cat. Amer. Amphib. Rept. 262:1-2.

2. Legler, J.M. (1965). A new species of turtle, genus Kinosternon, from Central America. Univ. Kansas Publ. Mus. Natur. Hist. 15(13):615-625.

3. Legler, J.M. (1966). Notes on the natural history of a rare Central American turtle, Kinosternon angustipons Legler. Herpetologica 22(2):118-122.

4. Rhodin, A.G.J. and R.A. Mittermeier. (1974). Pajakt efter Kinosternon angustipons, Centralamerikas sallsyntaste skoldpappa. Snoken-Nat. Swed. Herpetol. Assoc. 4(5):6-8.

5. Pritchard, P.C.H. (1979). Encyclopedia of Turtles. T.F.H. Publications, Hong Kong and New Jersey. 

Kinosternon creaseri Hartweg 1934

Order TESTUDINES

SUMMARY An apparently rare species confined to sinkhole pools and temporary ponds in relatively arid parts of the Yucatan Peninsula, Mexico. Known from only about 50 specimens and 17 localities. Basic ecological data and population status information are needed. No conservation measures taken.

DISTRIBUTION Known only from the Yucatan Peninsula of Mexico $(1,5)$ with localities in the states of Yucatan, Quintana Roo and Campeche (4).

POPULATION No data, appears to be rare.

HABITAT AND ECOLOGY Inhabits cenotes (pools in limestone sinkholes) and temporary ponds (1) scattered over relatively arid northern parts of the peninsula (4). Apparently estivates for much of the year and is active only during the rainy season (c June - October) (3).

THREATS TO SURVIVAL NO information.

CONSERVATION MEASURES TAKEN None.

CONSERVATION MEASURES PROPOSED The IUCN/SSC Freshwater Chelonian Specialist Group has listed a study of the distribution and population status of this species as a priority project.

CAPTIVE BREEDING None.

REMARKS This account was prepared by J.B. Iverson (member, IUCN/SSC Freshwater Chelonian Specialist Group), with minor additions.

REFERENCES 1. Hartweg, N. (1934). A new Mud Turtle from Chichen Itza, Yucatan. Occ. Pap. Mus. Zool. Univ. Mich. No. 277: 1.

2. Iverson, J. (in press 1982). Kinosternon creaseri. Cat. Amer. Amphib. Rept.

3. Iverson, J. (unpublished).

4. Pritchard, P.C.H. (1979). Encyclopedia of Turtles. T.F.H. Publications, Hong Kong and New Jersey.

5. Smith, H.M. and R. Smith. (1980). Synopsis of the Herpetofauna of Mexico. Vol. VI. Guide to Mexican turtles. Bibliographic Addendum III. John Johnson, North Bennington, Vermont. $1044 \mathrm{p}$. 

Kinosternon dunni Schmidt 1947

Order TESTUDINES

Family KINOSTERNIDAE

SUMMARY An apparently extremely rare species from a very limited geographic range along the Pacific Coast of Colombia. It is known definitely from only 6 localities. Basic ecological data and population status information are needed. No conservation measures taken.

DISTRIBUTION Only known from the Rio Baudo, Rio Decampado and Rio San Juan drainages in the Departamento del Choco on the Pacific coast of Colombia $(1,2,3,5)$.

POPULATION No data, apparently extremely rare. Only 5 museum specimens are known in collections outside Columbia.

HABITAT AND ECOLOGY A small species, but perhaps the largest in the genus (4); adult males reach at least $17.5 \mathrm{~cm}$ in carapace length, females at least $15 \mathrm{~cm}$ (1). Apparently feeds primarily on molluscs $(2,3)$. One dissected female contained 2 eggs $(2,3)$. Such small clutches may be laid at intervals throughout the year (4). The eggs, about 1.8 inches $(4.6 \mathrm{~cm})$ long by 1 inch $(2.6 \mathrm{~cm})$ wide, are the largest known in the genus (4). Very few ecological data available, preferred microhabitat is unknown.

THREATS TO SURVIVAL No information.

CONSERVATION MEASURES TAKEN None.

CONSERVATION MEASURES PROPOSED The IUCN/SSC Freshwater Chelonian Specialist Group has listed a study of the distribution and population status of this species as a priority project.

\section{CAPTIVE BREEDING None.}

REMARKS This account was prepared by J.B. Iverson (member, IUCN/SSC Freshwater Chelonian Specialist Group), with minor additions.

REFERENCES 1. Iverson, J.B. (1981). Kinosternon dunni. Cat. Amer. Amphib. Rept. 278:1-2.

2. $\overline{\text { Medem, }} \bar{F}$. (1961). Contribuciones al conocimiento sobre la morfologia, ecologia, y distribucion geografica de la tortuga Kinosternon dunni K.P. Schmidt. Novedades Colombianas 1(6):446-476.

3. Medem, F. (1962). La distribucion geographica y ecologia de los Crocodylia y Testudinata en el Departamento del Choco. Rev. Acad. Colombiana Cienc. Exactos. Fis. Natur. Bogota. II(44):279-303.

4. Pritchard, P.C.H. (1979). Encyclopedia of Turtles. T.F.H. Publication, Hong Kong and New Jersey.

5. Schmidt, K.P. (1947). A new kinosternid turtle from Colombia. Fieldiana: Zool. 31(13):109-112. 

SUMMARY A melanistic, highly fossorial subspecies of the Yellow Mud Turtle, occurring in and near temporary, semipermanent and permanent lentic freshwater habitats in sand areas of the midwestern United States. Secretive habits inhibit reliable population estimates, but extensive human-induced habitat destruction and alteration has restricted the turtle to only thirteen known populations, all isolated and limited or miniscule in geographic extent, and all but two with very small population size. The states of Illinois, Iowa, and Missouri have placed this turtle on their endangered species lists, and the largest known population (in lowa) is currently protected by local industrial interests on a designated preserve. The zoogeographic history, nesting behaviour, and fossorial ecology of $\underline{K}$. $\underline{f}$. spooneri are unique among turtles in numerous respects.

DISTRIBUTION The subspecies, as traditionally recognized $(11,23)$, is known from a number of isolated populations in the central, midwestern United States (central and northern Illinois, extreme southeastern Iowa, and extreme northeastern Missouri) (2). The distribution is considered to reflect the development of the 'prairie peninsula' in a xerothermic period of North America between 7000 and 4500 years before present (24). Many aridity-adapted southwestern species including $K$. flavescens were able to move northward and eastward and become established in midwestern North America. Subsequent development of more mesic conditions here restricted $K$. flavescens to isolated areas, mainly in sand areas near major rivers, that resemble in many respects the arid southwestern conditions to which they are adapted.

POPULATION Thirteen extant populations are currently known (2). Eight very small, scattered populations are known from Illinois. All are represented by fewer than twenty counted individuals and most are associated with lentic (standing water) habitat less than .5 ha in diameter surrounded by farm land $(2,19)$. One moderately large population (est. 124-153 individuals) and one small population (estimated 13) are known to exist in Missouri. The former population is scattered in suitable habitat within a four square mile portion of a creek drainage, while the latter exists in a nearby six hectare slough $(2,12)$. One very large population (est. 800-1232 individuals), and two 'populations' represented by one individual each are known from Iowa. The large population is restricted to the vicinity of lentic water sources within an approximately 1050 ha sand area. The other two specimens came from small pond and marshy areas near the Mississippi River, further to the south $(2,6)$. Estimates of population sizes by the mark-recapture techniques utilized must be considered tentative since the alternation of habitats, between aquatic, terrestrial and subterranean sites, strains the restrictive conditions necessary for their valid application $(3,12,22)$. Although no estimate of past population sizes are available, habitats known to contain Illinois Mud Turtles earlier in the century $(3,5,26)$ have been greatly altered or eliminated entirely with consequent elimination of populations $(3,15,17)$.

HABITAT AND ECOLOGY A small turtle associated typically with lentic water sources in areas with sandy substrates. Ideal habitat would include: 1) sand substrate; 2) sand prairie, scrub oak forest or sand prairie-scrub oak savannah 
vegetation; 3) a topography that is relatively flat or with minor relief due to the presence of dunes; 4) a temporary, semipermanent, or permanent lentic water source such as an ephemeral sand prairie pond, marsh, or flood plain slough; and 5) absence of environmental destruction or modification due to human activity (3). Other characteristic animals of the central Illinois sand prairie are the Illinois Chorus Frog Pseudacris streckeri illinoensis, the Six-lined Racerunner Cnemidophorus sexlineatus and the Western Hognose Snake Heterodon nasicus (3). Like $\underline{K} . \underline{f}$. spooneri, both $\underline{P}$. streckeri and $\underline{H}$. nasicus have the main portion of their ranges in the western U.S. and occur as relict populations in sandy areas of the central midwest (3). Some flexibility in habitat requirements is noted in that this turtle has been taken in non-sandy areas of Iowa (19), from a beach dune vegetation association near the shore of Lake Michigan (3), and that many of the extant populations, including the largest, exist in agriculturally and/or industrially modified areas $(2,3,19)$.

This turtle is highly fossorial, and may, in some years, spend up to nine months (mid-summer to early spring) burrowed underground in the vicinity of the population's water source $(8,27)$. Remarkable aspects of the still poorly known terrestrial-fossorial activity period include nest construction by digging with the forefeet (8), egg laying while enclosed within the covered nest burrow (8), building of false nests (8), and laboratory evidence of willingness to feed in a subterranean setting (16). Burrows are relatively shallow $(5-15 \mathrm{~cm}$ deep) and there is no evidence of horizontal tunnelling $(15,20,27)$. Onset of the terrestrial-subterranean period is associated with increasing temperature and/or evaporation of the water source. The above-ground largely aquatic period extends from early spring to mid-summer and some autumn aquatic activity is recorded (26). Copulation and most feeding evidently occur during the aquatic period. Drowned terrestrial insects, aquatic insect adults and larvae, fairy shrimps, snails, carrion, detritus and vegetation are eaten $(8,15,27)$.

Nesting extends from mid June to early July in Iowa. From one to seven hard-shelled, elliptical eggs are laid $(8,27)$. Two captive Illinois specimens laid three and four eggs respectively (25). One egg clutch is probably laid per year by K. f. spooneri $(7,27)$. Young hatch in September in Iowa $(8,27)$ and are secretive, their ecology is poorly known. Overwintering in the nest is likely (27).

Dark coloration, a $\underline{K}$. f. spooneri characteristic, may serve as camouflage since the bottoms of many ponds in which they occur are often covered with dark silt and dark leaves from surrounding oak trees, and the water is often stained darkly by tannic acid from this source $(15,18)$.

Predation on eggs by raccoons and skunks may be heavy $(8,27)$, and juveniles and adults are probably also killed by these and other predators, despite their ability to secrete a nauseating musk. Winter kills and road kills are additional known sources of mortality $(3,21,27)$.

THREATS TO SURVIVAL The most important overall threat to the existence of this turtle is the continued elimination of suitable aquatic habitats through alteration and drainage related to human development within its range. Remaining flood plain sloughs and lakes of the Illinois River which contained populations earlier in this century (5) now contain few or none $(3,15,17)$. These habitats have changed greatly in character due to channelization, drainage, siltation, and organic pollution $(1,17)$. Many suitable small aquatic habitats are privately owned, and many of these (some known to have contained $\underline{K}$. $\underline{f}$. spooneri) have been drained $(19,26)$. These bodies of water are usually too small and ephemeral to provide any recreational value for the land owner, and it is economically practical to drain these areas for increased row crop acreage (19). 
Many sand area ponds shown on recently printed topographic maps no longer exist $(19,20)$, and due to the secretive habits of this turtle it is likely that the land owners would be unaware of its presence before drainage. Many extant populations are so small that any normal source of mortality (i.e., predation, road kill, disease, winter kill, etc.) could have drastic consequences for population survival. The two larger populations of Iowa and Missouri are vulnerable due to the concentration of large numbers of individuals in suitable habitats of very limited geographic extent. A local ecological disaster in these flood-prone, and heavily agriculturally and/or industrially developed areas, whether natural or human-induced, could have dire consequences for the existence of the subspecies as a whole.

CONSERVATION MEASURES TAKEN The Illinois Mud Turtle has been granted endangered status on the endangered species lists of Illinois, Missouri, and lowa, and intensive surveys and research efforts have been conducted by state conservation departments, university biologists, and private concerns to better evaluate its population status and ecological requirements $(2,3,6,12,19,27)$. In Iowa, the largest population known is located on a private wildlife reserve dedicated by local industry and managed by a consortium of biologists and naturalists collectively called the Louisa Ecological Advisory Committee (2). Habitat improvement and research on this population is being sponsored by local industry (2). Illinois is practising habitat management and improvement in three populations known to exist on state owned lands, and Missouri is attempting to acquire private lands containing populations $(2,20)$. In a controversial decision, the U.S. Fish and Wildlife Service withdrew its proposal to list $\underline{K}$. $\underline{f}$. spooneri on the federal endangered species list, citing lack of sufficient information to justify listing $(9,10)$.

CONSERVATION MEASURES PROPOSED It is of critical importance to continue preservation and management of existing Illinois Mud Turtle populations, to promote ideal habitat conditions as much as possible within its range (which is highly developed and heavily populated by man), and to search for unknown populations which may still exist. Since many of the known populations exist on private land, and more may be found there, it is critically important that landowners cooperate in the conservation of this turtle, and continued efforts to promote their awareness of its presence, vulnerability, and requirements for survival are necessary. Predator control, restriction of public access, and under extreme circumstances (i.e, irrevocable habitat destruction), relocation of populations may need to be considered in individual habitats. Continued research and population monitoring is necessary to fill the considerable gaps in our knowledge of the life history and ecology of this secretive animal, thereby enhancing our ability to preserve and manage it. Research must be carefully controlled, however, and that requiring justifiable specimen sacrifice or other disruptive aspects should be limited to the large populations.

CAPTIVE BREEDING Fragmentary information is available concerning captive breeding of the subspecies $\underline{K}$. $\underline{f}$. spooneri. Specimens are known to have laid eggs in captivity (25), and courtship and successful egg incubation in captivity have been documented $(14,27)$. The closely related Yellow Mud Turtle ( $\underline{K}$. $\underline{\text { f }}$. flavescens) is rather easily maintained in captivity, and courtship, mating, egg-laying and hatching of normal offspring accomplished (13,14). The problem of temperature-related sex ratio anomalies seen in offspring of other hatchery-raised turtles must first be considered and resolved for the $\underline{K}$. $\underline{f}$. spooneri subspecies before captive breeding programs can be realized (4). Captive breeding and rearing of $\underline{K}$. $\underline{f}$. spooneri is therefore probably possible, but potential strain on wild populations used as breeding stock, relatively low fecundity, the design and operation of hatchery breeding facilities, and transplantation 
strategies must all be carefully considered before implementation.

REMARKS Further reseach is needed to clarify the complex taxonomic relationships between the forms of the geographically widespread Kinosternon flavescens $(2,3,9,11,23)$. The Illinois Mud Turtle is distinctive in ecology and morphology. It is geographically separate from other forms of $\underline{K}$. flavescens and thus is reproductively isolated.

While the Illinois Mud Turtle has no intrinsic economic importance, its remarkable zoogeographic history, nesting behaviour, and fossorial ecology exemplify the species' great heuristic importance.

This account was very kindly provided by Don Moll (Southwest Missouri State Univ.).

REFERENCES 1. Bellrose, F.C., Sparks, R.E., Paveglio, F.L., Steffeck, D.W., Thomas, R.A., Weaver, R.C., and Moll, D. (1977). Fish and wildlife habitat changes resulting from the contruction of a nine-foot navigation channel in the Illinois Waterway from La Grange Lock and Dam upstream to Lockport Lock and Dam. Contract report for the U.S. Army Corps of Engineers, Chicago District. Illinois Natural History Survey River Research Laboratory, Havana, Illinois.

2. Bickham, J.W. and Gallaway, B.J. (1980). A status report on studies of the taxonomy of the Illinois mud turtle (Kinosternon flavescens spooneri) with supplementary notes on its distribution and ecology. Contract Report for Monsanto Agricultural Products Company, St. Louis, Mo. LGL Ecological Research Assoc. Inc. Bryan, Texas.

3. Brown, L.E., and Moll, D. (1979). The status of the nearly extinct Illinois mud turtle (Kinosternon flavescens spooneri Smith 1951) with recommendations for its conservation. Milwaukee Public Museum Special Publications in Biology and Geology, 3. Milwaukee, Wisconsisn. 49 pp.

4. Bull, J.J. and Vogt, R.C. (1979). Temperature-dependent sex determination in turtles. Science 206: $1186-1188$.

5. Cahn, A.R. (1937). The turtles of Illinois. Illinois Biol. Monogr. 35: 1-218.

6. Christiansen, J.L. (1979). Survey for Illinois mud turtles in lowa. Unpublished contract report for LGL Ecological Research Associates. Drake University, Des Moines, Iowa.

7. Christiansen, J.L. and Dunham, A.E. (1972). Reproduction of the yellow mud turtle (Kinosternon flavescens flavescens) in New Mexico. Herpetologica 28: 130-137.

8. Cooper. J. (1977). Vest-pocket turtle. Nat. Hist. 86(4): 53-57.

9. Endangered Species Technical Bulletin (1980). Illinois mud turtle proposal withdrawn. 5(9): 5.

10. Federal Register $8 / 14 / 80$.

11. Iverson, J.B. (1979). A taxonomic re-appraisal of the yellow mud turtle, Kinosternon flavescens (Testudines: Kinosternidae). Copeia 1979: 212-225.

12. Kangas, D.A. (1979). The Illinois mud turtle in Missouri. Unpublished contract report for LGL Ecological Research Associates. Northeast Missouri State University, Kirksville, Missouri.

13. Lardie, R.L. (1975). Courtship and mating behaviour in the 
yellow mud turtle, Kinosternon flavescens flavescens. J. of Herpetology 9(2): 223-227.

14. Lardie, R.L. (1977). Unpublished data.

15. Moll, D. (1977). Ecological investigations of turtles in a polluted ecosystem: the central Illinois River and adjacent flood plain lakes. Ph.D. dissertation, Illinois State University, Normal. xv + 179 pp.

16. Moll, D. (1979). Subterranean feeding by the Illinois mud turtle, Kinosternon flavescens spooneri. J. of Herpetology 13(3): $371-373$.

17. Moll, D. (1980). Dirty River Turtles. Nat. Hist. 89(5): 42-49.

18. Moll, D. and Brown, L.E. (1976). The mud turtle Kinosternon flavescens spooneri -- nearly extinct in Illinois. The Explorer 1(5): 6-7. Reprinted in the Bulletin of the Chicago Herpetological Society 12(3): 67-68, 1977.

19. Moll, E.O. (1979). Observations on the distribution and ecology of the Illinois mud turtle, Kinosternon flavescens spooneri Smith in Illinois. Unpublished contract report for LGL Ecological Research Associates. Eastern Illinois University, Charleston, Illinois.

20. Moll, E.O. Pers. comm., to D. Moll.

21. Murphy, J.C. and Corn, M.J. (1977). A turtle vanishes (letter to the editor). Nat. Hist. 86(7): 8.

22. Poole, R.W. (1974). An introduction to quantitative ecology. McGraw-Hill, Inc. New York xii + 532 pp.

23. Smith, P.W. (1951). A new frog and a new turtle from the western Illinois sand praries. Bulletin of the Chicago Academy of Sciences 9(10): 188-199.

24. Smith, P.W. (1957). An analysis of post-Wisconsin biogeography of the Prairie Peninsula region based on distributional phenomena among terrestrial vertebrate populations. Ecology 38(2): 205-218.

25. Smith, P.W. (1961). The amphibians and reptiles of Illinois. Illinois Natural History Survey Bulletin 28(1): 1-298.

26. Smith, P.W. Pers. comm., to D. Moll.

27. Springer, M.D. and Gallaway, B.J. (1980). A final report: the distribution and ecology of the Illinois mud turtle Kinosternon flavescens spooneri. A synthesis of historical and new research information with recommendations for conservation. Contract report to Monsanto Agricultural Products Company, St. Louis, Mo. LGL Ecological Research Associates, Inc., Bryan, Texas. 

Sternotherus minor depressus Tinkle and Webb 1955

Order TESTUDINES

SUMMARY A small, distinctive turtle inhabiting permanent streams and stream impoundments of the Black Warrior River system in Alabama, U.S.A. from Wm. B. Bankhead Lake upstream. Intergrades with S. m. peltifer in a portion of the Black Warrior River system below Bankhead Lake. Fairly common in Bankhead Lake and in Lewis Smith Lake and in at least two tributaries to the latter. Also common in two other tributaries in the western portion of the range and in at least one short stream segment in the eastern portion. Populations in most of the historic range are in seemingly poor condition or are believed to have been extirpated. Adverse factors appear to be siltation and pollution, especially from coal mining operations, and, in the case of at least one population, over-collecting. The turtles are carnivorous, with most relying heavily on molluscs. Two clutches averaging 3 eggs per clutch are laid each season. Protective measures are needed. At present, protection is essentially non-existent.

DISTRIBUTION Confined to permanent streams and impoundments of streams of the Black Warrior River system of northern Alabama, U.S.A., from Wm. B. Bankhead Lake upstream (5).

POPULATION Common and apparently healthy in the Mulberry Fork area of Bankhead Lake; in portions of Lost Creek (a tributary to the Lake from the northwest); in Blackwater Creek (a tributary of the river to the Mulberry Fork ); and in a relatively short stretch of the Blackburn Fork, in the eastern portion of the range. Populations occur in Lewis Smith Lake and in at least two of its tributaries, although densities appear to be relatively low. Scarce or absent in many other streams within the range, including a lengthy stretch of the Locust Fork, where diseased animals have been found at one site (5). At several localities checked recently, the numbers of young $S$. $m$. depressus found suggest that the level of recruitment is abnormally low (5).

HABITAT AND ECOLOGY A small $(11.9 \mathrm{~cm}$, max.) aquatic turtle inhabiting permanent creeks, relatively large rivers, and shallow areas of stream impoundments $(4,5)$. Habitat requirements include the presence of large submerged rocks or rock formations, under or amongst which the turtles spend periods of inactivity (5). Molluscs provide the dietary staple of adults of most populations, juveniles rely heavily on insects (6). Apparently less tolerant of degraded water conditions than many other aquatic turtles of the region (5). Females produce 2 clutches of oblong, hard-shelled eggs per season, averaging 3 eggs per clutch (3). Nesting begins in May and may extend to early July (3). Natural nests have not been investigated. Basking occurs rarely and, in the case of adults, may indicate a poor state of health of the individuals or their habitats (5). The diel period of maximum activity appears to be from about sundown to early morning (5).

THREATS TO SURVIVAL Considering the range overall, siltation is believed to pose the major threat (5). Other threats include municipal and industrial pollution and contamination of habitats resulting from mining operations (5). The watershed of the upper Black Warrior River contains most of the Birmingham area industrial-residential complex and virtually all of the area within the turtle's 
range is underlain by coal (1). Strip-mining in the area is extensive and within the counties in which $\mathrm{S}$. $\mathrm{m}$. depressus occurs, the land area disturbed by mining is predicted to be $350 \%$ greater in the year 2020 than in 1975 (1). Watershed degradation by agriculture and certain forestry practices are believed to contribute in varying degrees to the degraded quality of some streams within the range (5). The rarity of the turtle makes it valuable in commercial trade, and overcollecting is believed to be a serious threat to at least one population (3). This threat is expected to become more serious in the future and to involve other populations unless protective measures are taken (5).

CONSERVATION MEASURES TAKEN The turtle is included in the 'threatened' category of the Alabama list of 'threatened and endangered species' (2). The listing confers no legal protection, however. The small population inhabiting the upper reaches of the West Sipsey Fork, in the Sipsey Wilderness, is legally protected.

CONSERVATION MEASURES PROPOSED Sternotherus $m$. depressus has been proposed for inclusion on the U.S.F.W.S. List of Endangered and Threatened Wildlife, under the 1973 Endangered Species Act (5). The proposal is as follows: (i), the population in the Locust Fork from U.S. Hwy. I-65 downstream to Bankhead Lake should be considered 'endangered'. (ii), all other populations should be considered 'threatened' except for those in Lewis Smith Lake and Bankhead Lake, which should be unlisted. Collecting should, except under extenuating circumstances, be restricted to authorized scientific investigators. Any measures to improve the conditions of the streams within the turtle's range would obviously be beneficial.

\section{CAPTIVE BREEDING No information.}

REMARKS Research is badly needed to determine the factor or factors responsible for the apparently low rates of reproduction and/or survival of young in many populations, and for the generally poor condition of the populations in the major portions of the Locust Fork and Mulberry Fork.

The taxonomic status of $\underline{S}$. $m$. depressus remains problematic, with several authorities according it the ran' of species. The taxon is very distinctive, but populations at several sites show clear evidence of intergradation between $\underline{S}$. $\underline{m}$.

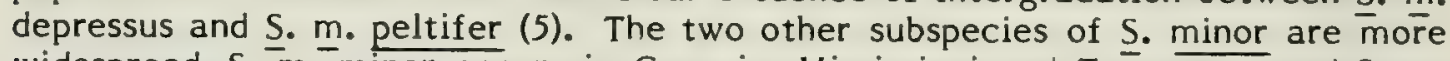
widespread; S. m. minor occurs in Georgia, Mississippi and Teñnessee, and $\underline{\mathrm{S}} . \underline{\mathrm{m}}$. peltifer in Alabāma, Florida and Georgia.

This account was kindly provided by R.H. Mount (Auburn Univ., AL).

REFERENCES 1. Anon. (1980). Black Warrior River Basin Cooperative Study and Appendix. U.S. Dept. Agr.

2. Boschung, H., (Ed.) (1976). Endangered and threatened plants and animals of Alabama. Al. Mus. Nat. Hist. Bull. No. 2, Univ. of AL., 93 pp.

3. Close, D. and Marion, K. (1981). Pers. comm.

4. Estridge, R. (1970). The taxonomic status of Sternothaerus depressus (Testudinata, Kinosternidae) with observations on its ecology. Unpub. M.S. thesis, Auburn Univ., Auburn, AL. 49 pp.

5. Mount, R.H. (1981). The status of the flattened musk turtle, Sternotherus minor depressus Tinkle and Webb. Unpub. report submitted to U.S. Fish and Wildlife Service. 120 pp.

6. Tinkle, D.W. (1958). The systematics and ecology of the 
Sternothaerus carinatus complex

Chelydridae). Tulane Stud. Zool. 6:1-56. 

Dermatemys mawii Gray 1847

Order TESTUDINES

SUMMARY A moderately large, highly aquatic species, occurring in freshwater rivers and permanent lakes in Central America from central Veracruz in Mexico southeast through Guatemala to Belize. Rather rare in parts of its restricted range, and apparently declining rapidly in some areas, notably parts of Mexico. Decline is due to over-exploitation of eggs and adults for food. Protected by a general fisheries law prohibiting taking of specimens less than $40 \mathrm{cms}$ in length, and by a poorly-enforced close season. Adequate protective legislation, an interim ban on fishing, and basic field research are required. The population status throughout the range requires clarification. Listed on CITES Appendix II.

DISTRIBUTION Restricted to coastal lowlands of the western Caribbean, from central Veracruz in Mexico southeast through northern Guatemala and Belize. Absent from the Yucatan Peninsula. May extend into Honduras (3).

POPULATION Rapidly declining over much of the main range in Mexico, no recent data from the southeast extremity of the range in Guatemala and Belize.

Mexico Exploitation for food appears to be rapidly depleting Dermatemys populations, and could lead to their extinction $(2,3)$. The species is now rare in Veracruz $(2,11)$ and Tabasco, the main markets for Dermatemys in Mexico (2). It was already considered rare by market vendors in Veracruz in 1970-1971 (6). The Tabascans, the major turtle consumers, now obtain supplies from the adjacent state of Chiapas, where turtles are not frequently eaten, and where some of the largest remaining populations are found (2). However, even here, it has already been exterminated from several localities (3). The 1980 report (3) of a study project on freshwater turtles in Chiapas comments that until recently individuals of $70 \mathrm{~cm}$ in length $(15-18 \mathrm{~kg})$ were caught frequently, present captures are now more often $40-50 \mathrm{~cm}$ in length $(10-13 \mathrm{kgs})$ indicating overexploitation. This is especially significant as the large individuals are the principal breeders (3). May be quite abundant where not heavily exploited (2).

A decade ago the species was said to be possibly abundant locally in Guatemala (6), new data are required from this area and from Belize.

HABITAT AND ECOLOGY A highly aquatic web-footed species (assigned to the monotypic family Dermatemydidae), the largest freshwater turtle in its range (to over $60 \mathrm{cms}$ carapace length, and $22 \mathrm{~kg}$ weight) (2). Very awkward on land, does not climb out on logs or river banks to bask (as do other freshwater turtles), but occasionally floats passively at the surface of quiet waters $(2,7)$. Inhabits large open rivers and permanent lakes, apparently prefers clear water, not typically found in seasonal or temporary ponds (2). Will tolerate brackish water, sometimes occurring in tidal reaches (9). Primarily nocturnal, becoming active around twilight after passing the day floating or hiding on the bottom (sometimes in large holes where several individuals may gather). Juveniles hide in vegetation in shallow water (2). The species can maintain activity for long periods without rising to breathe air, possibly much oxygen can be extracted from water directly (7), although details remain to be clarified. Not a very wary species, may be 
Dermatemys are entirely herbivorous, feeding on aquatic vegetation, or leaves and fruit that have fallen into the water (2).

In Chiapas (Mexico) the species may nest twice a year, in April and December. Mature eggs were found in the oviducts of specimens from Guatemala taken in February and March (5). December is considered to be part of the breeding season by market vendors in Veracruz (6). High water during the rainy season may help females to move up into shallow side channels, where some nesting occurs. Nests may be in sand, clay or mud (2), and are excavated at the very margin of the water or only a few feet from it (9). The eggs are hard-shelled, elongate $(70 \mathrm{~mm} x$ $30 \mathrm{~mm}$ ), and vary from 6-16 per clutch (or up to 20) (2). Otters appear to be regular predators on Dermatemys $(1,7)$; along the shores of the Rio Lacantun and Rio Usumacinta empty Dermatemys shells, gutted by otters, are commonly found (9).

THREATS TO SURVIVAL Dermatemys is extensively hunted for its eggs and its meat (said to resemble chicken breast), which is much appreciated and highly sought-after in parts of southern Mexico and Guatemala (2). Large specimens sell (1979) for up to US\$10 (2), or up to $\$ 30.50$ in Villahermosa, Tabasco (8). The major markets in Mexico are in the states of Veracruz and Tabasco (6) where the species is now rare. Most Dermatemys consumed in Tabasco now derive from the adjacent state of Chiapas, where turtle consumption is lower and Dermatemys populations larger (2). The Tabascans built an airstrip in the Rio Lacantun area specifically to remove Dermatemys (2). Around 200 Dermatemys are taken each season at EI Paso Dam in Chiapas (data of the Direccion de Pesca, Chiapas), and up to 1000 used to be taken each season from one lake in the Catazaja region (Chiapas) (2). Eighteen to 20 tons are taken annually from the Rivers Lacantun, Lacanja, Usumacinta and their tributaries (3).

CONSERVATION MEASURES TAKEN Protected by the general law on fishing, which prohibits taking turtles under $40 \mathrm{~cm}$ in length (2). Any number of turtles above this size, which would represent the main breeding population, may be taken in season. A ban imposed by the Fisheries Department in Mexico on the capture of this species from Ist September to 31 st December is widely ignored, with capture and sale of Dermatemys continuing year round in the south-east (3).

Listed on Appendix II of the Convention on International Trade in Endangered Species of Wild Fauna and Flora (CITES). Appendix II listing implies that commercial trade is allowed providing a permit from the country of export is obtained, this can provide a method of monitoring trade levels.

CONSERVATION MEASURES PROPOSED Legislation, capable of enforcement, is required to protect the species, and an interim ban on capture should be imposed (2). Field research is essential to evaluate the potential for sustained-yield harvesting, and for captive breeding, hatching and rearing programmes (2). The Freshwater Chelonia Specialist Group of the IUCN/SSC has assigned highest priority to a proposed status survey of this species in Mexico.

CAPTIVE BREEDING In captivity Dermatemys is very placid, even when kept in limited space, and requires clear water, temperatures between 24 and $29^{\circ} \mathrm{C}$ and shady areas (3). In January 1980 a female deposited 12 eggs in a nest in the sand at the side of an experimental pond at Puerto Arista, Chiapas. However the clutch was destroyed by a predator (4). It is hoped that breeding will occur in a captive colony of fourteen animals at the Tuxtla Gutierrez Zoo, Chiapas (10).

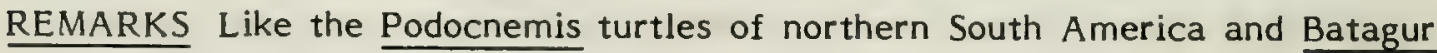


in southeast Asia (see data accounts for these species), Dermatemys is capable of converting otherwise unutilized aquatic vegetation into protein. With adequate conservation and manangement it has the potential to provide a valuable food source on a sustained-yield basis, and could be of considerable economic potential (3).

D. mawii is the only extant species of a distinctive group of turtles, known first from the Lower Cretaceous in Asia, with Tertiary fossils known from Asia, Africa, Europe, and North America $(4,7)$. The identity of some of these may be questionable.

Being named after Lt. Mawe, the specific name is often spelt mawei; the spelling actually used in the type description, mawii, is retained here (see 4).

Heavy exploitation for food may be threatening other turtles in southern Mexico, Guatemala and Belize, notably Staurotypus triporcatus, $\underline{\text {. salvinii and Claudius }}$ angustatus. These species require monitoring and are the subject of a high priority proposed project of the IUCN/SSC Freshwater Chelonia Specialist Group.

REFERENCES 1. Alvarez del Toro, M. (1972). Los Reptiles de Chiapas. Inst. Zool. del Estado. Tuxtla Gutierrez, Chiapas, Mexico. (Cited in 2).

2. Alvarez del Toro, M., Mittermeier, R.A. and Iverson, J.B. (1979). River Turtle in Danger. Oryx 15(2): 170-173.

3. Alvarez del Toro, M., Lopez de Lara, S., Kourchenko, M.L. (1981). Informe de los avances del proyecto de investigacion biologia de las tortugas de agua dulce del estado de Chiapas. Report 80-04-55. Direccion General de Investigacion Cientifica y Superacion Academica Secretaria de Educacion Publica.

4. Iverson, J.B. and Mittermeier, R.A. (1980). Dermatemydidae, Dermatemys. Catalogue Amer. Amphib. Rept. 237: $1-4$.

5. Lee, R.C. (1969). Observing the tortuga blanca (Dermatemys mawei). J. Int. Turtle Tort. Soc. 3(3): 32-34.

6. Mittermeier, R.A. (1971). Status - the market in So. E. Mexico. J. Int. Turtle Tort. Soc. 5(3): 15-19, 36-38.

7. Pritchard, P.C.H. (1979). Encyclopedia of Turtles T.F.H. Publications, New Jersey and Hong Kong.

8. Pritchard, P.C.H. (1981). In litt., 23 March.

9. Smith, H.M. and Smith, R.B. (1979). Synopsis of the Herpetofauna of Mexico. Vol 6. Guide to Mexican Turtles. J. Johnson, N. Bennington, Vermont.

10. Mittermeier, R.A. (1979). It might just be .... the best Zoo in Latin America. Animal Kingdom 82(1): 15-21.

11. Perez-Higareda, G. (1980). Checklist of freshwater turtles of Veracruz, Mexico. Part II. Central portion of the state. Bull. Maryland Herp. Soc. 16(1): 27-34. 

SUMMARY A moderately large aquatic species, occurring in brackish or freshwaters of southeast Asia, formerly extending from Sumatra in the south, along the Malay Peninsula to south Vietnam and the Bengal region. Severely depleted over much of this range, due to heavy exploitation of eggs and adults for food, and habitat disturbance and destruction. Females nest communally, during a well-defined nesting season, on sand banks of large rivers or the coast. The carefully dug and covered nest contains a relatively large number of relatively small eggs. This reproductive strategy (shared with marine turtles, and large freshwater turtles) renders the species extremely susceptible to human predation. Hatchery schemes, such as operated in the Malaysian states of Perak, Kedah and Trengganu, should be encouraged since most natural mortality occurs at the egg stage, but raising of hatchlings in captivity may be counter-productive. Further protective legislation for the species and its habitat is required. Listed on CITES Appendix I. With adequate research, protection and management the species could provide a valuable renewable source of food for human populations in southeast Asia.

DISTRIBUTION Recorded from Sumatra (2) in the south, northward through the Malay Peninsula to the Bengal region in the west and the Cochin China region of Vietnam in the east (12). A population has recently been reported in the Bangladesh Sunderbans $(16,18)$. The present range or occurrence of the species in northeast India, Kampuchea and Vietnam is not clear; Batagur may be largely limited to Sumatra, West Malaysia, Thailand, Bangladesh and Burma (10), but there are recent records from the Sunderban area of India (9). The species may have ranged more extensively up the Ganges system as 12 th century remains have been identified at Sarnath in Uttar Pradesh, India (and fragments, possibly from trade animals, have been reported at Mohenjodaro and Harappa) (17).

POPULATION Populations appear generally to have declined severely.

Bangladesh A significant breeding population has just been discovered (May 1982) in the Bangladesh Sunderbans (18). Local inhabitants have been taking 200 or more adults for several generations, but there is minimal egg exploitation (18).

Burma The present status of populations in Burma is unknown, but comparing late

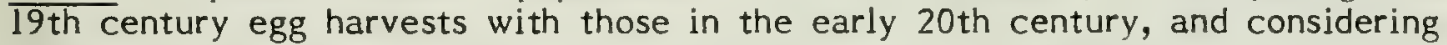
the reported decline in adult numbers, the species was already said to be decreasing rapidly and possibly on the verge of extinction in 1911 (3).

India Batagur was said to be very common at Calcutta in the mid 19 th century ( 13 - noted under the synonym Tetraonyx lessonii), but with heavy exploitation for food and habitat loss, the species is virtually certain to be severely depleted in India (recent status data are required). 
Malaysia The Perak River population (West Malaysia), cited as the only remaining large nesting aggregation (1), is estimated to have comprised 5700-8100 nesting females before World War II, but by the 1970's numbers were reduced to 400-1,200 nesting females (8). Before IVorld War II, 375,000-525,000 eggs were laid annually along the Perak, at present only 20,000-30,000 are laid in a good year (11). The present drastic decline apparently began after heavy exploitation for food.during the Japanese occupation in World War II (11).

Thailand The River Terrapin is in immediate danger of extinction in Thailand (14), where it occurs in two restricted areas in the Peninsula (1).

HABITAT AND ECOLOGY A moderately large web-footed aquatic species (may exceed $61 \mathrm{~cm}$ in shell length), typically found outside the nesting season in brackish water at the mouth of large rivers, or further upstream away from tidal influence $(6,8)$, but sometimes in freshwater lakes or canals (1). In West Malaysia, the Perak River population is present in tidal regions at the river mouth, where the river is $c 1.6-2.4 \mathrm{~km}$ wide and ranges from a few to many metres deep. The bottom is generally of clay or mud, and the banks lined with mangrove vegetation (notably Berembang Sonneratia caseolaris), and attap palm. Some individuals of the Trengganu River population occur above most tidal influence, in a region where the river is rarely more than a quarter of a mile wide, shallow with a sand and gravel bottom, and the bank vegetation is relatively sparse. Extensive sand banks line the channel (8).

Batagur are omnivorous feeders, but vegetable food predominates, individuals typically grazing on the stems, leaves and fruits of riverside plants $(6,8)$. On the Perak River, fruits of the berembang Sonneratia are an important and favoured food source. Molluscs, crustaceans and fish are also consumed. Also on the Perak, Batagur have been noted to move with the incoming tidal flow up tributaries to forage, and return with the ebbing tide back down the main channel (4).

Mating in the Perak River population appears to occur between September and November, by which time males have assumed their breeding colouration (skin of the head, neck and legs turning black, iris turning from yellow-cream to white) (6). Details of courtship and mating are unknown. As monsoon flooding subsides in November (somewhat later on the east coast), the females move upstream to nest. Large sand banks and islands are essential for nesting, high sloping banks are preferred to low flat banks. Females emerge in staggered waves over a three month period to bask, formerly in close-packed herds of up to 500 animals, and lay their eggs. In the Irrawaddy Delta of Burma, village informants reported in the early 20th century (3) that each female lays three times in a given season, starting with 30 eggs and decreasing to around 10 eggs in the third clutch. This pattern may occur in other parts of the species range $(1,4)$. On the Perak mean clutch size is 26.4 (8). Eggs are oblong in shape, up to $70 \mathrm{~mm}$ in length. Nesting females are extremely sensitive to disturbance. A body pit is excavated with both the fore and hind-limbs, then a six-to-twelve inch deep egg cavity is dug within it. Covering the eggs may take twice as long as digging and egg-laying. The sand covering is compacted by the female repeatedly raising her body (around $18 \mathrm{~kg}$ ) and dropping it on the sand, the resulting drumming sound is the source of the Malay name 'tuntong'. As the female returns to the water she throws sand backwards over the nest site, and usually also digs a false body pit. Hatchlings emerge in 70-80 days (data from artificially incubated eggs, and from the Batu Gajah hatchery - see below (8), and the Irrawaddy Delta (3)). 
The overall reproductive pattern is typical of that found in other large aquatic turtles ('Pattern I' of Moll) (7), involving multiple clutches of relatively small eggs produced during a well-defined nesting season, communal nesting in well-defined ancestral nesting areas, and careful construction of covered nests. This pattern is also shown by Podocnemis and marine turtles. Batagur is somewhat atypical in that clutch size is smaller than may be expected, while egg size is a little larger. Although the 'Pattern I' strategy involves a high numerical output of eggs, the regularity and site-specificity of egg-laying can allow significant predation; in particular, man frequently exerts a very heavy and deleterious predation-pressure.

Adult Batagur have few natural predators (8), other than man and sharks. The high-domed, seamless and heavily-buttressed shell probably reduces predation by saltwater crocodile Crocodylus porosus. Most mortality must occur in egg and juvenile stages. Otters and dogs may consume eggs during nesting, and monitor lizards Varanus are able to locate and excavate completed nests. Juveniles are doubtless eaten by aquatic predators including fish and crocodiles (4).

THREATS TO SURVIVAL The primary threats are over-exploitation of eggs and adults for food, and habitat destruction $(1,3,4,5,6)$.

In West Malaysia consumption of adult Batagur varies with race and religion, they are eaten by Chinese and Indian inhabitants and by indigenous native peoples, but not by the Islamic Malay population (5). Most adults for sale in markets may be caught accidentally by fishermen (4). However, eggs are widely prized as a delicacy and widely collected, and in West Malaysian markets eggs of Ratagur (also Callagur and Dermochelys) sell for nearly twice the price of marine turtle eggs (Chelonia, Lepidochelys), and around three times the price of chicken eggs (5).

Habitat destruction constitutes the second, and most insidious, category of threat. For example, on the Perak River clearing of forest and tin mining have created a large silt load, leading to increased flooding and silt deposition. One favoured nesting island which had held around 1000 nests in a season has been largely eroded away and now holds barely 100 nests. Silt deposited on sand nesting areas has promoted growth of grass and sedges such that most Perak River nest beaches require annual clearing by man. Nesting areas are also lost by commercial removal of sand. Clearing of riverside vegetation is a problem in the foraging area of Batagur, removing food sources (notably berembang fruit) and exposing the banks to erosion. Finally, construction of dams and harrages has blocked movement to nesting sites (e.g. along the Kedah River), and blocked access to food-rich tributaries for foraging (e.g. Parit Jerman on the Perak) $(4,6)$. In West Malaysia (4) some mortality is due to collisions with motor boats, killing by fishermen, and has probably also resulted from ingestion of various toxins introduced into rivers to kill fish.

Over-exploitation and habitat modification are similarly cited as threats to the Thailand Batagur population (1). It was already reported for Burma in 1911 (3) that increasing cultivation and steamer traffic on the river had prevented inland nesting of Batagur, and may have led to increased coastal nesting. Eggs and adults were, and doubtless still are, in great demand for food (3). The species was much used for manufacture of soup in Calcutta in the mid 19th century (13) and is occasionally sold in Bangladesh at Bagerhat and Chalna Bazaan, close to the Sunderbans (16).

CONSERVATION MEASURES TAKEN In Malaysia the states of Perak and Trengganu have legislation prohibiting killing or possession of Batagur without 
authority. Perak and Kedah have legislation giving the state authority to licence egg-collectors and lease collecting areas (one third of the eggs collected are retained by the licencee, one third are presented to the Sultan, one third are sold to the Game Department hatchery). However, many unlicensed individuals collect eggs illegally, and licencees may not accurately report eggs collected (4).

The Game Dept. hatchery programme at Ratu Gajah in Perak was the first to be established (in the 1950's, taken over by the Game nept. 1968) for Batagur anywhere in its range. Similar schemes are now in operation in Kedah and Trengganu states. At Batu Gajah eggs purchased from licensed collectors are transplanted to the hatchery and re-buried in an artificial sand beach.

The hatchlings are raised in a concrete pool for one or two years prior to release in the river. Hatchlings from natural nests may also be trapped by drift fences and sold to the hatchery. In the decade between 1969 and 1979, 6691 hatchings have been released. The new Kedah and Trengganu schemes have resulted, respectively, in 397 hatchlings and 1809 hatchlings in the 1978-1979 season (11). The success of such hatching programmes cannot be fully confirmed until artificially-hatched females are themselves shown to nest successfully. The hatchery at present significantly limits predation at the egg stage, which may account for over 90 per cent natural mortality in some species (percentage not known for Batagur) (4).

In Thailand twelve adults and six juveniles from the remnant Batagur population at Thale Luang have been taken into captivity at the Brackish Water Fisheries Research Station, Songkhla. Unfortunately, breeding facilities are not available (1).

Listed on Appendix I of the Convention on International Trade in Endangered Species of Wild Fauna and Flora (CITES). Appendix I listing requires that trade in the taxon and its products is subject to strict regulation by ratifying states and international trade for primarily commercial purposes is prohibited.

CONSERVATION MEASURES PROPOSED The distribution and status of Batagur populations throughout the species range requires investigation. Long-term research on basic life history parameters is necesssary, certain preliminary data are available for the Perak River population (4). Information from such research coupled with local education and effective legislation protecting both Batagur and its habitat, could provide the foundation for sustained exploitation of a valuable food resource.

In West Malaysia (4) efforts should be made to pass proposed protective legislation at a federal level, licensing and hatchery schemes should be extended to new nesting areas, poaching and illegal sales should be prevented. Forest clearance and dumping of pollutants in rivers should be curtailed. Benefits of future dam construction should be evaluated against reduced productivity of Batagur and fish. Collection of hatchlings should be discontinued, and pending further research, maintaining hatchlings in captivity should not be encouraged (the benefits of this practice are unknown) The IUCN/SSC Freshwater Chelonia Specialist Group plans highest priority projects on conservation of Batagur in Thailand, and a status survey throughout the range.

CAPTIVE BREEDING No data available. No significant breeding schemes appear to exist and may not be practical or desirable (4). Non-breeding Batagur are kept at certain Buddhist 'turtle temples' in Malaysia (e.g. Kek Lok Si Temple, Penang and Sam Poh Thong Temple, Ipoh), also at the Brackish Water Fisheries Research Station at Songkhla, Thailand, and probably in several zoos and private 
collections. Forty-eight Batagur have been raised from eggs hatched in 1968 at Batu Gajah, Perak, but facilities are inadequate for breeding.

REMARKS Conservation and rational management of this species has the potential to provide a valuable protein-rich food source for southeast Asian peoples, capable of sustained utilization.

REFERENCES 1. Bain, J.R. and Humphrey, S.R. (1980). A profile of the endangered species of Thailand. Report N0.4, Office of Ecological Services, Florida State Museum, Gainesville Florida 32611.

2. De Rooij, N. (1915). The reptiles of the Indo-Australian Archipelago. I. Lacertilia, Chelonia, Emydosauria. E.J. Brill, Leiden (reprinted 1970, A. Asher, Vaals).

3. Maxwell, F.D. (1911). Reports on inland and sea fisheries in the Thongwa, Myaungmya, and Bassein districts and the turtle banks of the Irrawaddy division. Rangoon Government Printing Office. 57 pp.

4. Moll, E.O.(1976). Ecology and management of the Tuntong (Batagur baska) in Malaysia. Unpublished report submitted to the Game Department of West Malaysia.

5. Moll, E.O. (1979). West Maláysian turtles: utilization and conservation. Herpet. Rev. 7(4): 163-166.

6. Moll, E.O. (1978). Drumming along the Perak. Natur. Hist. $87(5): 36-43$.

7. Moll, E.O. (1979). Reproductive cycles and adaptions. In Harless, M. and Morlock, H. (Eds), Turtles, perspectives and research. John Wiley \& Sons, New York. Pp. 305-331.

8. Moll, E.O. (in press, 1981). Natural History of the River Terrapin Batagur baska (Gray) in Malaysia (Testudines: Emydidae).

9. Mukherjee, A.K. (1975). The Sunderban of India and its biota. J. Bombay Nat. Hist. Soc. 72(1): 1-20.

10. Pritchard, P.C.H. (1979). Encyclopedia of Turtles. T.F.H. Publications, Hong Kong.

11. Siow, K.T. and Moll, E.O. (in press 1981). Status and conservation of estuarine and sea turtles in West Malaysian water. To appear in Bjorndal K. (Ed.), Proceedings of the World Conference on Sea Turtle conservation. Smithsonian Institute Press, Washington DC.

12. Smith, M.A. (1931). The fauna of British India including Ceylon and Burma. Reptilia and Amphibia, Vol.1, Loricata, Testudines. Taylor and Francis, London. (reprinted 1973, Ralph Curtis Books, Hollywood, Florida).

13. Theobald, W. (1868). Catalogue of reptiles in the Museum of the Asiatic Society of Bengal. J. Asiatic Soc. (extra number) Calcutta.

14. Wirot, N. (1979). The turtles of Thailand. Siamfarm Zoological Garden, Bangkok.

15. Anon. (1978). Pendomen Pengelolaan Satwa Langka Di Indonesia. Jilid 1; Mammalia, Reptilia dan Amphibia. Direktorat Jenderal Kehutanan (Direktorat Perlindungan dan Pengeawetan Alam). Bogor, 103pp.

16. Khan, Md.A.R. (1981). In litt., 15 July to F.O. Moll.

17. Nath, B. (1959). Animal remains of the 12th century A.D. from Sarnath in Uttar Pradesh, India. J. Zool. Soc. India. 10: $165-175$.

18. Whitaker, R. (1982). In litt., 5 May. 

TAO LAI TEEN BET (Thai)

Callagur borneoensis (Schlegel \& S. Müller 1870)

\section{Order TESTUDINES}

Family EMYDIDAE

SUMMARY A rather large aquatic estuarine turtle inhabiting areas of tidal influence of medium to large rivers in the Sundaland region, from southernmost Thailand southward through West Malaysia to the islands of Sumatra and Borneo. Very rare in Thailand, widespread but generally depleted and heavily exploited in peninsular Malaysia, no population information for Sumatra or Borneo. Mainly herbivorous, consuming fruit and greenery from riverside plants, notably Sonneratia. Reproduction is seasonal, time of nesting varies geographically. Females migrate downstream to nest on ocean beaches near the mouth of the home river (in mangrove areas they may use sand banks along the river). Two clutches of 10 to 20 large oval eggs are laid annually. The nest is shallow and poorly concealed. Hatchlings from marine nests move into less saline waters. Males exhibit seasonal dichromatism. Threatened primarily by very heavy exploitation of eggs for food. Four states in West Malaysia have legislation to prohibit killing of turtles and to lease nesting areas to licensed egg collectors. Trengganu has a hatchery scheme using eggs purchased from collectors. Additional hatcheries are needed. Distribution and status throughout range requires clarification.

DISTRIBUTION A turtle of the Sundaland region, occurring from the southernmost provinces of Thailand in the north, southward through West Malaysia to the islands of Sumatra and Borneo.

\section{POPULATION}

Indonesia No population estimates are available for Sumatra or Kalimantan.

Malaysia The species is widely distributed, but few large populations remain, it is now rarely seen on many rivers where it was once common (5). On the east coast of peninsular Malaysia the largest known breeding population is on the Setiu-Chalok river system, comprising approximately 200 adult females. Egg production along the east coast has been estimated at 16000 eggs (5), suggesting a nesting population of approximately 650 females. No comparable studies have been conducted on the west coast, however, a moderately large population exists in the Perak River (1). The species has been reported "uncommon" near Kuching in East Malaysia (Sarawak) (2), no recent data.

Thailand Reported very rare (7).

HABITAT AND ECOLOGY A moderately large $(50 \mathrm{~cm})$ aquatic estuarine turtle inhabiting areas of tidal influence of medium to large rivers $(1,5,5)$. In Sarawak (9) the species was often found in mangrove swamps, and was said to be fond of resting on submerged snags with just the head exposed above water. In peninsular Malaysia individuals are reported to frequently crawl out on logs or mats of vegetation to bask, a behaviour more characteristic of temperate zone aquatic 
turtles (5). Although somewhat omnivorous, the diet chiefly comprises fruits and greenery from riverside plants, fruits of the mangrove Berembang Sonneratia are a favoured item on the Perak River. The turtles also sometimes feed on a variety of village refuse, especially fruit scraps, discarded into the water (4).

Reproduction is seasonal. In peninsular Malaysia, nesting occurs from June-August on the east coast and and from October-January on the west coast (5). Nesting usually occurs at night at low tide on sand beaches along the sea within a few kilometres of the mouth of their home river, however, in mangrove areas lacking such beaches (notably along the west coast), sand banks within the river may be substituted (5). Males are not seen near the nesting beaches and presumably do not accompany females on their down-river nesting migration. Mating probably occurs prior to migration. Ten to 12 large oval eggs (c $70 \mathrm{~mm}$ long) are laid per clutch and two clutches are laid per year. In a Sarawak population, a clutch of 15-20 long oval eggs was laid in February and again in March (8). The nest is relatively shallow (30 cm deep) and poorly camouflaged, the nesting process may take only half an hour. Hatchlings emerge from the nest in approximately 70 days (5). Being unable to survive long in 100 per cent sea water, they presumably move directly into the rivers where they seek habitats of less than 50 per cent sea water (1). The species exhibits marked sexual and seasonal dichromatism (10). Breeding males have a white head with a broad mid-saggital red stripe, a bluish tip to the snout, and a light grey to cream coloured carapace. Non-breeding males have a dark grey head with a dull orange stripe and a dull brown to grey carapace (5). In Sarawak, young and half-grown individuals were reported to have a brilliant scarlet nose and pale yellow shell striped with black (9) (these may similarly represent male animals since the scarlet nose was said to be absent or very faint in nesting turtles).

THREATS TO SURVIVAL The primary threat appears to be over-exploitation of eggs for food (4,5). Most of the east coast nesting areas of peninsular Malaysia are licensed to egg collectors. Harvesting of eggs is efficient and nearly all eggs laid are collected. Even in areas of peninsular Malaysia where Callagur have become rare the concurrent egg production of sea turtles nesting on the same beaches continues to make egg collection profitable. Callagur eggs are preferred over those of sea turtles due to their large size and reputed better taste. In Malaysian markets they may fetch four to five times the price of chicken eggs. Adults do not appear to be regularly exploited.

CONSERVATION MEASURES TAKEN In West Malaysia, the states of Kelantan, Pahang, Perak, and Trengganu, have legislation prohibiting the killing of turtles and giving the state authority both to license egg collectors and to lease collecting areas (6). A hatchery programme, begun in 1978 at Mankok on the Setiu-Chalok river by the Trengganu Fisheries Department, purchases around a thousand eggs per year from collectors.

CONSERVATION MEASURES PROPOSED The distribution and status of Callagur populations requires study. Additional hatcheries are needed near the major nesting sites in West Malaysia and possibly though the range. The nesting site at Kuala Baharu, Trengganu has been proposed as a sanctuary by the State Fisheries Department. In Malaysia turtle sanctuaries are off-limits to tourists but controlled egg collecting is permitted:

\section{CAPTIVE BREEDING No information.}

REMARKS The heavy demand for Callagur eggs coupled with the turtle's low reproductive potential and stereotyped nesting habits make Callagur one of the most seriously threatened river turtles in Southeast Asia. 
Callagur is morphologically similar in several respects to turtles of the genus Kachuga, occurring in Burma and the Indian subcontinent, and may be closely related in particular to K. trivittata of Burma (3).

This account is based on a draft kindly provided by E.O. Moll. (Chairman of the IUCN/SSC Freshwater Chelonian Specialist Group).

REFERENCES 1. Dunson, W.A. and Moll, E.O. (1980). Osmoregulation in sea water of hatchling emydid turtles, Callagur borneoensis, from a Malaysian sea beach. J. Herpetol. 14(1): $3 \overline{1-36 .}$

2. Harrison, T. (1963). Notes on marine turtles: 14-Albino green turtles and sacred ones. Sarawak Mus. J. 11: 304-306.

3. McDowell, S.B. (1964). Partition of the genus Clemmys and related problems in the taxonomy of the aquatic Testudinidae. Proc. zool. Soc. Lond. 143 (2): 239-279.

4. Moll, E.O. (1978). Report on research on the distribution, ecology and management of coastal nesting turtles in Trengganu, West Malaysia. Unpublished report submitted to the Trengganu Department of Fisheries.

5. Moll, E.O. (1980). Tungtong laut. The river turtle that goes to sea. Nature Malaysiana 5(2): 16-21.

6. Siow, K.T. and Moll, E.O. (in press 1981). Status and conservation of estuarine and sea turtles in West Malaysian waters. To appear in Bjorndal, K.A. (Ed.) Proceedings of the World Conference on Sea Turtle Conservation. Smithsonian Institute Press, Washington D.C.

7. Wirot, N. (1979). The turtles of Thailand. Siam Farm, Bangkok.

8. Hose, C. (1916). Footnote in ref. 9, p.112.

9. Shelford, R.W.C. (1916). A naturalist in Borneo. London, T.Fisher Unwin.

10. Moll, E.O., Matson, K.E., and Krehbiel, E.B. (1981). Sexual and seasonal dichromatism in the Asian river turtle Callagur borneoensis. Herpetologica 37 (4): 181-194. 

SUMMARY A very small and secretive semi-aquatic species present in several small disjunct populations in the eastern United States; populations form two major groups, in the northeastern states, and in the southern Appalachians. Typically occurs in undisturbed sphagnum bogs and other shallow wetland habitats. Population density ranges from a low of 5 individuals per ha, following activity of commercial collectors, to a high of around $125 \mathrm{per}$ ha. The species appears rare over much of its range, some populations have been destroyed or depleted by habitat destruction and over-collection for the pet trade. There is evidence that the species is not as extremely rare as once thought. An omnivorous feeder. Mating occurs in spring, the nest typically contains a clutch of three eggs. Protected by legislation in most of its range, a few reserves contain the species. Listed on CITES Appendix II. Further research on distribution, ecological requirements and abundance is necessary. A breeding colony exists at Fort Worth Zoo.

DISTRIBUTION The Bog Turtle Clemmys muhlenbergii has a highly disjunct distribution in the eastern United States. Known populations form two major groups, in the northeastern states, and in the southern Appalachians. The former group includes the most extensive cluster of localities, ranging from southwest parts of New York State and adjacent western parts of Massachusetts and Connecticut, southward to northern parts of liaryland. Other northeastern populations occur in western New York State and Pennsylvania. The Appalachian group occurs in western North Carolina, extending into Virginia $(2,5)$.

POPULATION The species appears to be uncommon over much of its range, some populations have been destroyed or disturbed by habitat destruction and over-collecting (2). However, it has been suggested (1) that the secretive habits of the Bog Turtle may account in part for its apparent rarity, and there is evidence that the species is not depleted throughout its range (2). The species has long been considered the rarest turtle in North America $(3,4)$. Density estimates range from a low of 5 individuals per ha, following activity of commercial collectors, to a high of around 125 per ha (3). From one to 26 individuals were found at each of seven localities in North Carolina, a total of 54 were seen during $225 \mathrm{~h}$ of search (11).

HABITAT AND ECOLOGY A very small (maximum carapace length to nearly $11 \mathrm{~cm})$ semi-aquatic species, inhabiting undisturbed sunny and humid bogs, swamps, ponds and wet meadows. Typical habitats would include standing or slow-moving shallow water, on a muddy substrate, with an abundance of grass or moss cover. It is said to be most typically encountered walking in the shallow water of sphagnum bogs, with the feet wet but the carapace dry (2,7). Associated water-loving plants include sphagnum mosses Sphagnum, club mosses Lycopodium, skunk cabbage Symplocarpus foetidus, sedges Carex, bullrushes Scirpus, cattail Typha latifolia, speckled alder A.Inus rugosa, swamp-bay magnolia Magnolia virginiana, and swamp honeysuckle Rhododendron viscosum (9). Clemmys muhlenbergii has perhaps the most narrow habitat preference of all North American freshwater turtles (7), however, the distribution must be constrained by 
other factors since suitable habitat is present in parts of eastern North America where Bog Turtles are absent (2). Northeastern populations occur up to $245 \mathrm{~m}$ above sea level, but the southern populations range to $1,280 \mathrm{~m}$.

The Bog Turtle forages for food during the day in warm or hot weather, both on land and under water (9). The species is omnivorous, the diet including insects primarily, but also plants and carrion. Among a variety of items cited are, watercress, skunk cabbage, seeds of pondweed Potamogeton and sedges Carex, berries, earthworms, slugs and snails, aquatic insects, field crickets, butterfly larvae, tadpoles, frogs, water snakes and nestling birds (9). No detailed feeding studies have been performed.

Most activity occurs from early spring, when the turtles emerge from hibernation in deeper water areas, to mid-autumn, with the exception of a possible aestivation period in high summer. $C$. muhlenbergii is most active during warmer parts of the day, and frequently basks to elevate body temperatures (for example, on tussocks of grass emerging from shallow waters). Some populations show a migratory movement between hibernation sites and feeding-nesting sites in shallower water. The species appears to have homing ability, and is active within a relatively small home range (to maximum recorded of around $1.3 \mathrm{ha}$ ). (9).

Mating typically occurs from late April to early June, and nesting from June, sometimes into August. The nest is dug in moist earth of elevated ground, with moss and grass tussocks. The clutch typically comprises three eggs, about $1.2 " x$ $0.6^{\prime \prime}(3 \mathrm{~cm} \times 1.4 \mathrm{~cm})$, but may range from one to five in number. It is not known if more than one clutch is laid per year. Incubation period is typically seven to eight weeks (9).

Bog Turtles at all life stages may be preyed upon by racoons, skunks, dogs, foxes, and other large predators (9).

THREATS TO SURVIVAL Habitat destruction or modification, and over-collecting are the major threats to Clemmys muhlenbergii (2).

Although recent investigations have revealed that the Bog Turtle, a small and secretive species, is not as rare as previously believed, the rate at which known colonies have disappeared merits particular concern (10). Bog Turtle sites have been destroyed or disrupted by urban developments of various kinds (shopping centres, a golf course, a sewage disposal plant, a city park, a playground), by road construction, by dumping of scrap and other landfill activity, and by drainage for mosquito control, industrial development or extension of dairy farming land (9). Loss of wetland habitat is a continuing trend, and many northeast populations are near expanding urban and industrial centres (2).

Collecting of specimens for the pet trade is also a serious problem, particularly for small isolated colonies, but is secondary in importance to habitat loss (2).

CONSERVATION MEASURES TAKEN The Bog Turtle has legislative protection in nearly all states in which it occurs (New York, Connecticut, Pennsylvania, New Jersey, Maryland), and is denoted a species of special concern in North Carolina. Two Bog Turtle reserves are managed by the Pennsylvania Game Commission (Middle Creek Wildlife Management Area, Lebanon County; Pymatuning Wildlife Management Area, Crawford County). Some populations occur on U.S. Forest Service land in North Carolina, where the species appears to be under no immediate threat (2). Newly-discovered localities may often by kept secret by field workers. 
C. muhlenbergii is not presently included as an Endangered or Threatened species under the 1973 U.S. Endangered Species Act, but is listed on Appendix II of the Convention on International Trade in Endangered Species of Wild Fauna and Flora (CITES). Appendix II listing implies that commercial trade is allowed providing a permit from the country of export is obtained, this can provide a method of monitoring trade levels.

CONSERVATION MEASURES PROPOSED The present distribution and abundance of the Bog Turtle, throughout its range, requires clarification. This information would allow evaluation of the impact on the species of further habitat loss. Further research on habitat, ecology and geographic variation is necessary (2).

CAPTIVE BREEDING A breeding colony exists at the Fort Worth Zoo (8), but breeding potential is probably poor (6) and conservation efforts may more profitably be directed at natural populations (2).

REMARKS This account is based largely on a U.S. Fish and wildlife report compiled by R.B. Bury (ref.2).

REFERENCES 1. Arndt, R.G. (1978). The Bog Turtle ... an endangered species? Del. Conserv. 22(2): 18-21, 25. (Cited in reference 2).

2. Bury, R.B. (1979). Review of the ecology and conservation of the Bog Turtle, Clemmys muhlenbergii. Special Scientific Report - Wildlife No.219. U.S. Dept. of the Interior, Fish and Wildlife Service, Washington DC.

3. Eglis, A. (1967). Clemmys muhlenbergii rarest of North American turtles. Anim. Kingdom 70 (2): 58-61. (Cited in reference 2).

4. Ernest, C.H. and Barbour, R.W. (1972). Turtles of the United States. I Iniversity Press of Kentucky, Lexington.

5. Ernst, C.H. and Bury, R.B. (1977). Clemmis muhlenbergii (Schoepff). Catalogue Amer. Amphib. Rept. 204.1-204.2.

6. Honegger, R. (1979). Red Data Book, Vol. 3: Amphibia and Reptilia. IUCN, Gland (third edition, revised).

7. Pritchard, P.C.H. (1979). Encyclopedia of Turtles. T.F.H. Publications, Kong Kong.

8. Tryon, B.W. and Hulsey, T.G. (1977). Breeding and rearing the bog turtle Clemmys muhlenbergii at the Fort Worth Zoo. Int. Zoo. Yearb. $17125-130$.

9. Various authors cited in reference 2.

10. Williams, J.D. and Dodd, C.K. (1978). Importance of wetlands to endangered and threatened species. In Greeson, P.E. et al (Eds), Wetland functions and values: the state of our understanding. American Water Resources Association, Minneapolis, Minnesota.

11. Zappalorti, R.T. (1975). The status of the bog turtle Clemmys muhlenberhi (sic) in North Carolina. Pp 22. Unpublished progress report, National Audobon Society. (Cited in reference 2 ). 

Heosemys silvatica (Henderson 1912)

(Synonym: Geoemyda silvatica)

Order TESTUDINES

Family EMYDIDAE

SUMMARY A very small, distinctive, and almost unknown, terrestrial turtle. Endemic to India. Only two specimens known, both collected in 1911 at $450 \mathrm{~m}$ in dense rain forest near Kavalai in the former 'Cochin State Forests' of Kerala, southwest peninsular India. No record exists that the species has been seen since. Certainly rare, possibly threatened by rain forest modification. A field survey is planned for 1982. This species is one among many endemic species of various groups characteristic of the diminishing rain forest tract of southwest India.

DISTRIBUTION Endemic to India. Known only from two specimens collected near Kavalai, about 20 miles from Chalakudi, in the former 'Cochin State Forests' of Kerala State, southwest peninsular India $(3,8)$.

POPULATION Only two museum specimens are known (collected in 1911), providing the basis for the species' description in 1912; no record appears to exist of the species having been seen since, either at Kavalai or elsewhere in Kerala $(1,2,5,6,8)$.

The species may have been affected by the widespread clearance and modification of the rain forest tract in southwest India, although it is reported (1) that original forest is left around Chalakudi. The first specimen, a mature male, was found by Kadar tribals (3). There are no details of the discovery of the second specimen, but a collector from the Madras Government Museum sent to the forests in March 1912 was unable to find the species. It was concluded that the species is not common (3).

HABITAT AND ECOLOGY A very small (to near $12 \mathrm{~cm}$ ) terrestrial turtle, of a mainly freshwater family. The type specimen was collected in dense upland rain forest at c $450 \mathrm{~m}$ (1500 ft) altitude. Reported to inhabit a short underground burrow, not near water. The two known specimens, that were held in captivity for several months, subsisted entirely on vegetable material (3). No further information.

THREATS TO SURVIVAL No direct information. Possibly threatened by loss of rain forest habitat (e.g. 7).

\section{CONSERVATION MEASURES TAKEN None.}

CONSERVATION MEASURES PROPOSED A field survey of the type locality is planned for late 1982, with the preliminary objective of establishing if the species still exists. If a viable population is found it is intended to gather biological data that may aid in conservation of the species.

CAPTIVE BREEDING None.

REMARKS This small turtle is one of several equally distinctive and poorly-known amphibian and reptile species endemic to southwest Indian rain 
forests. Similar or higher endemicity is known among the plants, birds and mammals, for example, and conservation of $\mathrm{H}$. silvatica may be seen as one element in conservation of this unique and diminishing biotope.

This species was first assigned to the genus Geoemyda (3). All but one of the former Geoemyda species have recently been re-allocated among four other genera, on the basis of superficial and cranial differences (4). The form silvatica was one of five Asian species assigned to the genus Heosemys. However, it appears that the critical skull features were not examined in $\underline{\mathrm{H}}$. silvatica, and the true affinities of silvatica are not known with any confidence.

REFERENCES 1. Changappa, K.N. (High Range Wildlife Preservation Assoc.). (1982). In litt., 25 May.

2. Daniel, J.C. (Curator, Bombay Nat. Hist. Soc.) (1982). In litt., 8 February.

3. Henderson, J.R. (1912). Preliminary note on a new tortoise from south India. Rec. Ind. Mus. 7: 217.

4. MCDowell, S.B. (1964). Partition of the genus Clemmys and related problems in the taxonomy of the aquatic Testudinidae. Proc. Zool. Soc. Lond. 143: 239-279.

5. Murthy, T.S.N. (1982). In litt., 4 February.

6. Pillai, R.S. (Deputy Director, Zoological Survey of India, Southern Regional Station) (1982). In litt., 25 February.

7. Saharia, V.B. (Compiler and Editor) (1981). Wildlife in India. Dept. of Agriculture and Cooperation, Ministry of Agriculture, Govt. of India. (reference to southwest rain forests in chapters 3,4 and 5).

8. Smith, M.A. (1931). Reptilia and Amphibia, Vol. 1, Loricata, Testudines. In Fauna of British India, including Ceylon and Burma. London: Taylor and Francis Ltd. (reprinted 1973, Ralph Curtis Books, Holywood, Fla.) 
Pseudemys alabamensis Baur 1893

Order TESTUDINES

Family EMYDIDAE

SUMMARY A large, predominately freshwater turtle inhabiting, as far as is known, the lower part of the Mobile drainage system in Mobile and Baldwin counties, Alabama. May still exist in a lake in Little River State Park in southern Monroe Co., AL. It is found occasionally, perhaps as a waif, on Dauphin Island in Mobile Co., and there are records (undocumented) from Texas, Tennessee and Florida. Not abundant anywhere within its range. Most numerous in areas that support an abundance of submergent aquatic vegetation and along the stretch of the Tensaw River adjacent to Gravine Island, its major known nesting area. Almost nothing is known about the natural history of the species. The species is trapped for food, shot, egg predation by Fish Crows is intense, predation by Alligators on juveniles and small adults may be intense, and trawls are used to capture hibernating individuals. The long term effect of river traffic on the species is not known. Protective measures and a survey of its distribution, status, and natural history are needed. No protection is provided at present for this species.

DISTRIBUTION Verified records are confined to the lower part of the Mobile drainage system in Mobile and Baldwin counties in Alabama, and to the lake in Little River State Park in Monroe Co., Alabama $(4,6)$. There are undocumented records for Florida, Tennessee and Texas $(1,2,6)$.

POPULATION Not abundant anywhere in its range. Appears most numerous in areas where there is much submergent aquatic vegetation, and along Gravine Island where most nesting occurs. No quantative data available. The species was considered 'threatened' on the Alabama list of 'threatened and endangered species' (7), and it was recommended by Mount (6) and by McCoy and Vogt (4) that the species be considered 'threatened'.

HABITAT AND ECOLOGY A large (to maximum carapace length of $33.5 \mathrm{~cm}$ ) aquatic turtle primarily inhabiting the lower part of the flood plain of the Mobile drainage system. Very little is known about the natural history of $P$. alabamensis. Apparently strictly herbivorous. The major known nesting area of P. alabamensis is Gravine Island. Several clutches are probably laid per year. The animal basks regularly and appears to be quite wary. It appears to be most numerous in areas that support abundant submergent aquatic vegetation. Basic observations on nesting have only just been published (5). Nine nests were located in May-July 1978, located in the open sparsely-vegetated sand beach at the north end of Gravine Island. Nests were in fine moist sand at the base of vegetation, at various distances from water. Clutch size 3-6 eggs, nest depth $8-16 \mathrm{~cm}$. Predation by Fish Crows Corvus ossifragus resulted in 100\% egg mortality (5). Intense egg predation, coupled with predation on young and small adults by alligators Alligator mississippiensis, appears to result in a low level of recruitment. There is also significant artificial mortality of adults due to trapping, trawling for hibernating individuals, shooting, etc. $(3,4)$.

THREATS TO SURVIVAL The restricted range, the specialized nature of the habitat occupied, susceptibility to harvest by various means, the selling of harvested individuals for food, high levels of predation on eggs, juveniles and small adults, scarcity of suitable nesting areas, presence of river traffic, and the 
lack of any protection are at least some of the factors that threaten $P$. alabamensis. The effect of these factors is probably more serious due to the low numbers of individuals in the population.

CONSERVATION MEASURES TAKEN The species is included in the 'threatened' category on the Alabama list of 'threatened and endangered species' (7). No effective protection is provided for $\underline{\mathrm{P}}$. alabamensis.

CONSERVATION MEASURES PROPOSED The following have been proposed (4): (i) protect the principal habitat (weed beds, etc., nesting sites and hibernation areas, and (ii) restrict or eliminate the inadvertent harvest and destruction of turtles by shrimpers and commercial fishermen. It would also be advisable to prohibit the selling of $\mathrm{P}$. alabamensis, and the use of rifles along streams and rivers (except during the hunting season), provide protection for the species, purchase Gravine Island (the major known nesting. area for P. alabamensis) and prohibit or restrict recreational use of the island except during the autumn and winter seasons. A distributional study, a status survey and a study of the various natural history parameters of $\underline{P}$. alabamensis are required.

\section{CAPTIVE BREEDING No information.}

REMARKS The taxonomic status of $\mathrm{P}$. alabamensis, with regard to relationships

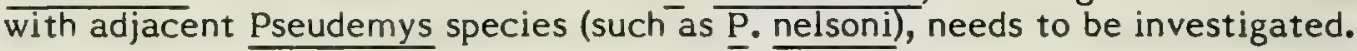

This account is based very largely on a draft kindly provided by J.L. Dobie.

REFERENCES 1. Carr, A.F. and Crenshaw, J.W., Jr. (1957). A taxonomic reappraisal of the turtle Pseudemys alabamensis Baur. Bull. Florida State Mus. 2(3): 25-42.

2. Crenshaw, J.E. (1955). The ecological geography of the Pseudemys floridana complex in the southeastern United States. Ph. D. Dissertation, University of Florida. 205 pp.

3. Dobie, J.L. (undated). Pers. obs.

4. McCoy, C.J. and Vogt, R.C. (1979). Distribution and population status of the Alabama Red-bellied Turtle, Pseudemys alabamensis. 14pp. Report of USFWS Contract Number 14- $\overline{16-004-79-038 . ~}$

5. Meany, D.B. (1979). Nesting habits of the Alabama Red-Bellied Turtle, Pseudemys alabamensis. J. Alab. Acad. Sci. 50: 113 (Abstr.).

6. Mount, R.H. (1975). The reptiles and amphibians of Alabama. Auburn Univ, Agr. Exp. Station, Auburn, A1. 347 pp.

7. Mount, R.H. (1976). Amphibians and reptiles. Pp 66-79 in Endangered and threatened plants and animals of Alabama. Boschung, H. (Ed.) (1976). Al. Mus. Nat. Hist. Bull. No. 2, Univ. of Al., 1-93. 
Pseudemys felis Barbour 1935

Order TESTUDINES

Family EMYDIDAE

SUMMARY An aquatic species, restricted to a few fluctuating freshwater ponds and sinkholes in an area of $2.5 \mathrm{~km}^{2}$ between Tea Bay and Knowles on the west coast of Cat Island, central Bahama Islands. Population numbers and trends unknown. In a recent dry season survey, evidence of only 12-17 individuals was found during two days, but the total population is probably significantly larger. Rarely seen except during the June-August rains. Breeding success is dependent on adequate rainfall. Collected locally for pets, exploited for food, habitat under threat if development occurs. It should be possible to purchase and protect part of the range. Nominally protected under Bahamian law.

DISTRIBUTION Restricted to a group of shallow freshwater ponds lying $50-250 \mathrm{~m}$ inland between Tea Bay and Knowles ( $4 \mathrm{~km}$ south) on the west coast of Cat Island, central Bahama Islands $(2,6)$. Introduced as pets in domestic locations in other parts of Cat Island (6), and introduced in Nassau, New Providence Island, where it may have interbred with other introduced turtle species (2).

POPULATION No precise estimate of the total population is available, but during two days in March 1981 only between 12 and 17 individuals were located (by sight or by tracks) in the main ponds (6). It is considered likely that many more turtles take refuge in the abundant small sinkholes and other solution features found in the limestone substrate (6). Local inhabitants suggest that there are hundreds of turtles in total (6), this requires verification. Successful reproduction is probably occurring since local people report presence of juvenile turtles in the June-August rainy season, and significant numbers of adults are also noted at this time (6). It is not known if breeding occurs among turtles held in domestic water supplies (6).

HABITAT AND ECOLOGY A small to medium size (to $25 \mathrm{~cm}$ carapace length) aquatic species, restricted to temporary and semi-permanent freshwater ponds and rain puddles within an area of $2.5 \mathrm{~km}^{2}(2,6)$. The nine main ponds are formed in shallow depressions in the oolitic limestone substrate, often incorporating deeper solution cavities, and the intervening area includes numerous small pools and sinkholes (6). The surroundings carry scrub vegetation including Buttonwood Conocarpus erecta and Sea Grape Cocoloba uvuoa, some small pools are overgrown with Buttonwood. The ponds are irregular in outline, of ten with eroded overhanging rock margins, and are part-filled with a fine limestone mud sediment. Ponds of $10-20 \mathrm{~cm}$ depth have clear water, firm sediment, contain a species of aquatic grass, and are slightly warmer (and slightly more brackish) than deeper ponds. The latter, $30-50 \mathrm{~cm}$ in depth, have deep soft sediment, murky water, and lack aquatic grass. The ponds have abundant aquatic vegetation (7). Three species of aquatic plant, including Chara foliosa, were noted, and beds of reed and sedge occur in the muddy margins of some ponds (6). The turtle is reputed to be mainly vegetarian, captive individuals are often fed custard apples, and two faecal samples obtained showed plant fibres and epidermis (6). The largely vegetarian diet appears secure, at least seasonally (7).

Local informants suggest that turtles lie buried in the mud during the dry season and then are rarely seen, but are often encountered on rainy nights in the 
June-August wet season, moving on the road or in scrub far from the ponds (6). During a recent investigation no evidence was found that turtles do bury themselves in the mud; most turtles were found in the water of the two deeper ponds and a large female was found in a small solution hole next to a nearly dried-up pond (6). Tracks indicated that turtles regularly move overland up to $100 \mathrm{~m}$ from one water body to another, and they are reported by islanders to move much further afield after rain (6). It is likely that the survival of $\mathrm{P}$. felis depends on the persistence of suitable deep refugia, such as solution holes, that retain water as the main ponds dry out between rainy seasons (6).

THREATS TO SURVIVAL The species is at risk by virtue of its very small range, comprising a series of fluctuating freshwater ponds and sinkhole refugia within an area of only $2.5 \mathrm{~km}^{2}$ on a single island. Pseudemys felis is of ten caught for use locally as pets. It is sometimes used for food although this is reported to be decreasing (6). Custard apples, a native fruit, have been used to bait hooks to catch turtles (1). Reproduction is probably dependant upon adequate rains but rainfall is variable (2). The Cat Island economy is not expanding at present (6), but the presence of fresh water and potentially fertile soil in and near the ponds means they are at risk in the event of any new development, similarly, the only north-south road on the island runs alongside the ponds and road development is a possible threat (6). The potential threat by habitat disturbance is high, while the culinary threat appears less intense (7).

\section{CONSERVATION MEASURES TAKEN Nominally protected under Bahamian law.}

CONSERVATION MEASURES PROPOSED A conservation project is planned by the IUCN/SSC Freshwater Chelonia Specialist Group, considered highest priority. Basic biological field research is required. Because of the restricted area of $\mathrm{P}$. felis habitat it should be feasible to purchase and protect a major portion (6). Local education among the people of Knowles may reduce human predation (6).

CAPTIVE BREEDING The number of $P$. felis in captivity is not known. If a survey of the population determines that it is necessary, a captive breeding project will be established in cooperation with the Bahamas National Trust (2). Breeding potential is probably good, based on breeding success of congeners, but Hodsdon and Pearson ( 3 ) reported no success.

REMARKS This taxon has frequently been assigned to the genus Chrysemys. A consensus opinion is emerging that the Painted Turtle Chrysemys picta is generically distinct from the remaining group of species frequently assigned to the same genus, for which group the name Pseudemys should be used $(4,5,8)$. The Cat Island turtles have on occasion (9) been treated as merely an introduced population of the Jamaican $\underline{P}$. terrapen.

A first draft for this account was kindly provided by $\mathrm{K}$. Bjorndal (member of the Freshwater Chelonia Specialist Group for the Caribbean area) and was supplemented by data supplied by courtesy of J. Perran Ross.

REFERENCES 1. Barbour, T. and Shreve, B. (1935). Concerning some Bahamian reptiles, with notes on the fauna. Proc. Boston Soc. Nat. Hist. 40: 347-366.

2. Bjorndal, K. (1981). In litt., 23 January (draft RDB account for P. felis).

3. Hods̄on, L.A., and Pearson, J.F.W. (1943). Notes on the discovery and biology of two Bahaman fresh-water turtles of the genus Pseudemys. Proc. Fla. Acad. Sci. 6 (2): 17-23.

4. Moll, E.O. and Legler, J.M. (1971). The life history of a neotropical slider turtle, Pseudemys scripta (Schoepff) in 
Panama. Bull. Los Angeles Co. Mus. Nat. Hist. (Sci.) 11: $1-102$.

5. Pritchard, P.C.H. (1979). Encyclopedia of Turtles. T.F.H. Publications, New Jersey and Hong Kong.

6. Ross, J.P. (1981). In litt., 1 May.

7. Ross, J.P. (1981). In litt., 17 June.

8. Vogt, R.C. and McCoy, C.J. (1980). Status of the emydine turtle genera Chrysemys and Pseudemys. Annals Carnegie Mus. 49 (5): 93-102.

9. Wermuth, H. and Mertens, R. (1977). Testudines, Crocodylia, Rhynchocephalia. Das Tierreich. 100:1-174. 

SUMMARY An aquatic species, restricted to the few freshwater ponds on Great Inagua Island, Bahamas. Total population may comprise 200-500 individuals, but breeding success is dependent on the highly variable rainfall. Nominally protected under Bahaman law. The Bahamas National Trust plans to extend the Inagua Park to include some breeding ponds.

DISTRIBUTION Limited to the few freshwater, or somewhat brackish, ponds in the vicinity of Man of War Bay and Northwest Point on Great Inagua Island, the southernmost of the Bahama Islands. Introduced near Nassau, New Providence Island, where it may have interbred with other introduced species.

POPULATION An accurate count is not available, population estimated at between 200 and 500 individuals $(2,10)$. May be locally abundant (9). A survey in August 1980 , following three seasons of adequate rainfall, revealed that some successful breeding had occurred (3), following several years without success up to 1977 (7). Two hatchlings, less than one month old were found at one pond, also three juveniles probably born in the first year of good rain. A fourth juvenile of the same size-class was found in another pond (3).

HABITAT AND ECOLOGY A moderate size (adult female carapace length to $c$ $24 \mathrm{~cm}$ ) aquatic species. The first reported specimens of $\mathrm{P}$. malonei were found in

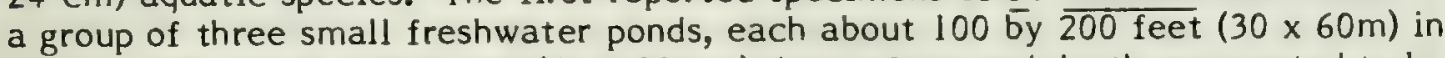
extent, and two to three feet $(60 \times 90 \mathrm{~cm})$ deep. Area and depth were noted to be dependent on rainfall, but the ponds appeared permanent (1). In one pond, female turtles were found hidden under the roots of rushes (6). There appeared to be fewer male turtles in each pond, those encountered were about one-third the size of females, and more cautious and agile (6).

There appear to be no rigid habitat preferences, any wet area, however transitory, may be utilized (4). Some specimens have been found in noticeably salty ponds, but salinity tolerances are not yet well known and turtles may inhabit such ponds only temporarily (4). A notable feature of the species' ecology is the apparent high mobility of individuals, especially after rains. After fairly heavy rains (June 1978) six turtles were found in one puddle, two days later both puddle and turtles were gone (4).

P. malonei is omnivorous; pieces of aquatic insects, fish eggs and aquatic vegetation, have been found in faeces (4). In one pond, large water boatmen (Corixidae) appeared to be the principal food (6). However, the available ponds differ greatly in the amount of vegetation and insects present, and the turtles' diet will vary accordingly (4).

In captivity (Miami), mating occurs around May, subsequently the females emerge from the water and seek suitable nesting sites (6). The nest is a circular depression two and a half to three inches $(63$ to $77 \mathrm{~mm})$ deep in the centre, and several inches in diameter. Excavation is done by the hind feet. All pebbles are carefully pushed away. Ten to 14 eggs are then laid, usually the former, and the nest then covered so no external trace remains. Two or three nests may be made, 
at one week intervals. The young emerge in August and disperse toward water (some young, in captivity at least, many remain in a state of aestivation for an undetermined period while still underground). (6).

A highly distinctive behaviour, apparently unique among turtles (5), is that captive female turtles have been reported to locate completed nests and facilitate emergence of the young by scratching earth away using the fore-feet (6). This behaviour requires confirmation in the wild population.

THREATS TO SURVIVAL Threatened primarily by natural mortality and low reproductive success, due to periodic drying-up of ponds. Formerly caught for human food (6), although (unlike the situation with P. felis on Cat Island) this may no longer be significant as inhabitants are well employed by the salt company. Some specimens are caught for sale to pet shops in Nassau, some losses may be due to predation by wild pigs and dogs (7).

CONSERVATION MEASURES TAKEN Nominally protected under Bahaman law, enforced by two wardens of the Bahamas National Trust (7).

CONSERVATION MEASURES PROPOSED The Bahamas National Trust has plans to extend the Inagua Park to include certain of the breeding ponds. A Conservation project (considered highest priority) is planned by the IUCN/SSC Freshwater Chelonia Specialist Group.

CAPTIVE BREEDING The proposed Bahamas Natural Trust captive breeding scheme on New Providence has been abandoned due to unforseen circumstances. Breeding potential in captivity is probably good $(6,7)$.

REMARKS This taxon has been treated as a subspecies of the Jamaican $P$. terrapen (12) and has frequently been assigned to the genus Chrysemys. $\bar{A}$ consensus opinion is emerging that the Painted Turtle Chrysemys picta is generically distinct from the remaining group of species frequently assigned to the same genus, for which group the name Pseudemys should be used $(8,9,11)$.

REFERENCES 1. Barbour, T., and Carr. A.F. (1938). Another Bahamian fresh-water tortoise. Proc. New England Zool. Club. 17: 75-76.

2. Bjorndal, K. (1977-1979). In litt., cited in reference 7.

3. Bjorndal, K. (1980). Pers. comm. October, Gainesville.

4. Bjorndal, K. (1981). In litt., 23 January.

5. Ehrenfeld, D.W. (1979). Behavior associated with nesting. In Harless, M. and Morlock, H. (Eds), Turtles, perspectives and research. John Wiley and Sons, New York. Pp. 417-434.

6. Hodsdon, L.A., and Pearson, J.F.W. (1943). Notes on the discovery and biology of two Bahaman fresh-water turtles of the genus Pseudemys. Proc. Fla. Acad. Sci. 6 (2): 17-23.

7. Honegger, R. (1979). Red Data Book, Vol 3: Amphibia and Reptilia. IUCN, Gland, (Third edition, revised).

8. Moll, E.O. and Legler, J.M. (1971). The life history of a neotropical slider turtle, Pseudemys scripta (Schoepff) in Panama. Bull. Los Angeles Co. Mus. Nat. Hist. (Sci.) 11: 1-102.

9. Pritchard, P.C.H. (1979). Encyclopedia of Turtles. T.F.H. Publications, Hong Kong and New Jersey.

10. Ross, P.A. (1979). In litt., 28 January, cited in reference 7.

11. Vogt, R.C. and McCoy, C.J. (1980). Status of the emydine turtle genera Chrysemys and Pseudemys. Annals Carnegie Mus. 49 (5): 93-102. 
12. Wermuth, H. and Mertens, R. (1977). Testudines, Crocodylia, Rhynchocephalia. Das Tierreich. 100: 1-174. 

Pseudemys rubriventris bangsi (Babcock 1937)

(Synonym: Chrysemys $\underline{\text { r. bangsi) }}$

Order TESTUDINES Family EMYDIDAE

SUMMARY An isolated subspecies of Red-bellied Turtle, restricted to southeast Massachusetts (U.S.A.), mainly in Plymouth County. Total population may be around 200, spread over 12 known ponds. A medium size, highly aquatic, freshwater form. Prefers ponds with a diverse aquatic flora, including milfoil Myriophyllum. Herbivorous. Probably a single clutch per season, comprising about 15 eggs. At risk due to the very small range, the very low number of individuals, low reproductive rate, and habitat disturbance. Listed as 'Endangered' under the U.S. Endangered Species Act. An area of Critical Habitat has been defined. Artificial induction of egg-laying, manipulation of sex ratios, and head-starting, are possible management procedures.

DISTRIBUTION Restricted to southeast Massachusetts (U.S.A.). Most localities are in Plymouth County, but there are three localities known in Carver County, and one record from Route 106 in Kingston. Eleven Donds in Plymouth Co. were found to hold this turtle in 1979-1980. The extremities of the known range encompass about $16 \mathrm{~km}$ in both N-S and E-W directions. The discovery of new localities in 1980 leads to some optimism that the actual range may be slightly larger than presently known (3).

POPULATION Total population for Plymouth County in 1979 was estimated at 80 animals. This estimate was derived from mark-recapture data from four ponds. Of 41 total captures the average was 10 turtles per pond, the total estimate was obtained by multiplying this average density per pond by the number of ponds then known to hold the subspecies. Subsequent observations at new localities allow the estimate for the total present (1981) population to be significantly greater than the 1979 estimate. The population at six of the 12 known ponds is estimated at 159 (3), and the total subspecies population may be approximately 200 non-hatchling animals (2). Federal Pond in Carver Co. probably holds over half the total population.

HABITAT AND ECOLOGY A medium size, highly aquatic, freshwater turtle. Females may reach about $32 \mathrm{~cm}$ carapace length, males typically about $27 \mathrm{~cm}(1)$. Inhabits ponds with a mud substrate in the shallower portions, and a highly diverse aquatic flora, usually including milfoil Myriophyllum. Ponds are small to moderate size, generally in 'pine barrens' habitat (1). Active between mid-April, when water temperatures rise to $13-14^{\circ} \mathrm{C}$, and mid-October, when water temperatures fall below this level. Individuals may wander overland for significant distances.

Apparently entirely herbivorous; stomach flushings obtained in 1979-1980 indicate the main plants utilized, in descending order or importance, are species of: Myriophyllum, Spirogyra, Utricularia, Sagittaria and Brasenia (3).

Nesting occurs in June or possibly May (4). Mean clutch size is 15.4 eggs (sample of 7 females greater than $25 \mathrm{~m}$ length). There is thought to be a single clutch per year (4). Annual productivity at Federal Pond (with by far the largest known population, estimated at 114-159 animals above $8 \mathrm{~cm}$ in length) (4) is estimated at 
a maximum of 385 eggs; total hatchling output may be a little more than 100 (3).

THREATS TO SURVIVAL At risk due to the very small range and low number of individuals. All but one or two of the 12 ponds known to hold the species in 1980 are within one area of 1,500 acres (1). One of the remaining ponds, Billington Sea, has been highly modified by development (1). Females have low reproductive rates. Human activities cause frequent disturbance.

CONSERVATION MEASIJRES TAKEN Listed as 'Endangered' under the IJ.S. Endangered Species Act 1973 (1). An area of Critical Habitat in Plymouth Co., Mass has been defined, including 11 ponds (1), some of which were confirmed to hold the subspecies in 1980 (3). Considerable research has been undertaken on the biology of the Plymouth Red-bellied Turtle $(3,4,5,6)$.

Induction of egg-laying in gravid females (by injection of synthetic oxytocin) has been performed to obtain eggs for incubation, with subsequent 'head-starting' and release of juveniles $(4,6)$.

CONSERVATION MEASURES PROPOSEN Further hormonal induction of oviposition, and subsequent artificial incubation and head-starting is thought to have great potential as a means of supplementing populations with deficient recruitment levels $(4,6)$. Current technical problems may be resolved by research on related non-threatened turtle species (4). It may also be possible, by controlling the temperature of incubation, to artificially bias the sex ratio toward females; this again may increase recruitment (sex in chelonians is determined at a critical phase in embryonic development during which temperature dictates either male or female development). The species is polygamous. More females in a population should result in increased annual productivity. The sex ratio at Federal Pond, the only large population known, is 1.875 females to 1 male. This may be due to more open, thus better insolated, nest areas, resulting in increased production of females.

\section{CAPTIVE BREEDING No information. See Conservation Measures Taken.}

REMARKS This taxon has sometimes been assigned to the genus Chrysemys. A consensus opinion is emerging that the Painted Turtle Chrysemys picta is generically distinct from the remaining group of species frequently assigned to the same genus, for which group the name Pseudemys should be used (8). The second (nominate) subspecies of P. rubriventris ranges from southern New Jersey, inland to the eastern tip of West Virginia, and south to extreme east North Carolina (7). The taxonomic distinctness of the Massachusetts population has been subject to dispute, but it is now generally regarded as a separate taxon $\underline{P} . \underline{r}$. bangsi.

Most information in this account is derived from the work of T.E. Graham.

REFERENCES I. Anon (U.S. Fish and Wildlife Service) (1980). Listing as Endangered with Critical Habitat for the Plymouth Red-Bellied Turtle in Massachusetts. Federal Register 45(65): 21828-21833.

2. Anon. (1981). Strategy prepared for Plymouth Red-bellied Turtle. Endangered Species Technical Bull. 6(6): 1,3.

3. Graham, T.E. (1981). The status of the Plymouth Red-bellied Turtle, Chrysemys rubriventris bangsi, from southeastern Massachusetts. Final Report (1980-1981), submitted to U.S. Fish and Wildlife Service.

4. Graham, T.E. (1981). Life history and status studies of the 
Plymouth Red-bellied Turtle Pseudemys (= Chrysemys) rubriventris bangsi in southeastern Massachusetts. Progress report, submitted to Mass. Division of Fisheries and Wildlife.

5. Graham, T.E. (1981). Troubled Turtles. Mass. Wildl. 32(3): 18-19.

6. Graham, T.E. (1981). New approaches to endangered turtle research. Bios. 50(3): 121-126.

7. Pritchard, P.C.H. (1979). Fncyclopedia of Turtles, T.F.H. Publications, Hong Kong and New Jersey.

8. Vogt, R.C. and McCoy, C.J. (1980). Status of the emydine turtle genera Chrysemys and Pseudemys. Annals rarnegie Mus. 49 (5): 93-102. 

Pseudemys scripta callirostris (Gray 1855)

(Synonyms: Chrysemys s. callirostris, $\underline{\text { P. ornata callirostris }}$

Order TESTUDINES Family EMYDIDÁE

SUMMARY A medium sized distinct subspecies of the widespread and rather generalized freshwater turtle, Pseudemys scripta. Present in extreme northern Colombia (in the lower Magdalena and Sinu drainages), and extreme northwest Venezuela (around Lake Maracaibo). Formerly more widespread in Colombia, populations now depleted over much of the range, locally extinct; status in Venezuela uncertain. Occurs in a variety of wetland habitats. Omnivorous. Probably two clutches per year, each of 9-25 eggs. Eggs and turtles heavily utilized as a food source, also threatened by habitat loss. Former mass export for the pet trade has decreased, but protective legislation is not fully enforced.

DISTRIBUTION Found in extreme northern Colombia and extreme northwest Venezuela (3). The present range is essentially the valleys of the lower Magdalena and Sinu rivers (5). Formerly the species extended west to the Cienaga de Marimonda and other localities on the east side of the Gulf of Uraba, and east to the Rio Rancheria in Guajira; but the easternmost population, at least, has been extirpated $(4,5)$. The subspecies is absent from the arid Guajira Peninsula and upland zones in eastern Colombia, but occurs again in extreme northwest Venezuela at a few localities in the Lake Maracaibo drainage (4).

POPULATION Apparently declining in Colombia $(1,2,4)$. Extinct in the Guajira region (4,5). Almost extirpated in the extreme north coastal zone, from Baranquilla through Cartagena to Sincelejo, very scarce in the Laguna de Betanci, still in fair numbers in the Ciénaga de Ayapel, Rio San Jorge and Ciénaga Crande, diminishing gradually in the lower Magdalena and the Caribbean coast generally $(1,2)$. The future of callirostris in Colombia is viewed with great concern (4). No status data for Venezuela, but callirostris may have an extremely limited range (4).

HABITAT AND ECOLOGY A rather generalized freshwater turtle, occasionally reaching $30 \mathrm{~cm}$ in length, but more usually around $20 \mathrm{~cm}$ (and thus somewhat smaller than other tropical forms of the $\underline{P}$. scripta complex) (4). Found in a variety of wetland habitats, including swamps, marshes and lagoons $(1,4,5)$. As with other forms of $\mathrm{P}$. scripta, probably opportunistic and omnivorous in feeding behaviour (4). Mating occurs in September-December, in deep quiet water; nesting occurs in December-April, the driest time of year. Eggs are elongạte, soft-shelled, ranging from $27 \times 21 \mathrm{~mm}$, weight $5.2 \mathrm{gm}$, to $41 \times 26 \mathrm{~mm}, 15.7 \mathrm{gm}(5)$. Clutch size $9-25$, sometimes up to 30 , probably correlated with size and age of the female. Probably two clutches per year. Nests are excavated a few or several metres from water, often partly or largely shaded by vegetation (5). Hatchlings emerge mostly in late April- early June, often coincident with the start of the rainy season (5).

THREATS TO SURVIVAL Heavily utilized as a food source throughout the range (4), including both turtles and eggs during the nesting season. Large numbers are caught early in the year and stored until sold in city markets during Holy Week, when consumption of mammalian meat is forbidden by the Catholic Church $(4,5)$. It is reported that turtle meat is so appreciated that this traditional period of 
self-deprivation has become a welcomed feast time (4). Eggs are also heavily exploited for food (4). Hatchlings are gathered in large numbers for the live animal trade, or to be made into various ornaments and trinkets (4). Turtles and eggs are often destroyed by the deliberate setting of fires during the dry season (4). Suitable wetland habitat is reportedly being lost locally (I).

CONSERVATION MEASURES TAKEN Nominally protected by legislation in Colombia (5); trade in hatchlings and adults, egg-collection (1), and setting of fires (4), are illegal. Mass export for the pet trade has ceased, although large numbers are still available in Europe (1).

CONSERVATION MEASURES PROPOSED Protection is required for suitable breeding sites $(2,5)$. Enforcement of existing legislation in Colombia prohibiting capture for food. Status in Venezuela requires investigation.

CAPTIVE BREEDING Although many specimens exist in captivity, the breeding potential is poor (i). No further data.

REMARKS Populations usually ranked as subspecies of pseudemys scripta are relatively widespread in the Americas, ranging from the eastern and southern states of the U.S.A. (from southeast Virginia), through Central America to Colombia and Venezuela in northern South America, and more locally south to Argentina (3). More easterly populations in Venezuela, formerly assigned to P. S. callirostris, are now considered sufficiently distinct to warrant description (in press) as a new subspecies of $\underline{P}$. scripta (4).

Some taxonomists have referred to the populations now usually known as $P$. scripta as ' $\underline{P}$. ornata', and the generic name Chrysemys is sometimes used for this and other species now usually assigned to Pseudemys (3).

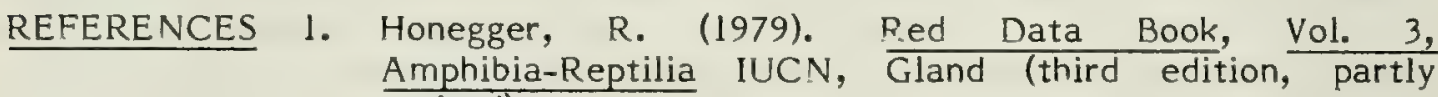
revised).

2. Medem, F. (1969-1979). In litt., to R. Honegger, cited in ref. 1 .

3. Pritchard, P.C.H. (1979). Encyclopedia of Turtles. T.F.H. Publications, New Jersey and Hong Kong.

4. Pritchard, P.C.H. (1982). In litt., 22 March. Manuscript of Monograph of the turtles of Venezuela, in press.

5. Medem, F. (1975). La reproduccion de la 'Icotea' (Pseudemys scripta callirostris) (Testudines, Emydidae). Caldasia 11 $(5 \overline{3}): 83-106$. 
Rhinoclemmys areolata (Dumeril, Bibron and Dumeril 1851)

Order TESTUDINES

Family

EMYDIDAE

SUMMARY A secretive species confined to the Atlantic versant of southeast Mexico, Belize, Guatemala, and northwest Honduras. Generally rare, but was once common in Guatemala and on Cozumel Island (Mexico). No conservation measures taken. Data on population status and other aspects of biology are required.

DISTRIBUTION Present on the Atlantic slopes of northern Central America. Known in Mexico from southern Veracruz, Tabasco, northern Chiapas, Campeche, Quintana Roo (including Cozumel Island), and Yucatan, and extends southward through Guatemala and Belize to northwestern Honduras $(1,3,4)$.

POPULATION Generally rare, but was once locally common (5). No recent data. Known from about 170 museum specimens (representing about 45 localities), nearly half of which are from Cozumel Island (off the Yucatan Peninsula) and the Peten region of Guatemala (3).

HABITAT AVD ECOLOGY Inhabits forests and savannas. Most commonly encountered during the wet season (3,5). Lays a single very large egg (3), probably more than once during the period of activity. Biological information on this species is almost completely lacking.

THREATS TO SURVIVAL No information.

CON SERVATION MEASURES TAKEN N one.

CON SERVATION MEASURES PROPOSER The IUCV/SSC Freshwater Chelonian Specialist Group has listed a study of the distribution and population status of this species as a priority project.

CAPTIVE BREEDIN G Has been bred in captivity at least once (2).

REMARKS This account was prepared by J.B. Iverson (member, IUCN/SSC Freshwater Chelonian Specialist Group).

REFERENCES 1. Ernst, C.H. (1980). Rhinoclemmys areolata. Cat. Amer. Amphib. Rept. 251: 1-2.

2. Ewert, M.A. (1979). The embryo and its egg: development and natural history, pp. 333-413. In Harless, $M$, and Morlock, H. (Eds.), Turtles: Perspectives and research. Wiley-Interscience, $N$ ew York.

3. Iverson, J.B. (unpublished).

4. Smith, H.M. and Smith, R. (1980). Synopsis of the Herpetofauna of Mexico. Vol. VI. Guide to Mexican turtles. Bibliographic Addendum III. John Johnson, North Bennington, Vermont. $1044 \mathrm{p}$.

5. Stuart, L.C. (1935). A contribution to a knowledge of the herpetology of a portion of the savanna region of central Peten, Guatemala. Misc. Publ. Mus. Zool. Univ. Michigan (29): $1-56$. 

SUMMARY An apparently rare species confined to two isolated areas in the Pacific coastal lowlands of Mexico. Basic ecological data and population status information are needed. No conservation measures taken.

DISTRIBUTION Present in lowlands on the Pacific coast of Mexico. The two described subspecies are separated by a gap of about 400 miles, including the entire state of Guerrero; R. $r$. perixantha from Michoacan, Jalisco and southern Colima, and R. r. rubida from a small part of Chiapas and several localities in Oaxaca $(1,5,7)$. Known from a total of less than 100 museum specimens and from about 35 localities.

HABITAT AND ECOLOGY Inhabits lowland tropical forests, where it lives terrestrially $(4,5)$, feeding at least in part on animal matter (2). In captivity it eats both plant and animal material (4). Apparently active only during the rainy season (June to November) (4).

THREATS TO SURVIVAL Vo information, except that the species sometimes appears for sale in the pet trade in the United States (4).

CON SERVATION MEASURES TAKEV N one.

COV SERVATION MEASURES PROPCSER The IUCN/SSC Freshwater Chelonian Specialist Group has listed a study of the distribution and population status of this species as a priority project.

CAPTIVE BREEDING Has been bred in captivity at least once (2).

REMARKS This account is based almost entirely on a draft prepared by J.B. Iverson (member, IUCN /SSC Freshwater Chelonian Specialist Group).

REFEREV CES 1. Ernst, C.H. (1991). Rhinoclemmys rubida. Cat. Amer. Amphib. Rept. 277: 1-2.

2. Ewert, M.A. (1979). The embryo and its egg: development and natural history, pp. 333-413. In Harless, M. and Morlock, H. (eds.), Turtles: Perspectives and research. Wiley-Interscience, $N$ ew York.

3. Hartweg, V. and Oliver, J.A. (1940). A contribution to the herpetology of the Isthmus of Tehuantepec. IV. Misc. Publ. Mus. Zool. Univ. Michigan (47): 1-31.

4. Iverson, J. (unpublished).

5. Mosimann, J.E. and Rabb, G.B. (1953). A new subspecies of the turtle Geoemyda rubida (Cope) from western Hexico. Occas. Pap. Mus. Zool. Univ. Michigan 548: 1-7.

6. Smith, H.M. and Smith R.B. (1975). An analysis of the knowledge of the turtle fauna of Mexico. Cheionia 2(3): 3-8.

7. Pritchard, P.C.H. (1979). Encyclopedia of Turtles. T.F.H. Puolications, Hong Kong and $\mathrm{V}$ ew Jersey. 

SUMMARY An aquatic species of the otherwise terrestrial emydid genus Terrapene. Restricted to marshy localities in the intermontane desert basin of Cuatro Cienegas, Coahuila State, northern Mexico. Populations may be relatively dense in some marshes (around 60 turtles per acre of marsh), but the species is threatened by drainage, is at risk also because of the very small range and the restricted movement hetween marsh populations. Habitat protection is required. Listed on CITES Appendix 1.

DISTRIBUTION Restricted to marshy localities within a semi-isolated intermontane basin, not exceeding $800 \mathrm{~km}^{2}$ in area, lying mostly south of Cuatro Cienegas town (Coahuila State, northern Vexico) in the Chihuahuan Desert (1).

POPULATION The species occurs in disjunct populations limited to marshy areas of the Cuatro Cienegas basin. Mark-recapture studies carried out between December 1964 and October 1966 suggest a typical density of 60 turtles per acre of marsh $(148 / \mathrm{ha})(1)$. While this is a much higher density than reported for terrestrial Box Turtles Terrapene, it is comparable to that of other aquatic turtles (data cited in (1)). It should be noted that this estimate refers to each acre of marsh, not to each acre of the entire basin. There are no more recent quantitative population estimates, these data are required to evaluate the impact of recent habitat changes.

HABITAT AVD ECOLOGY A secondarily aquatic species in the otherwise terrestrial genus of Box Turtles Terrapene (within the primarily aquatic family Emydidae). Preferred habitat is small spring-fed marshes, with shallow water, a mud bottom and dense aquatic vegetation, principally stoneworts Chara spp., the sedge Eleocharis rostellata, bullrushes Scirpus olneyi, and frequently the seep-willow Baccharis glutinosa. Each marsh system is sharply distinct from the halophytic grass communities in the surrounding dry zones (1).

Foraging behaviour and diet are more similar to other aquatic emydids than to terrestrial Terrapene. The species forages in shallow water, following an erratic course, the head is extended below the surface while the carapace remains above surface, the forelimbs being used to expose feeding sites. It is omnivorous and opportunistic, feeding almost equally (by volume) on aquatic plants and on invertebrates (notably stratiomyid fly larvae, beetles, Odonata nymphs, and Hemiptera) (1).

I. coahuila is active throughout the year except for short periods of extreme cold or heat. Mating occurs between September and June, most commonly in March and April (but has also been recorded in November and December). The female ovarian cycle appears intermediate between the extended cycle of tropical emydids and the short cycle of north temperate species restricted by cool temperatures. Egg laying occurs between May and September, typically with two or three eggs per clutch. It is estimated that half the females can produce two 
clutches each season and about a third may produce three clutches in a season. No data are available on age-specific mortality (1).

THREATS TO SURVIVAL The Coahuilan Box Turtle is at risk by virtue of its very small world range (the Cuatro Cienegas basin), its localized distribution within the basin, and the restricted movement of individuals across the inhospitable terrain separating each matsh population. It is threatened primarily by habitat destruction due to the demand for water for irrigation and industry $(1,3,4)$.

Canals are being dug, or deepened, to provide adequate water flow in the Rio Salado de los $\mathrm{N}$ adadores that in turn is the primary water source for a large steel mill complex in Monclova (4). Irrigation water is also derived from this river, but volumes are minor compared to steel mill requirements (4). Construction of irrigation canals destroyed one extensive marsh area (Posos de la Becerra) in December 1964; up to 7400 T. coahuila may have died or emigrated (1). The very large $T$. coahuila population at Rancho San Marcos was destroyed at some time between March 1964 and June 1968 (4). The marshy area around the spring at this locality was inadvertently drained by a culvert placed during construction of the Cuatro Cienegas to San Pedro de las Colonias highway. This highway has eased access to the Cuatro Cienegas basin, resulting in many more visitors to the area with consequent impact on the fauna (4). During the last five years the area around EI Mojanal has become increasingly dry due to agricultural usage, many dead turtles (taxon unspecified) were found there in 1976 (3). In 1979 a pipeline was being installed alongside the highway from the industrial town of Monterrey (3), it was reported at the time that the pipeline was heading for the mountains north of the town, and these mountains are the source of the Cuatro Cienegas aquifer (3). Although some sources (2 - quoting remarks of 11. L. Minckley, 4) report that aquatic habitats have not changed dramatically during the past decade or so, others (3) note much-increased agricultural and recreational impact on the Cuatro Cienegas area. Some injury and mortality can probably be attributed to the widespread practice of grass burning in the basin. (1).

CON SERVATION MEASURES TAKEN Listed on Appendix 1 of the Convention on International Trade in Fndangered Species of Wild Fauna and Flora (CITES). Appendix I listing requires that trade in the taxon and its products is subject to strict regulation by ratifying states and international trade for primarily commercial purposes is prohibited.

CON SERVATION MEASURES PROPOSEN Restrictions should be placed on the indiscriminate construction of irrigation canals, and an overall strategy is required to conserve prime aquatic habitats in the Cuatro Cienegas basin (see Remarks, first paragraph) (1). The IUCN/SSC Freshwater Chelonia Specialist Group plans a highest priority project on conservation of the Cuatro Cienegas basin endemic turtles. Recent population data required. The species should be protected by legislation to limit collecting (1).

CAPTIVE BREEDING Present numbers in captivity unknown. About 30 specimens have been maintained in an artificial outdoor pond at Arizona State University, copulation has been observed (1), but no further information is available. Has bred at Dallas Zoo (3).

REMARKS A high degree of endemism exists among the snails, crustaceans and fishes of the Cuatro Cienegas basin (6). Three of the four turtle taxa are endemic, comprising the species Terrapene coahuila, 'Trionyx ater' (also on CITES Appendix 1), and the subspecies Pseudemys scripta taylori (I). It has recently been proposed (7) that the population 'T. ater' has been absorbed by $\mathrm{T}$. spiniferus emoryi that has gained access to the basin following the construction of a network 
of irrigation canals. Accordingly ater is treated as an extinct subspecies, $\mathrm{T}$. spiniferus ater (7).

Terrapene coahuila may be descended from a common ancestor shared with the $T$. carolina subspecies T. c. triunguis, T. c. mexicana and T. C. yucatana, and may have entered the Cuatro Cienegas basin during a Pleistocene pluvial phase. Adoption of aquatic habits may have enabled the species to survive during subsequent arid conditions (5).

This account is based largely on the work of W.S. Brown (reference 1), and information received from K.R. Garstka, C.J. McCoy, and R.G. Webb.

REFERENCES 1. Brown, H.S. (1974). Ecology of the Aquatic Box Turtle, Terrapene coahuila (Chelonia, Emydidae) in northern Mexico. Bull. Florida State Mus., Biol. Sci. 19(1): 1-67.

2. Brown, K.S. (1981). In litt., 21 March.

3. Garstka, K.R. (1981). In litt., 9 February.

4. McCoy, C.J. (1981). In litt., 26 January.

5. Milstead, K. K. (1969). Studies on the evolution of Box Turtles (genus Terrapene). Bull. Florida State Mus., Biol. Sci. 14(1): $1-113$.

6. Minckley, X.L. (1969). Environments of the bolson of Cuatro Cienegas, Coahuila, Mexico, with special reference to the aquatic biota. Sci. Ser. No.2, Texas Western Press, Univ. of Texas, El Paso. 65pp. (cited in ref. 1).

7. Smith, H.M. and Smith, R.B. (1979). Synopsis of the Herpetofauna of Mexico. Vol.6. Guide to Mexican turtles. J. Johnson, N. Bennington, Vermont. Pp xvili + 1044 . 

Geochelone carbonaria (Spix 1824)

(Synonyms: Chelonoidis carbonaria, Testudo carbonaria)

Order TESTUDINES Family TESTUNINIDAE

SUMMARY Occurs over much of the tropical lowlands of South America, in both forest and savannah. Eaten widely and occurs in trade. Information on population status needed. Listed on Appendix II of CITES.

DISTRIBUTION Occurs over much of the tropical lowlands of South America, west of the Andes. The range extends from the Choco of Colombia, and western Panama, south through the Guianas and Rrazil (south as far as Rio de Janeiro) to Paraguay (2). Also found on Trinidad (probably naturally), and on several of the Lesser Antilles (probably introduced). Does not occur in the upper reaches of the Amazon drainage, in Amazonas (Brazil), Peru, southeast Colombia or Bolivia. Sympatric with $\underline{G}$. denticulata over much of the range (2).

POPULATION No quantitative data, strongly suspected to be declining in response to heavy exploitation $(3,5)$.

HABITAT AND ECOLOGY A medium sized species, adults reach about $30 \mathrm{~cm}(12$ inches) in length, the largest known specimen had a shell length of $45 \mathrm{~cm}$ (near 18 inches). The males are slightly larger than the females. There is considerable variation in colour and size over the range. Occurs in both forest and savannah areas, apparently favouring savannah areas in Surinam at least. In Colombia clutches of 5-15 eggs laid from July to September are reported, and round 8-13 eggs per clutch in Panama. In Guyana the species appears to excavate a typical tortoise nest, but local people in Panama maintain that the eggs are not buried but deposited in the leaf litter on the forest floor (2).

THREATS TO SURVIVAL This species is highly esteemed as a food source and is eaten widely, especially during Holy Week in Catholic areas. Reportedly it is the most popular wild meat amongst the San Blas Indians in Panama. Also occurs commonly in trade; hundreds per year are exported through Bolivia to Miami, and 600 were confiscated at one place and time in Venezuela $(2,3)$.

CONSERVATION MEASURES TAKEN Listed on Appendix II of the International Convention on International Trade in Wild Fauna and Flora (CITES). Appendix II listing implies that commercial trade is allowed providing a permit from the country of export is obtained, this can provide a method of monitoring trade levels.

CONSERVATION MEASURES PROPOSED A status survey of this species is needed (4,5). Regulation of trade is also desirable (4).

CAPTIVE BREEDING In 197947 individuals were bred in captivity at 7 centres (1).

REMARKS It has recently been proposed (6) that several taxa usually recognized as subgenera of Geochelone should be elevated to generic rank, in this case as Chelonoidis. This usage is not yet widespread. 
REFERENCES 1. Olney, P.J.S. (Ed.) (1981). International Zoo Yearbook. Vol. 21. Zoological Society of London.

2. Pritchard, P.C.H. (1979). Encylopedia of Turtles. T.F.H. Publications, New Jersey and Hong Kong.

3. Pritchard, P.C.H. (1981). Statements made at First Meeting IUCN/SSC Tortoise Specialist Group, Oxford 1-2 October.

4. Swingland, I.R. (1981). Report of First Meeting IUCN/SSC Tortoise Specialist Group, Oxford 1-2 October.

5. Anon. (1981). Various statements by participants at the First Meeting of IUCN/SSC Tortoise Specialist Group, Oxford 1-2 October.

6. Bour, R. (1980). Essai sur la taxinomie des Testudinidae actuels (Reptilia, Chelonii). Bull. Mus. natn. Hist. nat. Paris, 4 ser., 2, section A, No. 2:541-546. 
Geochelone chilensis (Gray 1870)

(Synonyms: Chelonoidis chilensis, Testudo chilensis and including $\underline{G}$. donosobarrosi, $\underline{G}$. petersi)

Order TESTUDINES Family TESTUDINIDAE

SUMMARY A medium size terrestrial tortoise, restricted to rather arid lowlands, mainly in the Chaco region, in southern South America. Ranges through Argentina from northern Patagonia north into western Paraguay and probably adjacent Bolivia. Central and northern populations in Argentina reportedly in severe decline due to over-exploitation for the international live animal trade. Specimens are exported through Bolivia mainly to U.S.A. Mainly herbivorous. Clutch comprises up to six eggs. Two new species have recently been described from within the range of $G$. chilensis, these are not widely recognised and may not be distinct species. Listed on CITES Appendix II.

DISTRIBUTION Widespread in dry lowlands of central South America; from the Gran Chaco region of Paraguay, probably parts of adjacent Bolivia, south through the Chaco region of north and central Argentina to the northern fringes of Patagonia $(1,4,7)$. See taxonomic comment in Remarks section, below.

POPULATION Reportedly in severe decline $(4,5)$ in the main part of the range, comprising the Argentinian Chaco; relatively secure in Paraguay. No data for Bolivia.

Argentina Northern and central populations reported to be declining severely, but southern populations ('G. donosoharrosi') appear secure, although existing in low density $(4,5)$. In the late 1960 s a maximum density of 15-20 $\underline{G}$. chilensis per acre were recorded in optimum habitat in Cordoba (1).

Paraguay Reasonably abundant in much of the range, the majority of which is inaccessible to man; no evidence for decline (8).

HABITAT AND ECOLOGY A medium size terrestrial tortoise, inhabiting arid lowlands, most typically in thorny chaco habitats $(1,7)$. Shallow pallets are excavated, deep enough to cover the anterior third or half of the shell, in which nights and much of the day are spent (1). A somewhat deeper pallet is formed for shelter during cold and dry periods (1). Mainly herbivorous, consuming the fruit of various trees and shrubs, pads and fruit of cacti, and grasses (1). Courtship occurs in November-December and a clutch of up to six round white eggs, $c 4.5 \mathrm{~cm}$ diameter, is laid in January (4).

THREATS TO SURVIVAL Threatened mainly by exploitation for the live animal trade, and by local utilization as a food source. In the north and centre of Argentina G. chilensis (and G. petersi) are collected, taken to Buenos Aires, and then exported via Bolivia in thousands (with other wildlife) to U.S.A. (5). Also reportedly exported, in the 1960 s at least, to Santiago (Chile) (1). In Argentina, adult specimens collected that are not sold for the wildlife trade are eaten by local inhabitants (4).

CONSERVATION MEASURES TAKEN Nominally protected by legislation in 
Argentina (Ley No. 13.908) (4). Export of wildlife from Paraguay is prohibited except under permit, reportedly (8) permits are now issued only for scientific specimens. Apparently not within any protected areas in Argentina (4).

Listed on Appendix II of the Convention on International Trade in Endangered Species of Wild Fauna and Flora (CITES). Appendix II listing implies that commercial trade is allowed providing a permit from the country of export is obtained, this can provide a method of monitoring trade levels.

CONSERVATION MEASURES PROPOSED Existing laws should be adequately enforced and international trade restricted. The taxonomic status of 'G. petersi' and ' $\mathrm{G}$. donosobarrosi' requires investigation (see Remarks).

\section{CAPTIVE BREEDING Potential for captive breeding reported poor (6). No} further data.

REMARKS All land tortoises in South America, other than the two forest and savanna Geochelone species in the northern half of the continent, have usually been referred to the single species $G$. chilensis. Two new species, G. petersi and G. donosobarrosi, have recently been described, based on specimens from central $\bar{A}$ rgentina and extreme northern Patagonia, respectively (3). The validity of these new taxa has not been widely accepted $(2,7,9)$; pending further discussion the older taxonomic arrangement is retained here. It appears that 'petersi' may be based simply on juvenile chilensis (2), but donosobarrosi appears more distinct and is the more likely of the two to deserve species status.

It has recently been proposed (10) that several taxa usually recognized as subgenera of Geochelone should be elevated to generic rank, in this case as Chelonoidis. This usage is not yet widespread.

REFERENCES 1. Auffenberg, W. (1969). Land of the Chaco Tortoise Geochelone chilensis. Internat. Turtle and Tortoise Soc. J. 3(3): $16-19,36-37$.

2. Auffenberg, W. (undated). Pers. comm., to P. Pritchard, cited in ref 7.

3. Freiberg, M.A. (1973). Dos nuevas tortugas terrestres de Argentina. Bol. Soc. Biol. Concepcion, Chile, 46: 81-93.

4. Freiberg, M.A. (1974). The Argentine Land Tortoise, Geochelone chilensis, an endangered species. Bull. Maryland Herp. Soc. 10(2): 39-41.

5. Freiberg, M.A. (1981). In litt., 16 March.

6. Honegger, R. (1979). Red Data Book, Vol. 3, Amphibia-Reptilia. IUCN, Gland (third edition, partly revised).

7. Pritchard, P.C.H. (1979). Encyclopedia of turtles. T.F.H. Publications, New Jersey and Hong Kong.

8. Scott, N. (1981). In litt., 23 December.

9. Wermuth, H., and Mertens, R. (1977). Testudines, Crocodylia, Rhynchocephalia. Das Tierreich 100: 1-174. Berlin, Walter de Gruyter.

10. Bour, R. (1980). Essai sur la taxinomie des Testudinidae actuels (Reptilia, Chelonii). Bull. Mus. natn. Hist. nat. Paris. 4 sér., 2, section A, No 2: $541-546$. 
Geochelone elephantopus (Harlan 1827)

(Synonyms: Chelonoidis species)

Order TESTUDINES

Family TESTUDINIDAE

SUMMARY Occurs on most islands in the Galapagos group (Ecuador) in the east Pacific. Populations severely depleted in nineteenth century through overcollection by whaling ships for stores. Natural reproduction presently reduced (and in some populations prevented) by introduced mammal predators. Important captive breeding and rearing projects are being carried out at the Charles Darwin Research Station. Strictly protected in the Galapagos, which were declared a National Park in 1959. Listed on Appendix I of CITES.

DISTRIBUTION Restricted to the Galapagos Islands (Archipiélago de Colon) (Ecuador), astride the equator in the east Pacific (See Population section for further details).

POPULATION Populations are isolated on different islands, or on Isabela by impassable lava flows. They have traditionally been treated as subspecies of Geochelone elephantophus but it has recently been proposed (1) that they might be more appropriately treated as full species of the genus Chelonoidis. Pending further discussion the more conservative arrangement is retained here. Population details for each subspecies are summarised below.

G. e. abingdoni Formerly restricted to the southern slopes of Pinta (Abington Island) (3,10). Only one known individual is alive ("Lonesome George"), and is currently maintained at the Charles Darwin Research Station. This population was severely depleted by whalers and fishermen, and the introduction of goats in 1958 resulted in massive destruction of vegetation $(12,14)$. Tortoise droppings, probably not more than a few years old, were found in the island in 1981, so there is a possibility that a second individual of this subspecies still exists (16). Further investigations are planned for 1982.

G. e. becki Northern and western slopes of Volcano Wolf, Northern Isabela (Albermarle). Present population may be as many as 2,00n. Reproduction appears to be successful despite the presence of black rats and feral cats, but the impact of these predators is not known $(8,13)$.

G. e. chathamensis Now confined to northeast San Cristobal (Chatham). Present population between 500 and 700. Heavily exploited and completely eliminated over much of its original range (3). Effective reproduction is now prevented by trampling of nests by feral donkeys, and the destruction of young by feral dogs $(6,8,13)$. Eggs from wild nests have been removed for incubation and rearing to the Charles Darwin Research Station (5). In 1979139 juveniles had been returned to the island and 13 were held at the station (13).

G. e. darwini West-central San Salvador (James Island). Large numbers of tortoises were removed from the island in the early nineteenth century by whaling vessels, and introduced goats reduced the coastal lowlands to deserts, restricting the remaining tortoises to the interior (8). The sex ratio is strongly imbalanced in favour of the males (8) and most nests and young are destroyed be feral pigs $(4,8)$. It is estimated that reproductive success diminished about 50 years ago and 
ceased altogether about 30 years ago (8). Some nests are now protected by lava corals and since 1970 eggs have been transported to the Charles Darwin Research Station for hatching and rearing. 115 individuals have been re-released on San Salvador (13).

G. e. elephantopus Cerro Azul, Eastern Isabela (Albemarle). Range overlaps with G. e. guentheri and it may eventually be shown that these two taxa should be combined $(6,8)$. This population was depleted by seamen in the last two centuries and by extensive slaughter in the late 1950's and 60's by employees of cattle companies based at Iguana Cove. Present population may number as many as 700 individuals. Although mating and nesting still occur naturally, very few young individuals are found, suggesting that predation by local feral dogs, cats and pigs is almost total $(6,8)$. Eggs and hatchlings are removed to the Charles Darwin Research Station. Since 1971, 114 indiviuals have been returned to the island (13).

G. e. ephippium Southwestern slopes of Pinzon (Duncan Island). Although relatively undisturbed by whalers, fairly large numbers of tortoises were removed by expeditions in the latter half of the nineteenth century and early this century $(2,8)$. Present population is about 150 adults. Since the introduction of black rats some time before 1900, there has been no natural recruitment. Despite the age of the remaining population the females are still laying fertile eggs. Since 1965, eggs have been transported to the Charles Darwin Research Station for hatching and rearing. So far 182 young tortoises have been returned to the island (13).

G. e. galapagoensis Floreana (Charles Island). Extinct. Formerly abundant but heavily exploited by visiting ships and a penal colony in the last century (8).

G. e. guentheri Volcano Sierra Negra, Isabela (Albemarle). Severely depleted by settlement and exploitation for tortoise oil which continued until the 1950s. 300-500 individuals remain, divided into two groups by settlements. About 300 occur in the east and 200 over the western and southwestern slopes $(4,13)$. Reproduction seems successful in the east but in the western-southwestern area pigs, dogs, rats and cats are present as predators (6).

G. e. hoodensis Formerly Espanola (Hood). This population was very heavily exploited by whalers in the nineteenth century. The population appears to have collapsed around 1850 (8). 14 adults ( 2 males, 12 females) were found in the early 70 's and are now held at the Charles Darwin Research Station as a breeding colony. Mating had not occurred naturally for some time because the individuals were so scattered that they did not meet. 129 young have now been produced. 79 have been returned to the island and 50 are held at the Station (13).

G. e. microphyes Southern and western slopes of Volcano Darwin, Isabela (Albémarle). Present population between 500 and 1,000 individuals (8), heavily exploited in the nineteenth century by whaling vessels. Reproduction appears to be successful. The effect of populations of rats and cats needs to be investigated (13).

G. e. phantastica Fernandina (Narborough Island). Only one specimen has ever been found, probably extinct (8).

G. e. porteri (Syn. G. e. nigrita). The main population occurs in southwest Santa Cruz (Indefatigable Island) with a very small population in the northwest (8). Total population estimated at 2,000-3,000. Depleted by heavy exploitation for oil at least until the 1930 s $(3,8)$. Reproductive success has been severely hampered for many years by the presence of feral dogs and pigs $(6,8,9,13)$. Approximately 15-20 hatchlings have been raised at the Charles Darwin Research station 
G. e. vandenburghi Caldera and southern slopes of Volcano Alcedo, Central Isabéla (Albemarle). The largest population in the archipelago, possibly numbering as many as 5,000 individuals. Reproduction successful at present $(6,8,13)$.

HABITAT AND ECOLOGY A very large species which may reach a carapace length of $122 \mathrm{~cm}$ (4 feet) and weight of $227 \mathrm{~kg}(500 \mathrm{lb})$ on the larger islands (8). Males are much larger than females (8). The different populations exhibit marked differences in size and shape. The populations may be divided roughly into two groups. Those from the smaller, drier islands tend to be smaller (females average $27 \mathrm{~kg}$, males $54 \mathrm{~kg}$ ) and have 'saddleback' carapaces (elevated above the neck and flared or reverted above the hind feet) and longer, thinner limbs. Conversely those from the larger, wetter islands are larger with dome-shaped shells (8). The saddleback would appear to be a modification allowing the tortoises to reach up and browse on the taller vegetation. This is particularly important since on the drier islands with tortoise populations the Opuntia cactus (a major source of water) has evolved an arborescent form (8). Mating appears to occur at any time of the year although it does have seasonal peaks. Almost any kind of green vegetation is taken as food, including Hippomane mancinella which is highly poisonous to most creatures (8). When possible G. elephantopus spends long periods of time partially submerged in pools; this may be both a thermoregulatory response and a protection from mosquitoes and ticks. At night this species may dig itself into soft ground or vegetation (8).

THREATS TO SURVIVAL Populations, particularly on the more accessible islands, were severely depleted by passing ships (particularly whalers) taking tortoises on board for supplies. A total of over 15,000 tortoises is recorded in the logs of 105 whaling ships between 1811 and 1844 (12). Increased settlement in the 20 th century encouraged commercial hunting of tortoises for oil and extensive collecting for museums (3). Introduced mammals now pose the greatest threat to the tortoises. Feral pigs, dogs, cats and black rats are extremely effective predators whilst feral goats, donkeys and cattle compete for grazing. Goats have had particularly drastic effects upon the natural vegetation (6).

CONSERVATION MEASURES TAKEN In 1959, Ecuador declared all uninhabited areas in the Galapagos to be a National Park, and made it illegal to capture or remove many species from the islands, including tortoises or their eggs; in 1970, it became illegal to export any Galapagos tortoises from Ecuador, regardless of whether they had been reared in captivity or the wild, or whether from continental Ecuador or the islands; United States Public Law 91-135 (December 5 1969) automatically prohibits importation of Galapagos tortoises into the U.S.A. because their export from Ecuador has been declared illegal (4). A 1971 decree makes it illegal to damage, remove, alter or disturb any organism, rock or other natural object in the National Park (6). The Galapagos National Park Service systematically hunt feral predators and competitors where necessary. Some nests are protected by lava corrals and the eggs of many of the populations are taken from the wild and hatched and reared at the Charles Darwin Research Station. Juveniles that have reached a size that ensures a good chance of survival are returned to their original ranges $(5,13)$.

Geochelone elephantopus is listed on Appendix I of the Convention on International Trade in Endangered Species of Wild Fauna and Flora (CITES). Appendix I listing requires that trade in the taxon and its products is subject to strict regulation by ratifying states and international trade for primarily commercial purposes is prohibited. 
CONSERVATION MEASURES PROPOSED Present efforts should be continued. A more radical programme of feral mammal eradication might be employed in some areas; in particular an effective means of controlling the Black Rat Rattus rattus is needed $(3,11)$. Further attempts should be made to find a mate for the captive male $G$. e. abingdonii. Electro-ejaculation followed by artificial insemination of a female with a similar shaped carapace might be considered (11).

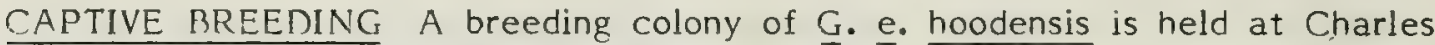
Darwin Research Station. One hundred and twenty-nine young had been produced by 1979 (see Population section) (13). Eggs of G. e. elephantopus, G. e. darwini, G. e. ephippium, are hatched and young reared at the station (see population section). In 1980223 individuals (of which 72 had been bred in captivity), were held in 54 collections; 125 of these were not identified subspecifically in available sources. Seventy-one were identified as G. e. elephantopus, 50 of these were bred in a major breeding project at Honolulu Zoo. Three male $\bar{G}$. e. becki were held at Zurich, one male and two females of G. e. guentheri were héld at Sydney and 21 G. e. porteri were held in 10 collections $(1 \overline{5})$.

REMARKS This account is largely based on a draft kindly provided by Réne Honegger (Curator of Herpetology, Zürich Zoo, and former Compiler, Amphibia and Reptilia Red Data Book).

This species is of great historical scientific interest since, by illustrating a correlation between geographic isolation and morphological divergence, it was instrumental in the formation of Darwin's concept of evolution through natural selection.

It has recently been proposed (1) that several taxa usually recognized as subgenera of Geochelone should be elevated to generic rank, in this case as Chelonoidis. This usage is not yet widespread. Also see first paragraph of Population section, above.

REFERENCES 1. Bour, R. (1980). Essai sur la taxinomie des Testudinidae actuels (Reptilia, Chelonii). Bull. Mus. natn. Hist. nat. Paris. 4e sér., 2, section $A$, no 2:541-546.

2. Hendrickson, J.R. (1966). The Galapagos tortoises Geochelone Fitzinger 1835 (Testudo Linnaeus 1758 in part). In Bowman, R.I. (ed.) The Galapagos: Proc. Galapagos Int. Sci. Proj. Univ. Calif. Press, Berkeley and Los Angeles, pp. 252-257. Not seen, cited in (3).

3. Honegger, R. (1979). Draft Red Data Book accounts for $\underline{G}$. elephantopus subspp.

4. MacFarland, C.G. and Black, J. (1971). The law and the Galapagos. Int. Turtle and Tortoise Soc. J. 5(4): 36-37. Not seen, cited in (3).

5. MacFarland, C.G. (1979). Pers. comm. to J.R. Hendrickson. Not seen, cited in (2).

6. MacFarland, C.G., Villa, J. and Toro, B. (1974). The Galapagos Giant Tortoises (Geochelone elephantopus) I. Status of the Surviving Populations. Biol. Consv. 6(2): 118-133. Not seen, cited in (3).

7. MacFarland, C.G., Villa, J. and Toro, B. (1974). The Galapagos Giant Tortoises (Geochelone elephantopus) II: Conservation Methods. Biol. Consv. 6(3): 198-212. Not seen, cited in (3).

8. Pritchard, P.C.H. (1979). Encyclopedia of Turtles. T.F.H. Publications, Hong Kong and New Jersey. 
9. Snow, D.W. (1964). The giant tortoises of the Galapagos Islands. Their present status and future chances. Oryx. 7: 277-290. Not seen, cited in (3).

10. Swingland, I.R. (1981). In litt.

11. Swingland, I.R. (1981). Report on 1st meeting of IUCN/SSC Specialist Group held 1-2 October. Oxford U.K.

12. Townsend, C.H. (1925). The Galapagos tortoises in their relation to the whaling industry. A study of old logbooks. Zoologica. 4: 55-135. Not seen, cited in (3).

13. Villa, J.L. (1979). In litt. Not seen, cited in (3).

14. Weber, D. (1971). Pinta, Galapagos: Une Ile à sauver. Biol. Consv. 6(2): 118-133. Not seen, cited in (3).

15. Olney, P.J.S. (Ed.) (1981). International Zoo Yearbook. Vol. 21 Zoological Society of London.

16. Laurie, A. (1982). Pers. comm., 21 June. 

Geochelone emys (Schlegel and Müller 1844)

(Synonyms: Manouria emys, Testudo emys, possibly also Testudo nutapundi)

Order TESTUDINES

Family TESTUDINIDAE

SUMMARY A large size Southeast Asian terrestrial tortoise. Present in India (extreme northeast), Bangladesh, Burma, west and peninsular Thailand and West Malaysia, Indonesia (Kalimantan, Sumatra), possibly East Malaysia. Mainly a hill species. Largely herbivorous. Clutch size 5-8 eggs. Heavily exploited for human food throughout the range, probably intensifying as human populations spread. Decline reported in Malaysia and Thailand. Listed on CITES Appendix II. Field research on biology and status required. Possible over-exploitation should be investigated and restricted if feasible.

DISTRIBUTION A Southeast Asian species; ranging from the Cachar and Naga Hills of Assam (extreme northeast India), through parts of Bangladesh, Burma, west and peninsular Thailand and West Malaysia, to Sumatra and Kalimantan (possibly also other parts of Borneo, i.e. Sabah and Sarawak) $(1,4,9,10,11)$. Old isolated records from China and Vietnam possibly refer to trade specimens (10). See Remarks for comment on ' $T$. nutapundi'.

POPULATION Apparently becoming scarce (9) and is considered threatened (6) over much of the range.

Bangladesh Reported rare, present in eastern hill districts only (13).

India The most threatened tortoise species in India, where it is extremely localized and heavily exploited for food (2).

Malaysia The most widespread of the three Geochelone species reported from West Malaysia; adequate populations remain in hill and mountain areas (8), but in lesser numbers elsewhere, possibly due to human predation and development. Local informants reported to one recent worker (7) that $G$. emys is no longer abundant in lowland forests, but individuals are still occasionally encountered. During a one year field project in riverine lowlands only about 12 were seen on sale in local markets (7). No data for Fast Malaysia (Sabah, Sarawak).

Thailand Formerly common and widespread in peninsular Thailand, but reported to be becoming rare in $1970(1,11)$.

No data for Burma or Indonesia.

HABITAT AND ECOLOGY A large terrestrial tortoise, largest of the Asiatic tortoises, reaching $47 \mathrm{~cm}$ in length (10) and $31 \mathrm{~kg}$ average weight (1). Mainly a species of hill and mountain forests $(1,10)$. Said to be fond of water $(10)$, although said to inhabit dry parts of the forest in Indonesia (4). Mainly herbivorous, but also takes a variety of invertebrates and small frogs (1). Age at maturity unknown. Average clutch size 5-8 eggs (12), eggs $50 \times 43 \mathrm{~mm}$ (10), clutches per year unknown. 
THREATS TO SURVIVAL Threatened mainly by exploitation for human food; it is reportedly killed whenever encountered by local inhabitants $(1,2,9,10)$. The large size and slow movements render the species an easy prey (10). Increasing human settlement (1) in its formerly remote habitat has probably increased the pressure on the species. Sold in markets in Malaysia $(7,8)$ and Thailand $(1)$, in Rangkok a small specimen would sell in recent years for about U.S. \$6. Significant numbers are in international trade (5).

CONSERVATION MEASIJRES TAKEN Listed, with all non-Appendix I Geochelone species, on Appendix II of the Convention on International Trade in Endangered Species of Wild Fauna and Flora (CITES). Appendix II listing implies that commercial trade is allowed providing a permit from the country of export is obtained, this can provide a method of monitoring trade levels. Commercial export of reptiles from India was banned in 1979.

CONSERVATION MEASURES PROPOSED Research in biology and population status is required. Fxploitation should be limited where feasible. Apparently no information is available on presence or absence of this species in present Reserve areas; this should be established.

CAPTIVE BREEDING No data. About 15 specimens are held in Kuala Lumpur ZOO (7).

REMARKS Specimens from the western highlands of Thailand, and northern parts of peninsular Thailand, also Assam and Burma, that would usually be identified as G. emys have, in a recent publication $(12,14)$ been considered distinct enough to warrant full species status, Testudo ( $=$ Geochelone) nutapundi. Since the scientific basis for this change does not appear to have been widely published, if at all, it has not as yet been possible for herpetologists to evaluate it. This matter requires investigation.

It has receritly been proposed (3) that several taxa usually recognised as subgenera of Geochelone should be elevated to generic rank, in this case as Manouria emys. This usage is not yet widespread.

The two currently-recognised extant tortoise species of the subgenus (or genus) Manouria i.e., (Geochelone (Manouria) emys, and G. (M) impressa) appear similar in several respects to aquatic emydid turtles, and are thus considered the most primitive overall of the Testudinidae (9), and of considerable zoological interest.

REFERENCES 1. Bain, J.R., and Humphrey, S.R. (1980). A profile of the endangered species of Thailand. Report No.4, Office of Ecological Services, Florida State Museum.

2. Biswas, S. (1981). Problems of conservation of land tortoises of India and proposal for their conservation. Unpublished MS.

3. Bour, R. (1980). Essai sur la taxinomie des Testudinidae actuels (Reptilia, Chelonii). Bull. Mus. natn. Hist. nat., Paris, 4 th ser., 2 sect. A, No. 2: 541-546.

4. De Rooij, N. (1915). The Reptiles of the Indo-Australian Archipelago. I. Lacertilia, Chelonia, Emydosauria. Leiden: E.J. Brill. (reprinted 1970, vaals: A. Asher).

5. Honegger, R. (1981). CITES Identification manual. Vol. 3: Reptilia, Amphibia, Pisces. - Testudines (text). CITES Secretariat, IUCN, Gland, Switzerland.

6. Mckeown, S., Juvik, T.O., and Meier, D.E. (1981). Observation on the reproductive biology of Geochelone emys 
and Geochelone yniphora in the Honolulu Zoo. Paper read at International Herpetological Congress, Oxford, U.K.; 8 October.

7. Moll, E.O. (1982). In litt., 22 April.

8. Moll, E.O. (1976). W'est Malaysian Turtles: utilization and conservation. Herpet. Rev. 7(4): 163-166.

9. Pritchard, P.C.H. (1979). Encyclopedia of Turtles. T.F.H. Publications, New Jersey, Hong Kong.

10. Smith, M.A. (1931). Reptilia and Amphibia. Vol. 1 Loricata, Testudines. In The Fauna of British India, including Ceylon and Burma. Taylor and Francis, London. (Reprinted 1973, Ralph Curtis Books, Fla, U.S.A.).

11. Taylor, F.H. (1970). The turtles and crocodiles of Thailand and adjacent waters. Univ. Kansas Sci. Bull. 49(3): 87-179.

12. Wirot, N. (1979). The turtles of Thailand. Siamfarm Zoological Garden, Bangkok.

13. Khan, Md. A.R. (1981). In litt., 7 February.

14. Reimann, cited in ref. 12, full name of author and citation of species description not given. 

Geochelone forsteni (Schlegel and Müller 1844)

(synonyms: Indotestudo forsteni, Testudo forsteni)

Order TESTUDINES Family TESTUDINIDAE

SUMMARY An apparently extremely rare, localized, and very little-known species of land tortoise. Restricted to Sulawesi (Celebes) and earlier also reported from Halmahera. Exists in the Morowali Reserve (central Sulawesi). Listed on CITES Appendix II. This species may possibly be based on introduced specimens of G. travancorica from southwest India. Further field and systematic studies required.

DISTRIBUTION Restricted to the islands of Sulawesi (Celebes) and Halmahera, Indonesia (2). On Sulawesi the species appears to be known only from the type locality (Mt Boliohuto, near Sulamatta, Buol, in the extreme north) (2) and from the Morowali Reserve (central Sulawesi) (6). No data for Halmahera. See taxonomic comments in 'Remarks'.

POPULATION Apparently extremely rare and localized on Sulawesi. During two and a half years in north and central Sulawesi one field biologist (7) did not see a single specimen of forsteni, nor evidence of its occurrence (e.g. pet animals, or empty shells in village middens). Most of this fieldwork was in rainforest above $800 \mathrm{~m}$, and did not include the actual type locality at $\mathrm{Mt}$ Boliohuto (7). Another biologist found no evidence of the species during about one and a half years in north Sulawesi (4). The only recent sighting of the species appears to be four specimens encountered in and near the Morowali Reserve in central Sulawesi (6). The tortoise seems to be extremely rare in this region; very few local villagers and tribespeople reported having seen a specimen (6). There appears to be no recent information on the species' occurrence on Halmahera.

HABITAT AND ECOLOGY A medium size land tortoise, probably reaching $25-30 \mathrm{~cm}$ carapace length. Very little biological information available. Of the four live specimens recently seen (6): one was being kept in a village; one was seen eating fallen fruit in a large forest clearing (an old garden area) a little way from a main river; one was a female observed partly dug into a grassy bank in grassland (possibly in the course of nesting); and one was seen crossing a maleo nest ground in a forest clearing at a stream edge, the tortoise walked into the shallow water, drank for a short period and proceeded into dense vegetation.

THREATS TO SURVIVAL The region of the type locality, near Sulamatta, is a government transmigration area (7) so any extant forsteni population may be subject to exploitation for food, and habitat loss. No other information.

CONSERVATION MEASURES TAKEN The only specimens recently observed were in and near the Morowali Reserve (6), central Sulawesi, and thus may be afforded some protection against habitat loss. Listed, with all non-Appendix I Geochelone species, on Appendix II of the Convention on International Trade in Endangered Species of Wild Fauna and Flora (CITES). Appendix II listing implies that cemmercial trade is allowed providing a permit from the country of export is obtained, this can provide a method of monitoring trade levels. 
CONSERVATION MEASURES PROPOSED Studies on the distribution and status of extant G. forsteni populations on Sulawesi would be desirable. Presence of the species on Halmahera requires confirmation.

CAPTIVE BREEDING None recorded, no captive specimens known.

REMARKS I am extremely grateful to W.H. Timmis (Curator of the Harewood Bird Garden, Leeds) for his generosity in providing unpublished field notes on his observations of $\mathrm{G}$. forsteni in central Sulawesi.

This form is morphologically similar to G. travancorica occurring in the Coorg and Travancore regions of southwest peninsular India. The possibility has been raised (5) that forsteni is based on introduced specimens of travancorica: If the distribution of forsteni was entirely natural, it might be expected that related forms (of the genus or subgenus Indotestudo) now present in India and southeast Asia would occur somewhere on the intervening islands of Sumatra and Borneo (5). Certainly there were long-term contacts between early Hindu cultures in India and parts of southeast Asia and Indonesia; such contacts could have facilitated intentional or accidental transfer of specimens of travancorica to Indonesia. However, patterns of animal colonization and extinction in the Indo-Australian Archipelago appear to have been extremely complex (eg. 1). It is not impossible that populations of the Indotestudo group have become extinct in the islands west of Sulawesi, indeed a very large tortoise species was present on Sulawesi itself in the Pleistocene (3). Very few museum specimens of forsteni are known. Direct evidence bearing on this question must await adequate comparative field and anatomical/serological studies.

REFERENCES 1. Darlington, P.J. (1957). Zoogeography: the geographical distribution of animals. John Wiley, N.Y.

2. De Rooij, N. (1915). The Reptiles of the Indo-Australian Archipelago. I. Lacertilia, Chelonia, Emydosauria. E.J. Brill, Leiden (reprinted 1970, A. Asher N.V., Vaals).

3. Hooijer, D.A. (1951). Pygmy elephant and giant tortoise. Sci. Monthly, 72: 3-8 (not seen, cited in 1).

4. MacKinnon, J. (cited by D. Watling, ref. 7).

5. Pritchard, P.C.H. (1979). Encyclopedia of Turtles. T.F.H. Publications, New Jersey and Hong Kong.

6. Timmis, W.H. (1982). In litt., 3 June.

7. Watling, D. (formerly with IUCN/WWF Conservation programme, Indonesia) (1982). Pers. comm., 18 January. 
Geochelone gigantea (Schweigger 1812)

(Synonym: Aldabrachelys gigantea, Testudo gigantea)

Order TESTUDINES Family TESTUDINIDAE

SUMMARY Natural range now restricted to Aldabra Atoll, Indian Ocean. Present population on Aldabra approximately 150,500 animals. Several introduced or captive populations exist, notably on islands in the Indian Ocean. No evidence of decline, but is at risk by virtue of the only natural population being concentrated on a single island vulnerable to development or natural disaster. The Seychelles Island Foundation has been established to conserve the atoll and its biota, in collaboration with the Government of the Republic of the Seychelles. Aldabra has been proposed as a Korld Heritage status protected area. Listed on CITES Appendix II

DISTRIBUTION This species' natural range is now restricted to Aldabra Atoll $\left(46^{\circ}\right.$ $20^{\prime} \mathrm{E}$. long., $9^{\circ} 24^{\prime} \mathrm{S}$. lat.), in the Indian Ocean, approximately $400 \mathrm{~km} \mathrm{N.VE}$ of Madagascar (5). Aldabra is an atoll about $29 \mathrm{~km}$ long, the coral limestone surface is often scrub-covered, and encloses a large central mangrove-fringed lagoon. The atoll is divided into four major islands, of which the southern (Grande Terre) is by far the largest.

Other small translocated populations exist. In the 1870 s concern was felt for the future of the Aldabra Tortoise, and a breeding group was introduced to the Seychelles (4). There are now several introduced colonies $(3,4)$ on various islands in the western Indian Ocean, including in the Seychelles group, Reunion, Mauritius, also Prison Island (near Zanzibar, Tanzania) and on a small island near N ossi Bé (Madagascar).

POPULATION Estimated to be $150,466+16,441$ animals on Aldabra. Comments by visitors to the atoll at the turn of the Tast century indicate that the population was then considerably smaller $(4,5)$. The species appears secure unless large-scale development or some form of natural disaster occurs on the atoll.

HABITAT AND ECOLOGY The only surviving species of a group of giant tortoises formerly present on many Indian Ocean islands, including Madagascar (2), G. gigantea may reach a carapace length of around $105 \mathrm{~cm}$. Frequents open grassy areas dotted with trees and bushes, scrubland and mangrove swamps. Heavy grazing over a very long period has probably induced the vegetation type called 'tortoise turf' (a dwarfed vegetation of grasses, sedges and herbs) which is a principal food source. Little browsing occurs although fallen leaves are eaten. Mating occurs from February to May and nesting takes place, where there is sufficient soil depth, from June to September. Each of the 3 islands on which tortoises are present have populations of different densities. Females in high density populations lay 4-5 eggs in a single clutch every few years, those in low density populations lay 14 eggs in each clutch and lay several clutches a year. Recruitment has effectively ceased in the high density population and it is probable that this particular population (on Grande Terre Island) is at the carrying capacity. Considerable work has been done on the ecology of this species by a series of workers (see references).

THREATS TO SURVIVAL The atoll itself is so inhospitable that it effectively 
prevents any typical threat, however, it was proposed to build an airbase on Aldabra in the mid-1960s and although the project was cancelled, the possibility of such military development still exists. If ever carried out this would largely or entirely extirpate natural populations of this giant tortoise species. The species is also at risk by virtue of its extremely limited range; there is always the possibility of a natural disaster, such as an epidemic disease or extreme weather conditions, striking the area.

CONSERVATION MEASURES TAKEN A Research Station with permanent staff is present on the Atoll. The Seychelles Islands Foundation has been established to conserve the atoll in collaboration with the Government of the Republic of the Seychelles.

Listed on Appendix II of the Convention on International Trade in Endangered Species of Wild Flora and Fauna (CITES). Appendix II listing implies that commercial trade in the taxon is allowed providing a permit from the country of export is obtained. This can provide a method of monitoring trade levels.

CAPTIVE BREEDING Some captive herds are successfully breeding where the appropriate conditions are provided, on the Seychelles and Mauritius, for example.

REMARKS Giant tortoises, formerly referred to several species, but now assigned to the single somewhat variable taxon $\mathrm{G}$. gigantea, are known from Madagascar, the Seychelles, and several other islands in the western Indian Ocean (2). Madagascar appears to have held a second species of Geochelone, and several related species existed on various Mascarene islands (2). The Madagascar species may have become extinct some time between one and two thousand years ago, while the Seychelles gigantea persisted in the wild until the nineteenth century (4).

Aldabra may have been colonised by oceanic drifting of giant tortoises from a parental stock in Madagascar (1); there is evidence that the atoll has been completely submerged twice during its occupation by giant totoises, so at least three colonisations are implied (1).

It has recently been proposed (6) that several taxa usually recognised as subgenera of Geochelone should be elevated to generic rank, in this case as Aldabrachelys. This usage is not yet widespread.

This account is based on a draft kindly provided by I.R. Swingland (Chairman, IUCN /SSC Tortoise Specialist Group).

REFERENCES 1. Arnold, E.N. (1976). Fossil reptiles of Aldabra Atoll, Indian Ocean. Bull. Brit. Mus. N at. Hist. (Zool.), 29(2):83-116.

2. Arnold, E.N. (1979). Indian Ocean giant tortoises: their systematics and island adaptions, Phil. Trans. R. Soc. Lond. B. 286:127-145.

3. Arnold, E.N. (1982) Pers. comm., 7 July.

4. Pritchard, P.C.H. (1979). Encyclopedia of Turtles. T.F.H. Publications, Hong Kong and $\mathrm{V}$ ew Jersey.

5. Swingland, I.R. (1982). In litt., May (draft RDB account for G. gigantea.)

6. Bour, R. (1980). Essai sur la taxinomie des testudinidae actuels (Reptilia, Chelonii). Bull. Mus. natn. Hist. nat., Paris., 4 th ser., 2, sect.A, N 0.2: $54 \overline{1-546 .}$ 
Additional sources listed in ref. 5, but not keyed into the text, are:

a. Coe, M., Bourn, D., and Swingland, I.R. (1979). The biomass, production and carrying capacity of giant tortoises on Aldabra. Phil. Trans. Roy. Soc. Lond. B 286; 163-176.

b. Coe, M., and Swingland, I.R. (in press, 1982). Giant tortoises. In Stoddart, D. (Ed.) Biogeography and ecology of the Seychelle Islands. Junk, Netherlands.

c. Gould, M., and Swingland, I.R. (1980). The tortoise and the goat: interactions on Aldabra Island. Biol. Consv. 17, 267-279.

d. Swingland, I.R. (1978). Reproductive effort and life history strategy of the Aldabran giant tortoise. Nature 269: 402-404.

e. Swingland, I.R. (1979). The conflict between feeding and overheating in the Aldabran giant tortoises. In Amlander, C.J., and Macdonald, D.W. (Eds.) In Telemetry and Radio Tracking, Pergamon, Oxford.

f. Swingland, I.R., and Coe, M. (1978). The natural regulation of giant tortoise populations on Aldabra Atoll. Reproduction. J. Zool. Lond. 186:285-309.

g. Swingland, I.R., and Coe, M. (1979). The natural regulation of giant tortoise populations on Aldabra Atoll. Recruitment. Phil. Trans. Roy. Soc. Lond. B, 286: 177-188.

h. Swingland, I.R., and Lessells, C.M. (1979). The natural regulation of giant tortoise populations on Aldabra Atoll. Movement polymorphism, reproductive success and mortality. J. Anim. Ecol. 48:639-654. 

Geochelone impressa (Günther 1882)

(Synonyms: Manouria impressa, Testudo impressa)

Order TESTUDINES Family TESTUDINIDAE

SUMMARY A medium size terrestrial tortoise restricted to forested highlands in Southeast Asia. Specimens known from localities in Burma, West Malaysia, Thailand, Vietnam; probably present in Laos, possibly Kampuchea. Reported very rare and localized. Biology almost unknown. Possibly threatened by habitat loss. Does not survive well in captivity, no captive breeding known. Listed on CITES Appendix II. Status and biology require investigation.

DISTRIBUTION A Southeast Asian species; specimens reported from the Karenni Hills in Burma, Thailand, the Langbian Plateau in the Annam region of mid-Vietnam, the Tonkin region of northern Vietnam, and West Malaysia (4). Also reported in Laos and possibly occurs in Kampuchea (1). Because of its specialized ecology, G. impressa is very localized within its general range. In Thailand, for example, it occurs only in the northwest highlands (Tak and Mae Hong Son Provinces) (5) adjoining the Karenni and Shan Hills of eastern Burma. In West Malaysia (2) the species is known only from the isolated uplands of S. Perak, the Larut Hills and Frasers Hill.

POPULATION Reported to be apparently rare (3); extremely scarce and localized (1); reported rare in Thailand (5). No quantitative data.

HABITAT AND ECOLOGY A moderate size terrestrial tortoise, to about $28 \mathrm{~cm}$ carapace length (5). Strictly a hill or mountain species, found only at considerable altitude $(4,5)$. In Thailand found at 700-2,000 feet $(213-609 \mathrm{~m})(5)$. Restricted to highland forest (5), typically fairly dry (1). Said to feed on bamboo and other grass shoots, and other plants (5), presumably also various fallen fruits. Possibly spends much of the day concealed and becomes active at twilight (1). Appears to mate during the rainy season in Thailand (5). Biology in the wild almost totally unknown.

THREATS TO SURVIVAL No data. Probably threatened in places hy loss of its highland forest habitat. Possibly used as a food source locally.

CONSERVATION MEASURES TAKEN Listed with all non-Appendix I Geochelone spp. on Appendix II of the Convention on International Trade in Endangered Species of Wild Fauna and Flora (CITES). Appendix II listing implies that commercial trade is allowed providing a permit from the country of export is obtained, this can provide a method of monitoring trade levels.

CONSERVATION MEASURES PROPOSED Field studies on status and biology are required.

CAPTIVE BREEDING No breeding in captivity known. Qeported to be extremely difficult to keep in captivity, only two specimens (both in Bangkok) are known to have survived longer than one year (1).

REMARKS It has recently been proposed (6) that taxa formerly treated as 
subgenera of Geochelone should be elevated to generic rank, in which case this species would be assigned to Manouria. This usage is not yet widespread.

REFERENCES 1. MGMorris, J.R., and Burns, D.M. (1975). Notes on Geochelone impressa. Chelonia 2(2): 5-7.

2. Moll, E.0.(1982). In litt., 22 April.

3. Pritchard, P.C.H. (1979). Encyclopedia of Turtles. T.F.H. Publications, New Jersey and Hong Kong.

4. Smith, M.A. (1931). Reptilia and Amphibia. Vol. 1 Loricata, Testudines. In The Fauna of British India, including Ceylon and Burma. Taylor and Francis, London. (Reprinted 1973, Ralph Curtis Books, Fla, U.S.A.).

5. Wirot, N. (1979). "The turtles of Thailand. Siamfarm Zoological Garden, Bangkok.

6. Bour, R. (1980). Essai sur la taxinomie des Testudinidae actuels (Reptilia, Chelonii). Bull. Mus. natn. Hist. nat., Paris, 4th ser., 2 sect. A, No. 2: 541-546. 
Geochelone platynota (Blyth 1863)

(Synonym: Testudo platynota)

Order TESTUDINES

Family TESTUDINIDAE

SUMMARY A virtually unknown species of land tortoise, endemic to Burma. Occurs in Upper Burma, south to Moulmein. Suspected to be threatened by over-exploitation as a food source. Specimens very rarely seen outside Burma, one or more are held at Rangoon Zoo. Listed on CITES Appendix II. Status survey required.

DISTRIBUTION Endemic to Burma. Fairly widespread in Upper Burma, extends south to Moulmein, apparently absent from Tenasserim (4).

POPULATION Suspected to be adversely affected by over-exploitation and habitat modification (5). No quantitative data. Reported common in the Pegu region in the 1860 s (1).

\section{HABITAT ANDECOLOGY No data.}

THREATS TO SURVIVAL The author of the original scientific description of this species (1) states that the indigenous peoples were so fond of eating the tortoise that it was impossible to procure a living specimen. Empty shells were commonly used in Rangoon bazaar for baling oil (1). Heavy exploitation, and possibly habitat disturbance locally, are thought to constitute the main threats to $\mathrm{G}$. platynota (5).

CONSERVATION MEASURES TAKEN Listed, with all non-Appendix I Geochelone species, on Appendix II of the Convention on International Trade in Endangered Species of Wild Fauna and Flora (CITES). Appendix II listing implies that commercial trade is allowed providing a permit from the country of export is obtained, this can provide a method of monitoring trade levels.

CONSERVATION MEASURES PROPOSED A field survey of status and ecology is required $(2,5)$.

CAPTIVE BREEDING No information. One or more specimens are held by Rangoon Zoo (Burma) (3). The species is very rarely seen outside Burma, there appears to be no recent records of captive specimens.

REMARKS This species may be the least known of all the living land tortoises (2).

REFERENCES 1. Blyth, E. (1863). A collection of sundries from different parts of Burma. J. Asiat. Soc. Bengal, 32: 73-90. (Although the description of this species is generally (4) attributed to E. Blyth, the paper in question appears to be credited to W.T. Blanford in the Journal cited).

2. Juvik, J.O. (1980). In litt., 30 October (to I.R. Swingland).

3. Juvik, J.O. (1981). Verbal statement at first IUCN/SSC Tortoise Specialist Group meeting (1-2 October 1981, Oxford, U.K.).

4. Smith, M.A. (1931). Reptilia and Amphibia, Vol. 1, Loricata, 
Testudines. In Fauna of British India, including Ceylon and Burma. London: Taylor and Francis Ltd. (reprinted 1973, Ralph Curtis Books, Hollywood, Fla.).

5. Anon. (1981). Various statements by members of the IUCN/SSC Tortoise Specialist Group at first meeting (1-2 October 1981, Oxford, U.K.). 
Geochelone radiata (Shaw 1802)

(synonyms: Testudo radiata, Ásterochelys radiata)

Order TESTUDINES Family TESTUDINIDAE

SUMMARY A large terrestrial species with a very attractive 'starred' pattern, endemic to Madagascar. Restricted to xerophytic Didierea forest with associated thornbush and grasses, in the arid south and southwest extremity of Madagascar. Remains relatively common (1974 survey) in the more inaccessible areas of the Mahafaly and Karimbola Plateaus, but severely depleted or eliminated in the east and west of the range. Large numbers were exported to the Mascarene Islands for food during the 18th and 19th centuries. There is significant current exploitation for food, pets, varnished shell curios, and also the live animal trade, although the latter has declined substantially as a result of trade controls. Survival prospects for $\mathrm{G}$. radiata may be adequate providing substantial portions of the range remain free of heavy exploitation and habitat destruction. Present in the Natural Reserve of Lake Tsimanampetsotsa. Protected by Malagasy law, export is restricted. Listed on CITES Appendix 1. Further field research into basic biology and the impact of current exploitation is required.

DISTRIBUTION An endemic Madagascar species. Restricted to the Didierea forest occurring in a narrow arc across southern Madagascar, G. radiata has been recorded from near Amboasary in the southeast to near Morombe on the southwest coast (9).

POPULATION Relatively common in 1974 (9) in the more inaccessible areas of the Mahafaly and Karimbola Plateaus, forming the present core of the range, but severely depleted in or eliminated from the extremities of the range, in the vicinity of Taolanaro (=Fort Dauphin) in the east, and Toliara (= Tuléar) and Morombe in the west (9). A relatively high density has been recorded along National Route 10 where it penetrates into prime radiata habitat; after heavy rain (when tortoise activity is most apparent) one tortoise may be encountered per kilometre of road. The species has been subject to heavy collection in this area for several years, suggesting that population densities may be satisfactory in more inaccessible areas (9). The species still appears to maintain good numbers south of the Onilahy River, in the territory of the Mahafaly and Antandroy (18).

Although populations are reported to be declining (2), at least locally (8), the short-term prospects for the survival of $\mathrm{G}$. radiata may be adequate insofar as significant portions of the present range remain relatively free of heavy exploitation or habitat destruction $(9,1974$ data).

HABITAT AND ECOLOGY A large terrestrial species, reaching around 15 inches (38cms) carapace length, and $28 \mathrm{lbs}(13 \mathrm{~kg}$ ) weight (14). Restricted to xerophytic forests of the cactus-like Didierea in the arid south and southwestern extremity of Madagascar, with an erratic annual rainfall of less than $400 \mathrm{~mm}$. Within this forest type, G. radiata apparently prefers areas with low thornbush and grass cover, rather than dense thickets of Didierea itself (the former may offer better food resources) (9). 
Most aspects of the biology of G. radiata, including feeding and reproductive ecology, remain largely unstudied in the wild. Probably the species feeds on fruit, grass and other green vegetation. In captivity, melon (14), Opuntia pads and fruit, and red items in particular (6) are favoured. It has been reported that, in the wild, a clutch of about 12 eggs is laid in September (13), but clutches of 3,4 and 6 are known in captivity (17). The eggs are almost spherical (36 to $42 \mathrm{~mm}$ in greatest diameter), and are laid in a flask-shaped nest six to eight inches ( 15 to $20 \mathrm{~cm}$ ) deep dug by the hind feet (17).

THREATS TO SURVIVAL Depletion or extinction of G. radiata around the port towns of Toliara (Tuléar), Morombe and Taolanaro (Fort Dauphin), is largely attributed to heavy commercial exploitation during the 18th and 19th centuries when large numbers were shipped to the nearby Mascarene Islands, notably Réunion, for food. Present exploitation is for food or pets (occasionally kept with the village chickens in the belief that their presence will ward off poultry diseases), or commercial collecting (with resale as food, varnished shell curios, or for the live animal trade) (9). Although the two indigenous tribes in the range of G. radiata (the Antandroy and Mahafaly) do not eat tortoises (18), they are a favoured food item for people from other parts of Madagascar, generally coming into the area as government workers (3). People now travel by boat southward across the mouth of the Onilahy in order to collect G. radiata for food (18). Present protective legislation is only weakly enforced although it is widely known that radiata is protected, the species can still be ordered secretly in many restaurants in the south (3). Prepared tortoise shells can be seen everywhere in Tuléar (3), there has been a lively trade in tortoise carapaces at Tananarive market (11). In Tulear in 1976 an adult specimen could be bought for $100 \mathrm{Fmg}$ (US $\$ 0.5)$, or less than the price of a chicken (18). Vehicles often stop along the National Route 10, connecting Taolanaro (Fort Dauphin) and Toliara (Tuléar) to allow passengers to collect tortoises seen on the road (9). There seems to be no regular large-scale collection (9), although heaps of carapaces from tortoises used for food may be seen from time to time (18). The species has also suffered from habitat destruction (4).

CONSERVATION MEASURES TAKEN The aridity and harshness of the habitat, and the sparsity of the human population, have afforded $G$. radiata a significant degree of protection. Furthermore, the indigenous Antandroy and Mahafaly tribespeople consider the species sacred and are inhibited from eating it by a traditional taboo (fady) (9).

The species is present in the Lake Tsimanampetsotsa Natural Reserve in the Mahafaly Plateau (1), and is protected under Decree No.61.096 of July 13, 1961 (infringements punishable by fine or imprisonment) (8). Export of live or preserved G. radiata is restricted, an export tax of Fmg 20,000 is levied on each specimen (18). Listed under Category 'A' of the 1968 African Conservation Convention (8).

Listed on Appendix 1 of the Convention on International Trade in Endangered Species of Wild Fauna and Flora (CITES). Appendix I listing requires that trade in the taxon and its products is subject to strict regulation by ratifying states and international trade for primarily commercial purposes is prohibited.

Trade controls appear to have resulted in a substantial decline in numbers of $\mathrm{G}$. radiata leaving Madagascar (9), this now occurs only exceptionally (18) and there is apparently no traffic through the capital Antananarivo (18).

CONSERVATION MEASURES PROPOSED Field research on the biology and population status of $\mathrm{G}$. radiata is necessary. The impact of present exploitation 
requires evaluation. Existing conservation laws could be more rigidly enforced.

CAPTIVE BREEDING Numerous specimens are present in various collections (8). Breeding has occurred on several occasions, in zoos in Cairo, Mauritius, Sydney, Zurich (7), also Colorado, Florida, and Texas in the U.S.A., but rarely with amateur collectors. Notably, G. radiata has been bred regularly since 1973 at the Gladys Porter Zoo, Brownsville, Texas (6). A 22 per cent fertility rate resulted from 110 eggs laid by one pair (over several years) (6).

REMARKS The Radiated Tortoise Geochelone radiata is widely regarded as extremely beautiful, by virtue of its large size and prominent black and yellow 'starred' pattern $(6,9,14)$. The species figures on a Fmg 20 airmail stamp of the Malagasy Democratic Republic.

G. radiata is probably the nearest relative of the endangered Angonoka G. yniphora, of northwest Madagascar; the range of their hypothesized common ancestor in generally xeric regions may have been split into southern and northwest enclaves as more mesic conditions spread after a Pleistocene arid phase (10).

There are several groups comprising many adult specimens introduced on Reunion, where breeding occurs with some regularity; the young are sold as pets (150 FF, E15), adults are very occasionally eaten (18).

The celebrated Tonga tortoise, 'Tu'i Malila', has been identified as a specimen of G. radiata with the starred pattern obscured by age. There is considerable doubt (15) about the story that this tortoise was presented to a Tongan chief by Captain Cook in 1773 or 1777 . It was present from at least the 1880 s and died in $1966(17)$.

Until quite recently $(12,14)$ this species, with many others, had been assigned to the genus Testudo, this usage is maintained by some authorities (16). The species has also recently (5) been assigned to the genus Asterochelys, this usage is not yet widespread. This account is based mainly on information very kindly provided by J. Andrianarivo, C. Blanc, R. Bour and J. Juvik.

REFERENCES 1. Andriamampianina, J. (1972). Les réserves naturelles intégrales de Madagascar. IUCN Publications, New. Ser., Supplementary paper No.36: 103-123. (Comptes rendus de la Conférence internationale sur la Conservation de la Nature et de ses Ressources à Madagascar).

2. Andrianarivo, J. (1981). In litt. 12th January.

3. Andrianarivo, J. (1981). In litt. 16th February.

4. Blanc, C.P. (1968-1969). In litt. cited in reference 8.

5. Bour, R. (1979). Les tortues actuelles de Madagascar (République malgache): liste systématique et description de deux sous-espèces nouvelles. (Reptilia-Testudines). Bull. Soc. Et. Sci. Anjou, N.S., 10: 141-154.

6. Burchfield, P.M., Doucette, C.S., and Beimler, T.F. (1980). Captive management of the Radiated tortoise Geochelone radiata at Gladys Porter Zoo, Brownsville. Int. Z00 Yb. 20: $1-6$.

7. Honegger, R. (1975). Breeding and maintaining reptiles in captivity. In Martin, R.D. (Ed.), Breeding endangered species in captivity. Academic Press, London. Pp. 1-12.

8. Honegger, R. (1979). Red Data Book, Vol 3: Amphibia and Reptilia. IUCN, Gland. (Third edition, revised).

9. Juvik, J.O. (1975). The Radiated Tortoise of Madagascar. Oryx 13(2): 145-148. 
10. Juvik, J.O., Andrianarivo, A.J., and Blanc, C.P. (1981). The ecology and status of Geochelone yniphora: a critically endangered tortoise in northwestern Madagascar. Biol. Conserv. 19: 297-316.

11. Kitchener, S.L. (1973). In litt., cited in reference 8.

12. Loveridge, A., and Williams, E.E. (1957). Revision of the African Tortoises and Turtles of the Suborder Cryptodira. Bull. Mus. comp. Zool. Harvard. 115(6): 163-557.

13. Paulian, R. (1955). Les Animaux Protegees de Madagasar. Publ. Inst. Rech. Sci. Tananarive. (cited in reference 14).

14. Pritchard, P.C.H. (1979). Encyclopedia of Turtles. T.F.H. Publications, Hong Kong.

15. Robb, J., and Turbott, E.G. (1977). Tu'i Malila, "Cook's Tortoise". Rec. Aukland. Inst. Mus. 8: 229-233.

16. Wermuth, H. and Mertens, R. (1977). Testudines, Crocodylia, Rhynchocephalia. Das Tierreich. 100:1-174.

17. Juvik, J. (1981). In litt., 27 April.

18. Bour, R. (1981). In litt., 16 February. 
Geochelone travancorica (Boulenger 1907)

(Synonyms: Indotestudo travancorica, Testudo travancorica)

Order TESTUDINES Family TESTUDINIDAE

SUM:MARY A medium size land tortoise, endemic to India, restricted to hill areas in eastern Kerala and Coorg. Apparently locally common in the early twentieth century; suspected to be threatened by habitat loss and human consumption; decline is reported in southern Kerala. Biology, present distribution and status very poorly-known. Field studies required. Listed on CITES Appendix II.

DISTRIBUTION Endemic to India. Restricted to hills in the Travancore region of southwest peninsular India. The range comprises the western slopes of the southern extremity of the Western Ghats in Kerala State, just extending in the north to the Coorg area of extreme south Karnataka State (5).

POPULATION Little information is available. Said to be not uncommon in parts of the Travancore hills at the beginning of the present century $(2,5)$. Suspected to be threatened by habitat loss and human consumption (1). Reported to have declined in south Kerala where the species still occurs in hill areas, but not in its earlier abundance (3). No recent quantitative data available.

HABITAT AND ECOLOGY A moderate size terrestrial tortoise, to around $28 \mathrm{~cm}$ length. A hill species, occurring up to $1000 \mathrm{~m}$ altitude (5). Present in rain forest (2). In general tends to occur in mesic forest areas (7). Breeding season November - January (7). Biology virtually unknown.

THREATS TO SURVIVAL Suspected to be threatened by habitat loss and human consumption (1). The original hill rain forest in southwest India has been extensively cleared and modified (4).

CONSERVATION MEASURES TAKEN Listed, with all non-Appendix I Geochelone species, on Appendix II of the Convention on International Trade in Endangered Species of Wild Fauna and Flora (CITES). Appendix II listing implies that commercial trade is allowed providing a permit from the country of export is obtained, this can provide a method of monitoring trade levels. Commercial export of reptiles from India was banned in 1979.

CONSERVATION MEASURES PROPOSED A field survey of the distribution, status and ecology of this species is required ( 1 ).

CAPTIVE BREEDING No information on breeding. Details of courtship behaviour in captivity, and breeding season colour change (affecting the skin of the nasal and orbital area, especially in males), are given in refs. 6 and 7.

REMARKS This tortoise is one of several equally distinctive and poorly-known amphibian and reptile species endemic to forest regions of southwest India. Similar or higher endemicity is known among the plants, birds and mammals, for example, and conservation of $\mathrm{G}$. travancorica may be seen as one element in conservation of this unique and diminishing biotope. 
It has recently been proposed (8) that several taxa usually recognized as subgenera of Geochelone should be elevated to generic rank, in this case as Indotestudo. This usage is not yet widespread.

REFERENCES 1. Biswas, S. (1981). Problems of conservation of land tortoises of India and proposal for their conservation. Unpublished MS.

2. Henderson, J.R. (1912). Preliminary note on a new tortoise from south India. Rec. Ind. Mus. 7: 217-218.

3. Pillai, R.S. (1982). In litt., 25 February.

4. Saharia, V.B. (Compiler and Editor) (1981). Wildlife in India. Dept. of Agriculture and Cooperation, Ministry of Agriculture, Govt. of India. (reference to southwest rain forests in chapters 3,4 and 5).

5. Smith, M.A. (1931). Reptilia and Amphibia, Vol. 1, Loricata, Testudines. In Fauna of British India, including Ceylon and Burma. London: Taylor and Francis Ltd. (reprinted 1973, Ralph Curtis Books, Hollywood, Fla.).

6. Auffenberg, W. (1964). Notes on the courtship of the land tortoise Geochelone travancorica (Boulenger). J. Bombay Nat. Hist. Soc., 61(2): 247-253.

7. Auffenberg, W. (1964). A first record of breeding colour changes in a tortoise. J. Bombay Nat. Hist. Soc., 61(1):191-192.

8. Bour, R. (1980). Essai sur la taxinomie des Testudinidae actuels (Reptilia, Chelonii). Bull. Mus. natn. Hist. nat. Paris, 4 ser., 2, sect. A, No.2:54 $1-546$. 
(synonyms: Testudo yniphora, Asterochelys yniphora)

Order TESTUDINES Family TESTUDINIDAE

SUMMARY A large terrestrial species, endemic to Madagascar, and restricted to a very small area around Baly Bay in the northwest. Extremely rare and in imminent danger of extinction. Maximum density is not likely to exceed five individuals per square kilometre, and the total species population, within the area of suitable habitat of less than $100 \mathrm{~km}^{2}$, may be only a few hundred individuals. The species prefers habitat comprising 'islands' of xeric scrub forest, such as thickets of Terminalia and bamboo Nastus, in exposed rocky or coastal areas, or in anthropogenic savanna-grassland. Herbivorous. Terminalia-Nastus thickets provide shelter during dry season inactivity (May-October), at night, and the hotter parts of the day. No data on reproductive ecology. Threatened by commercial and subsistence exploitation, habitat modification, and predation by feral pigs. Present exploitation for food or pets does not appear of major significance, but the species was exported for food to the Comoro Islands in large numbers, from the 17 th to late 19 th centuries. Protected by Malagasy law, export is restricted. Listed on CITES Appendix I. Strict protection of natural habitat is essential, Cape Sada provides a suitable reserve area. Further field research into basic biology is required.

DISTRIBUTION An endemic Madagascar species. Restricted to three 'islands' of forest in the vicinity of Baly Bay, including Cape Sada, in northwest Madagascar $(3,4,10,11)$.

POPULATION Geochelone yniphora is exceedingly rare and considered to be in imminent danger of extinction (4). During approximately 375 hours spent in directly searching for G. yniphora, over a five-year period between 1971 and 1976 , only five specimens were encountered in the wild. These comprise four found at Cape Sada in the wet season, and one near Ankoro on the opposite (west) side of Baly Bay, in addition, fresh tortoise droppings were found at two other localities east of Cape Sada. These findings represent one tortoise sighting per 75 man-hours in the field. This contrasts with one per eight hours reported for another Madagascar endemic G. radiata (1). It is estimated that density of G. yniphora is unlikely to exceed five individuals per square kilometre, even in the optimum scrub forest habitats. With less than $100 \mathrm{~km}^{2}$ of suitable habitat remaining within the species known range, this suggests a total possible species population of only a few hundred individuals (4). However, some recruitment is still occurring since, of the four Cape Sada specimens, one was a juvenile and one intermediate between juvenile and adult sizes (4). A recent estimate is that only 10-20 individuals remain (9). However, specimens are extremely well-camouflaged despite their size, suggesting that some individuals may be overlooked (10).

HABITAT AND ECOLOGY A large terrestrial species (to around $45 \mathrm{~cm}$ carapace ength, or $70 \mathrm{~cm}$ if measured over the dome), preferring mixed habitat, comprising 'islands' of xeric scrub forest within anthropogenic savanna-grassland or exposed rocky or coastal areas. The natural climax vegetation in much of the region is tropical deciduous forest, including such species as Erythrophleum couminga, 
Terminalia bovinii and Acridocarpus excelsus, frequently with an understory of bamboo Nastus spp. In the Baly Bay area this formation is frequently degraded to scrub forest or grassland by annual burning by local inhabitants, intended to promote herbaceous growth for grazing of cattle.

Both the natural closed-canopy deciduous forest, with scarcity of herbaceous tortoise food plants, and the anthropogenic grasslands, with the danger of fires, are avoided by G. yniphora. The favoured mixed habitats appear to combine open herbaceous zones for foraging and dense thickets for protection and concealment. Such mixed habitats comprise only a small proportion of the vegetation of the Baly Bay area (4).

Precipitation at Soalala, on the southeast of Baly Bay, is strongly seasonal, with over 90 per cent of the mean annual rainfall of $1231 \mathrm{~mm}$ occurring from December to March. The soil appears to have a low moisture storage capacity, much of the year's rainfall is lost as runoff and there is a moisture deficit during most of the dry season (May-October). (4).

The species is entirely herbivorous. Droppings collected from two adult tortoises at Cape Sada contained 90 per cent (volume) leaves of the leguminous shrub Bauhinia cf. pervillei, generally swallowed whole, with the remainder consisting of the grass Heteropogon contortus (bitten off in $2 \mathrm{~cm}$ lengths). A sample from another individual contained 95 per cent leaves of Foetidia retusa and Erythrophleum couminga, with 5 per cent sedges and grasses. One immature female at Cape Sada was observed feeding on newly-emerged shoots of Pycreus mundtii in open rocky terrain, droppings from this individual contained equal $\overline{\text { amounts }}$ of Pycreus and $\mathrm{H}$. contortus (4).

Geochelone yniphora appears to be largely inactive during the dry season (May-October), when it shelters amid surface litter in Terminalia-Nastus thickets. The dry season is also the season of lowest temperatures (mean low in coldest months, June and July, $24^{\circ} \mathrm{C}$; mean high in hottest month, December, $33^{\circ} \mathrm{C}$ ). Seasonal growth differences are apparently reflected in the well-marked growth rings on the carapace scutes. Specimens were encountered actively foraging only in the morning (0800-1000h) and late afternoon (after 1600h), with surface temperatures below $45^{\circ} \mathrm{C}$. Shelter is sought in Terminalia-Nastus thickets during the night and the middle of the day (4).

No data are available on reproductive biology of wild populations. See under Captive Breeding for observations of reproductive behaviour in captive individuals.

THREATS TO SURVIVAL The endangered status of G. yniphora is attributable to commercial and subsistence exploitation, habitat módification, and predation by feral pigs $(4,10,11)$. The species is further at risk by virtue of its extremely restricted range, and the reduced chances of contact between remaining isolated individuals.

From at least the 17th century, Arab traders collected large numbers of this species at Soalala for export to the nearby Comoro Islands as a food source (the first specimens known to science were obtained in the Comoros) (4). This trade extended into the late 19th century, but around Soalala at this time the species could still be readily collected using trained dogs (4). The indigenous people of the Baly Bay area regard $\mathrm{G}$. yniphora as taboo (fady) and do not eat it, although other ethnic groups may sometimes do so. The species is occasionally kept locally as a pet (often with the village chickens, in the belief that the species will ward off poultry diseases by eating the chicken droppings). Current commercial exploitation for food or the live animal trade does not appear to be a major factor in the species decline (4). A specimen was offered in Soalala in 1974 for 20,000 
The expansion of savanna grassland at the expense of dry tropical forest, produced by intentional annual burning to promote fresh herbage for cattle grazing, may have contributed to range contraction in the past and is a significant threat to remaining $\mathrm{G}$. yniphora.

A recent decision to develop major iron ore reserves in the Soalala area can be expected to have a significant impact on the environmental and economic structure of the region (4). The possible development of the beach at Cape Sada and extension of agricultural usage north of Cape d'Amparafaka are potential threats (10). Citation of predation by feral pigs as a threat rests on circumstantial evidence. Feral pigs are known to have a substantial impact on Galapagos Giant Tortoise Geochelone elephantopus, and in G. yniphora habitat around Baly Bay, pig trails and rooting activities are evident everywhere (4).

CONSERVATION MEASURES TAKEN The species is protected by Malagasy law, and is protected from local use as food by a taboo (fady) maintained by the indigenous people. Listed under Category 'A' of the $1 \overline{968}$ African Conservation Convention.

Listed on Appendix I of the Convention on International Trade in Endangered Species of Wild Fauna and Flora (CITES). Appendix I listing requires that trade in the taxon and its products is subject to strict regulation by ratifying states, and international trade for primary commercial purposes is prohibited.

CONSERVATION MEASURES PROPOSED Survival of G. yniphora in the wild is critically dependent on preservation of suitable natural habitat in the Baly Bay area (4). The Cape Sada peninsula has been proposed as the optimum site (2), combining presence of tortoises, absence of people, lack of agricultural or pastoral importance, suitable habitat including fire-resistant vegetation, and ease of protection. Tortoises held by local inhabitants could be moved to such a reserve, which should be adequately guarded. The Tamatave colony, maintained by the Malagasy Government, is in an area probably too humid for yniphora, and should be relocated to the northwest, possibly the Cape Sada region (4). Eggs and young should be protected from feral pig predation (2). Existing laws should be enforced. International support and local interest (see 11) is essential in the realisation of such aims (4).

The IUCN/SSC Tortoise Specialist Group plans a highest priority project on conservation of G. yniphora. Field research on the biology of the species is required, following immediate implementation of conservation action.

CAPTIVE BREEDING In 1971 Honolulu Zoo established a captive colony with six individuals ( 2 males, 4 females), two of which were wild-caught specimens and four village captives $(4,5,12)$. In 1973 a further three individuals were obtained (2 males, 1 female). Two of these were deposited with the San Antonio Zoo and the third in the private collection of W. Zovickian, New York Zoological Society. Since then three individuals ( 2 males, 1 female) have died. In 1981 one male and three females, including one female on loan from the San Antonio Zoo, were held at Honolulu, and a pair, (the male on loan from San Antonio) were with Zovickian (12). A further group (1 male, 3 females) are held at Tamatave, Madagascar (12). As yet no successful breeding has taken place in captivity. However, at Honolulu, courtship, nest construction and egg laying have been observed. Courtship behaviour is similar to that of the closely related G. radiata (see 13). One distinctive element sometimes seen is the repeated pushing of the male's enlarged epiplastral projection into the female's rear leg socket apparently to push or lift the female's shell. Since 1979 one female has laid several clutches. All eggs have 
been artifically incubated but none were fertile. Clutch size ranged from three to six eggs. Eggs were white, nearly spherical with a mean maximum diameter of $42-47 \mathrm{~mm}$ and weighed between 40.5 and $50 \mathrm{gm}$. Flask-shaped nest holes were excavated in moist soil, to an average depth of $11.1 \mathrm{~cm}$ and with average basal width of $11.6 \mathrm{~cm}$. Nesting typically took place in early morning. Sometimes several 'test holes' were started before the final nest was constructed. Current research is directed towards investigating the fertility of the male in the colony. The closely related G. radiata has been successfully bred in captivity and this may give cause for optimism with regard to the breeding of $G$. yniphora (12). A single male specimen is reportedly held (1980) at Takamatsu, Japan (14).

REMARKS Geochelone yniphora is noteworthy for the median anterior horn-like projection of the plastron, formed by extension of the two epiplastrals and fused gular plates (seen to a lesser extent in the South African Bowsprit Tortoise Chersina angulata) (5).

G. yniphora is probably the nearest relative of the vulnerable Radiated Tortoise $\bar{G}$. radiata, of southern Madagascar; the range of their hypothesized common ancestor in generally xeric regions may have been split into northwest and southern enclaves as more mesic conditions spread after a Pleistocene arid phase (4).

Until quite recently $(6,7)$ this species, with many others, had been assigned to the genus Testudo, this usage is maintained by some authorities (8). The species has also recently (3) been assigned to the genus Asterochelys, this usage is not yet widespread. This account is based on information kindly supplied by A.J. Andrianarivo, C. Blanc, R. Bour and J. Juvik.

REFERENCES 1. Baudy, R.E. (1970). In quest of Geochelone radiata. Int. Turtle Tort. Soc. J. 4(1): 19-23,27.

2. Blanc, C.P. (1973). Project 644. Status survey of Testudo yniphora. World Wildl. Yb. 1972-1973: 93-94.

3. Bour, R. (1979). Les tortues actuelles de Madagascar (République malgache): Liste systématique et description de deux sous-espèces nouvelles. (Reptilia-Testudines). Bull. Soc. Et. sci. Anjou, N.S., 10: 141-154.

4. Juvik, J.O., Andrianarivo, A.J., and Blanc, C.P. (1981). The ecology and status of Geochelone yniphora: a critically endangered tortoise in northwestern Madagascar. Biol. Conserv: 19: 297-316.

5. Juvik, J.O. and Blanc, C.P. (1974). The Angonoka of Cape Sada. Animals (since renamed Wildlife, London). 16(4): 148-153.

6. Loveridge, A., and Williams, E.E. (1957). Revision of the African Tortoises and Turtles of the Suborder Cryptodira. Bull. Mus. comp. Zool. Harvard. 115(6): 163-557.

7. Pritchard, P.C.H. (1979). Encyclopedia of Turtles. T.F.H. Publications, Hong Kong \& New Jersey.

8. Wermuth, H. and Mertens, R. (1977). Testudines, Crocodylia, Rhynchocephalia. Das Tierreich. 100: 1-174.

9. Blanc, C. (1981). In litt., 24 February.

10. Bour, R. (1981). In litt., 16 February.

11. Andrianarivo, A.J. (1977). L'Angonoka survivra-t-elle? (Testudo hyniphora) Etab. Ens. Sup. Sc. Agronomiques, Univ. de Madagascar (Dép. Eaux et Forêts) (Mém. Fin d'Etudes An. univers. 1976). Pp 1-55.

12. Mckeown, S., Juvik, J.O., and Meier, D.E. (1981). 
Observation on the reproductive biology of Geochelone emys and Geochelone yniphora in the Honolulu Zoo. (MS. copy of paper prepared for presentation at International Herpetological Congress, Oxford. October 1981).

13. Auffenberg, W. (1978). Courtship and breeding behaviour in Geochelone radiata (Testudines: Testudinidae) Herpetologica 34: 277-287.

14. Olney, P.J.S. (Ed.) (1981). International Zoo Yearbook 21, Zoological Society of London. 

SUMMARY Occurs from southwest Utah, United States to Sonora, Mexico. Populations are scattered and isolated, probably declining except in remote areas. Decline due principally to past over-collecting and present habitat destruction. Protected by state laws in U.S.A. and federal game laws in Mexico. The Beaver Dam population in Utah is listed as Threatened under the U.S. Endangered Species Act and an area of Critical Habitat has been declared. Listed on Appendix II of CITES.

DISTRIBUTION Occurs in southwest Utah, southern Nevada, western Arizona and south eastern California (Mojave Desert) in the United States. In Mexico through most of Sonora, including Tiburon Island, and northwest Sinaloa. May also occur in Baja California $(1,6,9,10)$.

POPULATION Although occurring over a wide range, distribution is not continuous, populations are mostly scattered and isolated (5). Probably declining in numbers throughout its range except in remote areas (6).

Mexico The status of individual populations is poorly known (5). Approaching extinction on Tiburon Island (10).

United States of America Highest densities occur in parts of California and Nevada. Much of the range in Nevada and Arizona has not yet been adequately surveyed (5). The Beaver Dam Slope population in Utah may once have numbered 2,000 , it is presently estimated at less than 350 (3). In general, distribution is discontinuous and populations exist at low densities (5).

HABITAT AND ECOLOGY Found in areas with low desert scrub, usually where the soil is compact enough for construction of burrows (6). This species exhibits marked behavioural differences in different environments and latitudes, in particular with regard to hibernation. In Utah, in the north of its range, G. agassizii hibernates in deep communal burrows; further south in Arizona the enlarged burrow of a ground squirrel will suffice; whilst in Sonora the winters are mild enough to make burrowing and hibernation unnecessary $(2,9)$. In Utah, populations make regular seasonal migrations between winter hibernacula in the foothills and summer foraging areas on the desert flats $(2,9)$.

Desert Tortoises emerge from winter hibernation in the spring and feed primarily on green annual vegetation that is high in water content. During the hot dry summer surface activity decreases, but may resume in the autumn (7). The drinking of surface water may be an important source of moisture. Desert tortoises have been observed drinking from depressions in open desert pavement areas in the Mojave Desert. These shallow depressions are scraped out directly by the tortoise or in other cases are enlarged from natural depressions acting as water catchiments (7).

Growth averaged $9 \mathrm{~mm}$ per year between 1963 and 1973 in southern Nevada. 
Growth was greatest following winters of high precipitation which resulted in increased production of annuals the following spring. Growth of tortoises generally occurred between April and July (8).

Female tortoises in Ivanpah Valley, California exhibited weight losses in May and again in June. These weight losses were interpreted as evidence of the laying of two clutches of eggs during 1980 (11). The eggs are hard shelled and spherical or slightly oval, clutch size may range between two and seven eggs. Eggs are laid in early summer, usually hatching in the autumn $(6,9)$. Sexual maturity may not be reached until 15-20 years of age. Individuals are long lived, possibly exceeding 50 years. There appears to be a high mortality of eggs and hatchlings and the reproductive rate is low (6).

THREATS TO SURVIVAL Habitat destruction - through residential development, land clearance for agriculture, surface mining, geothermal development, mineral exploration, overgrazing by livestock, defence installations, and unregulated use of off-road vehicles - constitutes the major current threat to this species (5).

In the past, large numbers were collected for the pet trade, and this may have had considerable impact particularly since females appear to have been taken more often than males $(3,5)$. Competition for food between tortoises and grazing livestock has been suggested as a further possible cause for decline, especially as an adequate diet is necessary for successful reproduction, but this is very difficult to verify $(3,4,5)$.

CONSERVATION MEASURES TAKEN All states within the range of the species protect it to some extent, in general these laws prohibit collection and trade. In Mexico it is protected by federal game laws, but these are not adequately enforced (5). Occurs in several reserves including 38 square miles of the Mojave Desert, California, which has been fenced in. The Beaver Dam Slope population in Utah has been classified as 'Threatened' under the U.S. Endangered Species Act and 35 square miles of land in Washington County, Utah have been declared Critical Habitat (3).

G. agassizi is listed on Appendix II of the Convention on International Trade in Endangered Species of Wild Fauna and Flora (CITES). Appendix II listing implies that commercial trade is allowed providing a permit from the country of export is obtained, this can provide a method of monitoring trade levels.

CONSERVTION MEASURES PROPOSED Habitat protection, and where necessary consistent management policies are needed. This may require federal intervention in the United States since much of the range is federally owned. Wherever possible disruption of the desert for recreation purposes such as motor vehicle racing should be regulated.

CAPTIVE BREEDING Breeding has taken place at San Diego Zoo and Sonora Desert Museum, Tucson, Arizona (6).

REMARKS Much of the information under Habitat and Ecology was kindly provided by P.A. Medica.

REFERENCES 1. Auffenberg, W. and Franz, R. (1978). Catalogue of American Amphibians and Reptiles. 212.1-2.

2. Auffenberg, W. and Iverson, J.B. (1979). Demography of terrestrial turtles. In Harless M. and Morlock, H. (Eds). Turtles: Perspectives and Reseach. Wiley Interscience, New York. 
3. Bender, M. (1980). Beaver Dam Slope population of the Desert Tortoise listed as threatened. Endangered Species Technical Bulletin 5 (9): 1-5.

4. Berry, K.H. (1978). Livestock grazing and the desert tortoise. Proceedings of Desert Tortoise Council Symposium 1978.

5. Dodd, C.K. (1981). A review of the status of the Desert Tortoise: a Federally Threatened Species? In Proceedings of the Desert Tortoise Symposium 1981.

6. Honegger, R. (1979). Red Data Book, Vol 3, Amphibia and Reptilia. IUCN Gland. (3rd edition, revised).

7. Medica, P.A., Bury, R.B. and Luckenbach, R.A. (1980). Drinking and construction of water catchments by the desert tortoise, Gopherus agassizii in the Mojave Desert. Herpetologica 36(4): 301-304.

8. Medica, P.A. Bury, R.B. and Turner, F.B. (1975). Growth of the desert tortoise (Gopherus agassizi) in Nevada. Copeia 1974 (4): 639-643.

9. Pritchard, P.C.H. (1979). Encyclopedia of Turtles. T.F.H. Publications, Hong Kong and New Jersey.

10. Smith, H.M. and Smith, R.B. (1979). Synopsis of the Herpetofauna of Mexico Vol 6 Guide to Mexican Turtles. J. Johnson, N. Bennington, Vermont.

11. Turner, F.B. Medica, P.A. and Lyons, C.L. (1981). A comparison of populations of desert tortoises (Gopherus agassizii) in grazed and ungrazed areas in Ivanpah Valley, California. Proc. Desert Tortoise Council Symposium (1981). 

Gopherus berlandieri (Agassiz 1857)

Order TESTUDINES

Family TESTUDINIDAE

SUMMARY Occurs from south Texas to northeast Mexico. Once abundant throughout its range, but becoming increasingly scarce; extirpated from some areas. Decline due mainly to over-exploitation for the pet trade and to a lesser extent for food. Protected in Texas. Listed on Appendix II of CITES. Status requires monitoring.

DISTRIBUTION Ranges from south Texas (around $29^{\circ} \mathrm{N}$ ) in U.S.A., then south in Mexico through eastern Coahuila (to $102^{\circ} \mathrm{W}$ ) and Nuevo Leon to southern Tamaulipas (north and east of the Sierra Oriental). Just extends into eastern San Luis Potosi and possibly the extreme north of Veracruz (5).

POPULATION Apparently reached maximum abundance in 'lomas' (low hills) west of Brownsville, Texas (4) and along the northern coastal plain of Tamaulipas (3). In southeast Texas in the 1960 s a maximum population density equivalent to one tortoise per $82 \mathrm{~m}^{2}$ (55/acre) and a minimum of one per $4302 \mathrm{~m}$ (11/acre) were recorded (7). Once abundant throughout its range but becoming increasingly scarce; extirpated from some areas (5). No recent quantitative data available.

HABITAT AND ECOLOGY About $15-18 \mathrm{~cm}$ (6-7 inches) long when mature, the largest recorded individual was $21.6 \mathrm{~cm}$ ( 8.5 inches) long (4). Occurs on well drained sandy soils, especially in scrub woodlands, mesquite and possibly chapparal $(1,2,3)$. Unlike other Gopherus species berlandieri does not dig burrows, except in exposed situations in the northern part of its range. More often it modifies the burrows of other animals or scrapes a shallow pallet, of ten at the base of a clump of vegetation $(1,4)$. Winter nights are sufficiently mild over most of its range for this to provide adequate protection (4). In the major non-burrowing part of the range tortoises move, apparently at random, from one locality to another through the entire active season (8). In thorn brush communities in Tamaulipas, food plants are widely scattered so individuals may move up to $400 \mathrm{~m}$ in one day (8).

Feeds mainly on grasses during the wetter periods of the year and on cactus pads, flowers and fruits (especially Opuntia lindheimeri) during the dry season (4). Details of courtship are not known. Nesting takes place during the warmer months, possibly from April to November and definitely from June to August (4). Hard-shelled, elongate eggs $50 \times 35 \mathrm{~mm}$ in size $(2 \times 1.4$ inches $)$ are laid in chambers $15 \mathrm{~cm}$ deep, in well-drained areas, relatively free from surface vegetation and frequently in the drip zones of shrubs $(1,4)$. Clutches of between 1 and 3 eggs, usually the former, have been found in the wild, but a young female held in captivity laid 3-4 eggs at a time (4).

THREATS TO SURVIVAL Exploited for food, and taken in very large numbers for the pet trade $(1,2,4,5)$. The low reproductive potential means that local populations cannot tolerate massive annual depletion. Berlandier's Tortoise is very difficult to keep outside its native habitat, therefore most specimens sold as pets are unlikely to survive more than a few months $(1,4)$. Large numbers are killed on the roads and populations close to major highways must suffer heavy losses (4). Also threatened by habitat loss (6). 
CONSERVATION MEASURES TAKEN It is illegal to collect, harm, trade in, import or export G. berlandieri in the state of Texas. However, there remains a considerable trade in the species (4).

The genus Gopherus is listed on Appendix II of the Convention on International Trade in Endangered Species of Wild Fauna and Flora (CITES). Appendix II listing implies that commercial trade is allowed providing a permit from the country of export is obtained, this can provide a method of monitoring trade levels.

CONSERVATION MEASURES PROPOSED The status of this species requires investigation (6).

CAPTIVE BREEDING The breeding potential is good provided the species is held within its normal range. Numerous specimens are probably held in captivity. No further information available (2).

REMARKS None.

REFERENCES 1. Behler, J.L. and King, F.W. (1979). Audubon Field Guide to North American Reptiles and Amphibians. Alfred A. Knopf. Inc., New York.

2. Honegger, R. (1979). Red Data Book, Vol. 3, Amphibia and Reptilia. IUCN, Gland (3rd edition, revised).

3. Morafka, D.J. (1981). In litt. May 5th.

4. Pritchard, P.C.H. (1979). Encyclopedia of Turtles. T.F.H. Publications, Hong Kong and New Jersey.

5. Smith, H.M. and Smith, R.B. (1979). Synopsis of the Herpetofauna of Mexico. Vol. 6, Guide to Mexican Turtles. J. Johnson, N. Bennington, Vermont.

6. Swingland, I.R. (1981). Report of Ist IUCN/SSC Tortoise Specialist Group. 1-2 October 1981, Oxford.

7. Auffenberg, W., and Weaver, W.G. (1969). Gopherus berlandieri in southeastern Texas. Bull. Fla. State Mus., Biol. Sci. 13: 141-203.

8. Auffenberg, W., and Iverson, J.B. (1979). Demography of terrestrial turtles. Chap. 25, pp. 541-569. In Harless, M., and Morlock, H. (Eds.). Turtles: Perspectives and research. N.Y., Wiley-Interscience. 
Gopherus flavomarginatus Legler 1959

(synonym: Gopherus polyphemus flavomarginatus)

Order TESTUDINES Family TESTUDINIDAE

SUMMARY A large terrestrial species, endemic to Mexico, confined to the Bolson de Mapimi in the Chihuahuan Desert of the north-central plateau. Populations are localized and discontinuous. Many colonies are already extirpated, many are depleted; total population may be between 10,000-20,000 animals. Maximum known density is 7 tortoises per ha, density is usually considerably lower. Primarily inhabits Tobosa Hilaria mutica grassland on gentle slopes at the fringe of basin floor flood plains. This grass is a major food item. The species digs long burrows for shelter from predators and extremes of temperature. Becomes dormant during the cold winters. Reproductive biology poorly known. Severely threatened by use as a human food source, habitat destruction and illegal trade. Protected by Mexican law. Some colonies are protected with - the Mapimi Biosphere Reserve. Most populations are unprotected, existing legislation is not adequately enforced. Listed on CITES Appendix I.

DISTRIBUTION At present restricted to northern central Mexico where populations exist in a series of disjunct closed basins known as the Bolson de Mapimi (centred on the Sierra Mojada), within the Chihuahuan Desert. The overall distribution area is about $150 \mathrm{~km}$ across at its maximum diameter, and covers less than $40,000 \mathrm{~km}^{2}$ at the intersection of northern Durango, southeast Chihuahua and southwest Coahuila states. The actual occupied range is perhaps only $10 \%$ of this area.

Fossil materia! indicates that the range of the Bolson Tortoise was much more extensive during Pleistocene times (13), when the species occurred from Oklahoma (U.S.A.) to Aguascalientes state in southern Mexico. Both climatic changes and 'overkill' by hunters are possible factors in the drastic range reduction; the present range is about $10 \%$ of that occupied in the Pleistocene (13).

POPULATION Populations of G. flavomarginatus are discontinuous and often restricted to narrow linear zones above the arid basin floor flood plains but below rock outcrops of the surrounding hillsides. Present information indicates there are no more than 12 such belts within the species' range. In better-censused belts at Mapimi (Durango) and Cerro Emilio (Chihuahua) there were not more than 1,000 tortoises in each, thus an extremely tentative estimate for the total population would be in the range of 10,000-20,000 individuals (13).

The species is and has been subject to heavy exploitation and habitat loss. Many colonies are known to be severely depleted, and colonies have been extirpated from several sites (13). For example, of the three localities that provided specimens for the first scientific description of the species in 1959 (8), the species is rare and still actively consumed by man at one site, and extinct at the other two sites (Carillo, Chihuahua; north of Lerdo, Durango) (13). Interviews with local residents indicate recent extirpation from several areas; the northern edge of the Laguna Mayran agricultural district (Durango), most of the appropriate habitat west of Highway 49, from a $10 \mathrm{~km}$ strip either side of the National Railroad line from Ceballos (Durango) to El Oro and Cuatro Cienegas (Chihuahua). This latter 
is considered particularly significant since it cuts diagonally through the core of the species' distribution $(10,13)$. In general, human predation for food appears to have eliminated the species from a corridor of about $10 \mathrm{~km}$ along all railroads and paved roads (10). Populations at many other localities are depleted or under heavy pressure (13). Maximum known population density is 7 tortoises per ha in Cerro Emilio (Chihuahua), in the north of the range. Maximum density of active burrows in the Mapimi Biosphere Reserve (Durango), around the centre of the species range, is 2 per ha in well preserved colonies, but densities vary from 5 to 26 per $\mathrm{km}^{2}$ in other areas within this Reserve $(10,11)$. Observations of active burrows were until recently thought to represent the number of tortoises present, but radiotelemetry of tortoises at Mapimi has shown that several tortoises may temporarily show a single burrow (10). Thus the number of active burrows can not be transformed directly into an estimate of population size (10). Age structure of the population in the Mapimi Reserve is $66.6 \%$ adults, $20.8 \%$ subadults, $10.4 \%$ juveniles and $2.1 \%$ small tortoises. The percentage of small tortoises is as high as $14 \%$ in less disturbed areas $(1,10)$.

It is considered probable that the Bolson Tortoise may be extinct in the wild within two or three decades unless effective conservation action is widely implemented $(6,13)$. Factors contributing to this situation include: the limited, shrinking, and increasingly fragmented range; the specialized habitat requirements; the persistent and increasing threats to the species; and the lack of protection for all but the populations within the Mapimi Reserve.

HABITAT AND ECOLOGY A large terrestrial tortoise species (to near $40 \mathrm{~cm}$ carapace length) showing predilection for habitats with low' slope (2-3\% grades), fine textured soil, and 'Tobosa' Hilaria mutica grasslands. Creosote bush Larrea divaricata is generally dominant among the sclerophyll shrubs present. The species avoids steeper areas with coarse textured soil and lacking $\mathrm{H}$. mutica, on which it depends partially for food. Occurs between 1000 and $140 \overline{0} \mathrm{~m}$ elevation. The warm steppe to desert region inhabited is characterized by strong seasonality. The average monthly temperature varies between a minimum of $11^{\circ} \mathrm{C}$ in January and February, when there are night frosts, and a maximum of $28^{\circ} \mathrm{C}$ during the summer. Average annual rainfall is $230 \mathrm{~mm}$ but there is a strong irregularity among years. Up to $80 \%$ of annual total precipitation is concentrated during the June-September summer period (4). The seasonal cycle is characterized by peaks of activity in the spring and summer months, reduced activity in autumn, and dormancy in winter (10). Reproductive behaviour may occur in the warm and relatively dry April-early June spring, but sustained activity is limited to the late June-October summer (10). The Bolson Tortoise shows a unimodal diurnal activity pattern during spring and autumn, and increasing bimodality through the summer. Highest activity levels have been recorded during afternoon periods $(10,12)$.

The Bolson Tortoise digs burrows up to $10 \mathrm{~m}$ in length and $1.5 \mathrm{~m}$ in depth, depending on them for shelter and thermoregulation $(1,10)$. There is typically a mound of soil $10-15 \mathrm{~cm}$ high at the burrow entrance; this may deflect floodwaters from entering the burrow, and also serves as a perch for basking during early morning and late afternoon (10). The burrow provides shelter from both excessively low and high temperatures, and from predators (10). Maximum burrow density is on slopes somewhat above the grasslands of maximal $\underline{H}$. mutica density. This species shows a degree of social organization. A dominance hierarchy system exists in males. Mean home range is 4.1 ha for adult males, 3.1 ha for adult females and 1.2 ha for juveniles.

The species is herbivorous. Twenty-one plant species have been identified in faecal samples from all seasons (1). Grasses comprise $64 \%$ of the diet, shrubs 
comprise $14 \%$ and annual herbs $5 \%$. The most important species in the diet (dry weight percentage) are: Bouteloua barbata (22.7\%), Hilaria mutica (15.2\%), Tridens pulchellus (14.9\%), Sida leprosa (13.5\%), Sphaeralcea angustifolia (9.8\%) and Chloris virgata (5.0\%). B. barbata is the most important food during the last

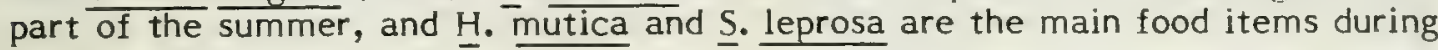
the rest of the year.

Reproduction is not well known and it seems to depend largely on climatic flutuations, possibly being precluded during extremely dry years. Mature eggs have been found in free-living females during late May and late July. Egg laying in captives has been observed during June-July. In captive females (7), clutch size varies from 3 to 9 , with zero to 3 clutches per year. The actual maximum egg output for one female in one yea- was 27 . The reproductive potential may be significantly lower in wild populations (10). Freshly dead hatchlings have been found in early July. Average annual growth is $13 \mathrm{~mm}$ as indicated by yearly carapace increase and plastral growth rings measurements.

THREATS TO SURVIVAL Several factors are affecting the species. Habitat destruction through overgrazing, ploughing and irrigation has apparently contributed to the extirpation of large tortoise colonies. Over-utilization as a food source is probably the main factor in the species' depletion. Illegal trade has also depleted large populations. Tortoises and their eggs have probably been an accessible and constant food source to inhabitants of the desert since pre-Columbian times. Human predation has increased since railroad construction in the 1940's; tortoises were eaten by construction workers and freight cars were loaded with tortoises to be shipped as a delicacy to coastal Pacific cities (11).

CONSERVATION MEASURES TAKEN The species is protected by Mexican law and is effectively protected within the boundaries of the Mapimi Biosphere Reserve through the collaboration of the residents of ranches and ejidos (cooperative farms of the Mexican Government Resettlement Programme) participating in this Reserve. Enforcement of legal protection is inadequate over most of the range due to lack of active resident personnel. Protection is also afforded by some private property owners. Mexican and U.S. border officials have been alerted to the identity and legal status of the tortoise (11).

Cooperative studies between Mexico and U.S.A. on the autoecology of the species are operating since 1978 and will be the basis of a management programme. Listed as 'Endangered' under the U.S. Endangered Species Act 1973.

Listed on Appendix I of the Convention of International Trade in Endangered Species of Wild Fauna and Flora (CITES). Appendix I listing requires that trade in the taxon and its products is subject to strict regulation by ratifying states and international trade for primarily commercial purposes is prohibited.

CONSERVATION MEASURES PROPOSED Declaration of more protected areas. One such area may be established in cooperation with the owners of Ranchos Benthon and La Ventura in the state of Chihuahua. This land still supports high density Bolson Tortoise colonies. A programme of protection for eggs and young is scheduled to start during 1982 at the Mapimi Reserve. Existing laws should be enforced throughout the entire range of the species. The present comprehensive joint Mexican-American project, involving autecological studies as a background to effective management and conservation, should be continued.

CAPTIVE BREEDING There are captive colonies in Mexico and the United States. The Mapimi Reserve headquarters houses three breeding pairs and functions as a recovery centre for tortoises wild-caught in the surroundings. The 
Aragon Zoo in Mexico City has a pair, not known to breed yet. A few persons in the cities of Torreon (Coahuila) and Camargo (Chihuahua) have succeeded in rearing young. Some captive breeding is occurring in the U.S.A.; one pair in Los Angeles, California (7) and two pairs at the Research Ranch, Elgin, Arizona (2). Hatchlings from the Los Angeles captives are being reared at Ojai, California.

REMARKS This account is based almost entirely on a draft very kindly provided by G. Aguirre, L.

The Bolson Tortoise is the largest terrestrial reptile in northern America. First made known to science in 1888 (as Xerobates polyphemus) (5), this tortoise has sometimes been regarded as a subspecies of Gopherus polyphemus (G. P. flavomarginatus), but the validity of G. flavomarginatus as a full species has been clearly demonstrated $(8,9)$. The adaptation of this tortoise to desert conditions, involving aspects of thermoregulation and habitat usage, make the species an especially suitable subject for comparative studies of the biology of desert organisms.

REFERENCES 1. Aguirre, G., Adest, G., Recht, M., and Morafka, D. (1979). Preliminary investigations of the movements, thermoregulation, population structure and diet of the Bolson Tortoise, Gopherus flavomarginatus, in the Mapimi Biosphere Reserve, Durango, Mexico. In Desert Tortoise Council Symposium Proceedings, 1979: 149-165.

2. Appleton, A. (1978). Bolson Tortoise (Gopherus flavomarginatus Legler) at the Research Ranch. In Desert Tortoise Council Symposium Proceedings, 1978: 154-174.

3. Auffenberg, W. and Franz, R. (1978). Gopherus flavomarginatus. Cat. Amer. Amphib. Rept.: 214.1-214.2.

4. Barbault, R. and Halffter, G. (1981). A comparative and dynamic approach to the vertebrate community organization of the Desert of Mapimi (Mexico). In Barbault, R. and Halffter, G. (Eds.). Ecology of the Chihuahuan Desert. Organization of some vertebrate communities. Instituto de Ecologia, Publ. 8.: 11-18. Mexico.

5. Duges, A. (1888). La tortuga polifemo. La Naturaleza, 1 (Set. 2): 146-147.

6. Smith, H.M., and Smith, R.B. (1979). Synopsis of the Herpetofauna of Mexico. Vol. 6, Guide to Mexican turtles. J. Johnson, Vermont.

7. Janulaw, J. (1978). Captive maintenance and breeding of the Bolson tortoise. In Desert Tortoise Council Symposium Proceedings, 1978: 157-163.

8. Legler, J.M. (1959). A new tortoise, genus Gopherus from Northcentral Mexico. Univ. Kansas Pub., Mus. Nat. Hist. II: 335-343.

9. Legler, J.M. and W'ebb, R.G. (1961). Remarks on a collection of Bolson tortoise, Gopherus flavomarginatus. Herpetologica, 17 (1): 26-37.

10. Morafka, D., Adest, G.A., Aguirre, G., and Recht, M. (1981). The ecology of the Bolson Tortoise, Gopherus flavomarginatus. In Barbault, R. and Halffter, S. (Eds.). Ecology of the Chihuahuan Desert. Organization of some vertebrate communities. Instituto de Ecologia, Publ. 8. : 35-78. México.

11. Morafka, D.J. (1982). The Status and Distribution of the Bolson tortoise, Gopherus flavomarginatus. In Bury, R.B. 
(Ed.). North American Tortoises: Conservation and Ecology. U.S. Fish and Wildlife Service, Wildlife Research Report, 12.

12. Nathan, G.B. (1979). Behaviour and ecology of Gopherus flavomarginatus in an experimental enclosure. M.S. Thesis. The University of Arizona. 72 pp.

13. Morafka, D.J. (1982). The autecology of the Endangered Mexican Bolson Tortoise (Gopherus flavomarginatus): a program for conservation, husbandry, and management. Unpublished project proposal, revised 10 February 1982. 

Gopherus polyphemus (Daudin 1802)

Order TESTUDINES

Family TESTUDINIDAE

SUMMARY Formerly common in southeastern United States, has been extirpated from much of its range and remaining populations are declining. Principal threat is loss of habitat to intensive land use. Exclusion of burning from natural and planted woodlands has led to habitat deterioration. This species has a very low reproductive potential, hence is very vulnerable to over-exploitation. Protected from human exploitation in Florida, Alabama and South Carolina. Listed on Appendix II of CITES. Habitat protection and suitable forest management together with regulation of collection needed.

DISTRIBUTION Ranges from coastal South Carolina through southern Georgia and most of Florida (except the Everglades) and eastwards through southern Alabama and Mississippi just into eastern Louisiana. Also occurs on islands off the Gulf coast of Florida (10).

POPULATION Formerly very common, this species has now been extirpated from much of its range and remaining populations are declining (4). In South Carolina an estimated 1500 individuals are found in 2-3 remaining colonies in Jasper County (2). In southern Georgia, where G. polyphemus still occurs on sand ridges in at least 81 counties, some of the largest and most continuous populations are found in the western fall line Sand Hills and the central Tifton Uplands (6). Elsewhere populations are small and discontinuous. Throughout the state populations have been fragmented by urban and agricultural development and depleted by over-harvesting and habitat deterioration (6). Gopher Tortoises are still common in central parts of peninsular Florida but peripheral populations in the west and south have disappeared or are declining rapidly. Colonies in the central regions of Florida have been reduced considerably by development for citrus growing, tourism and urban growth (9).

HABITAT AND ECOLOGY Occurs on dry, well to excessively drained soils, with adequate sand depth for burrowing (in excess of $1 \mathrm{~m}$ ). Such areas and their associated vegetation are usually referred to as sandhills. Low growing herbaceous vegetation, open nest sites and shade are required. Natural stands of long-leaf pine Pinus palustris and scrub oaks Quercus spp. are favoured habitat, but planted stands are also occupied where the canopy is sufficiently open to allow abundant herbs and nest sites with almost full sunlight. Roadsides and the edges of fields and denser plantations are also common burrowing sites $(1,3,5,9)$. Burrows are constructed immediately after hatching. Adult burrows may be 6 to $10 \mathrm{~m}$ long with a chamber 1.5 to $4 \mathrm{~m}$ below the surface (5). Adults use a minimum of three burrows during an activity season (11). Burrows often occur in high densities forming colonies. G. polyphemus feeds principally on grasses and grass-like plants but takes other herbaceous plants, especially wild legumes (Fabaceae) when available. Legumes appear to be particularly important in the diet of juveniles. Fleshy young shoots, the leaves and flowers of Morning Glory, various fruits, Ipomoea pandurata and mushrooms are also taken where available (3). Mating occurs from April to early June. A single clutch of white, nearly spherical eggs with thick calcareous shells is laid annually, usually at the entrance to the female's burrow $(4,8)$. In northern Florida, clutch size was found to average five eggs (4) whilst in southwestern Georgia the average was seven eggs (8). 
N ests are very liable to predation; nest loss of $87 \%$ has been recorded in southern Georgia. In the first years juveniles are also very vulnerable to predation. It has been estimated that in northern Florida mean mortality is $94.2 \%$ between egg laying and age one year. Egg predators include Armadillos Dasypus novemcinictus, raccoons Procyon lotor, gray foxes Urocyon cinereoargenteus and striped skunks Mephitis mephitis (8). Sexual maturity is reached at $16-21$ years and individuals may live from 40 to 60 years. Given such low reproductive potential, harvest can lead to rapid depletion, and recovery of depleted populations will be slow $(1,4,6,8)$.

THREATS TO SURVIVAL The most significant threat is loss of habitat to intensive land use, particularly housing projects, broad-scale agriculture, industrial centres, intensive forest management and sand extraction (6). Another factor of importance is the exclusion of fire from natural long leaf pine/scrub oak habitats. An open canopy and relatively litter-free ground are necesssary for food production and nesting, and such conditions are favoured by regular burning. Tortoise numbers may be reduced by as much as $60-80 \%$ when burning is excluded for eight or more years $(6,7)$.

Given its very low reproductive potential, this species is very susceptible to over harvest. In the past it has been collected extensively for human consumption, although this practice is now declining. Human predation may contribute considerably to local decline (6). Other threats include death on roads and as a result of off-road vehicles, possibly deleterious effects of large scale rattlesnake round-ups, and agricultural chemicals $(6,9,10)$.

CONSERVATION MEASURES TAKEN In Florida it is illegal to take, possess or sell G. polyphemus unless authorised by special regulation or special permit. Permits are granted on the basis that the permitted act must not be detrimental to the survival potential of the species within Florida (12). Also protected from exploitation in South Carolina and Alabama (6).

Listed on Appendix II of the Convention on International Trade in Endangered Species of Wild Fauna and Flora (CITES). Appendix II listing implies that commercial trade is allowed providing a permit from the country of export is obtained, this can provide a method of monitoring trade levels.

CONSERVATION MEASURES PROPOSED Forest management that promotes suitable habitat, in particular regular prescribed burning, thinning of dense oaks and re-establishment of the pine component to produce needle cast which carries fire $(1,7)$. In new plantations using low-intensity site preparation, planting fire-tolerant species at wide spacings and frequent burning will produce habitat that can be used by $\mathrm{G}$. polyphemus $(1,5,7)$. Further habitat protection in the form of state controlled management areas, covering large sand ridges known to support Gopher tortoise colonies, is desirable (6). Regulation or, where necessary, prohibition of collection is needed (6).

\section{CAPTIVE BREEDING Four individuals were born at Palm Desert Zoo in 1979 (13).}

REMARKS More than 30 commensals are found in G. polyphemus burrows (including Indigo Snake Drymarchon corais and Gopher Frö Rana areolata); some of these are found in no other habitats and are themselves threatened.

REFERENCES 1. Anon. (1980). Synopsis. In Landers, J.L., Garner, J.A., McRae, A. K., and Buckner, J.H.' The Gopher Tortoise: Distribution, Ecology, and Effects of Forest Management. Final report study E-1, Georgia Endangered Species 
Investigations.

2. Anon. (1981). South Carolina State Report. Endangered Species Technical Bulletin. Aug. 6(8): 11 .

3. Garner, J.A. and Landers, J.L. (1980). Food and habitat of the Gopher Tortoise in southwestern Georgia. In Landers, J.L., Garner, J.A., McRae, A. K., and Buckner, J.L. The Gopher Tortoise: Distribution, Ecology, and Effects of Forest Management. Final report study E-1, Georgia Endangered Species Investigations.

4. Iverson, J.B. (1980). The reproductive biology of Gopherus polyphemus (Chelonia: Testudinidae) The American Midland Naturalist. 103(2): 353-359.

5. Landers, J.L., and Buckner, J.L. (1980). The Gopher Tortoise, effects of forest management and critical aspects of its ecology. In Landers, J.L., Garner, J.A., McRae, A. X. and Buckner, J.L. The Gopher Tortoise: Distribution, Ecology, and Effects of Forest Management. Final report study E-1, Georgia Endangered Species Investigations.

6. Landers, J.A. and Garner, J.A. (1980). Status and distribution of the Gopher Tortoise in Georgia. In Landers, J.L., Garner, J.A., McRae, A.II. and Buckner, J.L. The Gopher Tortoise: Distribution, Ecology, and Effects of Forest Management. Final report study E-1, Georgia Endangered Species Investigations.

7. Landers, J.L., and Speake, D. X. (1980). Management needs of sandhill reptiles in southern Georgia. In Landers, J.L., Garner, J.A., McRae, A. K. and Buckner, J.L. The Gopher Tortoise: Distribution, Ecology, and Effects of Forest Management. Final report study E-1, Georgia Endangered Species Investigations.

8. Landers, J.L., Garner, J.A. and Mcrae, A. K. (1980). Reproduction of Gopher Tortoises (Gopherus polyphemus) in southwestern Georgia. In Landers, J.L., Garner, J.A., McRae, A.X. and Buckner, J.L. The Gopher Tortoise: Distribution, Ecology, and Effects of Forest Management. Final report study E-I, Georgia Endangered Species Investigations.

9. McDiarmid, R.K. (Ed.). (1978). Rare and Endangered Biota of Florida. Vol. 3 (Amphibians and Reptiles). University Presses of Florida, Gainsville.

10. Pritchard, P.C.H. (1979). Encyclopedia of Turtles. T.F.H. Publications, Hong Kong and N ew Jersey.

11. McRae, A.K., Landers, J.L. and Garner, J.A. (1980). Movement patterns and home range of the Gopher Tortoise. In Landers, J.L., Garner, J.A., MCRae, A.K. and Buckner, J.L. The Gopher Tortoise: Distribution, Ecology, and Effects of Forest Management. Final report study E-1, Georgia Endangered Species Investigations.

12. I.U.C.N. Environmental Law Centre, Bonn.

13. Olney, P.J.S. (Ed.) (1981). International Zoo Yearbook Vol. 21. Royal Zoological Society of London. 

Malacochersus tornieri (Siebenrock 1903)

Order TESTUDINES

Family TESTUDINIDAE

SUMMARY A small terrestrial rock-inhabiting species, found in scattered rocky hills and outcrops in arid scrub and savanna, in southern Kenya and north and east Tanzania. Unique in shell morphology and in ecology. Population levels uncertain, but the species has reportedly been affected by collection for the live animal trade. The clutch comprises a single egg, one or two clutches are laid per year. Listed on CITES Appendix II. Distribution and status require investigation. Numerous animals in captivity, has bred quite readily.

DISTRIBUTION Present in isolated localities in southern Kenya (south of a line joining Njoro in the west and Malindi on the coast) and north and east Tanzania (from Lake Victoria to Lindi near the Mozambique border (5). Recent available reports are only from the Kitui District of Kenya and Dodoma District of Tanzania (1).

POPULATION No precise estimates available, but reported to be undoubtedly declining (7) and threatened in some degree (2). Eleven individuals were once found under one rock (4), so density may be high locally. Reported by local informants to be still fairly abundant in Kitui District (1). Accurate recent data are required. No data for Tanzania.

HABITAT AND ECOLOGY A small (to around 160-180 $\mathrm{mm}$ carapace length) terrestrial tortoise, inhabiting rocky hills (kopjes) and outcrops in arid thornbush or savanna, from $30 \mathrm{~m}$ to $1800 \mathrm{~m}$ altitude.

The Pancake Tortoise is unique among Testudines in shell morphology and in ecology. The shell is extremely flat, sometimes even concave, and compressible. The limbs are unusually slender and flexible. When disturbed the animal tends to run away and hide under a rock slab or in a rock crevice, rather than withdraw into its shell (8). The lungs can be inflated to wedge the animal in position. The species can ascend vertical crevices using the rock-climbing technique known as 'chimney climbing' (3).

Captive animals accept a wide variety of fruits and vegetables, in the wild, dry grass has been recorded as a food item and probably a variety of vegetation is consumed. Mating occurs in January and February, and nesting in July or August (5) (nesting may be at any time of the year in captivity). The clutch comprises a single egg (c $47 \times 28 \mathrm{~mm})$, one or two clutches may be laid per year (8).

THREATS TO SURVIVAL - Reported to be seriously affected by exploitation $(6,7)$ for the pet trade (2). At present only small numbers are exported from Kenya, but this may be due to the difficulty in finding specimens (7). Exploitation is also reported to be heavy in Kenya (1). The presently known populations are in areas with fairly dense human populations and would be particularly vulnerable should the export volume increase (1). No population is known within a National Park or other effective conservation area. No information for Tanzania, no current threats known (1). 
CONSERVATION MEASURES TAKEN Listed on Appendix II of the Convention on International Trade in Endangered Species of Wild Fauna and Flora (CITES). Appendix II listing implies that commercial trade is allowed providing a permit from the country of export is obtained, this can provide a method of monitoring trade levels.

CONSERVATION MEASURES PROPOSED Present Kenya legislation does not require a permit for capture and export of amphibians or reptiles, this does not fulfil Kenya's CITES obligations (6) and should be rectified.

An investigation of current distribution and status is required to clarify present uncertainty.

CAPTIVE BREEDING Numerous individuals occur in zoos and private collections (2). The species has been bred in captivity (9), and breeding potential is good under suitable conditions (2).

REMARKS Although reported to be decreasing, no quantitative data appear to be available to substantiate this. Field investigation is required to establish whether the species is threatened or not.

REFERENCES 1. Duff-MacKay, A. (1981). In litt., 26 February.

2. Honegger, R. (1979). Red Data Book, Vol. 3: Amphibia and Reptilia. IUCN, Gland (third edition, revised).

3. Juvik, J.O. (1971). Chimney climber. Int. Turtle Tort. Soc. J. 5(5): 23-24.

4. Loveridge, A. (1923). Notes on East African tortoises collected 1921-1923, with the description of a new species of soft-shelled tortoise. Proc. Zool. Soc. Lond. 1923: 923-933.

5. Loveridge, A., and Williams, E.E. (1957). Revision of the African Tortoises and Turtles of the Suborder Cryptodira. Bull. Mus. comp. Zool. Harvard. 115(6): 163-557.

6. Norris, C.E. (1980). Excerpts from the report on trade in Fauna and Flora in Kenya for 1979. Traffic (International) Bull. 11(7): 61-68.

7. Norris, C.E. (Director, TRAFFIC (East Africa)). (1981). In litt., 31 January.

8. Pritchard, P.C.H. (1979). Encyclopedia of Turtles. T.F.H. Publications, Hong Kong.

9. Shaw, C.E. (1970). The hardy (and prolific) soft-shelled tortoises. Int. Turtle Tort. Soc. J. 4(1): 6-9, 30-31. 
Psammobates geometricus (Linnaeus 1758)

Order TESTUDINES

Family TESTUDINIDAE

SUMMARY A very small 'starred' terrestrial tortoise, endemic to South Africa, the rarest of a genus of three species restricted to southwest Africa. Confined to a narrow strip of coastal lowland, with Mediterranean macchia vegetation, extending from Cape Town $160 \mathrm{~km}$ northward to Eendekuil. Total number of individuals estimated between 2000 and 4000, divided between 10 to 15 isolated populations. About three quarters of the total population occurs in protected nature reserves. Numbers now appear stable, but the species has been eliminated from most of its former range by habitat loss due to agricultural and urban development. Two to three clutches of two to four eggs are laid per year. Rigidly and effectively protected as an Endangered Wild Animal under Cape provincial legislation. Several reserves are established, the largest (2880 ha) being in private hands, others are government reserves and more areas may be acquired. A long-term research programme is in progress. Listed on CITES Appendix I. Captive breeding has been successful on one occasion, but official policy is to maintain habitat protection as the prime conservation measure.

DISTRIBUTION Endemic to South Africa. Restricted to the extreme southwest of Cape Province, where it occurs in a strip of coastal lowland between the mountains and the sea, around $70 \mathrm{~km}$ wide and extending for $160 \mathrm{~km}$ from Cape Town northward to Eendekuil, with two isolated populations behind (east of) the mountains. The species has always been confined to this area, at least within historical times.

POPULATION Although the outer limits of its range may not have changed markedly, the species is now reduced to between 10 and 15 isolated populations, totalling perhaps 2000 to 4000 individuals. The latter estimate is based on a known population of 150 in a 30 ha area of optimum habitat (giving a maximum density of 5 individuals per ha), and a comparison with other areas available to the species. Numbers appear stable but certain areas outside nature reserves are at risk from extension of agricultural development. Probably at least three quarters of the total P. geometricus population is protected on nature reserves.

HABITAT AND ECOLOGY A very small (to c $150 \mathrm{~mm}$ carapace length) terrestrial species, confined to low-lying areas in macchia vegetation associated with the Mediterranean climate of the southwest tip of Africa. The soils are acid and nutrient-poor, waterlogged in winter and dry throughout the summer. Most populations exist between sea level and $80 \mathrm{~m}$ in the coastal plain, but there is a population at $200 \mathrm{~m}$ in the Breede River valley, and another at $600 \mathrm{~m}$ in the Ceres basin.

Sexual maturity is attained at seven or eight years. The clutch comprises two to four eggs, probably two to three clutches are laid per year. The eggs are laid in spring and hatch in autumn, after an incubation period of between four and six months, before winter rains inundate the soil. Longevity has not yet been estimated accurately, but it is believed that individuals may exceed 30 years.

THREATS TO SURVIVAL Habitat destruction is without doubt the major cause of 
the decline of the Geometric Tortoise. Nearly all low-lying land has been utilised for urban or agricultural development and $\mathrm{P}$. geometricus has proved to be intolerant of habitat modification. It is occasionally eaten by farmworkers and in the past was sought after for the pet trade; these impacts are considered to be negligible. The macchia vegetation is fire-adapted and fire-prone. Too frequent fires in surviving patches of natural vegetation with no potential donor populations nearby can result in local extinction. The spread of exotic vegetation is another major threat.

CONSERVATION MEASURES TAKEN The Geometric Tortoise is protected as an 'Endangered Wild Animal' in Cape provincial legislation. This law is rigidly and effectively enforced. No Cape species of tortoise may be kept in captivity without a permit. No commercial dealing in Cape indigenous reptiles or amphibians is allowed. An 8 ha provincial government reserve (with 22 ha de facto reserve adjacent) was established in 1972. Two other rivives of 30 ha each were established in 1978. The largest and most important reserve is in private hands (est. 1973) and is 2880 ha in extent; at least 1000 ha of this is suitable for $\underline{\mathrm{P}}$ geometricus. Another small area adjacent to this was also acquired by nature conservation authorities in 1978.

A research programme on P. geometricus has been in operation since 1976 and management plans are being drawn up for all reserve areas.

The species is listed in Appendix 1 of the Convention on International Trade in Endangered Species of Wild Fauna and Flora (CITES). Appendix I listing requires that trade in the taxon and its products is subject to strict regulation by ratifying states and international trade for primarily commercial purposes is prohibited.

CONSERVATION MEASURES PROPOSED The provincial authorities hope to purchase or acquire other small reserves containing unprotected tortoises. Shortage of money and staff precludes this at present. However, such natural areas are also rich in threatened plant species and multiple motivation may be successful.

The research programme currently in progress will continue at low key. 300 specimens have been marked and released for long-term study.

CAPTIVE BREEDING Nine specimens are being kept in captivity by private individuals under permit. Four hatchlings were obtained from one pair; the experiment is being continued in order to gain knowledge on captive management. However the authorities are at present opposed to captive breeding as a potential solution, as long as suitable natural habitat is available.

REMARKS The rarest species of the genus Psammobates, a group of three very small 'starred' tortoises, all with relatively restricted and largely allopatric distributions in southwest Africa.

This account is based on a draft kindly provided (17 February, 1981) by J.C. Greig (Herpetologist with the Dept. of Nature and Environmental Conservation of the Cape of Good Hope and member of IUCN/SSC Tortoise Specialist Group).

REFERENCES

Background information and further references are provided in:

1. Greig, J.C., and Burdett, P.D. (1976). Patterns in the distribution of southern African terrestrial tortoises (Cryptodira: Testudinidae) Zoologica Africana 11(2): 249-273.

2. Honegger, R. (1979). Red Data Book, Vol. 3: Amphibia and 
Reptilia. IUCN, Gland (third edition, part revised).

3. Pritchard, P.C.H. (1979). Encyclopedia of Turtles. T.F.H. Publications, New Jersey and Hong Kong. 

or TSAKAFY, KAPILA

Pyxis arachnoides Bell 1827

Order TESTUDINES

Family TESTUDINIDAE

SUMMARY A very small terrestrial species endemic to Madagascar. Restricted to xeric thorn-bush scrub of coastal regions in the south and southwest, from Morombe in the north to Amboasary in the south, extending $10-50 \mathrm{~km}$ inland. No precise population estimates available, but reported to be declining due to habitat destruction and over-collection. Rarely used for food, partly protected by impenetrability of its habitat. Aestivates underground during long dry season. Clutch comprises a single large egg, number of clutches per year unknown. Biology and status poorly known and require urgent investigation. Listed on CITES Appendix II. Representative populations require protection.

DISTRIBUTION An endemic Madagascar species. Restricted to south and southwest regions near the coast, extending from 10 to $50 \mathrm{~km}$ inland, reaching from Morombe in the north to Amboasary (near Fort Dauphin) in the south (4).

POPULATION No precise estimates available, but is reported to be declining (1), perhaps rapidly (8), and localized although apparently not rare north of the Onilahy river (4). Although the potential distribution area is relatively large, populations are of ten remote from one another, and contain a variable number of individuals (8).

HABITAT AND ECOLOGY A very small (to $\mathrm{c} 15 \mathrm{~cm}$ carapace length) terrestrial species, found in arid or semi-arid thorn-bush scrub including Didierea. Mean temperature of the coldest month $\mathrm{c} 19^{\circ} \mathrm{C}$, the sparse annual rainfall of less than $500 \mathrm{~mm}$ falls within a two to four month period. The tortoises aestivate underground during the long dry season. The clutch comprises a single large egg, 25-30 x 33-35 mm in size (4). Number of clutches per year unknown. Very little is known of the biology of $\underline{\mathrm{P}}$. arachnoides.

THREATS TO SURVIVAL Habitat destruction (by man and by bush fires) and over-collection for the pet trade and other purposes, are cited as the main threats $(1,8)$. The species is sometimes used in barter, at the port of Tuléar for example (4). Only rarely used for food.

CONSERVATION MEASURES TAKEN Protected to some extent by the aridity and harshness of its habitat (partly shared with Geochelone radiata). Probably exists within the Lake Tsimanampetsotsa Natural Reserve.

Listed on Appendix II of the Convention on International Trade in Endangered Species of Wild Fauna and Flora (CITES). Appendix II listing implies that commercial trade is allowed providing a permit from the country of export is obtained, this can provide a method of monitoring trade levels.

Each specimen exported is subject to a tax of Fmg 5000 (1).

CONSERVATION MEASURES PROPOSED Field research on biology, distribution and status is required. It would be desirable to have legislative protection of the species and suitable segments of habitat. 
There is interesting clinal variation in plastral mobility; in the southern subspecies P. a. matzi the anterior lobe of the plastron is highly mobile, it is less so (especially in adults) in the southwestern subspecies $\mathrm{P}$. a. arachnoides, and rigid in the western form P. a. brygooi (3). Conservation measures should thus cover populations from different parts of the range $(8,9)$.

CAPTIVE BREEDING A colony (2 males, 2 females) (April 1981) has been maintained at the Knoxville Zoo, Tennessee since 1975. Egg laying has occurred repeatedly but all eggs have been infertile (9).

REMARKS This species until quite recently (6) had been assigned to the genus Testudo, this is maintained by a few authorities (7). Sub-species of $\underline{P}$. arachnoides have recently been discussed by Bour $(3,10)$.

This account is mainly based on data kindly provided by C. Blanc and R. Bour.

REFERENCES 1. Blanc, C. In litt., cited in reference 5.

2. Blanc, C. (1981). In litt., 16 th January.

3. Bour, R. (1979). Les tortues actuelles de Madagascar (République malgache): liste systématique et description de deux sous-espèces nouvelles. (Reptilia-Testudines). Bull. Soc. Et. sci. Anjou, N.S., 10:141-154.

4. Bour, R.(1981). In litt., 16 February.

5. Honegger, R. (1979). Red Data Book, Vol. 3: Amphibia and Reptilia. IUCN, Gland (third edition, revised).

6. Loveridge, A., and Williams, E.E. (1957). Revision of the African Tortoises and Turtles of the Suborder Cryptodira. Bull. Mus. comp. Zool. Harvard. 115(6): 163-557.

7. Wermuth, H. and Mertens, R. (1977). Testudines, Crocodylia, Rhynchocephalia. Das Tierreich. 100:1-174.

8. Blanc, C. (1981). In litt., 24 February.

9. Juvik, J. (1981). In litt., 27 April.

10. Bour, R. (1981). Etude systematique du genre malgache Pyxis Bell, 1827 (Reptilia, Chelonii). Bull. Soc. Linn. Lyon 50(4+5): 132-176. 

or KAPIDOLO

Pyxis planicauda (Grandidier 1867)

(Synonym: Acinixys planicauda)

Order TESTUDINES

Family TESTUDINIDAE

SUMMARY A very small terrestrial species, endemic to Madagascar. Restricted to the Andranomena forest, an area of approximately $100 \mathrm{sq} . \mathrm{km}$ near Morondava on the central-west coast of the island. No precise population estimate available, but reported to be declining due to habitat destruction, and currently restricted to a very small area largely surrounded by unsuitable habitat modified for agriculture. Aestivates underground during long dry season. Clutch comprises a single large egg, number of clutches per year unknown. Biology and status poorly known and require urgent investigation. Listed on CITES Appendix II. Remaining habitat requires protection.

DISTRIBUTION An endemic Madagascar species. Apparently restricted to the Andranomena forest, an area of approximately $100 \mathrm{sq} . \mathrm{km}$ situated $20 \mathrm{~km}$ northeast of Morondava on the central-west coast of Madagascar. Records outside this area are unconfirmed (3), the species may occur as far north as Maintirano ( 8 ) but no specimens have been found in apparently suitable forests around the Andranomena area (4).

POPULATION No precise estimates are available, but the species is restricted to a very small area, and is reported to be certainly threatened (2) and declining (1).

HABITAT AND ECOLOGY A very small (c $125 \mathrm{~mm}$ carapace length) terrestrial species, occurring in dry lowland deciduous forest and bush, relatively less arid than bush zones further south in the range of the related species $\mathrm{P}$. arachnoides. Mean temperature in the coolest month is above $20^{\circ} \mathrm{C}$, annual rainfall, restricted to a four or five month period, is between 600 and $800 \mathrm{~mm}$. Numerous ponds are present in the Andranomena forest area (3). Virtually nothing is known of the biology of $\mathrm{P}$. planicauda. The single egg is relatively large, $25-30 \times 33-35 \mathrm{~mm}$ (3), and weighs $15-20 \mathrm{gm}$ (7). Number of clutches per year unknown. The species aestivates underground during the long dry period (3).

THREATS TO SURVIVAL Habitat destruction is cited as the cause of population decline (I). The present refuge of the species, the Andranomena forest, is largely surrounded by modified habitat and agricultural development. A vast area of cleared forest is devoted to a maize-growing scheme (3). Other remaining forest areas, although apparently suitable for $\mathrm{P}$. planicauda, have not been found to hold the species (4). Bush-Pig popuiations are increasing throughout Madagascar, and are considered a threat to tortoise eggs and young (10).

CONSERVATION MEASURES TAKEN The Andranomena area is privately owned, there is a possibility that it will be donated to WWF Madagascar for administration as a reserve, negotiations are currently (November 1981) in progress (9).

Listed in Appendix II of the Convention on International Trade in Endangered Species of Wild Fauna and Flora (CITES). Appendix II listing implies that 
commercial trade is allowed providing a permit from the country of export is obtained, this can provide a method of monitoring trade levels.

CONSERVATION MEASURES PROPOSED The remaining habitat must be protected. Field study on the status and biology of $\underline{P}$. planicauda is urgently required (3).

CAPTIVE BREEDING A pair have been maintained at Knoxville Zoo, Tennessee, since 1975, no eggs have yet been produced (April 1981) (8).

REMARKS This species has widely been treated as forming a separate mpnotypic genus Acinixys (5). Recent re-assessments $(3,6,11)$ support treating planicauda as the northern representative of the genus Pyxis (the second species, $P$. arachnoides, occurs along western and southern coastal regions of Madagascar).

This account is primarily based on information kindly provided by $\mathrm{C}$. Blanc and $\mathrm{R}$. Bour.

REFERENCES 1. Blanc, C. (1981). In litt., 16 January.

2. Bour, R. (1979). Les tortues actuelles de Madagascar (République malgache): liste systématique et description de deux sous-espèces nouvelles. (Reptilia-Testudines). Bull. Soc. Et. sci. Anjou, N.S., 10: 141-154.

3. Bour, R.(1981). In litt., 16th February.

4. Domergue, C.A., cited in reference 3 .

5. Loveridge, A., and Williams, E.E. (1957). Revision of the African Tortoises and Turtles of the Suborder Cryptodira. Bull. Mus. comp. Zool. Harvard. 115(6): 163-557.

6. Obst, F.J. (1980). Ergänzende bemerkungen zu den Testudiniden Madagaskars (Reptilia, Chelonia, Testudinidae). Zool. Abh. Mus. Tierk. Dresden 36(12): 229-232.

7. Pritchard, P.C.H. (1979). Encyclopedia of Turtles. T.F.H. Publications, Hong Kong.

8. Juvik, J. (1981). In litt., 27 April.

9. Albignac, R. (1981). Pers. comm. 25 November.

10. Blanc, C. (1981). In litt., 24 February.

11. Bour, R. (1981). Etude systematique du genre endemique malgache Pyxis Bell, 1827, (Reptilia, Chelonii). Bull. Soc. Linn. Lyon, 50(4-5): 132-176. 
Testudo graeca graeca Linnaeus 1758

Order TESTUDINES

Family TESTUDINIDAE

SUMMARY A medium size terrestrial tortoise. Present in a variety of habitats including heath, dunes and semi-desert. Occurs in parts of Spain and the Ralearic Islands, North Africa from Morocco east to Libya, and introduced to localities in France and Italy. Populations in North Africa depleted in areas of heavy commercial collecting, also threatened by habital destruction. Depleted in Spain. Legally protected in several countries, export from Morocco illegal since 1978. Listed on Appendix II of CITES. Basic information on the biology of this species is needed.

DISTRIBUTION The Spur-thighed Tortoise Testudo graeca graeca occurs in isolated colonies in southern Spain (Murcia-Almeria, Coto de Donana Reserve and the la Mancia-New Castille Region), southwest Mallorca, the Pityusen Islands (Ibiza and Formentera), and northern Africa from Morocco east to Cyrenaica in Libya. Introduced into peninsular Italy, Sicily and probably Sardinia $(4,8,12)$.

POPULATION Severely depleted in much of the range, notably in Morocco.

Algeria In the last century tortoises were reported to be extremely common in northern Algeria. Tortoises have been collected in the Oran region for export to France as pets since the end of the last century $(9,13)$. In 1973 half a million tortoises reportedly were sold in France annually. Requests for import of a total 700,000 specimens were received by the French Ministry of Agriculture in 1979 (9). In a 10 hour search in the Region of Oranois one recent worker reported finding only one individual (9). Elsewhere the species would appear to be relatively abundant. In some regions tortoises are reported to be found at sighting frequencies of 4 to 10 per hour (2). Still found in reasonable numbers in the Algiers region, despite well-developed agriculture (9).

France Introduced. Population status uncertain, not clear if regular breeding occurs $(11,13)$.

Italy Introduced to peninsular Italy, Sicily, probably also into Sardinia (4). Uncertain if regular breeding occurs in all localities. Precise status unknown, considered rare $(5)$ and threatened $(3,6)$.

Libya No data.

Morocco Traditionally supplied most specimens for the pet trade in Europe until 1978 when Morocco ratified CITES and banned the export of all wild animals including tortoises. At its peak the trade exported several hundred thousand tortoises annually. Populations now severely depleted. In heavily collected areas tortoises are now scarce: one worker recorded an average sighting frequency of 0.41 per man-hour in June 1978 (9). Comparisons between west Turkey and Morocco suggest that collection over the last 80 years could have reduced abundance by as much as $90 \%$ in some areas (9).

Spain Populations exist at low densities and have disappeared from many areas of 
Tunisia In the nineteenth century tortoises were reported to be common on the Tunisian plains. In the past small numbers have been exported to Italy (9). No recent data.

HABITAT AND ECOLOGY A medium sized terrestrial species, large individuals reaching more than $25 \mathrm{~cm}$ ( 10 inches) in length. Found in a variety of habitats, including sparsely vegetated coastal heathlands, sand dunes and semi-desert areas (14). This species hibernates during the winter but may emerge temporarily during warm days. Emerges finally as early as February in hot coastal areas. Mating occurs in the spring and eggs are usually laid in May and June (reported to be June and July in Israel). Clutch size ranges from 2-5, egg size approximately 3 $\times 4 \mathrm{~cm}$. Mainly herbivorous (12).

THREATS TO SURVIVAL The main threats to this species are habitat destruction and bulk trade collection. Habitat destruction is particularly significant in the Mediterranean coastal belt where large scale tourist development is occurring. Agricultural habitat modification also influence reproductive success (10). Large-scale collection for the pet trade has resulted in populations in northwest Africa being severely depleted; numbers may have been reduced by as much as $90 \%$ in some areas. Selective size collection both to meet voluntary agreements in the U.K. and to maximize profits has had an effect on the size and weight of tortoises remaining in the wild. In general, tortoises in areas of heavy collection tend to be smaller and lighter. Females tend to be larger than males and selective collection of the middle size range may have resulted in small males being left to mate with especially large females. This may affect reproductive success $(9,10)$. Following Morocco's ban on tortoise exports the bulk of this trade has switched to Turkey (2). Studies in Germany suggest that after arrival in northern Europe more than $80 \%$ of imported tortoises die in the first year. This is mainly due to stress caused by transportation, poor conditions in pet shops, and disease and parasite attacks encouraged by unsuitable climate (2,9). A further threat may be posed by the desertification of the range. The northward extention of the Sahara has resulted in retraction of $\mathrm{T}$. graeca distribution in Libya (10).

CON SERVATION MEASURES TAKEV Legally protected in France and Spain (8). Occurs in the Coto de Donana reserve in Spain (8). After ratifying CITES in 1978 Morocco banned the export of all wild animals, including tortoises (2).

Listed on Appendix II of the Convention of European Wildlife and Natural Habitats, Berne 1979 (8). This obliges contracting parties to take appropriate legislative and administrative measures to ensure strict protection of the species.

Listed on Appendix II of the Convention on Trade in Endangered Species of Wild Fauna and Flora (CITES). Appendix II listing implies that commercial trade is allowed providing a permit from the country of export is obtained, this can provide a method of monitoring trade levels.

CON SERVATION MEASURES PROPOSED Basic information on the biology of this species, including population structure and ecology, is needed. Further reserves which include populations of this species would be advantageous (8). Trade should continue to be restricted.

CAPTIVE BREEDING Large numbers of this species are kept as pets. Regular breeding in captivity is possible, given appropriate care and conditions (14). It has been suggested that captive-bred tortoises should replace wild-caught specimens in the live animal trade (14). 
REMARKS Testudo graeca is so named because the appearance of the carapace scales reminded Linnaeus of a Greek mosaic, it is not the typical and widespread tortoise in Greece. The subspecies $T$. g. ibera is named after Iberia in Transcaucasia and not the Iberian Peninsula (12).

The remaining subspecies of Testudo graeca are distributed as follows (12): T. g. ibera is found in parts of northeastern Greece (also Euboea), southern Yugoslavia, Bulgaria, eastern Romania, Turkey, Syria, northern Iraq, western Iran $(7,8,9,12)$. T. g. terrestris occurs in northeast Egypt, Libya and Israel, also Jordan, Lebanon, Syria and southeast Turkey $(7,12)$. I. g. zarudnyi is only found in eastern-central Iran $(9,12)$.

REFEREVCES 1. Andrada, J. (1980). Guia de campo de los Anfibios y Reptiles de la Peninsula Ibérica. Omega, Barcelona.

2. Anon. (1981). The Tortoise Trade. A report on an investigation carried out by the Royal Society for the Prevention of Cruelty to Animals.

3. Bruno, S. (1980). In litt.

4. Bruno, S. and Maugeri, S. (1977). Retilli d' Italia, Vol. I. Tartarughe-Sauri, Martello-Giunti, Firenze.

5. Capula, M. (1980). In litt.

6. Di Palma, M.G. (1980). In litt.

7. Honegger, R.E. (1981). Identification manual, Vol. 3. Reptilia, amphibia, pisces. Family Testudinidae. Secretariat of the Convention on International Trade in Endangered Species of Kild Fauna and Flora.

8. Honneger, R.E. (1981). Threatened Amphibians and Reptiles in Europe. Supplementary Vol., of Handbuch der Reptilien und Amphibien Europas, Kiesbaden Akad. Verlag.

9. Lambert, M.R.K. (1980): The Mediterranean Spur-Thighed Tortoise, Testudo graeca, in the wild and in trade. Proc. Euro. Herp. Symp. C. K.L.P. Oxford.

10. Lambert, M.R.K.(1981). The conservation of Mediterranean ( $W$-Palaearctic) tortoises: the problem posed. (Abstract). First Ordinary General Meeting Societas Europaea Herpetologica. 13-16, September, Vienna; Abstracts.

11. Parent, G.H. (1980). In litt.

12. Pritchard, P.C.H. (1979). Encyclopedia of Turtles. T.F.H. Publications, Hong Kong and N ew Jersey.

13. Rische, J.P. (1980). Pers. comm.

14. Kirsche, K. (1980). Conservation of Tortoises by breeding. Proc. Euro. Herp. Symp. Oxford C.K.L.P. p. 125 (Abstr.), also in ASRA Journal 1(3). 

Testudo hermanni Gmelin 1789

Order TESTUDINES

Family TESTUDINIDAE

SUMMARY A small terrestrial tortoise, restricted to southern Europe. The range extends around the Mediterranean, often in coastal areas, from nor theast Spain eastward to European Turkey; reaches parts of Romania and Bulgaria, also present on Mallorca, Corsica, Sardinia, Sicily and some Greek islands. Western populations (T. h. robertmertensi) are in general extremely localized and depleted; eastern populations (T. h. hermanni) are more widespread and sometimes with adequate numbers, but heavily exploited for the pet trade in many areas and declining in parts. Inhabits a variety of rather dry habitats (scrub woodland, heath or maquis, for example), in areas with hot summers, of ten at coastal sites. Mainly herbivorous. Clutch comprises 1-12 eggs, often around three, there may be two clutches per season. Threatened by habitat loss and over-collecting for the pet trade. Listed on Appendix II of the Convention on the Conservation of European Wildlife and Natural Habitats. Listed on Appendix II of CITES. Nominally protected by legislation in much of the range, present in a few protected areas.

DISTRIBUTION Restricted to southern Europe. Present in Albania, Bulgaria, France, Greece, Italy, Romania, Spain, Turkey and Yugoslavia.

In Spain, present in small numbers in the south of Menorca and two populations in northeast and southeast Mallorca (Balearic Islands), also on the mainland, in a small area in the north of Gerona province (11). Also reported from the area of Valencia (1), with scattered reports from elsewhere. There is a possibility that most $T$. hermanni colonies on the mainland are not indigenous (20). In France $T$. hermañn is similarly localized, occuring in the Albères hills along the French-Spanish border in the east Pyrenees, and the Maures and Estérel mountains in Var province (southeast France) (11). Also present on Corsica, mainly along the east coast. Hermann's Tortoise is present in peninsular Italy, mainly on the Ligurian and Tyrrhenian coasts and also occurs on Sicily, Sardinia, and certain smaller islands including Elba, Lampedusa and Pantelleria (30). In Yugoslavia the species ranges along the Adriatic coast from Dalmatia southwards, then southeast through parts of Macedonia to Albania and Greece, and just into southwest Romania. This species is the most widespread tortoise in Greece where it appears to occur over much of the mainland including the Peloponnese (4). It may be absent from parts of the southeast, around Corinth (4, map), and becomes progressively rarer east of Thessaloniki (25). Present on the Ionian Islands, including Corfu. Present in southern Bulgaria and European Turkey (22).

This species is usually (35) treated as comprising two subspecies; $\underline{T}$. $\underline{h}$. robertmertensi from central Italy, Sardinia and Corsica westwards, and $\bar{T}$. $\bar{h}$. hermanni from southern Italy and the Balkans. However, some doubt has been raised about the proper assignment of animals from peninsular Italy (30).

\section{POPULATION}

Albania No data.

Bulgaria Widespread (31), no further data. 
France During Neolithic times $T$. h. robertmertensi ranged across the entire Mediterranean region of mainland France, and also much further to the north (10). The species has since undergone a severe regression, due apparently to climatic and human influences, and is now restricted to hills in the province of Var in the extreme-southeast (the Massifs des Maures and Estérel), and the Albéres in the east Pyrenees. The tortoise is now regarded as severely threatened in France $(10,11)$. Extirpated in the early 19th century in Iles d'Hyéres due to over-exploitation (23). Although the general area of distribution may not have diminished greatly for several decades, the density of individuals is progressively decreasing (12). However, numbers remain locally adequate in parts of the Massif des Maures, particularly on higher ground (27), and Corsica (24).

Greece Populations are widespread and still generally in satisfactory condition, although an overall decline has been observed (15). In the northeast, the species becomes progressively rarer east of Thessaloniki (25). At a major 75 ha study site on coastal heath at Alyki (Macedonia), average T. hermanni density was 55 per ha, with a total population of around 5,000 (25). In optimal dry sandy heath habitat within this site, a maximum density of over 150 tortoises per hectare was observed (25).

Italy In general, rare and localized (30); has disappeared from much of the coast, but probably retains natural densities in some National Parks (eg. Maremma) or on private land $(6,7)$.

Romania Recorded from about 40 localities in the counties Mechedinti, Caras-Severin and Gorj; all near the Yugoslavian border in the extreme southwest (14). Reportedly decreasing drastically (16).

Spain Both Testudo species in mainland Spain are reported to exist in low density and to have disappeared from many areas (1). In the Balearics, populations are extremely localized in the south of Menorca (20), and local in Mallorca.

Turkey Restricted to localities in European Turkey (33,34), apparently not

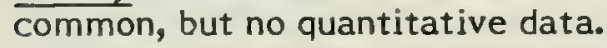

Yugoslavia Probably declining locally due to collecting for the pet trade (16). Healthy populations are known in parts of Dalmatia and Montenegro $(21,29)$. Around 125 individuals were noted in a $2 \mathrm{~km}^{2}$ area in Montenegro (21).

HABITAT AND ECOLOGY A small terrestrial tortoise, to around $20 \mathrm{~cm}$ length, individuals in western populations may be a little smaller. Inhabits a variety of of ten rather dry habitats, in areas with hot summers. Generally in lowlands and low hills. At one study site in northern Greece, maximal tortoise density was found in areas of dry sandy heath with a ground cover of lichens and herbs, Artemesia clumps, Hawthorn and Ruscus aculeatus (25). Elsewhere in the range, open deciduous woodland, wood edges, scrub fields and hillsides, maquis and garrigue vegetation, etc., may be inhabited $(4,29,30)$.

Mainly herbivorous, although invertebrates, carrion and faeces may be eaten on occasion. At one scrubland site in southern Yugoslavia (21) leguminous plants of the subfamily Papilionoidea provided the bulk of the diet.

Sexual maturity may be attained (in females) at around seven years. There is typically a period of winter hibernation, courtship may occur sporadically throughout the summer. Eggs are generally laid in May-June, with the hatchlings emerging in August-September. A flask-shaped nest $7-8 \mathrm{~cm}$ deep is excavated by 
the hind feet. The clutch comprises from one to 12 eggs, usually three. Eggs are hard-shelled, slightly elongate. There may be two clutches laid per season $(22,32)$.

THREATS TO SURVIVAL Threatened mainly by large-scale commercial collecting and habitat destruction. Western populations assigned to $\underline{T}$. $\underline{h}$. robertmertensi, particularly those in mainland France, are at risk due to the extremely localized distribution. About 103,450 ha of maquis and pine woods have been destroyed by fire in Var (France) in the last ten years, and $20 \%$ of the French hermanni population may have been destroyed in the fire of July $1979(9,12)$. Over-collecting and urbanization are further threats (11). On the Tyrrhenian coast of Italy, transformation of the coastal environment by building speculation, collecting for the pet trade, and use as food by local inhabitants, are cited as major threats (8). Populations in Yugoslavia have been subjected to extremely heavy collection pressure; as many as 40,000 animals were exported for the pet trade in the early 1970s (16). Ten thousand tortoises declared as hermanni from Turkey and 70,500 from Yugoslavia were imported into the U.K. in 1978 (3), and 38,600 from Yugoslavia into the F.R.G. in 1979 (17). The tortoises are eaten by man in some parts of the range, eg. Bulgaria (26).

CONSERVATION MEASURES TAKEN Listed on Appendix II of the 1979 Convention on the Conservation of European Wildlife and Natural Habitats (the Berne Convention) (2). This obliges contracting parties to take appropriate legislative and administrative measures to ensure strict protection of the species. As of 1981 (16) the Convention has been signed by Austria, Belgium, Denmark, Federal Republic of Germany, Finland, France, Greece, Ireland, Italy, Liechtenstein, Luxembourg, Netherlands, Norway, Portugal, Sweden, Switzerland, Turkey, United Kingdom.

Nominally protected within its range by legislation in Bulgaria, France, Romania, Spain (16), also Greece. Import of tortoises into France is prohibited (13). A major population of $\mathrm{T}$. hermanni occurs on private land in Mallorca and is the main subject of the Son Cifre Conservation Project (19). Some populations in Italy occur in protected areas, including the Parco Naturale Regionale della Maremma, in coastal Tuscany (5). A three-year research programme is in progress in the Massif des Maures (Var) (28), and research is under way at the Centro Biologico del Sur (Spain) (16).

Listed on Appendix II of the Convention on International Trade in Endangered Species of Wild Fauna and Flora (CITES). Appendix II listing implies that commercial trade is allowed providing a permit from the country of export is obtained, this can provide a method of monitoring trade levels.

CONSERVATION MEASURES PROPOSED Mass collection for the pet trade should be eliminated. Natural Reserves for the important French population in the Massif des Maures, also in the Albéres and the Balearic Islands, are urgently required. Basic biological data are required. Population status in general is poorly known; eastern populations in particular should be investigated to determine the extent of suspected local declines.

CAPTIVE BREEDING Regular breeding in captivity is possible, given appropriate care and conditions (18). It has been suggested that captive-bred tortoises should replace wild-caught specimens in the live animal trade (18).

\section{REMARKS None.}

REFERENCES 1. Andrada, J. (1980). Guia de campo de los anfibios y reptiles de la peninsula iberica. Barcelona: Editorial Omega. 
2. Anon. (1979). Explanatory report concerning the Convention on the Conservation of European Wildlife and Natural Habitats. Council of Europe, Strasbourg.

3. Anon., U.K. Dept. of Environment, CITES Report for 1978.

4. Arnold, E.N., and Burton, J.A. (1978). A Field Guide to the Reptiles and Amphibians of Britain and Europe. London: Collins..

5. Balleto, E. (1981). Pers. comm., 23 April.

6. Bruno, S. (1971). Red Book: Testudo hermanni Gmelin. Notiz. Unione Erpetol. Ital. 1(2): 30 .

7. Bruno, S. (1973). Problemi di conservazione nel campo dell' erpetologia. Atti 3rd Simp. naz. Conserv. Nat. Bari 2: $117-226$.

8. Chelazzi, G. (Ist. di Zoologia, Firenze). (1980). In litt.

9. Cheylan, M., Pers. comm. to M. Dumont, noted in reference 12.

10. Cheylan, M. (1978). Species account for Testudo hermanni, p. 76, In Anon., (Societe Herpetologique de France). Atlas preliminaire des Reptiles et Amphibiens de France. Montpellier.

11. Cheylan, M. (1981). Actual status and future of Hermann's Tortoise in western Europe. Paper presented at the 2nd European Chelonian Symposium, 3 October, Oxford.

12. Dumont, M. (1974). Les chéloniens de France. Leur avenir, leur protection. Le courrier de la nature. 33: 224-227. Also published (1972) in Natur. Orléan. 3(5): 10-12.

13. Dumont, M. (1979). Halte aux importations des tortues. Le courrier de la nature. 61: 20-22.

14. Fuhn, I.E. (1981). Rare and endangered amphibians and reptiles in Romania, proposal for conservation. Text of paper read at Societas Europaea Herpetologica meeting, 3-16 September, Vienna.

15. Gruber, U. (1982). Herpetofauna Griechenlands (text of lecture given at meeting of the Scientific Commission of the Hellenic Society for the Protection of Nature, 27 March, Karlsruhe).

16. Honegger, R.E. (1981). Threatened Amphibians and Reptiles in Europe. Supplementary volume of Handbuch der Reptilien und Amphibien Europas, Wiesbaden, Akad. Verlag.

17. Honegger, R. (1981). CITES Identification manual. Vol. 3: Reptilia, Amphibia, Pisces, - Testudines (text). CITES Secretariat, IUCN, Gland, Switzerland.

18. Kirsche, W. (1980). Conservation of Tortoises by breeding. Proc. Euro. Herp. Symp. Oxford C.W.L.P. p 125 (Abstr.), also in ASRA Journal I(3).

19. Kramer, T. (1981). Statement at first meeting of IUCN/SSC Tortoise Specialist Group, 1-2 October, Oxford.

20. Lopez Jurado, L.F., Talavera Torralba, P.A., Ibanez Gonzalez, J.M., Macivor, J.A., and Garcia Alcazar, A. (1979). Las Tortugas terrestres Testudo graeca y Testudo hermanni en Espana. Naturalia Hispanica, 17: 1-63.

21. Meek, R., and Inskeep, R. (1982). Aspects of the field biology of a population of Hermann's Tortoise (Testudo hermanni) in southern Yugoslavia. Brit. J. Herpetol. 6: $159-164$.

22. Pritchard, P.C.H. (1979). Encyclopedia of Turtles. T.F.H. Publications, New Jersey and Hong Kong. 
23. Risch, J.-P. (1979). Les tortues terrestres paléarctiques (Testudo spp.) en France: présence à l'état sauvage, maintien et reproduction en captivité, protection (Reptilia, Testudines, Testudinidae). Bull. Soc. Zool. Fr. 103(4): 524-527.

24. Rische, J.-P. (1980). Pers. comm.

25. Stubbs, D., Hailey, A., Tyler, W., and Pulford, L. (1981). University of London Natural History Society, Expedition to Greece 1980. Report, pp. 1-136.

26. Sura, P. (1981). Notes on the reptiles of Bulgaria. Brit. Herp. Soc. Bull. 3: 25-28.

27. Swingland, I. (1980). Pers. comm.

28. Swingland, I. (1981). Pers. comm., 1 October.

29. Windolf, R. (1980). Zur biologie, ökologie und zum artenschutz der Griechischen Landschildkröte (Testudo hermanni h.) in Jugoslavien. Ökol. (Z.f. Ökologie, Naturund Umweltschutz). 2(4): 14-20.

30. Bruno, S., and Margeri, S. (1977). Retilli d'Italia, Vol. 1, Tartarughe-Sauri. Firenze: Martello-Giunti.

31. Beskov, V., and Beron, P. (1964). Catalogue et Bibliographie des Amphibiens et des Retiles en Bugarie. Ed. Acad. Bulg. Sci., Sofia, pp. 1-39.

32. Street, D. (1979). The Reptiles of Northern and Central Europe. London: Batsford.

33. Basoglu, M., and Baran, I. (1977). Türkiye Sürüngenlen. Kisim 1. Kaplumbaga ve Kertenkeleler. (The Reptiles of Turkey. Part 1. The Turtles and Lizards). Fen. Fak. Kitaplar Ser. Ege Univ., No. 76. Bornova, Izmir.

34. Eiselt, J., and Spitzenberger, F. (1967). Ergebnisse zoologischer Sammelreisen in der Turkei: Testudines. Ann. Naturhistor. Mus. Wien. 70: 357-378.

35. Wermuth, H., and Mertens, R. (1977). Testudines, Crocodylia, Rhynchocephalia. Das Tierreich, 100, pp 1-xxvii, 1-174. Berlin: Walter de Gruyter. 

Testudo kleinmanni Lortet 1883

Order TESTUDINES

Family TESTUDINIDAE

SUMMARY A very small terrestrial tortoise, restricted to a narrow coastal zone in the southeast Mediterranean, from east Cyrenaica (Libya), west through parts of north Egypt including Sinai, to southwest Israel. Inhabits areas of sandy soils, dunes and solidified sands. Plant cover is generally very low (5-10\%) but is greater $(30-40 \%)$ where not overgrazed. Population density in Israel is $4-5$ specimens per $\mathrm{km}^{2}$, this is extremely low in comparison to that of small tortoises elsewhere. Habitat in Israel, Sinai, and probably throughout the range is severely degraded by overgrazing; tortoises have to move further to find food and shelter, and are more exposed to predation. Main predator is probably Brown-necked Raven Corvus ruficollis; populations of this crow are not high in open sandy habitats, but are increasing as settlements spread. Nominally protected by legislation in Israel, although ineffectively as habitat is not adequately protected; no data for Libya or Egypt. The $200 \mathrm{~km}^{2}$ Holot Agur reserve, recently approved, may be large enough to hold a viable $\underline{T}$. kleinmanni population. Field research on ecology is required, status in Libya and Egypt requires investigation. Listed on CITES Appendix II.

DISTRIBUTION Testudo kleinmanni occurs in a narrow belt along the coast of the Mediterranean from south-west Israel to east Cyrenaica (Libya), with a broad interruption caused by the heavy alluvial soils of the Nile Delta. Recorded from northern Sinai and northwest Egypt, extending westward into Cyrenaica (2). It has recently been found in southwest Israel, where it occurs in sandy areas, up to $60 \mathrm{~km}$ inland from the coast of the Mediterranean (south, southwest and west of Be'er-Sheva). As the species occurs only in sandy habitats, its distribution in Israel is restricted to an area of approximately $1000 \mathrm{~km} 2$. Its distribution is similar to that of the viperid snake Cerastes vipera - both species seem not to be able to withstand extremely arid conditions and occur therefore only close to the Mediterranean. The specimen of Testudo kleinmanni recorded from Bir Gindali (c $200 \mathrm{~km}$ from the coast of the Mediterranean) (3) near Cairo may be a displaced specimen, as tortoises are often collected as pets, may escape and be found outside their natural range. Tristram (6) records this species from "the region beween Hebron and Beersheba and of the Arabah, south of the Dead Sea". However, tortoises (Testudo graeca terrestris) at present occur only in the hills close to Hebron; in the remaining areas mentioned by Tristram no tortoises whatever are found.

POPULATION Very little is known about the population status of Testudo kleinmanni anywhere in its range. In Israel the population density is approximately 4 to 5 specimens per $\mathrm{km}^{2}$, about a quarter of which are young and immatures. This is a very low density, compared to other small tortoises, e.g. Testudo hermanni (4). This low density may not be natural, but the result of degradation of the habitat by overgrazing. In Sinai overgrazing is even more severe than in Israel and vast areas of $T$. kleinmanni habitat are now almost completely devoid of vegetation and probably uninhabitable by this species. This may be the reason that only one specimen (found dead) has recently been recorded from northern Sinai (7). The situation may be better in Egypt, for Flower (2) mentions 159 specimens that lived in the Giza (Cairo) Zoo during his stay there in the 1930s. Thirteen specimens, mostly from a locality in the extreme northeast, 
were collected during intensive field research in the 1960s (3). The present status of $T$. kleinmanni in Egypt is unknown. The entire distribution area of the Egyptian Tortoise is relatively small. As most of the area does not provide optimal conditions, and the population density is low, the entire world population of this species is probably small; possibly below 10,000 specimens altogether, and perhaps many fewer.

HABITAT AND ECOLOGY A very small species of terrestrial tortoise, males reach about $10 \mathrm{~cm}$, females about $13 \mathrm{~cm}$. The Egyptian Tortoise inhabits areas of sandy soils, dunes, (where they have a fair amount of plant cover of bushes and small shrubs), and solidified sands with a denser plant cover. The quality of the habitat depends on the amount of grazing.

At present most of the areas in which Testudo kleinmanni are found have a low plant cover of $5 \%$ to $10 \%$, this is an unusually open habitat for a tortoise species. The plant cover may increase where not degraded by overgrazing, and may reach $30 \%$ to $40 \%$. An increase in plant cover is the main factor in consolidation of sand dunes. On the other hand, overgrazing that reduces the plant cover may turn solidified sand dunes into shifting dunes again, as has happened in many areas in northern Sinai. A relatively dense plant cover can only develop in areas that receive a fair amount of rain, between $100-200 \mathrm{~mm}$. This precipitation also makes possible the development of a short-lived annual vegetation; this provides the main food for $T$. kleinmanni. The relatively high precipitation may be the main factor restricting T. kleinmanni to areas along the Mediterranean, because these areas receive a higher rainfall than areas further away from the coast.

The Egyptian Tortoise is active during the winter, when the other reptiles of its habitat are dormant, until early spring. This strategy protects it from one of the main day-active predators, the monitor lizard Varanus griseus, which feeds on any animal it can swallow (including young tortoises), and begins its activity in April. Testudo kleinmanni or their tracks are occasionally seen already in October, but the main activity is from December to March. In April, activity is already much reduced and from May to October tortoises or their tracks are rarely seen.

The tortoises are active at air temperatures between $18^{\circ}$ to $30^{\circ} \mathrm{C}$ and soil surface temperatures between $20^{\circ}$ to $32^{\circ} \mathrm{C}$. During their activity they may move considerable distances within a few hours, as can easily be seen by their tracks (later obliterated by the wind). The longest recorded distance covered by a female during her morning activity was $600 \mathrm{~m}$. When she eventually dug in, she was almost $400 \mathrm{~m}$ from the starting point.

During their activity the tortoises feed intensely, mainly on annual vegetation. Possibly they also feed on leaves of perennial bushes and shrubs, but most parts of these are out of reach. If ambient temperatures become too low or too high, the tortoises seek shelter. If deserted rodent burrows are available, these are used and, if necessary, enlarged. Otherwise active rodent burrows are entered. If no burrows are available, the tortoises dig burrows for themselves, always under bushes or shrubs. It is not known how deep they dig into the sand.

Nothing is known about their reproduction in nature (see Captive Breeding section, below).

THREATS TO SURVIVAL The main threats to the survival of this small tortoise are degradation of the habitat by overgrazing, and development for agriculture, industry and settlements. The tortoises have to cover larger distances in an overgrazed habitat in order to find food, and are thus more exposed to predation. In addition, in an overgrazed habitat the density of rodents is low and the 
tortoises have more difficulty in finding rodent burrows in which to hide, and shrubs (under which they could dig burrows of their own) are small and widely scattered.

Little is known about natural enemies. The most common diurnal predator of this habitat, Varanus griseus, is a threat only to young tortoises, and the activity periods of both species show little overlap. Large mammalian predators - hyenas and wolves - are rare in this area and are active at night. Bedouin dogs, active day and night, probably eat any tortoise they can crack. Foxes Vulpes vulpes arabica probably have little influence because of their nocturnal activity. Some tortoises found dead appear to have been killed by a blow with the 'nabout', the club-like stick used by the Bedouin.

The main predator, however, appears to be the Brown-necked Raven Corvus ruficollis and, in areas close to the Mediterranean, the Hooded Crow Corvus corone sardonius. Under a tree on which a pair of ravens perched were found the shells of seven Testudo kleinmanni that had been eaten, two of them still fresh and not yet completely eaten. One of them was seen to be dropped by one of the ravens. About half of the adult Testudo kleinmanni found are empty or almost empty shells, that had apparently been eaten by Ravens, who dismember the tortoise, working through the front and the rear opening of the shells. Sometimes the movable rear scutes of the plastron are bent or removed. This predation may be the direct reason for the low population density of this tortoise. The Egyptian Vulture Neophron percnopterus eats turtles and tortoises in the same way; however, it is very rare in this habitat.

This avian predation emphasizes the importance of dense vegetation, under which the tortoises are better protected than in an open habitat. At present Ravens are not common in the open sandy habitats inhabited by $\mathrm{T}$. kleinmanni. Populations of the Brown-necked Raven increase, however, around human settlements, and future developments will adversely influence populations of this tortoise, not only by destruction of habitat, but also by increasing predation pressure via increasing populations of ravens and dogs. The low reproductive capacity is another feature of $\underline{T}$. kleinmanni unfavourable for the survival of the species.

CONSERVATION MEASURES TAKEN The species is legally protected in Israel. However, this protection is quite meaningless, as habitat destruction and avian predation are the main dangers threatening this species. A few small nature reserves have been established in Israel in the distribution area of this tortoise. They may be useful in the future, when the vegetation has recovered from overgrazing. More important is a recently approved reserve (Holot Agur = Agur Sands) of more than $200 \mathrm{~km} 2$. This reserve, when properly managed, may be large enough to ensure the survival of a viable population of Testudo kleinmanni.

No data for Egypt or Libya.

Listed on Appendix II of the Convention on International Trade in Endangered Species of Wild Fauna and Flora (CITES). Appendix II listing implies that commercial trade is allowed providing a permit from the country of export is obtained, this can provide a method of monitoring trade levels.

CONSERVATION MEASURES PROPOSED In Israel control of feral dogs and Brown-necked Ravens may become necessary in the future. Feral dogs are already being controlled at present, but this control is only able to prevent an increase of populations of feral dogs and does not reduce their numbers. Establishment of reserves in Sinai and Egypt will be important for the survival of the Egyptian Tortoise in these areas. As very little is known about the ecology 
and population dynamics of Testudo kleinmanni, research using marked specimens and radio-tracking is imperative.

CAPTIVE BREEDING Nothing is known about the reproduction of this species in nature. Young specimens found in winter have the same size range as captive-bred specimens that hatched during September and October.

Growth rate in nature and in captivity seems to be similar, but the growth rings are more pronounced in nature, as wild specimens feed intensely during their activity season and do not feed during aestivation, whereas captive specimens feed almost throughout the year.

In the Giza (Cairo) Zoological Gardens (2) copulations were observed most frequently during September and October, and clutches of two eggs were laid in June. Hatchlings mostly emerged in October. At the Tel Aviv University Wildlife Research Centre copulations were observed in October, November, February and March. Eggs were laid between April 29th to July 22nd and young hatched between August 27 th to October 17th, with one exception: an egg laid on July $22 \mathrm{nd}$ hatched only on December 6 th. At $30^{\circ} \mathrm{C}$ incubation time was between 97 to 119 days. However, this incubation temperature does not seem to be the normal one, as 14 hatchlings that could be sexed were all males. The influence of incubation temperature on the sex of the hatchlings is well known for several chelonians $(1,5)$.

The reproductive potential is low: among 12 clutches laid at the Tel Aviv Centre were six of one egg, two of two eggs, three of three eggs and one of four eggs. It is likely that in nature they do not reproduce during drought years at all. Growth rate, on the other hand, is rapid in this small tortoise; males reach sexual maturity when four years old, perhaps even at three years, females when five years old. Growth slows down after six or seven years and growth-rings added thereafter are very narrow, making exact estimates of age difficult. In Israel this species seems not to reach a great age, possibily because of predation. Among 61 specimens checked, only one had worn scutes. If Testudo kleinmanni behaves in this respect as Testudo hermanni (4), few specimens reach an age of more than 15 years.

REMARKS This account is based on an extensive draft very kindly provided by $H$.

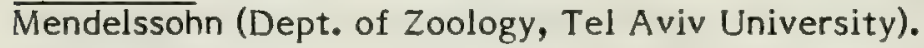

REFERENCES 1. Bull, J.J. and Vogt, R.C. (1979). Temperature-dependant Sex Determination in Turtles. Science 206: $1186-1158$.

2. Flower, S.S. (1933). Notes on the Recent Reptiles and Amphibians of Egypt. Proc. Zool. Soc. Lond.: 735-851.

3. Marx, H. (1968). Checklist of the Reptiles and Amphibians of Egypt. Special Publication, United States Naval Medical Research Unit. No. 3. Cairo, Egypt.

4. Stubbs, D.A. Hailey, Tyler, W. and Pulford E. (1980). Expedition to Greece. University of London Natural History Society.

5. Swingland, J.R. (1980). Environmental Sex Determination in Chelonians. ASRA Journal. I(2):34-36.

6. Tristram, H. $\bar{B}$. (1885). The Fauna and Flora of Palestine, Palestine Exploration Fund, London.

7. Werner, Y.L. (1973). The Reptiles of the Sinai Peninsula. Hebrew University of Jerusalem (in Hebrew). 


Order TESTUDINES Family CHELONIIDAE

SUMMARY A circumglobal species, nesting mainly in temperate and subtropical regions. Populations are still widespread, although some are known to have declined and others are suspected to have declined. The largest known nesting populations are those on Masirah Island (Oman) and in Florida (U.S.A.). A minimum of 30,000 females nest annually on Masirah. Between 6,000 and 15,000 females are estimated to lay in U.S.A., the great majority of these in Florida. Good numbers nest in Australia. Elsewhere numbers are either unknown, or low to moderate. A large sea turtle, to $90 \mathrm{~cm}$ carapace length (sometimes to $1 \mathrm{~m}$ ). A carnivorous species, feeding mainly on benthic invertebrates (especially molluscs and crustaceans). The relatively large head accomodates powerful jaw muscles. Nesting generally occurs in late spring and summer, usually at night. Eggs 40-42 $\mathrm{mm}$ diameter, mean clutch size from 101 (Masirah) to 126 (S. Carolina). Females typically nest 4-5 times a season, and can remigrate at 2-3 year intervals. Threatened mainly by incidental capture in trawls, loss of habitat due to coastal development, and local exploitation. Nominally protected by legislation in much of the range. Nesting occurs on relatively few protected beaches. Further protected areas, restriction of incidental catch and full implementation of protective legislation are required. Listed on CITES Appendix I.

DISTRIBUTION Found in temperate and subtropical waters worldwide (38). Almost all nesting areas except the Western Caribbean are either north of the Tropic of Cancer or south of the Tropic of Capricorn (45). Knowledge of movements away from nesting areas is scant, but Loggerheads are known to move very considerable distances fairly rapidly, suggesting purposeful non-random travel (39). Information about migratory movements derived from tagging programmes remains at a preliminary stage (39). Wandering individuals have been recorded in temperate and arctic waters, to $700 \mathrm{~N}$ at Murmansk, U.S.S.R., and to $35^{\circ} \mathrm{S}$ at Rio de la Plata, Argentina.

In the United States nesting occurs on suitable beaches from North Carolina to Southern Florida (38), with minor nesting sites further north in Virginia and south into Texas (51). The major nesting range extends from South Carolina south to the lower Gulf Coast of Florida; most nesting is in Florida where Melbourne Beach has the greatest concentration (7). The most northerly nesting record dates from 1972 at Ocean City, New Jersey (45). On the Gulf Coast of Florida very little nesting is recorded north of Sarasota County with the exception of Franklin County where nests are found regularly. (45). Individuals tagged in the south eastern United States have been recovered along the eastern seaboard as far north as New Jersey; and in the Florida Keys, the Bahamas, the Dominican Republic, Cuba, Yucatan and Belize. (39).

Some nesting occurs in the Western Caribbean, in Cuba, Jamaica, the Dominican Republic and Puerto Rico. The species is caught in Bahamanian waters with minor nesting sites at Andros, Abaco, Little Inagua and rreat Inagua (10). In Mexico there are minor nesting sites in Veracruz from Tampachichi to Barra de Corazones, and in Campeche from the Tabasco border to Laguna de Termino; with major sites on the northeastern coast of Yucatan, and in Ouintana Roo near Boca 
Paila (26,51). Scattered nesting continues along the eastern coasts and offshore cays of Belize, Guatemala, Honduras, Nicaragua and Colombia, and the western coast and islands of Venezuela. The Loggerhead is a common coastal species in Uruguay especially in the Atlantic areas of Rocha, but is not known to nest (22). Scattered nesting occurs in Brazil from Maranhao to Espirito Santo (51). Pacific coast nesting occurs in Panama $(45,51)$ and possibly Costa Rica (15). Also reportedly frequents Pacific beaches of Nicaragua (15). Reported relatively abundant in northern Chile. Not reported from Peru, but may occur along the southern coastline (23). In the eastern Atlantic nesting has been reported from Namibia (31). Large numbers of turtles, including Loggerheads, were encountered at Foz do Cunene in Parque Nacional de Iona, Angola in October 1971 and March 1972 , and it is possible that Loggerheads nest on this park's $160 \mathrm{~km}$ of coastline $(31,32)$. In Morocco, nesting is reported as far north as Menasra, and possibly at Plage Blanche $(8,51)$. Loggerheads have been reported as occuring in Mauritania (western part of Baie de Levrier, the Banc d'Arguin) and along the West coast of Africa including Senegal, Guinea Bissau, Sierra Leone, Ghana, Gabon (possibly Olive Ridley), and the Congo (8). Nesting used to occur on Goree Island, Senegal and the beach of Almadies, and may still do so, and is likely to occur along other parts of the coast of West Africa $(31,45)$. The only recent report (1979) of nesting in Senegal comes from one of the very small beaches of the Ile de Madeleine (off Dakar) (8).

Loggerheads occur in waters around the Azores, Madeira and the Canaries but are not known to nest there (8). Nesting on an unknown scale may take place in the Cape Verde islands; the Loggerhead certainly occurs in the area (8).

The Loggerhead is fairly common throughout the Mediterranean (18), with large scale nesting along the coast of Turkey to Israel especially at Mulga, Dalaman, Fethiye, Selcuk Izmir and Edremit Balikesin, and in Israel between Nahariya and Rosh Haniqra, and Alit and Northern Sinai (51). Smaller scale nesting occurs on the northwest coast of Cyprus $(17,45,51)$, Zakynthos $(35,37)$ and other Ionian islands of Greece (5), southern Sicily $(5,45)$ and Lampedusa (Isole Pelagie) with possibly some residual nesting in southern Italy, Sardinia and Corsica (5). Probably at least some nesting occurs along the entire Mediterranean coast of North Africa (45). There is some nesting in southern Sinai (51).

In the Indian Ocean there is large scale nesting in soutiern Africa, notably on Paradise Island, Mozambique, mainland Mozambique, and on the Tongaland coast of South Africa $(20,31)$. Tag returns from Tongaland indicate that Mozambique and Tanzania are important feeding grounds for the nesting populations in southern Africa $(20,39)$. Further important nesting sites occur on Madagascar particularly in the southeast around Fort Dauphin $(20,31,45,51)$ with some nesting on the west coast as far north as Morondava (45).

The largest known nesting population occurs on Masirah Island, Oman where an estimated 30,000 female Loggerheads nest each year (47).

The Loggerhead is caught in waters off India and Sri Lanka and possibly nests (20). It is listed as occuring in Pakistan, but this is unconfirmed (20). Loggerheads were suspected to nest in the Maldives but the identification was on the basis of egg sizes in a nest and may be invalid (20). There are reports of a large rookery on Diamond Island, Burma (51) but these are not based on recent data and may anyway refer to the Olive Ridley rather than the Loggerhead (6). In Indonesia and Thailand, apart from sporadic records, almost nothing is known of the status of the Loggerhead, although it reputedly nests in the West Sumatra area (44). 
Along the Chinese coast the Loggerhead sometimes occurs in seas adjoining the provinces of Gungdong, Gudhgxi, Fujian, Zhejiang, Jiangsu, Shandong and Hebei. Nesting appears to occur only in the Xisha Islands in the South China Sea (14). Nesting is reported in Taiwan (51). In Japan nesting occurs on all of the southern islands from the Ryukyu Islands to as far north as Kasima Nada on Honshu (45). Important sites include the east coast of Kyushu, the south coast of Shikoku, Kii Peninsula and the Shizuoka Prefecture (51).

Loggerheads are widespread and abundant in Queensland and West Australia (34). In Queensland there are three major rookery areas; the Capricorn/ Bunker group of islands including Wreck Island and Tryon Island; the Bundaberg to Round Hill Head coastline including the Mon Repos and Wreck Rock beaches; and the Swain Reefs islands of the southern Great Barrier Reef. Additional low density nesting occurs widely throughout the state south from Lizard Island (14\% $\left.41^{\prime} \mathrm{S}\right)$. Tag recoveries indicate that Loggerheads nesting in the Capricorn/Bunker and Bundaberg rookeries come from feeding grounds which extend along the entire Queensland coast, the eastern Gulf of Carpentaria and Papua New Guinea including the Trobriand Islands. There are large populations of Loggerheads in the Great Barrier Reef area (34). Elsewhere in eastern Australia sporadic nesting is reported as far south as Newcastle $\left(33^{\circ} \mathrm{S}\right)$ in New South Wales. In Western Australia Loggerheads are fairly common from Shark Bay northward with nesting occurring in the Shark Bay area including Dorre Island, north at least as far as Barrow Island $(9,34)$. Surveys of the Northern Territory and Western Australia have yet to be made and only partial knowledge of distribution and abundance exists for these states. $(9,34)$. The Loggerhead appears to be locally common in the southern part of New Caledonia, south of Noumea, possibly nesting $(45,55)$.

POPULATION Sea turtle populations are particularly difficult to census. Censusing populations at sea poses major logistical problems. Migratory routes, the developmental habitats of juveniles, and feeding grounds have not been identified sufficiently to allow for estimations of total population. Males never leave the water and juvenile numbers fluctuate greatly due to high hatchling mortality. The number of nesting females can be estimated more easily, by aerial and ground surveys of nests and nest tracks. Nesting populations vary strongly between years. The reasons for this are not fully understood. Nesting population estimates must therefore be based on several years' data. Resultant estimates of yearly female arrivals can be used as some index of population size. When relating this to the total number of reproductive females allowance must be made for the proportions of females exhibiting one-season nesting as opposed to cyclical remigration. Ignorance of natural sex ratios, and the age-structure of sea-turtle populations makes extrapolation to total population impossible (40).

Loggerhead populations are under pressure from local exploitation, accidental capture in shrimp trawls, and beach development throughout the world. $(16,46)$. Known population declines have occurred in Honduras, Quintana Roo (Mexico) and Colombia. Other populations are subject to considerable pressure but there are no comparative data to assess the effect (46).

Angola Very large numbers were encountered at Foz do Cunene in Parque Nacional do Iona, in October 1971 and March 1972. It is possible that this species nests in the park's $160 \mathrm{~km}$ of coastline (32).

Australia Widespread and abundant in Queensland, where an estimated 3,000 or more Loggerheads nest annually. Approximately 1,000 of these nest on Wreck Island (34). Sporadic nesting occurs as far south as Newcastle, New South Wales (34). Substantial numbers of Loggerheads nest in the Shark Bay area of Western Australia and are fairly common from Shark Bay northward (9). Comparison of 
present population levels with scant historical records is difficult but provides no evidence of significant decline in Australia (34).

Azores Caretta caretta occurs in large numbers around the Azores and the seas north of these islands (to about $420 \mathrm{~N}$ ) (8).

Bahamas Small numbers of Loggerheads nest on the coasts of Great and Little Inagua, but are now only rarely seen offshore. Sparse to moderate nesting occurs on the east coasts of Andros and Abaco where adults appear to be resident in all seasons (10), and sparse nesting occurs throughout the archipelago.

Belize Suitable nesting beaches occur along much of the Belize coast, and on offshore cays. The long-established presence of man, however, appears to have resulted in little or no nesting on Ambergris Cay in Northern Belize and along several of the smaller islands such as Cay Chapel, and St. Georges Cay in Central Belize. Loggerhead nesting has been recorded at Half Moon Cay on Lighthouse Reef. Loggerheads still nest in moderate numbers in southern Belize, especially on Nicolas, Ranguano and other smaller cays (10). Juveniles are more numerous along the southe $n$ than northern coast. Loggerheads are the most abundant mature resident turtles (10).

Burma In 1911 it was reported that one and a half million Loggerhead eggs were taken annually from Diamond Island, Burma, however it is very probable that in the report the Olive Ridley was misidentified as the Loggerhead (6). No more recent data are available.

Canary Islands The species has been recorded in the Canary Islands, and small specimens seem to be taken regularly by local fishermen during the summer. (8).

Colombia Minor nesting occurs on the Caribbean coast, near Santa Marta; possibly 400 females annually. This population is known to have declined (58).

Cape Verde Islands Several Loggerheads have been recorded from the Cape Verde Islands. A very young specimen from Sao Vincente, recorded in 1896, has been taken to imply that the Loggerhead has bred there at least once (8).

Cuba Loggerheads are caught at sea commercially. Nesting females are protected. There are indications that nesting populations may be declining (46).

Cyprus Small scale nesting occurs on the northwest coast of Cyprus. 890 hatchling Loggerheads were released from the Lara hatchery project in 1980 (24).

France Last recorded nesting in Corsica in 1932. No recent population data available (5).

Greece An average 15-20 Loggerheads have been reported to nest each night from June-August on the Island of Zakynthos (35). More recent data indicate an average of 41.7 females emerging nightly during the 1981 season, on five of the six known nest beaches (36). Precise data on population trends are not available but interviews with local inhabitants suggest a steady decline primarly due to tourist pressure and coastal development. $(35,37)$. 'Many' hatchlings and adults were reported from a beach of the Ionian Islands in 1978 and a Loggerhead was photographed nesting on Kilini beach on the Ionian coast of Greece in 1976 (5).

Guatemala Marine turtles, especially Loggerheads, are fairly regularly killed in shrimping trawls in Guatemalan waters. (10) 
Honduras Together with Green and Hawksbill Turtles, Loggerheads nest on extensive beaches between Puerto Cortes and La Ceiba, but their numbers are much diminished. Developmental habitat around all the Bay Islands is badly depleted. Loggerheads are taken incidentally in shrimp trawls fairly regularly (10).

Israel The population has declined from about 30-40 thousand individuals at the turn of the century; it is now approaching extinction (49).

Italy Non-breeding individuals occur in good numbers in Italian waters, (with over $\overline{2,000}$ specimens killed annually in Sicily (18)) probably originating mainly in the east Mediteranean and North Africa, to which they may return for breeding (5). A small amount of nesting may occur annually in southern Italy (5). The only nesting site documented in recent years is on Lampedusa in the Isole Pelagie, and is threatened by illegal camping and tourist development $(5,18)$.

Jamaica Loggerheads nest very sparsely and adults are occasionally caught in drift lines, in deeper waters (10)

Japan The situation is unclear but there are reports of extensive exploitation and disturbance with consequent population decline (46).

Madagascar Annual nesting females are estimated at around 300 (20), but despite protective legislation, all marine turtles a-e under pressure from exploitation and there are no marine reserves where Loggerheads can nest unmolested (31).

Madeira Large numbers of Loggerheads are found around Madeira and many are slaughtered for tourist souvenirs or local consumption. In 1979 the number of Loggerheads slaughtered annually was estimated at 2,000 (8).

Mexico A protected population nests in Quintana Roo, with about 500 annual nesters (58). Marine turtles are extensively exploited in Mexico, and although precise data are lacking, it seems probable that Loggerheads have declined to a low level $(10,26)$.

Mozambique An estimated 300 Loggerheads nest annually in Mozambique (20).

Nicaragua Loggerheads emerge very infrequently along most of the eastern Nicaraguan mainland and offshore cays (10).

Oman An estimated mimimum 30,000 Loggerheads nest annually on Masirah Island (47). This is the largest known nesting population $(20,31)$. The rapid development of a village near the main nesting beaches is a cause for some concern (47).

Panama On the Caribbean coast Loggerheads are only rarely seen on shore. Offshore adults are rare, but subadults are reported to be common in both $\mathrm{C}$ iriqui and Almirante lagoons (10). On the Pacific coast the Loggerhead is considered to be by far the most abundant species of marine turtle. Turtle populations in general have decreased drastically in the last 10 years. At least 30 Pacific beaches were formerly known to host moderate nesting aggregations; only 12 important beaches remain, and on these populations are not as large and the nesting season is not as prolonged as formerly. At the Biological Reserve at Isla de Canas thousands of turtles, including Loggerheads, are reported to nest on 70 $\mathrm{km}$ of beach (15).

Senegal The Loggerhead has been described as rare in Senegal (8).

South Africa Loggerheads nest on the Kwa-Zulu coast, an area known as 
Tongaland. These populations have been subject to some form of protection since 1916 and have been monitored since 1963/64. After a decade of little change, Loggerheads nesting annually have increased from a low of 184 , to 408 in $1978 / 79$ (31).

Turkey A 1979 survey estimated that 135,000 eggs were laid on a $100 \mathrm{~km}$ stretch of the Turkish coast, from Dalyankoy to Alanya, average egg loss is $47 \%$ thus leaving 63,000 healthy eggs. The majority of nests on which these data are based were Loggerhead, but a few Green Turtle nests may have been included. Only 100 $\mathrm{km}$ of a 2,000 km Mediterranean coastline was surveyed (21).

United States of America In 1978 the Loggerhead population in the United States was estimated at 25,000-50,000 individuals. Censuses indicate that about 22,000 nests are dug each year in the United States as a whole, with 19,895 of these occurring in Florida. Assuming 3.5 nests per turtle and 2.5 years between nesting this gives an estimate of a total 15,714 adult females nesting in the United States with 14,210 of these nesting in Florida. Another estimate (58) suggests 6,000-15,000 females nest annually in southeast U.S.A.. The Florida population probably represents more than $90 \%$ of the total United States population $(3,38)$. It is also second in size only to that of Masirah Island in Oman (10). Many of the Loggerheads' nesting beaches have been destroyed or modified by development (16) and this appears to have resulted in the displacement of Loggerhead females to more protected nesting grounds, or to more isolated areas even if less geomorphically suitable. For instance, increased nesting at the Cape Romain National Wildlife Refuge, South Carolina, is thought to be related to human development occurring to the north and south of the refuge, and it has been suggested that the abandonment of Jekyll Island rookery in favour of the Cumberland Islands in Georgia was due to development and encroachment on Jekyll Island (50). Principal nesting sites include Jupiter Island, Cape Romain, Cumberland Islands, Kennedy Space Centre, and Cape Sable (51). The major beach in Florida is Melbourne Beach (Brevard County) (7).

HABITAT AND ECOLOGY A large sea turtle, with a somewhat elongate red-brown carapace, typically to $36-38$ inches $(91.4-96.5 \mathrm{~cm})$ in length $(45)$. The maximum recorded carapace length is 45 and one quarter inches $(114 \mathrm{~cm})$, larger records appear to be in error or unsubstantiated (45). Typical weight of a mature specimen is $200-350 \mathrm{lbs}(90.7-158.8 \mathrm{~kg})$, few Australian adult Loggerheads exceed $150 \mathrm{lb}(68 \mathrm{~kg})(45)$. Compared with other sea turtles, the head is much larger in relation to body size, accomodating more bulky jaw-closing muscles (45).

Most nesting beaches are north or south of the tropics, in subtropical or temperate zones (45). However, the species does feed within the tropics. Primarily a neritic species; although long-distance movements are known, these often appear to take place along coastlines, not over open sea (25). Tagging programmes have demonstrated several apparently regular dispersal routes (39). Turtles from the Tongaland (South Africa) population move northward after nesting, to Mozambique and Tanzania (with a few tag returns from Madagascar and South Africa); Loggerheads from the north-east Queensland rookeries have been recorded along the Queensland coast to the eastern Gulf of Carpentaria and Papua New Guinea; those nesting in southeast USA move either northward along the eastern seaboard (north to New Jersey), or southward to the Gulf of Mexico, Cuba, Dominican Republic and mostly to the Bahamas (41). Recent findings (13) of large numbers of torpid Loggerheads in the Port Canaveral Ship Channel (Florida), apparently buried in mud, present the possibility that the species may hibernate in other temperate areas of the range. There is evidence that very young Loggerheads may spend the first several months of life associated with mats of Sargassum weed $(11,45)$. 
The Loggerhead is a carnivorous species, feeding mainly on benthic invertebrates, especially molluscs and crustaceans, also sponges (42). With its very bulky jaw musculature, Caretta is even able to crush the shells of Giant Clams Tridacna spp. and Queen Conches Strombus gigas (42). Sub-adult and adult Loggerheads in Mosquito Lagoon (Florida) feed almost entirely on Horseshoe Crabs Limulus polyphemus; Loggerheads in Australia have been recorded to eat horn shells (Certhidae), ear shells Haliotus spp. and turban shells Turbo spp.; nesting females off the Mon Repos beach feed mainly on prawns and fish (42).

Nesting is seasonal, generally occurring in late spring to summer; for example, November-January in Tongaland (South Africa), May-August in Florida and South Carolina (U.S.A.) (27). Nesting generally occurs at night (45). The nesting process conforms closely with the stereotyped pattern shared by all sea turtles $(12,45)$. Clutch size ranges from a mean of 101 (range 72-130) on Masirah Island (Oman) to 126 (range 64-198) at Cape Romain, South Carolina (27). Eggs are typically about 40-42 mm diameter (27). Incubation periods recorded range from 55 to 65.6 days (27). Studies on the Tongaland population have shown that females can nest in up to six seasons within a nine year period, but there is no universal remigration pattern (30). The most common remigration intervals are 2-3 years $(7,30)$. It may be that nesting in more than one season is not typical of the entire population of reproductive females, in any event, most females tagged on the nesting beach are never seen nesting in another season (30). Females may typically nest 4-5 times in one season (27), but a maximum of 7 nests has been recorded for one female at Little Cumberland Island, Georgia (33). There is some evidence that nesting Caretta show less site fixity, between or within seasons, than Green Turtles (7). In one extreme case, a female nesting on 9 July at Cape Lookout National Seashore (North Carolina) nested again 19 days later, $725 \mathrm{~km}$ to the south, at Canaveral National Seashore (Florida) (53). Hatchling output per season per female is 200 in the Tongaland population, and may be similarly high in the south-east U.S.A. populations (27). The growth rate of immature Loggerheads at Mosquito Lagoon (Florida) (59) was approximately twice that of Green Turtles in the same waters. At this locality Loggerheads would be expected to mature in 10-15 years and Green Turtles in 25-30 years. Growth rates would be expected to vary geographically, with differing water temperatures and food sources. An age at maturity of only four years has been reported in the Tongaland population (29).

THREATS TO SURVIVAL The major threats to survival of Loggerhead populations are incidental capture in trawls (46), loss of nesting habitat to coastal development $(16,50)$ and local exploitation $(46)$. Loggerheads are caught in trawl nets, particularly bottom trawlers fishing for shrimp and demersal fish, and often drown or are battered to death. Off the southeast coast of the United States up to 4,000 per year may be killed in this way (46). In 1980 there was a particularly high incidence of stranding of dead turtles in Virginia, South Carolina, Georgia and Florida; thought to be associated with pound net fishing in Virginia, sturgeon netting in South Carolina and shrimp trawling in South Carolina and Georgia. More than 1,800 sea turtles were reported as stranded (3). The stranding rate is reported to be increasing in the coastal waters of Georgia. Greatest mortality is amongst large juveniles and subadults $55-80 \mathrm{~cm}$ in carapace length, the group upon which future reproduction is dependent (46). Trawler activities are also reported to cause significant mortalities off the Pacific coast of Panama (15), the western Mediterranean (possibly 1,000 per annum) (46) and Colombia (46). A further major threat to the Loggerhead is loss of nesting habitat to coastal development; this has been particularly significant in the United States and the Mediterranean $(5,16,50)$. Artificial lights appear to cause disorientation of nestirig females and hatchlings. Hatchlings and adults may head inland and be killed on roads or die of desiccation $(7,19)$. Lights or other disturbance may be connected with a high 
proportion of false crawls (16). Studies on the coast of South Carolina suggest that Loggerhead females may remain in the surf zone for extended periods before coming ashore; this may imply a greater potential for disturbance than at first thought (2). On Hutchinson Island, Florida declines in nesting populations of Green and Loggerhead turtles over a 3 year period have been attributed to expanding urban development (50). In Kiawah Island, South Carolina, nesting activitiy was observed to be lowest in areas with beach homes and no restrictions on lighting or traffic. Beaches which were more isolated were increasingly used even when less geomorphically suitable (50). Increased nesting activity at the Cape Sable rookery within the Everglades National Park may be connected with the abandonment of increasingly disturbed beaches outside the park (16). A similar view is taken of increasing nesting at Cape Romain National Wildlife Refuge (50). Much of the northern Mediterranean is very heavily developed and most of the remaining nesting beaches are threatened by ever increasing tourist pressure $(5,36)$. The rapid development of a village close to the main nesting beach on Masirah Island (Oman) must be a cause for concern (47). Loggerheads are exploited for meat, eggs and tourist curios. The meat is generally regarded as less palatable than Green Turtle but is sought after in some areas (46). Large scale exploitation occurs in Campeche (Mexico), the Azores, Madeira and the Canary Islands (tourist trade) (52), Cuba, Mozambique (46) and the Dominican Republic (tourist trade) (10). Smaller scale local exploitation, mostly for food, occurs in India, China, Japan and Colombia (52). Studies of hatchling habitat in weedlines in the west Atlantic have exposed a possible further threat. The same currents which result in the Sargassum concentrating into bands also concentrate pollution, especially particulate waste such as tar balls and styrofoam plastic. Small turtles are indiscriminate feeders and ingest this material. Numerous Loggerhead hatchlings have been found dead or moribund in the storm wrack along the east Florida coast. Their jaws and throats were obstructed by tar. Further developments of the oil industry in the Caribbean gulf with the attendant risk of oil spills are likely to exacerbate this problem (11). The possible toxic effects of chemical pollution on marine turtles is not known but may be considerable and could pose a further threat to their survival (19). Egg predation by racoons Procyon lotor causes major losses in North America (7).

CONSERVATION MEASURES TAKEN The Loggerhead is totally or partially protected by law over much of its range including the United States of America, Mexico, Belize, Panama, the Bahamas, South Africa, Mozambique, Madagascar, Oman, Australia, Italy, Cyprus and Greece $(10,28,34,46,56)$. However in many areas legislation cannot be adequately enforced $(10,31)$. A new fisheries law in Oman (1981) bans all commercial exploitation of turtles; hunting and egg collection is only allowed on a subsistence basis. There is a closed season from mid-July to mid-October and local people are encouraged only to take eggs laid below the high water mark (4). In the United States Loggerhead nest within several refuges including Cape Romain, Wassaw Island, Blackbeard Island, Merritt Island and Hobe Sound, with hatcheries at Cape Romain, Merritt Island, Wassaw Island and Blackbeard Island (3). A restricted fishing zone to minimise incidental catch of turtles has been established near Cape Canaveral (1). On the Pacific coast of Panama significant numbers of Loggerhead are reported to nest within the Biological Reserve at Isla de Canas (15). Three of the nesting beaches on the Island of Zakynthos, Greece, were declared protected in 1980 (54) and in Cyprus there has been a hatchery at Lara since 1978 (28). Virtually all nesting beaches in Tongaland, South Africa now fall within Marine reserves (81). In Australia none of the major rookeries in Queensland are within National Parks or reserves but some of the smaller ones such as Heron and Bushy Islands are. In Western Australia Bernier and Dorre Islands and Barrow Island are Nature Reserves. Protected areas for the conservation of Loggerhead have been established in Japan in Hiwasa (Tokushima Pref.), Miyazaki (Miyazahi Pref.) and Omaezaki (Shizuola 
The Loggerhead turtle is listed on Appendix I of the Convention on International Trade in Endangered Species of Wild Fauna and Flora (CITES). Appendix I listing requires that trade in the taxon and its products is subject to strict regulation by ratifying states and international trade for primarily commercial purposes is prohibited.

CONSERVATION MEASURES PROPOSED Where possible, existing laws should be enforced and National Parks and Reserves adequately protected (43). Protective legislation and adequate enforcement is particularly important for major nesting concentrations, such as that at Masirah Island, Oman (1). Madagascar should be encouraged to re-establish her turtle reserves (1). Restricted fishing zones should be established in areas of high turtle concentration, particularly off major nesting beaches $(1,46)$ and high priority given to the development of fishing equipment which prevents incidental take of sea turtles (1), All states having populations of sea turtles, whether nesting, feeding or migratory, should be encouraged to enter into international regional agreements to develop and co-ordinate conservation programmes (1).

The practice of incubating sea turtle eggs in semi-natural or artificial nests, in the hope of decreasing egg and hatchling mortality, should be reviewed. It is now known that sex in some sea turtle species, and probably in all sea turtle species, is determined by temperature during a critical phase of development. To the extent that temperatures in non-natural nests differ from those in natural nests, the sex ratio among the hatchlings will deviate from the natural ratio. Production of an excess of males, or of intersexes, will clearly be deleterious; an excess of females may be less serious. See reference 60 , and sources cited therein.

CAPTIVE BREEDING Little information available. Breeding is reported at a few Seaquaria, including Seafloor Aquarium, Nassau, where a full breeding cycle has occurred (57).

REMARKS The Compiler is extremely grateful to A. Meylan for a critical review of a preliminary draft of this account.

REFERENCES 1. Anon. (In press, 1982). Sea Turtle Conservation Strategy. (Conservation/Management strategy prepared at 1979 World Conference on Conservation of Sea Turtles, Washington D.C.). In Bjorndal, K. (Ed.). The Biology and Conservation of Sea Turtles, Smithsonian Institute Press, Washington D.C.

2. Anon. (1981). South Carolina State Report. Endangered Species Technical Bulletin 6(8).

3. Anon. (1981). Sea turtle activity on refuges reported. Endangered Species Technical Bulletin. 6(7).

4. Anon. (1982). Oman protects marine wildlife. Oryx 16(3): 271.

5. Argano, R. (1979). Preliminary report on Western Mediterranean sea turtles. Annual Report WWF Proj. 1474.

6. Bhaskar, S. (in press, 1982). The status of the Sea Turtles in the East Indian Ocean. In, Bjorndal, K. (Ed.) The Biology and Conservation of Sea Turtles. Smithsonian Institute Press, Washington D.C. (Papers presented at The World Conference on Sea Turtle Conservation, Nov. 26-30, 1979, Washington D.C.).

7. Bjorndal, K.A., Meylan, A.B., Turner, B.J. (in press). Sea turtles nesting at Melbourne Beach, Florida. 1. Size, 
growth and reproductive biology. Biol. Conserv.

8. Brongersma, L.D. (in press, 1982). Marine Turtles of the Eastern Atlantic. In, Bjorndal, K. (Ed.). The Biology and Conservation of Sea Turtles. Smithsonian Institute Press, Washington D.C. (Papers presented at The World Conference on Sea Turtle Conservation, Nov. 26-30, 1979, Washington D.C.).

9. Burbidge, A.A. (1981). In litt. 5 Feb.

10. Carr, A., Meylan, A., Mortimer, J., Bjorndal, K., and Carr, T. (1982). Preliminary survey of marine turtle populations and habitats in the western Atlantic. Interim Report to National Marine Fisheries Service. Contract NA80-FA-C-00071. NOAA Technical Memorandum NMFS-SEFC.

11. Carr, A. (1982). Sargassum-raft reconnaissance: a search for a solution to the "Lost Year" puzzle. Annual Report, WWF Project 1800. (unpublished) (and see WWF Monthly Reports, February 1981, pp 25-29).

12. Carr, A. (in press, 1982). Notes on the behavioral ecology of sea turtles. In, Bjorndal, K. (Ed.). The Biology and Conservation of Sea Turtles. Smithsonian Institute Press, Washington D.C. (Papers presented at The World Conference on Sea Turtle Conservation, Nov. 26-30, 1979, Washington D.C.).

13. Carr, A., Ogren, L., McVea, C. (1980). Apparent hibernation by the Atlantic Loggerhead Turtle Caretta caretta off Cape Canaveral, Florida. Biol. Conserv. $\overline{19: 7-14 .}$

14. Chu-chien, Huang (in press, 1982). Distribution and population dynamics of the Sea Turtles in China seas. In, Bjorndal, K. (Ed.). The Biology and Conservation of Sea Turtles. Smithsonian Institute Press, Washington D.C. (Papers presented at The World Conference on Sea Turtle Conservation, Nov. 26-30, 1979, Washington D.C.).

15. Cornelius, S.E. (in press, 1982). The status of Sea Turtles on the Pacific Coast of Central America. In, Bjorndal, K. (Ed.). The Biology and Conservation of Sea Turtles. Smithsonian Institute Press, Washington D.C. (Papers presented at The World Conference on Sea Turtle Conservation, Nov. 26-30, 1979, Washington D.C.).

16. Davis, G.E. and Whiting, M.C. (1977). Loggerhead sea turtle nesting in Everglades National Park, Florida, U.S.A. Herpetologica $33(1): 18-28$.

17. Demetropoulos, A. (1978). In litt. 9 th Nov.

18. Di Palma, M.G. (1978). Notizie sulle tartarughe marine in Sicilia. II Naturalista Siciliano, S. IV, II (1-2): 1-6.

19. Frazier, J.G. (1980). Marine turtles and problems in coastal management. In, Edge, B.L. (Ed.) Coastal zone '80. Vol. III. Proceedings of the second symposium coastal and ocean management.

20. F azier, J. (in press, 1982). The status of Marine Turtles in the Western Indian Ocean. In, Bjorndal, K. (Ed.). The Biology and Conservation of Sea Turtles. Smithsonian Institute Press, Washington D.C. (Papers presented at The World Conference on Sea Turtle Conservation, Nov. 26-30, 1979, Washington D.C.).

21. Geldiay, R. Koray, J. and Balik, S. (in press, 1982). On the status of sea turtle populations (Caretta c. caretta and 
Chelonia m. mydas) in the Northern Mediterranean Sea. In, Bjorndal, $\bar{K}$. (Ed.). The Biology and Conservation of Sea Turtles. Smithsonian Institute Press, Washington D.C. (Papers presented at The World Conference on Sea Turtle Conservation, Nov. 26-30, 1979, Washington D.C.).

22. Gudynas, E. (1980). Notes on the Sea Turtles of Uruguay. ASRA Journal 1(3): 69-76.

23. Hays de Brown, C., and Brown, W.M. (in press, 1982). The status of sea turtles in Peru. In, Bjorndal, K. (Ed.). The Biology and Conservation of Sea Turtles. Smithsonian Institute Press, Washington D.C. (Papers presented at The World Conference on Sea Turtle Conservation, Nov. 26-30, 1979, Washington D.C.).

24. Head of Fisheries Dept., Cyprus (1981). Cyprus Turtle Conservation Report. 1980 WWF/IUCN Proj. 1815. (Unpublished).

25. Hendrickson, J.R. (1980). The ecological strategies of sea turtles. Amer. Zool. 20: 597-608.

26. Hildebrand, H.H. (in press, 1982). A historical review of the status of Sea Turtle populations in the western Gulf of Mexico. In, Bjorndal, K. (Ed.). The Biology and Conservation of Sea Turtles. Smithsonian Institute Press, Washington D.C. (Papers presented at The World Conference on Sea Turtle Conservation, Nov. 26-30, 1979, Washington D.C.).

27. Hirth, H.F. (1980). Some aspects of the nesting behaviour and reproductive biology of sea turtles. Amer. Zool. 20: 507-523.

28. Honegger, R. (1978). Threatened Amphibians and Reptiles in Europe. Nature and Environment Series, No. 15. Council of Europe, Strasbourg.

29. Hughes, G.R. (1976). Sea turtles in Southeast Africa. In, Proc. Symp. Endangered Widlife in Southern Africa. Univ. Pretoria. Pp. 81-87.

30. Hughes, G.R. (in press, 1982). Nesting cycles in Sea Turtles - typical or atypical? In, Bjorndal, K. (Ed.). The Biology and Conservation of Sea Turtles. Smithsonian Institute Press, Washington D.C. (Papers presented to The World Conference on Sea Turtle Conservation, Nov. 26-30, 1979, Washington D.C.).

31. Hughes, G.R. (in press, 1982). The conservation situation of Sea Turtle populations in the southern African region. In, Bjorndal, K. (Ed.). The Biology and Conservation of Sea Turtles. Smithsonian Institute Press, Washington D.C. (Papers presented at The World Conference on Sea Turtle Conservation, Nov. 26-30, 1979, Washington D.C.).

32. Huntley, B.J. (1972). An interim report on the status of Red Data Book species in Angola. (Unpublished).

33. Lenarz, M.S., Frazer, N.B., Ralston, M.S., and Mast, R.B. (1981). Seven nests recorded for Loggerhead Turtle (Caretta caretta) in one season. Herp. Rev. 12(1): 9.

34. Limpus, C.J. (in press, 1982). The status of Australian Sea Turtle populations. In, Bjorndal, K. (Ed.). The Biology and Conservation of Sea Turtles. Smithsonian Institute Press, Washington D.C. (Papers presented at The World Conference on Sea Turtle Conservation, Nov. 26-30, 1979, Washington D.C.). 
35. Margaritoulis, D. (1980). Nesting of the sea turtles Caretta caretta on Zakynthos Island. Nature Bulletin - Hellenic Society for the Protection of Nature. No. 22.41-43.

36. Margaritoulis, D. (1981). Sea turtle conservation on Zakynthos. Report on WWF/IUCN Proj. 1822.

37. Marinos, P. (1981). Sea turtle conservation in the Mediterranean. A preliminary report to the Ministry of Coordination, National Council for Physical Planning and the Environment Secretariat, Athens, Greece.

38. McDiarmid, R.W. (1978). Rare and Endangered Biota of Florida. Vol. 3. Amphibians and Reptiles. Univ. Presses of Florida, Gainsville.

39. Meylan, A. (in press, 1982). Sea Turtle migration - evidence from tag returns. In, Bjorndal, K. (Ed.). The Biology and Conservation of Sea Turtles. Smithsonian Institute Press, Washington D.C. (Papers presented at The World Conference on Sea Turtle Conservation, Nov. 26-30, 1979, Washington D.C.).

40. Meylan, A. (in press, 1982). Estimation of population size in sea turtles. In, Bjorndal, K. (Ed.). The Biology and Conservation of Sea Turtles. Smithsonian Institute Press, Washington D.C. (Papers presented at The World Conference on Sea Turtle Conservation, Nov. 26-30, 1979, Washington D.C.).

41. Meylan, A.B., Bjorndal, K.A., and Turner, B.J. (in press). Sea turtles nesting at Melbourne Beach, Florida, 2. Post-nesting movements of Caretta caretta. Biol. Consv.

42. Mortimer, J.A. (in press, 1982). The feeding ecology of the sea turtles. In, Bjorndal, K. (Ed.). The Biology and Conservation of Sea Turtles. Smithsonian Institute Press, Washington D.C. (Papers presented at The World Conference on Sea Turtle Conservation, Nov. 26-30, 1979, Washington D.C.).

43. Navid, D. (in press, 1982). Conservation and management of sea turtles. A legal overview. In, Bjorndal, K. (Ed.). The Biology and Conservation of Sea Turtles. Smithsonian Institute Press, Washington D.C. (Papers presented at The World Conference on Sea Turtle Conservation, Nov. 26-30, 1979, Washington D.C.).

44. Polunin, N.V.C., and Sumertha Nuitja, N. (in press, 1982). Sea Turtle populations of Indonesia and Thailand. In, Bjorndal, K. (Ed.). The Biology and Conservation of Sea Turtles. Smithsonian Institute Press, Washington D.C. (Papers presented at The World Conference on Sea Turtle Conservation, Nov. 26-30, 1979, Washington D.C.).

45. Pritchard, P.C.H. (1979). Encyclopedia of Turtles. T.F.H. Publications, Hong Kong and New Jersey.

46. Ross, J.P. and IUCN/SSC Marine Turtles Group (unpublished report, 1979). Present status of Sea Turtles - a summary of recent information and conservation priorities.

47. Ross, J.P., and Barwani, M.A. (in press, 1982). Review of sea turtles in the Arabian area. In, Bjorndal, K. (Ed.). The Biology and Conservation of Sea Turtles. Smithsonian Institute Press, Washington D.C. (Papers presented at The World Conference on Sea Turtle Conservation, Nov. 26-30, 1979, Washington D.C.).

48. Ruckdeschel, C. and Zug, G.R. (1982). Mortality of sea 
turtles Caretta caretta in coastal waters of Georgia. Biol. Consv. 22: 5-9.

49. Sella, Y. (in press, 1982). The sea turtles of the Eastern Mediterranean in danger of extermination. In, Bjorndal, K. (Ed.). The Biology and Conservation of Sea Turtles. Smithsonian Institute Press, Washington D.C. (Papers presented at The World Conference on Sea Turtle Conservation, Nov. 26-30, 1979, Washington D.C.). (Not seen cited in 37).

50. Shabica, S.V. (in press, 1982). Planning for protection of sea turtle habitat. In, Bjorndal, K. (Ed.). The Biology and Conservation of Sea Turtles. Smithsonian Institute Press, Washington D.C. (Papers presented at The World Conference on Sea Turtle Conservation, Nov. 26-30, 1979, Washington D.C.).

51. Sternberg, J. (1981). The worldwide distribution of Sea Turtle nesting beaches. Centre for Environmental Education, Washington D.C.

52. Sternberg, J. (1981). Worldwide map of sea turtle hunts. Sea turtle rescue fund, Centre for Environmental Education, Washington D.C.

53. Stoneburner, D.L. and Ehrhart, L.M. (1981). Observations on Caretta c. caretta: a record internesting migration in the Atlantic. Herp. Rev. 12(2): 66.

54. Yeroulanos, M. $(\overline{1980})$. In litt. 23 July.

55. Pritchard, P.C.H. (undated). Proposal for a Marine Turtle Survey in New Caledonia.

56. Argano, R. (1981). In litt. 24th February.

57. Meylan, A. (1982). Pers. comm., 2 July.

58. Ross, J.P. (in press, 1982). Historical decline of Loggerhead, Ridley and Leatherback Sea Turtles. In, Bjorndal, K. (Ed.). The Biology and Conservation of Sea Turtles. Smithsonian Institute Press, Washington D.C. (Papers presented at The World Conference on Sea Turtle Conservation, Nov. 26-30, 1979, Washington D.C.).

59. Mendonca, M.T. (1981). Comparative growth rates of wild immature Chelonia mydas and Caretta caretta in Florida. J. Herpetol. 15(4):447-451.

60. Morreale, S.J., Ruiz, G.J., Spotila, J.R., and Standora, E.A. (1982). Temperature-dependent sex determination: current practices threaten conservation of sea turtles. Science 216:1245-1247. 

Chelonia mydas (Linnaeus 1758)

Order TESTUDINES

Family

CHELONIIDAE

SUMMARY A circumtropical species, nesting mainly in tropical and subtropical regions. A large sea turtle, to $1 \mathrm{~m}$ length. Mainly herbivorous. Highly migratory, with well-developed homing abilities. Females appear to nest on their ancestral nest beach, and mating occurs of fshore from this nest beach; thus each nesting colony behaves as a separate reproductive unit. There is considerable difficulty in applying the traditional species concept in such a situation. At least one distinct group, nesting in the East Pacific, may be more appropriately considered as a full species C. agassizii. Average clutch size 110, females can lay 3-7 clutches per season, and some have been shown to re-migrate at 2-4 year intervals. Females may not attain maturity in the wild for 15-50 years. Although very many nesting locations are known worldwide, most populations are depleted and many are declining, some have already been extirpated (e.g. in the Caribbean). Only about a dozen large populations with around 2,000 or more nesting females per year are known at present; these occur on Ascension, around western and northern Australia, Costa Rica (Tortuguero Beach), Europa and nearby islands in the Mozambique Channel, Pacific Mexico, Oman, Pakistan, and possibly the Philippines, Sabah and Sarawak. In a good year over 10,000 females may nest on Europa, and up to 80,000 at Raine Island (Australia); these appear to be the only stable populations not heavily exploited. Heavily utilized in most of the range; adults and eggs for food, juveniles for curios, and adults also for hide and oil. Incidental catch causes much mortality. Nominally protected by legislation in much of the range. Some nest beaches protected. Legislation should be enforced, more protected areas are required (for nesting beaches, internesting habitat, and other life cycle phases). Listed on CITES Appendix I; France, Italy, Japan and Surinam have entered reservations on Appendix I listing. States with reservations on C. mydas should be encouraged to withdraw them. Has bred in captivity, but large-scale closed-cycle captive breeding has not yet been demonstrated to be possible.

DISTRIBUTION The 'species' Chelonia mydas (and to a perhaps lesser extent the four other circumglobal sea turtles) should not be regarded as a single potentially interbreeding assemblage, but a complex of discrete populations, largely or entirely genetically-isolated from each other. There is considerable difficulty in applying the traditional species concept in such a situation. Some geographic groups of the $\underline{C}$. mydas complex may be more appropriately considered as separate full species. For example, the population nesting in the Galapagos and east Pacific (C.m.agassizii) is sometimes regarded as a full species, the Black or East Pacific Turtle C. agassizii. This nomenclatural change may well be effective in conservation terms, since one particular population group can thereby be singled out as a target species. However, a more traditional position is taken here simply because no adequate overall examination of the systematics of the Green Turtle complex has yet been undertaken.

A pantropical species occurring in waters remaining above $20^{\circ} \mathrm{C}$ in the coldest month. Wandering individuals have been recorded as far north as the English 
Has been reported on the west coast of $\mathrm{V}$ orth America from Rritish Columbia to Baja California (3). Uncommon off the California coast (3,55). In Pacific Mexico, nesting takes place from Chiapas to Jalisco, concentrated in Michoan (94) especially on the beaches of Colola and Maruata (84) also on the Les Tres Marias and islands in the Golfo de Tehuantepec (94). Small scale nesting on the Islas Revillagigedo, Isla Socorro, Isla Clarion and Ile Clipperton (94). Little known about Guatemalan populations, but some nesting may occur in the south-west near Ocos and on barrier beaches near the Chiquimulilla Canal (33). Dispersed nesting occurs on all sandy beaches on the El Salvador coast (33) with some nesting on the Pacific coast of Honduras, $\mathrm{N}$ icaragua (33) and Costa Rica (94). Very little nesting on the Pacific coast of Panama, although Green Turtles have been observed in coastal waters (33). Very little information is available for Pacific Colombia although Green Turtles have been reported (48). Occur in the Galapagos in large numbers and are the most common marine turtle with nesting on most islands. Important feeding grounds near the western islands of Isabela and Fernandina (48). In Ecuador they occur from the Peruvian border as far north as Rocafuerte with nesting along the coast from Costa Rica Island to just north of Alacames, more common between Monta and Cojimies (48). Found along the entire Peruvian coastline, with fairly regular feeding concentrations at Bocapan, Punta Mero, Punta Sal, Restin, Casitas, Parachique, Lesbos de Tierra and Lesbos de Afuera Islands, Pisco and Lagunillas. Some nesting occurs in northern Tumbes. At least some of the large number of feeding turtles may have migrated from the Galapagos Islands (50).

Found in Uruguayan waters but is not known to nest (49). Vesting is reported in Brazil from Para to Sergipe especially on Atol des Rocas (94). Nesting on an unknown scale occurs on the western beaches of French Guyana especially at Les Hattes/Point Isere (94). Surinam beaches are subject to continuous erosion and alteration with resultant movement of nesting sites. The Marowijne mouth beaches, Eilanti beach, Dap Eiland beach, Tijgerbank (Baboensanti and Pruimenboom) and Galibi beach are probably the most important nesting areas. This population appears to feed off the Brazilian coast; particularly off the states of Maranhao, Piaui, Ceara, Rio Grande de Norte, Paraiba, Pernambuco and Alagoas (91). Vesting in Guyana is reported to occur on Shell, Papaya, Turtle, Laguan, Tiger Island, Suddie, Zeelandia, Mahaica-Mahaicong and Corentyre beaches, and Essequibo (94). Nesting also occurs in the northwest from the Moruca River to Waini Point, but this area may be threatened by mineral extraction (34).

Mainland nesting in Venezuela appears meagre, but further surveys are needed (22). Minor nesting sites are known at Cumana, Margarita, La Tortuga, Los Rocques and other islands (94). The second most important nesting site in the Caribbean is on Aves Island, Venezuela (22). Small scale nesting occurs in northern and eastern Trinidad and Tobago (22). There are foraging grounds in the Gulf of Paria (22). N esting occurs infrequently on the Colombian Caribbean coast between Cartagena and Santa Marta and occasionally among the Islas del Rosarios (22). There are important feeding areas around the Guajira Peninsula, also around Veneuela's Paraguana Peninsula. In Caribbean Panama Green Turtles occasionally nest on Changuinola, Bastimentos and Chirqui beach (22) Bocas is an important temporary feeding station for migrating individuals. Hatchlings have been found in the offshore Sargassum drift line (22). In the San Blas Islands Green Turtles of all sizes occur, but juveniles predominate (22). The largest Caribbean breeding colony nests in Costa Rica along 20 miles of beach between Rio Tortuguero and Rio Parismina. Immatures are found off southern Costa Rica between Moin and the Panamanian border (22). There are excellent foraging 
grounds around the $\mathrm{N}$ icaraguan coast and offshore cays. Tag returns indicate that the Miskito Bank is the main foraging ground of the Tortuguero colony (27). Aves Island turtles may also forage there. Nesting occurs in Honduras on beaches between Puerto Cortes and La Ceiba, and on Vivario, Becerro and Caratasca Cays (22). There are reports of nesting in Guatemala from Cabo de Tres Puntas to Rio Montagua; numbers are unknown (22). In the past nesting has been reported from several localities in Belize but it is not clear whether any persists (22). Juveniles and adults occur offshore in grass flats and around the Belize Barrier Reef (22). Scattered nesting occurs all along the coast and islands of Quintana Roo (Mexico), especially near Boca Paila, Isla Mujeres, and on the windward side of Isla Contoy (22). In Yucatan there is limited nesting along the northern coastline and on Arrecife, Alacran, Cayo Arenas, Los Triangulos and Cayos Arcas (22). Occasional nesting occurs in Campeche, mostly between the Tabasco-Campeche border and the Laguna de Termino with some some scattered nesting in Tabasco (22). Once nested in numbers in Veracruz near Cabo Rojo and abundantly between Montepio and Cerro San Martin; today they nest only rarely and in the coastal waters are reportedly very rare (22) A few C. mydas nest annually at Rancho Nuevo, Tamaulipas (22).

Good feeding grounds occur in Aransas Bay, Matagorda Bay and Laguna Madre, Texas, and were the basis of an active fishery in the nineteenth century. Occurs in greatly reduced numbers in the lower Laguna Madre near Port Isabel $(22,53)$. Known annual nesting in the United States confined to the east coast of Florida from Brevard County to Breward County with most nests found on Jupiter and Hutchinson Islands (3). Immature and sub-adult individuals are encountered occasionally in foraging habitat off the west coast of Florida and the east coast between Cape Canaveral and the Dry Tortugas (22).

Most of the Rahamas are unsurveyed but small numbers are known to nest on Great and Little Inagua and Abaco (22). Nesting is rare on the Caicos Islands (22). $\mathrm{N}$ o nesting is recorded from Jamaica (22). Offshore, moderate numbers are found in coral reefs and seagrass pasture. Occasional nesting occurs in the south of the Dominican Republic, and Green Turtles utilize feeding grounds around the island (22). Very little nesting by any species seems to occur in Puerto Rico. Some Green Turtles nest on Mona Island. On both Culebra and Vieques they nest infrequently and numbers have diminished. Nesting is very rare in the U.S. Virgin Islands, but individuals are found in coral reef and seagrass areas (22).

In Guadeloupe low density nesting is reported on islands in the Grand Cul-de-Sac Marin, the north and east coasts of Rasse Terre, and at several localities on Grand Terre. Also reported from Iles de la Petit Terre, Les Saintes, Marie Galante and La Desirade. Individuals of all ages are resident in Guadeloupe waters (22). Very little information available from nominica, but a fair numbers appear to be resident offshore (22). Although not nesting on Martinique they are the most common local species of marine turtles. Three turtles originally tagged at Aves Island and one at Tortuguero have been recovered in this area (22). In St Lucia nesting appears very rare, but both juveniles and mature individuals are resident in coastal waters (22). In St Vincent present all year along the west coast, but in small numbers and nesting seems rare (22). More common in the St Vincent Grenadines. Green turtles nest rarely in Grenada but there have been two reports of emergences on Marquis Island. However, in coastal waters Greens are the most numerous turtle (22). The Bermuda rookery was one of the first to be destroyed after the colonization of the V ew $\mathbb{K}$ orld. Between 1967 and 1977 an attempt to restablish nesting in Bermuda by transplanting eggs from Tortuguero was carried out. It will probably be several more years before the oldest survivors reach maturity, so there is no indication whether this experiment has succeeded (44). 
In mid-Atlantic there is a major rookery on Ascension Island (23,94). Tagging returns show that the turtles nesting there feed along the coast of Brazil (23). In the Cape Verde Islands there are reports from Sao Vincente, Sal, Boavista, Maio, Fogo and Sao Thiago, with nesting on Sal, Boavista and Maio (19).

In the Mediterranean Green Turtles nest in the Lara area in the west of Cyprus (36); in Turkey at Side and Silifke and on a larger scale at Mersin, Adama, Fernike, Yumurtalik and Samandigi (Sternberg); and in Israel at Ross, Hanigra, N ahariya, Atlit, Cesarea, Vetania, Tel-Aviv and the former occupied territories (94). There is an unconfirmed report of nesting on the south coast of Sicily near Gela (94), but much of this area has now been developed (20) and sea turtle nesting is unlikely or impossible. Green turtles have also been reported from the Black, Marmara and Aegean seas but are not known to nest (46).

On the west coast of Africa there are records from many localities with recent reports of nesting from Mauritania (Pointe de Arguin); Senegal (Langue de Barbarie, Plage de Almadies, Somone, Joal, Sangomar and islets in the mouth of Saloum); Sierra Leone (Turtle Island); Ghana; Fernando Poo (Macias N guema) (South Coast); Angola (south of Luanda) and very occasionally St.Helena (19). Reports from last century or early this century come from Liberia, Principe and Sao Thome, Ilheo das Rolas, the Congo and Zaire (19). Turtles including Greens appear to nest along the entire coast of Angola; the distribution is very uneven, with several dense concentrations (60). Greens are recorded from Namibia and South Africa but do not nest (60). Small scale nesting occurs on the mainland and offshore islands of Madagascar (94). Important nest sites occur in the Reunion dependencies of Europa and Les Glorieuses, with small scale nesting on the Iles Barren and Tromelin $(43,94)$.

Sea turtle populations on Mauritius and Rodriguez are insignificant but Green Turtles may occur (43). The St Brandon Islands have a nesting population and an active Green Turtle fishery (43). British Indian Ocean Territory has a small nesting population, the lagoons of this archipelago may be important nursery grounds (43). Greens feed and nest throughout the Seychelles, with most nesting concentrated in the Aldabra group (43). They have been recorded from Mayotte with some nesting, especially on Pamanzi Island (43). In the Comores a large nesting population occurs on Moheli. On the Tanzanian coast Greens nest on Maziwi, Shungu-Mbili Island and on the mainland south of Dar es Salaam (43). They are common along the entire eastern coast of Somalia, and turtles from Saudi Arabia migrate to feeding grounds off the Somali Coast (43). There are no records from Djbouti but it seems likely that Green Turtles occur (43). C. mydas have been reported nesting in the Dhalak Archipelago which appears to be the only important nesting area in Ethiopia $(43,87)$. Green Turtles have been seen off the Sudanese coast and may nest in large numbers on offshore islands (43). On the Red Sea coast of Egypt they have been reported from offshore islands and may breed; nesting occurs in Sinai at Abu-Rhodes, Ras Muhammad and Tiron and Sarafir islands (43). Virtually no information is available for the Gulf of Aqaba, or the Red Sea coast of Saudi Arabia apart from reports of commercial exploitation, from the latter probably referring to Green Turtles (43). In Yemen they are the most common marine turtle, with nesting on offshore islands. Major nesting sites in the People's Democratic Republic of Yemen include Ithmun, Sharma, Musa, Shihr and Shuhair. The major feeding pastures are in the west off Khar Umaria (87). There are important nesting grounds in Oman specifically at Ras al Had; feeding grounds occur at Sawqira Bay, the Gulf of Masirah and along the Batinah coast.(87). Virtually no information is available from the United Arab Emirates, although it is likely that Green Turtles occur (87). In Oatar small-scale nesting occurred at Ras Laffan and Umn Said, but seems to have ceased; there are feeding grounds off the east coast (87). Greens have been reported feeding near Bahrain 
(87). On the Gulf coast of Saudi Arabia nesting occurs on the islands of Karan, Jana, Kurayn and Jurayd and occasionally on other islands and the mainland. There are extensive feeding grounds (more than $1000 \mathrm{sq} \mathrm{km}$ ) offshore. (87). There is only one recent record from Kuwait. Nesting has been recorded from Iran on the gulf islands of Hormuz, Quesham, Larak, Shetvar and Lavan, and on the mainland near Beris and Bandar Bushr (87).

In Pakistan large numbers nest on the beaches of Hawkes Bay and Sandspit, outside Karachi, and may nest along the Makran coast to the west, at Omara, Somniani and Ras Jiunri $(1,6,43)$ with some nesting on the islands of the Gulf of Kutch especially Bhaidar (15) and on the mainland between Okha and Okha Madhi, and probably further south (15). On the west coast of India scattered nesting has been reported from Gorai (north of Bombay) to Morad (south of Calicut) and it is likely that some nesting occurs along the entire west coast (15). Nesting has even been reported around Bombay (15). There are large feeding grounds in the Gulf of Mannar and Palk Bay but no reports of nesting (15). Along the eastern coast Green Turtles are much less common, but are caught regularly on the Puri coast of Orissa (15). Nests infrequently in Sri Lanka (43). Greens are actively fished especially in the Gulf of Mannar and were once common all around the island (43). Fairly common in the Lakshadweeps, with 1 ost nesting on Suheli Valiyakara, Suheli Cheriyakara, Tinnakara, Pitti and Parali II $(15,43)$, similarly common in the Maldives nesting in fair numbers (43). In the Andaman and $\mathrm{V}$ icobar Islands nesting occurs on Little Andaman, South Sentinal, Katchal, Middle Andaman and Rutland Islands $(14,94)$.

In 1911 Maxwell reported that the Green Turtle was common in the Bay of Bengal, nesting in large numbers on Diamond Island, Oyster Is!and, Cocos and Preparis Islands, and in smaller numbers on the islands off the west coast of Burma (67). On the Indian Ocean coast of Thailand known to breed in the Tarutao Marine National Park, at the Laern Phan $\mathrm{Ka}$ marine reserve and elsewhere in Changwat Phuket and Changwat Phangnga (9). In the Gulf of Thailand nesting occurs at Ko Kram and Ko Kra. (9). On the west coast of peninsular Malaysia they were found nesting along with Hawksbills at Tanjong Kling in 1975. This beach has since been developed for tourism and industry and attempts to save the turtles are now considered hopeless (92). Greens also nested on the nearby islands of Pulau Besar and Pulau Upeh. Turtles now nest rarely on Pangkar Island, Pulau Sembilan, Pulau Pinang, Pulau Langkawi and several other islands off the Perak coast (92). On the east coast $\underline{C}$. mydas nests extensively along the coasts and islands of Trengganu, Pahang and Kelantan States (80). Important sites include the islands of Redang, Perhention and Tioman (94). They nest intensively at a number of sites in Indonesia, especially Riau Islands, Karimata, Kest Kalimantan, Kest Sumatra, Bengkulu, Ujung Kulon, (Java), Pangumbahan, (Java); Sukamade, (Java); Berau, (East Kalimantan); Ai-Ketapang, (Sumbowa); and Pulau Enu, (Aru Islands) (8I). In Sabah most turtle nesting occurs on Pulau Gulisaan, P. Bakkungun Kechil and P. Selingaan $(37,38,80)$. Most nesting in Sarawak occurs on the Turtle Islands, Satang Besar, Talang Talang Besar and Talang Talang Kechil, there are also good nessting beaches between Sematan and Sungai Semunsan. Some nesting also occurs at Tanjong Similajan. In the Philippines the main nesting sites are on islands in the Sulu sea close to the Sabah border including Pulau Boaan, P. Baguan, P. Taganak, and P. Bakkugan Besar. Important nesting also occurs at Cavili, Arena, Lumbucan, Bancoran and San Miguel Island with occasional nesting in other localities (80). Green Turtles occur along the coasts of Taiwan and the Chinese provinces of Fujian, Guangdong, Guangxi, Zhejiang, Jiangsu and Shandong, nesting occurs on the Xisha Islands (31). In Japan nests on Yakushima, Kagoshin Prefecture and on the Ogasawara Islands $(64,94)$.

In Queensland, Australia the Green Turtle is widespread and abundant, with three 
major rookery areas, the Raine Island/Pandora Cay area of the northern Great Barrier Reef, the Capricorn/Bunker group of islands of the Southern Great Barrier Reef and the Wellesley Group in the southern Gulf of Carpentaria. Smaller barrier reef rookeries include Bramble Cay, No 7 and No.8 Sandbanks, Bushy Island and Bell Cay. Large scale nesting also occurs on the islands of the Torres Strait $(28,65)$. Lower density nesting occurs widely throughout the state. Vesting occurs in many localities in Nestern Australia with major rookeries at Browse Island, Monte Bello Islands, Lacepede Islands, Dampier Archipelago and Barrow Island (65). Greens nest on most of the islands in the western Coral Sea especially the Diamond Islets. Feeding grounds for Australian nesting populations include the Coral Sea, southern Papua N ew Guinea, N ew Caledonia, the Torres Strait and the $\mathrm{N}$ orthern Territory (65) In Papua $\mathrm{N}$ ew Guinea they breed on several uninhabited island groups in Manus Province; the Sabben Islands, the Purdy Islands and the Johnson Islands. Elsewhere areas of strong Seven Ray Adventism (which forbids the eating of meat) provide safe locations for nesting turtles; these include the Hermit Islands, the $\mathrm{N}$ inigo Islands, Lou Island and Mussau Island of the St.Matthias Group (93). In the Trobriand Islands Green Turtles nest on a few beaches on Kiriwina Island and in larger numbers on outlying uninhabited islands such as Tuma, Munuwata and the Simlindon Islands. A major breeding area occurs on Long Island especially between Malala Village and Sororo. (93). It has been reported that many turtles are found around Luscany and Simsim Islands. A 5,180 ha feeding ground lies between Losuia and Vakuta Island (93).

Common in the Solomon Islands but nesting is scarce. Most nesting occurs on Hakelake Island, the islands around Kagina, Ausilala, and Maifu and Balaka Islands. Major feeding areas include the area from Baolo to Dedeu, Shoveo, Poro, Thousand Ships Bay, the north side of Kagina, the north coast of Choiseul, and N dovelle, Vori, Roviana and Morovo Lagoons (95). Vesting on an unknown scale occurs in Vanuatu, $\mathrm{N}$ ew Caledonia, D'Entrecasteaux in the Iles Chesterfield, the Ellice and Funafutio Islands, and the Fiji and Tonga Islands. (94). In Micronesia nesting occurs within the U.S. Trust Territories at Helen Reef, V garuangl and Merir Islands (82), Withi Atoll, Gielap, Lar and Pig Islands, Gaferut, Olimarao, Elato, West Fayu, Pikelot, East Fayu, and Oroluk in the Caroline Islands $(68,94)$; Tarague, Ritidian, Uruno, Orote, Cocos Islands, Asiga Beach and other localities in the Maranas (94). Small scale nesting occurs in the Truk Islands Ponape District, and Uje Long Islands. Larger numbers nest on Bikini and Taongi Atolls and in the Marshall Islands (94). Important breeding sites in the central Pacific include French Frigate Shoals in the Hawaiian archipelago; Canton, Enderbury and Birnie in the Phoenix group; Rose Atoll in American Samoa; and Palmerston and Penrhyn in the Cook Islands. Smaller scale nesting occurs in the Line and Tokelau Islands (13).

POPULATION See first paragraph of 'Distribution' above. Around 150 separate nesting areas are known worldwide (combining several atolls and islets) (94), but only between 10 and 15 populations of significant size (around 2,000 or more nesting females per year) are known (ref. 88 and sources cited below). These large populations occur on Ascension Island, Australia (Queensland: Capricorn/Bunker Group Islands, Raine Island/Pandora Cay on northern Barrier Reef, Wellesley Group in the gulf of Carpentoria; Western Australia, (probably five major rookeries including Lacepede Islands), Costa Rica (Tortuguero), Europa and Tromelin Islands (in Mozambique Channel), Mexico (Pacific coast), Oman (Ras al Had), and Pakistan (Hawkes Bay/Sandspit). Similarly large numbers have been reported from the Phillipines, Sabah, Sarawak and Surinam (88); but more recent data do not confirm this, and present numbers are not known in detail.

Among these major sites, the annual nesting population comprises several thousand turtles only at the three major rookeries in Queensland and at least one 
of the Kestern Australian sites, Costa Rica, on Europa and Tromelin (Reunion), Mexico, Oman and Philippines. Annual nesting numbers can vary drastically from one season to another. Raine Island, with up to about 80,000 nesting females per year, supports by far the largest known nesting Green Turtle population. According to one authority (88) only the populations nesting on Heron Island (Australia), Tortuguero (Costa Rica), Ras al Had (Oman) and Sabah (east Malaysia) are relatively secure at present. Another recent review (63) suggests that the only Green Turtle populations that are not declining, nor threatened with extinction, are those nesting on the islands of Europa, Tromelin and Glorieuse in the Mozambique Channel (Reunion dependencies) and on Raine Island (northern Barrier Reef, Australia).

Sea turtle populations are particularly difficult to census. Nesting females (or their nests or tracks) are the only group that can in practice be counted adequately; males never leave the water and hatchlings are thought to be subject to extremely high mortality rates once they enter the sea. Censusing on resident foraging grounds is very difficult and results are of limited use in assessing total population since most populations are distributed over a large number of feeding grounds, some of which may not have been identified. Several years' data must be used since nesting numbers vary strongly between years. Estimates of nesting female numbers cannot be extrapolated to total population estimates because of lack of knowledge about sex ratios and age structure of sea turtle populations (71).

Available information on population status is summarized below.

American Samoa On a one day visit in October 1971 Hirth counted 35 nesting pits on Sand Islet and 301 on Rose Islet. Fisherman in Pago Pago reported that August to September is the peak nesting season (13).

Angola Known nesting is on a small scale. Large numbers of marine turtles, including Greens, were encountered at Foz do Cunene in the Parque $\mathrm{V}$ acional do Iona in October 1971 and March 1972. It is possible that these nest on the Park's $160 \mathrm{~km}$ of coastline (61). In 1974613 nests made by Green and Leatherback Turtles were reported from $150 \mathrm{~km}$ of coast south of Luanda (60)

Ascension Island (UK) The nesting population is well protected and nesting numbers are holding steady at 1,800-2,000 females per year (73).

Australia The annual nesting population in the three major rookeries in Queensland is usually several thousand each. However, there have been marked fluctuations in annual nesting numbers throughout the Great Barrier Reef in recent years, the cause of which is unknown. For instance at Raine Island in the peak nesting season $1974-75$ over 11,000 nesting turtles came ashore on a single night (65) and an estimated 75,000 - 100,000 Greens nested there during the season (62). The next year, with all rookeries having much lower nesting densities, only 100 turtles nested nightly on Raine Island. In an average nesting season at Raine Island several thousand turtles can be expected to come ashore nightly. Smaller Great Barrier Reef rookeries, such as N $0.7 / \mathrm{N} 0.8$ Sandbanks, Bushy Island and Bell Cay each have annual nesting populations of several hundred (65). A maximum of 10,000 females nest annually in the Lacepede Islands (88). Only scant historical data on populations are available, but these indicate that no long-term decline in numbers seems to have occurred at any rookery, except Bramble Cay. In the last few decades nesting density had declined markedly at Bramble Cay, but it is not clear whether this is due to intensive harvesting in the past or the gradual movement and reduction in size of the island as a result of erosion and deposition (65). 
Bahamas At Great Inagua, the Green Turtle is the most common marine turtle, congregating in protected creeks around the island. At Andros and Abaco juvenile greens are most common. Eggs and turtles of all species are taken whenever possible despite legal protection. Numbers of nesting turtles have greatly decreased during the past 50 years (22).

British Indian Ocean Territory (BIOT) An estimated 300 females nest annually in this archipelago (43).

\section{Brazil Around 3000 - 10,000 females may nest annually (unconfirmed) (94).}

Burma In 1911 the annual take of Green Turtle eggs from Diamond Island was usually $1,600,000$ and often more. Several thousand more eggs were laid on the islands of the west coast. Large numbers nested on Oyster Island, the Cocos and Preparis Island (67). No more recent data are available.

Cape Verde Islands Nests in significant numbers (94); apparently much less common than in earlier centuries, decline probably due in part to over-exploitation (19).

Caroline Islands (US Trust Territories) Increasing human population pressure has resulted in the colonization of previously uninhabited islands and increased hunting of turtles. For instance on the Atoll of Croluk which was settled in the late 1960s residents are complaining of a decline in turtle numbers; present estimates of nesting females per year range from 40-100 individuals (68). Substantial populations are found in the extreme north and south of the Palau district. In the Ngaruangl lagoon villagers report that they can catch five Green Turtles in less than an hour. Greens are most abundant however at Merir and Helen's Reef, south of the main Palau group, where at most several dozen nest per night all year round (82).

Cayman Islands (UK) Once supported what may have been the largest Green Turtle rookery. Large scale commercial exploitation began in the 1650 s, resulted in severe decline by the late 1700s, and extinction of this population by 1900 (63).

Colombia Exploitation of all sea turtles has been heavy; Green Turtles are not common and populations are generally depleted. On the northern coast almost all nesting turtles are turned, and eggs taken. Turtles are netted offshore but there are too few to support a commercial fishery (22).

Comoro Islands Total nesting population is estimated at 1,960, with 1,850 of these nesting on Moheli (43).

Costa Rica Female arrivals at the Tortuguero nesting beach from 1971 to 1976 ranged from a low of 5723 in 1971 to a high of 23,142 in 1976. Based on this the sexually mature population of Green Turtles was estimated at 62,532. However this figure is based upon the assumption that there is a $1: 1$ sex ratio and is derived by doubling the estimated total number of mature females (27). Information about sex ratios remains scant however (71) and recent investigations into the relationship between sex determination and temperature, together with differential rates of exploitation, may mean that this assumption cannot necessarily be made (77). More recently, there was a low of 5,178 turtles nesting on the $35 \mathrm{~km}$ nest beach in 1979, and a high of 52,046 in 1980. Based on data collected in the decade 1971-1981, the average estimate of turtles nesting in a year is 23,692 (104). Locally common on the Pacific coast (33).

Cyprus The local population is tentatively estimated at 200-300 adults (36). 
About 2,000 Green Turtle hatchlings were released from the Lara hatchery in 1980 (51).

Dominican Republic Ruring the early years of the Spanish occupation sea turtles, probably mostly Green and Hawksbills, were reported extremely abundant. It seems likely that these stocks were exploited nearly to extinction at an early date (22). Green Turtles are still locally exoloited, for food and the tourist trade (22). Onlu occasional nesting occurs (22).

Ecuador mainland Although there is no accurate data available reports from local inhabitants suggest that numbers are low. For instance a $14 \mathrm{~km}$ section of beach between $\mathrm{EI} \mathrm{N}$ apo and Canoa, which is one of the higher density nesting beaches, reportedly has only ten turtles of all species per night during the peak of the season. Numbers of nesting females are so low that local inhabitants do not patrol the beach, although they will take nesting females and eggs if encountered (48). Galapagos Islands Green Turtles occur in moderate numbers. Since 1970 a total of 3,784 mature females and 10 mature males have been tagged on the six major nesting beaches. On Ouinta Playa, probably the most important nesting beach in the Galapagos, total numbers of nesting females recorded in a season range from 308-610 (48).

Egypt $n$ the Red Sea coast all species are said to be in decline in the former Israeli Administered Area due to human disturbance (87). In Sinai an estimated 80 Green Turtles nest annually at Abu-Rhodes, with further nesting at Ras Muhammad and on Tiran and Sarafir Islands (94).

El Salvador Nesting by all marine turtles is reported to have decreased abruptly in recent years. There is a well organised internal egg trade and turtles are caught in the nets of the shrimp fleet that operates in inshore waters from F.stero Jatepeque to the mouth of the Golfo de Fonseca (33).

Ethiopia The population is probably small. The nesting population in the Thalak Archipelago may have been heavily exploited (43).

Guadeloupe Although several nesting localities are reported from Guadeloupe, according to informants only a few turtles per night nest on any beach (22). Exploitation is intense with an estimated annual take of 30 metric tons of sea turtle (whole animal, all species combined) for 1959-1976 (22).

Guatemala During a nesting season from September to October at least 20 Green Turtles have been observed along a $15 \mathrm{~km}$ stretch of pacific beach near the Chiquimulilla canal. Populations are subject to commercial exploitation of eggs, which has increased with improved communications, and to losses as incidental catch in the expanding shrimping industry (33). No population figures are available for the Caribbean coast. However there is an active subsistence fishery and eggs are sold in Puerto Barrios and Guatemala city. Turtles are regularly killed in shrimping trawls (22).

Guyana Populations may have declined seriously as a result of long standing exploitation (90)

Haiti Very little information available. Once very abundant in Haitian waters but it is likely that only vestigial stocks remain (22). Vo data on nesting.

Hawaii (US) Almost all nesting in the archipelago occurs at French Frigate Shoals (10). In the years 1973-1978 the number of females nesting annually on French Frigate Shoals fluctuated between 94 and 248. Mean annual number is 180 . No 
population trend can be discerned. Prior to 1973 this breeding population was thought to be much larger because of inadequate data (10). Number of Green Turtles foraging and basking at Laysan and Lisianski Islands and to a lesser extent at Pearl and Hermes Reef, has declined severely within historical times (10); no more than 20 females are thought to nest annually in these areas.

Honduras 27 tags recovered from Tortuguero females have come from Honduras, mostly from the eastern sections of the coast (22). Numbers of Green Turtles nesting in Honduras are greatly diminished and developmental habitat around the Bay Islands is depleted. Regularly caught in shrimp trawls and in general seem to be taken whenever encountered (22).

India An estimated 200 females nest annually in India (43). In 1967 it was estimated that 3,000-4,000 sea turtles were being caught annually between Pamban and Cape Cormorin with a further 1,000 between Rameshwaram and Mimisal. About three quarters of these were $C$. mydas. Along the Puri coast, Orissa, 40-50 Green Turtles are caught daily (15).

Indonesia Egg production figures indicate that at least 25,000 females breed annually in western Indonesia. Green Turtles are the most common species of marine turtle in Indonesia. Egg yields indicate a general decline in numbers (81) and the level of exploitation of both adults and eggs has greatly increased recently (81).

Israel On the Mediterranean coast populations are decreasing as a result of commercial fishing in south-east Turkey, destruction of nesting beaches, disturbance whilst nesting and predation by jackals and dogs. At the beginning of this century a population of $30,000-40,000$ individuals occurred off Israel's northern shore; this has now almost disappeared (source cited in 66).

Jamaica Large populations of sea turtles, probably mostly Greens and Hawksbills, seem to have been exploited almost to extinction at a very early date (22).

Japan A long term hatching project in the Ogasawara Islands has not succeeded in restoring the population to the levels of the turn of the century (64).

Kenya Probably less than 200 nest per year (43). They were once plentiful but are reportedly greatly reduced in number as a result of hunting on the nesting beaches and capture using sucker fish on the feeding grounds (35).

Line Islands (Kiribati) In the 1850 s turtles were reported to abound at Fanning. This atoll has been continuously inhabited since 1852 and the present turtle population is small with sparse nesting. Similarly when Captain Cook discovered Christmas Atoll in 1777, 200-300 turtles were caught in eight days, in 1838 they still abounded. Since then Christmas has been used as a copra plantation and nuclear weapons testing site. In 1975 some nesting was still taking place (13).

Madagascar Exploited, despite legal protection, mainly for domestic consumption. There are no coastal reserves where turtles can nest undisturbed (60).

Malaysia In peninsular Malaysia a general decline in turtle populations has occurred as a result of development of coastal areas, much increased fishing and continued exploitation of eggs. In 1956 rough estimates indicated a population of 2,200 females breeding along the east coast. Surveys indicate a drastic decline in Green Turtle egg yields on this coast (92). An estimated maximum of 4,000 females nest annually in Sarawak and Sabah (88). The population in Sarawak is 
Mexico Pacific nesting populations are severely depleted $(32,100)$. On the Pacific coast an estimated maximum of 5,000 females nest annually (88). This estimate can now be revised upward slightly, utilizing more precise data from Michoacan (100). The 40 mile stretch of Michoacan coast between Rio Ticla and Rio de Hua Hua is thought to support breeding of about one-third of the entire mainland-nesting $C$. mydas in the East Pacific (California south to Ecuador) (100). While the species was once said to "darken the sea" by its numbers, and more than 10,000 females probably nested nightly during the season in the early twentieth century, regular aerial surveys during the 1981 season revealed only 35 (minimum) to 336 (maximum) turtles off the Michoacan nesting beaches. The nesting population, although very severely depleted, has held steady over the last few years with a maximum of 5,586 females (100). The male population gathered offshore, regularly surveyed by air, is thought to have declined by about $67 \%$ since 1979 (100). About 3,000 males have been harvested at sea since September 1981 (report dated March 1982) (100). The Pacific Mexico population is subject to heavy exploitation for eggs and meat, as well as high levels of mortality from incidental catch by shrimp trawlers. Incidental catch may account for as inany as 600,000 turtles per annum, most of these being male Greens or Ridleys (84). In 197310,000 East Pacific Green Turtles were harvested from the breeding waters, $90 \%$ males; and $75 \%$ of all eggs were collected. (41). On the Atlantic coast small scale nesting occurs in most states. However, much heavier nesting may have occurred in several areas in the past. In Tamaulipas turtles nesting between Boca ?esus Maria and Tuxpan may have supplied the nineteenth century Texas turtle cannery (22,53). Before the Second $\mathbb{K}$ orld $\mathbb{K}$ ar Green Turtles were reported to nest regularly at Playa Washington, $19 \mathrm{~km}$ south of the Rio Grande (22,53). Also formerly nested abundantly at Montepio, Cerro San Martin and Cabo Rojo in Veracruz. Turtles are heavily exploited along the entire coast and are also caught incidentally by shrimp trawlers. In Campeche a dramatic decline in catch of sea turtles has been reported (22)

Mozambique The most common marine turtle to frequent marine pastures along the mainland coast. An estimated 200 females nest annually on the Primeiras and Segundas Islands. A little nesting occurs in the north (43)

Nicaragua What is probably the most extensive grazing pasture in the world occurs along the coast and offshore cays of $\mathrm{N}$ icaragua (22). Many of the turtles tagged at Tortuguero have been recovered here. 725 tags have been recovered from the Miskito Cays, 142 from the Sandy Bay Cays and 263 from the mainland coast (22). In addition two tags have been recovered from turtles tagged whilst nesting at Aves Island, suggesting that the Miskito Bank may be a feeding area for two different breeding populations (22). From 1969-75 between 5,000 and 10,000 Green Turtles were killed annually off the east coast of Nicaragua. Since the slaughter houses closed in 1976, only hunting for local consumption has occurred (22).

Oman A minimum of 6,000 females nest annually at Ras al Had with smaller scale nesting taking place elsewhere. Subsistence hunting results in at least 1,000 Greens being captured each year (87).

Pakistan An estimated 5,000 may nest in Pakistan (43).

Panama Green Turtles nest at several localities, apparently not in large numbers (30). Human exploitation is heavy on the Caribbean coast (22). On the Pacific coast $\underline{\text { C. mydas }}$ is the least abundant sea turtle (33) 
Papua New Guinea The most abundant and widespread turtle in Papua New Guinea, also the most heavily exploited. In areas where turtles are hunted, population decline is now becoming obvious, with people having to go further afield to catch them. However in areas where Seven Day Adventism (which forbids the eating of meat) has become established, villagers report a noticable increase in populations in the last 30-50 years ( 93 ).

People's Democratic Republic of Yemen Up to 10,000 Green Turtles may nest annually in South Yemen (43). In the period 1967-74 800-4,000 per year were caught (87).

Peru Feeding concentrations occur offshore. These are exploited, the largest catch being in the area of Pisco, next to the Paracas Reserve. The estimated catch per annum at this port is at least 2,000 turtles. (50).

Philippines Tens of thousands have been reported to nest annually (88), but such numbers have not been confirmed recently. The population is subject to very heavy exploitation and appears to be declining $(35,38,88)$. Turtle egg gathering is reported to be becoming less lucrative; in the southern seas it is estimated that it is now possible to collect a maximum of only 500 eggs per week as opposed to $800-1,000$ eggs per week in the early 1970 s (35).

Phoenix Islands A maximum of 200 females may nest annually on Canton with greatest numbers present in October and $N$ ovember. Enderbury has been listed as one of the most important nesting sites in the Central Pacific. Large numbers of turtle tracks have been sighted on the beaches of Birnie Island (13).

Réunion and Dependencies (France) Large numbers nest in Réunion, especially on its dependant islands (Europa, Tromelin, Juan do Nova, Les Glorieuses and Mayotte). Annual estimates of nesting females have fluctuated strongly and range from 1,500-18,000 on Europa and 200-4,400+ on Tromelin. In 1973 70-80 nested on Les Glorieuses. Figures are not available for Juan do Nova, but populations seem to be limited (60). About $500 \mathrm{C}$. mydas are estimated to nest annually on Mayotte, the largest rookery being on Pamanzi Island. N umbers seern to be smaller than the habitat could support (43). About 200 females are estimated to nest on Iles Bawen (Bassas da India) annually (43).

St.Brandon Island On average 295 greens per year are recorded as killed by the local fishery; this is almost certainly an underestimate. The exploitation figures for the last 37 years show no sharp decline (60). The total nesting population is less than 1,000 and may be as small as 300 individuals (43).

Saudi Arabia The nesting population on the Gulf coast is estimated as several hundreds, with $80 \%$ of these nesting on Karan (87).

Senegal Seems to be the most common sea turtle in Senegal (19). Nesting occurs, no recent data on numbers.

Seychelles The population is severely depleted. Estimates of annual nesting numbers in the Archipelago vary from 1,000 (73) to 2,500 (43), mostly on Aldabra and Cosmoldo (73). At the turn of the century 12,000 were killed each year on Aldabra alone (73).

Solomon Islands On Hakelake Island there are between 15 and 20 nests per year, on Kagina between 10 and 15. On each of Ausilala and Maifu an estimated 100 nests are made annually. On Balaka more than 50 females nest annually. Many more feed in the area than nest. Still commonly encountered throughout the 
Solomons, although a slight decline in numbers may have occurred, especially in areas of dense human settlement (95).

Somalia The area is poorly documented but there are reports of large nesting grounds and rich turtle areas. It is possible that several thousand Chelonia nest on parts of the eastern coast (43).

Sri Lanka In the Gulf of Mannar, where the species is actively hunted, Green Turtles have been steadily declining (15).

Surinam Based on an estimated average of three nests per female per nesting season and an average interbreeding period of 2.3 years, the total breeding female population was estimated at roughly 5,000 individuals for the period 1976-79 (91).

Tanzania The total nesting population is estimated at less than 300. Populations are probably reduced from former levels by persistent predation and human development of nesting beaches (43).

Thailand In 1975 annual egg production (all species) for the whole of Thailand was estimated at 400,000 giving a population of less than 1,000 female sea turtles breeding in Thailand (80). A general decline in numbers of sea turtles seems to have occurred. Available statistics for egg yields on Ko Kram since 1955 show an approximate $70 \%$ reduction in the number of eggs collected annually (80). Much of the beach on Ko Kram is now covered with rubble, probably from fishermen blasting on the adjacent reef (81). Reported egg yields from two districts of Pha $\mathrm{N}$ ga Province appear to have remained stable since records began in 1964 but in Takuatung district reported annual yield has dropped by $40 \%$. Neclining egg yields probably indicate increasing interference with nesting turtles as well as falling populations (80). A rapid decline in turtle numbers has been reported at Tarutao N ational Park (47).

Tokelau In 1971 Hirth reported that nesting numbers were rapidly declining (13). About 120 females are thought to nest annually in recent years, comprising 70 on Nukunonu, 30 on Fakaofo and 20 at Atafu (11). Even with outboard motors and improved capture techniques, it is not possible to catch as many turtles as in the early years of this century (11). This nesting population migrates from more distant feeding grounds, possibly in Kestern Samoa (11).

Turkey Nesting is reported from the Mediterranean coast of Turkey (46), apparently only in small numbers although no quantitative estimates are available.

United States The nesting population in Florida is estimated to contain no more than 50 mature females (69). An active fishery once existed in Texas, but had disappeared by 1900. Currently found in greatly reduced numbers and mostly small sizes, in the lower Laguna Madre near Port Isabel (22).

Venezuela Between 600 and 2,000 Green Turtles nest annually on Aves Island $\overline{(22,88,94)}$. Hurricane David removed most of the sand from the island in 1979 , but this has now mostly been restored by wind and wave action. The effects of this on the nesting population are not yet known (22).

Yemen The most common species of marine turtle (43). Has been reported

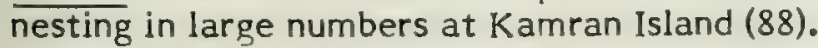

HABITAT AND ECOLOGY The Green Turtle is the largest of the hard-shelled sea turtles (the Leatherback Dermochelys can grow much larger) although size, weight, and carapace shape can vary markedly between different populations. A 
'typical' mature Green Turtle would have a carapace length of a little over $1 \mathrm{~m}$ (40 inches) and weigh 136-158 kg (300-350 lbs) (83). On the other hand, individuals from the east Pacific (assigned to the subspecies or species agassizi) average around $81 \mathrm{~cm}$ (32 inches) in length, while in the west Atlantic (eg Ascension, Surinam), they average $1.12 \mathrm{~m}$ or longer (83).

The Green Turtle is unique among sea turtles in being mainly herbivorous $(52,54,83)$. However some groups are not entirely so; hatchlings are mainly carnivorous (24), and male turtles off nesting areas in Michoacan (Pacific Mexico) have been recorded to take a variety of invertebrate prey (32). N evertheless, marine angiosperms (sea grasses) and various algae are the most frequently-recorded food items (75). The distribution of Green Turtles coincides quite closely with the distribution of sea grass pastures (54). Turtle Grass Thalassia testudinum was found to comprise on average $80 \%$ of the dry weight of stomach samples from 243 adult and subadult Green Turtles foraging off Vicaragua (75). Most of the remaining items were other sea grasses Halodule and Syringodium spp., with only $8 \%$ algae species (75). Other sea grasses commonly consumed in different parts of the range include species of Cymodocea, Halophila, Posidonia and Zostera (75). Turtles feeding on sea grasses appear to actively select the fresh green grow th near the basal leaf meristem (75), and there is some evidence (from a semi-captive group) that they may ensure a steady supply of younger more protein-rich growth by regularly cropping the same area of grass (Bjorndal, cited in 75). It has been shown (16) that around $15 \%$ of the daily energy intake is derived from fermentation by gut micro-organisms. In some areas, sea grasses are grazed in preference to algae growing at the same site. However, this is not a universal preference; for example, most stomach samples from 26 Green Turtles caught in the Torres Strait contained only red and green algae (mainly Hypnea and Caulerpa, respectively) even though sea grass pastures are present (45). The nutrient content of Caulerpa, with only $5 \%$ protein content, is similar to that of sea grasses in this region (45). In Hawaii (10), the Galapagos (75), and other areas lacking extensive sea grass pastures, algae are the major food source. While 56 species of algae have been recorded in the diet of $\underline{C}$. mydas in Hawaii, nine species form the main intake; Codium spp. and Ulva spp. p predominate, with other species varying according to locality (10). The green alga Ulva is also a main food item in the Galapagos (75). The growth rate of immature Green Turtles, in the Hawaiian Archipelago at least, appears to be limited by nutrient availability rather than by water temperature or other environmental parameters (12).

Moderate or very extensive migratory behaviour is typical of sub-adult and adult Green Turtles (27). One extreme is represented by a West Atlantic population that feeds off the Brazilian coast, but makes a $2,250 \mathrm{~km}$ tranș-oceanic crossing to nest on Ascension Island (23). Other groups make much shorter migrations, the turtles nesting at Tortuguero (Costa Rica) for example, mainly move northwards in coastal waters to feeding grounds at Miskito Cays (N icaragua) (27). In Hawaii Green Turtles move between different islands for feeding and for nesting (10). Migrating Green Turtles may travel around $20-40 \mathrm{~km} /$ day (27). It is suggested that migratory behaviour is particularly linked with herbivory, since the richest feeding grounds (notably sea grasses) are most of ten found in shallow areas of coastal deposition, and do not typically coincide with the best nesting grounds (often isolated predator-free island beaches). All populations, regardless of the extent of their migratory behaviour, appear to show strong philopatry (return to a particular regional shoreline) and site-fixity (return to a particular beach area) in nesting $(24,52)$.

Some aspects of the life history of the Green Turtle are known in outline, with particular reference to the colony nesting at Tortuguero (27). Broadly similar 
models may apply elsewhere, although significant differences are known or suspected (10,24). An individual Green Turtle hatchling moves initially into the 'lost year' habitat after entering the sea for the first time. Juveniles feed and grow in developmental habitats. Adults feed in adult resident habitat (which may cover an extensive geographical area), and sometimes make seasonal cyclic migrations, at two to five year intervals, to the nesting beach. Once at the nest beach, a poorly-known internesting habitat is occupied between each nesting emergence of the season. Sparse evidence tends to confirm a prevailing hypothesis that the lost year period ( a period of about 7-14 months during which very young turtles disappear from human sight) is spent drifting passively in pelagic algae, especially of the species Sargassum fluitans and S. natans. First-year turtles of three species, including Greens, have now been found in significant numbers in weedlines - long bands of sargassum mat concentrated by water currents $(25,29)$. There is evidence that the young turtles remain in the sargassum mat for significant periods. After the lost year young turtles, now about dinner-plate size, are regularly seen again in various inshore estuarine, coastal and reef-system habitats, where further development occurs $(22,27)$.

Green Turtles are particularly vulnerable to exploitation while occupying internesting habitat; at Tortuguero both males and females remain in a relatively narrow zone $4-8 \mathrm{~km}$ from the shore for the entire three month breeding season (104).

Nesting occurs throughout the year (with some strong seasonal peaks) at some nest sites, in the Indian Ocean and south-east Asia for example, but is more strictly seasonal elsewhere, in the Caribbean, South Atlantic and Pacific for example. The nesting season is July to September at Tortuguero (Costa Rica); January to June, peak February to April, on Ascension; May to September, peak June to July, at French Frigate Shoals (56). Peak nesting is generally in the summer (56). Most nest sites have a beach platform well above flood tide level, but sand composition and particle size is quite variable; similarly the presence or absence of vegetation along the nest beach does not seem to be a critical factor (56). Mating usually occurs within one kilometre of the nest beach (56). It has long been suspected that eggs laid in one season would have been fertilized two or three years earlier (54), but it has recently been argued (79) that sea turtles store sperm for one season's ovulation during one early season mating. N esting usually occurs at night (54) by a process corresponding closely with the stereotyped pattern shared by all sea turtles (26). The emerging female is extremely sensitive to disturbance, by lights, sound, or vibration for example, but is not easily disturbed once egg-laying has started (54). The entire process takes two to three hours (54). There is a strong positive correlation between size of nesting female and clutch size, both between different nesting populations, and in most known cases, within the population at any given site (56). Egg size, however, remains more or less constant, at about $45 \mathrm{~mm}$ diameter (56). Mean clutch size varies from 81 (range 19-131) in the Galapagos Islands to 147 (range 75-238) on Europa Island (sources in 56). Overall average clutch size is around 110. Many mature Green Turtle females lay between three and seven clutches a season, at 10-15 day intervals (54). On East Island in French Frigate Shoals, although up to six clutches have been recorded per season, the mean is only $1.8(10)$, and about $40 \%$ of the females nest only once in a season. There is a high degree of site fixity both during a season and between seasons $(54,56)$. Incubation period tends to be shorter at mainland sites, possibly reflecting higher egg predation by terrestrial vertebrates; mean period at four mainland sites is 52.7 days and is 60.8 days at four island sites (56).

It has been widely asserted that mature females nest on fairly regular cycles of two to four year intervals (54). There is now considerable doubt whether nesting 
cycles, which have been shown to exist in some tagged individuals, can safely be assumed to occur in the entire nesting population (59). It is pointed out that in five well studied Green Turtle nesting colonies, the percentage of females that are tagged and never seen again far exceeds that of females observed as remigrant nesters in future years (59). Remigration percentages observed are $0.9 \%$ (Sarawak), 1.0\% (Heron Island, Australia), 1.8\% (Ascension Island), 11.8\% (Tortuguero) and $24 \%$ (Surinam). These low frequencies of recapture of tagged females could be due firstly, to extremely inefficient beach patrols; secondly, extremely high tag losses; or thirdly, to extremely high mortality among mature turtles (59). Tag loss is significant and a new tag type is being investigated, but the possibility should be recognized that most female sea turtles may nest only once in their lifetime and remigrants are the fortunate few (59). The development of highly reliable tags is thus of very high priority. Hatchling production per female per year can be estimated for four sites (56); 67 (French Frigate Shoals), 78 (Tortuguero), 106 (Heron Island), 138 (Surinam). Life history parameters have recently been discussed (17) for female Green Turtles nesting at Tortuguero, Costa Rica. Survivorship curves calculated for 14 cohorts nesting for the first time in each of the 14 years $1959-1972$ show that adult survivorship between breeding seasons was low, particularly following the first nesting season, and thus the net rate of reproduction was low. Further, the survivorship steadily decreased during the period of study such that extinction of the population within 40 years was forecast (17). This low and decreasing survivorship is attributed to predation by man (17).

Estimates of age at sexual maturity have in the past usually ranged from four to seven years, or up to thirteen (54). Recently, growth rates of immature Green Turtles have been studied in some detail in the Hawailan population (12). If growth rates observed in immatures are maintained until maturity (and if the turtles utilize the same food resources), the minimum size at which breeding occurs in the Hawaii population $(81 \mathrm{~cm}$ ) would not be attained for 8.7 or 47.9 years (12). The former estimate refers to turtles foraging around Kau, with dense Pterocladia capillacea pastures, while the latter estimate of nearly 50 years refers to turtles at the localities using apparently poorer nutrient sources (12). Low growth rates have also been observed in Green Turtles feeding on the sparse algal growth around the Arnavon Islands (Solomon Islands), comparable to the slowest rates in Hawaii (95). At these rates maturity would not be attained by a $48 \mathrm{~cm}$ immature (possibly around 2 to 3 years old) for another 18 years (95). Similarly, studies of immature growth rates at a site in eastern Florida (106) indicate an age of $25-30$ years at maturity. In captivity, with a more nutrient-rich diet, the minimum age to maturity is 8 years, but the number of eggs and nests per season increases in subsequent season (96).

THREATS TO SURVIVAL Although traditionally used as a food source by many littoral peoples, the primary cause of decline in Green Turtle populations is systematic commercial exploitation of eggs and adults $(63,88)$. Adults may be exploited for meat (often wastefully marketed as a gourmet item in developed countries), for oil (for cosmetics) and for skins (for the leather trade). Stuffed juveniles are sold as curios. Adult females are readily taken when nesting, while both males and females are vulnerable to harvest or incidental catch while occupying the restricted internesting habitat during the breeding season. Local subsistence and local commercial exploitation appear to be having an increasing impact on sea turtle populations, as tribal cultures decline, modern technology (eg outboard motors) spreads, and human population in the tropics increases (88). A further major threat is incidental catch and drowning in shrimp trawls (88), and a possible, though largely unquantified, threat is the increased mortality of first year turtles due to pollution of Sargassumi weed mats which appear to be the main habitat of this age class (25). 
The effects of systematic mass exploitation are exemplified by the decline of Green Turtle populations in the Caribbean. Of 10 large populations known formerly, only two remain (88). The Cayman Islands held possibly the largest Green Turtle nesting colony that has ever existed. This area was exploited sporadically by the colonial powers in the sixteenth century, but regular large-scale exploitation started in the mid-seventeenth century. From this time the British fleet began to collect turtles and eggs to supply the colony in Jamaica, and turtles could be stored on board ship as a convenient source of fresh meat (63). It is asserted that the turtles were so extremely numerous that ships which had lost their bearing could navigate to the Cayman Islands simply by following the noise made by the masses of migrating turtles (source in 63). By the late seventeenth century a fleet of 40 sloops was operating out of Jamaica, taking nesting turtles from the Caymans and also now feeding turtles from southern Cuba, numbering about 13,000 per year (63). A thriving trade in imported live Green Turtles developed between the Kest Indies and London in the mid eighteenth century. By the late eighteenth century Green Turtle nesting on the Caymans was very much reduced, and by the end of the nineteenth century the Cayman Islands population was extinct and the Cayman turtle fishery shifted to Nicaragua's Miskito Cay area (63). Nicaragua itself began large-scale commercial exploitation of Green Turtles in 1970, since when about 10,000 turtles have been take. each year, and the population has declined drastically (63). The population feeciing on Miskito Cays nests further south at Tortuguero (Costa Rica), and until protected by declaration of a Park in 1975 the turtles were also being taken while nesting. The turtle processing plants in $\mathrm{V}$ icaragua were closed in 1976 (17). Turtles caught by the Cayman fleet in the 1940 s were exported to the United States and Europe.

The above example illustrates two points: firstly, that large-scale commercial exploitation is a cause of depletion or extinction of sea turtle stocks, and secondly, that the fishery tends to shift from one area to another (eg. Cayman Is., to Cuba, to Nicaragua-Costa Rica) as each stock in turn is depleted $(42,63)$. Similar extinctions of local populations are recorded in the Bahamas, Bermuda, the Dry Tortugas, and Florida (USA) (63), and depletion of stocks is reported from most parts of the range. This pattern is repeated worldwide when large scale commercial exploitation - whether local, or most especially, international replaces less intensive subsistence take $(63,88)$.

The Green Turtle has provided a valuable source of nutrients for many littoral peoples, but the rise of cash economies, spread of higher technologies, and increase in human populations are all factors that may lead to previously low level subsistence harvest rising to excess. In many countries around the Indian Ocean for example, increased human populations have often led to increased local exploitation (42); in the Solomon Islands and Tokelau Islands, formerly remote beaches are now readily accessible with outboard motor craft $(11,95)$; while on Masirah Island (Oman), there has been heavy predation on nesting beaches since use of motor vehicles became widespread about 15 years ago (87). Harvest of adults and eggs in Pacific Mexico has increased steadily in the present century, especially over the past several years, with increasing settlement and development (notably a coastal highway) along the littoral, and introduction of cash economies to the indigenous tribes.

Excessive egg harvest can also cause populations to decline. In the 'turtle islands' of Sarawak, for example, virtually all turtle eggs laid have been collected each year for several decades. In the 1930s over 2,000,000 eggs were collected annually and this has declined to fewer than 300,000 eggs in the 1970s (38). Sea turtle eggs are widely eaten, often for their supposed aphrodisiac properties, in Mexico and 
Incidental catch in bottom trawls (mainly for shrimp), during which a large proportion of trapped turtles either drown or are battered to death, is causing high mortality over much of the range, including Australia, Colombia, Ecuador, the Guianas, Malaysia, Peru, Pacific Central America $(33,88)$.

Finally, there is increasing evidence that Sargassum mats, congregated in long 'weedlines' by local water movements, provide the main habitat of first-year ('lost year') turtles. These same water movements also tend to concentrate oil particles, styrofoam, and other debris, and in the west Atlantic many young Green Turtles have been found dead, with tar balls in the respiratory tract or gut (25). Development of the oil industry, with transport of oil by pipeline and tanker, with the attendant risk of spillage, constitutes a further potential threat in parts of the Caribbean (104).

Many persons concerned with the biology and conservation of sea turtles are convinced that proposed and existing farming and ranching schemes, which might initially be expected to take the pressure of utilization off wild populations, actually maintain this pressure because such schemes are only economically feasible when international demand for sea turtle products is very high. There is then no way to prevent this demand being filled by wild-caught turtles $(39,40)$. If this argument (and the several subsidiary factors) is accepted, then commercial farming and ranching constitute a threat to the survival of the Green Turtle. Other authorities $(21,86)$ disagree with this interpretation and believe that commercial utilization though farming or ranching is actually the only realistic way in which conservation of present Green Turtle stocks can be effected.

CONSERVATION MEASURES TAKEN Partially or totally protected by law over much of its range, including Australia, Belize, Costa Rica, Galapagos, Reunion and its dependencies (Europa, Tromelin, Les Glorieuses and Juan de Vova), Mozambique, Madagascar, Angola, Mauritius, Guatemala, Nicaragua, Panama, Mexico, United States, Surinam, Thailand, Seychelles, Andamans, India, Pakistan, Italy, Peru, Kenya and Malaysia. (some of these laws include protection for eggs) $(1,8,9,14,18,22,33,38,48,50,54,57,60,65,74,80,85,89,92$,

97). However, in many areas the legislation is inadequately enforced and widely ignored $(22,33,50,60,85)$.

Some nesting beaches fall within Vational Parks or Nature Reserves and are accorded varying degrees of protection. The southern three-quarters of the Tortuguero beach, Costa Rica, comes under the jurisdiction of the Tortuguero $\mathrm{N}$ ational Park (22). In Surinam nests within the Galibi Sanctuary but a quota of 300,000-400,000 Green Turtle eggs may be taken and sold locally (91). They also nest within a Reserve in Chiriqui Province in Panama (33). On Aves Island (Venezuela) now well protected by personnel of the Estacion Cientifico Militar and on Isla Los Rocques by the Fundacion Centifico Los Roques (22). The Galapagos Islands are a $\mathrm{N}$ ational Park and all nesting beaches are completely protected (48). The Reunion dependencies of Europa, Tromelin, Les Glorieuses and Juan de $N$ ova have $V$ ature Reserve status and are accorded total protection (57). Receives total protection on Aldabra, which has $\mathrm{V}$ ature Reserve status, but the possibility of limited exploitation being allowed has been raised (74). In Oman commercial trawlers are barred from the area offshore from a major nesting beach. A new (1981) fisheries law there bans all commercial exploitation of turtles; hunting and egg collection is only allowed on a subsistence basis. There is a closed season from mid July to mid October and local people are encouraged only to take eggs laid below the high water mark (7). In Australia none of the major rookeries in Queensland are within $\mathrm{N}$ ational Parks, but several of the small 
ones are, including Lady Musgrove, Fairfax, Hoskyn, Heron and Bushy Islands. In Western Australia Greens nest in the Cape Range $V$ ational Park and in the Bernier and Dorre Islands, Barrow Island and Lacepede Islands $N$ ature Reserves (65). In Java, Indonesia C. mydas nests on Sukamade Beach in Meru Betiri Vildlife Park and both adult turtTes and eggs have been well protected since 1979 (18). On the uninhabited island of $\mathrm{V}$ usa Barung there are several reportedly productive nesting beaches. respite having $N$ ature Reserve status this island has received very little protection, and at least until 1981 permits for egg collection were issued. In 1981 the Indonesian $\mathrm{N}$ ature Conservation Agency had budgeted for the purchase of a patrol boat and the hiring of guards (18). Good numbers of turtles are reported to nest in Blambangan $\mathbb{H}$ ildlife Reserve tut the beaches receive no protection and eggs are regularly taken. Adults congregating offshore are speared and the meat sold in Bali. It is unlikely that this reserve will receive effective protection in the near future (18). In Thailand the Royal Thai Navy strictly controls the nesting beaches at Ko Kram and Green Turtles nest on the 51 islands of the Tarutao Marine $\mathrm{N}$ ational Park. The latter was considered an important nesting area in the early 1970s but since has suffered a serious decline. Present enforcement staff are too thinly spread to prevent poaching (9). In Malaysia the Marine Turtle National Park near Sandakan covers 1,700 ha including three turtle islands and the surrounding seas and coral reefs. Trawler operations are banned within a mile of the islands (38).

Hatcheries that handle Green Turtle eggs include those at Isla Los Roques (few Greens, mainly Hawksbills), Venezuela (22); four in El Salvador at least until 1979 (33); Sukamade Beach and Pangumbahan, Indonesia (18,80,92); Chendor in Pahang State, Dalam Ru and Pulau Perhentian in Kelantan State, Ifest Malaysia (80); Hawksbay, Pakistan (1); Lara, Cyprus, and Ogaswara Islands, Japan (64). Important hatcheries have been established at Maruata Bay and Colola in Michoacan (Mexico), mainly to protect the depleted East Pacific form of C. mydas (C. $m$. agassizii). Eggs are bought from local collectors, transplanted, and the hatchlings released at various times and places. Hatching success was high, over $71 \%$, in 1981. Between 1978 and 1981, a total of 687,000 hatchlings have been released. The programme in 1981 saved about $22 \%$ of the total Michoacan reproductive output from destruction by harvesting. In some areas collection of eggs is permitted under licence. For instance in Thailand many beaches are let out by local government on yearly contracts, these carry a stipulation that a certain percentage (often 10\%) of the eggs must be hatched and released. There are varying degrees of enforcement. Under a programme begun in $197450 \%$ of eggs from certain beaches are taken to fishery stations to be hatched, and head started. Another programme requires fishermen to fill out questionnaires reporting the number of nesting turtles in an area, but results from this are questionable since royalties on concessions depend on the estimated number of turtles nesting (9). Licensed egg-collecting arrangements also operate in Indonesia and Malaysia $(80,92)$.

Frorn 1967 to $1977,24,790$ eggs were transplanted from Tortuguero to Bermuda for hatching in an effort to re-establish a nesting population there. It is not known whether this has been successful since the survivors will probably not reach sexual maturity for several more years (44).

As from May 1979 the import into the U.S.A. of turtle products from mariculture operations, including the Cayman Turtle Farm, has been prohibited. This is interpreted as a conservation measure by those biologists who are convinced that such operations constitute a major threat to wild populations (see Captive Breeding and Remarks, below). Since this ban the activities of Cayman Turtle Farm have been much curtailed, and considerable stock has been disposed of. 
Breeding populations in Florida and on the Pacific coast of Mexico are listed as 'Endangered' under the U.S. Endangered Species Act 1973, all other populations are listed as 'threatened'.

Chelonia mydas is listed on Appendix 1 of the Convention on International Trade in Endangered Species of $1($ ild Fauna and Flora (CITES). Appendix 1 listing requires that trade in the taxon and its products is subject to strict regulation by ratifying states and international trade for primarily commercial purposes is forbidden. France; Italy, Japan and Surinam have taken reservations on the Appendix 1 listing.

CON SERVATION MEASURES PROPOSED Where possible existing laws should be enforced and $\mathrm{V}$ ational Parks and Reserves adequately protected (78).

Since Green Turtles are migratory species, passing through the jurisdictions of many countries, international co-operation and regional agreements on conservation are highly desirable (78). These could be based on existing conventions such as the Convention on the Conservation of Migratory Species of Wild Animals or the African Convention on the Conservation of $N$ ature (78) or on new regional programmes (5). In particular Costa Rica, Panama and Nicaragua should be encouraged to revive the San Jose Tripartite agreement of 1969 on the conservation of Green Turtles (5) and the Pacific States of Central and South America should be encouraged to establish complete protection in all east Pacific habitats (5). The $\mathrm{N}$ icaraguan government has expressed interest in establishing a Miskito Cays National Park to complement the protection of the nesting population of Tortuguero, Costa Rica (22). The governments of the Philippines and Sabah should be urged to establish a joint international turtle sanctuary covering the Sabah Turtle Islands National Park and the Philippine Turtle Islands (5).

Nesting beaches, feeding grounds, internesting habitats, migration routes and hibernacula should be protected wherever possible. For instance Mexico should be encouraged to curb exploitation of hibernating Green Turtles in the Sea of Cortez. Madagascar should be urged to re-establish turtle reserves. In Sri Lanka the seaward boundaries of the Wilpattu National Park could be extended to include sea grass feeding grounds (5).

Restricted fishing zones should be established in areas of high turtle concentration, particularly off major nesting beaches $(5,88)$ and high priority given to the development of fishing equipment or methods that reduces or prevents incidental catch of marine turtles (5). Trawlers and fishing boats of all nations should be discouraged from illegally exploiting turtle resources in national exclusive fishery zones (5). Ideally levels of exploitation should be based on the most realistic population models that can be developed. High priority should be given to ending the leather trade, where it still exists. This is a new industry and its closure would have relatively few economic and cultural side-effects. Eggs should be collected only for non-commercial consumption and programmes effected to ensure that the majority of eggs are left to hatch naturally. Conservation education should be used to counter local beliefs, where they prevail, about the special properties of eggs, particularly aphrodisiac (5).

All states party to CITES should fully implement their obligation and those states with reservations on $\underline{C}$. mydas should be urged to withdraw them. All trading nations not yet party to CITES should be encouraged to join the Convention (5).

The practice of incubating sea turtle eggs in semi-natural or artificial nests, in the hope of decreasing egg and hatchling mortality, should be reviewed. It is now 
known that sex in some sea turtle species, and probably all sea turtle species, is determined by temperature during a critical phase of embryonic development. To the extent that temperatures in non-natural nests differ from those in natural nests, the sex ratio among the hatchlings will deviate from the natural ratio. Production of an excess of males, or of intersexes, will clearly be deleterious; an excess of females may be less serious. See reference 105, and the sources cited therein.

CAPTIVE BREEDING Numerous specimens are held in zoos and aquaria, in conditions unsuitable for breeding (with one or two exceptions). Total numbers in captivity not known. Breeding has occurred on one occasion at Sea Life Park in Hawaii (10). Mating was observed here after a small captive group was transferred to a new pool, with adjacent sand beach area, in 1974. Four of the nine females were involved in nesting activity, and eggs were laid in 1976; 295 of 398 hatchlings produced were released off Oahu (10).

Captive breeding or rearing for commercial purposes has reportedly been attempted, or planned, in several areas; Australia, Cayman Islands, Indonesia, Malaysia, Mexico, Philippines, Reunion, Seychelles and South Yemen (sources in 39). It appears that closed-cycle breeding, not dependent on a continual intake of eggs, hatchlings or older turtles, has been a primary goal only in the case of the Cayman Turtle Farm on Grand Cayman Island (British West Indies). This farm (which began operations in 1968 as Mariculture Ltd) has certainly made most progress toward becoming a true closed-cycle farm (39). The breeding stock is composed of (i), an original captive wild stock of adults collected from Ascension, Costa Rica, Guyana, Surinam, and animals from $\mathrm{N}$ icaragua purchased from turtle boats landing at Grand Cayman; (ii), a farm-reared stock of turtles hatched from wild eggs; (iii), a farm-reared stock of turtles hatched from eggs laid on the farm (96). Captive wild adults first nested in 1973 when $43 \%$ of 11,385 eggs laid hatched successfully (96). Farm-reared animals first nested in 1975 (96). Vo wild Green Turtles have been added to the stock since 1977. No eggs have been taken since 1978 (4). Cayman Turtle Farm, after many years and many millions of dollars expenditure (96) has now succeeded in taking wild eggs, hatching them and rearing the young to sexual maturity, and producing eggs with viable hatchlings from among this farm-reared stock. Closed-cycle breeding will have been demonstrated to be possible if and when hatchlings from eggs conceived and laid on the farm themselves reach sexual maturity and produce a second generation of viable eggs. This second generation is not expected until 1982-1983 (4). At that time, it appears that these particular animals might be considered to fulfil the interpretation of the term "bred in captivity" adopted by CITES (2). Commercial captive breeding and the Cayman Turtle Farm in particular, have been subject to considerable dispute among sea turtle biologists. This topic is discussed further under the Remarks section, below.

REMARKS The economic and biological feasibility of turtle farming, and its effects on wild turtle populations, have been subjects of much controversy among sea turtle biologists and others $(21,28,39,40,86)$. At present there appears to be no consensus opinion acceptable to all concerned authorities. It has been argued $(21,86)$ that in developing countries, where most marine turtle habitats occur, exploitation and trade will persist regardless of legislation, and conservation of sea turtle populations may be achieved most effectively if the demand for sea turtle products is met by sale of goods from farmed or ranched animals. It was suggested that such a trade network should be subject to extremely rigorous national and international controls, and that a head-starting programme should be a mandatory part of any captive-rearing scheme (86).

One argument commonly raised in support of rearing programmes is that sea 
turtles are highly fecund; one female Green Turtle may lay around 500 eggs in one season; perhaps $99 \%$ of which, or more, will fail to survive to adulthood (21). Therefore, large numbers of eggs or hatchlings could be taken from the wild for consumption or to stock ranches or farms, without significantly affecting breeding stocks of wild turtles (86). Similarly, any factor reducing the massive loss of eggs (e.g. protecting beaches from nest predators, transplanting eggs to hatcheries), or of hatchlings (e.g. 'headstarting'), may increase recruitment into the population and thus permit some level of exploitation of adults (21).

The recent demonstration (e.g 77) that the sex of sea turtles is fixed during a restricted period in einbryonic development, and a temperature difference during incubation of only a few degrees can result in a clutch developing into male or female hatchlings, should justify some restraint in egg utilization for rearing. Artificial incubation procedures may drastically affect the sex ratio among hatchlings, and, since it is predicted that the sex ratio among hatchlings from any one nest beach will vary over the course of a season, the time of egg collection may affect the overall sex ratio among the season's hatchlings left to enter the sea (72). Any bias toward a predominance of males in the population would be deleterious.

It has been stressed that the 20,000 hatchlings collected from Europa Island (a Reunion Dependency in the Mozambique Channel) were all day time emergencies that would have been taken by Frigate Birds (60). These hatchlings were taken to a rearing station near St Leu on Reunion. This ranching scheme, also using hatchlings from Tromelin (another Reunion Dependency) is expected to take its first harvest in 1982.

However, many other biologists (40) are convinced that the known aspects of sea turtle biology are incompatible with ranching and farming, and that these activities are only economically practicable when international dernand, and thus also the market price, for turtle products remain very high. In an inflationary world the drive will be to open new markets and reach higher prices (40). It has been a matter of direct experience $(99,28)$ that many persons in the U.S.A., for example, who had never consumed any sea turtle food were induced to do so following active marketing of mariculture products. The major argument against turtle farming and ranching is that there can be no adequate control over the demand for and use of wild turtles so long as turtle farms/ranches operate, whose very existance requires the promotion of turtle products $(39,98)$. So while the ranching operation on Reunion, for example, may have no direct effect on the $C$. mydas populations being exploited for stock, any sale of its turtle products may well still entail the predicted deleterious effects arising from market expansion. A consensus position regarding sea turtle farming was formulated by participants at the 1979 World Conference on the Conservation of Sea Turtles, Washington D.C. (5). This is quoted verbatim below.

"1. Before the benefits and risks of commercial turtle culture can be fully evaluated, more data are needed, as follows:

First, the feasibility of complete, closed-cycle farming, with no dependence on wild populations (either eggs or adult breeders) should be studied. "Feasibility" refers to both biological and economic factors.

Second, the considerations that determine the minimum (and possibly maximum) sized operation that is commercially feasible ought to be ascertained.

Third, the impact of commercial turtle culture (farming and ranching) on prices of turtle products, on the creation of new markets, on the capture of turtles from wild populations, and on the trade in products derived from 
wild-caught sea turtles should be evaluated.

2. In the absence of definitive answers from the above inquiries, the following cautions are necessary:

First, commercial mariculture must be in conformity with all applicable conservation regulations and laws, whether local, national, regional or international.

Second, care should be taken that special legal provisions and exemptions for farmed products are not misused by importers and exporters of wild turtle products.

Third, any effort by commercial mariculture interests to develop markets for new turtle products or to create demand for turtle products where it did not previously exist is insupportable.

Fourth, the establishment of new commercial turtle "farms" must be discouraged until it is certain that such operations will no cause, directly or indirectly, a further decline in turtle populations."

The compiler is particularly grateful to A. Carr and A. lfeylan for comments on a preliminary draft of this account.

REFERENCES 1. Aban Marker Kabraji (1981). Progress Report on W KF Project. Unpubl. 1451.

2. Anon. (1980). Convention on international trade in endangered species of wild fauna and flora. Proceedings of the second meeting of the Conference of the Parties, San José, Costa Rica, 19-30 March 1979. (2 vols). CITES Secretariat, IUCV, Gland, Switzerland.

3. Anon. (1980). Green Sea Turtle. In, Selected Vertebrate endangered species of the sea coast of the United States. Biological Services Program FSW/OBS-80/01. 12., U.S. Fish and $\mathbb{1}$ ildlife Service.

4. Anon. (1980). Minutes of a meeting on sea turtle farming and conservation held at the U.K. Nature Conservancy Council, 23 Oct. 1980.

5. Anon. (in press, 1982). Sea Turtle Conservation Strategy. (Conservation/Management strategy prepared at 1979 World Conference on Conservation of Sea Turtles, Washington D.C.). In, Bjorndal, K. (Ed.) The Biology and Conservation of Sea Turtles. Smithsonian Institute Press, Kashington D.C.

6. Anon. (1981). Pakistan's turtles nest on holiday beaches. W WF Monthly Reports, March 1981. K WF Project 1451.

7. Anon. (1982). Oman protects marine wildlife. Oryx 16(3):271.

8. Argano, R. (1981). In litt. 24th February.

9. Bain, J.R., and Humphrey, S.R. (1980). A profile of the endangered species of Thailand. Report $\mathrm{No}$. 4, Office of Ecological Services, Florida State Museum, IJ.S.A.

10. Balazs, F.H. (1980). Synopsis of Biological Data on the Green Turtle in the Hawaiian Islands. NOAA Technical Memorandum N.M.F.S. VOAA-TM-NMFS-S IKFC-7.

11. Balazs, G.H. (1982). Sea Turtles and their traditional useage in Tokelau. Unpublished Project report prepared for WWF-US and Office of Tokelau Affairs.

12. Balazs, G.H. (in press, 1982). Growth rates of immature Green Turtles in the Hawailan Archipelago. In, Bjorndal, K. 
(Ed.) The Biology and Conservation of Sea Turtles. Smithsonian Institute Press, 1 rashington D.C. (Paper presented at the korld Conference on Sea. Turtle Conservation, N ov. 26-30, 1979, Washington N.C.).

13. Balazs, G.H. (1982 in press). Status of sea turtles in the Central Pacific Ocean. In Bjorndal, K. (Ed.). The Biological Conservation of Sea Turtles - Smithsonian Institute Press, Washington D.C. (Papers presented at The Korld Conference on Sea Turtle Conservation, Nov. 26-30, 1979, Kashington D.C.).

14. Bhaskar, S. (1979). Sea Turtle survey in the Andaman and vicobars. Hamadryad 4(3): 2-26.

15. Bhaskar, S. (in press, 1982). The status of the Sea Turtles in the East Indian Ocean. (Unpublished paper read at $\mathrm{K}$ orld Conf. on Sea Turtle Conservation, revised version in press in Bjorndal, K. (Ed.). The Biology and Conservation of Sea Turtles. Smithsonian Institute Press, Kashington D.C. (Papers presented at The Korld Conference on Sea Turtle Conservation, $\mathrm{N}$ ov. 26-30, 1979, Washington D.C.).

16. Bjorndal, K.A. (1979). Cellulose digestion and volatile fatty acid production in the Green Turtle, Chelonia mydas. Comp. Biochem. Physiol. 63A: 127-133.

17. Bjorndal, K.A. (1980). Demography of the breeding population of the Green Turtle, Chelonia mydas, at Tortuguero, Costa Rica. Copeia 1980 (3): 525-530.

18. Blouch, R.A. (1981). W WF Meru Betiri Project 10241980 Annual Report.

19. Brongersma, L.D. (in press, 1982). Marine Turtles of the Eastern Atlantic. In, Bjorndal, K. (Ed.). The Biology and Conservation of Sea Turtles. Smithsonian Institute Press, Washington D.C. (Papers presented at The Morld Conference on Sea Turtle Conservation, Nov. 26-30, 1979, Kashington D.C.).

20. Bruno, (1982) in litt. January.

21. Bustard, H.R. (1981). Turtle farming and conservation of Green Turtle (Chelonia mydas) Brit. Herp. Soc. Bull. No. 3: $36-40$.

22. Caribbean Conservation Corporation (1980). Survey and preliminary census of Marine Turtle populations in the Vestern Atlantic. Final report to Vational Marine Fisheries Service, Contract 03-78-008-0025. [N ow published with additional material as ref.30]

23. Carr, A. (1975). The Ascension Island Green Turtle Colony Copeia 1975 (3): 547-555.

24. Carr, A. (1980). Some problems of Sea Turtle Ecology Amer. Zool. 20: 489-498.

25. Carr, A. (1982). Sargassum-raft reconaissance: a search for a solution to the "Lost Year" puzzle. Annual Report, IK WF Project 1800. (unpublished) (and see WWF Monthly Report, February 1981, pp 25-29).

26. Carr, A. (in press, 1982). Notes on the behavioral ecology of sea turtles. In, Bjorndal, K. (Ed.). The Biology and Conservation of Sea Turtles. Smithsonian Institute Press, Washington D.C. (Papers presented at The Morld Conference on Sea Turtle Conservation, Nov. 26-30, 1979, Nashington N.C.).

27. Carr, A.F., Carr, M.H. and Meylan, A.B. (1978). The 
ecology and migrations of sea turtles, 7. The west Caribbean Green Turtle colony. Bull. Amer. Mus. N at. Hist. 162(1): $1-46$.

28. Carr, A.F. and Main, A.R. (1973). Turtle farming project in Northern Australia. Report on an inquiry into ecological implications of a turtle farming project. Commonwealth of Australia.

29. Carr, A., and Meylan, A.B. (1980). Evidence of passive migration of Green Turtle hatchlings in sargassum. Copeia 1980(2): 366-368.

30. Carr, A., Meylan, A., Mortimer, J., Bjorndal, K., and Carr, T. (1982). Preliminary survey of marine turtle populations and habitats in the western Atlantic. Interim Report to National Marine Fisheries Service. Contract NA80-FA-C-00071. NOAA Technical Memorandum N MFS-SEFC.

31. Chu-chien, Huang (in press 1982). Distribution and population dynamics of the Sea Turtles in China seas. In, Bjorndal, K. (Ed.). The Biology and Conservation of Sea Turtles. Smithsonian Insitute Press, Washington D.C. (Papers presented at The World Conference on Sea Turtle Conservation, Nov. 26-30, 1979, Kashington D.C.).

32. Cliffton, K., Cornejo, D.O., and Felger, R.S. (in press, 1982). Sea turtles on the Pacific Coast of Mexico. In, Bjorndal, K. (Ed.) The Biology and Conservation of Sea Turtles. Smithsonian Institute Press, Kashington, D.C. (Papers presented at the World Conference on Sea Turtle conservation, $\mathrm{N}$ ov. 26-30, 1979, Washington D.C.

33. Cornelius, S.E. (in press, 1982). The status of Sea Turtles on the Pacific Coast of Central America. In, Bjorndal, K. (Ed.). The Biology and Conservation of Sea Turtles. Smithsonian Institute Press, Washington D.C. (Papers presented at The Korld Conference on Sea .Turtle Conservation, N ov. 26-30, 1979, Washington D.C.).

34. Dalfelt, A. (1978). Nature Conservation Survey of the Republic of Guyana. IUCN Morges. Unpub. rept. 55 pp.

35. De Celis, N.C. (in press, 1982). Status of marine turtles in the Philippines. In, Bjorndal, K. (Ed.). The Biology and Conservation of Sea Turtles. Smithsonian Institute Press, Kashington, D.C. (Papers presented at the World Conference on Sea Turtle conservation, Nov. 26-30, 1979, K ashington D.C.

36. Demetropoulos, A. and Hadjichristophorou, M. (1980). Project Proposal, KIIF Proj. 1815.

37. De Silva, G.S. (1969). Turtle conservation in Sabah. Sabah Society Journal V (1): 6-26.

38. De Silva, G.S. (in press, 1982). The status of sea turtle populations in East Malaysia and the South China Sea. In, Bjorndal, K. (Ed.). The Biology and Conservation of Sea Turtles. Smithsonian Institute Press, Washington, D.C. (Papers presented at the 1 orld Conference on Sea Turtle conservation, Vov. 26-30, 1979, Kashington D.C.

39. Dodd, C.K. (in press, 1982). Does Sea Turtle Aquaculture benefit conservation? In, Bjorndal, K. (Ed.). The Biology and Conservation of Sea Turtles. Smithsonian Institute Press, Washington, N.C. (Papers presented at the Korld Conference on Sea Turtle conservation, Vov. 26-30, 1979, 
Kashington D.C.

40. Ehrenfeld, D. (in press, 1982). Options and limitations in the conservation of sea turtles. In, Bjorndal, K. (Ed.). The Biology and Conservation of Sea Turtles. Smithsonian Institute Press, Kashington, D.C. (Papers presented at the ilorld Conference on Sea Turtle conservation, Nov. 26-30, 1979, Kashington D.C.

41. Felger, R.S., Cliffton, K. and Cornejo, D.O. (1980): Marine Turtles, Mexico. Project 1471 K WF Monthly Reports. April 1980.

42. Frazier, J. (1980). Exploitation of Marine Turtles in the Indian Ocean. Human Ecology 8(4): 329-370.

43. Frazier, J. (in press, 1982). The status of Marine Turtles in the IVestern Indian Ocean. In, Bjorndal, K. (Ed.). The Biology and Conservation of Sea Turtles. Smithsonian Institute Press, Kashington D.C. (Papers presented at The World Conference on Sea Turtle Conservation, Nov. 26-30, 1979, Washington D.C.).

44. Frick, J., Kingate, D.B. and Burnett-Herkes, J. (1979). An attempt to re-establish a green turtle nesting rookery on Bermuda. (Paper presented at the World Conference on Sea Turtle conservation, N ov. 26-30, 1979, Kashington D.C.)

45. Garnett, S.T., and Murray, R.M. (1981). Farm management and nutrition of the Green Turtle (Chelonia mydas). Pp. 60-65, in Proc. Melbourne Herp. Symp.

46. Geldiay, R., Koray, J., and Balik, S. (in press, 1982). On the status of sea turtle populations (Caretta C. caretta and Chelonia $m$. mydas) in the Northern Mediterranean sea. Paper presented at the $\mathbb{K}$ orld Conference on Sea Turtle conservation, Nov. 26-30, 1979, Kashington D.C.

47. Ginsberg, J. (1981). The status of sea turtles in Tarutao National Park, Satun, Thailand Tigerpaper 8(2): 27-29.

48. Green, D., and Ortiz, F. (in press, 1982). The status of Sea Turtle populations in the central eastern Pacific. In, Bjorndal, K. (Ed.). The Biology and Conservation of Sea Turtles. Smithsonian Institute Press, Washington D.C. (Papers presented at The Korld Conference on Sea Turtle Conservation, Vov. 26-30, 1979, Washington D.C.).

49. Gudynas, E. (1980). Votes on the Sea Turtles of Uruguay. ASRA Journal 1(3): 69-76.

50. Hays de Brown, C. and Brown, K.M. (in press, 1982). The status of sea turtles in Peru. In, Bjorndal, K. (Ed.). The Biology and Conservation of Sea Turtles. Smithsonian Institute Press, Kashington, D.C. (Papers presented at the World Conference on Sea Turtle conservation, Nov. 26-30, 1979, Kashington D.C.

51. Head of Fisheries Dept., Cyprus (1981). Cyprus Turtle Conservation Report. 1980 W KF/IUCN. Proj. 1815.

52. Hendrickson, J.R. (1980). The ecological strategies of sea turtles. Amer. Zool. 20: 597-608.

53. Hildebrand, H.H. (in press, 1982). A historical review of the status of Sea Turtle populations in the western Gulf of Mexico. In, Bjorndal, K. (Ed.). The Biology and Conservation of Sea Turtles. Smithsonian Institute Press, Kashington D.C. (Papers presented at The World Conference on Sea Turtle Conservation, Nov. 26-30, 1979, (N ashington D.C.). 
54. Hirth, H.F. (1971). Synopsis of biological data on the Green Turtle Chelonia mydas (Linnaeus) 1758 FAO Fish. Synop. 85.

55. Hirth, H.F. (I980). Chelonia mydas. In: Catalogue of American Amphibians and Reptiles. 249: $1-4$.

56. Hirth, H.F. (1980). Some aspects of the nesting behaviour and reproductive biology of sea turtles. Amer. Zool. 20: 507-523.

57. Hughes, G.R. (1976). Sea turtles in South East Africa. In, Proc. Symp. Endangered Wildlife in Southern Africa. Univ. Pretoria. Pp. $81-87$.

58. Hughes, G.R. (1981). More comments on turtle farming (letter). Brit. Herp. Soc. Bull. N o. 3: 48.

59. Hughes, G.R. (in press, 1982). Nesting cycles in Sea Turtles - typical or atypical? In, Bjorndal, K. (Ed.). The Biology and Conservation of Sea Turtles. Smithsonian Institute Press, Kashington, D.C.

60. Hughes, G.R. (in press, 1982). The conservation situation of Sea Turtle populations in the southern African region. In, Bjorndal, K. (Ed.). The Biology and Conservation of Sea Turtles. Smithsonian Institute Press, Kashington D.C. (Papers presented at The World Conference on Sea Turtle Conservation, $\mathrm{N}$ ov. 26-30, 1979, $\mathrm{K}$ ashington D.C.).

61. Huntley, B.J. (1972). An interim report on the status of Red Data Book species in Angola. (Unpublished).

62. Jenkins, R.K.G. (1978). The status of endangered Australian Reptiles. In Tyler, M.J. (Ed.). The status of endangered Australasian wildlife. Royal. Zool Soc. S. Australia.

63. King, F. K. (in press, 1982). Historical review of the decline of the Green Turtle and the Hawksbill. In, Bjorndal, K. (Ed.). The Biology and Conservation of Sea Turtles. Smithsonian Institute Press, Kashington, D.C. (Papers presented at the Korld Conference on Sea Turtle conservation, $N$ ov. 26-30, 1979, Washington D.C.

64. Kurata, Y. (in press, 1982). Propagation of Green Turtles in Ogaswara Islands of Japan. In, Bjorndal, K. (Ed.). The Biology and Conservation of Sea Turtles. Smithsonian Institute Press, Washington, D.C. (Papers presented at the World Conference on Sea Turtle conservation, Nov. 26-30, 1979, Kashington D.C.

65. Limpus, C.J. (in press, 1982). The status of Australian Sea Turtle populations. In, Bjorndal, K. (Ed.). The Biology and Conservation of Sea Turtles. Smithsonian Institute Press, Washington D.C. (Papers presented at The Korld Conference on Sea Turtle Conservation, Nov. 26-30, 1979, V ashington D.C.).

66. Marinos, P. (1981). Sea turtle conservation in the Mediterranean. A preliminary report to the Ministry of Coordination $\mathrm{N}$ ational Council for Physical Planning and the Environment Secretariat, A thens, Greece.

67. Maxwell, F.D. (1911). Reports on inland and sea fisheries in the Thongwa, Myaungmya, and Bassein districts and the turtle banks of the Irrawaddy division. Rangoon, Government Printing Office. 57 pp.

68. McCoy, M.A. (in press, 1982). Subsistence hunting of turtles in the western Pacific: the Caroline Islands. In, Bjorndal, K. (Ed.). The Biology and Conservation of Sea Turtles. Smithsonian Institute Press, Kashington, N.C. (Papers 
presented at the Korld Conference on Sea Turtle conservation, $\mathrm{N}$ ov. 26-30, 1979, Washington D.C.)

69. McDiarmid, R. IV. (1978). Rare and Endangered Biota of Florida. Vol. 3. Amphibians and Reptiles. Univ. Presses of Florida, Gainsville.

70. Meylan, A. (in press, 1982). Sea Turtle migration - evidence from tag returns. In, Bjorndal, K. (Ed.). The Biology and Conservation of Sea Turtles. Smithsonian Institute Press, Washington D.C. (Papers presented at The, $K$ orld Conference on Sea Turtle Conservation, Nov. 26-30, 1979, Washington N.C.).

71. Meylan, A. (in press, 1982). Estimation of population size in sea turtles. In, Bjorndal, K. (Ed.). The Biology and Conservation of Sea Turtles. Smithsonian Institute Press, Kashington D.C. (Papers presented at The World Conference on Sea Turtle Conservation, Nov. 26-30, 1979, Kashington D.C.).

72. Miller, J.D., and Limpus, C.J. (1981). Incubation period and sexual differentiation in the Green Turtle Chelonia mydas L. Proc. Melbourne Herp. Symp., pp. 66-73.

73. Mortimer, J.A. (1981). In litt., 12th Dec.

74. Mortimer, J.A. (1982). Turtles around the Seychelles (Project 1809) iN WF Monthly Report. February 1982.

75. Mortimer, J. (in press, 1982). The feeding ecology of the Sea Turtles. In, Bjorndal, K. (Ed.). The Biology and Conservation of Sea Turtles. Smithsonian Institute Press, Washington, D.C. (Papers presented at the World Conference on Sea Turtle conservation, Nov. 26-30, 1979, Vashington D.C.

76. Mrosovsky, N. (1980). Thermal Biology of Sea Turtles. Amer. Zool. 20: 531-547.

77. Mrosovsky, N., and Yntema, C.L. (1980). Temperature dependence of sexual differentiation in sea turtles: implications for conservation practices. Biol. Consv. 18: $271-281$.

78. N avid, D. (in press, 1982). Conservation and management of sea turtles. A legal overview. In, Bjorndal, K. (Fd.). The Riology and Conservation of Sea Turtles. Smithsonian Institute Press, Washington, N.C. (Papers presented at the World Conference on Sea Turtle conservation, Nov. 26-30, 1979, kashington N.C.

79. Owens, D. K. (1980). The comparative reproductive physiology of Sea Turtles. Amer. Zool. 20: 549-563.

80. Polunin, N.V.C. (1975). Sea turtles: reports on Thailand, K. Malaysia and Indonesia, with a synopsis of data on the conservation status of sea turtles in the Indo- Kest Pacific Region. Unpublished report.

81. Polunin, N.V.C., and Sumertha Nuitja, N. (in press, 1982). Sea Turtle populations of Indonesia and Thailand. In, Bjorndal, K. (Ed.). The Biology and Conservation of Sea Turtles. Smithsonian Institute Press, Washington D.C. (Papers presented at The Korld Conference on Sea Turtle Conservation, N ov. 26-30, 1979, $\mathrm{W}$ ashington D.C.).

82. Pritchard, P.C.H. (1977). Marine Turtles of Micronesia. Chelonia Press, San Francisco.

83. Pritchard, P.C.H. (1979). Encyclopedia of Turtles. T.F.H. Publications, Hong Kong and V ew Jersey. 
84. Pritchard, P.C.H., and Cliffton, K. (1981). Final Report. Research and Conservation of Sea Turtles in Pacific Mexico, 1980-1981. K KF Project No. 1812.

85. Ray, C.C. (1969). Marine parks and inshore conservation in Kenya. Report to Perez Olindo, Director of Parks, Nairobi, Kenya.

86. Reichart, H.A. (in press, 1982). Farming and ranching as a strategy for Sea Turtle conservation. In, Bjorndal, K. (Ed.). The Biology and Conservation of Sea Turtles. Smithsonian Institute Press, Kashington, D.C. (Papers presented at the World Conference on Sea Turtle conservation, Nov. 26-30, 1979, Kashington N.C.

87. Ross, J.P., and Barwani, M.A. (in press, 1982). Review of sea turtles in the Arabian area. In, Bjorndal, K. (Ed.). The Biology and Conservation of Sea Turtles. Smithsonian Institute Press, Kashington, D.C. (Papers presented at the World Conference on Sea Turtle conservation, Nov. 26-30, 1979, Washington D.C.

88. Ross, J.P. and IUCN /SSC Marine Turtles Group (unpublished report, 1979). Present status of Sea Turtles - a summary of recent information and conservation priorities.

89. Schulz, J.P. (1975). Sea Turtles nesting in Surinam. Zoologische Verhandelingen (Leiden) 143.

90. Schulz, J.P. (1979). Notes on turtles nesting in Guyana and French Guiana. Paper distributed at $\mathbf{K}$ orld Conference on Sea Turtle Conservation, Washington D.C., 1979, Pp. 1-2.

91. Schulz, J.P. (in press, 1982). Status of Sea Turtle populations nesting in Suriname. In, Bjorndal, K. (Ed.). The Biology and. Conservation of Sea Turtles. Smithsonian Institute Press, Kashington N.C. (Papers presented at The Korld Conference on Sea Turtle Conservation, Vov. 26-30, 1979, Kashington D.C.).

92. Siow, K.T. and Moll, E.O. (in press, 1982). Status and conservation of estuarine and sea turtles in Kest Malaysian waters. In, Bjorndal, K. (Ed.). The Biology and Conservation of Sea Turtles. Smithsonian Institute Press, Washington D.C. (Papers presented at The Korld Conference on Sea Turtle Conservation, Nov. 26-30, 1979, Washington D.C.).

93. Spring, S. (in press, 1982). Status of Marine Turtle populations in Papua $\mathrm{N}$ ew Guinea. In, Bjorndal, K. (Ed.). The Biology and Conservation of Sea Turtles. Smithsonian Institute Press, Washington D.C. (Papers presented at The Horld Conference on Sea Turtle Conservation, Nov. 26-30, 1979, Kashington D.C.).

94. Sternberg, J. (1981). The worldwide distribution of Sea Turtle nesting beaches. Center for Environmental Education, Kashington D.C.

95. Vaughan, P.K. (1981). Marine Turtles: a review of their status and management in the Solomon Islands. Ministry of Natural Resources, Honiara, Solomons.

96. Kood, J.R., and Kood, F.E. (1980). Reproductive biology of captive Green Sea Turtles. Chelonia mydas. Amer, Zool. 20: 499-505.

97. Yeroulanos, M. (1980). In litt., 23 July.

98. Ehrenfeld, D. (1982). In litt., 21 December.

99. Carr, A. (1980). Pers.comm., October. 
100. Cliffton, K. (1982). Preservation of the East Pacific Green Turtle Chelonia mydas agassizi. Final Report on Project 1812 (Submitted to i $\mathrm{KF}$-US, $18 \mathrm{March}$ ) (Unpublished).

101. Hendrickson, J.R. (1979). Chemical discrimination of Tortoiseshell materials and reptilian leathers. Final report on Contract No $14-16-0002-3701$, U.S. Fish and Wildlife Service.

102. Smith, M.H., Hillestad, H.O., Manlove, M.N., Straney, D.O., and Dean, J.M. (1980) (?). Management implications of genetic variability in Loggerhead and Green Sea Turtle. Proc. XIII the Congress of Game Riologists: 302-312.

103. Carr,A.F. and Stancyk, S.E. (1975). Observations on the ecology and survival outlook of the Hawksbill turtle. Biol. Consv. $8: 161-172$.

104. Meylan,A. (1982). Pers.comm., 2 July.

105. Morreale, S.J., Ruiz, G.J., Spotila, J.R., and Standora, E.A. (1982). Temperature-dependent sex determination: current practices threaten conservation of sea turtles. Science, 216: $1245-1247$.

106. Mendonca, M.T. (1981). Comparative growth rates of wild immature Chelonia mydas and Caretta caretta in Florida. J. Herpetol., 15(4): 447-451. 
Eretmochelys imbricata (Linnaeus 1766)

Order TESTUDINES
Family CHELONIIDAE

SUMMARY A circumtropical species, nesting on beaches of tropical seas in the Atlantic, Indian and Pacific Oceans. Feeds largely on benthic invertebrates associated with coral reefs. Often assumed to be non-migratory, nesting on nearby undisturbed sand beaches, but there are no data to substantiate this, and tag returns show that some long-distance migrations do occur. Often nests on small islands but sometimes on mainland coasts. Nesting is generally diffuse, often with only single females emerging on any one beach during any one night; at several localities fewer than ten females may emerge in one night, and very exceptionally larger numbers have been recorded. The species is still widespread but exists in only low density almost throughout the extensive range. Most populations are known or thought to be severely depleted. Moderate population levels appear to persist around the Torres Straits islands, in the Red Sea and Gulf of Aden, and probably around the Arnavon Islands (Solomons), northern Australia, Palau group, Persian Gulf islands, Oman, parts of the Seychelles, possibly the Maldives and northwest Madagascar. A small to medium size sea turtle, morphologically distinct in possessing relatively thick imbricated carapace scutes and a somewhat bird-like 'beak' suited to probing for food in reef crevices. Clutch size varies between populations, correlated with size of female, range from 73 to 182. Between two and four clutches per season, females may re-migrate to nest mainly at three-year intervals (few data available). Threatened primarily by long-term and intensifying trade in 'tortoiseshell' - the thick carapace and plastral scutes, whose often attractive pattern is fully revealed when polished. Many littoral peoples have utilised tortoiseshell for artefacts and jewellery, but continuing demand in international trade has raised shell prices to the point where Hawksbills are pursued even when only rarely encountered. Other current threats are the widespread sale of polished carapaces, also stuffed and mounted young Hawksbills, as curios. Japan consumes nearly all tortoiseshell in international trade. Hawksbill eggs are eaten by man in most parts of the range and adults are also eaten widely. Highly effective spearguns are replacing less efficient nets as hunting equipment in some areas, notably the Caribbean. Listed on CITES Appendix I, with reservations entered by Japan and France. Nominally protected by legislation in much of the range, often ineffectually. Nesting occurs on relatively few protected beaches. Diffuse nesting habits, lack of data on population movements, and high susceptibility to disturbance on the nesting beach, all hinder application of effective conservation action. Primary action required is rapid termination of trade in Hawksbill shell and in stuffed juvenile Hawksbills.

DISTRIBUTION A circumtropical species, nesting is largely restricted to beaches of tropical or sub-tropical seas in the Pacific, Atlantic and Indian Oceans.

The species is uncommon in the east Pacific; nesting is sporadic or in low density along the Central American mainland from central Mexico south to Ecuador. Nesting is widespread, but usually in low density in the Caribbean and West Atlantic region; records extend from Florida (very sporadic), along the mainland coast from Veracruz in Mexico south to Surinam, and almost throughout the islands of the Greater and Lesser Antilles. Recorded in the East Atlantic south to Angola, known or suspected to nest in the Cape Verde Islands, Senegal, Mauritania and probably other areas. Known from the Mediterranean but no nesting records. 
Widespread through the Indian Ocean, with most nesting on islands, from Madagascar and Mozambique north to the Suakin Archipelago in the Red Sea, on several islands off the Arabian Peninsula and in the Gulf, west on most oceanic islands including the Seychelles, Lakshadweeps, Maldives, to Sri Lanka and southern India, the Andaman and Nicobar group. There is occasional nesting on both coasts of Thailand, mainly on islands, and in peninsular and east Malaysia, notably the Sabah Turtle Islands. Nesting occurs at many localities through inshore seas of Indonesia, and extends south to northern coasts of Australia, north to the Philippines, Ryukyu's and the Micronesian area, east through New Guinea, and throughout the Melanesian and Polynesian areas, with sparse breeding also in Hawaii $(54,56,61,66)$.

For further details, see Population section, below.

POPULATION Population estimates for sea turtles can be based only on an estimate of the total number of nesting females. These animals, or rather their nests or nesting tracks, are the only classes that can in practice be counted; males do not leave the water, and hatchlings are thought to be subject to extremely high mortality rates after entering the sea (72). Even a reliable estimate of nesting female numbers is rarely possible for Hawksbills since nesting is often diffuse $(19,22)$; females appear to emerge singly on many suitably isolated beaches within the range, but only rarely will nesting be concentrated in one place or at one time. For this reason usually only rather vague qualitative estimates of Hawksbill nesting density are possible, except for the few known concentrations and for a few closely-observed sites, where some numerical data are available. This same factor makes practical conservation more difficult, since a significant population segment can not be protected by legislation affecting any notable beach.

Although still widespread in tropical waters, nesting density is low almost throughout the range, with moderate nesting concentrations in only a few localities, and most populations are known or thought to be severely depleted $(17,21,22,61)$. The highest nesting concentrations recorded are in the Torres Straits islands, especially Long Island (45). Up to six Hawksbills may emerge nightly on Jabal Aziz, Perim and Seil Ada Kebir in the Red Sea and Gulf of Aden. At most other localities only one or two females may emerge to nest on a given night. Besides the Torres Straits and Red Sea-Gulf of Aden areas, moderate Hawksbill populations appear to persist around the Arnavon Islands (Kerehikapa and Sikopo) (Solomon Islands), in other parts of northern Australia, the Palau group (Micronesia), the Maldives, Lavan and Shetvar in the Persian Gulf, Masirah (Oman), northern Madagascar and parts of the Seychelles Republic, possibly at one or two sites in Indonesia.

Available information on population status and trends, whether in terms of imprecise estimates of relative abundance or numerical data on nesting frequency, are summarised below.

Australia The Hawksbill occurs in relative abundance along tropical coasts of northern and eastern Australia, from western parts of Western Australia across to southern Queensland (25), but nesting is more restricted. Abundant in waters off Western Australia, but no data on nesting (14). Sporadic nesting occurs in the Gulf of Carpentaria, low density nesting is reported in several areas of the Northern Territory, and there may be an important rookery in the Dampier Archipelago of Western Australia (45). However, most nesting occurs in Queensland where numerous small rookeries are present on the islands in central and eastern Torres Straits, and on the inner shelf islands of the northern Great Barrier Reef (45). Hawksbill are reported to nest on 11 out of 13 vegetated sand cays visited, on the inner shelf of the northern Great Barrier Reef (44), in contrast, there is no nesting in the outer cays. Rarely more than 10 females 
would emerge on one cay over a period of a few nights, but older tracks indicated up to 122 nestings (the laying season is protracted, some clutches are hatching while others are sill being laid) (44). In the Torres Straits, Long Island is the major rookery, with probably several hundred nestings per year (45). It has been reported that rookeries exist in Torres Strait in which up to 75 (15) or even 100 Hawksbill may emerge to nest during one night (16), however, this has not been confirmed (85) and would appear to be an entirely exceptional situation.

Bahama Islands Small numbers nest on beaches on the southeast of Great Inagua, somewhat greater numbers nest on Little Inagua, and sparse nesting occurs on Andros and Abaco (17). Numbers throughout have decreased during the past 50 years (17). Hawksbill are second in abundance to Green Turtle Chelonia mydas around Great Inagua, and, with Loggerhead Caretta caretta, is the most commonly encountered species in Andros and Abaco (17).

Belize The species still nests in moderate numbers only in southern Belize, especially the offshore cays where the Belize Barrier Reef also provides extensive foraging habitat (17).

Burma Rarely and sporadically nests, except on one small island off the Bawmi circle in the Bassein district where about 10,000 eggs (i.e. very approximately 100 nests) were reported to be laid annually around the turn of the century (73); no recent data.

Caicos Islands The Hawksbill is the most abundant marine turtle nesting in the group, although no concentrations are known and nesting is sparse (17). There is extensive foraging habitat (17).

Chagos Archipelago There is extensive nesting and foraging habitat, at most around 300 Hawksbill nest annually (estimated), peak nesting during the northwest monsoon (31).

Colombia Small numbers of Hawksbill nest on the Caribbean mainland and in the Islas del Rosarios, the latter also provide excellent reef foraging habitat (17). The species has been recorded on the Pacific coast, but there are no data on nesting (33).

Comoro Archipelago Generally low density, but possibly 50 females nest annually on Moheli and around 25 on Mayotte (31).

Cook Islands The species nests in low numbers, in Pukapuka, Rakahanga, Penrhyn and possibly Manihiki (8).

Costa Rica Some Hawksbill nesting takes place along the entire east coast, especially between Tortuguero and Parismina, and on coral beaches south of Cahuita to the Panama frontier (17). Up to 100 females may have nested annually at Tortuguero (61), but numbers are now very low, $2-8$ individuals might be seen during a season-long survey of 5 miles of the nest beach (85). Hawksbills nest rarely on the Pacific coast (74).

Dominica Hawksbills of all sizes are year-round residents despite lack of extensive reefs. Nesting volume on the several known nest beaches is not established (17).

Dominican Republic The species was probably extremely abundant in early years of the Spanish occupation but was severely depleted soon after colonization (17). Hawksbill nest sparsely arourid much of the eastern portion of the country, and individuals of all sizes occur on reefs along much of the coast (17). 
Ecuador, mainland Nests in small numbers along much of the coast, especially between Manta and Cojimies in Manabi Province; Galapagos Is, occasionally encountered, but does not nest (33).

El Salvador The Hawksbill is the rarest of four nesting sea turtles, populations in general have sharply declined in recent years (74).

Ethiopia Hawksbill are known in the Dhalak Archipelago (Red Sea) and are suspected to nest (31).

French Polynesia Some nesting Hawksbills, very uncommon (5).

Grenada Hawksbill are the predominant nesters in Grenada and the Grenadines, and there is excellent foraging habitat (reefs and shallow waters) (17); an estimated 50 females per year nest in the latter (61) but only small numbers on Grenada (85).

Guadeloupe The species nests on the main island and nearby islands, although only a few sea turtles of any species nest on any one beach on any one night. Hawksbills and Green Turtles are the main nesters, and both are resident in Guadeloupe waters, with numerous reefs and seagrass beds. Juvenile Hawksbills are particularly common in Grand Cul de Sac Marin (85).

Guatemala On the short Caribbean coast the Hawksbill is the most frequent nester of the four marine turtle species found in the good nesting habitat from Cabo de Tres Puntas southeast to Rio Montagua (17). There appears to be virtually no suitable foraging habitat (17). No nesting appears to have been confirmed recently on the Pacific Coast (74).

Guyana Nests in small numbers, 14 emergences and 12 fresh nests were recorded in one three-week period (75).

Haiti Marine turtles in general once abounded in Haitian waters, but there is little information on present nesting. Hawksbills have been recorded locally and Hawksbill products are sold locally and abroad (85). Populations are probably vestigial but no hard data are available (17).

Hawaii A small population occurs around the eight main inhabited islands at the southwest extremity of the archipelago; several nestings are recorded on black volcanic sand beaches on the island of Hawail, and one nesting on Molokai (8).

Honduras On the Caribbean coast the species nests on extensive beaches between Puerto Cortes and La Ceiba but numbers are greatly diminished (17). Good foraging habitat exists around reefs in the Bay Islands area and in the area southward to Cabo Gracias a Dios (17). Nesting is recorded on the Pacific coast, mainly on narrow rocky beaches of small inshore islands, no recent data (74).

India Reported to occur around mainland India, apparently not commonly, nesting may occur on islands in the Gulf of Kutch and along the Gulf of Mannar, especially on offshore islands (11,31). Hawksbill nest more commonly in the Lakshadweep islands (Laccadives), also in the Andaman and Nicobar Islands $(9,10,11,31)$. In a survey of the South Andaman Islands in 197823 sets of fresh Hawksbill tracks were found on The Twins and 10 fresh excavations on the southern coast of Rutland Island $(9,10)$.

Indonesia Hawksbill are reported present throughout Indonesia, but nowhere common (47). The species appears to occur primarily around the enclosed seas of 
the group (the Java, Flores and Banda Seas, etc.) (42,67). Segamat Island, off southeast Sumatra, may be the most important site in Indonesia (81). Hawksbills are reported to occur in good numbers on islands in the Makassar Strait (68), on Nangka and Namperak off Belitung, and on a few beaches in The Ai-Ketapang area of south Sumbawa (76). Only three Hawksbill nests were recorded during 1981 on Sukamade Beach in Meru Betiri Wildlife Reserve (east Java) (69). Very heavy exploitation occurs and sea turtle populations in general are thought to have declined (76). Hawksbill numbers in the Kai and Aru Islands appear to have decreased rapidly due to exploitation; 400-600 kg of tortoise-shell were exported from Aru in 1980, mostly from juveniles since adult animals are now rare (82).

Iran Significant nesting occurs on the Gulf islands of Lavan and Shetvar, and on Hormuz, Larak and Queshm, at the eastern end of the Gulf. About 100 females nest during April-May in the latter group, and about 300 females (500 nests in June 1971) on Lavan (Sheykh Shoieyb) and Shetvar (Shotur) (60). Shetvar may be the major site (31).

Jamaica The Hawksbill is the most common marine turtle nesting on the island, even so, only a few now emerge each year (17). The species occurs in moderate numbers and in all sizes in coastal waters, mainly along outer reef ledges (17). It is thought (17) that Hawksbill populations, once abundant, were exploited to near extinction after colonization. Turtle dealers have reported a continual dramatic decline in the number and size of turtles harvested through the last two decades (51).

Kenya Some good reef habitat exists, most Hawksbill nesting is in the north, especially on islands, probably less than 50 females per year (31).

Madagascar Good numbers still nest, mainly along the northern third of the island and in the southwest, but these appear to represent only a remnant of former numbers $(39,40)$. Tortoiseshell was exported in great quantity from at least the early 17th century until a sudden decline in the 1920 s attributed to overexploitation (39). In the mid $1800 \mathrm{~s}$ exports reached $4,000 \mathrm{~kg}$ of shell, representing a kill of about 1,600 adult Hawksbills, this level continued for around 100 years (39). Most Hawksbills are taken by the Vezo people in the southwest, hunting also occurs in the northeast, but northwest populations may suffer less exploitation $(39,40)$. It is estimated that over 2,500 Hawksbills are killed annually, mostly juveniles of less than $40 \mathrm{~cm}$ length, but about one quarter being adults (39).

Malaysia, West Malaysia All sea turtle populations here are reportedly declining (77). The Hawksbill has been recorded on both coasts but apparently never in abundance (77). On the west coast nesting has been recorded at Tanjong Kling about $11 \mathrm{~km}$ west of Malacca, in peak season five Hawksbills nested over six nights (77). This beach has since been developed and the last reported nesting was a single nest laid on 13 April 1978 (23). Hawksbill previously nesting on Pangkor Island and a few others off the Perak coast, but nesting is now rare (77). The species nests more regularly on the east coast, with Trengganu State providing 10,200 of the 18,600 Hawksbill eggs collected per year (mid 1970s) (77). Sarawak still nests frequently on the mainland of west Sarawak but numbers very low (58). Nesting occurs on the three turtle islands of Satang Besar, Talang Talang Besar and Talang Talang Kechil; sea turtle populations declining (29). Sabah Hawksbill nest mainly on a group of three islands in the Sulu Sea constituting the Turtle Islands National Park (Pulau Selingaan, P. Bakkungaan Kechil, P. Gulisan) near Sandakan (northeast Sabah), and sometimes on other islands in the Sulu Sea and on the Sabah mainland $(27,28,29)$. Sea turtle populations in general reported declining, and very heavily exploited (29). In 1969 only 61 nests were recorded in the Turtle Islands N.P., 39 of these on Gulisan (27). 
Maldives This group of thousands of atolls and islands provides extensive nesting and foraging habitat, and is probably one of the most important Hawksbill areas in the Indian Ocean region (31). The population probably once comprised tens or hundreds of thousands (31). Although tortoise-shell has been a key export for centuries, Eretmochelys was reported still plentiful at the turn of the century (31). Exploitation is probably depleting the population, but fair numbers are thought still to nest (31). Many are caught for the shell and souvenir trade, shell for the Sri Lankan industry (in Galle) is mostly imported from the Maldives (38).

Martinique Hawksbill (with Leatherback) is the predominant nesting turtle; low density nesting is known at several beaches, notably at Macabou. Extensive foraging and developmental habitat is present along the southern two-thirds of the east coast (17).

Mexico On the east coast Hawksbill nest sparsely on offshore islands between Isla Lobos and Anton Lizardo (Veracruz), there is also good foraging habitat here (17). The species formerly nested in abundance on the Veracruz coast between Montepio and Cerro San Martin, but only rarely at present (17). Occasional nesting occurs in Tabasco, and more frequently in the Tabasco-Campeche border areas. The species forages in significant numbers along the west coast of the Yucatan Peninsula north of Laguna de Terminos, Isla del Carmen and the Campeche Bank $(17,79)$. Some nesting occurs in Yucatan and Quintana Roo (rarely except on leeward beaches of Isla Contoy), where fringe reefs provide extensive foraging habitat (17). Hawksbills formerly occurred in abundance along the Pacific coast and may have nested south of Sonora, today they are extremely rare, although still taken by fishermen whenever encountered, and there are no known nesting beaches (24).

Mozambique Hawksbill occur more frequently in northern parts, nesting appears to be mainly on islands, probably less than 100 females annually (31).

New Caledonia Widespread but in low density, nesting status uncertain (52).

Nicaragua Sparse nesting occurs along much of the east coast, with significant beaches at Kings Cay, Asking Cay, Set Net Cay and Cocal (17). The only unspoiled nesting sites are in the Pearl Cays (17). Excellent foraging habitat extends around the offshore cays (17). Some nesting occurs on the Pacific coast, density unknown (74).

Oman About 50-80 females nest annually on the $1 \mathrm{~km}$ long Omedu beach at the southwestern tip of Masirah Island, with sporadic single nestings on other beaches $(59,60)$.

Palau Islands (U.S. Pacific Trust Territory). Hawksbills occur in relative abundance, with nesting reported on many islands (54). Relatively plentiful still in Palau lagoon, but long-term residents report steady decline in numbers; adults are hunted for food, shell and for souvenirs (especially since regular air services resulted in increased tourism, notably by Japanese), and over $80 \%$ of nests are predated (53).

Panama A number of good Hawksbill nesting beaches exist in Bocas del Toro Province (17). Historically, nesting was concentrated on the $30 \mathrm{~km}$ Chiriqui Beach, but this nesting population has been drastically depleted by exploitation (85). Extensive foraging habitat is present in Bocas del Toro Province, around Bastimentos, Isla de Colon and Zapatilla Cays. Hawksbills of all sizes occur in the region, although much less numerous than previously. Hawksbills are also found in the San Blas Islands (17). Hawksbill occur on the Pacific coast, but in low 
Papua New Guinea Relatively widespread and abundant, found wherever there are coral reefs (65), even more abundant than Green Turtle Chelonia mydas in some places, e.g., Lou Id. in Manus Province and Kairuri Id. in East Sepik Province. Nesting occurs widely around the main island, on inshore islands, and offshore islands including Manus, New Ireland, New Britain, Bougainville, Woodlark, and the Trobriands (65). Sea turtle populations in general are reported declining where there is heavy or increasing utilization (65).

Peoples Democratic Republic of Yemen Hawksbill nest in significant numbers on Jabal Aziz Island and on Perim in the Gulf of Aden, 46 females emerged to nest on Jabal Aziz over a 10 day period, the annual nesting population is estimated in the hundreds $(31,60)$. The Perim population is much smaller (31).

Peru Recorded in very small numbers in coastal waters of northern Peru, nesting is not known to occur (34).

Philippines Sea turtle populations in general reported severely reduced $(2,26)$; most nesting occurs around the Sulu Sea, in the Sulu Archipelago and Palawan, north to southern Negros in the central Visayas (2), especially in southern parts of this region. Hawksbill are encountered more rarely than Green Turtle Chelonia mydas, although historical sources indicate considerable abundance in the past (2). The Hawksbill is considered endangered (26). Density is very low in the central Visayas, the Hawksbill yield in 1978 in a fished area in Tanon Strait between Sibulan and Dumaguete was only $97 \mathrm{~kg}$ or approximately two turtles per sq. $\mathrm{km}$ (1). There were seven confirmed nestings in 1978-1980 in southern Negros Oriental and other parts of the central Visayas, with several other unverified reports (1). Hawksbill reported rare in the Turtle Islands (southern Sulu Sea), here and in the Tawi Tawi group (southern Sulu Archipelago) egg harvest (Green and Hawksbill) has halved since the early 1970 s and lack of adults of marketable size has forced turtle hunters to move farther afield and even outside Philippine waters (sources in 26). The group of 'Turtle Islands' in the south of the Sulu Sea are split between Philippines and Sabah territory.

Puerto Rico Despite extensive apparently suitable beaches very little nesting occurs on Puerto Rico itself, but Hawksbills nest on the nearby island of Mona, also on Culebra and Vieques (17). An estimated 50 females nest annually on Mona and 50 on Culebra (61). There is extensive reef foraging habitat in which Hawksbill of many sizes occur (17). All marine turtles have been heavily exploited throughout the region (17).

Qatar The islands of Sharaawh and Dayinah have nesting Hawksbills, hatchlings are seen in early July, no information on nesting numbers (60).

Reunion Probably no nesting occurs on the main island but at least Glorieuse among the four dependency islands has nesting Hawksbills, estimated around 50 annually (31). Recorded occasionally on Europa and Tromelin (41).

Samoa Hawksbill are known to nest on Tutuila, the Manua group, Swains and Rose Atoll in American Samoa, also on islets off the west end of Upolu in Western Samoa where around 45 females are thought to nest annually (8). Numbers of Hawksbill in Western Samoa are thought to have declined considerably within historic times, mainly due to over-exploitation of eggs and females $(5,8,88)$. No data on trends in American Samoa.

Saudi Arabia Hawksbill are reported to nest sporadically with Green Turtles Chelonia mydas on a few Gulf coast islands, notably Karan. No data for Red Sea 
Seychelles Hawksbills feed and nest throughout the group, but in general appear to have declined in numbers due to heavy exploitation $(30,31,32,80)$. Providence, Cerf, and the Platt Islands, for example, formerly had very large populations of nesting Hawksbills, but now hold only a small fraction of these numbers due to over-exploitation by hunting parties from Mahé (80). One important site, Cousin Island, has a mean annual nesting population of 28.2 females (1973-1978 data); this figure multiplied by the average interval between nesting gives a total island population of 76.6 females (32). The number nesting may have increased since the island was acquired and protected as a reserve by ICBP (30), although the evidence for this is inconclusive (80). Around 600 females may nest in the granitic Seychelles, and larger numbers appear to nest in the Amirante group (80). The Aldabra and Farquhar groups both have good numbers of foraging juveniles and adults, especially in the lagoons of Aldabra and Cosmoledo; good numbers nest on Cosmoledo and Farquhar (20). A few dozen Hawksbills may nest each year on some islands of the Amirantes group (80). Similar numbers appear to nest on Farquhar, also Cosmoledo in the Aldabra group, and good numbers of juveniles and adults forage in the area (80).

Solomon Islands Hawksbill are found throughout the group (70). Estimated numbers of nests are 800-950 around Santa Ysabel, mainly in the Arnavon Islands but also Ramos Island; 230-450 around Choiseul, mainly in Haycock and other islands around Wagina; 120-175 on New Georgia and 500-600 through the Shortland group (70). These estimates appear to be derived from actual observation (in the Arnavon Is.) and from interviews with local people. The number of nesting females involved will be considerably smaller, depending on the number of nestings by each per season. The Arnavon Is. appear to be the most important nest area for Hawksbill in all of Oceania, except perhaps Campbell and Long Is. in Torres Straits, Australia (70). There has been a marked decrease in Hawksbill numbers in recent years (70). Although quantitative population data are not available, this decline is unanimously reported by hunters, also shell exports have declined despite increased monetary incentives, many nest beaches known to have supported significant nesting no longer do so, and more efficient hunting methods have been introduced (night-diving with a torch). Also the mean carapace length of the population nesting on Kerehikapa (Arnavon Is.) has decreased over the past six years, suggesting over-exploitation of adults (70).

Sri Lanka Abundant during the nineteenth century, especially in the south (Palutapana, Amaidhura, for example), but now depleted and still declining $(11,31,38)$.

St. Lucia Hawksbill nest in small numbers on nearly all beaches, and are year-round residents in foraging and developmental habitats (17).

St. Vincent Hawksbills are the predominant nesters, emerging on most beaches, but in extremely reduced numbers. There is not extensive foraging habitat, but the species occurs sparsely all year (17). Nesting density is greater in the St. Vincent Grenadines; there are good foraging and developmental habitats. Exploitation has been heavy (17).

Sudan Hawksbill are recorded from the north, and are known to nest in good numbers in the Suakin Archipelago, and probably do so on several other Red Sea islands (31). The Suakin nesting population has been estimated at over 300 (49) although published observations of actual nesting appear to be lacking, with the exception of Seil Ada Kebir island (37). Here, 25 Hawksbill nests less than one week old were found on 11 March 1978, and between 11-18 March 42 nesting females were encountered (37). Nesting density on Seil Ada Kebir, ie. average six 
turtles per night on $1.8 \mathrm{~km}$ of beach, is similar to that found on Jabal Aziz (P.D.R. Yemen); this is higher than most other studied beaches (Tortuguero, Costa Rica; Shell Beach, Guyana; Cousin, Seychelles) and second only to one or two rookeries in Torres Strait, Australia with up to 75 (perhaps more) nightly (37). Classical and later sources indicate that Eretmochelys was once extremely abundant in the Red Sea, with trade in tortoiseshell being known from the time of the Pharaohs well on into the Middle Ages (37).

Surinam Nests regularly in Bigisanti and Galibi beaches, but in very low numbers; in the years 1967-1975 the maximum number of nest on Bigisanti was 29 in 1974, other years had less than half this amount (63).

Tanzania Occurs widely in abundant reef habitat, perhaps 50 nest annually including around 20 on Maziwi, the best rookery (31). Nesting may occur throughout the year, peak in February-March (31).

Thailand Occurs off both Thai coasts and nests at several localities, including Phuket and the Ko Adang group on the west coast, and Ko Kram in Changwat Chon Buri, the Ko Kra off Changwat Nakhon Si Thammarat and other sites in the Gulf of Thailand; at Ko Rung and Ko Kra in Ko Kut/Ko Chang group the Hawksbill is the commonest nesting species (7). Although formerly abundant, especially at Ko Klang in the Ko Adang group (now within Tarutao Marine National Park), the Hawksbill is now rare in Thailand (7).

Tokelau Hawksbill nest in low density, reported (in 1971) to be rapidly declining (source in 8).

Trinidad and Tobago The species nests sparsely on north and east coasts of Trinidad and on Tobago (17).

U.S.A. - Florida Hawksbill nesting is extremely rare and confined to southern beaches. Recent records involve nesting of one individual at Jupiter Island in three different seasons (17).

U.S. Virgin Islands Scattered Hawksbill nesting occurs, and individuals of most sizes are found, although rarely, in the extensive coral reef habitat in the group (17).

Venezuela Significant Hawksbill nesting is known on the $160 \mathrm{~km}$-long Los Roques Atoll, and the species may occasionally nest on islands such as Margarita and La Tortuga (56). In 1979 a total of 57 nests were recorded on the $28 \mathrm{~km}$ of sandy beach in the western islands of the archipelago (56).

HABITAT AND ECOLOGY A small to medium size sea turtle, the shell size and shape is somewhat variable through the range. Atlantic and Caribbean specimens are often larger than those in the Indian and Pacific Oceans. Carapace length (straight) in a series of 12 mature females at Shell Beach (Guyana) ranged from $81.3-88.9 \mathrm{~cm}$, mean $83.5 \mathrm{~cm}$, weight $44.5-75.0 \mathrm{~kg}$, mean $60.7 \mathrm{~kg}$ (56). Length in a series of 13 females on Jabal Aziz (South Yemen) ranged from $63.5-72.4 \mathrm{~cm}$, mean $69.6 \mathrm{~cm}$, weight $35.5-50.0 \mathrm{~kg}$, mean $43.6 \mathrm{~kg}(36)$. Ten females from the northern Great Barrier Reef ranged from $71.6-82.7 \mathrm{~cm}$ straight carapace length, mean 76.4 , mean weight of eight females after laying $49.5 \mathrm{~kg} \mathrm{(45).} \mathrm{The} \mathrm{species} \mathrm{is}$ distinctive in that the posterior margin of the carapace is markedly serrate (except in very old animals), the carapace scutes are unusually thick and typically overlap each other posteriorly (54). Further, the head is relatively narrow with the snout forming a tapered rather bird-like 'beak' (54).

The Hawksbill, once over $25-30 \mathrm{~cm}$ carapace length, is primarily an inhabitant of 
shallow tropical waters over rock or coral substrates, especially coral reefs where immature and adult Hawksbill are the turtles most frequently seen (19). It is suspected that hatchling sea turtles, including Hawksbills, drift in Sargassum rafts (86), and it has been shown in Venezuela (13) that captive animals preferred Sargassum to all other foods offered during the first several weeks after hatching. The gut of a $14 \mathrm{~cm}$ length young Hawksbill washed ashore in Florida contained predominately Sargassum fluitans (85). The dietary preference then shifted to fish (there appears to be no record of fish forming part of the natural diet), with an enormous increase in appetite after the second month, when,almost any marine animal or plant material would be consumed. The Hawksbill, although omnivorous, feeds mostly on benthic invertebrates; individuals are reported to scrape and chew at reef faces, apparently feeding on encrusting organisms, and the beak-like snout is well suited to probing in rock or coral crevices $(19,22)$. In a sample of 29 Hawksbill stomachs from Tortuguero Bank (Costa Rica), of the 20 that contained food the most frequent food item was the sponge Geodia gibberosa, followed by the ascidean Styela sp., and then a great variety of other items including Sargassum, marine angiosperms, other sponges, coelenterates, bryozoans, and molluscs (22). The overwhelming majority of food species consumed in the Caribbean are demosponges (85), while in the Seychelles turtles have often been observed feeding on soft corals cf. Sarcophyton (89). The stomachs of two Hawksbills from Pacific Honduras were packed with portions of the cylindrical fruits of red mangrove (22). In the Grenadines turtles in reef areas showed definite preference for clinoid sponges and colonial zooanthids (56). Since many invertebrates, especially sponges, are toxic, the typical diet can account for the occasional cases of human poisoning or fatality after eating Hawksbills (22). The role of Hawksbills in the ecology of coral reefs deserves further investigation.

Once an adequate feeding area is located the Hawksbill appears to be relatively sedentary, and of ten collects numbers of large barnacles (unlike highly migratory species such as Green Turtle Chelonia mydas or Leatherback Dermochelys coriacea) $(19,56)$. It has often been asserted (eg. 78) that the species is non-migratory, with feeding grounds, such as coral reefs, typically in close proximity to nesting grounds. However, there are no tag-return data to confirm this. Furthermore, it has been suggested that Hawksbill populations may include a proportion of long-distance migrants $(56,57)$; tagging records do establish that some long-distance movements occur. The two longest records involve Kerehikapa (Solomon Islands) (70); one turtle tagged at Sakeman Reef in the Torres Straits (Australia) on 31 March 1979 later nested at Kerehikapa on 16 February 1980 , distance travelled $3,600 \mathrm{~km}$; a turtle tagged at Kerehikapa on 5 December 1976 was later killed in Papua New Guinea in December 1979, distance travelled $1,400 \mathrm{~km}$. Twelve Hawksbills tagged at Tortuguero (Costa Rica) have been recovered away from the nest site, seven about $385 \mathrm{~km}$ to the north in the Miskito Cays region of Nicaragua, and two others possibly en route to Miskito (48). However, only relatively very few Hawksbill have been tagged to date, due largely to the diffuse nesting distribution, and no consistent pattern can be discerned in available recapture records (48). Knowledge of migratory behaviour is of critical importance to conservation action, so tagging efforts deserve high priority (48). The suspected proximity of feeding and nesting sites has important implications for the population structure of the species, and accordingly for appropriate conservation action. In the Torres Straits, for example, turtles from different islands tend to show a distinctive carapace pattern and this pattern was maintained under apparently identical culture conditions, suggesting a strictly genetic basis and thus the existence of distinct population demes (20). This would explain the rapidity with which some populations decline when heavily exploited, eg. in the Solomon Islands, the Serrano and Serranilla Banks, and the Caribbean coast of Panama (57). However, there is little objective evidence at present for such a model, nor any evidence for its universality. At Kerehikapa in the Solomon Islands, for example, mating Hawksbill are rarely seen and Hawksbills are rarely 
seen on the reefs, thus it is considered highly improbable that the turtles nesting on Kerehikapa are all drawn from the waters immediately surrounding the island (70). A similar situation is reported for Samoa (88). There is thus a possibility that Hawksbill populations include at least a proportion of animals that migrate long distances to nest; this requires investigation $(57,70)$.

Age to sexual maturity is unknown. Nesting is seasonal, although the season is often extended and at a few localities nesting may occur throughout the year but with one or two peaks. On Cousin (Seychelles), for example, laying begins near the end of August and continues until near the end of February, but there is a pronounced peak in October-January, correlated with onset of the northwest monsoon (32). Typically, nesting occurs on short isolated and sheltered sand beaches, on mainland shores or on continental or oceanic islands; some Hawksbill are found nesting on long exposed mainland beaches (e.g. Tortuguero, Costa Rica; Chiriqui Beach, Panama) more heavily utilized by other sea turtle species (56). Nesting is somewhat aggregated at a few localities, notably some Torres Straits islands, and Seil Ada Kebir and Jabal Aziz (up to 6 nightly), but overall although there are probably hundreds (85) or thousands (56) of tropical beaches on which Hawksbills emerge to nest, there are relatively very few on which more than one or two nest on any given night (56). This is a marked difference from other sea turtle species.

The nesting female typically emerges from the sea at night (predominantly by day throughout the Seychelles $(32,80))$. The emerging Hawksbill is usually both extremely wary and highly susceptible to any disturbance, and also appears very particular in making a choice of nest site, with extensive 'sand-smelling' perhaps utilizing olfactory and tactile senses. She may sometimes move hundreds of metres before nesting, of ten into trees or shrubs backing the beach (56), on Cousin most nest attempts were made under vegetation (32). The nesting process in Eretmochelys conforms broadly to the stereotyped pattern shared by all sea turtles (18). The flask-shaped nest cavity reaches a depth of $45-50 \mathrm{~cm}$, eggs are laid to within 12-20 cm of the surface, and the nest filled in. Clutch size varies markedly between populations and is strongly correlated with mean carapace length (78). The smallest females, nesting on Seil Ada Kebir in the Red Sea, average around $66 \mathrm{~cm}$ length with mean clutch size (fertile eggs only) of 73.2 , while the largest females, nesting on Cousin Island in the Indian Ocean, average $85.8 \mathrm{~cm}$ length with a mean clutch size of 182 (data summarized in 78). Other studied populations fall between these extremes. The overall productivity of any Hawksbill population is largely dependent on the size distribution of mature females, since there is a significant correlation between clutch size and the carapace length of the laying female (78). Thus exploitation of the largest individuals is most deleterious to the population. Eggs are round, about $4 \mathrm{~cm}$ diameter (78). Mean incubation period ranges from 58-64 days, hatchlings are 4.0 $-4.2 \mathrm{~cm}$ length (78). Between two and four clutches may be laid in one season (although few data are available), with a re-nesting interval of around 15-19 days, and the meagre evidence available suggest a three year re-migration interval is predominant although two and four year returns are known $(32,78)$. Annual hatchling productivity per nesting female appears to vary between 77 and 189 (78). Most hatchlings emerge at night (on Cousin at least (32)) so predation by birds is minor compared with predation by Ghost Crab Ocypode ceratopthalmus, often abundant and mainly nocturnal scavengers. Dogs, pigs and lizards are among the known egg predators.

THREATS TO SURVIVAL The main cause of the widely depleted status of the Hawksbill, and the main threat to present populations, is the continuing commercial demand for 'tortoiseshell' - the unusually thick and strikingly-patterned carapace and plastral scutes. Worked and polished tortoiseshell is an undoubtedly attractive material, and trade in tortoiseshell has 
been recorded in the classical world since the time of the Pharaohs, and certain ports in the Red Sea appear to have flourished largely on the tortoiseshell trade (37). Similarly in Asia (source in 56) ancient texts record that tortoiseshell was among gifts sent by the Sinhalese kings to foreign courts in pre-Christian times. Worked shell and artefacts made from it have held a high cultural or symbolic significance among many littoral peoples, especially in Oceania. The advent of cheap plastic substitutes led to a brief recession in the luxury market trade in the 1950 s, but more recently demand and shell prices have increased dramatically (21). In the Caribbean, Hawksbill shell fetches US\$110-130 per kg (1980), and a fisherman can earn up to $\$ 200$ on the shell from a single turtle (21). The discoverer of a recent Hawksbill nest will often return to the beach two weeks later and collect the female as she returns to re-nest (56). Although it would be expected that hunting pressure would decrease as the resource became increasingly rare, this is not occurring in the Caribbean, the reason being that inflated prices are also paid for Spiny Lobsters (Palinura) and Snappers (Lutjanidae) which inhabit the same reef habitats; these species provide a basic income and the odd Hawksbill encountered is taken as an extra prize (21). The large profit means that even remote areas are searched (85). The volume of international trade in tortoiseshell has increased enormously since the early $1970 \mathrm{~s}$, for example, Indonesia exported less than $10,000 \mathrm{~kg}$ of unworked tortoiseshell each year between 1967 and 1970, while in 1978 alone $219,585 \mathrm{~kg}$ were exported (46). It was estimated in 1973 (42) that about 5,000 Hawksbill were being killed annually for tortoiseshell in the Philippines and 35,000 in Indonesia. The major exporting countries during this period have been Indonesia, Thailand, Philippines, India, and Fiji; Malaysia and Singapore are major re-exporters of raw shell; Japan, Taiwan and Hong Kong are the major importers of raw shell (46). Japan alone (42) consumes over $90 \%$ of the world's supply. The raw tortoiseshell is worked mainly in the Far East, while Japan, Italy and West Germany between them imported over $90 \%$ of worked tortoiseshell in international trade in 1977 (further details on recorded international trade in ref 46). The tortoiseshell (bekko) industry is long-established in Japan. Small items such as hair clips or rings are currently on sale for a few U.S. \$, but spectacle frames may cost over $\$ 4,000$ (83). Tortoiseshell imports into Japan rose from $40,544 \mathrm{~kg}$ in 1978 to 63,555 in 1979 (83). In the Solomon Islands, heavy and increasing commercial demand has not only led to widespread decline of Hawksbill populations but also virtually ended local cultural use of shell in artwork (such as jewellery) and artefacts (such as lures for use in tuna fishing) (70).

A second major threat is posed by the collection of immature specimens to be stuffed, lacquered and sold in the tourist trade $(43,46)$. Polished shells alone are also marketed in the Caribbean, and probably elsewhere (85). The main producers are tropical countries with a substantial tourist trade (46), including Philippines, Indonesia, Thailand, the Maldives, the Seychelles, Madagascar, Caribbean countries and Hawaii. As with tortoiseshell, Japan is a major consuming country (46). Virtually all of the stuffed turtles produced in Singapore are either exported to Japan or sold to Japanese tourists (46), and it has been stated that demand has increased in parallel with an increase in Japanese tourists from 1972 on (42). The turtle is a symbol of longevity in Japan; while the crane represents a life of one thousand years, the turtle represents ten thousand years (84). It is thus common for households and restaurants to feature a lacquered turtle as a wall decoration (83). Crew members of Japanese fishing vessels collect and lacquer large numbers in the Maldives-Sri Lanka area (38). Stuffed turtles are generally one to two years old and $20-35 \mathrm{~cm}$ carapace length (42). Most stuffed Hawksbills traded in Singapore are animals from Indonesia, notably Sumatra, but there are a few taxidermy workshops in Ujung Pandang (Makassar) on Sulawesi whose products are distributed to other parts of Indonesia (Djakarta, Ambon, Bali), again for sale to Japanese tourists and fishermen. In parts of Indonesia very young animals are reared in large numbers in captivity for up to six months, until of suitable size for 
the curio trade $(42,54)$. Thirty-two to 105 thousand stuffed turtles are produced annually in Singapore, Indonesia and the Philippines (46).

Hawksbill turtles are also eaten in many areas; the Caribbean, Papua New Guinea, and the Solomons, for example $(65,70)$. Eggs are widely utilized along with those of other marine turtles (56). Hawksbill eggs are eaten throughout Indonesia (often along with the female turtle), or are collected for sale to hatcheries, or incubated and the hatchlings sold for rearing (81). Habitat destruction, notably loss of nesting beaches, is a further threat, in Malaysia (23), Sri Lanka (38) and the eastern Caribbean (17), for example.

Hawksbills are much less wary of people underwater than are Green Turtles, and their coral reef feeding habitat puts them in maximum contact with skin divers. Fishing with spearguns is an especially effective method of hunting the species, and is now replacing traditional net fisheries in many parts of the Caribbean, and probably elsewhere (85).

CONSERVATION MEASURES TAKEN Nominally protected in some degree by legislation in several countries including Ascension Island, Australia, British Indian Ocean Territory, Costa Rica, Cuba, Fiji, French Guiana, India (11), Israel, Mexico, Puerto Rico, Sabah, Sarawak, Seychelles, South Africa, Sri Lanka (38), Surinam, Tahiti, Thailand (7), Tonga, U.S. Pacific Trust Territory, Venezuela (56),(sources in 3) and several countries in the Caribbean (17). Thailand has recently imposed a ban on export of mounted Hawksbills (6). In the Seychelles it is prohibited to take Hawksbill of less than 24 inches $(61 \mathrm{~cm})$, fishermen are required to declare to local police all Hawksbill they capture (1,035 were declared in 1980-1981) (50). Since January 1981 it is illegal in the Seychelles for anyone but the Government to export Hawksbill shell, the Government buys shell from fishermen at a very low price to discourage trade (50).

Relatively few nesting beaches are protected or within protected areas, these include beaches in Ujung Kulon National Park and Meru Betiri Nature Reserve in Indonesia (62), the Turtle Islands National Park in Sabah $(27,28,29)$ (east Malaysia), the Los Roques islands in Venezuela (56), the whole of Cousin Island (Seychelles) is administered as a reserve by ICBP (International Council for Bird Preservation) $(30,32)$, and in several other areas in the Seychelles it is forbidden to take or disturb turtles (50).

In the Palau group (Western Caroline Islands) 'head-starting' programmes were operating unofficially in 1955 (abandoned due to theft of turtles) and officially in 1968-1970 when 4,000-5,000 young were hatched from collected wild-laid eggs, raised, and released. The objective is to reduce the suspected high mortality of very young turtles. In 1971 about 1,000 young, 6-8 inches $(15-20 \mathrm{~cm})$ in length, age about 6 months, were released on Koror; there was reportedly a noticeable increase in juveniles in surrounding waters the following year (53). Head-starting has been underway since 1971 in Western Samoa and is continuing at present (1979) (8). As many freshly laid eggs as possible are transferred from nest sites on the three offshore islets near Upolu (the main island) to a central protected facility on Upolu. It was originally intended to develop a ranching industry to supply shell and stuffed Hawksbills to Japan, but this proved unfeasible for many reasons, and the hatchlings at present are reared to the age of three months, marked, and released (8). There is evidence for some degree of effectiveness, since several marked immature turtles have been captured and found on sale in Apia market on Upolu (8). A comprehensive appraisal of this hatchery scheme is required (8), to aid in assessing the potential effectiveness of similar efforts in other areas. Head-starting is carried out at three sites in Caribbean Mexico; Isla del Carmen (Campeche), Isla Mujeres and Puerto Morelos (Quintana Roo) (79). There appear to be no objective data on the long-term effects of head-starting on 
sea turtle populations (55). In 1981 a hatchery was established at Palau Redang, Trengganu (west Malaysia), it is intended to incubate 2000 Hawksbill eggs per year (64); this sland is currently being developed into a strictly protected marine park (79). The National Parks and Wildlife Section in Sarawak attempts to transplant eggs to allow them to hatch in protected areas (58). A small-scale hatchery operates in Carriacou (in the Grenada Grenadines), using eggs from slaughtered females and nests discovered by local hunters (87).

The very important Hawksbill nest beaches on the Arnavon islands (Solomons) are within a 'Wildlife Sanctuary' about to be given final legislative approval (1981) (70). 'Head-starting' has been underway on Kerehikapa as part of the Arnavon Turtle Project (70).

Listed on Appendix I of the Convention on International Trade in Endangered Species of Wild Fauna and Flora (CITES). Appendix I listing requires that trade in the taxon and its products is subject to strict regulation by ratifying states, and international trade for primarily commercial purposes is prohibited. Reservations with regard to Appendix I listing have been entered by France and Japan.

CONSERVATION MEASURES PROPOSED It has recently been stated $(21,31)$ that an effective ban on international trade in this species is an absolute necessity for its survival. A significant step toward this ideal was made by listing on CITES Appendix I, but exports contrary to the provisions of this listing have still occurred (from Panama, for example (43)) and Japan, the country that' alone consumes almost all Hawksbill material in international trade, has ratified CITES but with a reservation on Hawksbill (as well as several other reptile and mammal species). States party to CITES that have taken reservations for Hawksbill should withdraw those reservations, and Japan should be encouraged to cease providing a major market for Hawksbill products (71). States not yet party to CITES that have Hawksbill populations should be encouraged to ratify the Convention, and current CITES states should be encouraged to abide strictly by its conditions (85). The use of old or antique tortoiseshell items, or of artificial substitute tortoiseshell, should be promoted in preference to continuing consumption of new Hawksbill shell (71). The comparatively new and totally unnecessary luxury trade in stuffed juvenile Hawksbills and polished shells should be ended (71).

Existing legislation, including that relating to protected areas, should be rigorously enforced. Measures should be taken to protect more known nesting beaches wherever this is likely to be effective. The U.S. Fish and Wildlife Service has proposed (4) that certain areas within the Commonwealth of Puerto Rico should be designated Critical Habitat in the terms of the Endangered Species Act, namely, Mona Island, beaches on Culebra Island, Cayo Norte and Isla Culebrita (apparently not yet within the Commonwealth). Adoption of this proposal should be encouraged. Head-starting at Palau (western Carolines) should be re-established (53).

Hawksbills nest within several proposed protected areas in Indonesia; Gosong Rengat Wildlife Sanctuary, Pancalirang and Peteloran W.S., Sangalaki and Semana Nature Reserves, Karimun Jawa N.P., Aru W.S. (62). In Oman, Masirah Island has been proposed as a protected area for turtle nesting (60).

The ecological characteristics of the Hawksbill are such that, firstly, protection of nesting beaches may not, in itself, be especially effective due to generally diffuse nesting habits (of course, the known sites of concentrated nesting are exceptions), and secondly, the species appears more susceptible than other sea turtles to disturbance at the nest site (eg. tourist activity, lighting) (35). These arguments suggest that prohibition of international trade in Hawksbill shell and curios is the best route toward possible recovery of the species. 
The practice of incubating sea turtle eggs in semi-natural or artificial nests, in the hope of decreasing egg and hatchling mortality, should be reviewed. It is now known that the sex of some sea turtle species, and probably all sea turtles, is determined by temperature during a critical phase of embryonic development. To the extent that temperatures in non-natural nests may differ from those in natural nests, the sex ratio among the hatchlings will deviate from the natural ratio. Production of an excess of males, or of intersexes, will clearly be deleterious; an excess of females may be less serious. See reference 90, and sources cited therein.

CAPTIVE BREEDING No information, apparently never attempted.

REMARKS The compiler is especially grateful to A. Meylan for a thorough and constructive review of a preliminary draft of this account, and to T. Milliken, J. Mortimer, N. Polunin, R.V. Salm, and K.T. Siow for comments and additional data.

REFERENCES 1. Alcala, A.C. (1980). Observations on the ecology of the Pacific Hawksbill turtle in the central Visayas, Philippines. Fish. Res. J. Philipp. 5(2): 42-52.

2. Alcala, A.C. and White, A. (1981). Project Proposal: Sea turtle nesting habitat protection and management, southern Negros Island, Philippines.

3. Anon (National Fish and Wildlife Lab., Gainesville). (1980). Hawksbill Turtle. In, Selected vertebrate endangered species of the seacoast of the United States. Biological Services Program FWS/OBS-80/01.22. U.S. Fish and Wildlife Service.

4. Anon. (1980). Puerto Rican beaches proposed as critical habitat for Hawksbill Turtle. Endangered Species Technical Bulletin, 5(2): 11 .

5. Anon (South Pacific Commission) (1980). Report of joint SPC/NMFS Workshop on marine turtles in the tropical Pacific Islands (Noumea, New Caledonia, Dec. 1979). SPC, Noumea, New Caledonia.

6. Anon (1982). TRAFFIC Bulletin (IUCN Wildlife Trade Monitoring Unit). 3(6): 69.

7. Bain, J.R., and Humphrey, S.R. (1980). A profile of the endangered species of Thailand. Report No. 4, Office of Ecological Services, Florida State Museum, U.S.A.

8. Balazs, G.H. (in press). Status of sea turtles in the Central Pacific Ocean. In, Bjorndal, K. (Ed.). The Biology and Conservation of Sea Turtles. Smithsonian Institute Press, Washington D.C. (Papers presented at The World Conference on Sea Turtle Conservation, Nov. 26-30, 1979, Washington D.C.).

9. Bhaskar S. (1979). Sea turtles on the South Andaman Islands Hamadryad 4(1).

10. Bhaskar, S. (1979). Sea Turtle survey in the Andaman and Nicobars. Hamadryad 4(3): 2-26.

11. Bhaskar, S. (1979). The status of the Sea Turtles in the East Indian Ocean. In Bjorndal, K. (Ed.), The Biology and Conservation of Sea Turtles. Smithsonian Institute Press, Washington D.C.) (Papers presented at The World Conference on Sea Turtle Conservation, Nov. 26-30, 1979, Washington D.C.).

12. Brongersma, L.D. (in press, 1982). Marine Turtles of the 
Eastern Atlantic. In, Bjorndal, K. (Ed.), The Biology and Conservation of Sea Turtles. Smithsonian Institute Press, Washington D.C. (Papers presented at The World Conference on Sea Turtle Conservation, Nov. 26-30, 1979, Washington D.C.).

13. Buitrago, (MS). Not seen, cited in ref (56).

14. Burbidge, A.A. (1981). In litt., 5 February.

15. Bustard, R. (1973). Saving the Hawksbill Turtle. Oryx 12(1): 93-98.

16. Bustard, R. (1974). Barrier Reef Sea Turtle populations. Proc. 2nd. Internat. Coral Reef Symp. 1:227-234.

17. Caribbean Conservation Corporation (1980). Survey and preliminary census of Marine Turtle populations in the Western Atlantic. Final report to National Marine Fisheries Service, Contract 03-78-008-0025.

18. Carr, A. (in press, 1982). Notes on the behavioral ecology of sea turtles. In, Bjorndal, K. (Ed.). The Biology and Conservation of Sea Turtles. Smithsonian Institute Press, Washington D.C. (Papers presented at The World Conference on Sea Turtle Conservation, Nov. 26-30, 1979, Washington D.C.).

19. Carr, A., Hirth, H., and Ogren, L. (1966). The ecology and migrations of sea turtles, 6. The Hawksbill Turtle in the Caribbean Sea. Amer. Mus. Novitates. 2248: 1-29.

20. Carr, A., and Main, R. (1973). Turtle farming project in Northern Australia. Report on an inquiry into ecological implications of a turtle farming project, Oct. 1973. Commonwealth of Australia.

21. Carr, A., and Meylan, Anne B. (1980). Extinction or rescue for the Hawksbill? Oryx 15(5): 449-450.

22. Carr, A., and Stancyk, S. (1975). Observations on the ecology and survival outlook of the Hawksbill Turtle. Biol. Conserv. 8: 161-172.

23. Chua, T.H. (1979). Conservation of the Hawksbill in Malacca. Can it be a reality? Malayan Naturalist 33(2): 15-17.

24. Cliffton, K., Cornejo, D.O., and Felger, R.S. (in press, 1982). Sea turtles of the Pacific Coast of Mexico. In, Bjorndal, K. (Ed.). The Biology and Conservation of Sea Turtles. Smithsonian Institute Press, Washington D.C. (Papers presented at The World Conference on Sea Turtle Conservation, Nov. 26-30, 1979, Washington D.C.).

25. Cogger, H. (1979). Reptiles and Amphibians of Australia. A.H. and A.W. Reed PTY., Sydney. 2nd Edn.

26. De Celis, N.C. (in press). Status of marine turtles in the Philippines. In, Bjorndal, K. (Ed.). The Biology and Conservation of Sea Turtles. Smithsonian Institute Press, Washington D.C. (Papers presented at The World Conference on Sea Turtle Conservation, Nov. 26-30, 1979, Washington D.C.).

27. De Silva, G.S. (1969). Marine turtle conservation in Sabah: Annual Report, Research Branch, Forest Dept.

28. De Silva, G.S. (1969). Turtle Conservation in Sabah. Sabah Soc. J. 5(1): 6-26.

29. De Silva, G.S. (in press). The status of sea turtle populations in East Malaysia and the South China Sea. In, Bjorndal, K. (Ed.). The Biology and Conservation of Sea Turtles. Smithsonian Institute Press, Washington D.C. 
(Papers presented at The World Conference on Sea Turtle Conservation, Nov. 26-30, 1979, Washington D.C.).

30. Diamond, A.W. (1976). Breeding biology and conservation of Hawksbill Turtles, Ertemochelys imbricata L., on Cousin Island, Seychelles. Biol. Conserv. 9:199-215.

31. Frazier, J. (in press, 1982). The status of Marine Turtles in the Western Indian Ocean. In, Bjorndal, K. (Ed.), The Biology and Conservation of Sea Turtles. Smithsonian Institute Press, Washington D.C. (Papers presented at The World Conference on Sea Turtle Conservation, Nov. 26-30, 1979, Washington D.C.).

32. Garnett, M.C. (1979?) The breeding biology of Hawksbill Turtles (Eretmochelys imbricata) on Cousin Island, Seychelles. International Council for Bird Preservation (British Section), unpublished Research Report.

33. Green, D., and Ortiz, F. (in press, 1982). The status of Sea Turtle populations in the central eastern Pacific. In, Bjorndal, K. (Ed.), The Biology and Conservation of Sea Turtles. Smithsonian Institute Press, Washington D.C. (Papers presented at The World Conference on Sea Turtle Conservation, Nov. 26-30, 1979, Washington D.C.).

34. Hays de Brown, C. and Brown, W.B. (in press, 1982). The status of sea turtles in Peru. In, Bjorndal, K. (Ed.). The Biology and Conservation of Sea Turtles. Smithsonian Institute Press, Washington D.C. (Papers presented at the World Conference on Sea Turtle Conservation, Nov. 26-30, 1979, Washington D.C.).

35. Hendrickson, J.R. (in press, 1982). Nesting behaviour of sea turtles with emphasis on physical and behavioral determinants of nesting success or failure. In, Bjorndal, K. (Ed.). The Biology and Conservation of Sea Turtles. Smithsonian Institute Press, Washington D.C. (Papers presented at The World Conference on Sea Turtle Conservation, Nov. 26-30, 1979, Washington D.C.).

36. Hirth, H. and Carr, A. (1970). The Green Turtle in the Gulf of Aden and the Seychelles Islands. Verhand. Koninkl. Nederl. Akad. v. Wetenschappen, afd. Natuurk. 58(5). North Holland Publ. Co., Amsterdam, London.

37. Hirth, H.F. and Abdel Latif, E.M. (1980). A nesting colony of the Hawksbill Turtle Eretmochelys imbricata on Seil Ada Kebir Island, Suakin Archipelago, Sudan. Biol. Conserv. 17: 125-130.

38. Hoffman, T.W. (1981). In litt., 5 March.

39. Hughes, G.R. (1973). The survival situation of the Hawksbill Sea-turtle (Eretmochelys imbricata) in Madagascar. Biol. Conserv. 5(2): 114-118.

40. Hughes, G.R. (1975). Fano: (Madagascar sea turtles). Defenders of Wildlife 50 (2): 159-163.

41. Hughes, G.R. (in press, 1982). The conservation situation of Sea Turtle populations in the southern African region. In, Bjorndal, K. (Ed.). The Biology and Conservation of Sea Turtles. Smithsonian Institute Press, Washington D.C. (Papers presented at The World Conference on Sea Turtle Conservation, Nov. 26-30, 1979, Washington D.C.).

42. Kakidachi, T., and Uchida, I. (1973, English version 1978). Preliminary report on the Hawksbill Turtle (Eretmochelys imbricata) in Indonesia, Philippines, Malaysia and Singapore. Japanese Tortoise Shell Association. (English 
version prepared by Balazs, G.H. (Hawaii Inst. Marine Biol.) and Nozoe, M.)

43. King F.W. (in press, 1982). Historical review of the decline of the Green Turtle and the Hawksbill. In, Bjorndal, K. (Ed.). The Biology and Conservation of Sea Turtles. Smithsonian Institute Press, Washington D.C. (Papers presented at The World Conference on Sea Turtle Conservation, Nov. 26-30, 1979, Washington D.C.).

44. Limpus, C.J. (1980). Observations on the Hawksbill Turtle (Eretmochelys imbricata) nesting along the Great Barrier Reef. Herpetologica 36(3): 265-271.

45. Limpus, C.J. (in press, 1982). The status of Australian Sea Turtle populations. In, Bjorndal, K. (Ed.). The Biology and Conservation of Sea Turtles. Smithsonian Institute Press, Washington D.C. (Papers presented at The World Conference on Sea Turtle Conservation, Nov. 26-30, 1979, Washing ton D.C.).

46. Mack, D., Duplaix, N. Wells, S. (in press, 1982). The sea turtle: an animal of divisible parts. International Trade in sea turtle products. In, Bjorndal, K. (Ed.). The Biology and Conservation on Sea Turtles. Smithsonian Institute Press, Washington D.C. (Papers presented at The World Conference on Sea Turtle Conservation, Nov. 26-30, 1979, Washington D.C.).

47. MacKinnon, J. (1981). In litt., 7 May.

48. Meylan, A. (in press, 1982). Sea Turtle migration - evidence from tag returns. In, Bjorndal, K. (Ed.). The Biology and Conservation of Sea Turtles. Smithsonian Institute Press, Washington D.C. (Papers presented at The World Conference on Sea Turtle Conservation, Nov. 26-30, 1979, Washington D.C.).

49. Moore, R.J., and Balzarotti, M.A. (1977). Report of 1976 Expedition to Suakin Archipelago (Sudanese Red Sea). Results of marine turtle survey and notes on marine and bird life. Mimeographed, iv + 27 pp. (Not seen, cited in ref 31).

50. Mortimer, J.A. (1982). Turtles around the Seychelles. Interim report, Project 1809. WWF Monthly Report, Feb. 1982.

51. Plotkin, M.J. and Fairbairn, P. (undated). The endangered vertebrates of Jamaica. Unpublished ms.

52 Pritchard, P.C.H. (undated). Proposal for a Marine Turtle survey in New Caledonia.

53. Pritchard, P.C.H. (1977). Marine Turtles of Micronesia. Chelonia Press, San Francisco.

54. Pritchard, P.C.H. (1979). Encyclopedia of Turtles. T.F.H. Publications, Hong Kong and New Jersey.

55. Pritchard, P.C.H. (1980). The Conservation of Sea Turtles: practices and problems. Amer. Zool. 20(3): 609-617.

56. Pritchard, P.C.H. (in press, 1982). Hawksbill account, in monograph on turtles of Venezuela (manuscript).

57. Pritchard, P.C.H., and Stubbs, T.H. (1982). Final Report Vieques Island Sea Turtle study. Unpublished.

58. Proud, K. (1981). In litt., 12 May.

59. Ross, J.P. (1981). Hawksbill Turtle Eretmochelys imbricata in the Sultanate of Oman. Biol. Conserv. 19: 99-106.

60. Ross, J.P., and Barwani, M.A. (in press, 1982). Review of sea turtles in the Arabian area. In, Bjorndal, K. (Ed.). The Biology and Conservation of Sea Turtles. Smithsonian 
Institute Press, Washington D.C. (Papers presented at The World Conference on Sea Turtle Conservation, Nov. 26-30, 1979, Washington D.C.).

61. Ross, J.P., and SSC Marine Turtle Group (1979). Present status of Sea Turtles. A summary of recent information and conservation priorities.

62. Salm, R.V.(1981). In litt, 1 October.

63. Schulz, J.P. (1975). Sea Turtles nesting in Surinam. Zoologische Verhandelingen (Leiden) 143.

64. Siow, K.T.(1981). In litt., 19 April.

65. Spring, S. (in press, 1982). Status of Marine Turtle populations in Papua New Guinea. In, Bjorndal, K. (Ed.). The Biology and Conservation of Sea Turtles. Smithsonian Institute Press, Washington D.C. (Papers presented at The World Conference on Sea Turtle Conservation, Nov. 26-30, 1979, Washington D.C.).

66. Sternberg, J. (1981). The worldwide distribution of Sea Turtle nesting beaches. Center for Environmental Education, Washington D.C.

67. Uchida, 1. (1979). Brief report on the Hawksbill Turtle (Eretmochelys imbricata) in the waters adjacent to Indonesia and Malaysia. Japan Tortoise Shell Society, Nagasaki (in Japanese).

68. Uchida, I. (1980). The report of a feasibility research on artificial hatchery and cultivation of Hawksbill turtle Eretmochelys imbricata in waters adjacent to Malaysia, Singapore and Indonesia. Japan Tortoise Shell Society, Nagasaki (in Japanese).

69. Blouch, R.A. (1981) 1980 Annual Report. WWF Project 1024 , Meru Betiri.

70. Vaughan, P.W. (1981). Marine Turtles: a review of their status and management in the Solomon Islands. Ministry of Natural Resources, Honiara, Solomons.

71. Anon. (In press 1982) Sea Turtle Conservation Strategy. IUCN, Gland. (Conservation/management strategy prepared at 1979 World Conference on Conservation of Sea Turtles, Washington, D.C.). In Bjorndal, K. (Ed.), The Biology and Conservation of Sea Turtles, Smithsonian Institute Press, Washington D.C.

72. Meylan, A. (in press, 1982). Estimation of population size in sea turtles. In, Bjorndal, K. (Ed.). The Biology and Conservation of Sea Turtles. Smithsonian Institute Press, Washington, D.C.

73. Maxwell, F.D. (1911). Reports on inland and sea fisheries in the Thongwa, Myaungmya, and Bassein districts and the turtle banks of the Irrawaddy division. Rangoon, Govt. Printing Office. 57pp.

74. Cornelius, S.E. (in press, 1982). The status of sea turtles on the Pacific Coast of Central America. In, Bjorndal, K. (Ed.). The Biology and Conservation of Sea Turtles. Smithsonian Institute Press, Washington, D.C.

75. Pritchard, P.C.H. (1969). Sea turtles of the Guianas. Bull. Fla. State Mus. 13(2):85-140.

76. Polunin, N.V.C., and Sumertha Nuitja, N. (in press, 1982). Sea turtle populations of Indonesia and Thailand. In, Bjorndal, K. (Ed.). The Biology and Conservation of Sea Turtles. Smithsonian Institute Press, Washington, D.C.

77. Siow, K.T., and Moll, E.O. (in press, 1982). Status and 
conservation of estuarine and sea turtles in West Malaysian waters. In, Bjorndal, K. (Ed.). The Biology and Conservation of Sea Turtles. Smithsonian Institute Press, Washington, D.C.

78. Hirth, H. (1980). Some aspects of the nesting behaviour and reproductive biology of sea turtles. Amer. Zool. 20:507-523.

79. Siow, K.T. (1982). In litt., 6 April (comments on preliminary draft of RDB Hawksbill account).

80. Mortimer, J. (1982). In litt., 21 May (comments on preliminary draft of RDB Hawksbill account).

81. Salm, R.V. (1982). In litt., 13 April (comments on preliminary draft of RDB Hawksbill account).

82. Compost, A. (1980). Aru Islands, Indonesia. Dugong and Turtle Survey. Project 1734. WWF Monthly Report, April, 1980.

83. Milliken, T. (1981). Wildlife shopping in Tokyo - 1981. Traffic Bulletin (IUCN Wildlife Trade Monitoring Unit), 3 $(3-4): 43-47$.

84. Milliken, T. (1982). Pers. comm., April.

85. Meylan, A. (1982). In litt., 5. May (Comments on preliminary draft of RDB Hawksbill account).

86. Carr, A., and Meylan, A. (1980). Evidence of passive migration of Green Turtle hatchlings in Sargassum. Copeia 1980 (2): 366-368.

87. Goodwin, M. (1980). Conservation of the Hawksbill Sea Turtle in Grenada. Caribbean Conservation News 2(4): 16-18.

88. Witzell, W.N., and Banner, A.C. (1980). The Hawksbill Turtle (Eretmochelys imbricata) in Western Samoa. Bull. Mar. Sci. 30(3): 571-579.

89. Polunin, N. (1982). In litt., 26 March (comments on preliminary draft of RDB Hawksbill account).

90. Morreale, S.J., Ruiz, G.J., Spotila, J.R., and Standora, E.A. (1982). Temperature-dependent sex-determination: current practices threaten conservation of sea turtles. Science, 216:1245-1247. 
SUMMARY A critically endangered sea turtle. The number of nesting females has been reduced from an estimated 40,000 seen on a single day's group nesting in 1947 to around 500 per season in the late 1970's. Largest group nesting in 1981 comprised 227 females. Nesting is mostly restricted to a $20 \mathrm{~km}$ stretch of beach on the Gulf of Mexico, near Rancho Nuevo, Tamaulipas State (Mexico). This highly restricted breeding range is in marked contrast to the scattered circumglobal distribution of most other sea turtles. Adult Kemp's Ridley are restricted to inshore waters around the Gulf, mainly the Mississippi delta area in the north, and the Tabasco-Campeche area in the south. Movement of hatchlings is unknown, but young and sub-adults occur in the Gulf, around the Florida coast and along the eastern U.S. seaboard to the New England area, with waifs occasionally reaching eastern Atlantic waters and the Mediterranean. A

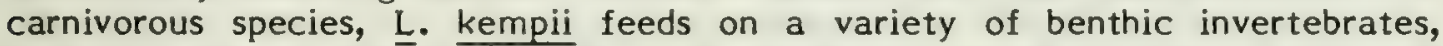
al though crabs are a favoured prey. Both Lepidochelys species, Kemp's Ridley and Olive Ridley $\mathrm{L}$. olivacea (not all populations) are distinct among sea turtles in that nesting females emerge onto the nesting beach in synchronized aggregations termed arribada ('arrival'). Kemp's Ridley arribadas are now desultory, comprising only 100-200 individuals. Females may nest annually or biannually, there may be one, two or rarely three nests per season. Eggs are c $39 \mathrm{~mm}$ in diameter, average 110 eggs per clutch. The demographic collapse of the species has been attributed to excessive predation on eggs by local people and by coyotes, over-exploitation of juveniles and adults for meat, and accidental catch of turtles in shrimp trawls. Pollution of the Mississippi drainage is a further probable threat. Accidental catch now appears to be the major direct threat to the species, with probably several hundred individuals being accidentally caught annually, and drowned or killed aboard trawlers. The nest site is strongly protected by the Mexican government, and over 800 clutches are transplanted annually to a central hatchery. A cooperative Mexican - U.S. programme is in progress, involving relocation of nests to Padre Id. (Texas), headstarting of hatchlings, further protection of the nesting beach, and research on fishing gear designed to exclude turtles from trawls. Captive breeding has been suggested as a possible conservation measure. Listed as Endangered under the U.S. Endangered Species Act. Listed on CITES Appendix I.

DISTRIBUTION The single major nesting ground is a $20 \mathrm{~km}$ stretch of beach on the Gulf of Mexico near Rancho Nuevo in the southern part of the State of Tamaulipas, northeast Mexico $(5,22,25)$. A few individuals have nested sporadically to the north and south of the primary nesting site, on Padre Island (Texas), in the States of Veracruz and Tabasco (Mexico). This highly localized nesting range is in marked contrast to the scattered circumglobal distributions of the other sea turtles (except Chelonia depressa, restricted to northern Australia). Major known feeding grounds for adult Kemp's Ridley are also in the Gulf of Mexico, including the crab-rich shallow waters off Louisiana, notably around the Mississippi Delta, and the Tabasco-Campeche area of Mexico. Adults are also recorded from other localities in the Gulf (4), from the Florida Keys eastward to the Mexican border, and around the Bay of Campeche. Juvenile Kemp's Ridley, $150-200 \mathrm{~mm}$ in length, have been known to occur in this same general area, but a 
major developmental feeding site may be the Big Gulley area off Mobile Point Peninsula (Alabama) $(3,6)$. Young of a similar size class are also found in New England waters (primarily Massachusetts) (2) and Chesapeake Bay (27), with waifs occasionally carried, presumably in the Gulf Stream, to the east Atlantic (records from Scotland in the north, Madeira in the south, and the Mediterranean) (2). Juveniles were formerly seasonally numerous around the Florida Peninsula, and less numerous northward along the U.S. Atlantic coast (6).

POPULATION The only type of population estimate for sea turtles that approaches feasibility is a count of mature nesting females (17). There are fewer difficulties applying this approach to Kemp's Ridley, where breeding females typically emerge onto a single beach in synchronized diurnal nesting aggregations (arribadas), than to other sea turtles. For $\underline{\mathrm{L}}$. kempii the minimum world population of reproductive females is most closely approximated by the number of females taking part in the largest arribada of the season.

In 1947 around 40,000 turtles nested in one arribada (22), in the mid-1960's numbers were reduced to c 5,000 turtles (21), in 1970 and 1971 the largest arribadas comprised c 2,000-2,500 females (22), in 1973 the largest comprised c 1,000 turtles (21), while by 1975 numbers had declined to perhaps 500 turtles $(3,10)$. Other estimates suggest arribadas comprising only 100-200 individuals since 1970 (24). Two recent population estimates of Lepidochelys kempii are: less than 2,000 individuals (presumably non-hatchlings) (24); or 4,000-5,000 (including both sexes) $(14,16)$. About 1,000 nests were made in each of the $1978-1981$ seasons $(20,29)$. There were a total of 44 emergences, both solitary and grouped, between 17 April and 4 July, in the 1981 nesting season. Of the two important arribadas, 227 nests were made on 8 May and 220 on 2 June (29). Kemp's Ridley must clearly be considered a critically endangered species, possibly beyond recovery, although conservation measures have been intensive in recent years (20).

HABITAT AND ECOLOGY A small sea turtle, to around $66-70 \mathrm{~cm}$ carapace length, with a distinctively broad and flattened carapace, more highly arched anteriorly. The adult population is restricted to the Gulf of Mexico, with the nesting grounds near Rancho Nuevo (Tamaulipas), and major feeding grounds in the shallow inshore waters of Lousiana and the Tabasco-Campeche region $(3,6)$. Sub-adult juveniles, between $30 \mathrm{~cm}$ and $60 \mathrm{~cm}$ in length, were frequently recorded from the northern Gulf, especially the west coast of the Florida Peninsula. Small juveniles, $15-20 \mathrm{~cm}$ in length, are also recorded from the northern Gulf, where the Big Gulley area off Alabama appears to be a major developmental staging area $(3,6)$. Other records of adults and immatures exist for inshore waters around much of the circumference of the Gulf. It thus appears that the entire life-cycle of a proportion of the total population of Kemp's Ridley is completed within the Gulf of Mexico. However, a certain proportion of juveniles, from small to sub-adult, is found outside the Gulf, along the eastern seaboard of the U.S.. In general, there is a progressive size-decrease from sub-adults found along the east coast of Florida, to small juveniles found in the New England region, and to the small or very small juveniles occasionally carried over to eastern Atlantic waters.

The New England population segment may be carried passively out of the Gulf and northward in the Gulf Stream, and then enter the temperate littoral habitat via northward-trending eddies separating from the Gulf Stream, or by active swimming. The fate of $\mathrm{L}$. kempii away from the Gulf of Mexico and the Florida coast is not known. There would seem to be two chief alternatives. Either they return by active swimming, navigating by unknown sensory cues, to attain maturity in the Gulf and breed, or they are lost forever from the reproductive section of the population $(6,8)$. There is some reluctance to concede the latter possibility and although there is no hard evidence whatsoever that any L. kempii along the eastern seaboard of the U.S. ever returns to the Gulf, tagging of 
individuals encountered in Atlantic waters could provide the necessary data (12). Before its recent drastic depletion, Kemp's Ridley was a regular and abundant species along the Florida east coast and in North Carolina (7), and similarly occurred regularly in New England waters, notably in Massachusetts where it is reportedly still seasonally common (12). These observations make it intuitively unlikely that Kemp's Ridley in the Atlantic are lost from the reproductive population. It is probable that the Atlantic coast, at least as far as North Carolina (7) or northward to the New England region (12) is a natural part of the developmental and foraging range of the species. There may possibly be a period of winter hibernation during the return journey $(7,22)$.

Like most sea turtles (the Green Turtle Chelonia mydas being the notable exception), $\underline{L}$. kempii is carnivorous in adult feeding habits. It appears to be mainly a bottom-feeding species. Fish, jellyfish, echinoderms, crustaceans, gastropod and cephalopod molluscs, are among recorded prey items (11), but crabs, notably portunids of the genera Ovalipes and Callinectes (9), appear to be

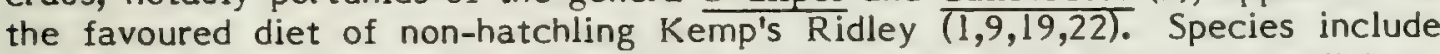
Spotted Lady Crab Palyonichus ocellatus, Dolly Varden Crab Hepatus epheliticus, also Blue Crab Callinectes sapidus, probably a Mud Crab Panopeus or Menippe sp., also Arenaeus sp., and Calappa sp. $(1,22)$. Prey of hatchlings and small juveniles, before shifting from the planktonic phase to bottom-foraging, is not known.

Sexual maturity may be attained after about six years (22), although this theoretical estimate requires verification (23), at a length of around $60 \mathrm{~cm}$. Mating occurs at the start of the nesting season, in the vicinity of the nesting beach (22). Nesting occurs between April and July, with the peak in May-June $(5,22)$. Females of both species of Lepidochelys, the Olive Ridley L. olivacea (most populations) and Kemp's Ridley L. kempii, emerge to nest in synchronized aggregations, termed arribadas (Spanish, 'arrival'). The arribada nesting strategy, with the sudden mass arrival of adults and subsequent mass emergence of hatchlings, may serve as a 'predator swamping' device $(10,22)$. The arribada may be coordinated by pheromonal communication; the two Lepidochelys species are the only sea turtles with a complete and well-developed series of inframarginal secretory pores, and are also the only species known to form arribadas (21) (however, this is purely circumstantial evidence).

Most remigrant females of both Lepidochelys species nest on a one or two year cycle; this is in contrast to most other sea turtles, where annual nesting is rare and a three year cycle is most typical (10). Most $\mathrm{L}$. kempii nest on a one-year cycle, less than $30 \%$ nest on a two-year cycle (16). $\bar{L}$. kempii may lay one, two or three clutches per season, at intervals of 20-28 days (10,22). Kemp's Ridley is unusual among sea turtles in that nesting is largely diurnal. Optimum weather conditions may be cloudy, relatively cool days with a strong north wind (21). The Tampaulipas nesting area is a broad beach, primarily of fine sand (5), backed firstly by vegetated dunes, and then in parts by lagoons or salt marsh. After emergence and passage up the beach, only a rudimentary body pit is briefly swept out by the fore-limbs. The egg cavity, around $40 \mathrm{~cm}$ deep, is dug by alternate motions of the hind-limbs (22). The clutch averages 110 eggs (range 54-185) (10). Eggs are white, spherical, averaging $38.9 \mathrm{~mm}$ in diameter (range $35-44.5 \mathrm{~mm}$ ), weighing around $30 \mathrm{~g}(24-4 \mathrm{lg})(10)$. Egg-deposition takes around 15 to 30 minutes (15) and is completed by pulling sand back into the cavity by the hind limbs.

As with the River Terrapin Batagur baska, the nest site is compacted by body pressure; but whereas Batagur repeatedly drops the entire shell onto the sand, $\underline{\mathrm{L}}$. kempii (like $\mathrm{L}$. olivacea) strikes with each lateral margin of the shell in turn (21,22). The entire period of emergence is typically only around 50 minutes (21), less than most other sea turtles. Incubation period is 45-60 days, most hatchlings emerge after 48-55 days, around dawn (15). Coyotes Canis latrans and humans are 
major predators on eggs of Kemp's Ridley. Hatchlings are taken by a variety of predators, including Ghost Crab Ocypode albicans, Black Vultures Coragyps atratus, and fishes (22).

THREATS TO SURVIVAL The dramatic decline of Kemp's Ridley in the 1950's and 1960's is attributed to several factors (21); intensive predation on eggs by local people and by coyotes, fishing for juveniles and adults, slaughter of nesting adults for meat, and incidental catch by trawlers. Exploitation for eggs and meat has continued until recently (24), although now illegal. However, the major current direct threat to the vestigial Kemp's Ridley population is accidental catch in shrimp trawls and shark nets. Turtles not drowned in the nets may be killed once hauled aboard, partly to avoid further damage to the net. Adult $\underline{L}$. kempii are normally bottom-feeders, foraging in the same crab-rich shallow inshore waters that are swept by shrimp trawls; the species is thus particularly vulnerable to this activity (11). Incidental catch of this species by U.S., Cuban and Mexican shrimp trawlers is estimated at 500 turtles per year (14). It has been reported (quoted in ref. 6) that one vessel alone took four or five Ridleys per tow in July 21,1977 , up to a total of about 100. This may be an exceptional record, but has been taken as evidence (6) that the area concerned ('Big Gulley', Alabama) is a major developmental site for L. kempii. A further, and more insidious, threat is probably posed by pollution of the Missippii drainage (27).

CONSERVATION MEASURES TAKEN The Mexican Government has conducted a tagging programme at the nesting beach since 1966, and has protected the area with armed patrols. About $800-900$ (20) or 1,000 (15) clutches of eggs are transplanted annually to a central hatchery to minimize predation by people and coyotes. In 1978 the Instituto Nacional de Pesca (Mexico), the U.S. Fish and Wildlife Service, U.S. National Park Service, U.S. National Marine Fisheries Service (N.M.F.S.), the Texas Parks and Wildlife Department and the Florida Audubon Society initiated a cooperative programme involving further protection of the nesting beach, translocation of c 2,000 eggs annually to Padre Island National Seashore in an attempt to establish a second breeding site, and headstarting of hatchlings (both from eggs hatched at Padre Island, and from Rancho Nuevo) at the N.M.F.S. laboratory in Galveston, Texas $(1,32)$. The N.M.F.S. laboratory has headstarted around 1,500-2,000 individuals annually since the late 1970s (31). The animals are released at Padre Island and at two sites in Florida (32). The relative merits of headstarting as a conservation technique are subject to debate (31). Headstarting projects will need to run for very long periods before their potential for increasing a breeding population can be accurately assessed (30). With protection of the nesting beach now relatively effective, the major present threat to the survival of $\underline{L}$. kempii, the incidental catch by shrimp trawlers, may be reduced in future by use of modified trawling gear designed to exclude turtles, recently developed by the N.M.F.S. (26). A restricted fishing zone has been established near Rancho Nuevo (28).

Listed as Endangered under the U.S. Endangered Species Act. Listed on Appendix I of the Convention on International Trade in Endangered Species of Wild Fauna and Flora (CITES). Appendix I listing requires that trade in the taxon and its products is subject to strict regulation by ratifying states, and international trade for primarily commercial purposes is prohibited.

CONSERVATION MEASURES PROPOSED The current measures, noted above, can be improved mainly by ensuring that the N.M.F.S. excluder device is widely used, and by restricting trawling in key areas and further reducing poaching (18). Only time will tell whether the Kemp's Ridley population is already too depleted to be capable of recovery. Captive breeding has been suggested as a possible future conservation measure. A small colony of half-grown individuals, hatched in 1978, is held at the Cayman Turtle Farm with this objective (20), however, there 
are considerable doubts about whether such measures could help restore the wild population (18). The Playa de Rancho Nuevo is one of seven Nature Reserves proposed for the Mexican coast (14). Further research into the movement of juveniles is needed, in particular by means of a tagging programme in northeast U.S.A. (28).

CAPTIVE BREEDING Not yet attempted (see previous paragraph). Adult and half-grown juveniles adapt well to captivity and have survived in public aquaria for many years (22).

REMARKS It has been suggested that $\underline{L}$. kempii may have speciated from a common ancestor shared with the east Pacific populations of $\mathrm{L}$. olivacea, following final emergence of the Panama Isthmus 3.5 to 4 million years. ago (6).

REFERENCES 1. Anon. (National Fish and Wildlife Lab, Gainesville). (1980). Kemp's Atlantic Ridley Sea Turtle. In, Selected vertebrate endangered species of the seacoast of the United States. Biological Services Program FWS/OBS-80/01.30. U.S. Fish and Wildlife Service.

2. Brongersma, L.D. (in press, 1982). Marine Turtles of the eastern Atlantic. In, Bjorndal, K. (Ed.) Biology and Conservation of Sea Turtles. Smithsonian Institute Press; Washington DC. (Papers presented at the World Conference on Sea Turtle Conservation, Nov. 26-30, 1979, Washington D.C.).

3. Carr, A., Meylan, A., Mortimer, J., Bjorndal, K., and Carr, T. (1982). Preliminary survey of marine turtle populations and habitats in the western Atlantic. Interim Report to National Marine Fisheries Service. Contract NA80-FA-C-00071. NOAA Technical Memorandum NMFS-SEFC.

4. Chavez, H. (1968). Marcado y recaptura de individuos de tortuga lora Lepidochelys kempi Garman. Inst. Nac. Investig. Biol. Pesq. No. 19. Reprinted in English 1969, Int. Turtle and Tortoise Soc. J. 3(4): 14-19, 32-36.

5 Chavez, H., Contreras, G.M., Eduardo Hernandez, D.T.P. (1967). Aspectos biologicos y proteccion de la tortuga lora, Lepidochelys kempi (Garman), en la costa de Tamaulipas, Mexico. Inst. Nac. Investig. Biol. Pesq. No. 17. Reprinted in English 1968, Int. Turtle and Tortoise Soc. J. 2(4): 20-29, 37, 2(5): 16-19, $27-34$.

6. Carr, A. (1980). Some problems of sea turtle ecology. Amer. Zool. 20: 489-498.

7. Carr, A. (1981). In litt., 12 May.

8. Hendrickson, J.R. (1980). The ecological strategies of sea turtles. Amer. Zool. 20: 597-608.

9. Hildebrand H. (In press, 1982). A historical review of the status of sea turtle populations in the western Gulf of Mexico. In, Bjorndal, K. (Ed.) Biology and Conservation of Sea Turtles. Smithsonian Institute Press, Washington DC. (Papers presented at the World Conference on Sea Turtle Conservation, Nov. 26-30, 1979, Washington D.C.).

10. Hirth, H.F. (1980). Some aspects of the nesting behaviour and reproductive biology of sea turtles. Amer. Zool. 20: 507-523.

11. Honegger, R. (1979). Red Data Book, Vol. 3 Amphibia and Reptilia. IUCN. Gland, (third edition, revised).

12. Lazell, J.D. (1980). New England waters: critical habitat 
for marine turtles. Copeia 1980(2): 290-295

13. Marquez, M.,R. (1972). Resultados preliminares sobre edad y crecimiento de la tortuga lora Lepidochelys kempi (Garman). Mem. IV Congr. Nac. Oceanogr. (Mexico): 419-427.

14. Marquez, M.,R. (Inst. Nac.de Pesca, Mexico) (1978). Natural reserves for the conservation of marine turtles of Mexico. Fla. Mar. Res. Pub. 33:56-60.

15. Marquez. M.,R.(1981). In litt., 23 April.

16. Marquez, M.,R., Villanueva, O.A.and Sanchez Perez M. (In press, 1982). The population of Kemp's Ridley Sea Turtle in the Gulf of Mexico. In, Bjorndal, K. (Ed) Biology and Conservation of Sea Turtles. (Papers presented at the World Conference on Sea Turtle Conservation, Nov. 26-30, 1979, Washington D.C.).

17. Meylan, A. (in press, 1981). Estimation of population size in sea turtles. To appear in, Bjorndal, K. (Ed.) Biology and Conservation of Sea Turtles. Smithsonian Institute Press, Washington DC. (Papers presented at the World Conference on Sea Turtle Conservation, Nov. 26-30, 1979, Washington D.C.).

18. Meylan, A. (1981). In litt., 12 May.

19. Mortimer, J.A. (in press, 1982) . The feeding ecology of sea turtles. In, Bjorndal, K. (Ed.) Biology and Conservation of Sea Turtles. Smithsonian Institute Press, Washington DC. (Papers presented at the World Conference on Sea Turtle Conservation, Nov. 26-30, 1979, Washington D.C.).

20. Pritchard, P.C.H. (1981). In litt., 30 March.

21. Pritchard, P.C.H. (1979). Encyclopedia of Turtles. T.F.H. Publications, New Jersey and Hong Kong.

22. Pritchard, P.C.H. and Marquez, M.R. (1973). Kemp's Ridley Turtle or Atlantic Ridley, Lepidochelys kempi, IUCN Monograph No.2: Marine Turtle Series. IUCN, Morges.

23. Ross, J.P. (1981). In litt., I May.

24. Ross, J.P. and the SSC Marine Turtle Group (1979). Present status of sea turtles. A summary of recent information and conservation priorities. Unpublished report.

25. Sternberg, J. (1981). The worldwide distribution of sea turtle nesting beaches. Center for Environmental Education, Washington D.C. 20006 (1925 K St. NW, Suite 206).

26. Anon. (1981). Construction, installation and handling procedure for the National Fisheries Service's Sea Turtle Exclusion Device. NOAA (Nat. Oceanic and Atmospheric Admin.) Technical Memorandum N.M.F.S.-SEFC-7 I.

27. Frazier, J. (1982). In litt., 4 February.

28. Anon (1979). Sea Turtle Conservation Strategy. (Conservation/Management Strategy prepared at 1979 World Conference on Conservation of Sea Turtles, Washington, D.C.).

29. Marquez, R.M. (1982). Atlantic Ridley Project 1981. Marine Turtle Newsletter No. 21: 4.

30. Pritchard, P.C.H. (1981). Criteria for scientific evaluation of head-starting. Marine Turtle Newsletter, No. 19: 3-4.

31. See various comments in Marine Turtle Newsletter, No. 19.

32. Klima, E.F., and McVey, J.P. (in press, 1982). Potential and problems of headstarting Kemp's Ridley Turtle. In, Bjorndal, K. (Ed.). The Biology and Conservation of Sea 
Turtles. (Papers presented at World Conference on Sea Turtle Conservation, Nov. 26-30, 1979, Washington D.C.). 

SUMMARY A circumglobal species, present in tropical regions of the Atlantic, Indian and Pacific Oceans. Typically nests on mainland beaches; there is little nesting on islands of the Indian Ocean, southeast Asia or Oceania, and no nesting in the Caribbean. Overall, although the Olive Ridley remains relatively widespread and numerous, most nest sites support only small or moderate-scale nesting (up to around 1,000 females per year), and most populations worldwide are known or thought to be depleted, of ten severely so. Where population densities are high enough, females emerge to nest in synchronised aggregations (arribadas), sometimes comprising up to 150,000 turtles. Very large arribadas now occur in only two areas; at two beaches in Orissa State (India) and at two beaches in Pacific Costa Rica. Of the several former major arribada sites in Pacific Mexico only La Escobilla (Oaxaca) retains mass nesting, but even this population is reported to have declined severely due to over-exploitation. A small-sized sea turtle, mean carapace length to around $68 \mathrm{~cm}$. There is evidence that some groups make moderately extensive post-nesting migrations, in the east Pacific for example, from nest sites in Mexico and other parts of central America southward to feeding grounds off Ecuador. Forages in tropical neritic waters, feeding mainly on benthic crustaceans, sometimes at considerable depth. Sexual maturity possibly attained at 7-9 years. Mean clutch size from 105 to 116 . Females may nest twice in a season, sometimes three times. Most remigrating females return to nest at either one or two year intervals. Threatened by legal and illegal commercial harvest of adults (mainly for food or skin for the leather trade), incidental catch in shrimp trawls and massive harvest of eggs from nest beaches. Nominally protected by legislation in much of the range, including India and Mexico, often ineffectually. One of the major Costa Rica arribada sites, at Nancite, lies within Santa Rosa N.P.; the second, at Ostional, was declared a marine turtle sanctuary in 1982. One of the major Orissa sites, at Gahirmatha beach, is within Bhitar Kanika Sanctuary. These populations are effectively protected while nesting but still subject to exploitation when at sea. A major conservation action has recently been taken by Ecuador in halting their Olive Ridley fishery. Several hundreds of thousands of turtles have been taken at sea in this area in the past decade, from the same populations often subject to heavy exploitation on their Mexican and Central American nest beaches. It remains for legal commercial exploitation in Mexico to be substantially reduced. Efforts should be made to end the relatively recent utilization of turtle skin by the leather trade. Listed on Appendix I of CITES.

DISTRIBUTION A circumglobal species present in tropical regions of the Pacific, Atlantic and Indian Oceans $(41,53)$. In the Pacific, not known to nest on Hawaii nor on most islands of Oceania, but low density nesting occurs at many points on the Pacific coast of Central America, from Baja California in northern Mexico, south through Guatemala, El Salvador, Honduras and Nicaragua to Panama. Within this area important mass-nesting beaches exist in Oaxaca, Mexico (and formerly in other states (33)) and in Costa Rica (53).

The Olive Ridley does not nest in the Caribbean (although individuals very occasionally occur in the eastern-most fringes). The only known important 
nesting by Olive Ridleys in the Kest Atlantic occurs in Surinam, with small numbers in Guyana.

Nesting occurs along the coast of West and Central Africa at least from Senegal south to Angola, but no information appears available on actual sites and abundance. In the Indian Ocean the species nests in good numbers in northern Mozambique, with minor nesting in Tanzania. Very rarely nests in South Africa. Minor or moderate nesting occurs on Masirah Island (Oman), in the Lakshadweep Islands (=Laccadives), the Andaman Islands, in the vicinity of Karachi (Pakistan), and at several sites around the Indian subcontinent, notably in Orissa State in the nor theast (with two very important sites), also Sri Lanka. Little nesting is known in Southeast Asia generally, with the exception of Trennganu (eastern Kest Malaysia), other records include Burma, Sarawak and Sabah (East Malaysia), Papua New Guinea (mostly on New Britain) and northern Australia (53).

Further details on specific nesting beaches are provided in the following section.

POPULATION Although the Olive Ridley remains widespread and relatively numerous in tropical waters, most nesting sites support only small or moderatescale nesting (up to around 1,000 females per year), and most populations are known or thought to be depleted, often severely so, and some are virtually extinct. Females of Lepidochelys species tend to emerge to nest in large synchronised concentrations (arribadas) when population density is sufficiently high. Very large arribadas now occur in only two regions; at two beaches in Orissa State (northeast peninsular India), on the Bay of Bengal, and at two beaches in Costa Rica, on the east Pacific. Relatively large (but depleted) populations also persist in several parts of Pacific Mexico, but of the several former very large arribada sites in Mexico only La Escobilla (Oaxaca) still supports dense nesting and this is reported to have declined in recent years. Populations in Panama and Surinam have also declined. It has been suggested (23) that all populations away from the major centres (cited as India-Sri Lanka, East Pacific, equatorial South Atlantic) may not be self-sustaining in the long term.

Angola The species is known to nest, probably mainly on nor thern coasts, but no data available on numbers or sites (29).

Australia No major rookeries are known; low density nesting is recorded or suspected to occur widely in northern Australia, from Coburg Peninsula in Northern Territory east to Crab Island in Queensland (32). Feeding populations are found in the Gulf of Carpentaria and around the Arnhem Land coast. No major change in population levels has been noted (32).

Burma In the first decade of the present century about 1.5 million eggs of 'Loggerhead' were taken on the turtle grounds of the Irrawaddy region (34) (almost certainly not Caretta caretta, but Olive Ridley Lepidochelys olivacea (4); these species were formerly confused taxonomically). It was estimated that around 3,750 females nested annually (this estimate assumed that each female laid 400 eggs per year, this is somewhat higher than is recorded elsewhere, so the population figure may be an underestimate). Eggs were laid on islands off the mouths of the Irrawaddy and Dalla Rivers, and to a lesser extent on the mainland from the To River along the coast to the Sandoway district (34). It was suggested that the turtles coming to nest were from feeding grounds around the Andaman Islands (34). No data available on present population, if extant.

Costa Rica Solitary females may emerge to nest along most of the Pacific coast (11), but mass nesting emergences (arribadas) are concentrated at Ostional and Nancite beaches in Guanacaste Province (12). Between 200,000 and 300,000 females participate annually in arribadas at each locality (12). Mass emergences 
on some scale may occur at any time of year. At Nancite, while dry season arribadas involve from several hundred to 20,000 females, peak numbers are reached in the rainy season, with 50,000 to 150,000 females emerging to nest (11). Since some females nest two or three times over the year, total nestings are higher in number; estimated between 350,000-425,000 at Nancite and probably 200,000-250,000 at Ostional (11). The Nancite nesting female population is thought to lie between a minimum of 220,000 and a maximum of 550,000, depending on re-migration frequency $(74,75)$. Comparing the size of present arribadas with those of ten years ago, no appreciable change has been detected at Nancite, but a reduction of about $30 \%$ has occurred at Ostional (attributed to egg poaching) (74). These beaches, along with those in Orissa (eastern India) and to a lesser extent La Escobilla (Mexico), are at present by far the most important Olive Ridley nesting sites anywhere in the species' range. Egg predation by humans is intense at Ostional, adults suffer high mortality due to exploitation in feeding grounds in other areas of the east Pacific and due to incidental catch in shrimp trawls, so the future of these populations is not secure. Another major problem is the extremely low hatching success (12).

El Salvador Olive Ridleys are the most abundant sea turtles, dispersed nesting occurs on all sandy beaches from July to December, but no large-scale nesting is known and sea turtle nesting in general is reported to have declined sharply in recent years (12).

\section{French Guiana Nesting occurs only very rarely $(19,67)$.}

Guatemala No quantitative estimates are available; Olive Ridleys nest in relatively small numbers along the Pacific coast. All sea turtle populations are reported to have declined over the past two decades (12).

\section{Guyana Nests in moderate numbers on Shell Beach (40).}

Honduras The species is known to nest along the short Pacific coast of Honduras, but only in small numbers; no recent data available (12).

India The Olive Ridley appears to nest, generally in small numbers, at many sites on both west and east coasts of the peninsula; records exist for the Gulf of Kutch, around the Saurashtra peninsula (3), the Bombay area, near Goa, the Gulf of Mannar and the entire east coast (54), but large scale nesting is restricted to Orissa in the northeast $(4,17)$. There are about 100 nests per $\mathrm{km}$ each season along a $50 \mathrm{~km}$ stretch of beach south of Madras (Tamil Nadu) (4). The species occurs in moderate numbers in the Lakshadweep (Laccadive) Islands, and the Andaman and Nicobar Islands (17). The coastline of Orissa is one of two regions, the other being the Pacific coast of Central America including Mexico, that between them support by far the largest known Olive Ridley nesting concentrations. In the late 1970s over 100,000 females were nesting annually on the $35 \mathrm{~km}$ beach at Gahirmatha within the Bhitar Kanika Wildlife Sanctuary (Cuttack Dist., Orissa) $(6,7,30)$. Mass nesting has recently been discovered about $100 \mathrm{~km}$ south of the Gahirmatha beach, between Nadiakhia muhana and Akasia muhana; this nesting area extends for $3-4 \mathrm{~km}$ and is estimated to support nesting by 100,000 female Olive Ridleys (31). Combining these populations with those nesting elsewhere in the state leads to an estimate of 300,000 Olive Ridley nesting annually in Orissa (31). It is not clear whether these numbers are maintained each year, and whether such large numbers nest each year at both major nest grounds.

Indonesia Appears to occur quite widely in Indonesian waters, but not in any large concentrations, and sea turtle populations in general are reported to have declined markedly $(38,39)$. Nesting records are very sparse; the species is said to nest in 
the Lesser Sunda Islands (39), on West Sumatra and the Nusa Tenggara Islands (37), and on Sukamade Beach within Meru Betiri Reserve (East Java). At Sukamade Beach 625 sea turtle nests were recorded in 1980 , only a small minority of which were Olive Ridley nests (5).

Madagascar No large-scale nesting known; nesting has been recorded in the northwest (28), although other reports indicate presence of a feeding population only (17).

Malaysia Kest Malaysia Reported in 1975 (38) to occur commonly, nests all along the east coast, mainly in Trengganu, also in Pahang and Kelantan States, but not common in any one area. Rare on the west coast, nesting was more frequent and widespread in the past (50). Egg collectors on the east coast have reported a decline in Ridley numbers (50). Sabah No nesting by the Olive Ridley is known (14). Sarawak Said to nest in small numbers (38), on the three 'turtle islands' of Satang Besar, Talang Talang Besar and Talang Talang Kechil (14).

Mexico A conservative estimate suggests that 3,185,000 Olive Ridleys, of both sexes, occurred in the seas of western Mexico in the mid-1960s, and probably around 10,000,000 before the 1950s (9). The major arribadas (see Habitat and Ecology) were centred on three nesting beaches; El Playon de Mismaloya, Piedra del Tlacoyunque and La Escobilla $(9,15,53)$. Estimated numbers of females nesting in the early 1970s (33) are: 50,000-100,000 at La Escobilla (Oaxaca); 20,000-50,000 at each of three sites, Chacahua-Playa Larga (Oaxaca), Piedra de Tlacoyunque (Guerrero), and Mismaloya (Jalisco); 10,000-20,000 at El Quelite-EI Marmol (Sinaloa) and at Cuajinicuilapa (Guerrero); 5,000-10,000 at each of nine sites between Chametla-Teacapan (Sinaloa) and Playa Potosi (Guerrero); and four sites with 1,000-5,000. However, it appears that arribadas at Tlacoyunque and Mismaloya had actually already collapsed by $1970(67)$, so the estimates given above for these sites presumably refer to pre-1970 populations. Massive over-exploitation has severely depleted Olive Ridley populations in Pacific Mexico; the total 1976 population (males and females) was estimated at 485,000 (9). It is considered (45) that the 1979 nesting population may have decreased to as little as $10 \%$ of that in 1974. Only the Oaxaca beaches, notably La Escobilla, still support large-scale arribada nesting; the immense breeding populations at Mismaloya, Tlacoyunque and elsewhere have crashed (9). The Oaxaca population is reported to be severely depleted and showing signs of collapse (9). Other authorities $(64,68)$ state that arribadas of around 75,000 females still occur at La Escobilla, and question the magnitude of decline at this site. There have been three arribadas at La Escobilla in most years since 1970, with an increase to four and five in 1980 and 1981 respectively (source in 69). However, this certainly does not imply an increase in the number of females taking part in arribadas, and there is tremendous concern that this last economically-viable Olive Ridley population in Mexico will be subject to continuing over-exploitation (69).

Mozambique The species appears to nest sporadically along northern coasts, perhaps 500-1,000 nests are laid per year (17).

Nicaragua The Olive Ridley is the most common of the five sea turtle species nesting on the Pacific coast. Several nesting beaches are known, the most important being in the Departments of Managua and Carrazo; in the former, the $20 \mathrm{~km}$ beach between Masachapa and Pochomil is known as a mass-nesting site for Olive Ridleys. The beach at Playa Chococente (Carrazo) may have up to 550 turtles per night (70). Local inhabitants report that the size and frequency of arribadas have decreased considerably (12).

Oman Olive Ridleys nest regularly around the south of Masirah Island, but only in very low numbers, estimated 150 females per year (44). 
Pakistan Nests at Hawkes Bay and Sandspit near Karachi in Sind, not in large numbers, and possibly in Baluchistan $(17,20)$.

Panama The Olive Ridley is the second most abundant sea turtle species on the Pacific coast. There are no precise population estimates available, but sea turtle populations in general are reported to have declined sharply in the last decade. At least 30 beaches were formerly known to support large nesting aggregations, but today 12 beaches are officially recognised as important nest sites; nesting, populations are smaller and the season is shorter (12).

Papua New Guinea The species is relatively uncommon in PNG waters (51), recent nesting records are restricted to Turubu Village in East Sepik Province and two areas on New Britain (52).

Senegal Reported to nest in small numbers (45), no details available.

Sri Lanka The most abundant sea turtle in Sri Lanka waters, several thousand may nest annually, with nesting spread through most of the year and occurring at sites all round the island (17). However, continual population decline is reported (25).

Surinam Olive Ridleys nest mainly on Eilanti beach west of the Marowijne estuary (47). This area is now virtually the only nesting site of any importance on the Atlantic coast of America, but there has been a marked steady decline in the number of nests laid, from 2,455 in 1967 to 531 in 1975 (47). Numbers nesting at Bigisanti beach, further west from Eilanti, rose slightly from 95 in 1964 to 236 in 1975. The estimated total number of nests in Surinam fell from 2,875 in 1967 to 1,070 in 1975; since no increase was noted elsewhere in the Guianas it was suggested that the Olive Ridley population is declining (47). Further decline was noted in subsequent seasons, with only 870 and 795 nests recorded in 1978 and 1979 respectively (48). The decline in numbers of nesting females, from an estimated 2,100-3,000 in 1967-1968, to 550-800 in 1978-1979, is attributed to incidental catch by offshore shrimp trawlers (48). Decline may also be attributed in part to marine erosion of the Eilanti beach in the 1970s; the beach is starting to re-form in the 1980s (62).

Tanzania Rarely reported, nests in small numbers (17).

Thailand The Olive Ridley is the most common sea turtle in Thai waters. The species occurs all along the west coast and may be considered still a common breeder at a few localities e.g. Laem Phan $\mathrm{Ka}$ reserve at Phuket Marine Biological Centre (2). Breeding also occurs in Tarutao National Park, but at low density (21). Sea turtle populations in general are reported to have declined markedly in Thailand (38).

HABITAT AND ECOLOGY A small-sized sea turtle; a sample of 53 females nesting at Playa Naranjo (Costa Rica) ranged from $57-72.5 \mathrm{~cm}$ in carapace length, mean length $65.2 \mathrm{~cm}$, mean width $56.5 \mathrm{~cm}(10)$. The mean length in a sample of 500 females at Eilanti (Surinam) was $68.5 \mathrm{~cm}$, range $63-75 \mathrm{~cm}(47)$.

Very little information is available on the biology of the Olive Ridley away from the nesting beach. Tagging has provided some data on post-nesting movements (33), but, with the exception of the Guianan population, little overall pattern is evident (35). Females tagged in the Guianas have been recovered southward to northern Brazil and, more frequently, northward to Venezuela, Trinidad and Barbados; several have been recaptured offshore from Surinam and French Guiana outside the nesting season, indicating that at least some individuals do not move 
far from their nest site (35). In the east Pacific, at least some of the turtles nesting in the Mexican states of Guerrero and Jalisco appear to disperse northward to feeding areas in the Gulf of California and along the west coast of Baja California; at least some of those nesting in Oaxaca disperse southward to El Salvador, Colombia and Ecuador. Most recoveries of turtles tagged in Mexico have been in Mexican waters (35). At least 53 females tagged in Costa Rica have been recovered at sea; one each from Mexico, Nicaragua, Panama, Colombia, two from El Salvador, four from Guatemala, 12 from Ecuador, and 29 were recaptured in Costa Rican waters (11).

The species appears to forage mainly in tropical neritic waters (further offshore than the Loggerhead Caretta caretta), where individuals may dive deeply to feed on benthic crustaceans, or float over deeper waters feeding on crustaceans such as Red Lobsterette Pleuroncodes sp. that rise to the surface at night (33), and on larger planktonic organisms that may be encountered (24). The main food items recorded are crabs and shrimps, but sessile and pelagic tunicates, jellyfish and other small invertebrates also appear in the diet (36), also fish eggs (66). Olive Ridleys have been captured in prawn trawls at depths of $80-110 \mathrm{~m}$, so they are certainly capable of foraging at relatively great depth.

Sexual maturity is thought by some to be attained at around 7-9 years (33), although others feel that the data on which this estimate is based are inadequate (60). Females of both species of Lepidochelys (L. Kempii, L. olivacea) tend to emerge to nest in synchronized aggregations, often termed arribadas (Spanish, 'arrival'), wherever population density is sufficiently high. The arribada nesting strategy, with the sudden mass arrival of adults and subsequent mass emergence of hatchlings, may serve as a 'predator swamping' device $(55,71)$. The arribada may be coordinated by pheromonal communication - the two Lepidochelys species are the only sea turtles with a complete and well-developed series of inframaginal secretory pores, and are the only species known to form arribadas (41) (however, most other sea turtle species posses fairly well-developed secretory pores at other sites (77)). At Gahirmatha beach (Orissa, India) small numbers of females may emerge almost throughout the year but the large arribada, involving over 100,000 females, occurs in February-March (30). Similarly at Playa Nancite (Costa Rica) relatively small numbers may emerge throughout the year; a typical dry season arribada would involve up to 3,000 females (in March for example), but major arribadas occur in the wet season (September-October), and involve up to 150,000 females (11). In Costa Rica solitary nesting takes place at the same time of year as the large arribadas, and a few tagged individuals have been shown to take part in both solitary (Playa Naranjo) and group (Nancite) nesting during the same breeding season (10). The record of one female tagged while nesting in Nicaragua and recaptured 30 days later while nesting in Costa Rica demonstrates that it is at least possible for females to nest on different beaches within a season (12). In Costa Rica, Olive Ridleys remain in the nearshore zone throughout the peak nesting period (11). Nesting emergence is mainly at night, sometimes by day (as is typical for Kemp's Ridley) (11). Six of the nine arribadas recorded in January-November at Nancite (Costa Rica) began on, or within one or two days of, the night of the last quarter moon, when a high tide peaked between nightfall and midnight (11). Strong and gusty winds are typical during arribadas (11), but the direction seems unimportant. Similarly at Eilanti (Surinam), nesting females mainly emerge when high water comes between about 19.00-23.00 hr., with a strong wind and rough sea (47). In Surinam, while there is an approximate two week interval between mass landings at Eilanti, no such periodicity is recorded for the small-scale nestings at Bigisanti (47). In Costa Rica there is normally a three week interval between arribadas in the peak season, but periodicity is not consistent and intervals have ranged from 14-48 days (12). The percentage of non-nesting emergences varies greatly; occasionally at Playa Nancite up to half of the females emerging do not appear to nest (11), thus the number of emergences 
does not necessarily equal the number of nests. Females at Playa Naranjo generally nest on a nearly level stretch of sand beach without vegetation, free of debris, not far from the high tide limit (10); similar preferences appear to be shown in most other parts of the range. The Olive Ridley completes its nesting relatively rapidly, usually in around 60 minutes, otherwise the process conforms broadly with that seen in other sea turtles (8). Egg-laying itself takes around 15 minutes (11). The nest cavity is relatively shallow (47). Both Lepidochelys species are distinctive in that the nest area, re-filled after laying, is compacted by audibly thumping the area with each side of the shell in turn (47). Mean clutch size varies from 105 (range 74-126) at Playa Naranjo (Costa Rica), to 114.7 $(94-140)$ in southeast India, and $116(37-166)$ at Eilanti (Surinam) (sources in ref. 55). Eggs are round, mean diameter is from $37.5 \mathrm{~mm}$ (Honduras) to $40.5 \mathrm{~mm}$ (Sri Lanka) (sources in ref. 55).

At Nancite, females usually nest twice, sometimes three times, during a season, at intervals determined by the timing of arribadas (12). In 1972 at least three large groups were active at successive overlapping two-month intervals; there is some evidence that these groups are maintained from year to year (12). In Surinam (Eilanti beach) the mean interval between nesting seasons is 1.4 years, nearly two-thirds of females tagged in one season return in the following season (47); in Mexico (La Escobilla) the predominant remigration interval is 2 years (55), or mean interval 1.3 years (64); in India (Gahirmatha) around $24 \%$ of females nesting in 1977-1978 nested again in the 1978-1979 season (7). The estimated annual hatchling output per female nesting at Eilanti is 96 , and 70 at La Escobilla (55).

Survival of eggs deposited at Nancite is extremely poor $(11,12)$. Because the eggs from one arribada do not hatch before the next (incubation $c 55$ days, arribada interval c 28 days), a large proportion are destroyed as the later females excavate their nests. Similarly, within one arribada $15-30 \%$ of earlier eggs may be destroyed by later nesters (12). Furthermore, the hatch rate of undisturbed eggs is extremely low. Hatching success in 1972 was estimated at much less than $1 \%$ (27), this has not changed over following years (11). The causes of this very low success rate are not clear, but may be found in a complex interaction of organisms having the turtle egg as a nutrient source, including Ghost Crabs, dipteran flies, and notably fungi and bacteria (11). However, hatching success may be around $23 \%$ at La Escobilla beach in Mexico, and $59 \%$ at Eilanti, Surinam (sources in 55). Egg and hatchling predators include a very wide variety of birds and mammals, including hawks, vultures, caracaras, opposums, raccoons, coyotes (11). Human predation on eggs is locally extreme throughout Central America $(11,22)$. Many nesting females show evidence of shark attack, often very recent, and large cats (puma or jaguar) may occasionally take nesting females (II).

THREATS TO SURVIVAL Three major threats to Olive Ridley populations have been identified: commercial harvest of adults, incidental catch in shrimp trawls, and harvest of eggs from nest beaches (sources cited below). These factors are of differing significance in different areas, although some populations (e.g. in Mexico) are affected by all three.

The Olive Ridley is the most economically important sea turtle in Mexico, and is the primary target for both legal and illegal fisheries due to the large aggregations found in the breeding season (9). It is estimated (9) that at least 2,000,000 Olive Ridleys were landed in Mexico in the five years up to 1969. During this period it was common practice to utilise only the skin of the neck, shoulder and limbs for the hide trade (9) - European and Japanese leather manufacturers having 'discovered' turtle leather in the mid 1960s - and the remainder of the animal was discarded. As part of an attempt to put exploitation on a more rational basis, the process was industrialised, and only processinc plants 
able to utilise the whole animal could be legalized (9). Although certain conservation measures are taken (catch quota, incubation of oviducal eggs, protection of nesting beaches), immense numbers of Olive Ridleys have still been taken in the recent past at sea near La Escobilla (Oaxaca), the last major arribada beach (9). By far the largest company (PIOSA) took 70,000 turtles from La Escobilla in 1977, in a season when the largest arribada comprised only 58,000 females (or 99,000 (64)), and took 58,000 in 1978; thus the greater part of the arribada was taken each year (9). In 1979 when the catch quota was halved, it was estimated that 36,000 females (or 46,000 (64)) took part in the largest arribada and PIOSA took 24,500 (9). Although protection of the Oaxaca nest sites by PIOSA (now taken over by the government-owned PROPEMEX) has almost certainly postponed the total collapse of this population, this is the likely outcome if current massive exploitation continues (9). In addition to legal industrialized fisheries, millions of eggs and many thousands of turtles are taken illegally by poachers each year (9).

There has also been, until very recently, an important Olive Ridley fishery in Ecuador. The species does not nest in Ecuador but migrates into Ecuadorian waters, and at least some of these individuals are known to have nested in Central America, including Mexico (where the same populations are exploited during the nesting season) and Costa Rica $(9,12)$. This species is the commonest sea turtle in Ecuador, it tends to remain further offshore than the other species; an island $30 \mathrm{~km}$ from shore and an area of sea $32-48 \mathrm{~km}$ from Esmeralda are the two main sites (22). Some turtles are taken as a local subsistence activity, but the vast majority were taken by one of three major companies (six before 1978) for export, mainly in the form of frozen meat for human use and salted skin for the leather trade (22). There has been a marked increase in export volume since 1970 and, although skin export only started in 1973, demand from the leather trade is such that this became the most important product (22). Approximately $107,714 \mathrm{~kg}$ were exported in the first six months of 1978, this was nearly as high as the entire 1977 output, itself double that of 1976. An estimated 100,000 Olive Ridleys were taken in Ecuador for the luxury goods trade in 1978, most of the 1977 products were exported to Japan and Italy (22). An estimated 150,000 turtles were taken in 1979 (18). Following ministerial discussions, and resolutions made at the 1981 New Delhi CITES Convention, the Ministerio de Recursos Naturales (MRN). prohibited all commercial exploitation of sea turtles in July $1981(18,26)$.

Many of the several thousand turtles killed recently in Baluchistan (Pakistan) for export of flipper skin are suspected to be Olive Ridleys (16). Harvest of Olive Ridleys on the nesting beach, or in offshore water, mainly for human consumption, is a major threat in other areas. In Sri Lanka, practically all turtles caught are eaten (25), in India the Gahirmatha rookery is well protected but exploitation is high elsewhere $(4,30)$. Egg harvest was formerly heavy at Gahirmatha but this was made illegal in the mid 1970s. Many thousands of females are killed in India (43) and poaching is heavy offshore (30) where effective control is impractical. The turtles may be utilized locally (as the eggs usually are), or transported in large numbers by train to urban centres such as Calcutta (4). It is reported that more than 100,000 eggs were harvested in January 1982 at Gahirmatha, for sale in Calcutta, while 500 adults were taken offshore from Digha beach (West Bengal); it is asserted that the catch of adults in Bengal and Orissa is increasing each season (63). Human predation on eggs is extreme at many nesting sites in Central America (11), including Mexico (9). For example, hundreds of thousands of eggs are removed from Ostional (Costa Rica) beach during most arribadas even though guards are usually present (the eggs are sometimes fed to domestic pigs and dogs) (11).

A third major threat in most parts of the range is heavy incidental catch by shrimp trawlers. In Central America the shrimping industry is relatively new, 
having started in 1941 in northern Mexico and spread into the tropical east Pacific in the 1950s (12). The fishery operates throughout the year. Many tag returns have come from turtles caught in trawls, and both juvenile and females are reported. Although there is reason to believe that commercial shrimping is a serious threat to sea turtles in the east Pacific (12), there is little quantitative information available. Turtles caught by trawlers that are not killed for their eggs may often be released (12). The severe decline in Olive Ridley numbers in Surinam, formerly including the major arribada site in the Atlantic, is attributed to high incidental catch in shrimp trawlers operating off the coasts of Surinam, French Guiana and Venezuela (48). This mortality is also significant off West Bengal, Orissa and Andhra Pradesh in India (30) and off southeast Africa (28) and Mexico. Development or other habitat modification in the vicinity of nest beaches is a further threat; on the Hawkes Bay and Sandspit beaches in Pakistan, for example, increased building of holiday accommodation is encroaching into the nesting area (46); in Sarawak access to nesting beaches is often blocked by drift wood washed in from upriver or from log-rafts being towed out to ships (42).

CONSERVATION MEASURES TAKEN Nominally protected by legislation in much of the range, often ineffectually. Since 1969 only those operations equipped to utilize the entire animal are legally allowed to exploit sea turtles in Mexico. PIOSA was the major company, but was sold to the state organization PROPEMEX in 1980. The industrialized fisheries protection programme includes nominal protection (not very effective (59)) of the Oaxaca nest beaches and the incubation of oviducal eggs. There are several problems associated with the latter, including low hatch rates (9). Poaching is everywhere a major problem, including in Oaxaca (9). In 1979 the government quota for capture of Olive Ridleys was halved. However, the number of Ridleys legally slaughtered is still extremely high, on many days 500 Ridleys were killed in the process of filling the October 1980 quota of 12,000 turtles (73). Elsewhere in Central America the Olive Ridley receives some legal protection in Guatemala, Honduras, Nicaragua, Costa Rica and Panama; however, in many areas the laws are inadequately enforced (12). In Costa Rica, large scale poaching of eggs has occurred at Ostional despite the presence of guards, but the major arribada beach at Nancite and the important Playa Naranjo site are well protected within the Santa Rosa National Park (11). The beach at Ostional has just (7 January 1982) been decreed an area protected for reproduction of marine turtles (61).

A major conservation action was taken by Ecuador in June/July 1981; the export of turtle skins and the commercial exploitation of sea turtles was prohibited by the Ministerio de Recursos Naturales $(18,26)$. It appears that a significant proportion of the turtle products exported from Ecuador in 1981 originated from a fishery operating in southern Colombia (26), it is not clear what effect the Ecuador ban will have on exploitation in Colombia. In 1979 the Manchalilla National Park was set up in Fcuador (22). This 35,000 ha park in the province of Manabi includes $43 \mathrm{~km}$ of coast and the Isla de la Plata, an important feeding area for migratory Olive Ridleys (22). Ports, such as Puerto Lopez, within the park and formerly important centres in the turtle trade can no longer be used to tranship turtles (22).

In Panama Olive Ridleys nest within the Biological Reserve of Isla de Canas (12). In Surinam females and their eggs are completely protected on the nest beaches, much of the nesting takes place within the Galibi Sanctuary (47); a hatchery programme handles a few Olive Ridley clutches (62). In Angola all sea turtles are legally protected but this is not enforced (28), a similar situation exists in Mozambique (28). At Hawkes Bay and Sandspit beaches, (Pakistan) a conservation programme has been established which includes patrolling of the beach, a hatchery, and a local education programme (1). In India all sea turtles are on schedule $I$ of the Indian Wildlife (Protection) Act and both turtles and eggs are 
locally protected. The major Olive Ridley rookery at Gahirmatha lies within the Bhitar Kanika Sanctuary (also holding an important population of the Estuarine Crocodile Crocodylus porosus). The sanctuary also includes 12 offshore islands where there are known to be more turtle nesting sites (4). In 1975 the Tamil Nadu Government outlawed the use of trawl nets by mechanised fishing boats and restricted fishing activity from these boats to between $6 \mathrm{am}$ and $6 \mathrm{pm}$. There is a hatchery handling some Olive Ridley eggs at Madras Snake Park (4). Olive Ridleys, their nests and eggs are legally protected in Sri Lanka (4). The species receives some legal protection in Malaysia; a hatchery has been established since 1978 at Penarik where it is intended to incubate 10,000 eggs annually from 1981 onward (49).

The Olive Ridley is listed on Appendix I of The Convention on International Trade in Endangered Species of Kild Fauna and Flora (CITES). Appendix I listing requires that trade in a taxon and its products is subject to strict regulation by ratifying states and international trade for primarily commercial purposes is prohibited. Japan has entered a reservation on Appendix I listing of this species.

CONSERVATION MEASURES PROPOSED Where possible, existing laws should be enforced and National Parks and Reserves adequately protected. (56). Where remaining, the leather trade should be brought to an end as soon as possible. This relatively new (post mid-1960s) trade supplies luxury markets only and has no cultural significance $(45,57)$. Restricted fishing zones should be established in areas of high turtle concentration, particularly off major nesting beaches $(45,57)$ and high priority given to the development of fishing equipment which prevents incidental take of sea turtles (57). Regional agreements on conservation are highly desirable, and ought to include large scale tagging programmes, using tags which offer no reward for their return (57). There is a particularly urgent need for a regional conservation/management programme in the East Pacific (76). Ecuador's recent unilateral prohibition on commercial Olive Ridley exploitation should be matched, where necessary, by similar efforts in other Pacific states. It has been suggested that major breeding beaches in Mexico should be declared National reserves $(9,65)$. Japan should be encouraged to withdraw their reservation on Appendix I CITES listing, and to cease providing a major market for newly imported Olive Ridley products (57).

CAPTIVE BREEDING No information on breeding. Three young Ridleys hatched from eggs taken from a natural nest have been maintained in captivity at Madras Snake Park Trust for at least two years (58).

REMARKS The Compiler is extremely grateful to K. Bjorndal, A. Carr, S.E. Cornelius, G. R. Hughes, R. Marquez, M., N. Mrosovksy and P.C.H. Pritchard for their kindness in reviewing a preliminary draft of this account.

REFERENCES 1. Anon. (1981). Pakistan's turtles nest on holiday beaches. K WF Monthly Reports, March 1981. W WF Project 1451.

2. Bain, J.R., and Humphrey, S.R. (1980). A profile of the endangered species of Thailand. Report No. 4, Office of Ecological Services, Florida State Museum, U.S.A.

3. Bhaskar, S. (1978). Notes from the Gulf of Kutch. Hamadryad 3(3): 5-7.

4. Bhaskar, S. (1979). The status of the Sea Turtles in the East Indian Ocean. (Unpublished paper read at Korld Conf. on Sea Turtle Conservation, revised version in press in Bjorndal, $\mathrm{K}$. (Ed.). The Biology and Conservation of Sea Turtles. Smithsonian Institute Press, Washington D.C. (Papers presented at The Horld Conference on Sea Turtle Conservation, Nov. 26-30, 1979, Kashington D.C.). 
5. Blouch, R.A. (1981). W WF Meru Betiri Project 1024. 1980 Annual Report.

6. Bustard, H.R. (1976). Korld's largest sea turtle rookery? Tigerpaper 3: 25.

7. Bustard, H.R. and Kar, C.S. (1981). Annual nesting of the Pacific Ridley Sea Turtle (Lepidochelys olivacea) in Orissa, India. Brit. J. Herpetol. 6:

8. Carr, A. (in press, 1982). Notes on the behavioral ecology of sea turtles. In, Bjorndal, K. (Ed.). The Biology and Conservation of Sea Turtles. Smithsonian Institute Press, Washington D.C. (Papers presented at The Korld Conference on Sea Turtle Conservation, Nov. 26-30, 1979, Washington D.C.).

9. Cliffton, K., Cornejo, D.O., and Felger, R.S. (in press, 1982). Sea turtles on the Pacific Coast of Mexico. In, Bjorndal, K. (Ed.). The Biology and Conservation of Sea Turtles. Smithsonian Institute Press, Washington D.C. (Papers presented at the Horld Conference on Sea Turtle Conservation, Nov. 26-30, 1979, Kashington D.C.).

10. Cornelius, S.E. (1976). Marine turtle nesting activity at Playa Naranjo, Costa Rica. Brenesia 8: 1-27.

11. Cornelius, S.E. (1981). In litt., 31 December.

12. Cornelius, S.E. (in press, 1982). The status of Sea Turtles on the Pacific Coast of Central America. In, Bjorndal, K. (Ed.). The Biology and Conservation of Sea Turtles. Smithsonian Institute Press, Kashington D.C. (Papers presented at The Korld Conference on Sea Turtle Conservation, Nov. 26-30, 1979, Washington D.C.).

13. De Celis, N.C. (in press, 1982). Status of marine turtles in the Philippines. In, Bjorndal, K. (Ed.). The Biology and Conservation of Sea Turtles. Smithsonian Institute Press, Washington D.C. (Papers presented at the Korld Conference on Sea Turtle Conservation, Nov. 26-30, 1979, Washington D.C.)

14. De Silva, G.S. (in press, 1982). The status of sea turtle populations in East Malaysia and the South China Sea. In, Bjorndal, $K$ (Ed.). The Biology and Conservation of Sea Turtles. Smithsonian Institute Press, Washington D.C. (Papers presented at the Korld Conference on Sea Turtle Conservaton, Nov. 26-30, 1979, Washington D.C.)

15. Frazier, J. (1979). Marine turtles in Peru and the East Pacific. Manuscript (not seen, cited in ref. 53).

16. Frazier, J. (1980). Exploitation of marine turtles in the Indian Ocean. J. Human Ecol. 8(4): 329-370.

17. Frazier, J. (in press, 1982). The status of Marine Turtles in the Kestern Indian Ocean. In, Bjorndal, K. (Ed.). The Biology and Conservation of Sea Turtles. Smithsonian Institute Press, Washington D.C. (Papers presented at The Korld Conference on Sea Turtle Conservation, Nov. 26-30, 1979, Washington D.C.).

18. Frazier, J., and Salas, S. (1982). Ecuador closes commercial turtle fishery. Marine Turtle Newsletter. No. 20:5-6.

19. Fretey, J. (1981). In litt., 26 May.

20. Ghalib, S.A., and Zaidi, S.S.H. (1976). Observations on the survey and breeding of marine turtles of Karachi coast. Agriculture Pakistan 27(1): 87-96.

21. Ginsberg, J. (1981). The status of sea turtles in Tarutao National Park, Satun, Thailand. Tigerpaper 8(2): 27-29. 
22. Green, D., and Ortiz, F. (in press, 1982). The status of Sea Turtle populations in the central eastern Pacific. In, Bjorndal, K. (Ed.). The Biology and Conservation of Sea Turtles. Smithsonian Institute Press, Kashington D.C. (Papers presented at The Korld Conference on Sea Turtle Conservation, Nov. 26-30, 1979, Washington D.C.).

23. Hendrickson, J.R. (1979). Chemical discrimination of tortoiseshell materials and reptilian leathers. Final report on Contract No. 14-16-0002-3701, U.S. Fish and Wildlife Service.

24. Hendrickson, J.R. (1980). The ecological strategies of sea turtles. Amer. Zool. 20: 597-608.

25. Hoffman, T.K. (1981). In litt., 5 March.

26. Hurtado, G.,M. (1982). The ban on the exportation of turtle skin from Ecuador. Marine Turtle Newsletter. No. 20: 1-4.

27. Hughes, D.A., and Richard, J.D. (1974). The nesting of the Pacific Ridley turtle Lepidochelys olivacea on Playa Nancite, Costa Rica. Mar. Biol. (Ber1.), 24(2): 97-107. (not seen, cited in ref. 11 ).

28. Hughes, G.R. (1976). Sea Turtles in South East Africa. In, Proc. Symp. Endangered Wildlife in Southern Africa. Univ. Pretoria. pp. 81-87.

29. Hughes, G.R. (in press, 1982). The conservation situation of Sea Turtle populations in the southern African region. In, Bjorndal, K. (Ed.). The Biology and Conservation of Sea Turtles. Sinithsonian Institute Press, Kashington D.C. (Papers presented at The Korld Conference on Sea Turtle Conservation, Nov. $26-30,1979$, $\mathrm{K}$ ashington D.C.).

30. Kar, C.S. (1980). The Gahirmatha turtle rookery along the coast of Orissa, India. Marine Turtle Newsletter No. 15: 2-3.

31. Kar, C.S. (1981). Discovery of second mass nesting ground for the Pacific Ridley Sea Turtle (Lepidochelys olivacea) in Orissa, India. Unpub. report.

32. Limpus, C.J. (in press, 1982). The status of Australian Sea Turtle populations. In, Bjorndal, K. (Ed.). The Biology and Conservation of Sea Turtles. Smithsonian Institute Press, Washington D.C. (Papers presented at The Korld Conference on Sea Turtle Conservation, Nov. 26-30, 1979, Washington D.C.).

33. Marquez, M.,R., Villanueva, O.,A., Penaflores S.,C. (1976). Sinopsis de datos biologicos sobre la tortuga golfina. INP Sinopsis sobre la pesca No. 2, Instituto Nacional de Pesca, Mexico. INP/S2. SAST - Tortuga Golfina - 5,31 (07), 016,01.

34. Maxwell, F.D. (1911). Reports on inland and sea fisheries in the Thongwa, Myaungmya, and Bassein districts and the turtle banks of the Irrawaddy division. Rangoon, Government Printing Office. $57 \mathrm{pp}$.

35. Meylan, A. (in press, 1982). Sea Turtle migration - evidence from tag returns. In, Bjorndal, K. (Ed.). The Biology and Conservation of Sea Turtles. Smithsonian Institute Press, Washington D.C. (Papers presented at The World Conference on Sea Turtle Conservation, Nov. 26-30, 1979, 1Kashington D.C.).

36. Mortimer, J.A. (in press, 1982). The feeding ecology of the sea turtles. In, Bjorndal, K. (Ed.) The Biology and Conservation of Sea Turtles. Smithsonian Institute Press, Washington D.C. (Papers presented at the World Conference on Sea Turtle Conservation, Nov. 26-30, 1979, Kashington D.C.) 
37. Nuitja, N.S. (1981). A distribution of sea turtles in Indonesia. (Report, unpublished?).

38. Polunin, N.V.C. (1975). Sea turtles: reports on Thailand, X. Malaysia and Indonesia, with a synopsis of data on the conservation status of sea turtles in the Indo- Kest Pacific Region. Unpublished report.

39. Polunin, N.V.C., and Sumertha Nuitja, N. (in press, 1982). Sea Turtle populations of Indonesia and Thailand. In, Bjorndal, K. (Ed.). The Biology and Conservation of Sea Turtles. Smithsonian Institute Fress, Kashington D.C. (Papers presented at The $\mathbb{K}$ orld Conference on Sea Turtle Conservation, Nov. 26-30, 1979, Washington D.C.).

40. Pritchard, P.C.H. (1969). Sea turtles of the Guianas. Bull. Fla. State. Mus. (Biol. Sci.), 13(2): 85-140.

41. Pritchard, P.C.H. (1979). Encyclopedia of Turtles. T.F.H. Publications, Hong Kong and New Jersey.

42. Proud, K. (1981). In litt., 12 May.

43. Ross, J.P. (in press, 1982). Historical decline of Loggerhead, Ridley and Leatherback Sea Turtles. In, Bjorndal, K. (Ed.). The Biology and Conservation of Sea Turtles. Smithsonian Institute Press, Washington D.C. (Papers presented at The Korld Conference on Sea Turtle Conservation, Nov. 26-30, 1979, Kashington D.C.).

44. Ross, J.P., and Barwani, M.A. (in press, 1982). Review of sea turtles in the Arabian area. In, Bjorndal, K. (Ed.) The Biology and Conservation of Sea Turtles. Smithsonian Institute Press, Kashington D.C. (Papers presented at the Horld Conference on Sea Turtle Conservation, Nov: 26-30, 1979, Washington D.C.)

45. Ross, J.P. and IUCN/SSC Marine Turtles Group (unpublished report, 1979). Present status of Sea Turtles - a summary of recent information and conservation priorities.

46. Salm, R.V. (1976)? Coastal resources in Sri Lanka, India and Pakistan. Description, use and management. U.S. Fish and Xildlife Service. 260 pp.

47. Schulz, J.P. (1975). Sea Turtles nesting in Surinam. Zoologische Verhandelingen (Leiden) 143.

48. Schulz, J.P. (in press, 1982). Status of Sea Turtle populations nesting in Suriname. In, Bjorndal, K. (Ed.). The Biology and Conservation of Sea Turtles. Smithsonian Institute Press, Washington D.C. (Papers presented at The Korld Conference on Sea Turtle Conservation, Nov. 26-30, 1979, Nashington D.C.).

49. Siow, K.T. (1981). In litt., 19 April.

50. Siow, K.T. and Moll, E.O. (in press, 1982). Status and conservation of estuarine and sea turtles in Kest Malaysian waters. In, Bjorndal, K. (Ed.). The Biology and Conservation of Sea Turtles. Smithsonian Institute Press, Washington D.C. (Papers presented at The Korld Conference on Sea Turtle Conservation, Nov. 26-30, 1979, Kashington D.C.).

51. Spring, S. (1980). Turtles, Men and Magic. Division of Wildlife, Port Moresby, Papua New Guinea.

52. Spring, S. (in press, 1982). Status of Marine Turtle populations in Papua New Guinea. In, Bjorndal, K. (Ed.). The Biology and Conservation of Sea Turtles. Smithsonian Institute Press, Kashington D.C. (Papers presented at The World Conference on Sea Turtle Conservation, Nov. 26-30, 1979, Kashington D.C.). 
53. Sternberg, J. (1981). The worldwide distribution of Sea Turtle nesting beaches. Center for Environmental Education, Washington D.C.

54. Whitaker, R. (1977). A note on sea turtles of Madras. Indian Forester. 103(11): 733-734.

55. Hirth, H.F. (1980). Some aspects of the nesting behaviour and reproductive biology of sea turtles. Amer. Zool. 20: 507-523.

56. Navid, D. (in press, 1982). Conservation and management of sea turtles. A legal overview. In, Bjorndal, K. (Ed.). The Biology and Conservation of Sea Turtles. Smithsonian Institute Press, Kashington D.C. (Papers presented at the World Conference on Sea Turtle Conservation, Nov. 26-30, 1979, Kashington D.C.).

57. Anon. (in press, 1982). Sea Turtle Conservation Strategy. (Conservation and management strategy prepared at 1979 Korld Conference on Conservation of Sea Turtles, Nov. 26-30, Washington D.C.). In Bjorndal, K. (Ed.), The Biology and Conservation of Sea Turtles. Smithsonian Institute Press, Washington D.C.

58. Whitaker, R. (1980). Captive rearing of marine turtles. J.Bombay nat. Hist. Soc. 76(1): 163-166.

59. Carr, A. (1982). In litt., May (comments on preliminary draft of RDB account for L. olivacea).

60. Bjorndal, K. (1982). In litt., May (comments on preliminary draft of RDB account for L. olivacea).

61. Robinson, D.C. (1982). Protection for Olive Ridleys at Ostional. Marine Turtle Newsletter, No. 21 (May): 2.

62. Mrosovsky, N. (1982). In litt., 24 May (comments on preliminary draft of RDB account for $\underline{L}$. olivacea).

63. Bobb, D. (1982). Massacre at Digha. India Today, 31 March, pp. 64-65.

64. Marquez, M.,R. (1982). In litt., 13 May (comments on preliminary draft of RDB account for $\underline{L}$. olivacea).

65. Marquez, M.,R. (1978). Natural reserves for the conservation of Marine Turtles of Mexico. In, Proc. Fla. Interregional Conference on Sea Turtles, 24-25 July 1976, Fla. Mar. Res. Pub., 33: 56-60.

66. Fritts, T.M. (1981). Pelagic feeding habits of turtles in the eastern Pacific. Marine Turtle Newsletter, No. 17 (Feb.): 4-5.

67. Pritchard, P.C.H. (1982). In litt., 27 April (comments on preliminary draft of RDB account for $L$. olivacea).

68. Marquez, M.,R., Penaflores, S.C., Villanueva, O.A., and Rios, I.D. (in press, 1982). Situacion actual y recomendaciones para al manejo de las tortugas marinas de la costa Occidental mexicana, en especial la tortuga golfina. Ciencia Pesquera, 2(1).

69. Frazier, J. (1982). Crying "wolf" at La Escobilla. Marine Turtle Newsletter, No. 21 (May): 7-8.

70. Pritchard, P.C.H. (1982). In litt., 27 April (citing information from S.E. Cornelius).

71. Pritchard, P.C.H. (1969). Studies of the systematics and reproductive cycles of the genus Lepidochelys. Ph.D. dissertation, University of Florida, Gainesville, pp i-xii, 1-197.

72. Pritchard, P.C.H. (1973). International migrations of South American sea turtles (Cheloniidae and Demochelidae). Anim. Behav., $21(1):$ 18-27.

73. Frazier, J. (1980). Oaxaca, 1980. Marine Turtle Newsletter, 
No. 18:4-5.

74. Cornelius, S.E., and Robinson, D.C. (1982). Abundance, distribution and movements of Olive Ridley sea turtles in Costa Rica, II. Final Report on U.S. Fish and Wildlife Contract No. 14-16-0002-81-225.

75. Cornelius, S.E. (1982). In litt., 27 April.

76. Hurtado, G.,M. (1982). Need for a regional Ridley program in the East Pacific. Marine Turtle Newsletter, No. 21 1: 1-2.

77. Hughes, G. R. (1982). In litt., 23 June (comments on preliminary draft of RDB account for $\underline{\mathrm{L}}$. olivacea) 

SUMMARY A circumglobal species, nesting on beaches of tropical seas in the Atlantic, Indian and Pacific Oceans, and foraging widely and regularly in temperate waters. Generally considered on the edge of extinction a few decades ago, continuing survey efforts have revealed previously unknown nest sites and allowed the world estimate of breeding female Leatherbacks to be revised upward from around 29,000 in 1971 (minimum) to 104,000 in 1981. This is largely due to confirmation of dense nesting in many parts of Pacific Mexico, which has an estimated annual nesting female population of up to 30,000; other major sites are French Guiana with 4,500-6,500 females annually, and Trengganu (West Malaysia) with $c$ 1,000-2,000 females annually. Major nesting is suspected in the Kepala Burung (Vogelkop) region of Irian Jaya (Indonesia). All other sites hold less than 1,000 females per year; of these, half a dozen hold a few hundred per year, and many hold only a few individuals. By far the largest extant sea turtle, approaching $1.8 \mathrm{~m}$ in length, the Leatherback is highly distinct both morphologically (in lacking cornified epidermal structures and a well-developed bony carapace and plastron) and ecologically (in its truly pelagic mode of life and diet of jellyfish and planktonic tunicates). In at least some parts of the range regular migrations occur into $\mathrm{cool}$ temperate waters to feed on seasonal concentrations of jellyfish. Typical nesting beaches have deep water approaches (no fringing reef), heavy surf, and sometimes a steep slope to the beach platform. Mean number of fertile eggs ranges from 66 to 104 on different beaches, typical clutch comprises c 85 eggs. Eggs are larger than those of other sea turtles, but clutch size is smaller. Females may re-nest at 9-10 day intervals, 4-6 times per season. Some females have been known to re-migrate at 2 or 3 year intervals. Threatened mainly by excessive harvest of eggs; take of adults for food (sometimes for oil or shark-bait), incidental catch in shrimp trawls and squid nets, also habitat disturbance, are important factors in different parts of the range. Many significant nest beaches are within protected areas and the species is nominally protected by legislation in much of the range. Killing of adults should be restricted, the possibility of sustainable egg harvest should be investigated, and nest sites should be protected. Captive breeding probably not feasible. Listed on CITES Appendix I.

DISTRIBUTION A circumglobal species, nesting occurs on beaches of tropical seas in the Atlantic, Indian and Pacific oceans, occasionally in the subtropics and Mediterranean (89). Most sites are located between $30^{\circ} \mathrm{N}$ and $20^{\circ} \mathrm{S}$. Away from the nesting site, individuals are known to move into temperate waters to feed. Major non-breeding Leatherback areas include, the New England area of nor theast U.S.A., including the Gulf of Maine (29); the eastern Atlantic, notably parts of the Bay of Biscay (13); the east Pacific between Peru and Ecuador (74), and the east coast of Australia $(11,88)$. Isolated records extend north to near $70^{\circ} \mathrm{N}$ in Iceland and Norway (8), to $60^{\circ} \mathrm{N}$ in Alaska (87), and south to $35^{\circ} \mathrm{S}$ in Uruguay (19), also one record from Foveaux Strait south of New Zealand (78).

Nesting distribution (For details, see Population section, below) Dense Leatherback nesting occurs along the Pacific coast of Mexico in Michoacan, 
Guerrero and Oaxaca. If, as seems probable, these records are referable to a single breeding assemblage, this represents the largest known population (45). Playa Naranjo in Costa Rica has become an important nesting beach (56). Low density nesting probably occurs sporadically elsewhere along the entire Pacific coast of Central America (43) from southern Baja California (Mexico) in the north, southward including El Salvador, Nicaragua, Costa Rica and Panama (12), and extending in South America to Ecuador (18) and possibly Peru (43).

On the Atlantic coast of the Americas nesting records extend from Flagler County on the east coast of Florida in the north (with an isolated record from North Carolina) (1), through the Caribbean region to Espirito Santo in Brazil (59) in the south. Most nesting in U.S.A. occurs in Martin and Palm Beach counties in Florida (1). Sparse or occasional nesting occurs on an island near Anton Lizardo in Veracruz and in Yucatan, Contoy Island (Quintana Roo) (75), between Cabo de Tres Puntas and Rio Montagua in Guatemala, possibly in Honduras, and in Nicaragua (9). A moderate size rookery occurs at Matina Beach (Costa Rica) $(9,59)$, and nesting extends along the coast from the Nicaragua border south to Moin. In 1979 two important nesting localities were discovered on Panama's Caribbean coast, at Playa Chiriqui and Playa Changuinola; a site was already known at Bahia Aglatomate, in the San Blas Islands (9). Low density nesting occurs in Colombia in the Gulf of Uraba and on the east coast of Santa Marta (9,59). Occasional nesting may occur in Venezuela but information is lacking. Small numbers nest at Shell Beach in Guyana. By far the largest nesting aggregation in the entire western Atlantic region occurs in Surinam on Matapica and Krofajapasi beaches and on the Surinam side of the Marowijne (Maroni) River estuary (43) and on the French Guiana side of the Maroni River, on beaches extending southeast to Organabo. Sporadic low density nesting appears to occur along the Brazilian coast, south to Espirito Santo $(9,59)$.

The Leatherback appears to prefer mainland nesting (59) and nesting is unknown or irregular on many of the Caribbean islands, but prominent exceptions are the Dominican Republic (47), islands adjacent to Puerto Rico, including Culebra, Mona and Vieques (9), and the U.S. Virgin Islands, notably at Sandy Point on St. Croix $(2,9,59)$. Small-scale nesting occurs on some of the Lesser Antilles (9), including Dominica, Guadeloupe, Martinique, St. Kitts, St. Lucia, St. Vincent and Grenada. Some nesting occurs on Tobago but larger aggregations nest on the north and east coasts of Trinidad $(9,59)$.

In the eastern Atlantic nesting on an unknown scale is recorded in Senegal, Liberia Ivory Coast, Ghana, Togo, Zaire and Angola $(8,26)$. Leatherbacks are occasionally found in the Mediterranean; nesting is known at Palmahim in Israel (50), and has been reported on one occasion in Sicily (61).

In the Indian Ocean medium density nesting occurs in southern Africa, notably along the Tongaland coast of northern Natal in South Africa (26), and along the Mozambique coast (15). Small-scale nesting is reported for the Lakshadweep Islands (Laccadives), also Goa and other parts of the west coast of India, to southern Kerala, parts of the east coast, and Sri Lanka. Larger aggregations are known in the Union Territories of the Andaman and Nicobar Islands $(5,6,15)$.

Nesting occurs in many parts of east and southeast Asia and Australia. Reported areas include the Tenasserim region of Burma (6); west and east coasts of Thailand, notably Changwat Phuket and Changwat Phangnga, both in western peninsular Thailand (4); peninsular Malaysia, notably at Trengganu on the east coast (54); at many localities in Indonesia $(32,42)$, notably in northern Irian Jaya $(41,49)$ but also on Java and Sumatra; and in parts of Papua New Guinea, including the island provinces; eastward to the Solomon Islands (60) and south to Mon Repos beach near Bundaberg in Queensland, Australia (31). Leatherbacks are reported in 
the South China Sea, and occasionally as far north as the Yellow Sea (62). The species appears not to nest in the Philippines.

POPULATION Population estimates for sea turtles can be based only on an estimate of the total number of mature nesting females. These animals, or rather their nests or nesting tracks, can be counted more readily than other classes (although still with considerable difficulty), whereas males do not leave the water and are rarely identified at sea and are thus impossible to count. Immature animals are similarly impossible to count at sea. The nesting track of Leatherbacks is distinctive in that it is usually wider than that of other sea turtles, often sinuous and with a distinct orientation circle; this aids in estimation of nesting density, particularly from the air.

While widely considered to be on the point of extinction a few decades ago, continuing survey efforts allowed the minimum world population of breeding female Leatherbacks to be estimated at around 29,000 in 1971 (43), with a maximum of 40,000 allowing for undiscovered or uninvestigated nest beaches. More recently, surveys carried out under WWF Project 1812 have confirmed and extended earlier reports $(33,73)$ of major nesting along the Pacific coast of Mexico in Michoacan, Guerrero and Oaxaca (45). On one $40 \mathrm{~km}$ beach at Tierra Colorada it is estimated that 500 turtles nested each night of the season (40) from October to January $(33,73)$. This is conservatively estimated at about one third of the nightly nesting in the entire Michoacan-Guerrero-Oaxaca area; allowing for other nest beaches in the area, and re-nesting of each turtle after about 10 days, the total number nesting per season may be estimated at 30,000. Multiplying by 2.5 to allow for a two or three year nesting cycle, the total breeding female population using this tri-state area is around 75,000 (45). This figure alone more than doubles the previous minimum world estimate of 29,000, and allowing for nesting in non- or partly surveyed areas of Mexico and Melanesia, a reasonable new estimate for the world total of breeding female Leatherbacks is 104,000 (45). Even this may be a significant under-estimate since a recent aerial survey along the north coast of the Kepala Burung (Vogelkop) region of Irian Jaya $(41,48,49)$ disclosed one $30 \mathrm{~km}$ stretch of beach with evidence of around 3,500 sea turtle nests, many of which were considered to be Leatherback (41). Ground surveys are planned for 1982 (41). This area may thus be comparable to the Trengganu area (peninsular Malaysia), that with 1,000-2,000 females nesting annually (46) is otherwise by far the largest nest site in southeast Asia.

It must be recognised that estimates of this kind are based on several unproven assumptions (45), notably about re-nesting and re-migration frequency. Some individual Leatherbacks have been shown to re-nest between four and seven times during a season, and similarly, some have been shown to re-migrate at two or three year intervals $(23,43,45)$. These figures are used as the basis for extrapolating from numbers nesting per night, or per season, to an estimate of the total breeding female population. It should be stressed that there are no data to indicate how typical these re-nesting and re-migrating intervals are for the female population as a whole $(79,85)$. It cannot be assumed that re-migration occurs in the entire female population (89). For example, in the Tongaland population, some marked females have re-migrated after a one (rare), two or three year interval; occasional females have even returned in four and five different years (89). However, $70 \%$ of the 321 nesting females tagged have never been seen again (89). If a similar proportion of single-season breeders occurs in other populations, then estimates of total mature female numbers - derived by multiplying the number of females nesting in one season by a factor expressing assumed multiple breeding - will be excessively high.

Even though the total population of Leatherbacks is very much larger than was once thought, and there is no evidence for an overall decline in the species (45), it 
remains true that breeding populations are mostly of relatively small size (with only a few hundred, or fewer, females nesting annually), are widely scattered through the tropics, and are often subject to heavy exploitation for food $(45,46)$. Certain populations are thought to have declined (46), namely, on the west coast of India (6), Sri Lanka (6,24), Thailand (4), Trengganu (54) and possibly French Guiana (52). On the other hand, populations in Surinam, U.S.A. (Florida) and South Africa (Natal) have reportedly increased following effective protection of nest beaches $(26,46,51)$. However, nesting numbers in Florida and $\mathrm{Natal}$ are insignificant on a global scale, and at least some of the females now nesting in Surinam appear to have moved from the nearby French Guiana beaches.

There are only three really major Leatherback nesting areas with over 1,000 females nesting annually (or four if the Irian Jaya populations turn out to be as important as suspected). These are: the Pacific coast of Mexico with c 30,000 females annually, total female population 50,000 (75) to 75,000 (45); French Guiana with c 4,500 - 6,500 annually (17), total c 15,000, this population now apparently partly shared with Surinam; Trengganu (Malaysia) with c 1,500 females annually; and possibly the Kepala Burung (Vogelkop) region of Irian Jaya. Perhaps half a dozen sites appear to hold a few hundred females per year, and many hold only a few individuals. Available data on most notable nesting areas are summarized below.

Angola At least thirty Leatherback nests were reported on one beach in the Parque Nacional da Quicama in December 1971 (27).

Australia Only one or two females nest annually along $100 \mathrm{~km}$ of Queensland coast from Mon Repos beach at Bundaberg north to Round Hill Head $(31,88)$.

Burma Very rare; a female attempted to nest near the mouth of the Ye River in Tennasserim in 1862, and the species was apparently familar to inhabitants of the Arakan coast at the turn of the century (81). No recent data.

Colombia Between 100 (46) and 200-250 (2) females nest annually along the Gulf of Uraba.

Costa Rica on the Caribbean coast, a moderate size Leatherback rookery, comprising around 500 females per year, is situated at Matina beach (9). Some nesting occurs along much of the Caribbean coast of the country (9). Recent reports (56) indicate that several beaches along the Pacific coast have many Leatherbacks nesting. The species appears to have increased in abundance on Playa Naranjo, a $6 \mathrm{~km}$ beach within Santa Rosa National Park. During September-November 1971, 18 females were tagged and 106 nesting emergences were recorded over 50 days. In November 1981 during only two nights, 22 and 10 females were tagged in 8.5 and 2.0 hours respectively. During the first night 44 Leatherbacks emerged and tracks of 118 that had emerged over the previous 3-4 nights were counted (56). Playa Naranjo thus rates as one of the more significant nest sites in the east Pacific (56), second to those in Pacific Mexico. The apparent increase in Leatherback nesting has occurred in parallel with a decrease in nesting by Green Turtle (Chelonia mydas) (s.1.) (56). Overall population increases are difficult to establish, since season to season fluctuations may mask overall trends (78).

Dominican Republic Until recently unknown as a Leatherback nest site, part of the Dominican Republic was surveyed by air and on the ground in March-April 1980 (47). Although reported uncommon by local informants, the species is thought to nest occasionally in very low densities on suitable beaches anywhere in the Republic, but four areas of more concentrated Leatherback nesting were identified on information from locals (47); Playa del Muerto, Playa Macao (both in 
Altagracia Province), Playa San Luis and Playa des Aguilas (Pedernales Prov.). There is very heavy predation on eggs and nesting females (47). Based on interviews with local informants, and assuming that each turtle nests three times during a 60 day season, it is tentatively estimated that 300 Dermochelys nest annually in the Dominican Republic (47).

French Guiana A series of eight beaches between the estuaries of the Maroni (Marowijne) River on the Surinam border and the Organabo River in the east provided a major nesting area for Leatherback $(16,43,44)$. The annual number of nesting females was estimated at 15,000 in 1971 (43). This very large population was thought to be by far the most important Leatherback nest area in the world prior to discovery of major nesting in Pacific Mexico. Due to marine action, the major Organabo beach moved westwards during the 1970s, and by 1979 was reduced to a sandspit washed over at high tide (65). Nesting may have decreased to some extent during this period (65). However, at least some of the French Guiana Leatherbacks have shifted their nest sites westward toward the Surinam border, and most nesting now occurs at Les Hattes - Awara (at the junction of the Maroni and Mana Rivers), with some nesting occurring on beaches that did not exist in 1960-1970 (17,78). The 1979 population is of approximately the same size as that reported in 1971 , with an estimated total mature female population of 19,596 , or 16,330 , or 13,996 (the estimates vary according to whether a given female nests 5,6 or 7 times a season) $(16,17)$. Only a fraction of the total population will nest in a given year (78); between 4,500-6,500 females in a season (17). It is reported (65) that the nest sites are now so crowded that a considerable number of nests is destroyed by later-nesting females, also there is massive disturbance of nesting turtles since cars can be driven right onto the beach (65) (more accessible than the old Organabo sites (78)).

India Moderate-scale nesting is recorded in the Union Territory of the Andaman and Nicobar Islands (5). In April 1979 about 80 Leatherback excavations were found on Great Nicobar Island and about 70 in January 1979 on Little Andaman (5). Isolated Leatherbacks occasionally nest on the mainland, including part of the west coast, south to Kerala, and the central east coast (6). Mainland nesting reportedly occurred more frequently around the turn of the century, for example around Quilon in southern Kerala (6). Granite blocks and embankments, designed as defences against sea erosion, now prevent turtles approaching beaches on much of the Kerala coast (72). Dermochelys nests in small numbers in the Lakshadweep (formerly Laccadive) Islands (6).

Indonesia Leatherbacks nest at several sites, but generally on a small scale $(32,39,42)$. About one female a year might nest on Citerem and Cibuniaga Beaches in southeast Java, less than five a year nest in southeast Sulawesi, less than 20 on Sukamade Beach in southeast Java and at Inggresau (on P. Yapen, Irian Jaya), with possibly similar numbers at several sites near Bengkulu in west Sumatra (91). Some nesting is known at the northern tip of P. Morotai (near Halmahera). At Sukamade Beach in southeast Java (regarded as the most important sea turtle nesting area in Java (7)), 16 nests were recorded between June-August 1980 after an absence of four years (7), and 21 nests were found in 1981 (71). However, the major nest site is on the northern coast of the Kepala Burung (Vogelkop) region of Irian Jaya. An aerial survey in September 1981 revealed a $30 \mathrm{~km}$ stretch of beach with evidence of about 3,500 sea turtle nests, many of which were thought to be Leatherback $(41,48,49)$. This area may thus be comparable to Trengganu (Malaysia) which, with 1,000-2,000 females nesting annually, had been considered by far the major Leatherback site in southeast Asia.

Malaysia Leatherback nesting is concentrated along a $20 \mathrm{~km}$ beach at Rantau Abang in Trengganu State on the east coast of peninsular Malaysia (54). This population is declining (54). The yield of Dermochelys eggs in Trengganu has 
declined by $66 \%$ since 1956 (54) (because eggs collected are not exactly the same as eggs laid, and due to different sampling techniques, this figure is only an approximation of population decline). Between 1,000-2,000 females nest annually (1974 data quoted in ref. 46). Regarding East Malaysia, Leatherbacks are not known to nest in Sarawak or Sabah, but are very occasionally sighted at sea in the area $(63,64)$.

Mexico Leatherbacks have been reported to nest in good numbers on parts of the Pacific coast of Mexico (33,73). Recent extensive aerial surveys on October 31 and November 1, 1980, along approximately $1000 \mathrm{~km}$. of coast from Maruata (Michoacan) south to the Isthmus of Tehuantepec (Oaxaca) revealed significant to high density Leatherback nesting along much of the coast (45). Hundreds of kilometers of Leatherback nesting beaches were surveyed on which nesting density, about one nest per $50 \mathrm{~m}$ at maximum, approached that found on the former $30 \mathrm{~km}$ French Guiana beach or the $20 \mathrm{~km}$ Trengganu beach in Malaysia, previously considered the first and second (respectively) most important for the species (45). A first estimate of the Pacific Mexico population of breeding females is 75,000; this is more than twice the estimate for the previous world population (45). Howeve, some authorities consider this estimate too high and suggest a figure of around 50,000 (75). There are major nesting beaches on the southeast coast of Guerrero between Bahia Dulce and Barra de Teconapa (estimated 5,000 females nesting per season) and at Bahia de Chacahua. Other localities include Mexiquillo, Colola, Maruata and Boca de Apiza in Michoacan; Mismaloya in Jalisco; Cuyutlan in Colima; Petacalo and Piedra de Tlacoyunque in Guerrero; La Escobilla and Bahia Blanca in Oaxaca. A secondary nesting beach has recently been discovered on the south-west coast of Baja California (33).

Mozambique Probably less than 50 Leatherbacks nest annually (15).

Papua New Guinea Leatherbacks nest regularly, but in small numbers, on many parts of the north coast and on some of the larger islands, including sites in West and East Sepik Provinces, Madang, and Milne Bay Province, and on Manus Island, New Britain, New Ireland and others (58). Although sea turtle populations in general are reported to be slowly declining in most areas of P.N.G., there appear to be no specific data on Leatherbacks (58).

Puerto Rico Small to moderate numbers of Leatherbacks nest on islands adjacent to Puerto Rico, including Culebra, Mona and Vieques (9). A study in 1981 recorded 26 Leatherback nests during the entire season on Vieques (78).

Solomon Islands Leatherbacks are known to nest on several islands of the group; the most important areas are Choiseul and New Georgia, each with 50-100 nests annually, and Ysabel, with over 100 nests (60).

South Africa Kwa Zulu coast (Tongaland) of Natal. Sea turtles are protected and nesting females have increased from 5 in 1966 to 70 in 1977/78 (26).

Sri Lanka Leatherbacks nest mainly in the southeast on the Yala coast, probably less than 100 females nest annually (15). The population is reported to be declining (24).

Surinam Nesting occurs in the Galibi Reserve on the Surinam side of the Marowijne estuary, and further west in the Bigisanti area (Matapica and Krofajapasi beaches) east of Paramaribo. The total number of nests, probably representing virtually all Leatherback nesting in Surinam, rose fairly steadily from 95 in 1964 to 1,625 in 1975 (51) and to 3,900 in 1979 (52). This rise in numbers is thought to be due at least in part to nesting females shifting from the French Guiana sites (52). Assuming a two-year nesting cycle and three nests per 
female each year, about 650 females nested in 1975 at Bigisanti and 200 at Galibi (51).

Thailand Has become rare, is found in waters of peninsular Thailand, breeds on the airport beach in Changwat Phuket, in the Laem Phan Wa marine reserve in Phuket, and in coastal Changwan Phangnga (4).

Trinidad and Tobago Some Leatherback nesting occurs on both islands, mainly on the north and east coasts of Trinidad, where the nesting population was estimated at 400-500 females in $1971(3,46)$.

United States Ten to 12 females nest annually on the east coast of Florida, mainly on beaches in Palm Beach and Martin counties (66).

\section{U.S. Virgin Islands Fifty to 70 Leatherbacks nest at Sandy Point on St Croix (2).}

HABITAT AND ECOLOGY Dermochelys coriacea is by far the largest existing species of turtle, with the biggest specimens approaching $1.8 \mathrm{~m}$ (6 feet) in carapace length $(43,44)$. The median carapace length in West Atlantic and Tongaland populations is around $1.5 \mathrm{~m}$ (43). Mature East Pacific Leatherbacks are smaller in size, etween $1.3-1.5 \mathrm{~m}$ in length (78). Individuals have been recorded weighing as much as $644 \mathrm{~kg}$ (79), but most mature individuals are at least $100 \mathrm{~kg}$ lighter than this. The species is morphologically highly distinctive; notably in lacking cornified epidermal structures (i.e. no scutes on the carapace or plastron, no cornified scales, no claws, no horny pads in the jaws), and in lacking a properly-developed bony carapace and plastron $(43,44)$. The carapace has the texture of hard rubber, and is raised up into seven longitudinal ridges. The Leatherback is ecologically unique among sea turtles in its truly pelagic mode of life, although sharing with all sea turtles the necessity to nest on land. The large body bulk with its low surface/volume ratio contributes to maintainence of adequately high core temperatures while foraging in cool temperate waters $(14,36)$. The front flippers are exceptionally long and powerful, and may span about $2.5 \mathrm{~m}$ when extended (44). The longitudinal flutings on the carapace may be associated with maintaining efficient laminar flow during sustained high-speed swimming (20). A powerful swimmer, inhabiting the open seas, individuals of this species are only rarely sighted away from nesting beaches (with the exception of those encountered in the few known regularly-frequented feeding areas), and ecological observations are correspondingly sparse.

The diet of Dermochelys is also unique among sea turtles; it consists almost entirely of jellyfish (Scyphozoa) including Cyanea capillata, Rhizostoma cuvieri, R.pulmo and Cabbage Head Jellyfish Stomolophus meleagris (67), Catostylus mosaicus and the Portuguese Man o' War Physalia utriculus (Hydrozoa) (11), and also planktonic tunicates such as Salpa, Pyrosoma (Thaliacea) and ascidians. Other items found in the gut of Leatherbacks are mainly animals such as amphipods or fishes that live associated with the primary prey $(67,86)$. Possibly linked with this diet are the pair of short pointed projections at the tip of the upper jaw, and the pointed posteriorly-directed papillae scattered over the lining of the mouth and oesophagus (restriced to the latter site in other sea turtles); both structures may aid in ingestion of gelatinous prey items. However, it appears that feeding Leatherbacks may often not differentiate between jellyfish and floating plastic debris; nearly $50 \%$ of non-breeding Leatherbacks examined had plastic (e.g. bags) or cellophane in the stomach, this may contribute to mortality (37).

While Dermochelys coriacea is mainly a pelagic species, at least four areas in temperate zones are known where concentrations may occur seasonally on or near the continental shelf; the eastern Bay of Biscay, especially the Pertuis Charentais off La Rochelle (13), the New England region of northeast U.S.A. (coastal 
Massachusetts, New Hampshire and Maine) (29), the east Pacific between Peru and Ecuador (74), and the eastern seaboard of Australia where large adults may be seen all year in larger bays, estuaries and rivers, notably off New South Wales (11). Dense concentrations of food items are also recorded in these areas, Cyanea capillata in New England (29) and Rhizostoma pulmo in the Pertuis Charentais (13); the seasonal appearance of Leatherbacks in these temperate waters may be correlated with this. The Gulf of Maine, for example, is reported to be highly productive in medusans (29). A concentration of about 100 Leatherbacks, between $1-2 \mathrm{~m}$ in length, was recorded in December 1956 in a $50 \mathrm{~km}$ stretch of sea north from Port Aransas, Texas (30). These were feeding among a dense aggregation of Cabbage Head jellyfish Stomolophus meleagris, such as occur annually with the onset of winter (22). It has been noted (8) that Leatherbacks may travel in small groups. Limited data $(14,36)$ indicate that Leatherbacks.can maintain a deep body temperature up to $180^{\circ} \mathrm{C}$ above that of the surrounding water (in an experimental tank of cold water) for an unknown period. This ability presumably facilitates foraging in cool temperate waters, and may be due to the large size, thick layer of oily tissue around the body, and the counter-current heat exchange system in the flippers (36). There are few long-distance recaptures of tagged Leatherbacks, but these do document some of the longest migrations recorded for any reptile (34). Five Leatherbacks tagged in the Guianas had travelled over 5000 $\mathrm{km}(68)$ to recapture sites in Ghana, Mexico (Campeche area) and U.S.A. About 35 individuals tagged at Trengganu have been recaptured, in the Philippines, Japan, Kalimantan, Hainan Island (China) and Taiwan (34), indicating a wide dispersal through southeast Asia and the South China Sea. This dispersal of Trengganu turtles is thought $(82)$ to be due to prevailing currents and not purposeful movement to feeding grounds.

Nesting is seasonal; occurring, for example, in April-July at most North Atlantic sites and November-January in the East Pacific (78). The age of sexual maturity is not known. However, in 1976 an experiment was initiated at Trengganu in which the pointed posterior tip of the carapace was excised in 11,502 hatchlings $(82,83)$. Fourteen young females with shortened carapaces were observed on the nest beach in 1981; if the assumption is made that these females were indeed among those marked as hatchlings, and do not simply bear a natural mutilation or growth peculiarity, this could be interpreted as suggesting a minimum age at maturity of five years (82). Observations in the 1982 and subsequent seasons are necessary before this preliminary indication can be regarded as established (82). In general, it appears that most Dermochelys nesting occurs on relatively undisturbed beaches, with a stable beach platform, deep water approaches extending close to the shoreline, and heavy surf (43). Such conditions are found at the major Trengganu rookery (21), in the Guianas (51), and similarly on the best of the Dominican Republic and Mexican nesting beaches (33,47). In 22 nest beaches in the Solomons, all were near river mouths and all had deepwater approaches (60). Leatherbacks almost never nest on beaches with a fringing reef (43). The presence of deep water close inshore may ease the approach of this mainly pelagic species to the beach.

The nesting female emerges from the sea at night and ascends the beach mainly by simultaneous heaving with the powerful fore flippers. The actual nesting process in Dermochelys conforms to the stereotyped pattern shared by all sea turtles (10). A shallow body-pit is scooped out by movements of all four limbs, the tail may be thrust into the sand as if to appraise its suitability for nesting (43). The nest cavity is excavated by strictly alternating thrusts of the hind limbs. After the eggs are deposited in the nest cavity, it is refilled with sand by the hind flippers, the nest area is compacted by the hind flippers and the weight of the body, and sand is distributed generally over the area by vigorous backward strokes of the fore flippers. The turtle then returns to the sea. Once egg deposition has started, the female is not readily disturbed (43). Mean number of 
fertile eggs ranges from about 66 (Playa Naranjo, Costa Rica) to 104 (Tongaland, South Africa), typical clutch size is around 85 (23); often a variable number of small yolkless eggs are laid towards the end of egg deposition $(23,43)$. Eggs are white, usually spherical, about $53 \mathrm{~mm}$ in diameter (23). Mean incubation period ranges from 56 days (Trengganu) to around 65 (Surinam) (23). Hatching success ranges from $63 \%$ (Trengganu) (23) to $76 \%$ (Tongaland) (43). Hatchlings are 55-63 $\mathrm{mm}$ in length, usually around $58 \mathrm{~mm}$.

Some tagged females have been shown to re-nest on several occasions within a season, and to make nesting re-migrations in different seasons $(23,43)$. The predominant re-nesting interval appears to be $9-10$ days; there may be six (occasionally nine) nestings per season in Surinam (43); an average of five (maximum nine) at Trengganu (83), at least four in Tongaland (43). At least some tagged females have been shown to re-migrate to nest at one (rare), two, or three year invervals $(43,90)$. However, since most females tagged while first nesting are never seen again, the extent to which re-migration is typical of the whole female population has been questioned (90). The available data do not appear to justify the common assumption that re-migration is characteristic of the whole population (90). Data from Trengganu indicate an annual productivity per female of 58 hatchlings (with mean clutch size of 83.5) (23). Leatherbacks are notable in producing fewer but larger eggs and hatchlings in comparison with other sea turtles (except Flatback Chelonia depressa) (23). Eggs and hatchlings are taken by Ghost Crabs Ocypode (although the relatively deep nest reduces egg loss), pigs and monitor lizards (where present); hatchlings are eaten by crabs, occasionally birds, small mammals, and sharks $(43,80)$. Adults may fall prey to sharks, or to large felids while nesting (43). A significant proportion of nests is laid below the high tide mark and thus lost to flooding (43). Much mortality is caused among nesting females in French Guiana by the turtles becoming entangled in masses of dead mangrove roots found along many beaches (17).

THREATS TO SURVIVAL Prospects for the continued survival of the Leatherback would seem to be rather better than for certain other sea turtles. The global intensity of exploitation is certainly less than that directed at the Green Turtle Chelonia mydas complex, Olive Ridley Lepidochelys olivacea or Hawksbill Eretmochelys imbricata. There is virtually no international trade in Leatherback parts or derivatives (45). Adult Leatherbacks are not consumed by man as widely as some species, notably Green Turtles and Olive Ridley, since their oily flesh is generally considered unpalatable (44). However, adults are heavily exploited for food in some parts of the range (46), and eggs are harvested intensively for food in most known nesting areas. This latter activity is said to constitute the primary threat to Leatherback populations (46). Almost all eggs laid in Mexico and Trengganu are harvested, and loss of nests by marine erosion is severe in the Guianas (78). Furthermore, it is reported that subsistence use of Leatherbacks meat as well as eggs - is increasing throughout the range (except possibly French Guiana and Surinam), and is likely to expand further as shorelines develop (92). Simultaneously, incidental catch (in shrimp trawls, various nets and on long lines) is also reported to be increasing markedly (92).

In the newly-reported nesting areas of Pacific Mexico, the remains of many adult Leatherbacks were seen in an aerial survey and it is estimated that hundreds may be slaughtered annually (45). Remains of 167 adults in total were noted on two beaches in Peru in October 1978 (sources in ref. 45). In recent years an estimated $20-30 \%$ of the breeding population in Trinidad (of 400-500 females) were killed annually (43). In Papua New Guinea adults, when found, are usually killed for their meat by coastal villagers, although Leatherback populations here are in low densities (57). About 100 adults may be killed annually by inhabitants of a single village in the Kai Islands near Irian Jaya (Indonesia) and exploitation may be on a similar level in much of this region (45). Leatherbacks are only rarely eaten in 
the Solomons, but among groups that do consume this species, it is considered an important cultural event (60). Leatherback flesh is used for bait, in Mexico (75) and (for sharks) in Indonesia (80). In some areas Leatherbacks are killed to be rendered into oil for caulking boats, on Larak Island in the Persian Gulf for example (28), or for oil lamps in Papua New Guinea (57), or for medicinal use in the Caribbean $(2,76)$ (eg. British Virgin Islands, Grenadines, Panama).

The most serious direct threat to the Trengganu population (82) is the large number of offshore fishermen using large mesh $(6-10 \mathrm{~cm})$ drift nets, in which turtles become entangled. Similarly, Leatherbacks are trapped in shark nets (75); and nylon monofilament drift nets used in the northwest Pacific by Japanese (and other) fishermen to catch squid are known to cause significant (and previously unsuspected) Leatherback mortality (77).

Egg collection is heavy in parts of Pacific Mexico $(45,73)$. At Trengganu, the nesting beaches are leased to the highest bidder, and nearly $100 \%$ of eggs laid are collected; the State Fisheries Department is able to buy back a proportion. At present this is about 10\% (82). Total egg production has declined since 1956 by around 66\% (54). Decline or loss of populations in India, Sri Lanka and Thailand appears to be due to excessive egg harvest (46). Heavy take of eggs is also reported in the Dominican Republic (47) and Trinidad (46) for example, and egg harvest on some scale is said to occur throughout the nesting range of Dermochelys (69).

Development is cited as a potential threat to the U.S. Virgin Islands population, nesting at Sandy Point on St. Croix (2). Similarly, in Sri Lanka increasing human use of Leatherback nesting beaches, notably for tourism, is considered the main cause of decline in nesting of this and other sea turtles (24). In European Atlantic waters some mortality is caused by turtles becoming entangled in lobster-pot lines or in nets, or being struck by ships' propellers (8).

CONSERVATION MEASURES TAKEN The Leatherback is nominally protected by legislation in most countries where nesting occurs $(2,25,26,46)$, including Australia, Costa Rica, Dominican Republic (47), French Guiana, Indonesia, Malaysia (Trengganu State), Mexico, Mozambique, South Africa (Natal), Sri Lanka, Surinam, and U.S.A. (Florida, also U.S. Virgin Islands and Puerto Rico). Certain nesting beaches are protected, for example at Rantau Abang in Trengganu State (Malaysia); in Yala Reserve, Sri Lanka; on Playa Naranjo in Santa Rosa N.P., Costa Rica; Galibi, Matapica and Krofajapasi (formerly within the Wia-Wia Nature Reserve, now protected by special decree) in Surinam; in Indonesia Sukamade Beach lies wi thin Meru Betiri Nature Reserve (Java) and important nest beaches in the Kepala Burung (Vogelkop) area of Irian Jaya and on Japen Island (Yapen) are within a projected Reserve network; Sandy Point (St. Croix, U.S. Virgin Islands) and adjacent waters are designated Critical Habitat for the Leatherback under the 1973 U.S. Endangered Species Act (2). The Recovery Plan (2) for the St. Croix population has been approved. Laying beaches in French Guiana will soon be protected in the Reserve of Basse-Mana (16).

While adults are widely protected by law, collection of eggs is permitted or controlled in some areas. In Trengganu State (Malaysia), for example, a Dermochelys hatchery, now run by the Fisheries Department, was set up in 1961 . Adult Leatherbacks are strictly protected on the nest beach, but virtually all eggs laid are gathered by licensed egg-collectors. The Fisheries Department buys back a proportion of the annual egg harvest for transplantation into the hatchery at Rantau Abang. Between 1961-1980, 730,060 eggs were transplanted, from which 360,520 hatchlings were produced for release (53). Usually more than 10,000 eggs (sometimes several tens of thousands) are incubated each year, with around $50 \%$ hatching success (54). The project is currently incubating about $10 \%$ of the eggs 
laid on the beach (53). Fees paid by egg-collectors for their license contribute towards the cost of running the scheme. The project may serve to some extent as a model for other areas and species, in that it combines species conservation through preserving adults and a proportion of the annual egg output, with local utilization of eggs as an important and valued food resource. Tourism provides a further economic benefit. However, it is suspected $(69,70)$ that the percentage of eggs bought for incubation may be too small to ensure the continued survival of the population at current levels. Data on life history parameters are inadequate to objectively define the proportion of eggs that can be taken without adversely affecting the population. Operation of drift-nets, which entrap turtles, is prohibited along $8 \mathrm{~km}$ of the Trengganu nest beach during the nest season ( 82 ). In French Guiana, an enclosure for artifical incubation of eggs, up to 8,000 annually, has been established at Hattes-Yalimapo (Maroni estuary) (16).

Listed in Appendix I on the Convention on International Trade in Endangered Species of Wild Fauna and Flora (CITES). Listed as Endangered under the 1973 U.S. Endangered Species Act.

CONSERVATION MEASURES PROPOSED Legislation to protect Leatherbacks exists in many parts of the range but is of ten ineffective (e.g. 42,45,73); ideally funds and personnel should be made available to enforce these laws. It should also be recognized, however, that meat and especially eggs of this species may provide an important source of nutrients or income to local subsistence peoples, in Pacific Mexico, for example. In such cases rational utilization may be the preferred course. It has been pointed out that killing breeding female Leatherbacks is damaging on both economic and biological grounds; the adult female is thought to take a long time to mature, but once mature is potentially able to lay many eggs (38). A female only has to nest in two seasons for the monetary value of her eggs to exceed that of her meat (data from Pacific Mexico) (38). Thus if exploitation is to occur, strictly regulated legal harvest of a proportion of Leatherback eggs laid may be appropriate; unregulated illegal killing of adults is unacceptable. However, firm recommendations on the preferable mode of utilisation cannot be made; a long-term tagging project in South Africa has shown that a large number of adults do not return to breed after the initial tagging. It is therefore possible that the egg cohort of any one year is of comparable importance to the population as are many of the adult egg-layers (79). The Trengganu egg harvesting and hatchery scheme (see Conservation Measures Taken) may serve as a model for other areas (and species). Malaysia should be encouraged to increase the level of egg purchase (for incubation), preferably to $50 \%$ (84). The feasibility of substainable egg harvest should be investigated (85).

The practice of incubating sea turtle eggs in semi-natural or artificial nests, in the hope of decreasing egg and hatchling mortality, should be reviewed. It is known that the sex of some sea turtle species, and probably all sea turtle species, is determined by temperature during a critical phase of embryonic development. To the extent that temperatures in non-natural nests differ from those in natural nests, the sex ratio among the hatchlings will deviate from the natural ratio. Production of an excess of males, or of intersexes, will clearly be deleterious; an excess of females may be less serious. See reference 93, and sources cited therein.

It has been proposed that $8 \mathrm{~km}$ of nesting beach in Trengganu should be fenced off as a turtle sanctuary (53). In Irian Jaya, beaches on the Vogelkop and on Japen Island are included in a planned Reserve network (41). In the Dominican Republic revised protective legislation awaits finalization, and a hatchery scheme may be possible (47). It has been suggested that New England waters in northeast U.S.A. should be proposed as Critical Habitat for Dermochelys (29). In 1978 several Natural Reserves to protect marine turtle rookeries were proposed on the Pacific 
coast of Mexico (73). Restricted fishing zones should be established in areas of high Leatherback concentrations and the use of excluder devices for trawl nets encouraged (84).

CAPTIVE BREEDING None at present, probably not feasible. It has been noted that the Leatherback, presumably due to its pelagic habits, has no 'reverse gear', and tends to repeatedly swim into any obstacle encountered, such as the wall of a holding tank (20). Hatchlings are difficult to raise in captivity (44) and few have survived more than a few months. However, rapid growth was noted in Leatherbacks raised to nearly two years at Miami Seaquarium; these individuals were fed entirely on jellyfish Cassiopea, and were capable of consuming around twice their own body weight daily (44). The species has also (75) been reared at Himeji Aquarium (Japan).

REMARKS The Compiler is extremely grateful to G.H. Balazs, A. Carr, G.R. Hughes, R. Marquez M., A. Meylan, R. Petocz, P.C.H. Pritchard, J.P. Ross, R.V. Salm, and K.T. Siow for their care in critically reviewing a preliminary draft of this account.

REFERENCES 1. Anon. (National Fish and Wildlife Lab., Gainesville). (1980). Leatherback Sea Turtle. In, Selected vertebrate endangered species of the seacoast of the United States. Biological Services Program FWS/OBS-80/01.12. U.S. Fish and Wildlife Service.

2. Anon, (Region 4 of the U.S. Fish and Wildlife Service). (1981). Recovery plan for St. Croix population of the Leatherback Turtle (Dermochelys coriacea).

3. Bacon, P.R. (1970). Studies on the Leatherback Turtle, Dermochelys coriacea (L.) in Trinidad, West Indies. Biol. Conserv: 2(3): 213-217.

4. Bain, J.R., and Humphrey, S.R. (1980). A profile of the endangered species of Thailand. Report No. 4, Office of Ecological Services, Florida State Museum, U.S.A.

5. Bhaskar, S. (1979). Sea Turtle survey in the Andaman and Nicobars. Hamadryad 4(3): 2-26.

6. Bhaskar, S. (1979). The status of the Sea Turtles in the East Indian Ocean. (Unpublished paper read at World Conf. on Sea Turtle Conservation, revised version in press in Bjorndal, K. (Ed.). The Biology and Conservation of Sea Turtles. Smithsonian Institute Press, Washington D.C.) (Papers presented at The World Conference on Sea Turtle Conservation, Nov. 26-30, 1979, Washington D.C.).

7. Blouch, R.A. Sinaga, T., and Sumarto, P. (1981). Leatherback Turtles return to Sukamade Beach. Tigerpaper $8(1): 124-125$.

8. Brongersma, L.D. (in press, 1982). Marine Turtles of the Eastern Atlantic. In, Bjorndal, K. (Ed.). The Biology and Conservation of Sea Turtles. Smithsonian Institute Press, Washington D.C. (Papers presented at The World Conference on Sea Turtle Conservation, Nov. 26-30, 1979, Washington D.C.).

9. Carr, A., Meylan, A., Mortimer, J., Bjorndal, K., and Carr, T. (in press, 1982). Preliminary survey of marine turtle populations and habitats in the Western Atlantic. National Oceanographic and Atmospheric Admin., Technical Memorandum NMFS-SEFC.

10. Carr, A. (in press, 1982). Notes on the behavioral ecology of sea turtles. In, Bjorndal, K. (Ed.). The Biology and 
Conservation of Sea Turtles. Smithsonian Institute Press, Washington D.C. (Papers presented at The World Conference on Sea Turtle Conservation, Nov. 26-30, 1979, Washington D.C.).

11. Cogger, H. (1979). Reptiles and Amphibians of Australia. A.H. and A.W. Reed PTY., Sydney. 2nd Edn.

12. Cornelius, S.E. (in press, 1982). The status of Sea Turtles on the Pacific Coast of Central America. In, Bjorndal, K. (Ed.). The Biology and Conservation of Sea Turtles. Smithsonian Institute Press, Washington D.C. (Papers presented at The World Conference on Sea Turtle Conservation, Nov. 26-30, 1979, Washington D.C.).

13. Duron, M., and Duron, P. (1980). Des Tortues luths dans le pertuis Charentais. Le courrier de la Nature 69:37-41.

14. Frair, W., Ackman, R.G., and Mrosovsky, N. (1972). Bodý temperature of Dermochelys coriacea: warm turtle from cold water. Science 177: 791-793.

15. Frazier, J. (in press, 1982). The status of Marine Turtles in the Western Indian Ocean. In, Bjorndal, K. (Ed.). The Biology and Conservation of Sea Turtles. Smithsonian Institute Press, Washington D.C. (Papers presented at The World Conference on Sea Turtle Conservation, Nov: 26-30, 1979, Washington D.C.).

16. Fretey, J. (1981). In litt., 26 May.

17. Fretey; J., and Lescure, J. (1979). Rapport sur l'étude de la protection des Tortues marines en Guyane francaise. Notes sur le project de réserve naturelle de Basse Mana. Ministere de la Culture et de l'environnement. Direction de la Protection de la Nature. Paris. Pp. 1-56.

18. Green, D.; and Ortiz, F. (in press, 1982). The status of Sea Turtle populations in the central eastern Pacific. In, Bjorndal, K. (Ed.). The Biology and Conservation of Sea Turtles. Smithsonian Institute Press, Washington D.C. (Papers presented at The World Conference on Sea Turtle Conservation, Nov. 26-30, 1979, Washington D.C.).

19. Gudynas, E. (1980). Notes on the Sea Turtles of Uruguay. ASRA Journal 1(3): 69-76.

20. Hendrickson, J.R. (1980). The ecological strategies of sea turtles. Amer. Zool. 20: 597-608.

21. Hendrickson, J., and Balasingam, E. (1966). Nesting beach preferences of Malayan sea turtles. Bull. Nat. Mus. Singapore. 33(10): 69-76.

22. Hildebrand, H.H. (in press, 1982). A historical review of the status of Sea Turtle populations in the western Gulf of Mexico. In, Bjorndal, K. (Ed.). The Biology and Conservation of Sea Turtles. Smithsonian Institute Press, Washington D.C. (Papers presented at The World Conference on Sea Turtle Conservation, Nov. 26-30, 1979, Washington D.C.).

23. Hirth, H.F. (1980). Some aspects of the nesting behaviour and reproductive biology of sea turtles. Amer. Zool. 20: 507-523.

24. Hoffman, T.W. (1981). In litt., 5 March.

25. Honegger, R. (1979). Red Data Book, Vol. 3, Amphibia and Reptilia. IUCN, Gland. (3rd edition, revised).

26. Hughes, G.R. (in press, 1982). The conservation situation of Sea Turtle populations in the southern African region. In, Bjorndai, K. (Ed.). The Biology and Conservation of Sea 
Turtles. Smithsonian Institute Press, Washington D.C. (Papers presented at The World Conference on Sea Turtle Conservation, Nov. 26-30, 1979, Washington D.C.).

27. Huntley, B.J. (1972). An interim report on the status of Red Data Book species in Angola. (Unpublished).

28. Kinunen, W., and Walczak, P. (1971). Persian Gulf sea turtle nesting surveys. Report to Iran Game and Fish Dept. Pp $1-12$.

29. Lazell, J.D. (1980). New England waters: Critical Habitat for Marine Turtles. Copeia 1980(2): 290-295.

30. Leary, T.R. (1957). A schooling of leatherback turtles, Dermochelys coriacea, on the Texas coast. Copeia 1957:232.

31. Limpus, C.J. (in press, 1982). The status of Australian Sea Turtle populations. In, Bjorndal, K. (Ed.). The Biology and Conservation of Sea Turtles. Smithsonian Institute Press, Washington D.C. (Papers presented at The World Conference on Sea Turtle Conservation, Nov. 26-30, 1979, Washington D.C.).

32. MacKinnon, J. (1981). In litt., 7 May.

33. Marquez, M.R., Villanueva, O., and Penaflores, C.S. (1981). Anidacion de la Tortuga Laud (Dermochelys coriacea schlegelii) en el Pacifico Mexico. Ciencia Pesqueras No. 1:45-51.

34. Meylan, A. (in press, 1982). Sea Turtle migration - evidence from tag returns. In, Bjorndal, K. (Ed.). The Biology and Conservation of Sea Turtles. Smithsonian Institute Press, Washington D.C. (Papers presented at The World Conference on Sea Turtle Conservation, Nov. 26-30, 1979, Washington D.C.).

35. Meylan, A. (in press, 1982). Estimation of population size in sea turtles. In, Bjorndal, K. (Ed.). The Biology and Conservation of Sea Turtles. Smithsonian Institute Press, Washington D.C. (Papers presented at The World Conference on Sea Turtle Conservation, Nov. 26-30, 1979, Washington D.C.).

36. Mrosovsky, N. (1980). Thermal Biology of Sea Turtles. Amer. Zool. 20: 531-547.

37. Mrosovsky, N. (1981). 'Plastic Jellyfish'. Marine Turtle Newsletter. 17:5-7.

38. Mrosovsky, N. (1981). Editorial (Leatherbacks in Pacific Mexico). Marine Turtle Newsletter, 18.

39. Nuitja, N.S. (1981). A distribution of sea turtles in Indonesia. Fakultas Perikanan, IPB Typescript. (Report, unpublished).

40. Penaflores, (1981). Pers. comm. cited in ref 45.

41. Petocz, R. (1981). In litt., 6 October.

42. Polunin, N.V.C., and Sumertha Nuitja, N. (in press, 1982). Sea Turtle populations of Indonesia and Thailand. In, Bjorndal, K. (Ed.). The Biology and Conservation of Sea Turtles. Smithsonian Institute Press, Washington D.C. (Papers presented at The World Conference on Sea Turtle Conservation, Nov. 26-30, 1979, Washington D.C.).

43. Pritchard, P.C.H. (1971). The Leatherback or Leathery Turtle Dermochelys coriacea. IUCN Monograph No. 1. International Union for Conservation of Nature and Natural Resources, Gland, Switzerland.

44. Pritchard, P.C.H. (1979). Encyclopedia of Turtles. T.F.H. Publications, Hong Kong and New Jersey. 
45. Pritchard, P.C.H., and Cliffton, K. (1981). Final Report. Research and Conservation of Sea Turtles in Pacific Mexico, 1980-1981. WWF Project No. 1812 (note Appendix 1. Pritchard, P.C.H. Nesting of the Leatherback Turtle, Dermochelys coriacea, in Pacific Mexico, and a new estimate of the world population of the species; submitted to Copeia).

46. Ross, J.P. (in press, 1982). Historical decline of Loggerhead, Ridley and Leatherback Sea Turtles. In, Bjorndal, K. (Ed.). The Biology and Conservation of Sea Turtles. Smithsonian Institute Press, Washington D.C. (Papers presented at The World Conference on Sea Turtle Conservation, Nov. 26-30, 1979, Washington D.C.).

47. Ross, J.P. (in press, 1982). The Leatherback Sea Turtle, Dermochelys coriacea, nesting in the Dominican Republic. Special Bulletin Mus. Comp. Zool., Harvard (E.E. Williams commemorative issue).

48. Salm, R.V. (1981). In litt, 1 October.

49. Salm, R.V. (1981). Trengganu meets competition: does Irian Jaya harbour southeast Asia's densest Leatherback nesting beaches? Conservation Indonesia (Newsletter of WWF Indonesia Programme) 5(3): 18-19.

50. Sella, J. (in press, 1982). The Sea Turtles in the eastern Mediterranean and Northern Red Sea. (not seen, cited in ref. 59).

51. Schulz, J.P. (1975). Sea Turtles nesting in Surinam. Zoologische Verhandelingen (Leiden) 143.

52. Schulz, J.P. (in press, 1982). Status of Sea Turtle populations nesting in Suriname. In, Bjorndal, K. (Ed.). The Biology and Conservation of Sea Turtles. Smithsonian Institute Press, Washington D.C. (Papers presented at The World Conference on Sea Turtle Conservation, Nov. 26-30, 1979, Washington D.C.).

53. Siow, K.T. (1981). In litt., 19 April.

54. Siow, K.T. and Moll, E.O. (in press, 1982). Status and conservation of estuarine and sea turtles in West Malaysian waters. In, Bjorndal, K. (Ed.). The Biology and Conservation of Sea Turtles. Smithsonian Institute Press, Washington D.C. (Papers presented at The World Conference on Sea Turtle Conservation, Nov. 26-30, 1979, Washington D.C.).

55. Siow, K.T. (undated). Pers. comm. cited in ref 34.

56. Cornelius, S.E. (1981). In litt., 31 December.

57. Spring, S. (1980). Turtles, Men and Magic. Division of Wildlife, Port Moresby, Papua New Guinea.

58. Spring, S. (in press, 1982). Status of Marine Turtle populations in Papua New Guinea. In, Bjorndal, K. (Ed.). The Biology and Conservation of Sea Turtles. Smithsonian Institute Press, Washington D.C. (Papers presented at The World Conference on Sea Turtle Conservation, Nov. 26-30, 1979, Washington D.C.).

59. Sternberg, J. (1981). The worldwide distribution of Sea Turtle nesting beaches. Center for Environmental Education, Washington D.C.

60. Vaughan, P.W. (1981). Marine Turtles: a review of their status and management in the Solomon Islands. Ministry of Natural Resources, Honiara, Solomons.

61. Bruno, S. (1970). Anfibi e rettili di Sicilia (studi sulla fauna 
erpetologica italiana XI). Atti della Acc. Gioenia di Scienze Naturali Catania, 2: 1-144.

62. Chu-chien, Huang (in press 1982). Distribution and population dynamics of the Sea Turtles in China seas. In; Bjorndal, K. (Ed.). The Biology and Conservation of Sea Turtles. Smithsonian Insitute Press, Washington D.C. (Papers presented at The World Conference on Sea Turtle Conservation, Nov. 26-30, 1979, Washington D.C.).

63. Proud, K. (1981). In litt., 12 May.

64. De Silva, G.S. (1978). Turtle notes (sighting of Dermochelys in Sabah waters). Borneo Research Bull. 10(1): 23-24.

65. Schulz, J.P. (1979). Notes on turtles nesting in Guyana and French Guiana. Paper distributed at World Conference on Sea Turtle Conservation, Washington D.C., 1979, Pp. 1-2.

66. Lund, F. (1978). Atlantic Leatherback account, in Mc Diarmid, R.W. (Ed.), vol. 3, Amphibians and Reptiles, in series Rare and Endangered Biota of Florida, P.C.H. Pritchard (Ed.), University Presses of Florida.

67. Brongersma, L.D. (1969). Miscellaneous notes on Turtles. II A-B. Proc. Koninkl. Nederl. Akad. van Wetenschappen. Amsterdam. Ser.C. 72(1): 76-102.

68. Pritchard, P.C.H. (1976). Post-nesting movements of marine turtles (Cheloniidae and Dermochelidae) tagged in the Guianas. Copeia 1976(4): 749-754.

69. Ross, J.P. and IUCN/SSC Marine Turtles Group (unpublished report, 1978). Present status of Sea Turtles - a summary of recent information and conservation priorities.

70. Mrosovsky, N. (1979). Editorial. Marine Turtle Newsletter. No. 13: 1-4.

71. Anon. (1982). WWF Annual Report for 1981 on Project 1024.

72. Anon. (1981). Turtle survey in Kerala. WWF India Newsletter 2(3) No 38: 14.

73. Marquez, M.R. (1978). Natural Reserves for the conservation of marine turtles in Mexico. Florida Marine Research Publications.

74. Hurtado, G.M. (1982). Pers. comm. to Marquez, M.R.

75. Marquez, M.R. (1982). In litt. 26 Feb. (comments on preliminary draft of RDB account for Dermochelys).

76. Meylan, A. (1982). In litt. February.

77. Balazs, G.H. (1982). Squid driftnet Fishery threatens Leatherback Turtles. Manuscript submitted to Oryx.

78. Pritchard, P.C.H. (1982). In litt., 2 February, $\overline{(\mathrm{com} m e n t s ~ o n ~}$ preliminary draft of RDB account for Dermochelys).

79. Hughes, G.R. (1982). In litt., 22 February, (comments on preliminary draft of RDB account for Dermochelys).

80. Petocz, R. (1982). In litt., 9 February, (comments on preliminary draft of RDB account for Dermochelys).

81. Maxwell, F.D. (1911). Reports on inland and sea fisheries in the Thongwa, Myaungmya, and Bassein districts and the turtle banks of the Irrawaddy division. Rangoon, Government Printing Office. 5 pp.

82. Siow, K.T. (1982). In litt. 8 February (comments on a preliminary draft of RDB account for Dermochelys).

83. Siow, K.T. (1978). Leathery Turtle (Dermochelys coriacea) conservation programme on Rantou Abang, the State of Trengganu, Malaysia. First Marine Science Conference 'Our Seas in Perspective'. 5-6 August.

84. Anon. (in press, 1982). Sea Turtle Conservation Strategy. 
(Conservation and management strategy prepared for 1979 World Conference on conservation of Sea Turtles, Nov. 26-30, Washington D.C.). In Bjorndal, K. (Ed.), The Biology and Conservation of Sea Turtles, Smithsonian Institute Press, Washington D.C.

85. Ross, J.P. (1982). In litt. 20 February (comments on a preliminary draft of RDB account for Dermochelys).

86. Balazs, G.H. (1982). In litt. 23 February (comments on a preliminary draft of RDB account for Dermochelys).

87. Hodge, R.P. (1979). (Range extension record for Dermochelys). Herp. Rev. 10(3):102.

88. Limpus, C.J., and McLachlan, N.C. (1979). Observations on the Leatherback Turtle, Dermochelys coriacea (L.), in Australia, Aust. Wildl. Res., 6:105-116.

89. Pritchard, P.C.H. (1980). Dermochelys coriacea. Catg. Amer. Amphib. Rept. 238.1-4.

90. Hughes, G.R. (in press, 1982). Nesting cycles in Sea Turtles - typical or atypical? In, Bjorndal, K. (Ed.) The Biology and Conservation of Sea Turtles. Smithsonian Institute Press, Washington, D.C.

91. Salm, R.V. (1982). In litt., 27 January (comments on a preliminary draft of RDB account for Dermochelys).

92. Carr, A. (1982). In litt., 9 February (comments on a preliminary draft of RDB account for Dermochelys).

93. Morreale, S.J., Ruiz, G.J., Spotila, J.R., and Standora, E.A. (1982). Temperature-dependent sex determination: current practices threaten conservation of sea turtles. Science, 216:1245-1247. 

Carettochelys insculpta Ramsay 1886

Order TESTUDINES

SUMMARY A moderate size aquatic species inhabiting rivers, grassy swamps and lagoons, in the southern lowlands of New Guinea, and recently discovered in the Northern Territory of Australia. No precise populations estimates available, may be locally moderately common. Omnivorous. Females emerge from the upper reaches of rivers in large numbers at night to lay eggs (clutch 15-34) in sand or mudbanks exposed in the dry season, also nests on the coast in places. Turtles and eggs are traditionally harvested. Stereotyped nesting habits render the species liable to over-exploitation. Biology and population status require investigation, with a view to long-term management and conservation. A highly distinctive species, the only living species of a widespread family known from Tertiary fossils.

DISTRIBUTION Present in rivers and lagoons in the southern lowlands of New Guinea, notably the rivers draining into the Gulf of Papua, including the entire Fly River basin at least as far north as Kiunga, and also the smaller rivers of the Western Province (Papua New Guinea) draining into the Torres Straits. Extends eastward to the Vaillala River, draining into the eastern Gulf (8), and westward to Danau Yamur (Lake Jamur) in western Irian Jaya (1). Distribution in Irian Jaya is poorly known. The species has recently been discovered in several rivers in the Northern Territory of Australia, including the Daly, Victoria and Alligator river systems (although breeding has not yet been confirmed) (1).

POPULATION Population status is poorly known and requires investigation. No precise estimates available. The species was long considered one of the rarest turtles in the world, but this was at least partly due to lack of data. Large numbers are said to breed in the upper reaches of the Fly River and other rivers, including the Strickland, draining into the Gulf of Papua, while large numbers of part grown animals are found in the mangroves of the Fly Delta (4). Reported to be moderately common in certain rivers, such as the middle Fly and the Aramia (4), and in Lake Jamur in Irian Jaya (1). However, in the Kikori River District (Gulf Province, P.N.G.) local inhabitants report that the population has been severely depleted over the last 20 years (8), and the smaller populations in Western Province appear to be declining (7). Also reported rare in Irian Jaya, with a sparse and limited distribution area (10).

HABITAT AND ECOLOGY A moderately large aquatic freshwater or estuarine turtle, generally to c $46 \mathrm{~cm}$ carapace length and over $15 \mathrm{~kg}$ weight (4), one female from P.N.G. reached $56.3 \mathrm{~cm}$ length and $22.5 \mathrm{~kg}(8)$. Occurs in rivers (including estuarine stretches), grassy lagoons, swamps, lakes and water-holes. In the Kikori River District adult specimens are typically found at the mouths of rivers in the Delta areas. The vegetation in these areas mainly consists of Sonneratia, Pandanus and Nipa species. Sub adults are normally found further inland where they are frequently caught in small creeks by prawn fishermen (8).

The species is ominivorous but predominantly vegetarian. In the Gulf Province of 
P.N.G. the major portion of the diet consists of the fruit of mangrove Sonneratia species, supplemented with various other plant and animal material (9). In Australia the main constituent appears to be fruits of Pandanus, also animals such as molluscs, water beetles and other insects (9).

Information regarding mating habits is very scanty. The Kiwai people of the Fly River maintain that this turtle mates on the mud banks on the riverside. The nesting season in Australia has not been identified but in the Gulf Province, P.N.G., normally takes place during the dry season, in mid-October to mid-February (8). During this period females migrate up the rivers to lay their eggs on large sand-banks. Nesting also takes place at the mouths of rivers (8), on sandy shores of islands in the Fly River delta (9), and on coastal beaches in the Western Province of P.N.G. (7). The females normally come ashore at night or early morning and excavate a nest cavity that averages $27 \mathrm{~cm}$ in depth, with a mean temperature of $31^{\circ} \mathrm{C}(8)$. No reliable information is avn: ule with regard to nesting behaviour. Locals in the Kikori district report that the females come ashore and excavate a nest with their fore-limbs, and then turn around to lay their eggs. When completed they close the nest cavity with their hind limbs (8). Clutch size ranges from 15-34. Eggs are typically round and hard-shelled, mean size is 43 $\mathrm{mm}$, mean weight $33 \mathrm{~g}(8)$. Although the reproductive potential per female per season is not as yet clear, evidence suggests that at least 2 clutches are produced per season (8). Hatchlings emerge between 114-118 days after laying (data from artificially incubated eggs), and have a mean carapace length of $53 \mathrm{~mm}$ with a mean weight of $27 \mathrm{~g}(8)$.

Adults probably have few natural predators other than man, their large resilient carapace protecting them from predators such as the salt-water crocodile (Crocodilus porosus) and the fresh-water crocodile (C. novaeguineae). However, sub adults may be preyed upon by the above crocodile species and also by sharks. Most mortality occurs at juvenile and egg stages, the major predators other than man being the monitor lizards $\underline{\text { Varanus }}$ indicus, $\underline{\mathrm{V}} . \underline{\text { salvator, }}(8)$ and $\underline{\mathrm{V}}$. prasinus (5).

THREATS TO SURVIVAL Continuing traditional hunting of turtles and harvesting of eggs in southern New Guinea constitutes the primary threat to the species. Both are sold from time to time in markets at Maimuru and Kikori, for example, in Papua New Guinea (3). In the Kikori River District, over 5,000 eggs have been sold in Kikori Market between October 1980 and February 1981, and at least 30 adults. Although the latter figure may appear low, especially when compared with the former, this is because most adults caught are eaten in the village rather than taken to the market (8). Methods of capture vary. In the nesting season in the Kikori area, villagers lie in wait for gravid females as they come ashore to lay their eggs. As many as 11 specimens have been observed being caught in this manner by one man in one hour. Out of the breeding season, villagers use a hook and line, baited with a crab or deshelled fresh-water mussel, to catch the turtle. In Western Province natives dig pit-traps on the sand banks during the breeding season (8). Out of season the Bagna people of the Fly River hunt for Pitted-Shell Turtles in the grass swamps. Once a specimen has been located, by pushing a canoe paddle into the mud at the bottom of the swamp, the hunter dives into the water in order to capture it (8). Egg collection is carried out either by lying in wait at night and than capturing the turtle and its eggs, or by following the turtle tracks the next day and discovering the nest, or by systematically prodding the sand bank with a stick or spear. One of the main factors leading to the decline of this species in the Kikori River District is the increase in river traffic. This is due firstly to the advent of outboard motors, and secondly, to the fact that formerly many clans lived in the relatively safe hinterland but now that clan warfare has ceased people have moved to more convenient positions along the river bank (8). 
Although at present habitat destruction is not a threat to the survival of the species, future plans for the development of the Gulf Province include intensive deforestation and a hydroelectric scheme (8).

CONSERVATION MEASURES TAKEN None at present. The presence of the species in certain Wildlife Management Areas in P.N.G. may protect it from non-native hunting pressures (7).

CONSERVATION MEASURES PROPOSED Distribution, population status and extent of utilization are very poorly known in Irain Jaya, these data are required. Further information on biology and distribution is also required in Papua New Guinea and Australia. The IUCN/SSC Freshwater Chelonian Specialist Group plans a high priority project on ecology, reproduction, and economic potential of long-term management/conservation of Carettochelys.

CAPTIVE BREEDING No information. Few specimens in captivity (7).

REMARKS The stereotyped mass nesting habits render Carettochelys (like Batagur, most Podocnemis, and most sea turtles) extremely susceptible to excessive predation, particularly by humans. Basic field information is necessary before populations, and pressures on them, can be assessed. The potential exists for utilizing $C$. insculpta and under sustainable yield management to provide a valuable protein source for local inhabitants.

C. insculpta is the only extant species of a once widespread family known from early Tertiary fossils in southern Asia, Europe and North America. The species is highly distinctive morphologically and of great zoologial interest. The lack of carapace scutes is a resemblance to the soft-shelled turtles (Trionychidae), whereas aquatic locomotion by simultaneous movements of the forelimbs, modified into enlarged pectoral flippers, is a resemblance to sea turtles. Carettochelys and a soft-shell Pelochelys are the only cryptodiran turtles (other than sea turtles) to reach Australasia, otherwise inhabited by pleurodires (sidenecked turtles).

This account is based on a draft very kindly provided by M.R. Rose with additional data from F. Parker and A. Rhodin.

REFERENCES 1. Brongersma, L.D. (1958). The animal world of Netherlands New Guinea. J.B. Wolters, Groningen.

2. Cogger, M.G. (1979). Reptiles and Amphibians of Australia. A.H. and A.W. Reed, Sydney. (Second edition, revised).

3. De Rooij, N. (1915). Reptiles of the Indo-Australian Archipelago. Vol. I. Lacertilia, Chelonia, Emydosauria. E.J. Brill, Leiden. (reprinted 1970, A. Asher, Vaals)

4. Parker, F. (1981). Draft Red Data Book account of Carettochelys insculpta, 14 February.

5. Pernetta, J.C. and Burgin, S. (1980). Census of crocodile populations and their exploitation in the Purari River area. Purari River (Wabo) Hydroelectric Scheme. Environmental Studies, Vol.14. Office of the Environment, Government of Papua New Guinea.

6. Pritchard, P.C.H. (1979). Encyclopedia of Turtles T.F.H. Publications, New Jersey and Hong Kong.

7. Rhodin, A.G.J. (1981). In litt., 7 May.

8. Rose, M.R. (1981). Draft Red Data Book account of Carettochelys insculpta, 21 April. 
9. Schodde, R., Mason, I., and Wolfe, T.O. (1972). Further records of the Pitted-shelled Turtle (Carettochelys insculpta) from Australia. Trans. R. Soc. S. Aust. 96(2): $115-117$.

10. Anon. (1978). Pendomen Pengelolaan Satwa Langka Di Indonesia. Jilid I; Mammalia, Reptilia dan Amphibia. Direktorat Jenderal Kehutanan (Direktorat Perlindungan dan Pengeawetan Alam). Bogor, 103pp. 
Trionyx nigricans Anderson 1875

Order TESTUDINES

Family TRIONYCHIDAE

SUMMARY A large freshwater turtle, existing only as a single semi-captive population comprising 150-200 individuals, in a large artificial pond associated with the shrine of the Islamic Saint Byazid Bostami at Nasirabad, near Chittagong in southeast Bangladesh. The species appears to depend largely on food bought by visitors to the shrine and given to the turtles. Nesting probably occurs in the sides of the pond. Water conditions appear unhygienic, and all old turtles have skin disease evident on the head, neck and feet. The turtles are strictly protected at the shrine, but to alleviate the risk of serious disease decimating the population, a second colony could be established. Basic biological data are required. Listed on CITES Appendix 1.

DISTRIBUTION Restricted to an artificial pond (tank) associated with the shrine of the Islamic saint Hazrat Sultan Byazid Bostami, on a hillock at Nasirabad, about four miles northwest of Chittagong in southeast Bangladesh (1).

POPULATION The present population is estimated to include 150-200 individuals, comprising 30-40 young, 60-90 juveniles above $20 \mathrm{~cm}$ in shell-length, and 60-70 adult and old turtles (1). In 1970 the population was reported to include several hundred individuals (source quoted in 1). It is not clear how accurate the latter estimate is, nor if there has been a real decline in numbers.

HABITAT AND ECOLOGY A large freshwater turtle, up to around $81 \mathrm{~cm}$ in length (4). The pond at the Bostami shrine may have been excavated centuries ago, with the purpose of storing rain-water from the hill for drinking, cooking, and washing before prayer at the mosque. It has since been excavated and enlarged several times, and is currently about $50 \times 100 \mathrm{~m}$ in extent. The banks have two tiers, the highest has a $3 \mathrm{~m}$ wall on two sides, the second has no walls but gently sloping sides leading to the bottom of the pond, also about $3 \mathrm{~m}$ in total depth. There are flights of steps on two sides, allowing visitors access to feed the turtles, and the turtles themselves have access to the adjacent hillside through an opening in the surrounding wall (1).

The water is extremely turbid, although less so when water levels are high (to $\mathrm{c} 5$ $\mathrm{m}$ ) during the monsoon. During the dry season the highest tier dries up entirely and the level drops to $\mathrm{c} 2.5 \mathrm{~m}$. The pond lacks vegetation entirely. Some fish species have been introduced into the pond, including Tilapia nilotica, Labeo spp., and other carp; these are often harvested. Smaller fishes, crabs and prawns may be of natural occurrence (1).

Trionyx nigricans depends almost entirely on food supplied artificially by humans. Visitors to the shrine may purchase a variety of items, including cattle offal, plantains, prawns and fish fry. This food may be offered on the end of wooden skewers, or simply tossed into the water (1).

It was reported at the beginning of this century (2) that female turtles leave the 
pond to lay their eggs on the nearby hillside. This might have been true then, but at present they probably lay in the sides of the pond (1).

THREATS TO SURVIVAL The species is not currently threatened by any extrinsic factor, but is inherently at risk because of its extremely small population, restricted to a single pond. The rather unhygienic conditions in which the turtles exist would seem to be conducive to disease. All old individuals have a skin disease evident on the head, neck and feet (1). The possibility of serious disease affecting the entire population must be considered (3).

CONSERVATION MEASURES TAKEN The turtles are venerated by the Islamic population and are generally held to be associated with the saint Byazid Bostami. They are strictly protected at the shrine (1).

Listed on Appendix I of the Convention on International Trade in Endangered Species of Wild Fauna and Flora (CITES). Appendix I listing requires that trade in the taxon and its products is subject to strict regulation by ratifying states and international trade for primarily commercial purposes is prohibited.

CONSERVATION MEASURES PROPOSED To minimize the risk of disease decimating the single population, it would be prudent to consider establishing a second population in another pond. The reproductive biology of the species is virtually unknown, as is the extent to which survival is dependent on artificial feeding. These, and other biological parameters, should be investigated.

CAPTIVE BREEDING The entire population exists in a state of semi-captivity.

REMARKS The origin of this population is entirely unknown. The turtles appear to have been introduced to the Bostami pond (1), the first specimens known to science were from this pond ('Chittagong Tanks'), and no specimens are known from elsewhere. Possibly the present population is descended from introduced individuals of the more widespread Trionyx gangeticus, which $I$. nigricans resembles in many respects, or from an unknown species of Trionyx that is now extinct.

REFERENCES 1. Ali Reza Khan, Md. (1980). The 'holy' turtle of Bangladesh. Hornbill $1980(4): 7-11$.

2. Annandale, N. (1912). The Indian Mud-Turtles (Trionychidae). Rec. Ind. Mus. 7: 151-178.

3. Moll, E.O. (1981). Pers. comm., 28 April.

4. Pritchard, P.C.H. (1979). Encyclopedia of Turtles. T.F.H. Publications, Hong Kong. 
RERE (Madagascar)

Erymnochelys madagascariensis (Grandidier 1867)

(Synonym: Podocnemis madagascariensis)

Order TESTUDINES

Family PELOMEDUSIDAE

SUMMARY An endemic Madagascar aquatic turtle. Present in large slow-moving rivers, backwaters and lakes in the west of the island, from the Mangoky river in the southwest to the Sambirano in the north. Found in savanna and forest regions, up to $800 \mathrm{~m}$. No precise population estimates available, but widely considered rare, and may be declining. Clutch comprises up to 24 eggs, $30 \times 40 \mathrm{~mm}$, number of clutches per year unknown. Biology little known. Adults are exploited for food, also suffering from habitat modification. Biology and status require investigation. A species of great zoogeographic interest, most closely related to South American turtles of the genus Podocnemis.

DISTRIBUTION An endemic Madagascar species. Present in the more extensive aquatic habitats at low to moderate altitudes in the west and northwest of the island from the Mangoky river and Lake Ihotry near Morombe in the southwest, northward to the Sambirano basin west of the Massif de Tsaratanana $(3,4,8)$.

POPULATION No precise estimates available. Widely considered rare $(1,2,3,4)$ and reported to be declining $(2,3)$, but also reported abundant (date unknown) in permanent lakes along the Tsiribihina and its affluents (8). Population status requires investigation.

HABITAT AND ECOLOGY A moderate size aquatic species, sometimes reaching $500 \mathrm{~mm}$ in length and $15 \mathrm{~kg}$ (8), inhabiting quiet slow-moving stretches of large rivers, also backwaters, lakes and pools. Most widely distributed in the lowlands, but may extend to $800 \mathrm{~m}$ (4). Present in both savanna and forest regions. Much of the range has a dry tropical climate with eleven to eight dry months, but a summer monsoon affects the northwest where the dry period last five to six months. Annual rainfall ranges from around $500 \mathrm{~mm}$ in the southwest to around $1,600 \mathrm{~mm}$ in the northwest (8). Populations subject to low winter temperatures may aestivate in the mud during this period, and emerge as temperatures rise with the start of the summer rainy season (8).

Carnivorous in habits, the species feeds on molluscs, arthropods, fish and amphibians (8).

Egg-laying has been observed in July and in January. The clutch comprises up to 24 oval eggs, $39-42 \mathrm{~mm}$ long by $29-30.5 \mathrm{~mm}$ (8). Number of clutches per year unknown.

THREATS TO SURVIVAL Adults are exploited for food $(3,4,8)$. Large numbers are eaten by the riverine Sakalava people and others living around Lake Kinkony (near Soalala in the northwest), where the surroundings of the village huts may be strewn with empty sun-bleached Erymnochelys carapaces (8). Habitat modification, notably transformation of river banks into rice plantations (impairing reproduction), is a second cause of decline $(2,3)$. It has been suggested 
(6) that the Madagascar form of Pelusios castaneus, of a widespread and expansive African genus, may eventually out-compete E. madagascariensis (although at present they occur on opposite sides of the island).

CONSERVATION MEASURES TAKEN Since 1974 not sold in Antananarivo market, and not supposed to be served in hotels or restaurants. However, in 1976 it was still to be found on butchers' stalls in the Maevatanana market, for example (4).

All species of Podocnemis are listed on Appendix II of the Convention on International Trade in Endangered Species of Wild Fauna and Flora (CITES); until recently Erymnochelys madagascariensis was generally also regarded as a species of Podocnemis, and the intention may have been to list this species also, regardless of a change in generic assignment. This point requires clarification. It has been recommended that the species should be listed on Appendix II (3). Appendix II listing implies that commercial trade is allowed providing a permit from the country of export is obtained, this can provide a method of monitoring trade levels.

CONSERVATION MEASURES PROPOSED A thorough investigation of the biology and population status is required, in part to provide a basis for rational management of the species as a valuable food resource. Protection should be made effective in nominally protected areas, such as Lake Kinkony (3).

\section{CAPTIVE BREEDING No information. Probably difficult (3).}

REMARKS This account is based primarily on data kindly provided by Ch. Blanc and R. Bour.

This species is of very great zoological interest as the only living Podocnemis-like turtle outside South America. It was long assigned to the South American genus Podocnemis by most authorities, but recent karyological (7) and serological (5) data, combined with certain morphological differences, have led to assignment of madagascariensis to a separate monotypic genus Erymnochelys. Fossil Podocnemis turtles are known from Africa (where the genus is now extinct) and South America.

REFERENCES 1. Andrianarivo, J. (1981). In litt., 12 January.

2. Blanc, C. (1981). In litt., 16 January.

3. Blanc, C. (1981). In litt., 24 February.

4. Bour, R. (1981). In litt., 16 February.

5. Frair, W., Mittermeier, R.A., and Rhodin, A.G.J. (1978). Blood biochemistry and relations among Podocnemis turtles (Pleurodira, Pelomedusidae). Comp. Biochem. Physiol 6l(B): 139-143.

6. Pritchard, P.C.H. (1979). Encyclopedia of Turtles. T.F.H. Publications, New Jersey and Hong Kong.

7. Rhodin, A.G.J., Mittermeier, R.A., Gardner, A.L., and Medem, F. (1978). Karyotypic analysis of the Podocnemis turtles. Copeia 1978 (4): 723-728.

8. Tronc, E., and Vuillemin, S. (1974). Contribution a l'étude de la faune endémique Malgache: étude ostéologique de Erymnochelys madagascariensis Grandidier, 1867 (Chélonien, Pelomedusidae). Bull. Acad. Malg. 51(1): 189-224. 
SUMMARY A medium size freshwater turtle, the smallest species of the genus, largely restricted to black water lakes, streams and flooded forest in the Rio Negro system of northwest Brazil. Also extends into southern Venezuela in the upper Orinoco, and a few other areas in Amazonia. Predominantly herbivorous. Nests singly or in small groups, on small partly-vegetated beaches. Clutch comprises 5-14 eggs, clutches per year unknown. Heavily exploited for food. Existing legislation, nominally protecting the species, should be better enforced. Rational utilization could provide a continued food resource in the protein-poor Rio Negro area and in the upper Orinoco drainage. Listed on CITES Appendix II.

DISTRIBUTION Largely restricted to the 'black water' Rio Negro in northwest Brazil, but also extends into the Casiquiare and upper Orinoco in southern Venezuela, and a few isolated reports exist for other parts of Amazonia $(1,3)$.

POPULATION Little information available. Reported in 1974 (3) to be apparently still abundant, especially in the smaller black water tributaries of the Rio Negro. However, it has been suggested $(2,3)$ that the species may require Vulnerable status due to heavy and largely uncontrolled hunting.

HABITAT AND ECOLOGY A medium size freshwater turtle, the smallest member of the genus Podocnemis, rarely exceeding $30 \mathrm{~cm}$ leng th or two kg weight $(1,3)$. Mainly restricted to nutrient-poor 'black water' lakes, rivers and streams, and igapo forest. Rarely found in the main course of the Rio Negro. Omnivorous but predominantly vegetarian, feeding on aquatic plants and fruits that fall into the water. Nesting season in Brazil is August-September, and females may also lay during a slight rise in river level that occurs in early November (4). Nests in December on the Rio Atabapo in Venezuela, on white sand beaches (5). Nests singly or in small groups, usually at night on small sandy shrub and grass-covered areas (campinas), also on low beaches (4). The clutch comprises 5-14 eggs (1), numbers of clutches per season not known. The eggs are either hard-shelled or flexible, small relative to those of other Podocnemis, and distinctly elongate.

THREATS TO SURVIVAL Adults and eggs are heavily exploited for food. Animals may be caught by harpoon, net or baited line, and females are taken on nesting grounds. There is little or no control over exploitation in the smaller and more remote settlements (1). This species forms a major part of the diet of indigenous peoples in black water areas of Venezuela's Territorio Federal Amazonas, where it is the second most eaten chelonian (5).

CONSERVATION MEASURES TAKEN Nominally protected by legislation in all countries in which it occurs (1).

Listed in Appendix II of the Convention in Interational Trade in Endangered Species of Wild Fauna and Flora (CITES). Appendix II listing implies that commercial trade is allowed providing a permit from the country of export is obtained, this can provide a method of monitoring trade levels.

CONSERVATION MEASURES PROPOSED Existing legislation should be better 
enforced, in particular eggs and nesting females require strict protection. Data on population sizes and ecology are required as a basis for rational exploitation (1).

CAPTIVE BREEDING Not hardy in captivity, so captive breeding probably not feasible (1). No other information.

REMARKS This species could continue to be a significant food resource in the protein-poor Rio Negro area, given proper management (1).

REFERENCES 1. Mittermeier, R.A. (1978). South America's River Turtles: saving them by use. Oryx 14(3): 222-230.

2. Mittermeier, R.A. (1981). In litt., 2 November.

3. Mittermeier, R.A., and Wilson, R.A. (1974). Redescription of Podocnemis erythrocephala (Spix, 1824) an Amazonian Pelomedusid turtle. Papéis Avulsos Zool., S. Paulo. 28(8): 147-162.

4. Vanzolini, P.E. (1977). A brief biometrical note on the reproductive biology of some South American Podocnemis (Testudines, Pelomedusidae). Papéis Avulsos Zool. S. Paulo. 31(5): 79-102.

5. Paolillo, A. (1982). In litt., 14 January. 
TARTARUGA (Brazil)

CHARAPA (Peru)

ARRAU (Venezuela)

Podocnemis expansa (Schweigger 1812)

Order TESTUDINES

Family PELOMEDUSIDAE

SUMMARY The largest species of Podocnemis, occasionally reaching around 1 metre in length. Formerly widespread throughout the Amazon and Orinoco drainages. Present in Bolivia, Brazil, Colombia, Guyana, Peru, Venezuela, probably Ecuador, possibly French Guiana and Surinam. Extremely abundant in previous centuries, already declining in the latter part of the 19th century, now severely depleted through most of the range and locally extinct. Occurs in large rivers, oxbow lakes, lagoons and flooded forest. Individuals move out of major river courses during flood periods and re-enter them as the sandy nesting beaches become exposed in the dry season. Females gather in large numbers off the nest beach to bask, and emerge in large groups to lay eggs. The clutch of $50-150$ eggs is laid in a deep nest chamber excavated by the hindlimbs. The nest area is carefully covered and compacted. Although widely utilized by indigenous peoples, decline of the species is attributed to extreme exploitation of eggs and adults for food and oil following European colonization. Nominally protected by legislation in Brazil, Colombia, Peru and Venezuela. This is largely unenforced and effective protection is limited to certain nesting beaches in Brazil, within the IBDF management programme, and Venezuela. The IBDF action involves translocating emerged hatchlings in an attempt to minimize mortality at this stage. Listed on CITES Appendix II. Exploitation should be limited to allow recovery of depleted populations, and research and management developed to allow rational utilization of what could constitute a valuable food source.

DISTRIBUTION Widespread in the Amazon and Orinoco drainages. Present in Bolivia, Brazil, Colombia, Peru, Venezuela, probably Ecuador; also present in the Essequibo system of Guyana, and perhaps (presence unconfirmed) extends into Surinam and French Guiana $(11,12,15)$.

POPULATION Very abundant in previous centuries $(4,5,10,11,16,17)$, Podocnemis expansa was already rapidly declining in the latter half of the nineteenth century, and is now severely depleted throughout most of its range $(10,11,14,16,17,19)$.

Brazil In Brazil, the core of the range, many former nesting beaches are deserted (20), it is rare today to find a single P. expansa in the Upper Amazon (10). The species was still plentiful enough in the mid-19th century on the Rio Madeira for example, for the gathering of nesting females to impede river traffic, and on one occasion (also on the Madeira) rows of turtles eight to ten deep stretched along the waterside for six to seven miles (16). Similarly, in the late eighteenth century P. expansa were reported to be exceptionally large and abundant around Itacoatiara (Amazonas), they were still an important dietary item in the mid-nineteenth century (sources in ref. 17), but today they are virtually eliminated and the few that appear on the market come mainly from the Rio Uatuma, $80 \mathrm{~km}$ away (17). Due in part to the efforts of the Instituto Brasileiro de Desenvolvimento Florestal (IBDF) in preventing hunting and protecting P. expansa nesting beaches, populations elswhere in Brazil, although depleted, appear to be 
now stable or increasing. In $1978,480,786$ hatchlings were recorded (2) at Leonardo Beach on the Rio Trombetas, corresponding to nesting of approximately 4,925 adult females. These data suggest an increase of around $50 \%$ when compared with 1976 IBDF figures recording around 212,000 hatchlings (14). However, these apparent increases probably reflect nesting females moving into the relatvely undisturbed nesting beach from other areas, as there has not yet been time for the reproductive segment of the population to have increased (3). On other rivers a total of approximately 458,000 hatchlings were counted in 1979; Rio Tapajos - 18,000; Xingu - 146,000; Purus - 49,000; Jurua - 80,000; Guaporé 12,000; and Branco - 153,000. There are no data on total population sizes in these areas, there is a very high mortality of emerged hatchlings but these numbers may give some idea of the number of nesting females involved. Overall, population numbers appear stable on the Guaporé, Branco, Purus and Jurua, and increasing on the Trombetas, Tapajos and Xingu (14).

Peru The species is rare in most areas of Amazonian Peru, but viable populations still exist in a few isolated areas, for example in the National Reserve of Pacaya-Samiria $(18,19)$.

Venezuela The overall decline of the species is exemplified by data from the upper Orinoco in Venezuela. Whereas Humboldt estimated 330,000 animals in 1799 and 1800 , numbers were down to an estimated 123,600 in 1945, 36,100 in 1950, and 13,800 in $1965(11,13)$. Surveys in 1981 indicate that the present population may be only one-third (1/3) of that estimated in 1965 (22). The site of this investigation, Playa del Medio on the Rio Orinoco, is the major expansa nesting area in Venezuela (22). The 1981 season was atypical climatically, with unexpected summer flooding, and it is possible the results were affected by this; however, the results are thought to adequately represent the general situation in Venezuela (22). Pararuma beach, formerly one of the most important sites in Venezuela, had only 30 nesting animals in 1981 (22). Another population, on the Rio Meta along part of the Colombia-Venezuela border, is now also greatly reduced (22).

No details available on populations in Colombia, where decline has occurred (9), or other peripheral populations in Bolivia, Ecuador and the Guianan region.

HABITAT AND ECOLOGY A large freshwater turtle, by far the largest of the Podocnemis species, a maximum length of $107 \mathrm{~cm}$ has been recorded, (21) although the mean leng th of a more typical sample of 38 was around $70 \mathrm{~cm}$ (20). Males are smaller than females. Individuals may reach $50 \mathrm{~kg}$ (11). Occurs in large rivers, oxbow lakes, and during the flood season, in lakes formed by rivers and in flooded forest areas (igapos) (14). Turtles re-enter rivers at the start of the dry season as nesting beaches become exposed.

Podocnemis species are omnivorous but predominantly vegetarian, feeding on aquatic plants and fruits that fall into the water, but also consuming animal material such as dead fish (11).

The nesting season varies from June - July in the upper Amazon in Brazil, to October - November in the lower Amazon. In the Iquitos region, and the basins of the Rio Tapiche and Rio Pacaya, nesting is in August - September (19). In Venezuela, the species nests from mid-February to early March, when water levels in the Orinoco and its tributaries are at their lowest (hatching here is in early May)(22). On the Rio Trombetas in Brazil the nesting season is in the middle of October, turtles begin to gather off the principal nesting beach (Leonardo's beach) in September. Sand beaches are required. Basking behaviour by the 
females, which can be observed until the end of the laying season, begins 15 days before the season begins. This behaviour occurs during the hottest hours of the day, generally from 10-11 in the morning until 3-4 in the afternoon. At times 500 animals can be seen basking, with others swimming in the shallow water with their heads above water, breathing or watching the beach (14). Mating is also said to occur on the beach (21). Nesting generally begins on October 15 th at night when groups of 25-35 individuals come up to the beach to nest (14).

The turtles emerge silently from the water, led initially by a few individuals, and head toward the higher surfaces of the beach. The actual nesting process is complex, and completion of the nest hole itself may take around 100 minutes (20). An irregular shallow body pit is first scooped out by forceful sweeps of the body and scooping with all four limbs. A deeper pit is then formed, using first one hindlimb then the other, and swinging the body back and forth through $90^{\circ}$ as each hindlimb is used in turn. The finished pit is $70-100 \mathrm{~cm}$ deep and $100-150 \mathrm{~mm}$ in diameter at the mouth. At this stage the turtle's head is about level with the sand surface, and the egg chamber is then formed at the bottom of the pit, partly using the hind margin of the carapace. Egg-laying takes around 15-35 minutes, during this time the body is at an extreme angle, more than $45^{\circ}$ and sometimes almost vertical. The clutch may comprise 50-150 eggs (11), in Peru the range in examined nests was 80-133 (19), mean clutch size on the Rio Trombetas in Brazil is $93,95 \%$ of which hatch after 48 days incubation (14). Number of clutches per year unknown. After egg-laying the nest is filled and smoothly covered, and the turtle returns to the water. As with the River Terrapin Batagur baska, the sand is compacted by the raising and rapid lowering of the shell onto the surface (20), this activity seems less prominent in $\mathrm{P}$. expansa.

Podocnemis expansa and $\mathrm{P}$. sextuberculata are notable in that nesting is restricted to relatively low beaches or bars of pure sand, they are thus particularly vulnerable to fluctuations in water level at the nest site (21). For example, in 1973 all expansa nests on the Rio Trombetas (the largest known present-day nesting area in Brazil) were flooded and destroyed before hatching, and at Playa del Medio on the Venezuelan Orinoco $25-80 \%$ of the annual egg production may be lost in this manner (11). In Venezuela this factor certainly appears to be the principal source of egg and hatchling mortality; natural norf-human predation seems to be much less significant (22). Whereas most Podocnemis nest singly or in small groups, P. expansa is exceptional in nesting in large synchronized aggregations. The social nesting of $\mathrm{P}$. expansa recalls the social nesting of most marine turtles (20), in particular the synchonized mass nesting (arribada) of most Lepidochelys populations. However, it differs in several respects. For example, in P. expansa, nests are concentrated in a restricted area of beach, and the nesting females are highly tolerant of disturbance by other females (20). The reverse is the case in gregarious sea turtles. It may be that only nests (deeper than other Podocnemis) in the given area of beach have a good chance of remaining above rising flood waters.

THREATS TO SURVIVAL The major current threat to the species, apart from natural mortality due to flooding of nests, is the very heavy exploitation of adults (including nesting females) and eggs for food. An adult P. expansa can provide up to $13-14 \mathrm{~kg}$ (30 lb) of meat (16), and this turtle has always been a valuable food resource for the human population, both the local inhabitants and through more distant market outlets $(11,16,17)$. However, the increasing rarity of the species has raised the market price of P. expansa until this food source is out of reach of those people who would most need it. Fifty years ago in Manaus, a large $\underline{P}$. expansa cost the equivalent of US $\mathrm{l}$, , but the present-day equivalent may be up to US $\$ 80$ or $\$ 100(11,17)$. An animal of $30 \mathrm{~kg}$ or more is worth $\$ 150(14)$. In 
Itacoatiara, much closer to remaining expansa localities, the price is still $\$ 60$, and probably fewer than 50 are consumed each year (17). A similar price rise has occurred in Venezuela (16). On the illegal market in Venezuela, one animal can fetch Bs. 400 in Puerto Ayacucho (capital of the Territoria Federal Amazonas); higher prices can be reached, in San Fernando de Apure and Caicara del Orinoco for example (22).

Although expansa is one of several turtles that provided a valuable food resource (also a medium of exchange and a source of raw materials) for the indigenous peoples of Amazonia, and is often embodied in tribal mythology, the intensity of exploitation only rose to critical levels following European colonisation $(16,17)$. European traders and missionaries were perhaps mainly interested in expansa as a source of oil for cooking, lighting and other purposes. The finest oil was prepared by boiling fresh turtle fat, the rest of the turtle was typically thrown away (16). A coarser oil was prepared by crushing eggs. The extent of this exploitation in the eighteenth century was enormous; it was estimated that 5,000 jars of oil were harvested annually from three major nest beaches on the Orinoco, each jar contained 25 bottles, each bottle the contents of about 200 eggs. Depending on the precise clutch size, this would represent the wasted reproductive effort of about 400,000 females $(10,11)$. A similar intensity of exploitation was maintained in the Brazilian Amazon (16,17). The females, after laying, were gathered into artificial enclosures along the rivers to provide a food store, for use notably when fish were harder to catch during the flood periods; it is estimated (17) that two million Podocnemis were killed annually in the mid-eighteenth century in the state of Amazonas alone. Intensive predation on adults and eggs, sustained over three centuries, has brought $P$. expansa to its present severely depleted condition. The survival of the species may be largely due to the introduction of kerosene and vegetable oils in the latter part of the nineteenth century, replacing turtle products (16).

Habitat modification, notably clearance of floodplain forests that provide a food source for $P$. expansa and other Podocnemis, and changes in river regime following construction of hydroelectric dams, constitutes an as yet unquantified threat (17). The expansa population in Venezuela is thought to be seriously affected by the number of motorized cargo-boats travelling daily between Puerto Ayacucho and the lower Orinoco; this traffic causes great disturbance to the nesting beaches during the breeding season, when turtles are aggregating, basking and nesting (22).

CONSERVATION MEASURES TAKEN Nominally protected by legislation in Brazil, Colombia, Peru and Venezuela (11), no data from other countries in the range. This legislation is difficult or impossible to enforce, and effective protection is largely limited to the major nesting beaches in Venezuela (protected by the National Guard) (22) and beaches protected by the Instituto Brasileiro de Desenvolvimento Florestal (IBDF) in Brazil. The latter include beaches on the Rios Trombetas, Xingu, Tapajos, Guaporé, Branco, Purus and Jurua (14). Exploitation is unchecked in other parts of Amazonia (11), in Peru for example, where legislation simply means that trading continues covertly (19). Weak enforcement in Colombia allows smuggling of expansa into adjacent Brazil (6) and Venezuela (9).

In Brazil, the IBDF programme involves strict protection of nesting beaches, from the pre-nesting aggregation of females until hatching of the eggs (14). Hatchlings are protected from predation in enclosed waters until full absorbtion of the yolk sac (assumed to be the greatest attractant to predators), they are then released in shallow water near lakes, far from predators congregated at the nest beach (14). 
This work is financed by Programas de Polos Agropecuarios e Minerais de Amazonia (POLAMAZONIA). The IBDF, assisted by the Universidade de Brasilia, is collecting data on population size and trends, migration, hatchling and adult behaviour, etc., and attempting to develop an economic model relating to the feasibility of rearing turtles (14). If appropriate, IBDF intends to promote captive breeding or some form of husbandry, and to instruct farmers in the necessary techniques. At present there are no data on the effects of the IBDF programme of translocating hatchlings to lakes away from the nest beach. Doubts have been expressed as to the likelihood of such hatchlings finding the traditional nesting areas or establishing a new site, and the success of the programme cannot be confirmed until translocated hatchlings have been observed to breed and nest successfully. The effect of similar efforts in Venezuela in the 1950s and 1960s was uncertain and the schemes were abandoned (16). At present in Venezuela, hatchlings are sometimes rescued from nests in danger of flooding, but the effectiveness of this is unknown (22).

Listed on Appendix II of the Convention on International Trade in Endangered Species of Wild Fauna and Flora. Appendix II listing implies that commercial trade is allowed providing a permit from the country of export is obtained, this can provide a method of monitoring trade levels.

CONSERVATION MEASURES PROPOSED The primary requirements are to limit continuing over-exploitation, continue and extend protection of nesting beaches, and continue ecological studies with a view to rational management $(11,14,16,17,18,19)$. Action in Brazil, Peru and Venezuela provides an essential foundation: Specific data should be sought on the movements and fate of hatchlings translocated in the IBDF programme, to aid in design of future conservation action.

The IUCN/SSC Freshwater Chelonian Specialist Group plans highest priority projects on the ecology and conservation of this and related species.

CAPTIVE BREEDING No information. May be feasible but careful management and utilization of natural population may be the preferable course (11).

REMARKS This species, and other Podocnemis, have potential as a cost-effective, relatively easy to manage, renewable natural resource. They convert otherwise unused vegetable material into animal protein and fats, of great nutritive value to human population in northern South America $(11,16)$. This potential can only be realized if present short-term exploitation is immediately curtailed, and rational management schemes devised to allow adequate recovery of depleted populations.

This account is based in part on information very kindly supplied by L.F.M. de Padua, A. Paolillo, and P. Soini.

REFERENCES 1. Alfinito, J. (1980). A tartaruga verdadeira do Amazonas sua criacao. Belém, FCAP. Servico de Documentacao e Informacao. FCAP Informe Tecnico No.5.

2. Alho, C.J.R., Carvalho, A.G., and Padua L.F.M. (1979). Ecologia da tartaruga da Amazonia e avaliacao de seu manejo na Reserva Biologica de Trobetas. Brazil Florestal 9(38): 29-47. IBDF, Brazil.

3. Ayres, J.M., and Best, R.C. (1979). Strategies for the conservation of the fauna of Brazilian Amazonia. Acta Amazonica 9(4). Suppl: 81-101. 
4. Bates, H.W. (1863). The naturalist on the River Amazon. John Murray, London.

5. Coutinho, J.M.S. (1868). In Goeldi, E.A., ref. 7.

6. Foote, R.W. (undated). In litt., to R. Honegger.

7. Goeldi, E.A. (1906). Chelonios de Brasil. Bol. Mus. Paraense Emilio Goeldi 4: 699-756.

8. Honegger, R. (1979). Red Data Book, Vol 3: Amphibia and Reptilia. IUCN, Gland (third edition revised).

9. Medem, F. (undated). In litt., to R. Honegger, cited in ref. 8.

10. Mittermeier, R.A. (1975). A turtle in every ppt. Animal Kingdom. 78(2): 9-14.

11. Mittermeier, R.A. (1978). South America's River Turtles: saving them by use. Oryx 14(3): 222-230.

12. Mittermeier, R.A. (1981). In litt., 31 January.

13. Ojasti, J. (1971). La tortuga arrau del Orinoco. Defensa de la Naturaleza. 1(2): 3-9.

14. Padua, L.F.M. de (1981). In litt., 16 March.

15. Pritchard, P.C.H. (1979). Encyclopedia of Turtles. T.F.H. Publications, New Jersey and Hong Kong.

16. Smith, N.J.H. (1974). Destructive exploitation of the South American River Turtle. Yearbook, Assoc. Pacific Coast Geographers. 36(c): 85-102. Oregon State Univ. (Reprinted 1975 in Chelonia 2(5): 3-9,30).

17. Smith, N.J.H. (1979). Aquatic turtles of Amazonia: an endangered resource. Biol. Conserv. 16(3): 165-176.

18. Soini, P. (1980). Informe de Pacaya No.2: Reproduccion, Manejo y Conservacion de los Quelonios del genero Podocnemis (Charapa, Cupiso y Taricaya).

19. Soini, P.(1981). In litt., 27 March.

20. Vanzolini, P.E. (1967). Notes on the nesting behaviour of Podocnemis expansa in the Amazon Valley (Testudines, Pelomedusidae). Papéis Avulsos Zool. S. Paulo. 20(17): 191-215.

21. Vanzolini, P.E. (1977). A brief biometrical note on the reproductive biology of some South American Podocnemis (Testudines, Pelomedusidae). Papéis Avulsos Zool., S. Paulo. 31(5): 79-102.

22. Paolillo, A. (1982). In litt., 14 January. 
Podocnemis lewyana Dumeril 1852

Order TESTUDINES

Family PELOMEDUSIDAE

SUMMARY A little known, moderate size, freshwater turtle inhabiting the Rio Magdalena and Rio Sinu drainages in Colombia, isolated from other Podocnemis, all of which occur in Amazonia and the Orinoco region. Prefers rivers with many backwaters and oxbow lakes providing shelter from the current during flooding and aquatic vegetation for food. Rare, declining rapidly in some areas. Eggs and adults are heavily exploited for food by riverine peoples, also sold to merchants in coastal towns. Mainly herbivorous. Two periods of nesting each year, but primarily December-March. Number of clutches per year unknown. Clutch comprises 15-40 round or elliptical eggs. Nominally protected by legislation. Listed on CITES Appendix II. Further information on ecology and status urgently required.

DISTRIBUTION Restricted to the Rio Magdalena and Rio Sinu drainages in Colombia $(5,6)$. The precise distribution limits to the east and west are uncertain, but the species is not present in rivers to the east of Santa Marta (in the east), nor those opening into the Gulf of Uraba (in the west) $(1,2)$. Podocnemis lewyana occurs northwest of the Cordillera Oriental and is thus separate from other Podocnemis, which are distributed in the Amazen and Orinoco drainages.

POPULATION No precise estimates available. Although reported to be still abundant in 1965 (2), more recently said to be rare (4) and declining in some areas (1), declining rapidly in the Magdalena and Sinu (3).

HABITAT AND ECOLOGY A moderate size freshwater turtle (the largest in its area); females may reach to $48 \mathrm{~cm}$ length and over $8 \mathrm{~kg}$, males to over $30 \mathrm{~cm}(2)$. Omnivorous but primarily vegetarian. Occurs in rivers, preferring those with numerous beaches, and many backwaters and oxbow lakes with abundant aquatic vegetation providing both food and shelter from the current during floods (1).

There appear to be two nesting periods, primarily in December-March, and secondarily in July-August. However, it is not known if any given female breeds more than once in a year $(1,2)$. The species prefers to nest in sand beaches on rivers and their major tributaries, but may also nest on stony beaches or pasture near water (2). The nest is $17-30 \mathrm{~cm}$ deep (2). The clutch comprises $15-40$ eggs, depending on the size of the female (2). The eggs are slightly flexible, varying from round to elliptical, $37-38 \mathrm{~mm}$ by $31-45 \mathrm{~mm}$ (1). Breeding biology is poorly known.

THREATS TO SURVIVAL Heavy human exploitation for eggs and meat $(1,2,4,5)$. The species provides a valuable food source for the local riverine population during summer, and is also sold in great quantities to merchants in the coastal towns (2). They are sold in great numbers during Holy Week, but much less than 'Icotea' Pseudemys scripta callirostris (1).

CONSERVATION MEASURES TAKEN Nominally protected by legislation. Listed on Appendix II of the Convention on International Trade in Endangered Species of Wild Fauna and Flora (CITES). Appendix II listing implies that commercial trade 
is allowed providing a permit from the country of export is obtained, this can provide a method of monitoring trade levels.

CONSERVATION MEASURES PROPOSED Further data on ecology and current status are urgently required (1).

The IUCN/SSC Freshwater Chelonian Specialist Group plans a highest priority project on ecology and conservation of this species.

\section{CAPTIVE BREEDING No information.}

REMARKS This species, and other Podocnemis, have potential as a cost-effective, relatively easy to manage, renewable natural resource. They convert otherwise unused vegetable material into animal protein and fats, of great nutritive value to human populations in northern South America (4). This potential can only be realized if present short-term exploitation is immediately curtailed, and rational management schemes devised to allow adequate recovery of depleted populations.

REFERENCES 1. Dahl, G., and Medem, F. (1964). Informe sobre la fauna acuatica del Rio Sinu. Parte II. Los reptiles acuaticos de la hoya del Sinu. Corporaction Autonoma Regional de los valles del Magdalena y del Sinu. C.V.M., Dept. de Investigaciones Ictiologicas y Faunisticas. Pp. 110-152.

2. Medem, F. (1965). Anexo I. Lista de reptiles acuaticos coleccionados durante la expedicion. In, Dahl, G., Medem, F., and Ramos Henao, A. (Eds). El 'Bocachico, contribucion al estudio de su biologia y de su ambiente. Departamento de Pesca de la Corporacion Autonoma Regional de los Valles del Magdalena y del Sinu. C.V.M., Talleres Graficos. Banco de la Republica. Pp. 103-1 10.

3. Medem, F. (1979). In litt., 19 January, to René Honegger.

4. Mittermeier, R.A. (1975). A turtle in every pot. Animal Kingdom (April/May 1975). 78(2): 9-14.

5. Mittermeier, R.A. (1978). South America's river turtles: saving them by use. Oryx 14(3): 222-230.

6. Pritchard, P.C.H. (1979). Encyclopedia of Turtles. T.F.H. Publications, New Jersey and Hong Kong. 
Podocnemis sextuberculata Cornalia 1849

Order TESTUDINES

Family PELOMEDUSIDAE

SUMMARY A moderate size freshwater sideneck turtle, one of the smallest in the genus Podocnemis, present in river systems of the Amazon, Putumayo and Caqueta, in Brazil, southeast Colombia and northeast Peru. No detailed information on population status. Declining in some areas due to heavy exploitation for food. Mainly carnivorous. Nests at night, singly or in groups of three or four, typically on low sand beaches. Probably a single clutch per season, of 6-22 elliptical eggs. Nominally protected by legislation in Brazil, Colombia and Peru. Listed on CITES Appendix II. Present over-exploitation should be curtailed, and studies on ecology and conservation are required.

DISTRIBUTION Present in the river systems of the Amazon, Putumayo and Caqueta, in Brazil, southeast Colombia and northeast Peru.

POPULATION No detailed information available. Since P. sextuberculata is a diffuse-nesting species, it is less susceptible to human predation around nest sites than the social-nesting P. expansa. However, extinction of local populations is possible (5), and it is forecast that unless hunting is controlled $P$. sextuberculata will virtually disappear from the Upper Amazon in fifteen or twenty years (2). On the other hand, the range of sextubercula appears to have extended up the middle Putamayo during the 1970 s, possibly following decline of Podocnemis expansa and P. unifilis in this area (1). Only rarely observed in the Pacaya basin of northeast Peru (6).

HABITAT AND ECOLOGY A moderate size freshwater turtle, one of the smallest Podocnemis, sometimies reaching $340 \mathrm{~mm}$ shell leng th and $3.5 \mathrm{~kg}$ (3).

Reported to be primarily carnivorous, perhaps feeding on fish (4). Pieces of fish are used as bait when catching this species on hook and line (5).

The time of nesting varies between end June - mid August in northeast Peru (6), July in the Upper Amazon (Solimoes), October in the Caqueta to November December in the Putumayo (4). Nesting occurs at night, singly or in groups of three to four, typically on low beaches of pure sand on the river bank or in mid river. This particular nest site preference is shared with P. expansa (7). Occasional nesting in clay banks may be attributed to heavy human predation at typical sand nest sites (hunters may now hunt non-sand areas), or high water conditions (1). Nests are generally only a few metres from the water edge (6). The clutch comprises 6-22 relatively large elliptical eggs (3), the mean clutch size in seven nests from the Tapiche and Pacaya basins (Peru) was 12.4 (6). Females probably lay only once per season (6). Egg size is variable, often around $41 \times 27$ $\mathrm{mm}$. Incubation period is approximately 84 days in Peru (6).

THREATS TO SURVIVAL Threatened primarily by extensive human consumption $(2,3,5)$. Adult turtles are captured with gill nets set out for fish, on hook and line, or by harpoon. Nesting females are also taken as they emerge on to nesting beaches at night, and the eggs are considered a delicacy (5). It is reported that collection of nesting $\underline{P}$. sextuberculata females and eggs during September October is a major occupation in several smaller towns of the Upper Amazon, and 
in one village the species appears to provide the major protein source for several months of the year (2). A typical sextuberculata weighing around $1 \mathrm{~kg}$ would sell for US $\$ 1$ in Itacuatiara (Amazonas), but there is little trade in this species and most are consumed directly in rural areas (5). Exploitation has shifted on to smaller Podocnemis species such as sextuberculata now that the large P. expansa has declined in abundance (3).

CONSERVATION MEASURES TAKEN Nominally protected by legislation in Brazil, Colombia and Peru (3), but there is little or no enforcement $(3,5)$.

Listed on Appendix II of the Convention on International Trade in Endangered Species of Wild Fauna and Flora (CITES). Appendix II listing implies that commercial trade is allowed providing a permit from the country of export is obtained, this can provide a method of monitoring trade levels.

CONSERVATION MEASURES PROPOSED Existing legislation should be more widely enforced. Current over-exploitation should be curtailed and management plans prepared with a view to maintaining the species as a significant food source in Amazonia.

The IUCN/SSC Freshwater Chelonian Specialist Group plans a highest priority project on ecology and conservation of this and related species.

REFERENCES 1. Foote, R.W. (1978). Nesting of Podocnemis unifilis (Testudines: Pelomedusidae) in the Colombian Amazon. Herpetologica 34(4): 333-339.

2. Mittermeier, R.A. (1975). A turtle in every pot. Animal Kingdom. 78(2): 9-14.

3. Mittermeier, R.A. (1978). South America's river turtles: saving them by use. Oryx 14(3): 222-230.

4. Pritchard, P.C.H. (1979). Encyclopedia of Turtles. T.F.H. Publications, Hong Kong and New Jersey.

5. Smith, N.J.M. (1979). Aquatic turtles of Amazonia: an endangered resource. Biol. Conserv. 16(3): 165-176.

6. Soini, P. (1980). Informe de Pacaya No. 2: Reproduccion, Manejo y Conservacion de los Quelonios del Gener Podocnemis (Charapa, Cupiso y Taricaya). Unpublished report. Cahuana, Rio Pacaya, Peru.

7. Vanzolini, P. (1977). A brief biometrical note on the reproductive biology of some South American Podocnemis (Testudines, Pelomedusidae). Papéis Avulsos Zool., S. Paulo. 31(5): $79-102$. 
TARICAYA (Peru)

Podocnemis unifilis Troschel 1848

Order TESTUDINES

Family PELOMEDUSIDAE

SUMMARY A moderate size freshwater turtle inhabiting large rivers, backwaters, lagoons and flooded forests, mainly in the Amazon and Orinoco drainages of northern South America, and extending into the Guianas. Widespread, still relatively common in a few areas but locally depleted due to continuing heavy human predation on nesting females and eggs. Feeds mainly on aquatic vegetation and fruits of waterside plants. Persistence of the species in spite of exploitation may be attributable to flexible nesting habits. Nests singly on riverside beaches or many metres inland. Beaches may be near horizontal or steeply sloping, extensive or mere forest clearings, composed of sand, loam or clay. May lay two clutches per season, comprising 14-49 eggs. Protected in Brazil, Colombia and Peru. These countries, and Venezuela are investigating the possibility of captive breeding or management of natural populations as a renewable natural resource. Podocnemis turtles convert otherwise unused aquatic vegetation into animal protein and fats, potentially of long-term nutritive benefit to human populations in northern South America, if only short-term over-exploitation can be curtailed. Listed in CITES Appendix II.

DISTRIBUTION Widespread in the Amazon and Orinoco drainages and occurs in several rivers in the Guianas. Present in Amazonian Brazil, extending into Bolivia, Peru, Ecuador, Colombia, Venezuela, Guyana, Surinam (probably stragglers from Amazon tributaries) and French Guiana $(2,6,11)$.

POPULATION No precise estimates available, but heavily exploited and becoming depleted in many areas $(5,6)$. Population estimation for Podocnemis unifilis (and most other species of the genus) is difficult since females typically nest singly not, as in $\mathrm{P}$. expansa for example, in synchronized aggregations on exposed beaches. Still relatively common in Amazonian Peru, where the congeneric species $P$. expansa and $P$. sextuberculata are rare (11). The key to persistence here, and in other areas, appears to be the relatively wide nest-site tolerance (see next section).

HABITAT AND ECOLOGY A moderate size freshwater turtle, females reaching a maximum confirmed carapace length of $44.3 \mathrm{~cm}$ (12), and $12 \mathrm{~kg}$ weight, males are rather smaller. Inhabits a variety of aquatic habitats, including large rivers, backwaters, oxbow lakes, ponds, lagoons and seasonally flooded forests $(2,11)$. Typically, rivers are only occupied during the nesting season, at other times of year unifilis inhabits lagoons and backwaters, and none are to be found in rivers (10).

Podocnemis species are omnivorous but predominantly vegetarian, feeding on aquatic plants and fruits that fall into the water, but also scavenging dead fish and other animal material (6). When floodplain forests around Itacoatiara (Amazonas) become inundated in May-June, unifilis move in to feed on falling fruits and flowers (9). Fruits consumed include those of Munguba Bombax munguba, Caiembé Sorocea duckei and Cramuri Gymnoluma glabrescens (9). The species feeds mostly during the day (9). An unusual mode of feeding has been 
observed in a captive unifilis population (1), few observations appear to have been made on feeding in wild unifilis. Individuals were seen to raise the head slightly above water and open the mouth until the lower jaw is parallel to, and just below, the surface, so that water spills in as the throat is distended by protraction of the hyoid. Then the mouth is shut and the hyoid abducted, expelling water but retaining the fine particulate material (neuston) from the water surface. It was suggested that this technique may be related to the non-breeding habitat of unifilis, where swamp pools and oxbow lakes, of ten partially dried, may provide a dense nutritive neuston layer (1).

The breeding season tends to be well-defined but variable between localities, correlated both with the river regime and to some extent with the nesting season of related species. Nesting in the Rio Purus of Brazil is in June-July, while nearer the Amazon mouth in the Trombetas it is in September-October, in December in the Negros (12), mainly July-August in the Rio Pacaya (10) and December-January in the Orinoco (13). In certain regions of Brazil where data are available, the species of Podocnemis tend not to lay synchronously (12). On the Trombetas, for example, nesting of $\mathrm{P}$. unifilis begins about 20 days before $\mathrm{P}$. expansa at the same location (2). Podocnemis unifilis typically nests singly (12), but groups of up to 20 females are known, in Amazonian Peru for example (11). Most species of the genus lay singly or in small groups, except the mass-nesting $P$. expansa. Dark nights are preferred and nesting even occurs on rainy nights, unlike $\underline{\mathrm{P}}$. expansa (2). Podocnemis unifilis, $\underline{\mathrm{P}}$. vogli and of ten $\underline{\mathrm{P}}$. erythrocephala may move quite far from beaches to nest $(2,12)$ and unifilis in particular will accept a wide variety of substrates $(2,11)$. These three species, notably unifilis and vogli, also lay hard-shelled eggs (presumably reflecting an increased risk of water loss), in contrast to the flexible eggs of other Podocnemis. Overall, P. unifilis may nest on almost any kind of river bank, ranging from pure sand to pure clay, and from near horizontal to quite steeply sloping (to at least $\left.45^{\circ}\right)(11)$. Sandy beaches are preferred however $(3,10)$, for example at a study site on the Rio Pacaya (10) $95 \%$ of nests were in sand areas although this substrate formed only $23 \%$ of the shoreline. The nest site may be an expanse of beach or a small forest clearing (2), a nest has even been recorded in a recently burnt field many metres from the river and several metres above water level (12). Females congregate on and near the beaches during the nesting season, basking on the sands or half-submerged in the warm water along the shoreline (10). This pre-laying basking may last several days and appears to play an important role in maturation of eggs (10).

The clutch may comprise 16-33 eggs in Brazil (12), a range of $14-49$ is reported in Peru (11) and clutches are generally larger in this extremity of the range (10). It is conceivable that lower clutch sizes are a result of selective human predation on large females, laying larger clutches (10). Maximum recorded clutch size in Venezuela is 28 (13). Mean clutch size in Colombia is 27.3 (3). Eggs are 43-48 $\mathrm{mm} \times 28.5-31.5 \mathrm{~mm}$, weight $21-28.5 \mathrm{~g}$ (3). Larger females lay more and larger eggs (more rounded) eggs than smaller females (12). More that one clutch may be produced in one season, but this requires confirmation. The nest is relatively shallow, 16-26 cm (10), relatively rapidly excavated and filled (12). No initial body pit is dug, the forelimbs remain stationary and the rear feet are used alternately to dig the nest hole (3). Total laying time is around 25 minutes (3). The nest is filled again using the hind limbs, the sand is stamped flat with an open foot, and then loosely swept over prior to returning to the water. The entire operation may take about 2.5h (3). Natural nest predation on the Rio Pacaya is much higher on nests in small beaches or ravine banks than on large beaches (10). At this study site, the large teiid lizard Tupinambis (Tegu) is the only non-human predator able to locate and open nests, avian and mammalian predators are only then able to consume eggs. A major factor in reduced predation on large beaches is that the activity of Tupinambis, away from vegetation, is limited to a zone up to $4.5 \mathrm{~m}$ from cover, large beaches have an extensive area beyond this zone in 
which Tupinambis itself is exposed to predation by raptors (10). Usually, nests not found within four days are safe from predation. Predation is lower when the sand is dry and mobile and the eggs thus difficult to expose. Losses from other factors, such as flooding, were low during the study (10). Raptors, caiman and fish prey on emerged young, Jaguar may be the major predator on adults (10). The Common Caracara Polyborus plancus has been observed feeding on hatchlings heading from the nest to the river (13). The period from laying to hatchlings leaving the nest is around 84 days. The shell is first ruptured after about 64 days, the young remain in the shell for a further 2-5 days while the yolk sac is completely absorbed. After leaving the shell the young gather at the top of the nest chamber and emerge from the nest after a further 2-5 weeks, always at night and typically after rain $(10)$.

In optimum unifilis habitat along the Rio Pacaya in Peru, the net egg production has been estimated at 3,000 eggs per $\mathrm{km}$ of river, per year (10). At the $1.5 \mathrm{~km}$ study area (10), egg production was about 6,120 per year; with losses of $30 \%$ by nest predation (excluding man) and other causes, net annual production reduces to 4,500; with further losses due to infertility, mortalitiy of embryos, this reduces to about 4,000 emergent hatchlings. Net annual egg production for the optimum unifilis habitat along the Pacaya may be around 100,000 eggs (10).

The ability of this species to persist in spite of heavy exploitation has been attributed to the variety of nesting locations accepted (11). Since most egg-collecting by humans occurs on river beaches, nests in other places may be the only ones to escape human predation (11). On the other hand, females nesting away from rivers, and presumably also hatchlings returning to the river, may be more subject to predation by other animals (12).

THREATS TO SURVIVAL Adult turtles, notably nesting females, and eggs, are heavily exploited by humans through most of the range. Both the meat (6) and eggs (2) of unifilis are said to be preferred to those of other Podocnemis. This is certainly true in Venezuela where $\underline{P}$. unifilis is the chelonian most heavily exploited as a human food source (13). The heaviest exploitation in Podocnemis has been directed at the large mass-nesting species $P$. expansa, but as this species has declined, exploitation has shifted to smaller species such as unifilis. The analogy with the situation affecting Whales is clear $(6,9)$. Now in several medium size towns in the Upper Amazon, such as Coari, Tefé, Fonte Boa, and Codajas, boatloads of nesting unfilis females are brought in from previously little-touched beaches on the Jura and Purus Rios (6). Eggs of the few females that are able to lay are also taken (6). On the Rio Pacaya, man is the most important nest predator (10), and on the principle nest beaches on the Pacaya Reserve $100 \%$ of nests may be taken (10). Around Itacoatiara, unfilis is caught throughout the year but mainly when the floodplain forests are inundated in May-June (9). Trotlines with four to six hooks are set out beneath fruiting trees. One turtler may put out up to 24 lines, and in one case 120 unifilis were captured in a six week period (9). The species is also caught with a harpoon designed for this particular purpose, and also caught in gill nets (9). In this locality around 30 unifilis were landed each day during May, June and July 1977, at this time a $7 \mathrm{~kg}$ female could fetch US $\$ 10$, and a $2 \mathrm{~km}$ male around $\$ 1(9)$. Many turtles are smuggled to Manaus, the state capital, where they are worth four to five times the local prices (9). Floodplain forest, an important feeding area for $\underline{\mathrm{P}}$. unifilis and $\underline{\mathrm{P}}$. expansa, is being cleared at an increasing rate to accommodate cultivation by the expanding rural population (9). Hatchlings were heavily exploited in the 1960's by the live animal trade in the U.S. and Europe, this trade has largely ceased following widespread implementation of CITES (4).

CONSERVATION MEASURES TAKEN Nominally protected in Brazil, Colombia, Peru and Venezuela. Information not available from other countries in the range. 
Legislation is not fully effective. In Peru, for example, intensive exploitation of eggs and adults continues, the difference being that market sales do not take place openly (11). Similarly, exploitation continues in Brazil, however, in localities where unifilis nests on the same beach as expansa, the former benefits from the strict protection given to the latter by IBDF (Instituto Brasileiro de Desenvolvimento Florestal) (2). This protection involves control of nesting beaches, hunting activity, and inspection of transportation.

Listed on Appendix II of the Convention on International Trade in Endangered Species of Wild Fauna and Flora (CITES). Appendix II listing implies that commercial trade is allowed providing a permit from the country of export is obtained, this can provide a method of monitoring trade levels.

CONSERVATION MEASURES PROPOSED The species should be protected by effective legislation throughout its range, and population surveys conducted, as initial steps in a programme of rational utilization. Such programmes are under consideration or in progress in Brazil, Colombia, Peru and Venezuela.

CAPTIVE BREEDING No information. Captive breeding is probably feasible due to the flexibility in nest location and the hardiness of the species. However, careful management of natural populations may be the preferable course in the long-term (6).

REMARKS This species, and other Podocnemis, have potential as a cost-effective, relatively easy to manage, renewable natural resource. They convert otherwise unused vegetable material into animal protein and fats, of great nutritive value to human population in northern South America (6). This potential can only be realized if present short-term exploitation is immediately curtailed, and rational management schemes devised to allow adequate recovery of depleted populations.

The parallel in feeding habits between certain Podocnemis, such as P. unifilis, and the large Asiatic emydid turtles Batagur and Callagur, is of interest. Both groups favour feeding on fruits falling into the water from trees at the riverside or in flooded forest, and in both cases fruit dropped or dislodged by feeding monkeys has been observed to attract aggregations of turtles. The large monotypic Australasian form Carettochelys similarly feeds mainly or: fruits of mangrove and pandanus.

REFERENCES 1. Belkin, D.A., and Gans, C. (1968). An unusual chelonian feeding niche. Ecology 49(4): 768-769.

2. Fernando, M. de Padua, L. (1981). In litt., 16 March.

3. Foote, R.W. (1978). Nesting of Podocnemis unifilis (Testudines: Pelomedusidae) in the Colombian Amazon. Herpetologica 34(4): 333-339.

4. Honegger, R. (1979). Red Data Book, Vol 3: Amphibia and Reptilia. IUCN, Gland (third edition revised).

5. Mittermeier, R.A. In litt, cited in ref. 4.

6. Mittermeier, R.A. (1978). South America's River Turtles: saving them by use. Oryx 14(3): 222-230.

7. Mittermeier, R.A. (1981). In litt., 31 January.

8. Pritchard, P.C.H. (1979). Encyclopedia of Turtles. T.F.H. Publications, Hong Kong.

9. Smith, N.J.H. (1979). Aquatic turtles of Amazonia: an endangered resource. Biol. Conserv. 16(3): 165-176.

10. Soini, P. (1980). Informe de Pacaya No.2: Reproduccion, Manejo y Conservacion de los Quelonios del genero Podocnemis (Charapa, Cupiso y Taricaya). 
11. Soini, P. (1981). In litt., 27 March.

12. Vanzolini, P.E. (1977). A brief biometrical note on the reproductive biology of some South American Podocnemis (Testudines, Pelomedusidae). Papéis Avulsos Zool., S. Paulo. 31(5): 79-102.

13. Paolillo, A. (1982). In litt., 14 January. 

Phrynops dahli Zangerl and Medem 1958

Order TESTUDINES

Family CHELIDAE

SUMMARY An isolated species of chelid turtle with a very restricted range in the vicinity of Sincelejo in Bolivar State, Colombia. Extremely rare within its range. Nearly all preferred habitat destroyed. May be faced with extinction unless definitive measures are taken. Basic biological data are necessary and a captive breeding programme may be required. No conservation measures taken.

DISTRIBUTION Extremely restricted range centred around Sincelejo, state of Bolivar, Colombia, possibly including the middle and upper Rio Sinu drainage $(1,3)$.

POPULATION Specimens only known from Sincelejo where the species is extremely rare and poorly known by the local inhabitants. Few people at other localities appear to recognize the species by its local name of 'carranchina'.

HABITAT AND ECOLOGY Prefers ponds and small brooks within the forest. Does not inhabit larger rivers or lagoons. Often traverses great distances on land, and may spend several weeks aestivating under forest leaves. It is a bottom feeder, primarily carnivorous, but may feed on vegetable matter at times. Mating occurs in June-July, with approximately six eggs, measuring c $28 \times 23 \mathrm{~mm}$ to $35 \times$ $29 \mathrm{~mm}$, laid in September-October (1).

THREATS TO SURVIVAL Severe habitat destruction around Sincelejo in particular, and in the Rio Sinu drainage in general has converted nearly all prior $\mathrm{P}$. dahli habitat to pasture land (1). Because of the extremely restricted range of the species, and its apparent rarity, this habitat destruction poses a definite threat to its continued survival.

\section{CONSERVATION MEASURES TAKEN None.}

CONSERVATION MEASURES PROPOSED The IUCN/SSC Freshwater Chelonian Specialist Group plans a highest priority project investigating population status and ecology in the wild. A captive breeding programme may be essential to prevent extinction.

CAPTIVE BREEDING None at present. Earlier attempts at the Instituto Roberto Franco in Villavicencio, Colombia had limited success (1). Present number in captivity very small (2).

REMARKS This is the only species of chelid turtle known to occur north of the Cordillera Oriental, and may represent the northernmost limit of distribution of the family. It is closely related to Phrynops nasutus and P. wermuthi.

This account was kindly prepared by A. Rhodin (member, IUCN/SSC Freshwater Chelonian Specialist Group).

REFERENCES 1. Medem, F. (1966). Contribuciones al conocimiento sobre la ecologia y distribucion geografica de Phrynops (Batrachemys) dahli. Caldasia 9:467-489.

2. Slavens, F.L. (1980). Inventory of live reptiles and amphibians in North American collections. Private 


\section{Distribution.}

3. Zangerl, R. and Medem, F. (1958). A new species of chelid turtle, Phrynops (Batrachemys) dahli, from Colombia. Bull. Mus. Comp. Zool. 119:375-390. 
Phrynops hogei Mertens 1967

Order TESTUDINES

Family

CHELIDAE

SUMMARY An aquatic side-necked turtle with a restricted range in southeast Brazil, and extremely rare within that area. Only a handful of specimens are known to science and virtually no information is available on ecology or population status. Basic biological data are needed and a captive breeding programme is recommended.

DISTRIBUTION Restricted range in southeast Brazil, in the low-lying areas of the Rio Paraiba drainage in the states of Rio de Janeiro and southern Minas Gerais, and the Rio Itapemirim of southern Espirito Santo. Evidently not found around Sao Paulo, originally considered the type locality $(1,2,3)$.

POPULATION No specific information available. Appears to occur in small disjunct populations throughout its range. Extremely rare wherever encountered, and usually not known by local inhabitants $(2,3)$.

HABITAT AND ECOLOGY Nothing known. Appears to inhabit stillwater lagoons and small streams.

THREATS TO SURVIVAL Habitat destruction and water pollution. Extreme deforestation has resulted in increased siltation, and caused certain small streams in the Rio Paraiba drainage to dry up (2).

\section{CONSERVATION MEASURES TAKEN NONE.}

CONSERVATION MEASURES PROPOSED The IUCN/SSC Freshwater Chelonian Specialist Group has proposed a highest priority project to determine the biology and status of this species in the wild. A captive breeding programme has also been recommended, as the possibility of the establishment of a natural reserve seems unlikely (2).

CAPTIVE BREEDING None. Only four live specimens known to occur in Captivity $(2,3)$.

REMARKS A total of only 15 specimens of this species are known to science. It is sometimes confused with Phrynops geoffroanus, but is clearly differentiated by its total lack of vermiculations on the head, neck and shell.

This account was very kindly prepared by A. Rhodin (member, IUCN/SSC Freshwater Chelonian Specialist Group).

REFERENCES 1. Mertens, R. (1967). Bemerkenswerte Susswasserschildkroten aus Brasilien. Senck. Biol. 48:71-82

2. Mittermeier, R.A., Rhodin, A.G.J., da Rocha e Silva, R., and Araujo de Oliveira, N. (1980). Rare Brazilian sideneck turtle. Oryx 15(5): 473-475.

3. Rhodin, A.G.J., Mittermeier, R.A., and da Rocha e Silva (1982). Distribution and taxonomic status of Phrynops hogei, a rare chelid turtle from southeastern Brazil. Copeia 1982 (1): $179-181$. 

SUMMARY A widespread but apparently very rare chelid turtle from the western Amazon basin. Probably occurs as small disjunct populations. Individual animals are solitary and primarily bottom foragers. Very few specimens are known to science. Basic ecological and population status information are needed. No conservation measures taken.

DISTRIBUTION Apparently relatively widespread in the western portions of the Amazon basin, with the range extending from the Rio Vaupes region of Colombia $(1,2)$ in the northwest, to Manaus in Brazil (3) in the east, and to Carauari in Brazil in the southwest.

POPULATION More than a couple of specimens have never been recorded from any locality except for the Rio Vaupes population in Colombia, where the species appears to be locally relatively abundant $(1,2)$. It is a solitary species and apparently rare throughout most of its range, with only a handful of specimens known to science.

HABITAT AND ECOLOGY Occurs in small, shallow streams and lagoons, which can be either white or black water and either fast or slow current (1). The diet is primarily carnivorous, though vegetable matter is also occasionally eaten (2). Egg-laying in Colombia appears to occur between December and February, with up to six eggs being laid $(1,2)$, hatching apparently in September (2). Diurnal in habits, most of its active time is spent foraging under dead leaves and other bottom substrate (1). Only occasional basking has been observed, usually in the early morning (2).

THREATS TO SURVIVAL The species appears rare throughout its range; possibly occurring as a series of small, disjunct, potentially vulnerable populations. There do not appear to be any exploitative pressures on the species, but habitat destruction might well pose a significant threat.

\section{CONSERVATION MEASURES TAKEN None.}

CONSERVATION MEASURES PROPOSED The IUCN/SSC Freshwater Chelonian Specialist Group plans a highest priority investigation of the ecology and population status of the species. Captive breeding may be indicated in the future.

CAPTIVE BREEDING None. Limited experience with care in captivity has shown a high mortality rate from fungal disease $(2,4)$. Very few specimens in captivity (5).

REMARKS This is the most vividly coloured South American chelid turtle, with its head and limbs having a striking red colour.

This account was kindly prepared by A. Rhodin (member, IUCN/SSC Freshwater Chelonian Specialist Group).

REFERENCES 1. Lamar, W.W. (1979). In litt. (to Anders Rhodin). 
2. Medem, F. (1975). El primer hallazgo de la tortuga Phrynops rufipes (Spix), en Colombia. Rev. Acad. Colomb. 14:49-66.

3. Muller, P. (1966). Ein Wiederfund der Roten Krotenkopf-Schildkrote (Phrynops rufipes). Aquar. Terr. Zeit. 19:373-374.

4. Pritchard, P.C.H. (1981). Pers. comm. (to Anders Rhodin).

5. Slavens, F.L. (1980). Inventory of live reptiles and amphibians in North American collections. Private Distribution. 
SUMMARY An apparently extremely rare species from a very limited geographic range centred in the Argentinian and Paraguayan Chaco. Basic ecological and population status information is needed. No conservation measures taken.

DISTRIBUTION Known from the Chaco region of Argentina, having been collected at Presidencia Roque Saenz Pena, Chaco $(2,3)$, near Resistencia, Chaco (1), and at Pozo del Tigre, Formosa (7). Also recorded from Apalue, Paraguay (8). Current pet market animals appear to come from southern Bolivia.

POPULATION No data. Less than 10 specimens currently known to science. In addition, several animals have recently appeared in the live animal trade.

HABITAT AND ECOLOGY Appears to inhabit slow streams and lagoons, but no specific information available. In Formosa said to inhabit only lakes in the forest, not small streams, and to be quite rare, being encountered only when heavy rains cause the lakes to overflow and inundate the forest (7). No reproductive data available. Diet carnivorous in captivity (3).

THREATS TO SURVIVAL Unclear. The apparent extreme rarity of the species coupled with current pet market pressures may represent a threat.

\section{CONSERVATION MEASURES TAKEN None.}

CONSERVATION MEASURES PROPOSED The IUCN/SSC Freshwater Chelonian Specialist Group has proposed a priority project to investigate basic ecology and population status of the species.

CAPTIVE BREEDING None. Very few live specimens known to occur in captivity $(4,6)$, the fate of recent specimens in the live animal trade is unknown.

$\underline{\text { REMARKS }}$ This species is most closely related to Platemys spixii.

This account was very kindly prepared by A. Rhodin (member, IUCN/SSC Freshwater Chelonian Specialist Group).

REFERENCES 1. Freiberg, M.A. (1940). Una nueva especie de tortuga para la fauna Argentina. Mem. Mus. Entre Rios 12: 1-5.

2. Freiberg, M.A. (1945). Una nueva especie de tortuga del genero Platemys Wagler. Physis 20:19-23.

3. Freiberg, M.A. (1947). El alotipo de la tortuga Platemys pallidipectoris Freiberg. Physis 20:112-114.

4. McMorris, J.R. (1982). Pers. comm., to A. Rhodin.

5. Mertens, R. (1954). Bemerkenswerte Schildkroten aus Sudund Zentralamerika. Aquar. Terr. Zeit. 7:239-247.

6. Sachsse, W. (1981). Pers. comm., to A. Rhodin.

7. Saporiti, E.J. (1943). Nuevo hallazgo de la tortuga acuatica Platemys spixi D. y B. - Ampliacion de su distribucion geografica. Rev. Argent. Zoogeogr. 3: 73-74.

8. Schenkel, E. (1901). Achter Nachtrag zum Katalog der herpetologischen Sammlung des Basler Museums. Verhandl. Naturf. Ges. Basel 13: 142-199. 

Platemys spixii Duméril and Bibron 1835

Order TESTUDINES

Family CHELIDAE

SUMMARY A small sized freshwater turtle. Present in coastal localities in Uruguay and southern Brazil, where reported rare and threatened by habitat loss; also present inland further north in Brazil and at a few inland sites in Uruguay and Argentina, where status is unknown. Effective protection is required for threatened habitats in coastal Uruguay; distribution and status in remainder of range requires investigation.

DISTRIBUTION Restricted to parts of eastern South America. Present in coastal areas of the Dpt. Rocha, Uruguay, with at least six known localities between Balneario Atlantica and Santa Teresa (1). There are three records from inland Uruguay, in Tacuarembo and Rivera, but no recent confirmation of the species' existence here (1). The range extends northward around the Lagoa dos Patos in coastal Rio Grande do Sul, Brazil. Further Brazilian records are to the north and further inland, from the Sao Paulo hinterland and the upper Rio San Francisco (Minas Gerais and possibly Bahia) (4). Most of the few Argentinian records in the literature appear to be in error, except an adult recorded in Corrientes (4).

POPULATION Considered rare and certainly threatened in Uruguay, and in Rio Grande do Sul (1) where frequency decreases northward along the coast (2). It has been questioned whether the species is significantly threatened in Rio Grande do Sul or Sao Paulo (3). There appear to be no recent data on the status of populations reported from localities inland or north of the southern coastal sites in Uruguay and Brazil (1).

HABITAT AND ECOLOGY A small size (to $17 \mathrm{~cm}$ carapace length) freshwater turtle. Coastal localities include various sized ponds, marshes and lakes among sand dunes. Laguna Carpinchos, for example, is a small freshwater lagoon covered by hyacinths, in the P.N. Santa Teresa (Rocha, Uruguay) (5). No further data available.

THREATS TO SURVIVAL Habitat loss is the principal threat in coastal Uruguay and Brazil (1). New fishing ports, industrial ports and oceanic superports are planned or under construction at some localities (1). In the sandy coastal zones of Uruguay wetlands are disappearing due to afforestation, and drainage followed by burning-over (for example, in P.N. Santa Teresa in the Laguna Negra area). Habitat modification is similarly high around the Porto Alegre metropolitan area in Rio Grande do Sul, Brazil (1).

CONSERVATION MEASURES TAKEN None. The species is present in the Taim Ecological Research Station (Rio Grande do Sul, Brazil) and in the Parque Nacional Santa Teresa (Rocha, Uruguay); but this does not imply effective protection (1).

CONSERVATION MEASURES PROPOSED Basic data on distribution and ecology are required. The status of the species in northern Brazil and in Argentina requires investigation (1). The almost inaccessible marshlands east of Lagoa dos Patos (Rio Grande do Sul) may constitute a natural refuge; the occurrence of $\underline{P}$. spixii here should be investigated (1). Effective protected areas are urgently 
required for threatened habitats and species in coastal Uruguay (1).

CAPTIVE BREEDING No information.

REMARKS If secure populations of Platemys spixii were found to exist in the more northerly Brazilian localities, and in Argentina, the species as a whole would probably not be considered threatened.

REFERENCES 1. Gudynas, E. (1982). In litt., 6 March (draft Red Data Book account).

2. Lema, T. de., and Fabian-Beurmann, M.E. (1977), Levantamento preliminor dos répteis da regiao da fronteria Brasil-Uruguai. Iheringia, Ser. Zool. 50: 61-92. (not seen, cited in ref. 1).

3. Rhodin, A.G.J.(1982). In litt., 28 March.

4. Rhodin, A.G.J., da Rocha e Silva, R., and Mittermeier, R.A. (1982). Distribution of the South American Chelid Turtles Platemys radiolata and $\mathrm{P}$. spixii. (unpublished MS.).

5. Skuk, G. (Centro de Ēstudios de Ciencias Nat.) (undated). Pers. comm. to E. Gudynas (not seen, cited in ref. 1). 
Pseudemydura umbrina Siebenrock 1901
Order TESTUDINES
Family
CHELIDAE

SUMMARY A small semi-aquatic inhabitant of ephemeral winter-wet swamps on the northeastern fringe of the city of Perth, Kestern Australia. A very rare and critically endangered species. Suitable habitat has always been scarce and the species is now restricted by urban and agricultural development to two very small populations on the swamp reserves of Ellen Brook (65 ha) and Twin Swamps (155 ha). 1978 population estimates suggest 10-45 individuals at Ellen Brook, 13-45 at Twin Swamps; the former population appears relatively stable, the latter has steadily declined from over 100 animals present in the mid-1960's. Lives and feeds in water when present, aestivates underground or under plant litter during summer. Carnivorous, feeds on aquatic crustacea, insects and larvae, tadpoles, aquatic earthworms. Fecundity is low, a single annual clutch of three to five relatively large hard-shelled eggs is laid. Dessication during aestivation is lethal to hatchlings that have not grown sufficiently. Growth at all stages is dependent on adequate water depth and temperature, particularly toward the end of the annual period of activity. Sexual maturity is typically not attained for 10 to 15 years or longer. Recruitment has been low or zero in recent years. Populations are limited by loss of habitat, and currently threatened by dependence on adequate winter rainfall (inadequate in recent years), and predation. Survival of the species is probably dependent on intensive reserve management and continuation of present captive breeding programme. Habitat and the species strictly protected. Listed on CITES Appendix 1.

DISTRIBUTION Formerly restricted to ephemeral winter-wet swamps within the present metropolitan area of Perth, Western Australia. Recorded from scattered localities on the Swan Coastal Plain near the base of the Narling Scarp, within a narrow strip of land three to five $\mathrm{km}$ across, extending some $30 \mathrm{~km}$ from Guildford Airport (Perth) in the south, to Bullsbrook East in the north. Most of this land is now cleared and urbanized or under intensive agriculture, P. umbrina is now almost totally restricted to the two $N$ ature Reserves of Ellen Brook $(65 \mathrm{ha})$ and Twin Swamps (155 ha), near Upper Swan $(2,3)$.

POPULATION 1978 population estimates (95\% confidence limit), calculated from $\overline{1963}$ to 1979 mark-recapture data, are: Ellen Brooks Vature Reserve, 10 to 45 individuals, Twin Swamps Nature Reserve, 13 to 45 . Overall results from two estimation methods used suggest that the Ellen Brooks population is relatively static, comprising 15-20 individuals, while numbers at Twin Swamps have declined steadily from over 100 individuals in the mid-1960's to around 20 by 1977 and 1978. Recruitment from the hatchling age class into the 1 -year-old class has been generally low or zero, except at Twin Swamps in 1964 and $1965(2,3)$.

HABITAT AN D. ECOLOGY Pseudemydura umbrina is a small (rarely over $15 \mathrm{~cm}$ length) semi-aquatic inhabitant of ephemeral winter-wet swamps formed over clay or sand over clay depressions. Maximum water depth of Ellen Brook swamps is $45 \mathrm{~cm}$ (mean c $20 \mathrm{~cm}$ ), the area is dry in summer and autumn. Standing water remains for a very variable time at Twin Swamps. There is no evidence of water pollution at Ellen Brook, but North-west Swamp at Twin Swamps has relatively high phosphate levels probably due to drainage from adjacent agricultural land. 
The area has a typical Mediterranean climate, with winter rainfall and hot dry summers $(2,3)$.

P. umbrina lives and feeds in water when it is present (usually from June to October or early $N$ ovember). Animals appear to move freely from pool to pool. As the shallower pools dry up (usually around October) individuals may move into deeper pools or directly into refuges; all tortoises are in refuges by mid-November or December. At Ellen Brook all aestivating tortoises located were found in underground holes and tunnels in the vicinity of the dried-up pools. At Twin Swamps individuals move initially into leaf litter of Regelia ciliata heath or Banksia woodland, all tortoises found in January were in Banksia woodland (in leaf litter, under branches or in tunnels). Individuals at Twin Swamps typically dig themselves into the substrate so that only the nostrils and carapace remain exposed (this may reduce cutaneous water loss). Individuals may move from one site to another. Some tortoises leave their refugia in late April or May when the first heavy rains fall, most do not enter the swamps again until they are filled to several centimetres depth, by June or July. Animals during the winter were torpid below $14^{\circ} \mathrm{C}$ body temperature but active above $15^{\circ} \mathrm{C}$, during the summer body temperatures range from 20 to $28^{\circ} \mathrm{C}$, the tortoises move to refugia when no water below 28 or $30^{\circ} \mathrm{C}$ is present. Basking has been observed on only one occasion in the field (although frequent in the Perth Zoo captive population), and appears to be of little significance. Dessication rates during summer aestivation are higher in juveniles than adults, dessication is lethal in hatchlings that do not attain sufficient size during their first winter-spring, a common occurrence in years of below average rainfall. Tunnels used as refugia at Ellen Brook probably provide a much higher relative humidity than sites used at Twin Swamps (3). Permanent water in or near the reserves is not used by $P$. umbrina, it is occupied by the chelid Chelodina oblonga, a larger and more aggressive species, but much less resistant to dessication.

P. umbrina is carnivorous, taking only live aquatic organisms in the wild. Analysis of stomach contents (of one female) and faeces, indicate prey comprising aquatic crustacea (chiefly Eulimnadia: Conchostraca), insects and larvae (mainly Coleoptera and Diptera), small tadpoles, and the aquatic earthworm Eodrilus cornigravei (3).

Sexual maturity is not usually reached for 10 or 15 years, sometimes longer. Size at maturity is around $120 \mathrm{~mm}$ carapace length, males do not exceed $155 \mathrm{~mm}$ carapace length, fernales are smaller than males (unlike other Australian chelids) and reach around $133 \mathrm{~mm}$. Mating occurs in winter and spring (in captive animals). N esting follows in early summer (around $\mathrm{N}$ ovember). Although most Australian chelids lay more than one clutch per year, there is no evidence that this occurs in P. umbrina. The single clutch comprises three to five hard-shelled eggs (average size from one clutch of five, $37.6 \mathrm{~mm}$ by $20.0 \mathrm{~mm}$ ), laid in a chamber dug 75 to $100 \mathrm{~mm}$ below the surface. The eggs are proportionately larger than those laid by other Australian chelids (6) being the same size as those of certain Chelodina spp, where the females grow to around twice the size of $p$. umbrina and may lay two or three times the number of eggs. Vesting in the wiId has not been observed. Hatchlings emerge the following winter (May, June) after about 180 days, and have a carapace length of $29 \mathrm{~mm}$ (3).

Growth, and the length of time taken to reach sexual maturity, appear to be proportional to the period during which standing water is available for feeding. The pattern of rainfall is also significant since heavy rain can rapidly fill the swamps after summer drying, but the same amount divided into a number of lighter falls may have little effect. Growth is also faster at high temperatures. Most growth occurs in spring and early summer at the end of the annual period of 
THREATS TO SURVIVAL The Western Swamp Tortoise is restricted to a specialised habitat, most of which has been greatly modified during the past 150 years. The two $\mathrm{N}$ ature Reserves, including the entire known breeding range, are on the edge of, and include only about 1.5 per cent of, its former range. Most of the former range has been cleared and is now urbanized or under intensive agriculture. Besides the scarcity of habitat, the species is also inherently at risk because of the very small population size.

The only Australian chelid where the female is smaller than the male, P. umbrina has a low fecundity, only three to five eggs are produced per clutch, and only a single clutch per year. Recruitment into the population, the rate of growth and thus attainment of sexual maturity, are dependent on the amount and periodicity of winter rainfall. Feeding takes place only in standing water of suitable depth and temperature. Dessication occurs during summer aestivation, this is lethal to hatchlings that have not grown sufficently during their first winter-spring, a common occurrence during years of below average rainfall. Predation by introduced red fox Vulpes vulpes, and destruction of summer aestivation habitat by wildfire (relevant to Twin Swamps habitat only), are further threats to the species.

Recent very low or zero recruitment, at the Twin Swamps $\mathrm{N}$ ature Reserve in particular, appears to be primarily a result of an unusual sequence of low-rainfall years, exacerbated by predation.

CONSERVATION MEASURES TAKEV The two remaining breeding sites of P. umbrina, at Ellen Brook and Twin Swamps, were declared $N$ ature Reserves by the Viestern Australian Government in 1962. Both are Class A reserves under the 1933 Land Act, and cannot be put to another use except by Act of Parliament. They are vested in the Western Australian Wildlife Authority. The species is totally protected by legislation and may not be taken for any purpose. Population monitoring is continuing. Predator control being attempted. Listed on Appendix I of the Convention on International Trade in Endangered Species of $\mathbb{W}$ ild Fauna and Flora (CITES). Appendix I listing requires that trade in the taxon and its products is subject to strict regulation by ratifying states and international trade for primarily commercial purposes is prohibited.

CONSERVATION MEASURES PROPOSED Monitoring of wild populations, management of the Nature Reserves and captive breeding will be continued by the Western Australian Department of Fisheries and Wildlife (2).

CAPTIVE BREEDING A captive colony established in 1962 was transferred to Perth Zoological Gardens in 1963. The first successful breeding occurred in 1966, a total of 26 hatchlings were produced up to May 1977, 10 of which were surviving in April 1978. The colony comprised 21 individuals in July 1978 (6). Recently a mature female held at the Western Australian Wildlife Research Centre at $\mathbb{N}$ aneroo, laid three eggs following hormone injections (1). Two hatched after 23 and 27 weeks in an incubator.

REMARKS The Western Swamp Tortoise was first discovered in 1839, and known only by the single original specimen (deposited in the Vienna Museum) until 1953.

Pseudemydura umbrina is a relict species of a monotypic genus, the most terrestrial-adapted Australian chelid, and the smallest of all chelids (other species present in South America and $\mathrm{N}$ ew Guinea, besides Australia). It is highly distinct within the Chelidae of Australia and $V$ ew Guinea in several morphological and 
serological features (4), and is thought primitive in some respects within the entire family (5).

This account is based almost entirely on information kindly provided by A.A. Burbidge.

REFEREN CES 1. Anon. (1980). Western Swamp Tortoise breeds in captivity. State Wildl. Authority N ews Serv. 10(2): 6-7.

2. Burbidge, A.A. (1981). In litt., 20 January (Draft account of Pseudemydura umbrina).

3. Burbidge, A.A. (1981). The ecology of the Kestern Swamp Tortoise. Pseudemydura umbrina (Testudines, Chelidae). Aust. Wildl. Res. 8(1): 203 -222.

4. Burbidge, A.A., Kirsch, John A.K., and Main, A.R. (1974). Relationships within the Chelidae (Testudines: Pleurodira) of Australia and N ew Guinea. Copeia 1974 (2): 392-409.

5. Gaffney, E.S. (1977). The side-necked turtle family Chelidae: a theory of relationship using shared derived characters. Amer. Mus. N ovit. N 0.2620. Pp. 1-28.

6. Spence, T., Fairfax, R., and Loach, I. (1979). The Kestern Australian swamp tortoise Pseudemydura umbrina in captivity. Int. Zoo. Yb. 19: 58-60. 
SUMMARY The Chinese Alligator is a critically endangered species, endemic to the People's Republic of China, where it is restricted to the lower Yangzi (Yangtze or Chang Jiang) valley in the provinces of Anhui, Zhejiang and Jiangsu. Current population estimates for the entire range are not available, but there are at least 300 individuals in Anhui Province, reportedly the region with most alligators. Chinese sources suggest that the species has declined to near-extinction. Threatened by habitat loss and wilful killing. Maximum size about two metres. Much of the life cycle is spent in burrows excavated in the banks of rivers, streams and ponds. Hibernates from late October to March-April. Diurnal activity in May after emergence shifts towards nocturnal activity in June, coincident with the mating period. A mound-nesting species, 10-40 eggs are laid in July-August. Hatchlings emerge after about 70 days and growth is rapid until sexual maturity is attained at four to five years. Diet consists of freshwater molluscs, fish and other available fauna. The species is fully protected under Chinese law and several reserves have been declared. Listed on CITES Appendix I. Captive breeding has occurred at Shanghai Zoo and at Rockefeller Wildlife Refuge, Louisiana. A current China-U.S. cooperative study is expected to yield new data that will aid conservation efforts.

DISTRIBUTION Endemic to the People's Republic of China, where formerly more widespread but now restricted to the lower Yangzi (Yangtze or Chang Jiang) valley in Anhui (Anhwei), Zhejiang (Chekiang) and Jiangsu (Kiangsu) Provinces (11). Historically most A. sinensis occurred in the Wuhu region of Anhui and the Nine Streams in Jiangxi, including Jingxian, Nanling, Xuancheng, Ningguo, Wuhu, Guangde and other areas $(11,18)$. First mentioned in literature in the oracular bone inscriptions of the Yin portion of the Shang dynasty (1401 B.C. - 1154 B.C.) the range of Chinese Alligator formerly extended more widely along the lower and middle Yangzi River basin west to the ancient Yunmeng swamp in Hubei Province and the Dongting $\mathrm{Hu}$ in Hunan Province and north to the Huang Ho (Yellow River). The major portion of the population existed in the area now comprising Anhui, Jiangsu, Zhejiang, and Jiangxi Provinces (18).

POPULATION The population in Anhui Province is currently estimated (16) to comprise over 300 individuals, with immatures predominating. Sources in China suggest that this area has the largest alligator population (17). The species has declined and may well be faced with extinction in the near future $(1,11,16,17)$. Over 500 A. sinensis were counted in 1956, but only around 100 in 1976 (12). However, breeding females and young have been observed.

HABITAT AND ECOLOGY Alligator sinensis, originally described by Fauvel (7) and later by Boulenger (3), is a relatively small, semi-aquatic and secretive crocodilian, occurring in the lower Yangzi and adjacent lakes and ponds, where it inhabits low beaches and dense stands of cane, and spends much of its life in burrows excavated in the banks of rivers and ponds $(6,8,9,11,15)$. Following increasing disturbance of wetlands in the Jiangnan plain, alligators are reported (20) to have moved into pools in lightly wooded hill country in the upper reaches of the Quingyi and Zhanghe rivers, and significant numbers are now established there. It is a very small species, growing to a maximum length of two meters (9). 
The majority of the remaining population in southern Anhui Province lives on embankments composed of coarse sandy soil in which they excavate their dens or burrows (11).

The period from late October to late March or mid-April is spent hibernating in burrows. In both the early and late phases of hibernation the alligators emerge from their dens on clear days, but are in a state of torpor, moving slowly and barely able to vocalize. In late October, both air and substrate temperatures are dropping and the animals go into complete hibernation. According to Huang $(9,11)$ the animals neither eat nor move during this time and their respiration is greatly reduced. Hsiao (8), however, claimed that the hibernating alligators change position in their hibernacula. The cave itself may extend to a depth greater than $3 \mathrm{~m}$ from the surface, where mid-winter temperatures may drop to as low as $10^{\circ} \mathrm{C}$. These caves have a complex structure, some with many openings and diverticula $(5,6)$. The structure of the cave differs according to whether the resident is male, female, young or old $(5,6,11)$. As ground temperature increases after mid-April, the animals emerge from their caves with greater and greater frequency. By early May the animals leave the caves in the daytime and show a great amount of diurnal activity (11). In June the animals show increasing amounts of nocturnal activity. This coincides with the peak of mating behaviour, when males and females emit roaring vocalizations (12). Mating occurs in water, the male climbing on to the female's dorsum wrapping his tail under hers in order to effect copulation. Between July 10th and August 10th the female selects as a nest site a concealed area facing the sun adjacent to water $(6,11)$. Using her forelimbs and snout, the female clears a small area, then begins to build a nest out of dried leaves and various grasses. The female lays 10 to 40 eggs (or 16-47) (12) in the nest, then adds more leaves and shapes the covered nest into a mound $(6,11)$. Eggs are ovoid and have a hard white calcareous shell $(6,9,11)$. The eggs have an average length of $60.5 \mathrm{~mm}$, average width of $35.4 \mathrm{~mm}$, and average weight of $44.6 \mathrm{gm}$ (11). Incubation is about 70 days long and most eggs hatch successfully. The narrow end of the eggshell is broken by the egg caruncle, slitting the shell and allowing the young alligator to free itself of the egg. In observed nests, all the young hatched within a period of one week. The newly hatched young are black with yellow stripes and are very agile. At hatching the average length is $21 \mathrm{~cm}$, average weight $30 \mathrm{gm}(6,11)$. The young grow quickly in the early years after birth, but more slowly after the age of five (12). Sexual maturity is reached after four to five years (12). The life span can be over 50 years (12).

The diet of the Chinese Alligator consists of snails, freshwater mussels, fish, and other items (12). Analysis of stomach contents showed river-snails to comprise $41 \%$ of the diet and spiral-shelled snails $22 \%$.

THREATS TO SURVIVAL Expanding human population, loss of habitat, and wilful killing by local inhabitants, are primary factors in the decline of A. sinensis $(11,12,16)$. Animals residing in grassy bank areas are subjected to flooding, and many drown in their caves if they are unable to reach an air pocket or the water's surface. In times of drought, available habitat is further reduced and animals leave their drying ponds in search of water and suitable reproduction sites. Drought could severely effect the remaining populations since most individuals do not live in contiguous watercourses and ponds are frequently distantly scattered (16). There has been an unconfirmed rumour (19) that hides claimed to be Chinese Alligator have recently been offered for sale through Hong Kong and another port. The belly hide does have well-developed osteoderms (21).

CONSERVATION MEASURES TAKEN Several conservation areas, for example the Wuhu Alligator Sanctuary, have been set aside in China, and the Chinese alligator has been listed as a first class endangered species, putting the species 
under governmental protection $(10,11,14)$. An alligator rearing station has recently been established at the Xiadu Commune Tree Farm in Xuancheng County, Anhui Province (16). Local residents are being encouraged to sell the animals they capture to the farm. The workers are also asked to inform farm personnel of the presence of nests with eggs on their communes, and to protect nests and eggs from wanton destruction by children (16). The Xuancheng station held about 90 individuals, mostly adults, in July 198! (17). There is some public interest in the species within China, for example a recent article in The People's Daily (Renmin Ribao) stated that the alligator is near extinction (1).

Alligator sinensis is listed on Appendix I of the Convention on International Trade in Endangered Species of Wild Fauna and Flora (CITES). Appendix I listing requires that trade in the taxon and its products is subject to strict regulation by ratifying states and international trade for primarily commercial purposes is prohibited.

CONSERVATION MEASURES PROPOSED A cooperative China - U.S. study of breeding behaviour, and a population survey, has been undertaken in 1981 under the auspices of the Institute of Zoology, Chinese Academy of Sciences, Beijing. The full potential of the Xuancheng rearing station could be approached if management techniques were substantially improved.

CAPTIVE BREEDING Three captive adults are maintained in a natural enclosure at Rockefeller Wildlife Refuge in Louisiana, U.S.A., in a breeding project sponsored by the New York Zoological Society, the National Zoological Park, and Rockefeller Wildlife Refuge. Nesting occurred in 1977, 1978, 1979, and 1980 (12). There are a total of 21 young surviving; three from the 1979 hatch and 18 from 1980. The three adult individuals are probably more than 40 years old, and comprise one pair from NYZS and a second female from the National Zoo (4). Four hatchlings from 1980 have been sent to the Houston Zoo (Texas) with the aim of starting a second breeding group (4). The project now has one additional female from Munich Zoo, another from Stuttgart, and one from Budapest (4). Xinhua (2), the Chinese press agency, reported the successful hatching of 12 young at the Shanghai Zoo in 1980.

REMARKS More information on the status of $\mathrm{A}$. sinensis should be available some time in 1982, following studies recently undertaken by Dr M. Watanabe and Dr. Huang Chu-chien in cooperation with the Institute of Zoology, Chinese Academy of Sciences, Beijing (started late April 1981).

This account is based almost entirely on a draft kindly provided by Dr M. Watanabe, with additional data supplied by courtesy of Dr Huang Chu-chien.

REFERENCES I. Anon. (1980a). Protect wild animals and plants. Renmin Ribao. Oct. 22, 1980: 2.

2. Anon. (1980b). Rare river crocodiles bred in captivity. Xinhua Press Release No. 102003.

3. Boulenger, G.A. (1890). Remarks on the Chinese alligator. Proc. Zool. Soc. Lond. 1890: 619-620.

4. Brazaitis, P.(1981). In litt., 1 February.

5. Chen Bihui and Li Binghua (1979). Initial observations on ecology of the Chinese alligator. J. Anhui Teacher's College 1:69-73.

6. Chu Cheng-kuan. (1957). Observations on the life history of Chinese Alligator (Alligator sinensis Fauvel). Acta Zoologica Sinica 9: 129-143.

7. Fauvel, A.A. (1879). Alligators in China. J. N. China Branch Royal Asiatic Soc. New Series No. 13: 1-36f. 
8. Hsiao, Sidney, D. (1934-35). Natural history notes on the Yangzi Alligator. Peking Natur. Hist. Bull. 9: 283-292.

9. Huang Chu-chien. (1978). A general account of our country's amphibian and reptilian resources. Natural Resources 2: 92-100.

10. Huang Chu-chien. (1979). The rare and valuable Chinese alligator. Zhejiang Ribao. May 30, 1979.

11. Huang Chu-chien. Ms. The Chinese Alligator: ecology and changes in geographical distribution.

12. Huang Chu-chien. (1981). In litt., 23 March.

13. Joanen, T., McNease, L. and Behler, J. (1980). Captive propagation of the Chinese Alligator (Alligator sinensis). Paper presented at Southern Zoo Workshop, June 13, 1980, Monroe, Louisiana.

14. Li Yuxia. (1979). Protect the rare and valuable animal, the Chinese Alligator. Anhui Ribao. July 16, 1979.

15. Wang Yang. (1962). The Yangzi alligator. China Reconstructs. March, 1962: 38-39.

16. Watanabe, M. (1981). In litt., 26 June.

17. Watanabe, M. (1981). In litt., 6 September.

18. Zhang Mengwen and Huang Zhujian (Chu-chien). (1979). Chinese crocodilian species: the Chinese alligator and the salt water crocodile. Dongwu Zazhi 2: 52.

19. Watanabe, M. (1981). In litt., 7 October.

20. Huang Zhujian (1981). The Chinese Alligator Oryx 16(2): 139-140.

21. King, F.W. (1981). In litt. 
Caiman crocodilus (Linnaeus 1758)

Order CROCODYLIA

Family ALLIGATORIDAE

Note The taxonomy of what may be termed the 'Caiman crocodilus complex' is in a highly confused state. Taxa recognized by some authorities are not recognized by others. For example (references in following accounts):

(1) While a major field authority on South American crocodilians proposed several years ago that the southernmost populations (C. C. yacare) are distinct enough to require full species status (C. yacare), this opinion has been ignored by most subsequent workers.

(2) The form ranging from Mexico south through Central America to Colombia and northwest Venezuela has usually been referred to as C. C. fuscus; it has been proposed that this name should only be applied to the central and eastern populations in Colombia and those in northwest Venezuela, while populations from Pacific Ecuador and Colombia north through Central America are distinct at subspecies level and named $C$. c. chiapasius. While this treatment may be reasonable it is not based on readily-available published work.

(3) Two new subspecies $C$. $c$. mattogrossiensis and C. c. paraguayensis have recently been describéd, and accepted in a major checklist of the group, while these taxa are regarded as totally without foundation by others more familiar with the field situation.

Overall it appears that variation within the C. crocodilus complex is far from adequately represented by the present taxonomy. These might be considered fairly academic questions, but these uncertainties do appear to hinder effective conservation. It is clearly difficult to design or justify legislation when there is not a consensus position on the taxonomic treatment of animals from a particular area of concern, nor on which populations are most distinct and might thus deserve priority protection (if other factors are equal).

Pending adequate research into the systematics of the group a fairly conservative arrangement has been followed here; accounts for four commonly accepted taxa follow. It should be recognized that this arrangement is unsatisfactory to the extent that it does not adequately reflect the biological situation. Both the taxonomy and the status categories are liable to revision. 

Caiman crocodilus apaporiensis Medem 1955

Order CROCONYLIA

Family ALLIGATORIDAE

SUMMARY Present along a $200 \mathrm{~km}$ stretch of the upper Rio Apaporis, southeast Colombia. Population status and biology not known. Suspected to be depleted to some extent. Principal threats include extremely limited distribution, occasional hide hunting, possible interbreeding with adjacent $C$. crocodilus subspecies, and lack of effective protection. Listed on Appendix I of CITES, listed as Endangered under the U.S. Endangered Species Act. Specimens are currently maintained at the Instituto Roberto Franco, and at the Atagawa Tropical Garden and Alligator Farm (Japan)(it is not confirmed that specimens outside of Colombia are true C. C. apaporiensis, not a slender-snouted form of C. C. crocodilus). No captive breeding has been reported.

DISTRIBUTION The upper Rio Apaporis in southeast Colombia. Reported from a $200 \mathrm{~km}$ stretch between the falls of Jirijirimo and Puerto Yaviya.

POPULATION No data available. Suspected to be depleted to some extent. See 'Threats to Survival' below.

HABITAT AND ECOLOGY Very few data available. Inhabits the mountainous rivers, tributaries, and lagunas of the upper Apaporis river. Adult size about 1.5 to $2 \mathrm{~m}$. No further information.

THREATS TO SURVIVAL At risk by virtue of the very restricted range. Occasional hide hunting, lack of adequate local protection, and possible hybridization with Caiman c. crocodilus entering the area due to hunting pressure elsewhere (2), pose serious (but unquantified) threats to the survival of the subspecies. Hunting in the Vaupés-Apaporis-Caqueta-Putumayo area appears to have decreased recently as local people have turned to planting coca (1).

CONSERVATION MEASIJRES TAKEN Listed on Appendix I of the Convention on International Trade in Endangered Species of Wild Fauna and Flora (CITES). Appendix I listing requires that trade in the taxon and its products is subject to strict regulation by ratifying states and international trade for primarily commercial purposes is prohibited. Listed as Endangered under the U.S. Endangered Species Act. Nominally fully protected in Colombia (4).

CONSERVATION MEASURES PROPOSED Conservation status, taxonomic status and biology require investigation. Enforce a total ban on the hunting of the taxon, and the export of hides or products for commercial purposes.

CAPTIVE BREEDING No captive breeding has been reported to date. Federico Medem captured 11 specimens for the Instituto Roberto Franco in Colombia, in 1979. The only known male since died. The Atagawa Tropical Garden and Alligator Farm, Shizuoka, Japan, listed 6 specimens in their collection in 1981 (but the identification of these appears to be in doubt).

REMARKS Caiman crocodilus apaporiensis (= Caiman sclerops apaporiensis) was described by F. Medem in 1955 (5), based on 21 animals he collected on the Rio Apaporis. The full extent of morphological variation in C. crocodilus populations in surrounding areas is not known (5). 
Parts of hides and manufactured products may be indistinguishable from those of other Caiman crocodilus taxa.

This account is based mainly on the work of F. Medem, the major authority on the genus Caiman, and on a draft provided by P. Brazaitis.

REFERENCES 1. Medem, F. In litt., to P. Brazaitis.

2. Medem, F. (1971). Situation Report on Crocodilians from three South American countries. Proc. of First Working Meeting of Crocodile Specialists. IUCN Publ. New Ser. Supplementary Paper, No. 32: 54-71.

3. Medem, F. (1973). Survey of South American countries. Status Report. (Unpublished manuscript) (not seen, cited in 6).

4. Foote, R.W. (1979). In litt., to R. Honegger.

5. Medem, F. (1955). A new subspecies of Caiman sclerops from Colombia. Fieldiana, Zool., 37: 339-344.

6. Brazaitis, P. (1981). In litt., draft RDB account for C. $\underline{\text { c. }}$ apaporiensis. 
SUMMARY Inhabits quiet waters in northern South America, including the Amazon basin. Populations at present appear stable in much of the range, with the exception of those in Colombia and Peru, which are seriously depleted. Apparently responding to protective legislation in Brazil. Maximum size 2.0 - 2.5 $m$. Breeding occurs near the end of the dry season, nesting from mid-August to early November. Fourteen to 40 eggs are laid, hatching in c 90 days. Juveniles feed on aquatic invertebrates while adults feed on snails and a variety of other organisms. The excrement can provide an important nutrient input in certain otherwise nutrient-poor aquatic ecosystems. A highly adaptable caiman, quick to occupy available habitat, including man-made. Illegal hide hunting and lack of enforcement to curtail smuggling are major factors threatening the taxon. Hatchlings are killed for curios. Habitat in some areas is being lost to agriculture. Listed on CITES Appendix II. Nominally totally protected in Brazil, Ecuador, and Venezuela, under $1.5 \mathrm{~m}$ in Peru and Colombia; legislation largely unenforced. Breeds well in captivity. One of a number of subspecies, whose hides are difficult to distinguish from, each other in small samples, Renewed commercial exploitation of crocodilians for their hides has increased the hunting pressures on this and related taxa.

DISTRIRUTION Northern parts of South America east of the Andes; Peru, Ecuador, Colombia, Venezuela, Trinidad and Tobago, Guyana, Surinam, French Guiana, and with the exception of a few southern tributaries, the Amazon basin of Brazil (3).

POPULATION Populations of Spectacled Caiman generally appear to be at least stable throughout much of South America, with the exception of Colombia, Peru and some parts of Guyana. This taxon might well be more appropriately considered non-threatened, were it not for the reported recent increase in hunting pressure, and the lack of data - due to trans-border smuggling - concerning the extent of exploitation in particular areas.

Brazil Recovering rapidly since professional hunting was banned (12). Is. now caught fairly frequently in gill nets in floodplain lakes, even near Manaus, and can be seen without difficulty on tributaries of the Amazon such as the Rio Negro and Rio Tocantins (19).

Colombia Reported in late 1970 to be rarely hunted on the Vaupes and Guayabero-Guaviare rivers because the price of petrol, salt and air transport to Villavicencio and Bogota were too high. Juveniles are now seen of ten, with some adults reappearing. There is a healthy population in the 'Tomo-Tuparro' Faunistic Territory, a 600,000 ha. reserve maintained by INDERENA. In 1975350 caimans, mostly juveniles were counted in the lagoons and backwaters of the Capanaparo River (17). However, some hunting continues in the Llanos (Orinoco plains), the fact that most hides are between $30-60 \mathrm{~cm}$ may suggest that adults have been virtually wiped out from this area (10).

Ecuador No recent data, reported not seriously endangered in 1973 (9).

French Guiana Reported in 1973 to be in no serious danger of extinction (9). 
Guyana In 1973 Guyana populations were still abundant in most areas but were declining in areas where habitat had been lost to agriculture, particularly rice fields (9).

Peru Reported seriously depleted in 1973, judging by a rapid decline in numbes of hides exported (9).

Surinam Reported in 1973 to be abundant in suitable habitat in Surinam, with populations as close to an untouched state as could be found (9).

Trinidad and Tobago Abundant in parts of Trinidad but illegally hunted on a limited scale. Still abundant in the vicinity of the capital. The population in Tobago is not subject to hide hunting (9).

Venezuela Still relatively abundant (9). In Estado Bolivar it is difficult to find a body of water where this species does not occur; the population in this state may be as large as half a million (15). However, they are so easily hunted that they could be quickly eliminated from many areas (15). In very dry years populations in savannas may be reduced by as much as $80 \%$ because of mortality in small individuals. However, populations seem able to recuperate. In the last 20 years the construction of dams and reservoirs on cattle ranches has greatly increased available habitat (15).

HABITAT AND ECOLOGY Caiman c. crocodilus seems to prefer the quiet waters of lakes, ponds, swamps and marshes, sometimes in brackish waters (15), or along the bends and meandering tributaries of large rivers where the currents are slight. However it may also occur in fast flowing water and near rapids (12). Maximum size is reported to be 2 to $2.5 \mathrm{~m}$, probably representing the larger males.

Studies in the Venezuelan Llanos suggest that behavioural adjustment to the daily pattern of solar radiation plays a major role in determining daily activity. Individuals tend to submerge during the hottest part of the day, particularly at the end of the dry season. At this time of year they may also be found buried in the mud of shallow pools and in leaf litter in shaded parts of the forest. When water temperatures are seasonally high $\left(29^{\circ}-30^{\circ} \mathrm{C}\right)$ daylight hours are spent in the water, in the evenings many individuals move on shore and remain there for much of the night. When water temperatures fall, individuals spend several hours in the morning on land on sunny days. Body temperatures are maintained relatively constant $\left(30-33^{\circ} \mathrm{C}\right.$ during the day, and $26-30^{\circ} \mathrm{C}$ at night) during the transition from dry to wet seasons (18).

Juveniles of up to nearly a meter in length feed entirely on aquatic invertebrates, such as crustaceans and insects. Adults are opportunistic feeders taking whatever they can kill, ranging from snails to small deer and pigs $(1,4,6,7,9,11,13)$. A majority of all food items found in the stomach contents of caimans caught during the wet season in Bolivar State, Venezuela were frogs, especially Bufo granulosus and Pleurodema brachyops (13). There seemed to be little feeding during the dry season (13). Anurans have been reported in the diet from Venezuela, armoured catfish as the main food item in Guarico state, whilst the aquatic snail Pomacea ursus and crabs are most frequently taken in Apure state (13).

Copulation usually takes place near the end of the dry season, with nesting from mid-August to early November. In the Venezuelan Llanos courtship and breeding was observed from May-August during the early wet season, with nesting beginning in August, and reaching a peak in September. Nesting strategies are 
related to rainfall patterns and vary depending on local conditions. Mound nests, constructed of vegetable materials, average $117 \mathrm{~cm}$ length, $104.5 \mathrm{~cm}$ width and $44.5 \mathrm{~cm}$ height (11). Fourteen to 40 eggs are laid and hatch in 70 to 90 days, at nest temperatures of $28^{\circ}$ to $32^{\circ} \mathrm{C}$. In areas where hunting activity has not altered behaviour the female defends the nest very actively (14). Eggs vary from spherical to elliptical, average size $63.8 \mathrm{~mm} \times 40.7 \mathrm{~mm}$ average weight $59.9 \mathrm{gms}$. The major egg predator in the Venezuelan Llanos is the lizard Tupinambis sp. (11). In Venezuelan Guayana young caimans remained together for around 18 months (13).

The production of excrement by large populations of caimans may form an important input of nutrients in certain otherwise nutrient-poor aquatic ecosystems. The decline in caiman populations in certain mouth lakes of the central Amazon region has been followed by diminished fish populations, attributed to a decline in the invertebrate prey of young fishes (16).

Caiman c. crocodilus is highly adaptable, and is quick to re-establish itself in habitat vacated by . Melanosuchus niger and $\mathrm{C}$. intermedius. This may account for the temporary increase in some populations as Melanosuchus becomes extinct. The species has in fact established itself in man-made ditches and canals in parts of Florida, U.S.A., and in newly-formed artificial lakes behind the Transamazon Highway in Brazil (6). In studies carried out at Lago Amana (an affluent of the Rio Japura) and the Parque Nacional da Amazonia, numbers appeared to be limited by habitat preference rather than disturbance by man, despite heavy hunting pressure. It is possible that $C$. $c$. crocodilus may be able to withstand hunting better than the Melanosuchus niger because of its small size at sexual maturity. This is likely to be less than the size at which it is hunted most intensively, in contrast to $M$. niger which is taken at a size much smaller than that at which it is likely to breed. Therefore the potential for recruitment to the breeding population may be much greater for $\underline{C}$. $\underline{c}$. crocodilus (6).

THREATS TO SURVIVAL Illegal hide hunting and the lack of adequate enforcement to control smuggling, are the major factors contributing to the pressures placed upon the subspecies (9). A total of 101,641 C. crocodilus hides were exported from Peru from 1962-1967. Hides under $1 . \overline{2} \mathrm{~m}$ may still be exported. Although the export of caiman skins under $1.5 \mathrm{~m}$ has been prohibited in Colombia since 1973 a trade in this species continues. In $1974556,422 \mathrm{C}$. crocodilus were exported, $84 \%$ under the minimum legal length (19). Leticia, in the Colombia Amazon, is a major outlet $(9,19)$. Many skins come from individuals killed in Peru and Brazil and smuggled over the border (19). The minimum legal size restrictions are not enforced (19). Additionally, hatchlings are killed in large numbers and are preserved as curios for sale to tourists. For many years, Spectacled Caiman hatchlings from Colombia and Ecuador had provided crocodilian pets for the world pet trade. It is estimated that legal export figures reflect about one half of the true number of hides exported from Colombia and Peru, a large number of those animals killed spoil before reaching the tanneries. In many instances, the animal is killed for its flanks only, the remainder of the body left to waste. Bolivia is the main tanning country in South America (20).

Although the belly skin of the Spectacled Caiman contains well-developed osteoderms (4), renewed hunting pressures are being applied to the species as the more desirable hides of the Black Caiman and true crocodiles become unavailable. It is reported (20) that commercial interests, with the renewed legal trade in hides of some populations of American Alligator, have rekindled the demand for crocodilian products in world fashion. The hide of Caiman is an economically attractive product with which to meet this demand (20). 
Conversion of habitat to agricultural purposes has caused a decline in some regions, such as the rice fields in Guyana. Consumption of the meat on a non-commercial basis by local people is not an important threat at present $(8,9,10)$.

CONSERVATION MEASURES TAKEN Complete protection is afforded the species in Brazil (necreto Presidential No. 58.054, 23 Mar 1966; Decreto-Lei No. 289, Feb 1967), Ecuador (No. 818, Article 2, 1970), and Venezuela (1974). There is no direct trade in crocodilian skins through major Rrasilian ports. However because of the size, and remoteness of much of the Amazon basin within Brazil it is very difficult to enforce the law and hundreds of thousands of crocodilian skins are transported annually across remote parts of the Colombia border (6). It is also protected in Trinidad (Ordinance No. 26, Page 13, 1958), under $1.2 \mathrm{~m}$ in Peru (Resolucion No. 2525, 18 Nov 1955), and under $1.5 \mathrm{~m}$ in Colombia. There are no protective laws for the species in Guyana, Surinam, and French Guiana.

Listed on Appendix II of the Convention on International Trade in Endangered Species of Wild Fauna and Flora (CITES). Appendix II listing implies that commercial trade is allowed providing a permit from the country of export is obtained, this can provide a method of monitoring trade levels.

CONSERVATION MEASURES PROPOSED Adequate enforcement to control hide smuggling through the city of Leticia from surrounding countries; Leticia appears to be exempt from many of Colombia's present regulations (20). Total protection for crocodilians in Peru is necessary if the species is to survive there.

CAPTIVE BREEDING Caiman c. crocodilus is a taxon that may be suited biologically and economically to captive propagation in large numbers (20). Captive breeding has been successful in the Atlanta Zoo, Georgia, U.S.A. (4). Caiman crocodilus has been bred in at least nine institutions in five countries (2).

REMARKS There is difficulty in determining the subspecies identity of products, particularly small samples, made from the hides of Caiman crocodilus (5). Thus the international traffic in caiman hides and products includes, undetected, samples from all subspecies whatever the legislative status.

This account is based in part on a draft provided by $\mathrm{P}$. Brazaitis, and on material received from J.W. Lang, S.J. Gorzula and P.E. Vanzolini.

REFERENCES 1. Alvarez Del Toro, 1!. (1969). Breeding the Spectacled Caiman, Caiman crocodilus, at Turtle Gutierrez Zoo International Zoo Yearbook, Zool. Soc. London, England, Vol. 9: 35-36.

2. Behler, J. (1980). Breeding Crocodilians; the Current State of the Art. Department of Herpetology, New York Zoological Park. Occasional papers.

3. Brazaitis, P. (1973). The Identification of Living Crocodilians. Zoologica (N.Y.) 58(4): 59-101.

4. Hunt, R.H. (1969). Breeding the Spectacled Caiman, Caiman crocodilus, at Atlanta Zoo. International Zoo Yearbook, Zool. Soc. London, England, Vol. 9: 36-37.

5. King, F.W. and Brazaitis, P. (1971). Species Identification of Commercial Crocodilian Skins. Zoologica (N.Y.) 56(2): 15-70.

6. Magnusson, W.E. (1980). Biological Aspects of the Conservation of Amazonian Crocodilians in Brazil. Report Instituto Nacional de Pasquisos Da Amazonia. Presented at 
5th Working Meeting of IUCN/SSC Crocodile Specialist Group, Gainsville, Aug 1980.

7. Maness, S.J. (Sept. 1980). Inpublished Manuscript. Status of Crocodylus acutus, Caiman c. fuscus, and Caiman crocodilus crocodilus from venezuela. In litt., to P. Brazaitis (not seen).

8. Medem, F. (1971). Situation Report on Crocodilian from three South American countries. Proc. of First Working Meeting of Crocodile Specialists, Survival Service Commission, IUCN Publications, New Ser., Suppl. Paper 32:54-71.

9. Medem, F. (1973). Survey of South American countries Status report. Unpublished manuscript (not seen, cited in 20).

10. Medem, F. (1980). Caimans and Crocodiles - A Tale of Destruction. Oryx 15(4): 390-391.

11. Staton, M.A. and Dixon, J.R. (1977). Breeding Biology of the Spectacled Caiman, Caiman crocodilus crocodilus, in the Venezuelan Llanas. U.S. Department of Interior, Fish and Wildlife Service, Wildlife Research Report 非, Washington, D.C.

12. Vanzolini, P.E. and Gomes, N. (1979). Notes on the ecology and growth of Amazonian caimans (Crocodylia, Alligatoridae). Papéis Avulsos de Zoologia 32(17): 205-216.

13. Gorzula, S.J. (1978). An ecological study of Caiman crocodilus crocodilus inhabiting savanna lagoons in the Venezuelan Guayana. Decologia 35, 21-34.

14. Godshalk, R. (1981). In litt., 6 July to P. Brazaitis.

15. Gorzula, S.J. (1981). In litt., April 7th.

16. Fittkau, E.J. (1970). Role of caimans in the nutrient regime of mouth-lakes of Amazon affluents (An hypothesis) Biotropica 2(2): 138-142.

17. Medem, F. (undated, post 1978?). The present status of the Crocodilians in Colombia, Bolivia and Brazil. Inpublished Report.

18. Lang, J.W. (1977). Thermal ecology and social behaviours of Caiman crocodilus in the Llanos of Venezuela. Progress report to the National Zoological Park, Smithsonian Institution.

19. Smith, N.J.H. (1980). Caimans, copybaras, otters, manatees and man in Amazonia. Biol. Conserv. 19: 177-187.

20. Brazaitis, P. (1981). In litt., draft RDB account for $\underline{C}$. $\underline{C}$. crocodilus. 

SUMMARY Occurs from southern Mexico southward through Central America to Colombia, Ecuador, and Venezuela. Occurs in brackish, salt, and fresh water. Seriously depleted in Colombia and Ecuador, rare in Venezuela, status uncertain in much of Central America. Feeds primarily on snails, crustaceans and fish. Average size $1-2 \mathrm{~m}$. Breeding may occur throughout the year. Fifteen to 30 eggs are laid in a mound nest of organic debris constructed by the female. Hatching takes place in 75-80 days. Hide hunting remains the most significant threat. Listed on Appendix II of CITES. Nominally protected by a total ban on exploitation in Venezuela, Ecuador and Mexico. Size limitations exist in Panama and Colombia. Caiman c. fuscus might lend itself well to captive propagation. Populations in Mexico south through Central America to the Pacific coasts of Colombia and Ecuador are sometimes regarded as a distinct subspecies (C. C. chiapasius), and the name C. c. fuscus restricted to populations in the Magdalena and Sinu systems of Colombia and in Venezuela (not followed here).

DISTRIBUTION Extends from southern Mexico (Isthmus of Tehuantepec) and Nicaragua south through Central America to the Pacific slopes of Ecuador, Colombia including the Magdalena and Sinu rivers, and northwest Venezuela $(2,4,6)$. Introduced into Lanier Swamp, in the southwest of Isla de Pinos (Cuba) where it is regarded as a threat to the endemic Crocodylus rhombifer because it takes the young. See 'Remarks'.

POPULATION Depleted in Colombia and Ecuador, relatively abundant in parts of southern Mexico. No recent data on populations in Central America. Further information is given below for those countries for which it is available.

Colombia Seriously depleted $(5,6)$. Along the Caribbean coast between Ciénaga Grande and the Magdalena River illegal hunting is common, also on the lower and middle Magdalena. Almost all hides are of hatchlings or juveniles (9). Some refuge is found in lagoons along the lower and middle Magdalena Valley, where aquatic vegetation has become more extensive with the decline of manatees (9).

Ecuador Seriously depleted, must be considered endangered $(5,6)$.

Mexico Reported to be relatively abundant $(1,6)$. At Chiapas still common in some areas but declining due to over-exploitation (3). In recent years exploitation has diminished somewhat as the species has become more scarce (1).

Venezuela Has always been rare, does not appear to be the subject of intensive hunting pressures (4).

HABITAT AND ECOLOGY Prefers quiet waters and is often found in swamps, lagoons, small streams, and tributaries, rather than in the larger rivers. It does, however, enter brackish and salt water, which accounts for it occurrence in forest ponds on off-shore islands. Adults feed on snails, crustaceans and fish $(1,2,6)$. The distribution overlaps that of Crocodylus acutus and $\mathrm{C}$. moreletii, but $\mathrm{C}$. $\mathrm{C}$. fuscus is only sympatric with C. acutus. A small form, reaching $\mathrm{I}$ to $2 \overline{\mathrm{m}}$ in Tength. Breeding takes place all year in Colombia, but usually from January to March. Fifteen to 30 eggs are laid in a mound nest, constructed by the female 
from organic debris. A well-developed pattern of maternal care has been reported from observations made in Mexico. Hatching takes place in 75-80 days (1).

THREATS TO SURVIVAL Hide hunting is the most significant threat $(5,6)$. It is stated (IO) that the hide industry in the U.S.A. is again actively promoting crocodilian fashions. At one time large numbers of hatchling caimans were exported from Colombia and Ecuador for sale in the pet markets of the United States and Europe. This traffic has somewhat diminished in recent years. The sale of hatchlings as preserved curios still occurs. Marked habitat destruction has occurred in Colombia including the officially protected mangroves of the Isla de Salamanca National Park (9).

CONSERVATION MEASURES TAKEN There is a total ban on hunting and the export of hides from Mexico. Size limitations exist in Panama and Colombia and there has been a total ban on the export of live animals and hides from Ecuador since 1972. Venezuelan crocodilians have also been protected by a total ban since $1974(4,5,6)$.

Listed on Appendix II of the Convention on International Trade in Endangered Species of Wild Fauna and Flora (CITES). Appendix II listing implies that commercial trade is allowed providing a permit from the country of export is obtained. This can provide a means of monitoring trade levels.

CONSERVATION MEASURES PROPOSED It has been suggested (10) that the subspecies should be upgraded from Appendix II to Appendix I of CITES. However, this may be premature until studies have be made to determine the status of Venezuelan populations, as well as those in the various Central American countries.

CAPTIVE BREEDING Caiman c. fuscus may lend itself to captive propagation (10). C. crocodilus has been successfully bred in at least nine institutions in five countries, in recent years.

REMARKS There is difficulty in distinguishing small samples of hides or products of Caiman crocodilus subspecies from each other (3). Thus the international traffic in caiman products includes, undetected, hides of all subspecies whatever the survival or legislative status. South American caimans face renewed hunting pressures as the crocodilian hide industry resurrects crocodilian fashions in the U.S. (10).

F. Medem (the major authority on the genus Caiman) recommends (cited in 11 , for example) that the populations of the Magdalena and Sinu river systems in Colombia (extending into northwest Venezuela) be considered distinct from those of the Colombian Pacific coast, Central America and Mexico (6). By this interpretation, which does not appear to be widely followed, the coastal form is referred to as Caiman $c$. chiapasius (Bocourt) and the name $\underline{C}$. $\underline{\text {. }}$ fuscus is restricted to the Magdaleña-Sinu and Venezuela population.

This account is based on a draft kindly provided by P. Brazaitis.

REFERENCES 1. Alvarez Del Toro, M. (1974). Los Crocodylia De Mexico, Cestudio Comparativo, Instituto Mexicano De Recursos Naturales Renovables, A.C., Mexico, D.F., April 1974: 1-70.

2. Brazaitis, P. (1973). The Identification of Living Crocodilians, Zoologica (N.Y.) 58(4): 59-101.

3. King, F.W. and Brazaitis, P. (1971). Species Identification 
of Commercial Crocodilian Skins. Zoologica (N.Y.) 56(2): 15-70.

4. Maness, S.J. (1980). In litt., to P.E. Brazaitis. Unpublished manuscript. Status of Crocodylus acutus, Caiman c. fuscus, and Caiman Crocodilus crocodilus, from Venezuela. (Not seen, cited in 10).

5. Medem, F. (1971). Situation Report on Crocodilians from three South American countries. Proc. of First Working Meeting of Crocodile Specialists, IUCN Publ. New Ser. Supplementary Paper, No 32: 54-71.

6. Medem, F. (1973). Survey of South American counties, Status report. (Unpublished manuscript). (Not seen, cited in 10).

7. Varona, L.S. (1980). Protection in Cuba. Oryx 15(3): 282-284.

8. Alvarez del Toro, M. (1981). In litt. 26 May.

9. Medem, F. (1980). Caimans and Crocodiles, a tale of destruction. Oryx 15(4) 390-391.

10. Brazaitis, P. (1981). In litt. (Draft RDB account for Caiman crocodilus subspecies)

11. Smith, H.M., and Smith, R.B. (1979). Synopsis of the Herpetofauna of Mexico. Vol. V., Guide to Mexican Amphisbaenians and Crocodilians. John Johnson, North Bennington, Vermont. 

Caiman crocodilus yacare (Daudin 1802)

Synonym: (Caiman yacare)

Order CROCODYLIA

Family ALLIGATORIDÁE

SUMMARY A fresh water form inhabiting the marshes, lagoons, lakes and rivers of central-southern South America. Status uncertain; each of the four countries in the range appears to hold some adequate populations, although other populations are reported depleted or extirpated. Occurs sympatrically with Melanosuchus niger and Caiman latirostris in parts of the range. Food consists largely of snails and fish. In Brazil, nesting takes place in the rainy season, an average of 21 to 38 eggs are laid, hatching around March. Yacare are reported to attain lengths of 2.5 to $3 \mathrm{~m}$. Hide hunting, both legal and illegal, is the main threat to its survival. Caiman c. yacare is listed on Appendix II of CITES and as Endangered under the U.S. Endangered Species Act. Nominally completely protected in Argentina, Brazil and Paraguay, controlled by a hunting season and $1.5 \mathrm{~m}$ size limit in Bolivia. Legislation often inadequately enforced. It has been proposed that the subspecies should be temporarily upgraded to Appendix I of CITES, whilst further biological and population studies are made. Yacare have an excellent captive breeding potential. Some authorities consider this form to be a full species, Caiman yacare.

DISTRIBUTION Central-southern South America; in the Paraguay River drainage from the Pantanal and Mato Grosso regions of southwest Brazil, through eastern Bolivia and Paraguay to Argentina north of $30^{\circ} \mathrm{N}$; also the southern tributaries of the Amazon in Bolivia (the Mamore, Itenez and Beni) and Brazil (the Araguaia above its confluence with the Tapirape), also the Guapore on the Bolivia-Brazil border $(1,3,4,5,14)$.

POPULATION Overall status uncertain; each of the four countries in the range is reported to hold some apparently adequate populations, while the taxon is depleted or extirpated elsewhere. Under considerable hunting pressure.

Argentina Reportedly approaching extinction $(5,6)$. However, a population estimated at 200,000 individuals in 1979 (not confirmed by ground census) remains in the Esteros de Ibera, an immense swamp $200 \mathrm{~km} \times 100 \mathrm{~km}$ at its widest point (7).

Bolivia A 1978 census in the Mamoré, Beni and Itenez regions, covering an area of $693,082 \mathrm{sq} \mathrm{km}$, resulted in approximate total of 3,500,000 individuals (16). Reported relatively common in 1973 in the Rio Madre de Dios (15). Recent studies (17) at Lugo Tumi-Chucua (Beni) indicated over-hunting; immatures were common, an average of ten caimans per night were seen. Reported to be relatively common in the eastern lowlands in 1976-77 (8), including the Isiboro-Sécure National Park (13), also reported expirpated from parts of the eastern plains (15). From January Ist to August 31st 1976124,114 Yacare hides were exported (13).

Brazil Reported relatively common in parts of the Mato Grosso area, although severely depleted locally (18). A significant population occurs in the Caracara Reserve and at the Paraguai Pantanal $(2,13)$. In $197730-40$ adults were observed from May to June along a $20 \mathrm{~km}$ stretch of road from Cuiaba to Poconé, 20-30 large individuals were also observed basking at a cattle ranch within $10 \mathrm{~km}$ (13). 
Paraguay Years of excessive hunting have drastically reduced populations (5). However, some individuals remain even in traditional hunting areas. Much of the range is relatively inaccessible and some populations are likely to persist (9).

HABITAT AND ECOLOGY Reported to attain lengths of 2.5 to $3 \mathrm{~m}(3,5)$, maximum size recently encountered in Bolivia (9) was $.88 \mathrm{~m}$ snout-vent length in females, $1.2 \mathrm{~m}$ snout-vent length in males. Prefers open waters, marshy savannah, lakes, lagoons and rivers; avoids brackish or salt water. Occurs in sympatry with Melanosuchus niger, when it retreats to smaller creeks and streams to avoid the larger species, and with Caiman latirostris in the south. It appears to be capable of out-competing C. latirostris for available habitat (2). However, this may be the result of selective hunting for $C$. latirostris, with the consequent expansion of C. c. yacare into the vacant niche (7). Yacare are migratory and may travel overland for considerable distances while moving from stream to stream. Snails, crabs (14) and fish (7) are major food items; rodents, snakes and turtles are also consumed $(1,2,3,5)$. In Corrientes a principal prey is Serrasalmus spilopleura, a species of pirana. This species has increased rapidly in the last decade in Corrientes, possibly as a result of the decrease in Yacare, and is reportedly preying heavily on the offspring of other species including game fish (7). Where Yacare have been eliminated, the incidence of schistosomiasis among cattle has risen sharply, possibly in proportion to an increase in abundance of snails (an intermediate host for the parasite causing schistosomiasis) upon which Yacare feed (5).

In Brazil nesting takes place during the rainy season between December and April (2). Eggs are laid in a mound nest of organic material, constructed by the female. Average nest size in Brazil was $134 \times 117 \mathrm{~cm}$, and $40.5 \mathrm{~cm}$ high (2). Eggs are elliptical, white, hard-shelled and rugose; around $68 \times 43 \mathrm{~mm}$, weighing around $73 \mathrm{gm}$. Average egg size varies considerably between clutches (2). Average clutch size in Brazil is 31 (range $21-38$ ), in Bolivia $33.6(23-41)(8)$. The peak of hatching is in March. During incubation, the female visits the nest at intervals, usually at night. Nests are often abandoned when disturbed by man. At hatching time the female opens the nest, allowing the hatchlings to escape, there is some evidence that she may crack open the eggs to ensure a simultaneous hatch (2). It is not known how long the female guards hatchlings after they enter the water (2).

Major egg predators at Paconé, Brazil include the Coati Nasua nasua and the Crab-eating Fox Cerdocyon thous, with local reports of predation by tegu lizard Tupinambis sp. and Capuchin Monkey Cebus apella (2).

THREATS TO SURVIVAL Commercial exploitation of the Yacare caiman in the form of legal and illegal hide hunting is the single most significant threat to the survival of the taxon (5,7). Many hides have been exported by Paraguay to France, Germany (FRG) and the United States despite national protective legislation and the Convention on International Trade in Endangered Species of Wild Fauna and Flora. Paraguayan authorities claim that the export documents are forgeries (10). Although Bolivian protective laws are now more strongly enforced the hide industry remains powerful. Large numbers of hides are taken from Brazil and Paraguay and are then tanned and exported from Bolivia (5). Most skins of a shipment of 300,000 caiman hides from Bolivia recently intercepted in Florida are thought to have originated in the Pantanal region of southwest Brazil (18). An estimated 20,000 caimans, largely Yacare, are taken annually from Corrientes, Argentina (3). With the renewed interest in utilizing crocodilian products, even dried and salted raw skins have recently been exported to infant tanneries in the United States, only to be siezed in violation of the countrys' Endangered Species Act (14). Habitat destruction may also be 
significant. In Corrientes, Argentina, much former habitat has been lost to agriculture or ranching whilst in Misiones much of the jungle has been cleared for timber and replaced with non-native species (7).

CONSERVATION MEASURES TAKEN Protected by a total ban on commercial hunting in Argentina (Ley Nacional No. $13 \mathrm{~m}$ 908, Decreto Reglamentario No. 15, $501 / 53$ (1953)), as well as the export of raw or tanned hides and goods. No wildlife or products may be exported from Brazil (Decreto Presidencia No. 58, 054, 23 Mar 1966, Decreto Lei No. 289, Feb 1967). Bolivia (Decreto Supremo No. 08063, 16 Aug 1967) permits hunting from January to July, with a minimum size limit of $1.5 \mathrm{~m}$. Nominally protected in Paraguay by Presidential decree No 18.796 which prohibits hunting, commerce, import or export of all species of wildlife, parts or products $(10,11)$. Listed as Endangered by the Pan American Union, 1967. Existing legislation is not fully enforced (14).

Listed on Appendix II of The Convention on International Trade in Endangered Species of Wild Fauna and Flora. Appendix II listing implies that commercial trade is allowed, providing a permit from the country of export is obtained. This can provide a means of monitoring trade levels. Listed as Endangered under the United States Endangered Species Act, and thus banned from import into the U.S.

CONSERVATION MEASURES PROPOSED A major requirement is to limit smuggling by proper enforcement of existing laws. It has been proposed by some $(14,19)$ that Caiman c. yacare should be upgraded from Appendix II to Appendix I of CITES, at least until adequate studies have been completed, evaluating the status of populations and the effect of hunting on their reproductive potential. This proposal is not endorsed by all authorities (8). There appear to be good populations still in parts of Bolivia, Brazil and Paraguay (8,9). Present uncertainty about the taxonomic status and distribution of Yacare, in particular in relation to the remainder of the 'Caiman crocodilus complex', should be resolved. This and thorough field surveys of status, are urgently required.

CAPTIVE BREEDING Successful breeding in captivity has been reported from the following zoological institutions: the Fort Worth Zoological Park and the San Antonio Zoo, Texas, The New York Zoological Park, New York, U.S.A. It would appear, that like other Caiman crocodilus, the captive breeding potential for this economically valuable taxon is good (14).

REMARKS Although generally treated as one of the several subspecies of Caiman crocodilus, F. Medem, the authority on the genus, prefers to regard this form as a full species, Caiman yacare (21).

Two recently-described taxa accepted by some authorities (20), C. c.

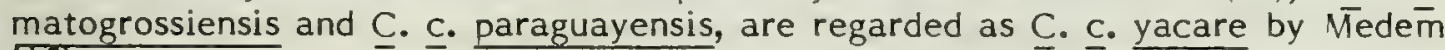
(15).

This taxon produces the most desirable hide of all the Caiman crocodilus group, and is the largest form in the group. Although Yacare does bear ventral osteoderms, these are not as extensive as in other Caiman crocodilius. Flank hides are comparable in size and near in quality to the Black Caiman Melanosuchus niger. Thus, shoes made from Yacare may retail at prices nearly equal to Black Caiman, are made of more readily available hides, and are cheaper to purchase raw. Profits for those items become greater, and commercial demand is therefore great. In Argentina $C$. latirostris hides are preferred to $C$.. . yacare (7). It is difficult for law enforcément agents to distinguish small products made from Yacare hide from those made from of other members of the genus Caiman (14). 
This account is based in part on a draft provided by P. Brazaitis.

REFERENCES 1. Brazaitis, P. (1973). The Identification of Living Crocodilians. Zoologica (N.Y.) 58(4): 59-101.

2. Crawshaw, P.G., jr. and Schaller, G.B. (1980). Nesting of Paraguayan Caimans (Caiman yacare) in Brazil. Papeis Avulsas Zool. (Sao Paulo) 33(18): 283-292.

3. Fitch, H.S. and Nadeau, M.R. (1979): Progress Report, WWF Project No. 79. 3162. An assessment of Caiman latirostris and Caiman crocodilus yacare in Argentina.

4. King, F.W. and Brazaitis, P. (1971). Species Identification of Commercial Crocodilian Skins. Zoologica (N.Y.) 56(2): 15-70.

5. Medem, F. (1973). Survey of South American countries, Status report. (Unpublished manuscript) (not seen, cited in 14).

6. Freiberg, M.A. (Mus. Argentina de Ciencias Naturales, Buenos Aires) (1981). In litt., 6 April.

7. Fitch, H.S. and Nadeau, M.R. (1980). An assessment of Caiman latirostris and Caiman crocodilus yacare in northern Argentina. Unpub. Final report on WWF Project No. 79. 3162.

8. Lovisek, J. (1981). In litt., 11 June, to P. Brazaitis.

9. Scott, N.J. (1981). In litt. II Jan.

10. King, F.W. (1981). In litt. 10 Feb.

11. Brazaitis P. (1982). In litt. 23 Jan.

12. Medem, F. (1980). Caimans and Crocodiles, a tale of destruction. Oryx 15(4): 390-391.

13. Medem, F. (undated, post 1978?). The present status of the Crocodilians in Colombia, Bolivia and Brazi!. Inpublished report.

14. Brazaitis, P. (1981). In litt., (draft Red Data Book account for Yacare).

15. Medem, F. (1982). In litt., 26 May, to D. Mack (Traffic U.S.A.).

16. Bejarano, B., G. (Director of Wildlife, Hunting and National Parks; Bolivia) (1982). In litt., 2 May, to D. Mack (Traffic U.S.A.).

17. Fugler, C.E. (1982). January. Current status of crocodilian populations in eastern Bolivia. Unpublished report.

18. Crawshaw, P. (1982). In litt., 24 February, to P. Brazaitis.

19. Mack, D. (1982). Pers. comm., June.

20. Wermuth, H., and Mertens, R. (1977). Testudines, Crocodylia, Rhychocephalia. Das Tierreich 100: 1-174. Berlin: Walter de Gruyter.

21. Medem, F. (1960). Notes on the Paraguay Caiman, Caiman yacare Daudin. Mitt. Zool. Mus. Berlin, 36(1): 129-142. 
SUMMARY A small highly aquatic species present in parts of northern Argentina, Bolivia, western Brazil, Paraguay and Uruguay. Has declined throughout the range and is locally extinct. Inhabits marshes, lagoons, streams and rivers, of ten with dense aquatic or waterside vegetation. Feeds on aquatic insects, snails, crustaceans and small vertebrates. A mound-nesting species, clutch size is variable, often around 40 . In captivity the female responds to hatchling vocalisation by breaking open the nest and carrying young to water. Adults attend the young. Threatened primarily by hide-hunting (the skin yields a high quality fine leather) also by habitat destruction. Nominally protected by legislation in most of the range. Listed on CITES Appendix I. Exploitation must be stopped and adequate sanctuaries established. Has bred in captivity.

DISTRIBUTION Southeastern South America, in Argentina, Bolivia, Brazil, Paraguay and Uruguay. The range extends along southeast coastal regions of Brazil from Rio Grande do Norte and the Recife area southwards to Lagoa dos Patos and Lago Merim (17), including the Rio San Francisco system, westward to the Mato Grosso and upper Rio Paraguay; the swamps of the lower Rio Polocios below the mouth of the Madidi in eastern Bolivia (5); the lower Pilcomayo, Paraguay, and Parana river systems of Paraguay and northern Argentina; the Uruguay system and coastal wetlands in Uruguay. Further details in following section.

POPULATION Declining rapidly throughout the entire range, locally extinct (5).

Argentina Extinct along the Pilcomayo, Paraguay and lower Parana, in the provinces of Jujuy, Formosa, Chaco, Santa Fe and Entre Rios (7). Almost extinct in Corrientes Province $(6,7)$ along the mid Parana system except in the Esteros de Ibera, a population remains in extreme northeast Argentina in Misiones Province, on the Alto Iguazu along the Brazil-Argentina border (6). The total population along the stretch included within the Iguazu National Parks in Argentina and Brazil is estimated at 380 individuals, while 5,000 to 7,000 may remain in the extensive and relatively inaccessible marshes of the Esteros de Ibera in Corrientes (6).

Bolivia Rare, thought to be a recent immigrant in minor numbers, possibly following decline of Caiman crocodilus yacare (5).

Brazil Reported in 1972 (14) to be threatened with extinction, also considered (11) to have suffered a drastic range reduction although not nearly extinct. Further data required. Reported "reasonably abundant" on the coast of Sergipe (15), but only small specimens. Still present in the region of Porto Alegre in the north of the Lagoa dos Patos, and near Taim east of the Brazilian portion of Laguna Merim $(17,18)$.

Paraguay Scarce and declining (5), no further details. 
Uruguay Declining (9), present in the northwest in the Rio Uruguay drainage (Dpts. Salto and Artigas) and recently discovered in the region of Laguna Negra and the Uruguayan portion of Laguna Merim $(1,9,17)$.

HABITAT AND ECOLOGY A small highly aquatic species, maximum length is around $3 \mathrm{~m} \mathrm{(4),} \mathrm{most} \mathrm{adults} \mathrm{are} \mathrm{probably} \mathrm{between} 2 \mathrm{~m}$ and $1.5 \mathrm{~m}$. Caiman latirostris inhabits marshes, swamps, lagoons, and small streams, closely associated with dense aquatic vegetation. It is frequently found in brackish and salt water, and often inhabits coastal mangroves (5). Not found far from water (6). Highly adept in the water (6). The remnant populations in Argentina occur in the broad and shallow Rio Iguazu, bordered by subtropical jungle, and in the Esteros de Ibera, an immense inland swamp $200 \mathrm{~km}$ long, with shallow water and dense vegetation (6). Considered one of the most wary of crocodilians, an important factor in the species' continued survival (12).

In the Iguazu, individuals emerge to bask for only about 30 minutes in the early morning during summer, in spring and autumn morning basking may last up to four hours (less for larger individuals) with an additional period in late afternoon, in winter caimans only emerge on warmer sunny days (6). Estimated preferred body temperature is $31-32^{\circ} \mathrm{C}(6)$. Small specimens sometimes climb trees to bask (6). This species appears more tolerant of a cool climate than more tropical crocodilians, existing in areas with lower winter temperatures and less solar radiation (6). In the Iguazu the main stream is avoided and each individual has a home range based on aggregations of flotsam at the river's edge or at the downstream end of small islands. The site is used for basking and much time is spent submerged with just the head exposed. Usually there is only one caiman at each site with larger specimens occupying the best (6). During most of the year, dispersal is limited by rapids but these can be avoided by moving through inundated jungle when the river floods. Gastroliths found in the stomachs of Iguazu specimens may have a hydrostatic function, aiding in submergence.

Food consists of aquatic insects, snails, crustaceans including crabs, and small to medium size vertebrates. In northeast Argentina the principal prey item of small to intermediate size $C$. latirostris is the freshwater snail Ampullaria americanista (13), while in Uruguay the snail Pomacea canaliculata is a major prey $(2,9)$ (these latter generic names may be synonymous, ref 21). The species forages at night and prey taken depends to some extent on the size of the caiman.

Nesting is in August-January in Brazil (5), January in Uruguay (9), and January-March in Argentina (6). A mound-nesting species. Nesting may occur on river islands, or in nearby jungle during very wet years (6). At a nest site at Iguazu, decaying vegetation had been collected from a radius of $4.5 \mathrm{~m}$ and scraped up into a nest mound $1.63 \mathrm{~m}$ in diameter and $.41 \mathrm{~m}$ high (6). The clutch comprised 39 eggs, with 19 in a lower layer separated by a thin layer of vegetation from the upper layer of 20 eggs. Clutch size is variable; 20-40 (9) or 40-60 eggs are reported (5) and even 60-90 in Paraguay (5) (the later figure possibly indicates laying by two females). Eggs are very rugose, hard-shelled, elliptical, about 66 $\mathrm{mm}$ long by $46 \mathrm{~mm}$, weight $84 \mathrm{~g}$. Incubation period is 63-70 days (6) or about 86 days at a nest temperature of $30-32^{\circ} \mathrm{C}$ (5). In captivity (16) the male of a breeding pair has been observed to assist in the earliest stages of nest building. The female became more aggressive during incubation (70 days) and remained near the nest for most of this period, leaving it only to feed (16). The nest was sited to receive little insolation, this is so in natural nests also (6), which are generally sited close to water. The female in the captive pair was observed to break open the nest, presumably in response to hatchling vocalization, and carry the hatchling in her mouth to water; this has also been reported in natural nests by poachers and hide merchants (5). Hatchlings cluster together near the nest site for their first year $(6,16)$, in captivity also with the young of the previous year 
(16). Both parents closely attend the hatchlings (16) and at the same time loose interest in the yearlings. Major egg predators at Iguazu are Tayra Eira barbara, a hawk Buteo magnirostris and the large teiid lizard Tupinambis texguixin; hatchling predators include Tayra, adult male $\underline{C}$. latirostris, and the stork Euxenura maguari (13).

THREATS TO SURVIVAL Threatened primarily by commercial exploitation for hides $(5,6,7,9)$. Although now nominally protected in most of its range, poaching continues uncontrolled. Habitat loss, including drainage, river channeling, forest clearance and construction of hydroelectric dams, is also cited as a threat, notably in Uruguay (5) and in northeast and southeast Brazil (15). In Argentina much habitat has been lost to agriculture or ranching in Corrientes, while in Misiones habitat has been lost due to clearing forests for timber and reforestation with exotic species (6). Populations recently confirmed in the Laguna Merim-Lagos dos Patos system are subject to increasing habitat modification (17). In Uruguay extensive drainage is expected to reduce populations in the Laguna Merim, and fertilizer run-off is a possible additional threat (9). Populations remaining in the Laguna Negra marshes are threatened by drainage now underway (17). The Los Patos Lake in Brazil receives significant pollution from Porto Alegre and other industrial centres, and plans exist for new industry and a super-port at Rio Grande city (17).

CONSERVATION MEASURES TAKEN Protected by a total ban on hunting and commercial exploitation in Argentina (Ley Nacional No.13, 908 Decreto Regularementario No.15, $501 / 53$ (1953); Brazil (Decreto Presidencial No.58.054, 23 March 1966, Decreto-Lei No.298, Feb. 1967); and Uruguay (Decreto No.508/969, 9 Oct. 1969). Protected under $1.50 \mathrm{~m}$ in Bolivia (Decreto Supremo No. 08063, 16 Aug 1967, Art. 20). Protected in Paraguay (Decreto 18.796, 1976) (19). Broad-nosed Caiman are present in the Natural Reserve and Ecological Station of Taim in southern Brazil (9), and in National Parks in Brazil and Argentina along the Rio Iguazu (6).

Listed on Appendix I of the Convention on International Trade in Endangered Species of Wild Fauna and Flora (CITES). Appendix I listing requires that trade in the taxon and its products is subject to strict regulation by ratifying states and international trade for primarily commercial purposes is prohibited. Italy has entered a reservation to Appendix I listing. Listed as Endangered under the United States Endangered Species Act, 1973. Recognised as Endangered by the Pan American Union, 1967 (6).

CONSERVATION MEASURES PROPOSED An immediate unified moratorium on the taking and exploitation of this species must be established throughout the countries in which it occurs if the species is to survive in viable numbers (5). Existing legislation is not adequately enforced. Further sanctuaries for C. latirostris are required. Biological field studies should be continued and extended. Further data on distribution and population status are required (5).

CAPTIVE BREEDING Like most of the caimans, the potential for captive breeding appears to be good. Breeding has been reported from Thuringer Zoopark, Erfurt (East Germany), the Jardin Zool do Rio de Janeiro (Brazil), and at the Fundacao Zoobotanica do Rio Grande do Sul, Porto Alegre (Brazil) an adult pair has bred in 1976, 1979 and 1980, producing 22 young in total (3). 26 specimens are reported on hand at the Atagawa Tropical Garden and Alligator Farm, Shizuoka, Japan 1981. A private preserve was established in 1969 by Sr. Crispin Piris, Asuncion, (Paraguay), in which juveniles were raised and liberated. Recent progress is unreported (5).

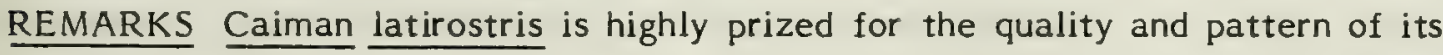


hide. The ventral scales are uniform, in wide transverse rows, and are usually attractively pitted (10). The belly hide is particularly suited for the manufacture of fine handbags and cases, and unlike Caiman crocodilus is extremely soft textured and pliable when tanned. Next to Melanosuchus niger, Caiman latirostris has one of the most desirable hides of the southern South American species (5).

Hides of Caiman species are still being exported in large numbers from Paraguay to France, Federal Republic of Germany and U.S.A. despite CITES legislation; Paraguay has claimed that the relevant export documents are forgeries (20).

In Misiones and other parts of northeast Argentina an increased incidence of the cestode Fasciola hepatica, parasitic on cattle and humans, has been reported, coincident with a decline in crocodilians. This parasite has a freshwater snail as

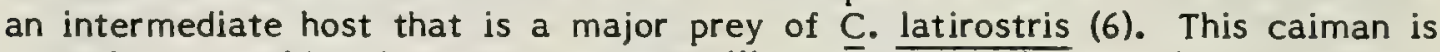
sometimes considered to exert a controlling factor on the jurasite, but this is doubted by some (2).

Freiberg and de Carvalho (8) propose two races of Caiman latirostris, Caiman latirostris latirostris from Bolivia, Brazil, Paraguay, Uruguay and Misiones in northeast Argentina, and Caiman latirostris chacoensis in Argentina from $32^{\circ}$ south northward to Entre Rios, Sante Fe, Choco, Formosa and Jujuy provinces, also Corrientes in the nor theast (8).

This account is largely based on drafts very kindly provided by P. Brazaitis and E. Gudynas, and reports of fieldwork by H.S. Fitch and M.R. Nadeau..

REFERENCES 1. Achaval, F. (Univ. de la Republica, Montevideo) (1980). In litt., 19 August, to H.W. Campbell.

2. Achaval, F., Meneghel, M., and Melgarejo, A. (1980). Status report on Caiman latirostris. Unpublished report.

3. Behler, J. (1980). Breeding Crocodilians; the current state of the art. Department of Herpetology, N.Y. Zoological Park Occasional papers.

4. Brazaitis, P. (1973). The identification of living crocodilians. Zoologica N.Y. 58(4): 59-101.

5. Brazaitis, P.(1981). In litt., 10 June (draft Red Data Book account for Caiman latirostris).

6. Fitch, H.S., and Nadeau, M.R. (1980). An assessment of Caiman latirostris and Caiman crocodilus yacare in northern Argentina. Unpublished final report on WWF Project No.79.3162.

7. Freiberg, M.A. (Mus. Argentina de Ciencias Naturales, Buenos Aires) (1981). In litt., 6 April.

8. Freiberg, M.A. and De Carvalho, A.L. (1965). Physis Buenos Aires) 25(70): 351-360.

9. Gudynas, E. (Coastal Research Programme, Montevideo) (1981). In litt., 17 February (draft Red Data Book account for Caiman latirostris).

10. King, F.W. and Brazaitis, P. (1971). Species Identification of Commercial Crocodilian Skins. Zoologica (N.Y.) 56(2): 15-70.

11. Magnusson, W.E. (Inst. Nac. de Pesquisas de Amazonia) (1981). In litt., 3 April.

12. Medem, F. (1973). Survey of South American countries, Status Report Unpd. manuscript.

13. Nadeau, M.R. (1980). Work in preparation noted in ref 6 .

14. Vanzolini, P.E. (1972). Repteis e Anfibios Ameacados de Extincao no Brasil. In, Especies de Fauna Brasileira 
Ameacadas de Extincao, pp.155-157. Academia Brasileira de Ciencas, Rio de Janeiro.

15. Vanzolini, P.E. (Mus. Zool. Univ. Sao Paulo) (1981). In litt., 12 February.

16. Widholzer, F.L., Borne, B., Tesche, T. (in press, 1981). Procreation of Caiman latirostris Daudin, 1802 in captivity (Crocodilia, Crocodylidae) (to appear in International Zoo Yearbook).

17. Gudynas, E. (1982). In litt., 5 March.

18. Gudynas, E., and Fabricio Filho, J.A. (1981). Notas para la conservacion de los costas de Uruguay y Rio Grande do Sul, Brasil. Bol. S.P.N. (Uruguay) 1: 3-15.

19. Brazaitis, P. (1982). In litt., 23 January.

20. King, F.W. (1981). In litt., 10 February.

21. Gudynas, E. (1981). In litt., 30 October. 

Melanosuchus niger (Spix 1825)

SUMMARY The largest species of New World crocodilian, Melanosuchus niger has been known to exceed $6 \mathrm{~m}$ in length. The species formerly occurred throughout the Amazonian region, from the Amazon mouth in the east to Ecuador in the west. Favoured habitats include quiet river backwaters, lagoons, inundated forest or grassland, or large rivers lacking rocky banks. While extremely abundant in many areas in the last century, the species has been heavily exploited by hide-hunters from the early 1930's onward. Its large size and relative lack of bony osteoderms made it the favoured target species. The Black Caiman is now severely depleted virtually throughout its range, and is locally extinct or on the verge of extinction. The biggest known population, possibly comprising over 1,000 large individuals, is located at Kaw (French Guiana). Other good populations occur in east Ecuador, notably at Limon Cocha, and in Manu National Park (Peru). Fish and capybara are among favoured prey items. A mound-nesting species, the clutch typically comprises 35-50 eggs. The female usually guards the nest. Nominally protected by legislation in most parts of the range. Present in the Manu National Park. Listed in CITES Appendix 1. Existing legislation should be rigidly enforced and all hunting prohibited. Existing populations and their habitat at Kaw and Limoncocha should be rigidly protected in the immediate future.

DISTRIBUTION Restricted to the Amazon basin $(7,16,21)$. Formerly widespread in the Amazon region of northern Brazil, also present in adjacent areas of eastern French Guiana, southwest Guyana (outside the Amazon drainage, on the Rupununi and probably Essequibo Rivers), southern Colombia (Putumayo and Caqueta Rivers), eastern Ecuador, northeast Peru, northeast Bolivia. Also reported from Paraguay on the basis of descriptions received from hunters and hide dealers (12).

POPULATION The Black Caiman was formerly widespread in Amazonia and extremely abundant at several localities. It was probably the most conspicuous (if not necessarily the most common) crocodilian in Amazonia (6). With the exception of a very few peripheral populations in more remote lakes and rivers mainly in the Kaw region of French Guiana, eastern Ecuador and parts of Peru the species is now severely depleted throughout the Amazon basin and locally extinct $(7,8,10,18)$. No populations comparable in density to those encountered in the nineteenth century are now known (18). The total present population may be less than $1 \%$ of the population existing at that time (18). The species was formerly renowned for the large size attained by many individuals (to over $6 \mathrm{~m}$ ). Large specimens are now very rarely seen (8), although it is reported that individuals of over $6 \mathrm{~m}$ can be seen in the Kaw region (18).

French Guiana The Black Caiman occurs only in the extreme northeastern corner of the country. The seasonally flooded grasslands around the remote Kaw River (les Marais de Kaw), and the largely inaccessible swamp area (la Savanne Angelique) bordered by the Kaw River, the Montagnes de Kaw and the Montague de Gabrielle, between them hold perhaps the largest Melanosuchus population left in South America (14,18). Population estimates vary; a former animal dealer 
familiar with the area suggests 1,500-2,000 large individuals remain at Kaw, while a French herpetologist has suggested that 1,000 would be the maximum for the entire country (18). Some very large individuals, around $5 \mathrm{~m}$ long and larger, remain at Kaw (18). Black Caiman are also sometimes found in other areas around Kaw (18). Poachers have exterminated populations in creeks and swamps west of Kaw, and in the lower Oyapock River and its tributaries. The Kaw area is relatively small and is unprotected, so the future of the Black Caiman population here is not assured.

Guyana Present in the south, in the Rupununi, Essequibo and Berbice Rivers (18). Now severely depleted (18). Formerly very abundant in the Rupununi District but reduced to near extinction by hide hunting; the species was said (in 1973) (10) to be recovering somewhat following a five year ban on commercial hunting imposed in 1970.

Paraguay There are unconfirmed reports that Black Caiman may occur in the Rio Paraguay drainage, presumably having moved downstream from the adjacent Mato Grosso region of Brazil. This population, if present, would be severely threatened (18).

Peru Formerly very abundant throughout the upper Amazon drainage in Peru, now considered on the verge of extinction due to excessive hide hunting (18). Good populations remain in the Manu National Park, and possibly in the large swamp area along the lower Rio Madre de Dios (although poachers have recently been active here (19)). Approximately 150 adult Melanosuchus were present in Manu N.P. in the early 1970 s (source in 18). A population also exists in the Pacaya-Samiria Reserve, its status is currently being investigated (18).

Bolivia Formerly widespread in northern and eastern parts, now severely depleted and locally extinct (18). During a late 1976 survey in the eastern lowlands only five Melanosuchus nests were found compared with 37 of Caiman crocodilus yacare (4). Decline is attributed to excessive hide-hunting which is continuing today (18).

Brazil Brazilian Amazonia was formerly the main distribution area of the Black Caiman. The species once occurred throughout the region and existed in extreme abundance in some parts, for example, on the Rio Solimoes and the large delta islands. Populations are now severely depleted everywhere or locally extinct, mainly due to hide-hunting (18).

Colombia Formerly very abundant on the Colombian Amazon from Leticia to the Rio Atacuari on the Peru border, also quite common on the major tributaries. Excessive hide-hunting resulted in rapid decline throughout, and the species was becoming rare by the late 1950s. Now severely depleted and widely extinct. There are very few recent records and most refer to isolated individuals, for example during a 1977 two-month survey of the Amazon and Putumayo two biologists found only one specimen, a $62 \mathrm{~cm}$ captive juvenile (18).

Ecuador Present in the Rio Napo drainage, extending east almost to the foothills of the Andes, also in tributaries of the Maranon (upper Amazon) (18). The species appears still to be widely distributed in Amazonian Ecuador below 250m (15). Good populations remain in eastern Ecuador (10), most notably at Limon Cocha (cocha $=$ lagoon) $(15,18)$. At the lake at Limon Cocha it is possible during relatively dry periods (December-February) to encounter up to 200 individuals in a few hours night searching, some even approaching $5 \mathrm{~m}$ in length (15). The species may be relatively common in the lower Rio Aguarico and the Rio Yasuni-Rio Lagartococha area near the Peruvian border (15). 
HABITAT AND ECOLOGY A large species that has been known to exceed $6 \mathrm{~m}$ in ength, M. niger inhabits freshwaters, preferring quiet backwaters or large bends in big rivers, oxbow lakes, lagoons, and flooded forests or periodically-inundated grassland $(7,9,16,17,18)$. Also fond of creeks and swamps on the Amazon delta islands of Marajo, Mexiana and Caviana and along the Rio Branco (18). Not typically found in small forest streams (5). The species does not avoid strong currents and was formerly also found along the Amazon River itself, but it does not frequent rivers with rocky banks (9). The population around Kaw (French Guiana) inhabits an area of seasonally-inundated grassland, retiring to deeper waters during the dry season (14). The lake at Limoncocha (15) differs from others in the vicinity in that it is large, somewhat eutrophic, and much of the shoreline is retreating into swamp forest. The water is murky with green algae, and there are dense fish populations. The other lakes and lagoons in the region are smaller, with steep banks, clear but brownish water, and apparently much smaller fish populations; these lakes also appear to lack $\mathrm{M}$. niger (although sparse populations of Caiman and Paleosuchus are present).

The Black Caiman, like other crocodilians, is carnivorous in feeding habits $(17,18)$. Juveniles, up to $1 \mathrm{~m}$, feed on small fish, amphibians, insects, crustaceans and snails. Larger individuals take a variety of prey, including rodents (especially capybara), otters, dogs, pigs, small deer, cattle, turtles and other caiman $(7,18)$ and particularly fish such as catfish and piranha Serrasalmo spp. (1). Fish are the major prey in the Manu National Park of Peru (17). During the dry season of the lower. Amazon basin, fish populations are concentrated in shrinking pools and provide a convenient food source $(16,18)$. There may be a period of aestivation in this region (7).

Formerly the largest abundant predator in tropical South America, the ecological importance of $\mathrm{M}$. niger has become apparent following its widespread decline. In parts of Boliviā and Brazil, capybara Hydrochaerus have become very abundant and destructive to local crops, due to population expansion following elimination of M. niger, a major predator of capybara (18). Further, in parts of lower Amazonia, Black Caiman excrement provided nutrient input into lakes and swamps that was utilized by a variety of zoo- and phytoplankton, including invertebrate larvae. These organisms in turn formed the prey of fish hatchlings. The decline in populations of some valuable fish species appears to be due to decreased survival of hatchlings, following decreased planktonic food supply, following the elimination of M. niger, whose excrement formed the base of the food chain (2).In some areas of Bolivia an increase in Piranha Serrasalmus populations was noted following Black Caiman decline, and cattle crossing flooded grassland were frequently attacked by these fish (18).

Breeding biology is little known (13). A mound-nesting species, the nest consists of a pile of vegetable debris about $1.5 \mathrm{~m}$ wide and $.8 \mathrm{~m}$ high (7). The clutch usually comprises 30-60 white hard-shelled eggs, one $4 \mathrm{~m}$ female was found to contain 68 eggs, and up to 75 are occasionally reported (13). Mean clutch size in 5 nests from eastern Bolivia was 41 (4). In Colombia and Brazil it has been reported that the eggs are deposited in two layers separated by a layer of rotted leaves $(7,13)$. Eggs are around $83-90 \mathrm{~mm}$ long by $50-57 \mathrm{~mm}$ diameter (16). Nesting in Bolivia takes place in September-November, hatching in December-early February (13). Nesting in Colombia is late November-late December on the Putumayo, December-January on the Caqueta (13). In the Rio Napo region of Ecuador (20) the majority of nests are constructed in October, the female remains near the nest, frequently on top of the nest if exposed to the sun, and defends it vigorously. Hatching occurs in November-March, depending on the time of laying. Incubation period is five to six weeks, perhaps longer in shaded forest sites. Nest-guarding has also been reported in Bolivia, but is not shown by all females in the Marajo region of Brazil (13). The position of a guarding female 
THREATS TO SURVIVAL The very large size attained by Melanosuchus, and the relative lack of osteoderms in the lateral portions of the belly skin, has led to extremely heavy exploitation by hide-hunters for the leather industry. This is the major factor contributing to the decline of the species (1). The species has also suffered from loss of habitat to logging and agriculture (1), including cattle ranching (3), and persecution as a pest in cattle areas. For example, in the seasonally flooded grassland of the Amazon delta islands, campaigns were mounted in the dry season in which several hundred caimans would be killed over a couple of days (18). Many millions of Black Caimans were killed for hides in the middle decades of this century (18). This volume declined markedly in the 1950's and 1960's as the difficulty of finding the species increased, and the less desirable hides of Caiman crocodilus were exported in correspondingly greater numbers (8). Data from Colombia (II) exemplify the level of exploitation suffered by Melanosuchus; the species was extremely abundant at the start of the 20th century, hide-hunting started in the early $1940^{\prime} \mathrm{s}$, according to official statistics over 66,000 hides were exported in 1970 and 1972 alone, and at present the species is virtually extinct in Colombia. The tanning industry in Bolivia is second only to mining, oil and gas in export value, and exploitation is intense; light aircraft have been used to locate isolated lakes and ponds in the forest so that hunting crews can cut trails to the area and take available caimans (18). Although the species was once the mainstay of the hide industry in Brazil, it now probably contributes less than 1000 hides per year (6). However, it may be that while M. niger itself now exists at too low a density for commercial exploitation in most $\overline{\text { areas, }}$ its occurrence in sympatry with Caiman crocodilus is detrimental. The latter species appears to be able to colonize habitats modified by man, such as the artifical lakes behind the Trans-Amazon Highway near the Rio Tapajos, and areas vacated by other crocodilian species such as $\underline{M}$. niger. It is more wary than $M$. niger. It breeds at a relatively small size (less than the size hunted most intensively). These factors mean that $\underline{C}$. crocodilus is able to sustain even quite strong hunting pressure, thus hide-hüting can remain profitable, and the remaining individuals of $\underline{M}$. niger can be taken (6). The Black Caiman is relatively approachable and is hunted at a size much less than breeding size (6). There is still some hunting for meat or fat in parts of the range (18). Dry season burning of dried-out swamps is a major threat to the Kaw population, and the area's inaccessibility will soon be ended with construction of a road to Kaw (18). It has been noted that French Guiana is administered as a department of France so that hide shipments are not strictly international (18) and thus not covered by the provisions of the Convention on International Trade in Endangered Species of Wild Fauna and Flora (France has in any case entered a reservation to CITES Appendix I listing). It is suspected that French tanners will push for exploitation of the very important Melanosuchus populations in French Guiana (18).

CONSERVATION MEASURES TAKEN The Black Caiman is nominally protected by legislation in most countries within its range (18). Bolivia; Decreto supremo No. 08063 of 16 August 1967, Article 20, prohibits hunting between 31 July and 1 January, the size limit outside the close season is $2.5 \mathrm{~m}$. No attention is paid to this legislation (18). Brazil; not included on list of endangered species in Brazil, commercial exploitation is prohibited under Law No. 5.197/67, this is enforced sufficiently in some areas to provoke hunters to operate in adjacent countries. Colombia; totally protected under Resolucion No. 411 , of 16 July 1968, Ministerio de Agricultura and Res. No. 573, of 24 July 1969, INDERENA. Ecuador; protected by legislation and export banned since 1972 (15), this is effective to some extent as there is little evidence of large-scale traffic in crocodilian skins. French Guiana; protected but without real control (18). Guyana; five-year prohibition on hunting passed in 1970 (18), present situation unknown. Paraguay; all wildlife is protected by Decreto No.18.796, prohibiting hunting, 
commercialization and export, however Melanosuchus is not recognised offically as resident in Paraguay as its reported occurrence is not documented by any scientific publication (19). Peru; Protected in Manu National Park and under law No.21147, protecting all forms of wildlife except those important as a food source for local people (19).

The only good Melanosuchus population within a protected area is that in the Manu National Park of Peru (17), and small numbers occur in the Parque Nacional de Amazonia on the Rio Tapajos, Brazil (6).

Listed on Appendix I of the Convention on International Trade in Endangered Species of Wild Fauna and Flora (CITES). Appendix I listing requires that trade in the taxon and its products is subject to strict regulation by ratifying states and international trade for primarily commercial purposes is prohibited. France has entered a reservation on Appendix I listing.

CONSERVATION MEASURES PROPOSED In general, more rigorous enforcement of existing legislation is required, to allow opportunity for remnant populations to recover. Illegally taken Black Caiman hides continue to find their way into the world market and this should be curtailed. For example, evidence of poaching was found in the Madre de Dios area of Peru in August 1980 (19). It is essential that the flourishing population at Limon Cocha (Ecuador) remains free of exploitation. This may be achieved through rigid enforcement of existing protection laws or ideally by setting the area aside as a National Park or reserve (the lake also holds the threatened freshwater turtle Podocnemis unifilis (15)). Studies are required on the feasibility of the latter course. Limon Cocha is an ideal site for a long-term ecological study of Melanosuchus (15), in an apparently near-primordial condition. It is also essential that the largest known Black Caiman concentration, in the Kaw region of French Guiana, rapidly receives full protection (before a planned road to Kaw is built). Protection has been planned since 1975 (22) but has been postponed due to lack of funds. The French Government is to be approached with the recommmendation that protection of Kaw is implemented as soon as possible (18). France should be strongly discouraged from allowing trade in Melanosuchus hides.

CAPTIVE BREEDING Because of its large size, the breeding potential of this species in captivity in large numbers appears to be limited. Most specimens in zoological collections at this time are juveniles or sub-adults. Three American zoos have embarked on a Black Caiman breeding programme; the Oklahoma City Zoo, the Metro Zoo (Miami, Florida), and the New York Zoological Park (1).

REMARKS The genus Melanosuchus is represented by only a single species, $M$. niger. In comparison with species of Caiman and Paleosuchus, the ventral scales of $M$. niger possess only moderately developed osteoderms, small or absent laterally, and when tanned the skin produces a high quality leather. The average market hide is $1.5 \mathrm{~m}$ to $3 \mathrm{~m}$ in length. Products are distributed as complete belly skins, throats, flanks, and tails (of particularly large individuals). A renewed interest in stimulating the use of crocodilian products in world fashion has increased the demand for hides of this species (1). Many hides are exported from Colombia and the tanneries in Bolivia as 'Tinga' i.e. Caimain crocodilus. These hides frequently originate in Brazil, where little can be done to effectively prevent smuggling in remote areas (1).

This account is based on a review paper (ref. 18) by M.J. Plotkin et al, on a draft kindly compiled by Peter Brazaitis (Bronx Zoo), and on other information received through the courtesy of W.E. Magnusson, R.A. Mittermeier, K. Miyata, M.J. Plotkin, F. Wayne King, and the work of F. Medem. 
1. Brazaitis, P. (1981). In litt., 10 June. (Draft Red Data Book account).

2. Fittkau, E.J. (1970). Role of caimans in the nutrient regime of mouth-lakes of Amazon affluents. Biotropica 2(2): 138-142.

3. Honegger, R. (1979). Red Data Book, Vol 3: Amphibia and Reptilia. IUCN, Gland (third edition, revised).

4. Lovisek, J. (1981). In litt., 11 June, to P. Brazaitis.

5. Magnusson, W.E. (1980). Habitat separation of Amazonian crocodilians. Paper presented at the 23rd annual meeting of the Society for the Study of Amphibians and Reptiles (Crocodile Symposium). Milwaukee, U.S.A. (6-10 August).

6. Magnusson, W.E. (1980). Biological aspects of the conservation of Amazonian crocodilians in Brazil. Paper presented at 5th Working Meeting of the IUCN/SSC Crocodile Specialist Group, Gainesville, U.S.A. (August).

7. Medem, F. (1963). Osteologia craneal, distribucion geografica y ecologia de Melanosuchus niger (Spix) (Crocodylia, Alligatoridae). Revista Acad. Colombiana Ciencas. 12 (45): 5-19.

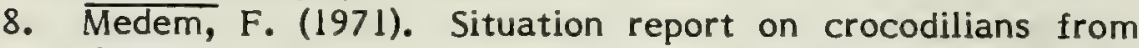
three South American countries. IUCN Publ. New Ser. Suppl. Pap. No. 32: 54-71. (Proceedings of the First Working Meeting of Crocodile Specialists, N.Y., 1971).

9. Medem, F. (1971). Biological isolation of sympatric species of South American Crocodilia. IUCN Publ. New Ser. Suppl. Pap. No.32: 152-158. (Proceedings of the First Working Meeting of Crocodile Specialists, N.Y., (1971).

10. Medem, F., presented by Dr. F. Wayne King (1973). Summary of the surveys of the status of crocodilian species in South America undertaken by Professor F. Medem. IUCN Publ. New Ser. Suppl. Pap. No.41: 33-35. (Proceedings of the Second Working Meeting of Crocodile Specialists, St. Lucia, Zululand).

11. Medem, F. (1974). The present status of crocodilians in Colombia, Bolivia and Brazil. Unpublished report submitted to New York Zoological Society.

12. Medem, F. (1975). Conservation status of crocodilians in Paraguay. Unpublished report submitted to New York Zoological Society.

13. Medem, F. (1980). The breeding biology of the Black Caiman (Melanosuchus niger) - what we don't know. Paper presented at 23rd annual meeting of the Society for the Study of Amphibians and Reptiles (Crocodile Symposium) Milwaukee, U.S.A. (6-10 August).

14. Mittermeier, R.A., Plotkin, M.J., and Constable, I. (1979). Large population of the giant Black Caiman found in French Guiana. Unpublished report.

15. Miyata, K. (1981). In litt., 2 March.

16. Neill, W.T. (1971). The last of the ruling reptiles. Colombia Univ. Press, N.Y. $48 \overline{6 \text { pp. }}$

17. Otte, K.-C. (1974). Project 579, Research Programme Melanosuchus niger in the Manu National Park. World Wildl. Yb. 1973-1974: 257-260.

18. Plotkin, M.J., Mittermeier, R.A., Medem, F., and Constable I.D. (in press, 1982). Distribution, ecology, and conservation of the Black Caiman (Melanosuchus niger). Bull. Mus. Comp. Zool. Harvard. 
19. Plotkin, M.J. (1981). In litt., received 16 April.

20. Rodriguez, O. (1972). In litt., 29 August, to F. Medem (cited in ref. 13).

21. Wermuth, H., and Fuchs, K. (1978). Bestimmen von Krokodilen und ihrer Häute. Gustav Fischer, Stuttgart.

22. Condamin, M. (1975). Projects de reserves naturelles sur le littoral Guyanais. Unpublished report, (not seen, cited in ref. 18). 

SUMMARY A moderate size, rather slender-snouted crocodile. Ranges from central Mexico south through parts of Central America to northern South America (to northern Peru on the Pacific, Venezuela on the Caribbean); also present in extreme southern Florida (IJ.S.A.) and Cuba, Jamaica, Haiti and Dominican Republic in the Greater Antilles. Formerly widespread and of ten abundant, now severely depleted throughout the range, mainly due to hide-hunting, aggravated more recently by habitat loss. Many populations extirpated. Remnant populations still subject to exploitation and persecution. The most locally dense population appears to be that in Lago Enriquillo in the Dominican Republic, where 175-250 adults may remain (the security of this population is not assured). Primarily a coastal form, typically associated with mangrove swamps and brackish bays, but extends inland in lakes and the lower reaches of large rivers. Adults may feed mainly on fish. Mainly a mound-nester, mean clutch size around 40 eggs. The female guards the nest, assists in hatching, and parents may guard hatchlings. Few protected populations. The Florida population, including about 20 breeding females, is mostly within the Everglades N.P. (but reproductive success is very low). Nominally protected by legislation in much of the range, often not enforced. Listed as Endangered under the U.S. Endangered Species Act. Listed on CITES Appendix I.

DISTRIRUTION A mainly Central American species, extending from central Mexico southward through the Central American isthmus, in places on both the Pacific and Caribbean coasts, as far as Peru and Venezuela; also present in southern Florida (U.S.A.), and on Cuba, Jamaica, Haiti and the Dominican Republic in the rreater Antilles area $(8,9,15)$. Recorded from Belize, Colombia, Costa Rica, Cuba, Nominican Republic, Ecuador, El Salvador, Guatemala, Haiti, Honduras, Jamaica, Mexico, Nicaragua, Panama, Peru, United States, Venezuela (8). Apparently absent from Puerto Rico. Vagrant individuals have been noted in the Cayman Islands and Trinidad, and pre-Colombian crocodile fossils are known from the Bahamas (8).

POPULATION The American Crocodile appears to be seriously depleted throughout its former range. Only small isolated populations are known to persist, typically in relatively inaccessible areas; these remnants are still subject to exploitation for hides or local consumption. The densest remaining population known in recent years is centred on Lago Enriquillo in southwest Dominican Republic, where 175-250 adults may remain, but the future of this population is not assured. Unless cited otherwise, all data and opinions given in this section are taken from a recent authoritative review (8).

Belize Apparently severely depleted but available data are inadequate. It was reported in 1971 that $\underline{C}$. acutus was rare inland but somewhat less rare on the offshore islands (15). More recent surveys indicate that the species no longer exists on the islands (16), and there were no certain sightings on the mainland (1). However, during the latter survey, although a related species $\underline{C}$. moreletii was definitely recorded, certain animals were noted as very moreletil-like while others were very acutus-like (2) and it has been asserted (5) that one particular specimen encountered in a beach area must have been acutus. Although 
crocodiles do exist on the Belize mainland, the true distribution and status of $\underline{C}$. acutus relative to $\underline{\mathrm{C}}$. moreletii remains uncertain.

Colombia Severely depleted due to hide-hunting. Formerly present along both the Caribbean and Pacific coasts and in associated drainages (8). Now absent from most of the former range, remaining populations in some river systems are considered unlikely to recover without re-stocking, and no known populations are even moderately abundant (8).

Costa Rica Formerly present along both coasts and in the larger rivers; now severely depleted and only occasionally encountered, mainly in Guanacaste Province and the Tempisque River and major tributaries (15). Present in Santa Rosa National Park, where a $60 \mathrm{~cm}$ individual and several smaller ones were recently (18) seen in the estuary behind Nancite beach.

Cuba Previously present throughout the island, and on offshore islets (8), mainly in saline 'r brackish-water habitats but also in inland freshwater lagoons (17). The species is now depleted (8) and is declining rapidly (17). Large individuals are only very rarely observed (17). Better populations remain in the chain of offshore islets along the northern and southern coasts than on the main island (17).

Dominican Republic The species formerly occurred in suitable habitat around the coast and inland in large rivers but is now depleted or eliminated over much of the historical range (8). Small remnant populations persist in mangrove swamps off the Rio Montezuma in the northwest, and possibly in the Rio Samana, and an important population exists in the saline Lago Enriquillo in the southwest (8). This latter population, estimated to comprise 175-250 adults, may be the most locally dense population extant anywhere in the range of $C$. acutus (8). However, there appears to be a very high mortality rate among hatchlings as water salinity increases due to diversion of freshwater inflow from the lake (8), and the nesting area on Isla Cabritos in Lago Enriquillo is subject to disturbance by grazing livestock (3), so the future of this population is not assured.

Ecuador Formerly very abundant along the Pacific coastline and inland in larger rivers, with populations in the thousands in the Rio Guayas, Rio Daule, and their tributaries, and large populations also in the lower reaches of the Mataje, Santiago and Esmeraldas (8). The species is now very rare and appears to be extinct over most of its former range, due to excessive hide-hunting $(8,13)$. A few small scattered populations remain; for example, groups of fewer than ten animals each have been found in recent surveys (13) in the Estero de Bajen, the Reserva Ecologica de Churute (near the Gulf of Guayaquil), and in a few inland freshwater swamps in the provinces of Los Rios and Guayas. The few known remnant populations are considered in imminent danger of extinction (8).

El Salvador Little information is available on past or present distribution. Reported to be declining a decade ago, with populations perhaps existing in Guija and Jocotal Lakes (15).

Guatemala Seriously depleted in the Pacific region, where some small populations are suspected to persist (8). Recent reports from the Caribbean coast do not clarify whether Crocodylus acutus or C. moreletii is involved, in any event, crocodilians are now very scarce even in areas where they were formerly numerous.

Haiti The species formerly occurred around the coast and on Ille-a-Vache but is now rarely encountered, although moderate numbers were reported to persist in 1974 in the region of Gonaives in the northwest and in inland lakes near the 
Honduras Formerly present in both Pacific and Caribbean regions (possibly replaced by $\underline{C}$. moreletii in inland waters in the extreme northwest). Still

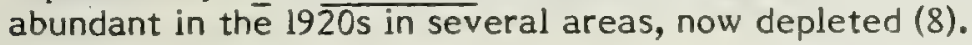

Jamaica Reportedly formerly abundant, mainly in mangrove swamps along the southern coast (14). The 1969 population was estimated to comprise around 2,000 adults; hide-hunting and wetland drainage has led to marked decline (14) and a 1975 survey of most available habitat on the south coast revealed a total of 41 crocodiles (8). The species now appears restricted to isolated populations and occasional individuals within the historic range (8). It is also reported that the species may be found in almost any south coast wetland of one hectare or more in area (14). The major population is said to occur in the Black River Morass area, now undergoing severe habitat modification (8), although several other refuge localities are reported (14).

Mexico Severely depleted, mainly due to over-exploitation by the hide trade (at a peak during the years of the Second World War). Now only scattered localized populations remain. Fieldwork along the east coast over the past decade reveals that both indigenous Crocodylus species are now very rare, but $\underline{C}$. acutus is much less frequently encountered than $\mathrm{C}$. moreletii. There is uncertainty over the historic distributions of these two species in Mexico; it may be that records of $\mathrm{C}$. acutus north of Campeche are based on mis-identified moreletii, while most goōd $\overline{\text { records }}$ on the west coast refer to acutus (8).

Nicaragua Severely depleted, apparently no data available on distribution and detailed status of existing populations. While one hide dealer had over 2,000 crocodile and caiman skins available in 1971, this stock was drawn from many parts of the country (and even from Costa Rica) (8).

Panama Formerly present along Pacific and Caribbean coasts and along all larger rivers. N ow severely depleted (8).

Peru Present in lower reaches of the larger rivers draining to the Pacific. The Rio Chira appears to have formed the southern extremity of the species' range. A population persists in northern Peru in the Rio Tumbes, where only 22 juveniles and subadults were counted in 1970 (8).

U.S.A. Restricted at present, and historically, to the southern extremity of the Florida peninsula. In pre-war years breeding populations appear to have reached as far north as Lake Korth in Palm Beach County, also Biscayne Bay in Cade County. Present nesting records are restricted to the Florida Bay area in the extreme south, and parts of the Florida Keys. In this area nesting has ceased in the central Keys and on almost all the Bay islands, and now occurs only on the Florida Bay mainland, and on adjacent Key Largo. In the lower Florida Keys breeding may occur among a small population on Little Pine Key and one or two others islets all within the Key Deer National Wildlife Refuge. Nensity may always have been low outside this core breeding area. The total population in south Florida early in the 20 th century may have been $1,000-2,000$ animals. This population has declined, with a significant range contraction, but breeding numbers, although very low, have remained steady through the 1970's in the central Florida Bay - Key Largo region. There appear to be 20 breeding females, with a mean annual output of 275 hatchlings. Total non-hatchling population is 100-400 animals. Most nest sites are within the Everglades Vational Park. (All the above data are from references 10 and 12). Considered endangered until all nest sites are adequately protected and there is some evidence for significant 
Venezuela Historically, known from lowlands around Lake Maracaibo southward along the Atlantic coast to the Manzanares River near Cumana. Now extinct over much of the former range, only a few small isolated populations known, for example, around the Gulf of Cuare and the region of the Parque Nacional Morrocoy (8).

HABITAT AND ECOLOGY A large sized, fairly slender-snouted species, larger males have sometimes attained around $4.6 \mathrm{~m}$ (15ft) (4). Primarily a coastal form, the American Crocodile is typically associated with mangrove swamps, also brackish or salt-water bays, brackish creeks, and may extend inland in lakes and the lower reaches of larger rivers $(4,9,14)$. Most available ecological data relate to the Florida population. In Florida the species enters coastal canals and flooded pits (4). Adults maintain dens near nest sites, usually burrows dug 3-9 $\mathrm{m}$ into creek banks, with the entrance at or below the waterline (10). Crocodiles often move considerable distances.

Adults are suspected to feed mainly on fish, while smaller crocodiles, especially juveniles, feed on a variety of aquatic invertebrates $(4,11)$. While the species appears to prefer quiet waters, larger individuals routinely enter deeper bays at night, probably in search of mullet and other fishes (II).

Age at sexual maturity is unknown, but females of $2.5 \mathrm{~m}$ in length made repeated visits to three active nests in Florida Bay and were assumed to be breeding (10). The majority of females nesting in Florida build mound nests of soil or sand, but some individuals excavate hole nests (no correlation with substrate or nest position) (10). In this region nests are typically on well-drained soil and adjacent to water of sufficient depth to allow approach by this route. Nests in Florida Bay were either in open hardwood thickets along fairly narrow deep-water creeks with steep banks, or among hardwood shrubs and trees at the head of narrow shell-sand beaches, or amongst Black Mangrove Avicennia nitida thickets backing low marl banks $(10,11)$.

Nest mounds vary in size and increase as the female increases in size, diameter is up to around $4.5 \mathrm{~m}$, height up to $.65 \mathrm{~m}$. Fernales appear to return to the same nest site in succeeding years (10). The primary nest is usually accompanied by up to five secondary nests (often resembling hole nests) that may receive some eggs. The nesting female begins visiting the nest site in March and nightly digging activity increases over the following weeks until eggs are laid, usually between 25 April and 5 May (10). Eggs hatch between 25 July and 10 August. Eggs are 6.4-7.6 $\mathrm{cm}$ (2.5-3 inches) long by $4.5-5 \mathrm{~cm}(1.75-2$ inches) wide (9). Clutch size $(\mathrm{n}=20)$ ranges from 19 to 81 , mean size 44. True mean clutch size may be lower since three nests in this sample may have included clutches laid by two females. The female guards the nest during incubation, although she retreats if confronted by man (9). One of the breeding adults, presumably the female, opens the nest and assists in the hatching process, and the parents are suspected to guard the hatchlings for a period (4). Forty nesting attempts resulted in 26 successful and 14 unsuccessful nests, ie. $65 \%$ produced a hatch. There was only $48 \%$ hatching rate by eggs in successful nests. There is no evidence for recruitment of young into the Florida population (4). Relatively low nest temperatures, especially in shaded soil nests, may be one limiting factor. Predation on eggs and hatchlings by Raccoon Procyon lotor is also significant.

THREATS TO SURVIVAL Over-exploitation for hides, often over several decades, is clearly indicated as the major cause of the present severely depleted condition of the American Crocodile (8). Increasingly, this primary threat is accompanied 
by habitat loss and other effects of human activity, and perhaps other factors (8). In Florida, for example, the initial decline in numbers attributable to hunting and general persecution is aggravated by the effects of tropical storms, by local salinity increases (due to decreased freshwater input following drainage and channelization inland) which increases mortality in small-size crocodiles, and also by poor nesting success. In the Dominican Republic the major Lago Enriquillo population is affected by increasing salinity levels in the lake, such that hatchlings can no longer survive; this salinity rise is attributed to diversion of freshwater streams for irrigation purposes (8). In Jamaica the Black River Morass, a main refuge of crocodiles where populations elsewhere were generally depleted by hunting, has been affected by encroaching cultivation and drainage (8). It is reported that some hunters switched operations to Jamaica following U.S. legislation protecting the American Crocodile and the Alligator. (14).

CONSERVATION MEASURES TAKEN Nominally protected by legislation, usually not adequately enforced, in ; Colombia (Res. No. 411, 16 July 1968, Min. de Agricultura; Res. N!o. 573, 24 July 1969, INDERENA); Costa Rica (partial protection - hunting closed season); Cuba (Res. No. 21-79, partial protection hunting banned locally); Dominican Republic; Ecuador (Res. No. 818); Jamaica (partial); Mexico (partial - no commercial hunting); Peru (Res. Suprema No. 343); Venezuela (7). In the U.S.A. the entire species is listed as 'Endangered' under the 1973 Endangered Species Act, 'Critical Habitat' has been designated and a Recovery Plan approved (4).

Some groups are known to occur in National Parks or protected areas (8); Costa Rica (Santa Rosa N.P., Nancite), Venezuela (P.N. Morrocoy), U.S.A. (Everglades N.P., and in approved Crocodile Lake National Wildlife Refuge on Key Largo) (4).

Listed on Appendix I of the Convention on International Trade in Endangered Species of Wild Fauna and Flora (CITES). Appendix I listing requires that trade in the taxon and its products is subject to strict regulation by ratifying states and international trade for primarily commercial purposes is prohibited.

CONSERVATION MEASITRES PROPOSED Existing legislation should be adequately enforced. Remaining adequate populations, at Lago Enriquillo (Dominican Republic) and Florida Bay (U.S.A.) for example, should be rigidly protected and managed as appropriate.

CAPTIVE BREEDING Numerous specimens are held in various zoos (7). Nesting occurred in a group of 2 males, 2 females at the National Zoo in Santo Domingo (Dominican Republic) (6). Following mating activity in November and December 1976, one female laid a clutch of 34 eggs in a hole nest. The clutch was artificially incubated, 14 of the 25 fertile eggs, hatched. At least five were abnormal, probably due to artificial incubation procedures.

REMARKS None

REFERENCES 1. Abercrombie, C.L., Davidson, D., Hope, C.A., Scott, D.E., (1980). Status of Morelet's Crocodile Crocodylus moreleti in Belize. Biol. Conserv. 17: 103-113.

2. Abercrombie, C.L., (1981). In litt. 17 January.

3. Anon. (1980). Project 1490, Conservation of the American Crocodile, Dominican Republic. In. Current Projects. (Fund raising goals). WWF-USA.

4. Anon. (National Fish and Wildlife Lab. Gainesville) (1980). The American Crocodile. In, Selected Vertebrate Endangered Species of the Seacoast of the United States. 
FWS/OBS-80/01.47. Biological Services Program. Fish and Wildlife Serv., U.S. Dept. of Interior.

5. Campbell, H.W., (1981). In litt. 26 February.

6. Duval, J., (1978?). 14 American Crocodiles hatch at ZOODOM. AAZPA Newsletter XVIII No 8. (American Assoc. of Zoological Parks and Aquariums).

7. Honegger, R., (1979). Red Data Book, Vol. 3: Amphibia and Reptilia. IUCN, Gland (third edition, partly revised).

8. King, F.W., Campbell, H.W., and Moler, P.E., (1980). Review of the Status of the American Crocodile. Unpublished. IUCN/SSC Crocodile Specialist Group.

9. Neill, W.T., (1971). The last of the ruling reptiles. Columbia Univ. Press, New York.

10. Ogden, J.C., (1978). Status and nesting biology of the American Crocodile, Crodylus acutus, (Reptilia, Crocodilidae) in Florida. J. Herpetol. 12(2): 183-196.

11. Ogden, J.C., (1979). American Crocodile. In McDiarmid, R.W., (Ed). Rare and Endangered biota of Florida, Vol. 3, Amphibians and Reptiles. Gainesville, Univ. Presses of Florida. Pp. 2I-22.

12. Ogden, J.C., (1981). In litt. 19 February.

13. Parrales, A.F., Alcivar, R.Z., and Fritts, T.H., (1980?). Estudios basicos sobre el crocodrilo (Crocodylus acutus) en la cuenca del Rio Guayas Ecuador. Unpublished report, 30 pp.

14. Plotkin, M.J., and Fairbairn, P., (unpublished). The endangered vetebrates of Jamaica. Manuscript.

15. Powell, J., (1971). The status of crocodilians in the United States, Mexico, Central America and the West Indies. In, Crocodiles IUCN Publ. N.S. Suppl. Paper No. 32 Pp. 72-82.

16. Ross and Ross (undated). Pers. comm., cited in ref. 8.

17. Varona, L.S., (1981). In litt. 2 March.

18. Vaughan, C., (1979). In litt. 18 October, to H.W., Campbell. 


\section{Crocodylus cataphractus Cuvier 1825}

\section{Order CROCODYLIA}

SUMMARY A medium size slender-snouted species, mainly restricted to rain forest areas in West and Central Africa where it inhabits rivers and larger water-bodies. Status poorly known. Appears to have declined in many countries although adequate populations persist in some more remote areas. A mound-nesting species. Few biological data available. Decline is attributed to excessive hide-hunting. Although commercially inferior, hide of $\mathrm{C}$. cataphractus is increasingly utilized following decline of $\mathrm{C}$. niloticus. Nominally protected by legislation in much of the range. Listed on CITES Appendix I. Existing populations should be more effectively protected. More data on population levels and biology required.

DISTRIBUTION Fairly widespread in west and central Africa, primarily in rain forest, from Senegal in the west to Tanzania in the east. Present in Angola (Cabinda enclave, possibly also northern Angola), Benin, Cameroon, Central African Republic, Chad, Congo, Equatorial Guinea (Macias Nguema), Gabon, Gambia, Ghana, Guinea and Guinea Bissau (probably), Ivory Coast, Liberia, southern Mali, southern Mauritania, Nigeria, Senegal, Sierra Leone, extreme eastern Tanzania, Togo, Upper Volta, Zaire, Zambia $(1,2,5,6,8,9)$.

POPULATION Distribution and status of extant populations of Crocodylus cataphractus are very poorly known, very few recent data are available, reports are sometimes contradictory. Base-line surveys would be desirable, especially at sites now reported to hold adequate populations, in order to enable future changes to be monitored. Rarely found in abundance (3), for example during three months of intensive collecting in the Lower Congo at the start of this century only very few specimens were encountered (4). Appears to have declined generally and is regarded as threatened to some degree in many countries in the range although adequate populations persist at some localities. The species could be found with little difficulty in Cameroon and Gabon, once distant from human habitation (10).

Available information has been summarized by Pooley (6): Angola, endangered; Benin, reported very common in 1959 along the lower Oueme River and its tributaries, no recent data; Cameroon, endangered but also reported quite common in more remote tributaries of the Cross River (1); Central African Republic, has declined throughout; Chad, reportedly present in the south, in tributaries of the $\mathrm{R}$. Chari, no recent data; Congo, secure populations remain in remote northern tropical forests near the Central African Republic border, where there are large areas of inundated forest; Gabon, adequate populations remain in more remote areas, along parts of the Ogooue River for example (1), however, on the lower Ogooue between Lambarene and Port Gentil, no cataphractus were seen in a brief survey in February 1979 (although locals reported them still present) while the species was abundant during night surveys in June 1976 (11); Gambia, appears widely but thinly distributed, rare or endangered; Ghana, no recent data on status, sometimes present in coastal lagoons and in larger rivers of the forest zone, also Lake Volta and tributaries; Ivory Coast, reportedly not endangered; Liberia, status uncertain, reported common in mangroves on the outskirts of Monrovia and (in 1968) abundant in several localities, also considered endangered; 
Mali, status uncertain, decline reported; Nigeria, status uncertain, rare or endangered; Senegal, severe decline since $\sqrt{970}$, occurs in Gambia River and tributaries; Sierra Leone, uncommon; Tanzania, vulnerable, present only at a few localities in the extreme west, around the eastern shore of Lake Tanganyika; Togo, no data; Upper Volta, once common, had disappeared from most localities by the 1970's; Zaire, no recent data; Zambia, status unknown, restricted to the Lake Mweru region in the extreme north.

HABITAT AND ECOLOGY A medium size species, maximum length is about $4 \mathrm{~m}$, average adult size $2-2.5 \mathrm{~m}$ (2). Mainly restricted to tropical rain forests where it inhabits rivers and larger water-bodies $(3,5,8)$, but also extends into rivers in light savanna woodland, in parts of Senegal for example (8), and occurs in the brackish water of coastal lagoons $(4,8)$. Appears to prefer to leave the water at sheltered and inaccessible places. Specimens observed in the lower Congo region (4) were lying singly in shade near the river shore, several feet above water level, and when disturbed either ran further into swamps or plunged into the river. Although the long and slender snout may be correlated with fish-eating habits, adults appear to take a variety of other aquatic or waterside vertebrates, and crustaceans; shrimps (Palaemonidae), crabs (Thelphusidae), anurans, water-snakes, and grasshoppers are taken by young C. cataphractus (4). The nest is formed of a mound of vegetable debris. No further details on reproductive biology in the wild available.

THREATS TO SURVIVAL The decline reported from several countries is attributed to hide-hunting and loss of habitat $(6,7)$. Crocodylus cataphractus is widely utilized for food $(1,6)$ and the hide is used locally in preparation of leather goods. No precise figures are available on the volume of past or present international trade in C. cataphractus hides, but it is reported that hunters are turning increasingly to the commercially inferior hides of $\mathrm{C}$. cataphractus and Osteolaemus, now that the Nile Crocodile C. niloticus has declined severely over much of its range $(6,7)$.

CONSERVATION MEASURES TAKEN Nominally protected by legislation in many countries of the range (6). Angola, hunting and skin export prohibited under Decree 14539; Chad, skin export controlled; protected in the breeding season in Gabon; protected (details unavailable) in Gambia, Ghana, Ivory Coast; partly protected in classified forestry areas in Mali; hunting controlled in Senegal, restricted to animals of over $19 \mathrm{~cm}$ belly width; protected in Tanzania, no hunting of crocodiles under $2 \mathrm{~m}$ length; hunting controlled by licensing in Zambia. Nominally protected within National Parks or reserve areas in Cameroon, Chad, Congo, Gabon, Ivory Coast, Mali, Senegal, Upper Volta, Zaire and Zambia. No information for Benin, Central African Republic, Nigeria, Sierra Leone, Togo. Not protected in Liberia.

Listed on Appendix I of the Convention on International Trade in Endangered Species of Wild Fauna and Flora (CITES). Appendix I listing requires that trade in the taxon and its products is subject to strict regulation by ratifying states and international trade for primarily commercial purposes is prohibited. Austria, France, Italy and Zambia have entered reservations to Appendix I listing.

CONSERVATION MEASURES PROPOSED Existing populations should be more effectively protected and managed where feasible, particularly those where adequate numbers are still maintained. Base-line data on population levels are necessary to allow appraisal of future changes, Little appears to be known about the biology of this species, more information is required if management is intended. 
Zoo (U.S.A.) produced eggs in 1980. One male is held at each of three other zoos in the U.S.A. (12). It is hoped to achieve breeding in a group of four animals held in natural pens at the St. Lucia Crocodile Centre, Natal, but the females are still immature (13).

REFERENCES 1. Abercrombie, C.L. (1978). Notes on West African crocodilians (Reptilia, Crocodilia). J. Herpetol. 12(2): 260-262.

2. Brazaitis, P. (1973). The identification of living crocodilians. Zoologica (NY), 58(4): 59-101.

3. King, F.W. and Brazaitis, P. (1971). Species identification of commercial crocodilian skins. Zoologica (NY), 56(2): $115-170$.

4. Lang, H. (1919). Notes published in: Schmidt, K.P. (1919). Contributions to the herpetology of the Belgian Congo based on the collection of the American Congo Expedition, 1909-1915. Bull. Am. Mus. Nat. Hist. 39(20): 385-624.

5. Neill, W.T. (1971). The last of the ruling reptiles, Colombia Univ. Press., New York. 486 pp.

6. Pooley, A.C. (1980). The status of crocodiles in Africa 1980. Unpublished paper presented at Fifth Working Meeting of IUCN/SSC Crocodile Specialists Group, Gainesville, 12-16 August 1980.

7. Pooley, A.C. (1981). Disappearing African Crocodiles. Oryx 16(1): 38-40.

8. Villiers, A. (1958). Tortues et crocodiles de l'A frique noire francaise. Initiations Africaines. 15: 1-354. Inst. Francais D'Afrique Noire, Dakar.

9. Wermuth, H., and Mertens, R. (1977). Testudines, Crocodylia, Rhynchocephalia. Das Tierreich 100: 1-174.

10. Abercrombie, C.L. (1981). In litt., 17 January.

11. Powell, J.H. (1979). In litt., 15 June (to IUCN/SSC Crocodile Specialists Group).

12. Brazaitis, P. (1982). In litt., 3 March.

13. Pooley, T. (1982). In litt., 3 February. 

SUMMARY A moderately large freshwater species, restricted to the Orinoco drainage of Venezuela and eastern Colombia. Large size and lack of osteoderms in the belly skin led to very heavy exploitation by the hide trade. Severely depleted throughout the range, almost extinct in Colombia. Possibly only 500 non-hatchlings survive in Colombia and 1000 in Venezuela. Inhabits lakes and deep slow stretches of large rivers. A hole-nesting species, the clutch comprises 15 to 70 eggs laid in January/February, hatchlings emerge around March. Protected by legislation in Colombia and Venezuela but this is not adequately enforced and hide-smuggling continues, this should be corrected. Captive breeding may be a suitable conservation measure. Listed on CITES Appendix 1.

\section{DISTRIBUTION Restricted to the Orinoco drainage of Venezuela and eastern} Colombia (2).

POPULATION Very common up to the mid 1930's (11), now severely depleted, very rare throughout the range $(3,4,10,11,12)$. Possibly only about 1500 non-hatchlings survive in the wild (4).

Colombia Extremely depleted and almost extinct. Surveys carried out between 1973 and 1975 in the Colombian Orinoco plains, between the Guayabero-Guaviare rivers in the south and the Arauca in the north, revealed only 280 adult individuals within 252,530 sq. $\mathrm{kms}(9,10,12)$. This includes most of the Colombian range. Juveniles and a certain number of adults can be assumed to have escaped detection, but numbers are very low and $\mathrm{C}$. intermedius is on the verge of extinction in Colombia (12). The potential for existence of additional isolated populations is much lower in Colombia than in Venezuela; total estimate is about 500 (4). The primordial population in Colombia probably numbered into hundreds of thousands (14).

Venezuela Very rare (4) and heavily depleted (8). In a recent survey, carried out for the Fundacion para la Defensa de la Naturaleza (WWF-Venezuela), 273 adult individuals were located and the total wild population was estimated at about 1,000 (4).

HABITAT AND ECOLOGY A moderately large slender-snouted freshwater species, males reported to $6.78 \mathrm{~m}$, females reach $4-4.5 \mathrm{~m}$. Average size is $3.5-5$ $m$ (3). The Orinoco Crocodile prefers wide and very deep parts ('charcos') of large rivers during the dry season, but wanders over great distances in the wet season, when individuals may occupy lakes and pools to avoid the strong river currents. Juveniles seek shelter in quiet waters with abundant aquatic vegetation (10). Males defend a well-defined territory (11). A shy and elusive species, difficult to census (1), may only have become secretive quite recently (11). Feeds primarily on fish, small mammals and birds (3). Young animals (under $90 \mathrm{~cm}$ ) feed mainly on beetles and other insects, snails, crabs, and other invertebrates (11).

A hole-nesting species, the clutch comprises 15 to 70 eggs laid in a nest usually excavated in a sandbank high above the river (11). Nesting occurs in January/February, hatchlings emerge in late February to late March. The female 
protects the hatchlings for a variable period (11). May aestivate during the dry season in some areas (2), in the Arauca and Casanare for example, in water-eroded caves in steep river banks (10):

THREATS TO SURVIVAL Very severely depleted by hunting for the hide trade, the species was in great demand due to its relatively large size and lack of osteoderms in the belly skin. Hide hunting began in the 1920's, increased considerably in 1933-1934 and declined after 1948 because of lack of crocodiles in commercially exploitable density $(11,12)$. An absolute minimum of over 250,000 hides were taken from the range in Colombia between the 1930's and mid 1940's $(11,12)$. A hide dealer in Venezuela has reported that it was not unusual to buy 4,000 skins of Orinoco Crocodile in one day in the late 1920's and early 1930's (14). Crocodiles are still regularly killed when encountered as a supposed threat to men and domestic stock (11).

CONSERVATION MEASURES TAKEN The Orinoco Crocodile is totally protected in Colombia (Resolucion 411, 16 July 1968, Ministerio de Agricultura and Resolucion 573, 24 July 1969, INDERENA) and in Venezuela. Legislation is not adequately enforced (12), and illegal hide smuggling continues (15). Probably present in Venezuela in the Parque Nacional. Aguaro-Guariquito, State of Guarico (7). Reported present in the P.N. Natural La Macarena in Colombia (16). Unfortunately, the largest remaining wild populations are outside protected areas (4).

Listed on Appendix I of the Convention on International Trade in Endangered Species of Wild Fauna and Flora (CITES). Appendix I listing requires that trade in the taxon and its products is subject to strict regulation by ratifying states and international trade for primarily commercial purposes is prohibited.

CONSERVATION MEASURES PROPOSED Protective legislation should be enforced, and an immediate total ban on hide hunting imposed (12). Scattered breeding and protective efforts should be coordinated. The Camatagua Reservoir in Venezuela should be established as a well guarded refuge and study site, where additional specimens might be introduced to form a breeding nucleus (1). Every attempt should be made to propagate and study the biology of the species both in captivity and the wild (3). A programme analogous to those operating with Gharial (Gavialis gangeticus) in India and Nepal may be possible for C. intermedius (hatchlings from captive or wild-laid eggs are raised to a suitable size and released into strictly protected areas).

CAPTIVE BREEDING At least 31 individuals are held in captivity in Venezuela (5), including 11 adults and sub-adults at Parque Loefling (Puerto Ordaz, Estado Bolivar, run by Corporacion Venezolana de Guayana), 10 at Hato El Frio (field station of the Universidad Simon Bolivar), 4 adults at Bararida (Barquisimento) and 2 on a private wildlife refuge (T.Blohm), plus 2 juveniles and 2 singles elsewhere.

Nesting has occured in the Parque Loefling colony in 1971, 1974, 1976 and 1981, at Hato El Frio in 1979 and 1980 and on the T. Blohm refuge in 1979 and 1980. Hatchlings were produced at Parque Loefling (1981 nests destroyed by rain) (5), and 14 hatchlings from the 29 eggs in the 1980 nest of the Blohm pair (1). Outside Venezuela, Metro Zoo (Miami, USA) bred the Orinoco Crocodile in 1980, is securing additional specimens, and is establishing a long range breeding programme (3). Six specimens, comprising two adult males, two juveniles females and two small juveniles, are maintained at the 'Roberto Franco' Station of Tropical Biology, Villavicencio (Colombia), for a future breeding programme (12).

REMARKS The belly skin of this species lacks ventral osteoderms and, when 
tanned, produces a high quality leather, hardly distinguishable from Crocodylus acutus in small samples. The hide industry formerly distinguished the species by the presence of "squiggle" like trails on the ventral scales. Investigations (11) showed these to be parasitic worm trails, also found on some African, Asian, and Austrialian species of crocodilians. The hide industry was still utilizing the skin of this species in 1973 (3).

This account is based largely on a draft very kindly provided by P. Brazaitis (Supt. of Herpetology, New York Zoological Park) and on information from S. Gorzula.

REFERENCES 1. Blohm, T. (1981). In litt., to P. Brazaitis, 9 March.

2. Brazaitis, P. (1973). The identification of living crocodilians. Zoologica (N.Y.). 58(4): 59-101.

3. Brazaitis, P. (1981). In litt., draft Red Data Book account.

4 Godshalk, R. (1981). In litt., to P. Brazaitis, July.

5. Gorzula, S. (1981). In litt., 7 April

6. King, F.W., and Brazaitis, P. (1971). Species identification of commercial crocodilian skins. Zoologica 56(2):15-70.

7. Maness, S. (1981). In litt., to P. Brazaitis, 23 March.

8. Medem, F. Paper presented by Dr. F. Wayne King (1971). Summary of the surveys of the status of crocodilian species in South America undertaken by Professor F. Medem. IUCN Publ. New Ser. Suppl. Pap. No.41: 33-35. (Crocodiles Proceedings of the Second Working Meeting of Crocodile Specialists, St. Lucia, Zululand.

9. Medem, F. (1974). Project 748. Orinoco Crocodile - status survey. World Wildl. Yb. 1973-1974: 254-256.

10. Medem, F.(1976). Project 748. Orinoco Crocodile - status survey. World Wildl. Yb. 1975-1976: 191-193.

11. Medem, F. (1976). Das Orinoko-Krokodil, Crocodylus intermedius, in Kolumbien: studien uber seine Naturgesichte und Verbreitung. Natur u. Mus 106 (8): 237-244.

12. Medem, F. (undated, post 1978?). The present status of the crocodilians in Colombia, Bolivia and Brazil. Unpublished report.

14. Medem, F., and Donadio, A. (1978). No tears for crocodiles The Ecologist 27.6.78.

15. Medem, F. (1980). Status of crocodilians in Colombia. TRAFFIC (Int.) Bull. 11(5-6): 55 (includes a note on smuggling in Venezuela).

16. PADU (Protected Areas Data Unit), Kew, U.K. 

SUMMARY A small to moderate size slender-snouted species, inhabiting freshwater rivers, streams and ponds, Crocodylus johnsoni is endemic to northern Australia. Sometimes found in tidal waters with $\mathrm{C}$. porosus. Widely depleted due to heavy exploitation for the hide trade, curtailed by legislation since 1962 in Western Australia, 1964 in Northern Territory, and 1974 in Queensland. Depleted populations now appear to be recovering somewhat. While the species is abundant in some areas, populations remain critically small in others, and present protective measures should not be relaxed. Typically a hole-nester, the clutch comprises c 13 eggs, laid in August/September, hatching in November. High mortality of eggs (64\% in McKinlay River) and first-year hatchlings (over 90\%). Present in several National Parks. Has bred in captivity at Melbourne Zoo. Listed on CITES Appendix II:

DISTRIBUTION Restricted to rivers and other aquatic habitats in northern Australia, from the Fitzroy River in the Kimberley region of Western Australia, through northern parts of the Northern Territory, to nor theast Queensland $(1,4)$.

POPULATION Before receiving legislative protection Crocodylus johnsoni was widely exploited by the hide trade and severely depleted in many areas, but now appears to be responding to protection (8). No precise figures are available, but the total population has been tentatively estimated at 100,000-200,000 (11), and the species may be moderately common in many parts of the range (8). It has been suggested (14) that the tentative total population estimate requires clarification with further data. In Western Australia, where the species has been protected since 1962, C. johnsoni is considered widespread and abundant within its known range (2). The species was found in all areas of suitable habitat during a recent survey of the Daly-Victoria River area of western Northern Territory (5). Protection was not initiated until 1974 in Queensland, and recovery is correspondingly less advanced (11), populations are probably still critically small (8).

In general, density in downstream areas may vary from zero to sometimes even 50 or 100 individuals per $\mathrm{km}$, depending on the type of habitat and the former intensity of hunting (11). Density may be around 10 per $\mathrm{km}$ in rocky upstream areas that have not been hunted (11). Population estimation for C. johnsoni is difficult since the species utilizes scattered billabongs and lagoons, as well as rivers and streams where counting may be more straightforward (11).

HABITAT AND ECOLOGY A small to moderate size species, reaching about $3 \mathrm{~m}$ in length, with a slender elongate snout (1). Mainly inhabits freshwater rivers, streams, ponds and lagoons, but also occurs in relatively saline tidal streams, where it may be sympatric with the Saltwater or Estuarine Crocodile Crocodylus porosus (9). Recent surveys (10) suggest that such areas may be much more extensive than believed hitherto. It appears that as the larger and more aggressive $C$. porosus become scarce, $C$. johnsoni may move into vacated tidal areas, some of which may have a salinity up to C 25 parts per thousand (notable for a species considered intolerant of saline waters) (10). This is partly analogous to the situation in the Orinoco region of South America, where the smaller Caiman c. crocodilus appears to be moving into areas where Crocodylus 
intermedius has been exterminated (13). Conversely, C. porosus is sometimes found in entirely freshwater habitats more typical of johnsoni (12), including in Kakadu National Park (7).

The species generally forages at night, feeding on fish, frogs, crustacea, and small reptiles, birds and mammals (4). A narrow snout in crocodilians appears to be correlated with fish-eating habits.

Typically a hole-nesting species, mainly nesting in exposed. situations in sandbanks, but often in humus and sometimes in gravel or clay. Colonial nesting was common on the Mackinlay River in Northern Territory, at one site 18 nests were found in close proximity within $50 \mathrm{~m}$ of the bank (and in two instances females excavated another crocodile's nest) (15). The nest typically has a distinct egg chamber $(20 \times 14 \times 13 \mathrm{~cm}$ deep), the topmost egg is $20( \pm 8 \mathrm{~cm})$ below the surface (15). Females normally attain sexual maturity at about $145 \mathrm{~cm}$, males at $165 \mathrm{~cm}$. Nesting occurs in August/September, hatchlings $(20-25 \mathrm{~cm}$ in length) emerge in November after $12-13$ weeks at temperatures of $\mathrm{c} 29^{\circ} \mathrm{C}$, with the onset of winter rains. Mean clutch size is $12.6(+3.1)$, ranging from 4 to 18 , in the McKinlay River area of the Northern Territory (11). Eggs are approximately $6.6 \times$ $4.2 \mathrm{~cm}$, weight $68 \mathrm{gm}$ (15). Females do not appear to closely attend the nest, although they do excavate their nest at hatching time and once in the water may remain with the crêche of young. Males in captivity show aggressive territorial interactions at the start of the breeding season (16). There is a high rate of egg-predation (64\% on the McKinlay River), mainly due to varanid lizards, and wild pigs to a lesser extent. Mortality of hatchlings in their first year appears in excess of $90 \%(11)$.

THREATS TO SURVIVAL $C$. johnsoni has been depleted due to excessive hunting for the hide trade. The skin of johnsoni was at first in less demand that that of porosus, due to greater ease of access to porosus along navigable rivers, the smaller size of johnsoni and the presence of bony osteoderms in the belly scales (8). As porosus became shot-out, exploitation of johnsoni became economic. By netting water-holes it was possible to eliminate entire population groups (8). C. johnsoni also suffers persecution from confusion with $\mathrm{C}$. porosus, a known predator on man and his domestic animals (8). In Queensland and Northern Territory stuffed hatchlings were sold as tourist souvenirs (3). A possible but unconfirmed present threat in the Northern Territory is the activity of introduced buffalo Bubalis bubalus; these animals trample vegetation around water-holes, increase soil erosion and increase turbidity of the water (8).

CONSERVATION MEASURES TAKEN The species has been totally protected in Western Australia since 1962, in Northern Territory since 1964, but not until 1974 in Queensland. The Australian government has banned export of crocodile skins and products since December 1972 , and banned import early in $1973(7,8)$. A trial raising programme is beginning in the Northern Territory, based on eggs and hatchlings taken from the wild under strict supervision (11).

C. johnsoni is well-represented in a number of National Parks, for example Kakadu N.P., Katherine Gorge N.P. (both in Northern Territory), and Geikie Gorge N.P. (Western Australia) $(7,8)$.

Listed on Appendix II of the Convention on International Trade in Endangered Species of Wild Fauna and Flora (CITES). Appendix II listing implies that commercial trade is allowed providing a permit from the country of export is obtained, this can provide a method of monitoring trade levels.

CONSERVATION MEASURES PROPOSED Protective legislation and enforcement is adequate, no further action suggested. It is essential that present measures are not yet relaxed, as unregulated exploitation could rapidly reverse 
CAPTIVE BREEDING Many specimens are held in various collections, about 400 juveniles and 100 sub-adults and adults in the Northern Territory (11). C. johnsoni may breed in suitable captive conditions, and has done so at Melbourne Zoo $(6,16)$. A breeding farm may soon be established in Queensland (9).

REMARKS Crocodylus johnsoni is a little known and distinctive species, endemic to Australia, and the conservation measures taken should not yet be relaxed.

Much basic biological information on johnsoni remains to be gathered or published, the Queensland National Parks and Wildlife Service has now been studying the species since 1976, and the Northern Territory initiated a comprehensive study in 1978 (11). The ecological requirements of johnsoni, and the field interrelations between $\underline{\mathrm{C}}$. johnsoni and $\underline{\mathrm{C}}$. porosus require investigation.

This account is largely based on data kindly provided by A.A. Burbidge, R.W.G. Jenkins, H. Messel and G.J.W. Webb.

REFERENCES 1. Brazaitis, P. (1973). The identification of living crocodilians. Zoologica (NY) 58(4): 59-101.

2. Burbidge, A.A. (1981). In litt., 5 February.

3. Bustard, H.R. (1973). Conservation review - Australia. IUCN Publ. New Ser. Suppl. Pap. 41: 45-47. (Crocodiles Proceedings of the Second Working Meeting of Crocodile Specialists, Zululand 1973).

4. Cogger, H.G. (1979). Reptiles and Amphibians of Australia. A.H. and A.W. Reed, Sydney. (Second edition, revised).

5. Cogger, H.G. (1978). Pers. comm. cited in reference 8.

6. Dunn, R.W. (1977). Notes on the breeding of Johnston's Crocodile at Melbourne Zoo. Int. Zoo Yearbook 17: 130-131.

7. Jenkins, R.W.G. (1981). In lit ., 11 March.

8. Jenkins, R.W.G. (1979). The status of endangered Australian reptiles. Chapter 16, pp. 169-176, in Tyler, M.J. (Ed.). The status of Endangered Australasian Wildlife. Royal Zool. Soc. South Australia, Adelaide.

9. Messel, H. (1981). In litt., 2 February.

10. Messel, H., Vorlicek, G.C., Wells, A.G., and Green, W.J. $(1979,1980,1981)$. Surveys of tidal river systems in the Northern Territory of Australia and their crocodile populations. Pergamon Press Ltd., Oxford, England and Sydney, Australia. (A series of 17 Monographs).

11. Webb, G.J.W. (1981). In litt., 5 January.

12. Webb, G.J.W. (1977). Habitat and nesting. Chapter 14, PP 239-284, in Messel, H., and Butler, S.T. (Eds). Australian Animals and their Environment. Shakespeare Head Press, Sydney.

13. Webb, G.J.W. (1978). The status, conservation and management of world crocodilians, and an assessment of the potential for commercial exploitation of crocodiles in Australia. Unpublished report to the Aust. Nat. Parks \& Wildl. Service.

14. Messel, H. (1981). In litt., 6 April (Comments on first draft of Red Data Book C. johnsoni account).

15. Webb, G.J.W. (1981). Nesting biology of Crocodylus johnsoni in the Northern Territory. Chap. 20, p 107, in Banks, C.B., and Martin, A.A. (Eds) Proceedings of the Melbourne Herpetological Symposium. Zoological Board of Victoria, Royal Melbourne Zoological Gardens. 
16. Dunn, R.W. (1981). Further observations on the captive reproduction of Johnstone's crocodiles. Int. Zoo Yearbook. 21: $82-83$. 
SUMMARY A relatively small crocodilian, endemic to the Philippines, occurring in freshwater marshes, ponds, and tributaries of large rivers, on the islands of Luzon, Mindoro, Busuanga, Masbate, Negros, Samar, Mindanao and Jolo. Reported critically endangered, with only 500-1,000 animals remaining, and no large populations. Initial decline is attributed to excessive hide-hunting, but present hide trade appears minimal and primary current threat is habitat modification due to expanding agri- and aquaculture projects. A recent Smithsonian Institution/World IVildlife Fund project (1980-1982) has involved extensive field surveys, publicity, and has resulted in establishment of a crocodile breeding facility in conjunction with Silliman University (Damaguete, Negros). Three clutches of 34 eggs were produced by a captive pair in April-July 1981, none hatched successfully. Captive breeding is seen by personnel involved in the project as a primary measure in conservation of $\mathrm{C}$. mindorensis. It is intended to release young bred in captivity into a sanctuary area on Negros. Listed on CITES Appendix I.

DISTRIBUTION Endemic to the Philippines, Crocodylus mindorensis has been recorded from Luzon, Mindoro, Busuanga, Mindanao, also Jolo in the Sulu Archipelago (6); also recently reported from the central islands (Visayan group) on Negros, Samar (8) and Masbate (9) (the specimen reported on Masbate may actually have been the last individual there (14)). May possibly occur on other Visayan islands (10). See Remarks, below.

POPULATION After recent field surveys through much of the Philippines group, C. mindorensis is reported in critical danger of extinction $(7,8,9)$. The total number surviving (presumably non-hatchlings) is estimated at 500-1,000, no large population is known to exist in any one area (9). It has recently been confirmed that C. mindorensis still occur at Nabunturan, Calarian Lake and Macasendy Marsh on Mindanao, and in the Pagatban River in Negros Oriental $(8,14)$. The species appears most numerous in Mindanao and the Sulu Archipelago (1). Probably already extinct in Masbate, Jolo and Busuanga (14).

HABITAT AND ECOLOGY A relatively small crocodilian, reaching nearly $3 \mathrm{~m}$ length, inhabiting freshwater marshes, small lakes, ponds, and tributaries of large rivers (10). Observations suggest that $\mathrm{C}$. mindorensis use burrows (14). It appears that the nest is constructed during the dry season (14). A captive female laid three clutches between April and July 1981, consisting of 13,7 and 14 eggs. The nest mound was approximately $1.5 \mathrm{~m}$ diameter by $41 \mathrm{~cm}$ high. Egg size varied from 6.1 to $7.2 \mathrm{~cm}$ by 3.6 to $4.2 \mathrm{~cm}$. The female actively defended the nest, lunging with mouth open and hissing when disturbed. Most of the eggs were infertile. Incubation time in the laboratory at $28-30^{\circ} \mathrm{C}$ was around 85 days (1). Virtually no published information is available on the natural history of this species.

THREATS TO SURVIVAL Initial decline of the species is attributed to uncontrolled hide hunting $(4,5)$. Recent investigations reveal that current trade in crocodile skins and products is minimal, probably reflecting the depleted condition of crocodile populations (8). The skins and juvenile crocodiles that are in trade 
are exported through the Sulu Archipelago to Sabah (East Malaysia) (8). It is not known what proportion, if any, of this trade involves C. mindorensis rather than the other crocodilian species present, $C$. porosus. Crocodile products available in the tourist industry are mainly imported Caiman articles originating from South America (8).

The primary current threat to C. mindorensis is habitat modification for government-endorsed agriculture and aquaculture projects (8), including fish ponds, rice paddies, coconut and sugarcane plantations (10). The population in the Pagbatan River ( $N$ egros) may become further threatened by pollution arising from copper extraction recently developed in the area by the Construction Development Corporation of the Philippines (CDCP) (2). In general crocodiles are disliked and feared by local inhabitants (14).

CON SERVATION MEASURES TAKEN A large part of the Philippine Islands has been surveyed recently under the Smithsonian Insitution/W WF Philippines Crocodile Conservation project ( K WF Project 1489, started August 1980). This project has resulted in establishment of a crocodile breeding station at Silliman University, Dumaguete City, Vegros Oriental (8). It is intended to release captive-bred young in a sanctuary area on Negros, the area is to be determined by, and monitored by, Silliman University in cooperation with the Bureau of Forest Development of the Ministry of $N$ atural Resources $(2,8)$. It is forseen that local communities supporting location of a sanctuary in their area may eventually benefit by harvest of crocodile skins and meat (2).

Listed on Appendix I of the Convention on International Trade in Endangered Species of Wild Fauna and Fora (CITES). Appendix I listing requires that trade in the taxon and its products is subject to strict regulation by ratifying states and international trade for primarily commercial purposes is prohibited.

CON SERVATION MEASURES PROPOSED Continuing efforts will be made toward captive breeding (8). If captive breeding is able to increase numbers of $\mathrm{C}$. mindorensis, a major priority will be establishment of suitable reserve areas. If the crocodile breeding/sanctuary project fails, the species may become extinct in the wild within a few years (9). Personnel of Silliman University hope to work on the biology of captive and wild specimens (in the Pagatban River) (2). A detailed survey of crocodile distribution in the Agusan River drainage should be undertaken to locate possible undetected populations of $\mathrm{C}$. mindorensis (14). Conservation of non-essential natural resources is not given high priority in the Philippines, any conservation programme which offers some possibility of ultimate utilization is more likely to win support from the government (14).

CAPTIVE BREEDING The first known nesting of C. mindorensis in captivity occurred in 1981 at the Silliman University crocodile breeding centre, now housing four crocodiles (9). Data on breeding biology have been collected (9). A 10 or 11 -year old female laid 34 eggs in 3 clutches from April-July 1981. Only two eggs were fertile and neither hatched successfully (14). The male of the pair is probably 15 years old (3).

REMARKS The Philippines Crocodile was originally described as a full species Crocodylus mindorensis by K.P. Schmidt in 1935 (11). Most authors since then have regarded these populations as constituting only a subspecies of the freshwater crocodile in the $\mathrm{New}$ Guinea area, $\mathrm{C}$. novaguineae, i.e. $\mathrm{C}$. $\mathrm{n}$. mindorensis. However, it has been stated that all specimens of mindorensis can be readily distinguished morphologically from all $\mathrm{V}$ ew Guinea specimens (6), and recent field-workers $(2,8,9)$ and taxonomists $(12)$ have treated the Philippines form as a full species again. This opinion is not yet universal (13). 
REFERENCES 1. Alcala, A.C. (1981). Pers. comm. to Sue Kells, 5 June.

2. Alcala, A.C. (undated). ix WF Project Proposal - Silliman University Crocodile Programme.

3. Alcala, A.C., and Ross, C.A. (1981). In litt. 9 March (Comments on previous edition of RDB data sheet for Philippine Crocodile).

4. Brazaitis, P. (1973). The identification of living crocodilians. Zoologica (N.Y.) 58(4): 59-101.

5. Honegger, R. (1979). Red Data Book, Vol. 3: Amphibia and Reptilia. IUCN, Gland (Philippines crocodile sheet dated 1975).

6. N eill, K.T. (1981). The last of the ruling reptiles. Colombia Univ. Press, N ew York. 486 pp.

7. Ross, C.A. (1981). In litt., to K. King and H. Campbell. January.

8. Ross, C.A. (1981). First report on SI/K WF Project 1489 Conservation of Philippine crocodiles.

9. Ross, C.A. and Alcala, A.C. (1981). Crocodiles in the Philippines on the brink of extinction (single page summary press statement).

10. Ross, C.A. and Datuin, C.P. (1981). Crocodiles in peril. Canopy International. 7(2):7.

11. Schmidt, K.P. (1935). A new crocodile from the Philippines Islands. Field Mus. V at. Hist. Zool. Ser., 20(8): 67-70.

12. Hermuth, H. and Mertens, R. (1977). Testudines, Crocodylia, Rhynchocephalia. Das Tierreich 100: 1-174. Berlin, Walter de Gruyter.

13. Wermuth, H. and Fuchs, K. (1978). Bestimmen von Krokodilen und ihrer Häute. Stuttgart, Gustav Fischer.

14. Ross, C.A. (1982). Final report on SI/U WF Project 1489 Philippine Crocodile. 



\title{
Crocodylus moreletii Duméril, Bibron \& Duméril 1851
}

\author{
Order CROCODYLIA
}

Family

CROCODYLIDAE

SUMMARY A small to moderate sized crocodilian inhabiting freshwater lagoons, swamps, streams and backwaters, in forested areas or with abundant peripheral vegetation and floating aquatic plants. Present in Atlantic regions of Central America, from Tamaulipas in Mexico southward to Belize and northern Guatemala. A mound-nesting species, 20 to 45 tough-shelled eggs are laid. Reproduction appears to be possible after only five years growth. The belly skin lacks osteoderms and the species has been extensively exploited for the high-quality leather that can be prepared from its hide. Hide-hunting has led to extreme depletion of most $\underline{C}$. moreletii populations. Although now illegal throughout the range, this exploitation is continuing. Certain populations in Mexico and Belize could probably respond well to total protection. The species can be bred in captivity, the breeding group at Tuxtla Gutierrez Zoo (Chiapas, Mexico) has produced young for re-stocking natural habitats in Chiapas. Nominally protected by legislation in Mexico, Belize and Guatemala. Listed on CITES Appendix I. Present legislation should be more rigidly enforced. National parks are required for selected populations.

DISTRIBUTION Extends from central (possibly northern) Tamaulipas through the other Atlantic states of Mexico to the Yucatan Peninsula, and southward through Belize and northern Guatemala nearly to the Motagua River valley (17). May also occur in northern Honduras. Has been reported. from the Pacific coasts of Mexico (15) but some or all of these records may refer to Crocodylus acutus (11).

POPULATION This species is now rare and depleted through most of its range $(2,4,15)$. No information from Guatemala.

Belize Severely depleted (2). Very tentative estimates suggest a minimum of 2200-2500 moreletii over nine months in age in the northern half of Belize (3). Small to medium size individuals $(0.5-1.5 \mathrm{~m})$ are not uncommon in some parts (2). In some lagoons, partially protected from exploitation, two to 10 individuals may be encountered per $\mathrm{km}$ of shoreline (3). Visits in 1980 to certain areas of Belize previously surveyed in 1978 and 1979 revealed fewer crocodiles, apparently correlated with greater ease of access by hunters (3). Although heavily depleted, moreletii populations in Belize probably still retain the capacity for recovery within a few years, if given strict protection (2).

Mexico Depleted, populations locally extinct, for example in the Los Tuxtlas region (Veracruz) $(4,13)$. Breeding populations can still be found in Mexico $(4,13,14)$, and small to medium size animals $(0.5-1.5 \mathrm{~m})$ are not uncommon in parts (14), large individuals are very scarce. A 1971 estimate suggested a minimum of 200 moreletii within an area of $50 \mathrm{sq}$. miles $(12,950 \mathrm{ha})$ at Lago de Catemaco (Veracruz) (6).

HABITAT AND ECOLOGY Typically occurs in quiet and shallow freshwater swamps, backwaters, vegetation-choked streams, ponds and lagoons with floating vegetation and densely vegetated banks, or within forest areas $(2,4)$. Such areas may be subject to annual flooding, and have a dry season during which moreletii may burrow into muddy banks or under tree roots (4). The species may also occur 
in rivers, and in Belize individuals have even been seen foraging in rapids (3). Feeds on fish, small mammals and crustacea (5).

A mound-nesting species, the nesting female will tear up grass and plants up to a radius of about $5 \mathrm{~m}$ and gather loose plant debris (leaves and twigs) in a central mound, up to $3 \mathrm{~m}$ in diameter by about $1 \mathrm{~m}$ high $(4,14)$. Most nests are on land within a few metres of water (6), but nests may be constructed in the water over an accumulation of aquatic plants (14). Twenty to 45 (4) eggs may be laid. Over 70 eggs have been reported in a single nest (14), but this was almost certainly the result of two females laying eggs in a single nest mound (19). Eggs are tough-shelled, similar to a hen's egg in shape, c $10 \mathrm{~cm}$ long (14). In Chiapas (Mexico) nesting occurs in April-June before annual flooding, incubation is c 80 days (4), hatchlings are $16-17 \mathrm{~cm}$ long (14). The nesting female remains near the nest to guard against intruders, and is thus highly susceptible to human predation (4). In a captive breeding group at Atlanta Zoo (USA), females have been shown to respond to the grunting vocalization of hatchlings by aiding their release from the egg and carrying them to water (8).

Although Morelet's Crocodile is generally considered a relatively small species, animals of $3 \mathrm{~m}$ are known, but are now very rarely found. It appears that moreletii can reproduce while still relatively young (4), after five years. The continuing survival of the species has been attributed to this fact, and that such small individuals can readily conceal themselves amidst floating vegetation. However, animals in Belize do not usually attain the heavy girth characteristic of breeding-size crocodilians until a length of $\mathrm{c} 1.75 \mathrm{~m} \mathrm{(3).} \mathrm{The} \mathrm{age} \mathrm{and} \mathrm{size} \mathrm{at} \mathrm{first}$ breeding is a matter of great significance to the recovery prospects of the species, and requires fur ther investigation.

THREATS TO SURVIVAL Threatened primarily by over-exploitation for hides and meat. The belly skin of moreletii lacks osteoderms and yields a smooth flexible leather $(4,10)$. Skins of moreletii (also Crocodylus acutus and $\mathrm{C}$. intermedius,

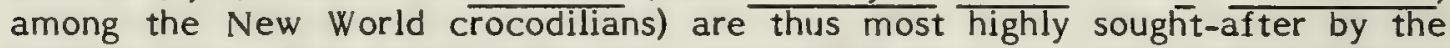
leather trade. Only 50 years ago 1,000 hides might be sold in one day at market in Villahermosa (Tabasco state, Mexico) (4). This over-exploitation for hides has led directly to the present greatly depleted condition of moreletii $(2,4,15)$. Habitat modification has been of secondary importance. In Belize, developing road communications have to some extent allowed hide-hunters access to previous moreletii refuges (3). Although full-time or seasonal professional hide-hunters have declined in numbers (along with their prey) in both Mexico (4) and Belize (2), hunting pressure is generally still strong. At Lake Catemaco (1971) local fishermen claimed to take crocodiles only irregularly, and that most killing is now done by tourist 'sportsmen' (6). Most hide-hunting in Belize is now done as a rewarding sideline by subsistence farmers or others, who have no interest in the long-term survival of the resource they are exploiting, and who, unlike some older professionals, will not leave a certain number of adult crocodiles in a given area, or ignore juveniles (2). Until recently one individual has been licensed to export hides from Belize. Exported hides went initially to Belgium, and then appear to have been re-sold to a tannery in Italy (3). However, since at least early 1981 (precise date unknown) the export of all crocodilian hides from Belize has been prohibited (1).

CONSERVATION MEASURES TAKEN All crocodilians are protected by legislation in Mexico and Guatemala (7), although this is only sporadically enforced. However, in Veracruz (in 1971) local fishermen reported that it was now difficult to sell hides, so legislation was presumably having some effect (6). The hide trade in Belize has operated at the fringe of legality. Although there has been confusion over the true extent of legal protection (2), it appears that export of all crocodilian hides from Belize is now illegal $(1,3)$. 
Listed on Appendix 1 of the Convention on International Trade in Endangered Species of Wild Fauna and Flora (CITES). Appendix I listing requires that trade in the taxon and its products is subject to strict regulation by ratifying states and international trade for primarily commercial purposes is prohibited.

CONSERVATION MEASURES PROPOSED For Belize, it has been suggested that a five to 10 year prohibition on crocodile hunting could allow extant populations to recover to the point where they could sustain a regular, monitored utilization for their commercially-valuable hides (2). Such a resource could be of immense value to the Belizean economy, and could in theory provide a local protein source although crocodiles are not eaten at present (2). The temporary prohibition could best be enforced by controlling hide buyers, and it seems that hide export is already illegal. Proposed legislation currently (1981) under consideration (3) would include both Crocodylus moreletii and $\mathrm{C}$. acutus on a list of protected species, impose a seven year ban on commercial trade in wildlife and derivatives, and establish a national parks system. There is a degree of optimism that this legislation will be submitted and passed (3), and the Belize government should be encouraged to do so. The upper reaches of the Macal River would provide an excellent site for a national park; natural scenery is unsurpassed in Belize, there is a good variety of vertebrate species, including an adequate population of readily visible moreletii, and access can be readily controlled (3). More typical swamp-lagoon habitat should also be preserved in Belize, Guatemala and Mexico. Lago Catemaco (Veracruz) has been proposed as an ideal site in Mexico (6).

CAPTIVE BREEDING Morelet's Crocodile can breed quite readily in suitable conditions in captivity, and has done so since 1972 at Tuxtla Gutierrez Zoo (Chiapas, Mexico), and also at Atlanta (Georgia) and Houston (Texas) Zoos in the United States. The important Tuxtla Gutierrez group comprises six adult pairs producing 60 offspring per year. These are raised in captivity for one year and then released in parts of Chiapas where re-stocking programmes are in operation (12). Significant behavioural observations have been made on the major Atlanta Zoo colony $(8,9)$.

REMARKS The systematics and ecology of Crocodylus in the New World require further investigation. Morelet's Crocodile was not widely regarded as a separate species until 1924 (16), having been confused with both the Cuban Crocodile C. rhombifer and the American Crocodile C. acutus. There is much uncertainty still about the identification of Crocodylus in Central America; some 'acutus' from the Atlantic coast of Mexico may actually be moreletii, while some 'moreletii' from the Pacific coast may be acutus $(11,15)$. In Belize very moreletii-like animals and very acutus-like animals may be seen in the same lagoon, all tentatively identified as C. moreletii (1). There are also appreciable differences between northern and southern populations of moreletii. These phenomena deserve investigation.

Some hides (and products) from $\mathrm{C}$. moreletii may be identified by proximal caudal scale inclusions $(5,10)$. These extra scales appear between normal scale rows on the ventral tail surface, whereas when present in $\mathrm{C}$. acutus the inclusions are limited to the lateral surface of the tail (19).

REFERENCES 1. Abercrombie, C.L. (1981). In litt., 17 January.

2. Abercrombie, C.L., Davidson, D., Hope. C.A. and Scott, D.E. (1980). Status of Morelet's Crocodile Crocodylus moreleti in Belize. Biol. Conserv. $17: 103-113$.

3. Abercrombie, C.L., Hope, C.A., Holmes, J.M., Scott, D. and Lane, J.E. (1980). Investigations into the status of the Morelet's Crocodile (Crocodylus moreletii) in Belize, 1980. Unpublished report presented to the fifth IUCN/SSC 
Crocodile Specialist Group working meeting. Aug. 12-16, 1980. Gainesville, Florida.

4. Alvarez de Toro, M. (1975). Morelet's Crocodile. Wildlife, World Conservation Yearbook. 1975: 88-91.

5. Brazaitis, P. (1973). The identification of living crocodilians. Zoologica (N.Y.) 58(4): 59-101.

6. Campbell, H.W. (1972). Preliminary report: status investigation of Morelet's Crocodile in Mexico. Zoologica (N.Y.) $57(3): 135-136$

7. Honegger, R. (1979). Red Data Book, Vol 3: Amphibia and Reptilia. IUCN, Gland (third edition, revised).

8. Hunt, R.H. (1975). Maternal behaviour in the Morelet's Crocodile, Crocodylus moreleti. Copeia 1975: 763-764.

9. Hunt, R.H. (1977). Aggressive behaviour by adult Morelet's crocodiles, Crocodylus moreleti, toward young. Herpetologica 33:195-201.

10. King, F.W. and Brazaitis, P. (1971). Species identification of commercial crocodile skin. Zoologica (NY). 56(2): 15-70.

11. King, F.W., Campbell, H.W. and Medem, F. (1979). Review of the status of the American Crocodile, Crocodylus acutus. Unpublished report supporting proposal to transfer C. acutus populations outside the U.S. from CITES Appendix II to I.

12. Mittermeier, R.A. (1979). The Best Zoo in Latin America. Animal Kingdom 82(1): 15-21.

13. Pérez-Higareda, G. (1979). Morelet's Crocodile (Crocodylus moreleti Duméril and Duméril), in the region of Los Tuxtlas, Veracruz, Mexico. Bull. Maryland Herp. Soc. 15(1): 20-21.

14. Pérez-Higareda, G. (1980). Notes on nesting of Crocodylus moreleti in southern Veracruz, Mexico. Bull. Maryland Herp. Soc. 16(2): 52-53.

15. Powell, J.H. (1971). The status of crocodilians in the United States, Mexico, Central America, and the West Indies. In, IUCN Publ. New Ser. Suppl. Pap. No. 32: 72-82. (Proceedings of the First Working Meeting of Crocodile Specialists, N.Y., 1971.

16. Schmidt, K.P. (1924). Notes on Central American crocodiles. Field Mus. Nat. Hist. Zool. Ser. (Chicago) Publ. 200, 13(6): 79-92.

17. Smith, H.M. and Smith, R.B. (1979). Synopsis of the Herpetofauna of Mexico. Vol. V. Guide to Mexican Amphisbaenians and Crocodilians. John Johnson, North Bennington, Vermont.

18. King, F.W. (1981). In litt., March.

19. Ross, C.A., and Ross, F.D. (1974). Caudal scalation of Central American Crocodylus. Proc. Biol. Soc. Wash. $87(21): 231-234$. 
SUMMARY Widespread through Africa south of the Sahara, but absent from much of the extreme south and southwest; extends northward along the $\mathrm{N}$ ile as far as Lake Nasser. More widespread in prehistoric and historic times. A large crocodilian species, typical adult length c $3.5 \mathrm{~m}$, very occasionally to around $5 \mathrm{~m}$. Present in a variety of wetland habitats, including rivers, lakes and swamps. Fish, often those predatory on human food fishes, form a major part of the diet of animals over $1 \mathrm{~m}$ in length. Sexual maturity attained at around 12-15 years, length 2-3 m. A hole-nesting species, clutch size 16-80. The female attends the nest, opens the nest at hatching time and carries the hatchlings to water. Both parents defend their creche of hatchlings for 6-8 weeks. The species has been subject to many years of intensive hide-hunting and populations are widely depleted, of ten severely so. Several good or adequate populations remain, notably in Botswana (Okavango), Ethiopia (Omo River), north Kenya, Malawi (Lake Mialawi), parts of South Africa, throughout the range in Zambia and Zimbabwe, and possibly elsewhere. Few populations are not subject to actual or potential exploitation or habitat loss. Listed on CITES Appendix I; reservations to this listing have been entered by Botswana, France, Italy, Zambia and Zimbabwe. It is essential that the hide trade remains as strictly-regulated as possible. The operation and effects of commercial farming and rearing programmes should be monitored. The possible beneficial effects of healthy $\mathrm{N}$ ile Crocodile populations on the density of human food fish populations requires investigation.

DISTRIBUTIOV Widely distributed in Africa south of the Sahara, but absent from arid regions of the northeast and much of southwest Africa (9,23). Present on Madagascar. In the northeast, absent from the Red Sea Coast, much of Ethiopia, Djibouti, and much of Somalia. In the southwest, absent from $V$ amibia except the Cunene River (at the N amibia-Angola border), most of Botswana except Okavango and Chobe swamps, Lesotho, much of South Africa except parts of Transvaal and the Zululand region of iv atal (12).

At present known to occur in Angola, Benin, Botswana, Rurundi, Cameroon, Central African Republic, Chad, Congo, Egypt, Ethiopia, Gabon, Gambia, Ghana, Ivory Coast, Kenya, Liberia, Madagascar, Malawi, Mali, Mozambique, Vamibia, Viger, Nigeria, Rwanda (?), Senegal, Sierra Leone, Somalia (?), South Africa, Sudan, Swaziland, Tanzania, Togo, Uganda, Upper Volta, Zaire, Zambia and Zimbabwe (20).

The Nile Crocodile was somewhat more widespread in prehistoric and historic times; in the late nineteenth century records extended in South Africa along the southeast coast as far as the Keiskamma River in east Cape Province $(9,12)$, and in the late nineteenth century and up to at least 1924 crocodiles were present in $\mathbb{N}$ adi Iherir in the Tassil-n-Ajer mountains of the central Sahara (southern Algeria) (9), until at least 1961 present in the Ennedi Mountain region of northeast Chad, in the early twentieth century a specimen was taken at Lake Galula in Mauritania. The species is not now known to exist in these localities at the fringe of the Sahara, nor in the central Sahara; the recorded individuals are interpreted as relicts of larger populations formerly more widespread during less arid conditions in some phase of the Pleistocene or later (similarly, rock paintings in Tassili show 
a comparatively rich fauna of large mammals around 7,000 years ago (6)). In classical times crocodiles extended along the entire course of the $N$ ile to the delta, and in coastal regions perhaps to Tunis (18) and to the $\mathrm{N}$ ahr es Zerka ( $\mathrm{K}$ adi Zarga) near Caesarea in the Palestine region, where a remnant population persisted until at least the 1870 s (9). The species is now absent from the lower $\mathrm{N}$ ile and the Mediterranean coast.

The Nile Crocodile has been recorded on Zanzibar (Tanzania), the Comoro Islands, and the species was reported common by early colonists in the Seychelles (La Digue, Silhouette and Mahe) but populations here were extinct by the early $1800 \mathrm{~s}$ (9).

POPULATION Overall, the Nile Crocodile appears to be depleted to a greater or lesser extent over most of the range, but with many good or adequate populations remaining, notably in Botswana (Okavango-Chobe swamps), Ethiopia (Omo River), Kenya (northern waters, especially Lake Turkana), Malawi (Lake Malawi), South Africa ( $\mathrm{Natal}$, Transvaal, especially in protected areas), Zambia (throughout range) and Zimbabwe (throughout range), possibly also in Congo (northern forests), Ivory Coast, Senegal (locally, in protected areas). However, few of these populations are not subject to some degree of threat in terms of over-exploitation or habitat destruction $(12,20)$.

Unless attributed otherwise, the information below is from a recent extensive compilation by A.C. Pooley (ref. 20). Vo recent population data available for Benin, Rwanda, Somalia, Togo.

Angola Occurred in most major rivers and in their tributaries, present in good numbers on the lower Cunene, Cuanze and rivers to the east. Populations now depleted, considered Rare or Vulnerable.

Botswana The species is limited to the Okavango and Chobe swamps, northward to the Caprivi Strip (connecting with Cunene and Zambesi populations (12)). The Okavango Delta, covering $15,540 \mathrm{sq} . \mathrm{km}$, mostly dense relatively inaccessible papyrus swamp, is the main crocodile locality. This area holds adequate numbers of C. niloticus, apparently stable. Considered Out of Danger or Indeterminate.

Burundi Present in Lake Tanganyika and reported common in 1977 at the mouth of the Rusizi River near the capital Bujumbura.

Cameroon Rare, almost disappeared from inhabited areas. There is little regular commercial exploitation since suitable populations have not existed for at least a decade (1). Considered by local informants to be virtually extirpated (2).

Central African Republic Extremely depleted due to hide hunting, but still widespread, in moderate numbers in eastern rivers. Extirminated from Saint Floris V.P. since the 1950's.

Chad Present in Chari and Lagone rivers flowing into Lake Chad, and other smaller lakes, also rivers bordering the Central African Republic were reported quite rich in crocodiles. Subject to very heavy hunting pressure, major remaining populations are in Lake Chad and the Bahr Salamat basin.

Congo Severely depleted, adequate secure populations are reported to persist in northern forested areas.

Egypt The $\mathrm{V}$ ile Crocodile in classical times extended north to the Nile relta, but by the late 1700's the species was absent from the lower Vile, by the late 1800's 
the species appeared to be restricted to the $\mathrm{N}$ ubian area of southern Egypt above the first cataract, and in 1972 (9) the $V$ ile Crocodile was considered extinct in Egypt. It was suspected (9) that habitat changes following construction of the Aswan Dam could lead to re-colonisation of the area by the Vile Crocodile, and subsequent reports indicated (14) that crocodiles are indeed present in Lake $\mathrm{N}$ asser, and are common enough to present a nuisance to fishermen. No quantitative estimates of present population available.

Ethiopia Subject to heavy exploitation for hides, seriously depleted in parts although adequate populations remain locally, for example in the proposed Mayo N.P. in the eastern Rift, and notably in lower reaches of the Omo River (8). Over 70 crocodiles were observed in 1978 in Lake Chamo, and over 40 in the short stretch of river connecting Lake Abaya with Lake Chamo (22). Hatchlings were observed in Lake Chamo in 1978 (22).

Gabon Widespread, reported abundant in the coastal strip between Port Gentil and Mayumba. Also reported severely depleted (1), and considered by local informants to be virtually extirpated (2).

Gambia Formerly widespread, extremely depleted (except in Abuko V.P.) but with indications of some recovery reported in 1980.

Ghana Exploited for hides, reported threatened to some degree, the lake formed by Akosombo dam on the Volta has provided extensive suitable habitat. Status not clear.

Ivory Coast Reported Out of Danger (1980), but probably depleted, no quantitative data available.

Kenya Considered Out of Danger (1980). Crocodiles were heavily exploited in all Kenyan waters, except Lake Turkana (due to its remoteness and the high incidence of osteoderms in belly skins of $\mathrm{C}$. niloticus at this locality) and populations were severely depleted at time of 1955 ban on commercial hunting. Now a substantial recovery in the northern Uaso $\mathrm{N}$ yiro, Tana, and Sabaki rivers (to the point where stock and humans are being taken with some regularity), but introduction of gill-net fishing industry in Lake Turkana has led to some mortality. Local declines probably continue outside protected areas.

Liberia Few data, considered depleted and endangered but also reported common in mangroves on the outskirts of the capital (Monrovia).

Madagascar During the nineteenth century reported very common in most waters, especially the Betsikoka River, and still widespread and reasonably abundant up to at least the mid 1950's. The Nile Crocodile is now very diffuse and rare (5).

Malawi Although there appears to have been a decline in crocodile numbers in some areas, the species remains relatively widespread and fairly common in most parts of Lake Malawi, with the densest concentration between the lower Shire River and Elephant Marsh.

Mali Few data, reported in 1971 to be depleted even in reserves, and endangered.

Mozambique Formerly widespread but in general now very severely depleted, especially in the Sabie, Incomati, Umbeluzi, and Maputo Rivers, and Lakes Satine, Poolele, Bambene, Quissico, Inhampavale, Xuali, Mandjane, Chinguti, Piti and Catuane. Secure populations remain in Maputo Game Reserve and Gorongoza $\mathrm{N}$ ational Park, and probably also remain elsewhere in less densely populated areas. 
Namibia Occurs only in the extreme north, in the Kunene (Cunene) and Okavango Rivers (along the $\mathrm{N}$ amibia-Angola border) and in the Zambezi, Chobe and Linyanti flood plains in the Caprivi area. Considered Vulnerable overall, but with fair populations in the Kunene and Caprivi areas, Endangered in the Kavango area.

Niger Still widespread, but uncommon in reserves and reported certainly endangered. Probably still present in Arli, Pendjari, Singou, Mekrou and Alibori Rivers. Individuals up to $4 \mathrm{~m}$ have been reported in the Pendjari and Mekrou. Present in the $\mathrm{N}$ iger, small numbers seen between $\mathrm{N}$ iamey and the Mali frontier.

Nigeria Formerly widespread except the extreme north, still widely distributed but rare. Only a few individuals remain on the $\mathrm{V}$ igerian shores of Lake Chad (16).

Senegal Formerly known to occur in the Senegal, Faleme, Gambia and Casamance Rivers, also various smaller rivers. Populations have declined, the species has been considered endangered. Reported still reasonably common in 1977 on the Gambia and its tributaries, and common in the Parc $\mathrm{V}$ ational du N iokolo Koba.

Sierra Leone The species is rarely seen, populations depleted.

South Africa The species occurs in good numbers in the several perennial rivers within Kruger $\mathrm{N}$ ational Park in Transvaal, these populations appear secure so long as the rivers remain unaffected by industrial or other use. The species is widespread in other Transvaal watercourses, status considered vulnerable or endangered. In $\mathrm{N}$ atal, fair populations exist in $\mathrm{N}$ dumu, Hluhluwe, Umfolozi and Lake St. Lucia Game Reserves, and small isolated populations occur in many other areas. In the Maputaland region of $\mathrm{Natal}$, about 400 crocodiles (c 32 nests annually) over $1 \mathrm{~m}$ in length were present in 1971-1973 (this population is shared with Mozambique and Swaziland), less than 50 occur in the Pongolo floodplain, at least 20 crocodiles occur in the Mkuze system, about 60 (with 30 nests) at Lake Sibaya, very few remain in the Lake Zilonde and Kosi Lake area, and about 20 occur in Lake Mgobezeleni, Hlabanyathi and Manzengwenya Pans (21). Overall, the species appears to persist in low numbers over much of the known range, despite heavy exploitation, persecution, and increasing habitat disturbance, with fair or good populations primarily in protected areas.

Sudan Formerly present in good numbers in many parts, and reported very abundant in Darfur region, over-exploitation over at least the past two decades has led to extreme depletion.

Swaziland Depleted. Occurs in small numbers in Usutu, Umbeluzi, Vkomati and Ngwavuma rivers. Unprotected except for about 30 individuals in two small sanctuaries. Survival prospects poor.

Tanzania Kidespread but seriously depleted, now considered rare, adequately protected only in $\mathrm{V}$ ational parks, Game Reserves and controlled areas.

Uganda Formerly widespread and locally common, now severely depleted and considered Endangered. Decline due to over-exploitation is exemplified by data from the $\mathrm{N}$ ile in the Kabalega region; in 1967 at least 700 crocodiles were present, in late 1977 about 173 were present, and only 79 were counted in June $1980(13)$.

Upper Volta Status uncertain, considered rare and depleted, but may persist in the Black Volta, Red Volta and White Volta Rivers. 
Zaire Formerly widespread, considered to be declining rapidly in many parts of the country but may be locally common. Several accidents involving humans have been reported recently. Very rare in estuarine regions.

Zambia Widespread, especially in Lake Mweru wa $\mathrm{N}$ tipa, Lake Kariba on the Zambezi, and the Zambezi River and tributaries. Illegal hunting is reported outside protected areas leading to local declines. In 1980 the species was said to be abundant throughout its range in Zambia (3).

Zimbabwe $\mathbb{K}$ idespread, notably in the Zambezi and assuciated waters, and Lake Kariba, also the many waterways shared by Zimbabwe, Botswana, Mozambique and South Africa. Despite illegal hunting, now considered cut of Danger. Good concentrations exist in remote parts of Lake Kariba, populations here may have increased in recent years following reduced fluctuation in water levels.

HABITAT AN $\cap$ ECOLOGY A large-sized species, adults may occasionally reach $5 \mathrm{~m}$ in length, a more typical adult size is around $3.5 \mathrm{~m}$. Exceptional lengths of $6.4 \mathrm{~m}$ (in the former Emin Pasha Gulf, Lake Victoria) to $7.9 \mathrm{~m}$ (Lake Kioga) have been recorded in the past (9). The $V$ ile Crocodile occurs in a variety of mainly freshwater habitats, notably larger rivers, lakes, and freshwater swamps, but records exist also from river mouths, estuaries and mangrove swamps $(9,23)$.

Vuch of the daylight period is spent basking at the water's edge. If the temperature rises excessively the preferred body temperature of near $25^{\circ} \mathrm{C}$ can be maintained for a time by gaping, when heat is lost with evaporation from the expanse of moist huccal membrane (9). Basking may cease around noon when the crocodiles seek the shade of nearby vegetation, partly submerge at the water edge, or float in the shallows, but is resumed until dusk when the animals return to the water (9). The early evening is generally the period of most activity (9).

The composition of the diet varies with age and size (7). Very young individuals spend much time on land and consume a very wide variety of invertebrates, including insects, arachnids and crustaceans. Anurans form a significant part of the diet until the crocodiles reach around $1.5 \mathrm{~m}$, but are rarely taken by individuals over $2.5 \mathrm{~m}$. Once a length of $1 \mathrm{~m}$ is attained, fish are taken and form an increasing proportion of the diet; fish are the main food item in crocodiles between $2.5-3.5 \mathrm{~m}$ (7). Thus, any population of Vile Crocodiles will contain a significant proportion of individuals preying mainly on fish (9). Vile Crocodiles are recorded to sometimes select strategic locations where water conditions force large numbers of fish into easily-harvested concentrations (9). A degree of co-operation between individuals is sometimes apparent, for example, when water levels rise and river water enters depressions along the riverside, subadult crocodiles have been observed to maintain an orderly semicircle at the entrance and thus intercept a higher proportion of the fish entering the depression than would be the case if intraspecific rivalries occurred (18). An interesting parallel in feeding behaviour with the Estuarine Crocodile Crocodylus porosus has been recorded, both species have been observed to swim slowly along the river-bank with the tail bent toward the bank, small fish rush along in the shallows ahead of the disturbance caused by the tail where they can be seized with a sideways lunge ( 18 - vile Crocodile, 15 - Estuarine Crocodile). As subadults increase in size they becorne able to deal with increasingly large prey, while still able to feed opportunistically on smaller items (18). Large adults can routinely capture antelopes, especially waterbuck, sitatunga and lechwe, also zebra, warthog, domestic goats and cattle, and even animals as bulky as Cape Buffalo (18). Prey caught on land is of ten pulled into water and killed by drowning, and if of large size is torn into pieces, often by the crocodile seizing portions in the jaws and spinning itself rapidly along its longitudinal axis. There may be group 
co-operation in tearing up large prey unmanageable by a single individual (18). Birds of various species are eaten by crocodiles of most age groups, ranging from small passerines to ducks, geese, herons and storks (9). Vestling weaverbirds in riverside vegetation may be tumbled into the water by the crocodile's tail bending the reeds (18), and $\mathrm{N}$ ile Crocodiles of ten lie in wait underneath nesting colonies of cormorants and darters (9) (another behaviour shared with Estuarine Crocodile, where individuals may lurk beneath. Flying Fox colonies). In the Bangweolo Marshes the main food is large water snails Lannistes, and in the Luangwa valley Cane Rats are the major mammalian prey (9). Humans are taken occasionally (9). Carrion, as well as live prey is taken readily (9). The low rate of metabolism, and the ability to maintain body temperature by basking, mean that large quantities of food are not required by larger crocodiles $(7,9,18)$.

Sexual maturity (in southern Africa) is attained at around 12-15 years of age, $2-3 \mathrm{~m}$ length, $70-100 \mathrm{~kg}$ weight (18). A dominance hierarchy is established among mature males at the start of the mating season, aggressive display interactions result in subdominant males being excluded from territory occupied by mated pairs (18). There is evidence suggesting that the $\mathrm{N}$ ile Crocodile is rnonogamous at least during the sexually active phase of the reproductive cycle (18). A hole-nesting species, the nest is excavated with the hind legs and the eggs buried under $30-45 \mathrm{~cm}$ of soil. The females tends to return to her first nest site each year, remaining at it after mating, and defending it against other females until the eggs are laid (18). Clutch size varies from 16 to over 80 , the larger females laying more eggs in a clutch and also larger eggs $(85-125 \mathrm{gm})$. Both parents remain in the vicinity of the nest throughout the 84-90 day incubation period, the female in particular stays in close attendance and does not feed, while the male does not closely approach the nest and leaves at times to feed (18). At hatching time the young crocodiles call from within the egg, the female responds by excavating the nest with her forelimbs and jaws, and carries the hatchlings in her mouth down to the water. Further vocalizations by the group of hatchlings may elicit a vocal response from nearby subadult and adult crocodiles, and the parental male may approach at this time (18). The crèche of hatchlings does not disperse for six to eight weeks, during which period both parents remain nearby and defend the brood against predators, including other crocodiles, at times in response to hatchling distress calls. At the end of the crèche period, the young disperse and will move away from, rather than towards, any larger crocodile encountered. The young show burrowing behaviour, and burrows often excavated communally, are used for shelter up to the age of five years. Predation on hatchlings (by crabs, large fish, reptiles, water birds and mammals) is thought to be substantially reduced by the relatively high degree of parental care and social co-operation (18), unique among reptiles (although of course highly developed among birds, considered the closest living relatives of crocodilians) and now demonstrated to varying degrees in other crocodilians,

THREATS TO SURVIVAL The present seriously depleted condition of $\mathrm{N}$ ile Crocodile populations over much of the range is attributed to heavy and largely uncontrolled hunting for hides $(9,12,19,20)$. Hunting pressure is still the major threat to the species' survival; al though in many areas populations are so reduced that large-scale commercial hunting operations are not feasible, crocodiles are still taken on a more opportunistic basis. Even where full or partial nominal legislative protection exists, the financial rewards are such that hunting continues to be profitable to hunters and traders, and to certain government departments that earn a substantial revenue from licence and export fees $(19,20)$. It has been estimated that, at the very least, 3,000,000 crocodiles have been killed in Africa for skins between 1950-1980 (19). The situation is typified by data from Iganda; very large $\mathrm{N}$ ile Crocodile populations existed in postwar years, at least 7,700 were taken each year betwen 1950-1965 with an export total of 108,000 for the 15 
year period (including a substantial number originally imported from adjacent countries), stocks were depleted below commercially-exploitable levels by 1965 and the species remains extremely rare in the country. Hides that should be subject to legislative control in their country of origin frequently evade control by being smuggled across the border into an adjacent country (20). Several additional threats are evident. Habitat disturbance is widespread, including clearance of riverine forest, drainage of swampland, changes in water regime due to irrigation schemes, burning of reed beds, trampling of nest sites by cattle - all consequences of increasing human pressure on the environment. At Lake St. Lucia in $\mathrm{N}$ atal (South Africa) for example, an estuarine site, irrigation schemes upstream have resulted in increased salinity levels (40 adult crocodiles died from this cause in 1970); in addition there is increasing human recreational pressure on the Lake, including boat and shore angling, boat tours, also dredging activity (20). Widespread and increasing use of gill nets, instead of various traditional nets and fish traps, causes significant mortality as crocodiles are readily entangled and drown; at Lake Turkana in northern Kenya for example, the formerly abundant crocodile population is affected by the use of large-mesh gill nets set for Lates niloticus (20). There is hunting for food and eggs, or for medicinal purposes, mainly by tribal peoples; crocodiles are frequently shot as vermin or as a potential hazard to humans, at waterside hotels on Lake Malawi for example; widespread civil disorder with ready availability of high-powered arms and amrnunition also appears to have led to increased killing of crocodiles (20).

The proliferation of commercial farming and rearing schemes poses a potential threat to the species (24). The operation of such schemes, and the effect on wild populations, must be monitored and regulated (24).

CONSERVATION MEASURES TAKEN Nominally protected by legislation in many parts of the range (20):- protected in Angola, Gambia, Ghana, Ivory Coast, Kenya, Uganda; partially protected by hunting and skin export restrictions in Botswana, Chad, Congo, Gabon, Mali, Malawi, Mozambique, Namibia, Senegal, Sierra Leone, South Africa, Sudan, Tanzania, Zaire, Zambia, Zimbabwe; apparently protected only within parks and other designated areas in Cameroon, Ethiopia, N igeria and Upper Volta (20). Vo protection in Liberia, Swaziland, Togo 20 ). No information for Benin, Burundi, Central African Republic, Madagascar, Rwanda, Somalia (20).

Present in protected areas in Botswana, Cameroon, Chad, Congo, Ethiopia (e.g. Omu Game Park and projected Mago N.P.), Gabon, Gambia (Abuko N.P.), Ivory Coast (Parc National de la Comoè, Reserve d'Assagny, P.N. de Tai), Kenya, Mali, Malawi (e.g. Liwonde N.P), Mozambique (Gorongoza N.P., Maputo Elephant Reserve, part of Lake $\mathrm{N}$ yasa), $\mathrm{N}$ iger (the 'W' N ational Park), Nigeria (Gashaka, Yankari), Senegal (e.g. Viokolo Koba N.P.), South Africa (Vatal - V dumu Game Reserve, Lake St. Lucia; Transvaal - e.g. Kruger N.P.), Swaziland, Tanzania (e.g. Selous Reserve), Upper Volta, Zaire (Virunga N.P.), Zimbabwe (20).

In $\mathrm{N}$ atal (South Africa) captive breeding for the purpose of restocking depleted waterways was first achieved in February 1974 at Vdumu Game Reserve, and continued (providing extensive important data on breeding biology) at the Lake St. Lucia Estuary Crocodile Centre. A total of 858 young crocodiles have been released into several different localities under this scheme (a few in Swaziland and Mozambique) operated by the $\mathrm{N}$ atal Parks Board (21). In 1979, 87 females at two farms produced 1,906 eggs in Zimbabwe (19).

Certain waterways in Borno State, northeast $V$ igeria have been re-stocked with Vile Crocodiles; in 197715 confiscated animals were released in Gashaka Game Reserve, in 197920 animals bred at Kyarimi Park Zoo were released in rumti 
Game Reserve, and it was intended (1980) to release a further 50 captive-bred crocodiles in Pandam G.R. (16). Over 100 young $N$ ile Crocodiles were produced at Kyarimi in 1978, and it is hoped that further captive breeding may lead to effective conservation and management of stocks in the wild, and possibly to commercial crocodile farming (16). Crocodile farming for commercial purposes is also being investigated in Ivory Coast, Zambia, Mozambique and South Africa (19). In Zimbabwe, key populations on the Zambezi and Lake Kariba are protected and a quota of eggs can be collected by each of four licensed rearing stations (4). About $5 \%$ of the young crocodiles reared from these eggs are returned to the Dept. of $\mathrm{V}$ ational Parks and $\mathrm{K}$ ildlife Management for re-stocking, the remainder are killed (12). The belly skins are sold for the luxury leather trade, back skins are tanned locally for belt manufacture, osteoderms and feet are made into key rings, dried gall-bladders are sold to Hong Kong for medicinal purposes, heads may be sold as curios or skulls sold for zoology teaching, and the caracases are fed to other growing crocodiles (12). This full utilization is in contrast to the wasteful killing of adults for belly hide alone (12). Each of the four rearing stations is allowed to take up to 2500 eggs per year (4). In 1978, 696 reared crocodiles were cropped, in 1979-612, in 1980-943 (4). It is claimed (12) that repeated egg collection under this scheme has not adversely affected the wild population on the Zambezi, which remains large, stable and adequately protected, between Victoria Falls and Maputa Gorge.

Listed on Appendix I of the Convention on International Trade in Endangered Species of $\mathbb{W}$ ild Fauna and Flora (CITES). Appendix I listing requires that trade in the taxon and its products is subject to strict regulation by ratifying states and international trade for primarily commercial purposes is prohibited. Reservations with regard to this listing have been entered by Botswana, France, Italy, Zambia and Zimbabwe.

CON SERVATION MEASURES PROPOSED The hide trade must remain as strictly regulated as possible. The unregulated proliferation of commercial farming and rearing operations poses a potential threat, such operations should be monitored and regulations relating to their effect on wild populations backed up by effective legislation (24). Existing legislation should be inore effectively enforced. Where commercial exploitation is considered desirable or necessary, this should be based on appropriate management procedures. Existing populations, especially the larger ones, should be adequately protected and monitored.

CAPTIVE BREENING Breeding in captivity is quite feasible under suitable conditions (10). Breeding primarily for re-stocking, or for commercial purposes, has occurred in V dumu Game Reserve and Lake St. Lucia Crocodile Centre, both in $\mathrm{V}$ atal (20,21), and at Kyarimi Zoo, Vigeria (16) (see Conservation Measures Taken). The Vile Crocodile has bred in Zoos at Tel Aviv (Israel), Kumasi (Ghana), Cologne (Kest Germany), Katowice (Poland) (11). During 1979 the species was bred at Berlin Zoo (K. Germany), nudley Zoo (U.K.), Tampa (U.S.A.) (17).

REMARKS It appears that good populations of food fishes, in particular the Tilapias (which often provide the main protein source for local peoples), are often correlated with the presence of healthy $v$ ile Crocodile populations $(7,9)$. It has been shown $(7,9)$ that crocodiles feed heavily on fishes such as Catfishes, Barbus and Lungfishes, that prey on Tilapias. Following widespread depletion of Nile Crocodile, a decline in Tilapia fisheries coupled with an increase in density of Tilapia predators, has been evident in several places $(7,9)$. This apparent relationship requires further investigation.

The compiler is extremely grateful to T. Pooley for comments on a preliminary draft of this account. 
REFERENCES 1. Abercrombie, C.L. (1978). Votes on llest African

Crocodiles. J. Herpetol. 12(2): 260-262.

2. Abercrombie, C.L.(1981). In \itt., 17 January.

3. Anon (Wildlife Conservation Society of Zambia) (1981). Crocodile in Zambia: status report for 1980. $1 \mathrm{p}$.

4. Blake, D.K. (1981). In litt., 23 September.

5. Blanc, C. (1981). Pers. comm. 3. October, Oxford.

6. Cloudsley-Thompson, J.L. (1977). Wan and the biology of arid zones. Edward Arnold, London.

7. Cott, M.B. (1961). Scientific results of an inquiry into the ecology and economic status of the $\mathrm{N}$ ile Crocodile (Crocodilus niloticus) in Uganda and Northern Rhodesia. Trans. Zool. Soc. Lond. 29(4): 211-317.

8. Ghiglieri, M.P. (1981). Wildlife Log on the Omo River. Oryx 16(2): 142-143.

9. Guggisberg, C.A.iर. (1972). Crocodiles: their natural history, folklore and conservation. David and Charles, Newton Abbot.

10. Honegger, R. (1979). Red Data Book, Vol. 3: Amphibia and Reptilia. IUCV, Gland (third edition, revised).

11. Honegger, R. (1978). Stocks and Captive breeding, 1972 (1973)-1975 (1977). Report prepared for fourth meeting of crocodile specialists. Madras, 1978.

12. Loveridge, J.P. (1980). Crocodile research and conservation in southern Africa. South Afr. J. Sci. 76: 203-206.

13. Malpas, R. (Editior) (1980). Kildlife in Uganda 1980: a survey. Report to the Minister of Tourism and Vildlife, Uganda. Pp. 118.

14. Mason, L.V., Lackey, R.T., Brown, K.Y. and Thelan, K.D. (1977). Protection, conservation and management of endangered and threatened species in Egypt. Report of the U.S. Fish and Wildlife Service/National Park Service Study Mission. Pp. 20.

15. Messel, H., et al (1981). Monograph 1, in series Surveys of tidal river systems in the $N$ orthern Territory of Australia and their crocodile populations. Pergamon Press Ltd., Dxford (UK) and Sydney.

16. Morgan-Davies, A.M. (1980). Tránslocating Crocodiles. Oryx 15(4): $371-373$.

17. OIney, P.J.S. (Ed.) (1981). International Zoo Yearbook, 21.

18. Pooley, A.C. and Gans, C. (1976). The Nile Crocodile. Scientific American 234(4) (April): 114-124.

19. Pooley, A.C. (1980). The decline of crocodiles in Africa. Traffic (Int.) Bull. 11 (9 and 10): 93-94.

20. Pooley, A.C. (1980). The status of crocodiles in Africa 1980. Paper contributed to 5th Korking Meeting of IUCV Crocodile Specialists Group, Gainsville, Florida. 12-16 August 1980.

21. Pooley, A.C. (1980). Crocodile research in Maputaland. In, Bruton, M.N. and Cooper, K.H. (Eds). Studies on the ecology of Maputaland. Pp. 293-299. Rhodes University, Grahamstown, and Kildlife Society, nurban.

22. Stephenson, J. (1978). Field notes. Ethiopian $\mathbb{K}$ ildlife and $\checkmark$ at. Hist. Soc. N ewsletter. No. 128: 5-7.

23. Neill, W.T. (1971). The last of the ruling reptiles. Colombia Univ. Press, N ew York. 486 pp. 
24. Pooley, A.C. (1982). In litt. 10 May, (Cornments on preliminary draft of RDB Nile Crocodile account). 
SUMMARY A small to moderate size crocodilian, occurring mainly in freshwater habitats, almost restricted to the island of New Guinea (Papua New Guinea and Irian Jaya) but also reported from the Aru Islands. Intense exploitation for hides, at a peak in the 1960s, has led to widespread depletion of populations, but adequate populations are known or thought to persist, mainly in remote and inaccessible lowland grass swamps. Difficult terrain and secretive habits inhibit reliable estimation of population size or location but may also hinder exploitation. Remains largely submerged in water during daylight, rarely basks, emerges at night. Feeds mainly on fish and waterfowl, also other small vertebrates. Sexual maturity in females attained at $1.8-2 \mathrm{~m}$, age 6-8 years (possibly up to 10 years in the wild), and $2.5 \mathrm{~m}$, age uncertain (possibly 10 ), in males. A mound-nesting species, nesting occurs during first rains but before maximal rainfall. Females guard nest. Clutch size in one area 24-45, mean 36; egg size $43 \times 72 \mathrm{~mm}$, weight $86 \mathrm{gm}$. Females and males may excavate nest, assist hatchlings to water, and females associate with own hatchlings. Hide hunting and collection of young to stock rearing farms are present threats to survival. Partly protected by legisation, not fully effective. Few protected areas. In Papua New Guinea a FAO/UNDP project exports hides mainly from village 'farms' stocked with wild-caught young, the effect on wild populations is unknown, possibly deleterious, but may be clarified as result of monitoring scheme now in progress (FAO/UNDP participation terminated 1981). Rearing projects, similar to the PNG model, are to be promoted in Irian Jaya. Listed on CITES Appendix II.

DISTRIBUTION Restricted to the island of New Guinea (Papua New Guinea and Irian Jaya) $(18,22)$ and reported from the nearby Aru Islands (15) (about $130 \mathrm{~km}$ from Irian Jaya). Absent from the island provinces of Papua New Guinea (22). In Papua New Guinea, present in areas of suitable lowland freshwater habitat, eastern limit (known at present) reached at Robinson River near Abau (Central Province), full detailed range uncertain (22). Probably similarly widely distributed in Irian Jaya but little information available, the Idenburg and Rouffaer Rivers in the Meervlakte (West Lakes Plain) are reported important breeding areas (22).

The freshwater crocodile in New Guinea was originally described as a full species (23), but several authors have treated this form and the freshwater crocodile in the Philippines as two subspecies of one species, C. $n$. novaeguineae and $\mathrm{C}$. $\mathrm{n}$. mindorensis respectively. A recent tendency, followed here, is to regard the Philippines crocodile as a full species C. mindorensis, in which case the New Guinea form also reverts to a monotypic species C. novaeguineae (24). There is significant scale variation between different populations in different areas of Papua New Guinea (26).

POPULATION Overall, populations of $\underline{C}$. novaeguineae appear to be widely depleted to some extent, severely depletéd in places, but adequate densities are retained in parts of both Irian Jaya and Papua New Guinea. The difficult terrain and secretive habits appear to have inhibited accurate estimation of population status, base-line data are required to enable trends to be monitored.

Indonesia Remains common in some areas of Irian Jaya, but locally over-hunted $(13,14,15)$. Both crocodilians in Irian Jaya, $C$. novaeguineae and $\mathrm{C}$. porosus, are reported in general severely depleted from primordial levels (due to unrestricted 
commercial exploitation) (13,14). Extensive prime habitat remains $(13,14)$. Formerly very common in the Mamberamo delta but becoming rare (16), reported over-harvested by 1959 (22). A reasonable population is reported to exist in Merauke, in lakes and lagoons $65 \mathrm{~km}$ inland (21). No data on Aru Islands population.

Papua New Guinea Good numbers remain in large tracts of inland grassy swamp, especially in more remote areas $(6,22)$. The upper and middle Strickland River, with up to 2.23 crocodiles $/ \mathrm{km}$, primarily adults and subadults, may remain at historic population levels (29). Locally overhunted $(6,22)$, with severe decline noted, for example, in Fly and Sepik River populations, and Lake Murray (18). There is some evidence for slight recovery of novaeguineae in Lake Murray and the Fly River, due in the former to Government releases (10 adults in 1980) and escapes from the Baboa crocodile station, and in the latter to reduced hunting pressure $(28,29)$. Crocodile density is still $(1978-1980)$ only 0.18 crocodiles $/ \mathrm{km}$ on Lake Murray, and 1.8, 0.35, on the lower and middle Fly (29). In Papua New Guinea a density of 2 or more crocodiles $/ \mathrm{km}$ appears indicative of healthy crocodile populations (29). The maximum density observed during extensive day and night surveys (between October 1978-July 1980) of over 2,703 km of river and lakeshore in Papua New Guinea's Western and Southern Highlands Provinces was only 2.23 animals $/ \mathrm{km}$ (on the middle Strickland) (29). It is considered that crocodile hunting should be banned on rivers with a density index of under 0.5 (29). A recent survey of navigable portions of the Purari River revealed a low density of crocodiles, subject to substantial exploitation; hunters interviewed suggested that the population had declined in the last decade (19). However, significant numbers of novaeguineae may exist undetected in large areas of grass swamp connected by creeks to the main river (19). It was suggested by local hunters that crocodiles move into remote swamps during the breeding season and only appear in more accessible river channels as water levels in the swamps decline (19). This factor may operate in other areas, and may tend to protect a proportion of the population from exploitation, however, this has not been demonstrated. It has been stressed that although hunting pressure may be less in remote grass swamps, it is probably never negligible, due mainly to the versatility of native canoes (32). In the Lake Murray area, low water surveys of $1,302 \mathrm{~km}$ resulted in a count of 1,112 crocodiles, probably indicating about 1,765 actually present. Yet in 1980 alone, 2,002 young live crocodiles (including $1.1 \% \mathrm{C}$. porosus) and 1,100 skins were taken out of the area; it is considered that the permanent swamps adjacent to main navigable areas provided the additional crocodiles (29). The number of C. novaeguineae skins in trade in the 1960's increased as hunters turned to this species after shooting-out most $C$. porosus in accessible waterways, but this was followed by a marked decline after 1966 aș $\mathrm{C}$. novaeguineae populations in turn became depleted (6). The volume of $\bar{C}$. novaeguineae skins produced in the PNG trade has more than doubled between 1975 and 1979; it is not possible to state whether the breeding populations are becoming increasingly supportive of harvesting, or are simply being over-exploited (22). Nearly half the skins produced are from West Sepik and East Sepik Provinces, most of the remaining half are from Western Province (22); it is possible that this reflects the relative density of novaeguineae populations, or more likely, simply the areas of major exploitation (27).

HABITAT AND ECOLOGY A relatively small crocodilian, average adult size 1.8-2 $\mathrm{m}$ (4), maximum male Tength possibly around $3.5 \mathrm{~m}$ (22), maximum actually recorded $3.35 \mathrm{~m}$ (28). Mainly occurs in freshwater habitats, but sometimes in brackish areas (4), for example near the mouth of the Fly River (source in 22). Primarily a lowland species, maximum known elevation is August River (West Sepik) c $600 \mathrm{~m}$ above sea level (source in 22). Appears to exist in a number of isolated populations centred on extensive areas of freshwater swamps and marshes (18). The New Guinea crocodile was formerly abundant, for example, in Lake 
Murray, a vast shallow lake basin, with highly indented shoreline and forested islands, the surroundings with rain forest, Melaleuca swamp and sago (18). In Waigani Swamp, the species was reported to avoid deep open water of the larger lakes, and prefer deep slow-flowing channels and small lakes overgrown with herbaceous aquatics (18). Most remaining good populations appear to occur in remote areas of extensive grass-swamp $(6,22)$.

Generally very secretive in habits. Juveniles, in particular, disperse into flooded swamplands during high water, possibly in response to harassment by larger individuals (29). Smaller crocodiles rarely enter the midstream of rivers but prefer near-shore cover (29) such as emergent vegetation, overhanging branches and fallen trees. Captive individuals (at Moitaka Crocodile Farm, PNG) would emerge to bask in direct sunlight only occasionally, usually during periods of cool rainy weather. Most of the daylight hours were spent submerged or with only the head at the water surface. The crocodiles would emerge in late afternoon and remain out of the water all night and into the early morning. Body temperature was typically close to $30^{\circ} \mathrm{C}$ during daytime. The major behavioural pattern involved heat avoidance rather than heat gain (10). Similar behaviour is recorded in wild populations (18). In Papua New Guinea about 12 times as many C. novaeguineae could be found on land at night than in day time $(28,29)$.

An opportunistic feeder, the known diet includes waterfowl such as crakes, rails and grebes $(18,22)$ but fish are thought $(28)$ to be the main food. One individual was seen to seize a water lizard (species unknown) at night (18). Stomach contents of a $135 \mathrm{~cm}$ novaeguineae included a $60 \mathrm{~cm}$ watersnake Amphiesma mairii, a rallid bird, grasshoppers, leaves, and $40 \mathrm{gm}$ pebbles (22). Presumably small mammals are also taken. Hatchlings feed on invertebrates such as mosquitos, grasshoppers and water bugs (source in 34).

Sexual maturity may generally be attained in females at $1.8-2 \mathrm{~m}$, age 6 to 8 years, and 2.0-2.5 m, age uncertain, in males (12). Females estimated at $1.5 \mathrm{~m}$ total length have been observed guarding nests in Waigani Swamp (17), and a female of $34 \mathrm{~cm}$ belly width, $1.7 \mathrm{~m}$ length, was found to contain 30 eggs (8). First breeding in the wild may typically occur at around 10 years of age in both sexes (28). It should be noted that the PNG legislation prohibiting trade in skins over 20" (51 $\mathrm{cm}$ ) belly width exposes young breeding females to legal hunting mortality for $1-2$ years until this size is attained (30). A near 1:1 sex ratio was found in a sample of 2,031 wild novaeguineae from the Fly River (30).

At Moitaka (PNG) courtship begins with the first rains, egg deposition follows after 4-8 weeks. Nesting is largely restricted to November-December before rainfall increases markedly at the end of December (12). This timing may indicate hatchling requirements for increased vegetative cover and food supply (22). In a captive group (Moitaka Crocodile Farm, PNG) it appears likely that territorial behaviour and operation of a well-defined social hiearchy occur all year round, not only during the breeding season when most observations have been made (10). However, individuals of the species appear more tolerant of conspecifics than in $\underline{C}$. porosus (10). Territorial behaviour by males increases in frequency in September and October prior to courtship and mating in November (10). A male will establish dominance by patrolling and challenging other males that venture into the water. Headslapping (an explosive 'biting at the water') is performed mainly by the dominant male, other males that headslap are immediately challenged. A female responds to a male's headslap by swimming toward the male and lifting her snout out of the water when approached closely (10). Copulation may follow 5-15 minutes of courtship behaviour during which each animal alternatively submerges, producing bubbles at the water surface, and re-emerges, with their heads in close contact (10). In this captive situation the dominant male probably inseminated about $90 \%$ of the females. 
The nest is constructed over a period of 1-2 weeks, and all eggs of a clutch are laid in one night (10). In Papua New Guinea most nests were 6-9 m back from the water's edge, often well-shaded at a tree base, on densely-vegetated high ground $(10,18)$. In the middle Sepik region 12 of 13 nests examined were built under shade trees or at the edge of small sago or pandanus palm swamps ( 9 of these were made by $\mathrm{C}$. novaeguineae, 1 by $\mathrm{C}$. porosus and 3 could not be attributed) (8). Most nests were built on floating grasses, over up to $4 \mathrm{~m}$ depth of water (8). The nest is constructed of a mound of vegetable debris derived from plants at the nest site, $125-160 \mathrm{~cm}$ base diameter, $44-65 \mathrm{~cm}$ height (8). The egg chamber was not more than $20 \mathrm{~cm}$ from the top of the nest, temperature in two nests was 30.5 and $34^{\circ} \mathrm{C}$. All novaeguineae nests were between $0.5 \mathrm{~m}$ and $2 \mathrm{~m}$ from a waterhole (8). Clutch size 27-45, mean 36 eggs (8); clutch size at Moitaka 12-43, mean 30 eggs (11). Mean egg size (middle Sepik) (8) $43 \times 72 \mathrm{~mm}$, weight (Moitaka) (11) 86 gms. The female typically guards the nest, often nesting at the mouth of a tunnel in dense vegetation leading from the nest to the water (18). A female was present at two novaeguineae nests on the middle Sepik, but each retreated rapidly without showing defensive behaviour, possibly due to regular visits by local landowners to collect eggs (8). In a captive enclosure the female would approach intruders coming close to the nest (10). Incubation period is about $80-85$ days (11). Both male and female adults have been observed (at Moitaka) to excavate the nest and transport the hatchlings by mouth to the water (10). Males appear to associate with particular nests in the area he frequents, and females may accept eggs or young of other females near their own nests (10). After hatching the females become increasingly territorial and attempt to exclude all other females from the area where her hatchlings reside (10). Hatchlings of up to 2 weeks of age were found to show distinct thermophily, preferring body temperatures of 33.4 $33.9^{\circ} \mathrm{C}, 1.4-2.9^{\circ} \mathrm{C}$ above later levels; this may aid rapid assimilation of yolk remaining from the egg and so increase hatchling survival by allowing normal feeding to start earlier (12). Egg predators probably include varanid lizards, wild pigs and (certainly) man. Some nests are likely to be lost to flooding (22), but this will be less where nests are built on floating vegetation (8).

THREATS TO SURVIVAL The primary factor leading to depletion of C. novaeguineae populations over the past few decades is over-hunting for skins. The hide of $\mathrm{C}$. porosus is considered commercially superior to that of $\mathrm{C}$. novaeguineae, but hunting of novaeguineae in Papua New Guinea increased to a peak in 1965-1966 following severe decline of porosus in 1955-1960 (6). A similar pattern is reported in Irian Jaya (14). Hunting for the skin trade, and collecting of young animals for the government-organised crocodile rearing programme (see below), are present factors affecting crocodile populations in Papua New Guinea $(5,6,19,22)$. The same factors operate in Irian Jaya $(13,14)$, but collection of young for rearing appears to be on a smaller scale at present. In both countries the annual catch appears to be largely dependent on seasonal water levels; in wet years the crocodiles appear able to disperse widely and into more inaccessible sites, but in dry years they are concentrated in deeper pools and waterways, more accessible to hunters (25). Hunters in Irian Jaya are having to travel further upstream to more remote areas to find crocodiles $(13,14)$. Hunting in Irian Jaya is organised by Chinese traders using transmigrants from Java or Sulawesi to liase with villagers who perform the actual hunting (13). In 1972-1973 on the Eilanden River, Indonesian soldiers based at Agats were hide hunting and organising local people into hunting parties (2l). Reportedly thousands of juvenile crocodiles (proportion of novaeguineae unknown) were being purchased ready for shipment to rearing farms in Singapore, a collection station was controlled by merchants in Jayapura and another located on Biak; these crocodiles and hides were traded through Jakarta or direct with Singapore (2I). Large crocodiles are reported rarely seen and accessible stocks of juveniles appear depleted since raising farms have difficulty obtaining a supply (21). About 10,000 skins are exported annually 
from Irian Jaya (13), around $90 \%$ of skins are C. novaeguineae (14); in 197935,470 novaeguineae hides were exported from Papua New Guinea (22). The monetary value of skins is so high that even mature females at their nests are being killed (8.22). Collection of eggs for food is also widespread $(6,8)$.

CONSERVATION MEASURES TAKEN Nominally protected to some extent by legislation in Irian Jaya and Papua New Guinea. The species is listed as protected in Irian Jaya (Law No. 327/Kpts/Um/5/1978), but it has been proposed that limited hunting should be allowed by permit under control of the Ministry of Agriculture (360/Kpts/Um/8/1975) (14). In Papua New Guinea the two indigenous crocodilians, $\underline{C}$. porosus and $\underline{C}$. novaeguineae, are utilized in an FAO/UNDP-aided scheme whereby hatchlings are taken from the wild, reared in village pens or larger commercial establishments, and killed for their skins after about three years when belly width approaches $51 \mathrm{~cm}\left(20^{\prime \prime}\right)$; the maximum width permitted for sale and export $(2,9)$. A minimum export width of $18 \mathrm{~cm}$ was imposed early in 1981 (3). It is claimed that the scheme not only maintains rural economies and counters urban drift, but also conserves wild crocodile populations since the hatchlings collected are considered a harvestable surplus and recruitment into the breeding segment, itself untouched, is able to continue. Full scale FAO/UNDP involvement ended in 1981 (except for persons assisting with monitoring). This project is discu sed further under the Remarks section.

In Irian Jaya the species appears to occur in the Gunung Lorentz Nature Reserve, although severely depleted, and in Pulau Dolok and Wasur Game Reserves (14), also in proposed Mamberamo-Foja, Jayawijaya, Bintoni Bay and Danau Bian Nature Reserves (31). Certain areas in Papua New Guinea are subject to rules of utilization agreed by village councils; of several such possible wildlife management areas containing crocodile habitat, only the Tonda WMA (southwest Western Province) currently has legal status (22). Some areas in Papua New Guinea have local laws prohibiting use of crocodiles, or their eggs, although village elders have noted lack of respect for local prohibitions among the younger generation (22).

Listed on Aprendix II of the Convention on International Trade in Endangered Species of Wild Fauna and Flora (CITES). Appendix II listing implies that commercial trade is allowed providing a permit from the country of export is obtained, this can provide a method of monitoring trade levels.

CONSERVATION MEASURES PROPOSED Despite legal protection, $90 \%$ of crocodile skins exported from Irian Jaya are from $C$. novaeguineae, varying in size from 9-38 inch belly width (c 23-96.5 cm) (14). Although full legal controls are not being implemented, exports have been significantly reduced (14). Crocodile rearing as opposed to indiscriminate hunting of wild adults, is to be officially encouraged (14). Commercial utilization is seen as the only route to effective conservation (31). The real difficulties of preventing over-exploitation are recognized, and it is hoped that a development and management plan can be formulated that will incorporate effective restraints (31). Hunting should be subject to more effective controls, and its impact on wild populations should be monitored. Research should be carried out on the extent to which juvenile mortality is density-dependent, and on the recruitment rates necessary to balance adult mortality due to natural causes or hunting (30). Crocodile hunting in Papua New Guinea should be halted where density is less than 0.5 animals $/ \mathrm{km}$, including on Lake Murray, the Leva, Boi, lower Kaim, middle Fly and Agu Rivers (29). Killing of large adults, especially breeding females, should be prohibited; although killing of females found at the nest provides a relatively easy short-term reward, it reduces the possibility of rational long-term management of the crocodile resource by reducing breeding success. The maximum legal skin size in Papua New Guinea trade should be reduced from $51 \mathrm{~cm}$ to $41 \mathrm{~cm}$ ( 16 inches) to ensure 
protection of females in the first year of breeding (30). It has been proposed that an eastern portion of the Lakes Plains area (part of the Mamberamo-Foja proposal) should be established as a reserve, with controlled harvesting allowed in the western portion (Roofaer River Crocodile Management Area) (14). Another area, bordered by the Catalina, Eilanden and Sirets Rivers holds a surviving novaeguineae population in ideal habitat, and has been proposed as a reserve (but will probably be used as a Crocodile Management Area, with controlled harvesting $(30))$.

CAPTIVE BREEDING The Moitaka Government farm near Port Moresby, Papua New Guinea, is breeding and rearing the species (and C. porosus), mainly with the aim of improving rearing technology at the village level and developing efficient techniques for captive breeding (22). No information available on adult or hatchling numbers. A few specimens are held in zoos around the world (7), no data on past breeding, none recorded recently.

REMARKS In Papua New Guinea plans to simultaneously develop the crocodile skin industry and manage wild crocodile populations were supported by FAO-UNDP, and the Project 'Assistance to the Crocodile Skin Industry' became operational in January 1977) (2). It was argued that since there is a very high mortality of hatchling crocodiles in the wild, a harvestable surp! us existed that could be taken and reared to commercial size in captivity, without affecting the status of wild populations. Rearing stations are mainly village-based and owned by local people and it was intended that rational management instead of indiscriminate hunting would be of long-term economic benefit. By the end of 1979 over 200 village crocodile-rearing stations were established (9). However, only about $15 \%$ of the 'farms' have been rearing crocodiles satisfactorily, due to lack of expertise in animal husbandry, seasonal fluctuations in water, difficulty in obtaining crocodile food, and other factors (9). The PNG Government has attempted to avoid loss of interest at the village level, and reduce dealing in small skins, by buying and redistributing young crocodiles when farm stock was to be disposed of; between June-December 1979 about 5000 young were handled in this scheme, with villagers receiving more than double the price than for sale of equivalent skins (9). Thus for the first time it is now possible for villagers to earn more from a reduced harvest (3). The young are sold to the three large-scale commercial farms. It has been suggested that this buying scheme has increased hunting pressure on wild populations (5). It has also been argued (5) that the basic assumption, that there is a very high density-dependent hatchling mortality, may only apply to populations at the carrying capacity of the environment. Density-dependant mortality would be expected to be lower in populations already depleted by exploitation. A further problem is that since most mortality in farm animals occurs at less than $10 \mathrm{~cm}$ (4") belly width, villagers are encouraged to collect larger stock, which are those that have already survived the phase of maximum natural mortality. The effect of the rearing programme on wild populations is as yet unknown, as is the maximum sustainable yield (5). It has been recommended (28) that village level farms should be eliminated. However, although the practical difficulties of monitoring wild crocodile populations in PNG are immense, a recently developed monitoring scheme is being implemented (3). It should be noted that in PNG the land, including crocodiles, is owned by local people under traditional tenure (3). The relative success of the project may be considered not in terms of what might theoretically be done, but in terms of what can in practice be done and what was being done before the project started (3). However, it is reported (1) that up to mid 1979 only a few hundred skins had been produced in captivity. Skin exports meanwhile had increased from 19,639 in 1975 to 43,093 in 1979, (around 80\% of which were C. novaeguineae) (22). This tends to confirm the view (5) that hunting pressure on wild populations is increasing. On the other hand, 1975 was a wet year (in which crocodiles may disperse widely into accessible waterways), while 1979 was a dry year (in which 
crocodiles are most readily accessible to hunters in remaining waters)(26). One recent reviewer (33) has concluded that the reconstruction of the crocodile skin industry has not shown the progress envisaged. The PNG programme can hardly be considered a confirmed success until it is demonstrated that exploitation is being limited to a level consistant with long-term survival of the resource. Despite valid reservations, the PNG project does constitute the closest approach yet achieved toward rational utlization of any crocodilian resource.

Much information incorporated in this account, and many useful comments on a preliminary draft, have been received from J.W. Lang, also J.J. Montague; other useful data have been provided in particular by M. Bolton, J. Lever, J.C. Pernetta and R.Petocz. The Compiler is most grateful to all these persons for their kind assistance.

REFERENCES 1. Balson, E. (1979). Six monthly Progress Report. Assistance to Crocodile Skin Industry, Papua Region, No. 6 Unpublished. FAO/UNDP Crocodile Project File, PNG/74/029. (not seen, cited in ref. 5)

2. Bolton, M. (1978). Crocodile farming in Papua New Guinea. Oryx. 14(4): 365-369.

3. Bolton, M. (1981). In litt., 26 August.

4. Brazaitis, P. (1973). The identification of living crocodilians. Zoologica (NY), 58(4): 59-101.

5. Burgin, S. $(19 \overline{80})$. Crocodiles and crocodile conservation in Papua New Guinea. Background paper given 30 October at Conference on Traditional Conservation in Papua New Guinea: Implication for Today. Port Moresby, 27-31 October.

6. Downes, M.C. (1971). Regional situation report - Papua and New Guinea. In., Crocodiles, IUCN Publ. New. Ser. Suppl. Paper 32:41-43. (Proceedings of the First Working Meeting of Crocodile Specialists, Bronx Zoo NY, March 1971).

7. Honegger, R. (1979). Red Data Book, Vol. 3: Amphibia and Reptilia. IUCN, Gland. (New Guinea Crocodile sheet dated 1975).

8. Jelden, D.C. (1981). Preliminary studies on the breeding biology of Crocodylus porosus and Crocodylus novaeguineae on the Middle Sepik (Papua New Guinea). Amphibia-Reptilia 3/4: 353-358.

9. Kwapena, N., and Bolton, M. (1980). The National Crocodile Project in Papua New Guinea. Unpublished report pp $1-7$.

10. Lang, J.W. (1980). Behaviors of the Saltwater Crocodile (Crocodylus porosus) and the Freshwater Crocodile (C. novaguineae) and recommendations on captive breeding. Unpublished preliminary report to the Wildlife Division, Dept. of Lands and Environment, Papua New Guinea. Pp $1-7$.

11. Lang, J.W. (1980). Reproductive behaviours of New Guinea and Saltwater Crocodiles. Text of paper presented at SSAR symposium on reproductive biology and conservation of crocodiles, 7-9 August 1980, Milwaukee.

12. Lang, J.W. (1981). Thermal preferences of hatchling New Guinea Crocodiles; effects of feeding and ontogeny J. them. Biol. 6: 73-78.

13. Lever, J. (1980). Crocodile status in Irian Jaya. 2-page report to IUCN/SSC Crocodile Specialist Group, unpublished.

14. Lever, J. (1980). Crocodile conservation and industry 
development in Irian Jaya. Report on consultancy sponsored by FAO, prepared for the Directorate of Nature Conservation, Directorate General of Forestry. Bogor, Indonesia. Pp. 1-53 plus Appendices 1-9.

15. MacKinnon, J. (1981). In litt., 7 May.

16. Mulyana, Y. and van der Zon, A.P.M. (1979). Development of Nature Reserves in Irian Jaya (Indonesia). Tigerpaper $6(1): 23-25$

17. Neill, W.T. (1946). Notes on C. novaeguineae. Copeia 1946 (I): 17-20.

18. Neill, W.T. (1971). The last of the ruling reptiles. Colombia Univ. Press, New York. 485 pp.

19. Pernetta, J.C. and Burgin, S. (1980). Census of crocodile populations and their exploitation in the Purari area. Purari River (Wabo) Hydroelectric Scheme. Environmental Studies Vol. 14. Office of Environment and Conservation, and Dept. of Minerals and Energy, PNG.

20. Schultze-Westrum, T. (1979). Project 1528, Conservation in Irian Jaya. WWF Yearbook 1978/79: 86-95.

21. Webb, G.J.W. (in preparation 1981) A guide to the status, conservation and management of world crocodilians. Report to Australian National Parks and Wildlife Service.

22. Whittaker, R. (1980). Interim report on the status and biology of crocodiles in Papua New Guinea. Field Document No. 1, FAO Project PNG/74/029, Assistance to the Crocodile Skin Industry. Wildlife Division (Dept. of Lands and Environment) and FAO, Port Moresby.

23. Schmidt, K.P. (1928). A new crocodile from New Guinea. Field Mus. Nat. Hist. Zool. Ser., Publ. 247, 12(14): 177-181.

24. Wermuth, $H$. and Mertens, R. (1977). Testudines, Crocodylia, Rhynchocephalia. Das Tierreich 100: 1-174. Berlin, Walter de Gruyter.

25. Bolton, M. (1982). In litt., 27 April (comments on draft RDB account for $C$. novaeguineae).

26. Lever, J. $(1 \overline{9} 82)$. In litt., 16 February (comments on draft RDB account).

27. Lang, J. (1982). In litt., 7 February (comments on draft RDB account).

28. Montague, J.J. (1982). In litt., 19 February (comments on draft RDB account).

29. Montague, J.J. (1981). Characteristics of a crocodile population in Papua New Guinea. Unpublished M.Sc thesis, submitted to Michigan State University, Dept. of Fisheries and Wildlife.

30. Montague, J.J. (1982). Morphometric, injury and growth analysis of Crocodylus novaeguineae from the Fly River drainage. Unpublished Ph.D. Thesis, submitted to Michigan State University, Dept. of Fisheries and Wildlife.

31. Petocz, R. (1982). In litt., 14 March (comments on draft RDB account).

32. Pernetta, J.C. (1982). In litt., March (comments on draft RDB account).

33. Burgin, S. (1980). A review of crocodile farming in Papua New Guinea. Science in New Guinea 7(2): 73-88.

34. Burgin, S. (1980). The status of the biology and ecology of Papua New Guinea's Crocodile, Crocodylus novaeguinea (Schmidt) Science in New Guinea 7(3):163-170. 
SUMMARY A large fairly broad-snouted species (very few individuals over $4 \mathrm{~m}$ in length are now known) inhabiting still or slow-flowing freshwater habitats, including rivers and man-made ponds and reservoirs. The range is centred on the Indian subcontinent, extending into Pakistan, Iran, Nepal, Sri Lanka and possibly still Bangladesh. Depleted to a greater or lesser extent throughout the range, in the recent past by intensive hide-hunting, at the present mainly by catching in fishing set-nets, habitat modification and human egg predation. Adequate population levels are maintained primarily in Sri Lanka, but also Nepal and the states of Gujarat and Tamil Nadu in India where Mugger have a wide but diffuse distribution. Burrows are excavated and provide shelter during summer and winter temperature extremes. Mugger may wander great distances both during the dry season and during monsoon flooding. A clutch of 10-35 eggs, is laid during late February-early April (in India) in a pitcher-shaped nest excavated in a high sloping bank. Eggs are $4-5 \mathrm{~cm}$ by $6-8 \mathrm{~cm}$, incubation period $50-65$ days. Sexual maturity in females is attained around age six, at $1.7-2 \mathrm{~m}$ length, later in males. Nominally protected by legislation throughout the range. Many states in India operate rehabilitation schemes, under which eggs are collected from wild-laid nests, hatched in captivity, and young Mugger released into suitable habitat, mostly within Sanctuary areas. Survival rate of released animals is generally high, up to $100 \%$ at one locality. Similar projects are under consideration in Pakistan. Several Indian zoos have bred Mugger, and captive breeding is becoming more widespread. The success of hatchery schemes and of captive breeding efforts suggest that the species may have potential for rational commercial utilization. Listed on CITES Appendix I.

DISTRIBUTION A species centred on the Indian Subcontinent, the range at present includes parts of Bangladesh (possibly), India, Iran, Nepal, Pakistan, and Sri Lanka. The Mugger occurs in scattered populations over most of India, except the states of Jammu and Kashmir, Himachal Pradesh and Punjab in the extreme northwest, and the nor thwest desert regions (6). The eastern limit of distribution may have extended beyond the Darrang district (20) into Arunachal Pradesh (6), both in the Assam region of India, there are no recent records from Assam (25) although the species may persist (34). The species is unknown in Burma at present, although there is a single old unconfirmed record from Thayetmyo (20). Mugger formerly occurred in Bangladesh and may still occur in some unsurveyed rivers, but there are no recent records (15). The species extends in the north into the terai regions of lowland Nepal (6). In Pakistan, C. palustris occurs in Sind and Baluchistan (1), and has been reported from Punjab (12). In Sind, Mugger are associated with the lower Indus drainage, including marshy areas along the Nara Canal, Jamrao head and Haleji Lake (Thatta Dist.) (1). In Baluchistan, the species occurs in the Hab River near Diwana (Las Bela Dist.), Hingol River (Chagai Dist.), and the Dasht River (Makran Dist.) (1). The western limit of Mugger distribution is reached further along the Makran coast, in the Sarbaz River in the Baluchistan region of Iran (2). The species range extends southward through peninsular India to the island of Sri Lanka. 
Bangladesh No recent reports of Crocodylus palustris. Not uncommon throughout the country prior to 1950, but following uncontrolled hunting, egg collection and habitat changes, the species may well be extinct in Bangladesh, although a few individuals may survive in remote areas, such as the northern (less saline) parts of the Sunderbans $(15,31,35)$. New data required.

India Formerly very abundant, but now heavily depleted throughout the range (6,10). Mugger still occur in small scattered and isolated populations in many states. The species is present in Kerala, Tamil Nadu, Karnataka, Andhra Pradesh, Maharashtra, Madhya Pradesh, Orissa, Gujarat, Rajasthan, Uttar Pradesh, Bihar and West Bengal (25). No information for Haryana. Absent from Jammu and Kashmir, Himachal Pradesh, Punjab, and desert areas of Rajasthan (6), possibly also absent from Assam (25) and other states in the extreme northeast, it is intended to clarify the possibility that Mugger persist in Assam (34). The best remaining populations are in Tamil Nadu (southeast India) and Gujarat (west) (6). Tamil Nadu was estimated by some authorities (25) to hold fewer than $200 \mathrm{C}$. palustris in total, and all other states with Mugger appear to hold considerabiy fewer than this. The present Tamil Nadu population is unknown, it is probably significantly more than 200 since 215 captive reared Mugger of about $1 \mathrm{~m}$ length have been released in the state (34). The second largest grouping occurs in Gujarat (25), where the largest known single population of c 60 individuals is present in the Hiran Lake in Gir National Park $(21)$. Other authorities $(4,5)$ stress the difficulty (mainly due to the time required) of obtaining reliable figures for Mugger population numbers, and prefer not to provide numerical estimates. In the state of Rajasthan the species has been introduced in many temple tanks and worshipped and this belief has allowed it survive $(10,18)$. Surveys in South Indian states have shown populations which may respond very well to conservation management.

Iran The Iranian population, restricted to the Sarbaz River drainage, was estimated at over 50 individuals $(3,16)$, on the basis of two surveys performed in 1970. However only 18 crocodiles were actually observed; and it has been suggested that the total estimate may be too high (2). The population appears to have been depleted by hide-hunting and other factors, and no crocodile over $2 \mathrm{~m}$ in length was observed $(3,16)$. Crocodiles are restricted to the Kolani Marsh area at the mouth of the Sarbaz, and a stretch further upstream between Rask and Bahu Kalat. Although depleted, the species was said in 1970 (3) to be in no immediate danger of extinction in Iran. There are no data available on present status in Iran.

Nepal No detailed estimates available. Reported to be relatively common throughout, in marshy lakes, ponds and small rivers (17). About 200 Mugger were present in Royal Chitwan National Park alone in 1978 (34).

Pakistan Endangered $(1,12)$. Very rare (25). There may be over 100 surviving in Sind (14), where a recent census indicated 51 individuals in the Nara Canal (1). No details available for populations in Baluchistan.

Sri Lanka A recently-published estimate suggests a total of c $2800 \mathrm{C}$. palustris in Sri Lanka (excluding first-year hatchlings) (26). Although the species is heavily depleted, several localities hold populations of up to 100 individuals (estimated total, based on a lesser number actually counted), and greater concentrations exist within the Yala and Wilpattu National Parks, and at Panama Wewa where 72 Mugger were counted in 1977 (estimated total 100-200) (26). A relatively very large population of 248 Mugger was observed at Katagamuwa tank in July-August 1979 , but in the next month all but about 60 had migrated away as the water level 
was reduced to a small shallow pool (11). Available evidence suggests that the largest remaining populations of Mugger occur in Sri Lanka, and also the densest concentration of populations $(25,25,28)$. Population status may be sound at present, but decline continues with habitat modification and killing for meat $(13,38)$.

HABITAT AND ECOLOGY A large moderately broad-snouted crocodile that may reach a length of $5 \mathrm{~m}$, most individuals now known do not exceed 3-4m (this may be due to hide-hunters having killed all large specimens in the late 1960s). Mugger may occur in any kind of freshwater habitat and are occasionally reported in brackish waters well within tidal limits. Prefers still waters with a depth of $3-5$ $\mathrm{m}$. May be present in rivers, streams, jungle pools, and frequently found in man-made lakes (tanks), ranging in size from village ponds to large irrigation reservoirs (6). This adaptability to man-made water bodies appears to be a significant factor in the widespread persistence of Mugger populations. In Sri Lanka for example, there are no natural freshwater lakes, but there was widespread construction of tanks between the 5th century $B C$ and the 13 th $A D$, these tanks now provide the major Mugger habitat and dense populations are unknown in other habitats $(13,26)$. Similarly what may be the largest single concentration of Mugger in India occurs in Gujarat, in the Hiran Lake, a reservoir formed by the Kamleshwar Dam (21), and reservoirs provide the main habitat in Tamil Nadu (32). In north Indian rivers, Mugger distribution overlaps with that of Gharial, Gavialis gangeticus, but the two species are seldom seen basking or nesting together. Mugger prefer to bask on rocks in mid-river, or usually on muddy banks (where individuals can be inconspicuous when motionless). In the drier months, Mugger living in rivers occupy the deepest pools and are known to wander several kilometres away from dry rivers in search of water and food. The species avoids fast-flowing rivers during monsoon periods, and there are many records of Muggers seen in riverside villages at this time of year (6). Burrows are excavated in the banks of inhabited waters, sometimes to a depth of $8-10 \mathrm{~m}$, these may provide shelter from extremes of temperature since new burrows may be made both in summer and winter. In captivity several $1.2 \mathrm{~m}$ individuals have been seen to co-operate in constructing a burrow (6).

Hatchlings predominantly feed on water insects and young fish. With increasing size the diet shifts to larger prey, that includes frogs, small mammals and birds. Very large individuals are known to have taken big game like Sambhar (Cervus unicolor), Gaur (Bos gaurus) (19). In captivity juveniles have been seen capturing squirrels, mongooses, kites, crows, monkeys and paddy birds. Mugger taking fish from set nets in the river show a preference for catfish (6).

Mugger of all sizes prefer to remain in groups in their respective size class, except for males during the breeding season. In captivity female Mugger start egg laying from year six onwards, when they are about 1.7 to $2 \mathrm{~m}$ in size (6). Males may attain maturity rather later, at about 10 years, $2.6 \mathrm{~m}$ length (38). Attainment of sexual maturity in the wild may be delayed as wild Mugger do not seem to grow as fast as captive crocodiles, the latter may attain a growth rate of 40-50 cm per year in optimum conditions during the first three years (23). In captivity, during the courtship season (from November to February in India) males exhibit a strong dominance heirarchy and dominant males mate with several females. In captivity one dominant male is stated to have mated with eight females in one breeding season (24). Mating takes place in the open water. The females start digging trial nest pits at least a fortnight before actual egg laying and as many as four trial pits have been observed in the wild. Nesting has been known within a burrow. Eggs are laid in a nest chamber of 35 to $50 \mathrm{~cm}$ depth, usually of a wide-mouthed pitcher shape, dug well away from the water's edge often in a high sloping bank $(5$ to $15 \mathrm{~m})$. Mugger appear very flexible in nesting requirements, as in many other aspects of their biology (38). Clutch size ranges 
from 10 eggs (a small female laying for the first time) up to 46 . Eggs are $4-5 \mathrm{~cm}$ by $6-8 \mathrm{~cm}$, weighing 80 to $120 \mathrm{gm}$, laid between late February and the first week of April. Nest temperatures vary from $30^{\circ}$ to $34^{\circ}$. Incubation period varies from 50 to 65 days. Hatchlings that are ready to emerge make grunting noises from within the nest, stimulating the nest-guarding female to excavate the nest and release the hatchlings to the water. Hatchlings are 25 to $30 \mathrm{~cm}$ in total length at the time of hatching and weigh about 60 to $100 \mathrm{gm}$.

There are many egg predators in the wild including mongoose, jackal, monitor lizard and sloth bear. Hatchling predators in addition include birds such as herons and storks. Natural calamities like flooding and desiccation also take a heavy toll.

THREATS TO SURVIVAL In India (6) the major present threats to survival of C. palustris in the wild, in order of importance are: (a) set net fishing (nylon gill nets set across rivers or standing bodies of water, usually set out in the evening and taken in the next morning when trapped crocodiles are clubbed to death), (b) egg predation by humans, (c) habitat destruction, (d) medicinal use of crocodile parts. The species has also been severely depleted by widespread and intensive hunting for the skin trade, now limited by protective legislation (25). In India new man-made lakes form suitable habitat for $C$. palustris which prefers non-flowing waters. However, since most such man-máde lakes are utilized for commercial fisheries, with extensive use of set nets, existing Muggers are killed and/or introductions of Mugger opposed. In addition to natural predation of Mugger eggs, mass egg-robbing by tribals for food, and also medicinal uses, pose a major threat. This threat is very prevalent in south India but in recent years, with the conservation agencies protecting habitats, this disturbance has generally decreased (7). Habitat destruction is a common problem in almost all parts of India. New land-use practices extending right up to the river's edge, and clearing of riverine forest, destroy the nesting habitats of Mugger. In new man-made lakes, there is a great contraction of the shoreline between the nesting season and the hatching season, due to heavy use of reservoir water for dry season crop irrigation. This adversely affects the micro-climate of the Mugger nests resulting in zero or low percentage hatching. Furthermore, the emerging hatchlings have to cover very considerable distances to reach the water, during which time they are exposed to higher risk of predation. Clearing of riverside vegetation also destroys the hatchling and juvenile habitat, and in the absence of vegetational cover, insects are scarce, resulting in the loss of an important part of the diet of small crocodiles. In India the traditional medicine men still believe in the curative powers of crocodile meat and fat for a number of diseases. Even other parts like bile, liver, bone, teeth, etc., are used as medicine. Until recently this was one of the major threats to the Mugger population. This may have decreased to some extent, but such medicines are still available and in demand, mainly in urban areas such as Madras, at a very high price (38). Mugger are great wanderers, particularly during the dry season when they move in search of water, and are killed when seen in populated areas. This is still reported every year in various parts of the country (6).

In Sri Lanka a main threat is illegal killing by bands of itinerant fishermen (26), the resulting meat may be sold for medicinal purposes or as 'dry shark' for food. Mugger are caught in nets prior to, or during, fishing. The actual poaching and subsequent sale of crocodile meat are both easy to conceal (26). A second factor in Sri Lanka, as in India, is habitat destruction, notably the clearance of forest cover around tanks, and other changes in land use $(13,26)$. Poaching for hides, and habitat destruction are threats to the species in Iran (2). No specific information on current threats in Pakistan.

CONSERVATION MEASURES TAKEN Crocodylus palustris has total legislative protection in Bangladesh, India, Iran, Nepal, Pakistan and Sri Lanka (except that 
in Sri Lanka the animal may be hunted under special licence). Export is banned in India, Pakistan and Sri Lanka.

More than 2000 eggs/year are collected for captive hatching by different state crocodile projects in India. This could increase by at least another 2000 if detailed surveys are carried out in areas not yet adequately surveyed and new nesting areas located. Collection of wild-laid eggs is carried out by Government Wild Life conservation agencies (State Forest Dept. Wildlife Depts.) for captive hatching and rearing for eventual release in suitable wild $\underline{C}$. palustris habitat. Madras Crocodile Bank Trust, a WWF-India aided conservation agency, now participates in this programme by providing supplementary captive-bred hatchlings for release into the wild. The Madras Crocodile Bank has recently (October 1981) sent 50 yearling Mugger to the Wildlife Dept. in Ranchi (Bihar) for rearing in the new Muta Mugger Sanctuary and release in 1982 in the Bhera River. Another 50 Mugger bred at the MCB have gone to the Kerala Forest Dept., and 30 to Andhra Pradesh (39). Many Indian states including Tamil Nadu, Gujarat, Orissa, Andhra Pradesh, Kerala, Uttar Pradesh, Maharashtra and Karnataka are now involved in this programme. Starting in 1975, the Government Wild Life conservation agencies of various states have produced over 3,000 Mugger and 400 of them have been released in suitable areas. These release sites include Cauvery River, Krishnagiri Reservoir and Hope Lake in Tamil Nadu, Ethiopothala Falls, Kinnerasani Sanctuary, Pakhal Sanctuary and Nagarjuna Sagar Reservoir in Andhra Pradesh, Shivpuri National Park in Madhya Pradesh and the Similipal National Park in Orissa. Monitoring programmes carried out in these areas have shown encouraging survival results. In Ethiopothala Falls the survival is $100 \%$ after three years. In other places the survival ranges up to $90 \%$. At least four sanctuaries have been declared for this species in Andhra Pradesh and Orissa and a further eight existing sanctuaries and National Parks have been selected for immediate restocking at the present time. Successful captive breeding programmes are now in operation in many Indian zoos (see below).

The intensive conservation programme in India has recently had a notable success, when the first-ever breeding of Mugger reintroduced into the wild occurred in the Nagarjuna Sagar-Srisailam sanctuary at Ethipothala Falls on the Chandravanka River (A.P.). In a group of eight 3-6 year old Mugger released in this area between February 1977 and September 1980, one of the five females laid nine eggs, four of which hatched in the wild on 13th June 1981. The young were subsequently observed with the mother. Mugger had been extinct in this area for at least 15 years prior to this small-scale reintroduction. Over the next two or three years most of the 184 mugger released in three sanctuaries in Andhra Pradesh are likely to attain maturity, and the breeding population of reintroduced crocodiles is expected to build up rapidly (34).

It has been noted that there is a possibility that strongly biased sex ratios are being produced by rearing projects involving artifical incubation (37). Recent work with chelonians (eg. 40) has demonstrated that incubation temperatures of only a few degrees difference can result in egg clutches developing into all males or all females; a similar effect has now been demonstrated in American Alligator Alligator mississippiensis (37). If this also occurs in other crocodilians, and if incubation procedures in the rearing projects are producing sex ratios strongly biased toward one sex (especially if toward all males), then the projects will be having a largely negative effect (37). This matter requires investigation.

Mugger also occur within protected areas in Iran, Nepal and Sri Lanka. The Bahu Kalat Protected Region in Iran, including much of the Sarbaz River, was established in 1971 for $\mathrm{C}$. palustris (2). Enforcement of protective legislation in ths region is extremely unlikely (2), and enforcement in Sri Lanka is minimal outside protected areas (26). 
Listed on Appendix I of the Convention on International Trade in Endangered Species of Wild Fauna and Flora (CITES). Appendix I listing requires that trade in the taxon and its products is subject to strict regulation by ratifying states and international trade for primarily commercial purposes is prohibited.

CONSERVATION MEASURES PROPOSED The present status of $\underline{\text { C. palustris }}$ throughout its distribution range must be clarified. Wild breeding populations in suitable habitats should be located and the areas declared as sanctuaries to maximise protection. Research in India has provided considerable information on the ecology and life history of this species. If these data were utilized in conservation programmes, and combined with effective legislation, C. palustris could be used as an exploitable wildlife resource. The urgent need in India is to continue to restock suitable wild habitats with Mugger, declaring such areas as sanctuaries, in order to create more natural populations before habitat is lost to increasing human pressure. In its wide distribution limits in India there are still many states that have not taken up Mugger conservation seriously and as such the available resource (wildlaid eggs) is under-utilised. Similar projects are under consideration in Pakistan $(1,14)$, and these should be given full support. The possible bias in sex ratios among hatchlings being produced by artificial incubation procedures (see fourth paragraph in previous section) should be investigated and rectified if necessary. Protective legislation could be more rigorously enforced.

CAPTIVE BREEDING Several Indian Zoos have been breeding Mugger since the first success at Jaipur Zoo in 1960. Foremost amongst these are Jaipur Zoo and Ahmedabad Zoo (breeding since 1967). The Madras Snake Park and Crocodile Bank Trust (breeding since 1975), Delhi Zoo (breeding since 1976), Vizag Zoo (breeding since 1978), Hyderabad Zoo (breeding since 1980) and Baroda Zoo, have also bred Mugger. The Madras Crocodile Bank has produced around 800 hatchlings from captive stock (38). In Andhra Pradesh the species has bred in 1981 in both zoos in the state, with 28 hatchlings from 30 eggs in a nest at Vishakhapatnam and 16 hatchlings from 18 eggs in two nests at Hyderabad (34). New captive breeding programmes have been taking up at Nanadan Kanan, Orissa; Satkosia Gorge Project site, Orissa; Bannerghatta National Park, Bangalore, and many other Indian Zoos are converting their existing exhibit pools into breeding pools (6). Mugger bred for the first time at both new Orissa sites in 1981 (34).

In Pakistan, two females are present in the Karachi Zoological Garden, one pair with the Game Department of the Government of the Punjab (Lahore), and one pair with four young (two pairs) at the Manghopir Shrine in Karachi (1). In Bangladesh a total of eight specimens are held in a tank attached to the shrine of Hazrat Khan Jahan Ali of Bagerhat and at Dacca Zoo.

REMARKS This account is based primarily on an extensive draft, relating to Mugger in India, kindly provided by B.C. Choudhury (Andhra Pradesh Forest Dept. Crocodile Conservation Project, Nehru Zoological Park, Hyderabad).

Although it is not Government of India policy to promote crocodile farms at this time (4), the rehabilitation schemes within India have demonstrated the potential of Mugger as a subject for commercial utilization through farming operations or free range sustained yield exploitation $(6,25)$.

The role of freshwater crocodilians in the ecology of fishes of commercial significance in the Indian sub-continent requires urgent investigation (33). In Africa, a positive correlation has been demonstrated between the existence of healthy Crocodylus niloticus populations and good populations of fishes of the commercially important genus Tilapia (30). It appears that $\mathrm{C}$. niloticus feeds preferentially upon predatory catfish, that in turn feed heavily on Tilapia; decline 
of crocodiles leads to decline of one factor limiting catfish populations. A similar relationship has been postulated to exist in India, where the catch of predatory 'coarse' fish has increased as the crocodile population has decreased; in Tamil Nadu, the two reservoirs with the highest yield of food fishes are also those with the highest $\underline{C}$. palustris populations (33). It may be recalled that, when feeding from fish caught in gill-nets, $C$. palustris prefer catfish (6). This mainly circumstantial evidence deserves fürther enquiry.

Mugger populations in Sri Lanka have been widely treated as a separate subspecies, $\underline{\text {. }}$ p. kimbula, distinct from all other populations, referred to as $\mathrm{C}$. $\mathrm{p}$. palustris. It has recently been proposed that this distinction in unjustified (4).

REFERENCES 1. Ahmed, M.F. (Director, Zoological Survey of Pakistan) (1981). In litt., 18 March (Information prepared by the Zoological Survey Dept.).

2. Anderson, S.C. (1979). Synopsis of the Turtles, Crocodiles and Amphisbaenians of Iran. Proc. Calif. Acad. Sci. (Ser. 4). 61(22): $501-528$.

3. Bosch, M., Bullock, S., and Kinunen, W. (1970). Crocodiles. Second Survey. F.-6-49. Job Completion Report, Division of Research and Development. 21 pp. +5 maps. Unpublished.

4. Bustard, H.R. (1981). In litt., 6 March.

5. Choudhury, B.C. (1979). In litt., 19 October (to René Honegger).

6. Choudhury, B.C. (In. prepn.). Captive breeding of Mugger Crocodile (Crocodylus palustris) in India - Achievements and future.

7. Choudhury, B.C. and Whitaker, R. (1979). Crocodile egg collection in Tamil Nadu. Indian Forester, 105(2): 121-128.

8. David, R. (1970). Breeding the Mugger Crocodile and Water Monitor Crocodylus palustris and Varanus salvator at Ahmedabad Zoo. International Zoo Yearbook. 10: 116-117.

9. Dharamkumarsinghji, K.S. (1947). Mating and the parental instinct of the Marsh Crocodile (Crocodylus palustris Lesson). J. Bombay Nat. Hist. Soc. 47: $174-76$.

10. FAO. (1974). India. A preliminary survey of the prospects for crocodile farming (based on the work of H.R. Bustard, Consultant). FAO, Rome.

11. Farook, S.M.S. (1980). Proposed study on the crocodiles of Sri Lanka (unpublished report).

12. Ghalib, S.A., Rahman, H., Iffat, F. and Hasnain, S.A. (19??). A checklist of the reptiles of Pakistan. Rec. Zool. Surv. Pak. 8(1,2): 37-59.

13. $\overline{\text { Hof }} f$ man, T.W. (1981). In litt., 5 March.

14. Khan, A.A. (Deputy Conservator of Forests, Punjab Govt. Wildlife Dept.) (1981). In litt., 22 April.

15. Khan, Md. A.R. (1981). In litt., 7 February.

16. Kinunen, W., and Bullock, S. (1970). Baluchistan crocodile investigations. Job Report, Division of Research Development. 19pp +2 maps. (Unpublished).

17. Maskey, T.M. (Senior Warden, Royal Chitwan N.P.) (1981). In litt., June (Report on Gharial in Nepal).

18. Mukherjee, A.K. (1974). Some examples of recent faunal impoverishment and regression. In Ecology and Biogeography in India. (Ed.) Mani, M.S., Dr. W. Junk, S.V. Publishers, The Hague.

19. Ramanand. Undated pers. comm. to B.C. Choudhury (cited in ref. 6). 
20. Smith, M.A. (1931). The Fauna of British India including Ceylon and Burma. Reptilia and Amphibia. Vol. I. Loricata, Testudines. Taylor and Francis Ltd., London. (Reprinted 1973 by Ralph Curtis Books, Hollywood, Florida).

21. Whitaker, R. (1978). Notes on the status of the Gir crocodiles. J. Bombay Nat. Hist. Soc. 75(1): 224-227.

22. Whitaker, R. (1979). The crocodilians of Corbett National Park. Indian J. Forestry 2(1): 38-40.

23. Whitaker, R. (1981). Optimum growth rates of captive Mugger. (Crocodylus palustris) at Madras Crocodile Bank. Indian Forester 107(2): 102-103 (plus two plates).

24. Whitaker, Undated pers. comm. to B.C. Choudhury (cited in ref.6).

25. Whitaker, R., and Daniel, J.C. (1980). The status of Indian crocodilians. J. Bombay Nat. Hist. Soc. 75 (suppl.): 1238-1245.

26. Whitaker, R. and Whitaker, Z. (1979). Preliminary crocodile survey - Sri Lanka. J. Bombay Nat. Hist. Soc. 76(1): 66-85.

27. Whitaker, $Z$. and Whitaker, R. (1978). Notes on captive breeding in Mugger (Crocodylus palustris). J. Bombay Nat. Hist. Soc. 75(1): 228-31.

28. Whitaker, Z. and Whitaker, R. (1979). Never a smile for a crocodile. Animal Kingdom (Oct./Nov.) 82(5): 31-34.

29. Yadav, R. N. (1969). Breeding the Mugger Crocodile (Crocodylus palustris) at Jaipur Zoo. International Zoo Yearbook. 9: 33.

30. Cott, H.B. (1961). Scientific results of an enquiry into the ecology and economic status of the Nile Crocodile. (Crocodilus niloticus) in Uganda and Northern Rhodesia. Trans. Z001. Soc. Lond. 29(4): 211-356.

31. Gittins, S.P., and Akonda, A.W. (1980). Wildlife conservation in Bangladesh. Unpublished ms. $11 \mathrm{p}$.

32. Whitaker, R. (1979). Future of crocodiles in Tamil Nadu. Indian Forester 105(8): 592-593.

33. Whitaker, R., and Daniel, J.C. (1978). The status of Asian crocodilians. Tigerpaper 5(4): 12-17.

34. Bustard, M.R. and Choudhury, B.C. (1981). In litt., 20 June (comments on first draft of Red Data Book account of Mugger).

35. Choudhury, B.C. (1981). In litt. 10 July.

36. Khan, Md. A.R. (1980). Present status and distribution of Crocodiles and Gavial in Bangladesh. Paper presented at 5th meeting of the IUCN/SSC Crocodile Specialist Group; August 1980, Gainesville, U.S.A.

37. King, F.W. (1981). In litt. (comments on draft RDB account for C. palustris).

38. Whitaker, R. (1981). In litt., 10 August (comments on draft RDB account for $C$. palustris).

39. Anon, (1982). News item in Hamadryad 7(1): 1.

40. Mrosovsky, N., and Yntema, C.L. (1980). Temperature dependence of sexual differentiation in sea turtles: implication for conservation practices. Biol. Consv. 18: $271-280$. 
SUMMARY A widespread species, occurring from Sri Lanka, eastern India and Bangladesh, through coastal southeast Asia to the Philippines, Western Carolines, and south through Indonesia to Papua New Guinea and northern Australia, east to the Solomon Islands and Vanuatu. Individuals have been recorded at sea and on land far beyond the breeding range. Very severely depleted, rare and declining through most of the range, adequate population levels are maintained in parts of north Australia and New Guinea. The largest extant crocodilian, reported to have attained around $9 \mathrm{~m}$ length, a few individuals of 6-7 $\mathrm{m}$ still occur, notably in the Bhitarkanika Sanctuary (Orissa). Typically asssociated with brackish waters, such as coastal mangrove swamp-forest, but also extends to freshwater rivers and grass-swamp. Juveniles eat mainly crustacea, insects and small fish, adults take an increasing proportion of larger vertebrates. Males are sexually mature at around $3.2 \mathrm{~m}, 16$ years, and females at $2.2 \mathrm{~m}, 10$ years. A mound-nesting species, typically nesting in the wet season. Clutch size $25-90$ eggs, usually around 50 . Incubation 80-90 days. The female remains near the nest and may actively defend it. She assists hatchlings to leave the nest in response to calling within the egg, and may carry them to water and remain near them for an appreciable period. Threatened by extensive hide-hunting and habitat destruction. The high commercial value of skin of this species is due to the relatively small size of the belly scales and the relatively large area without osteoderms. Nominally protected by legislation through much of the range, mostly ineffectually. Present in a few reserves and National Parks. Active research and management programmes are operating in Australia, India and Papua New Guinea. Listed on CITES Appendix I, except the population in PNG, listed on Appendix II to facilitate trade in skins from the PNG rearing scheme. Several party nations have entered reservations to CITES Appendix I listing. Further research, effective implementation of legislation, and more protected areas are required. Breeds under suitable conditions in captivity, is bred on a few commercial farms, more rarely in zoos. The PNG rearing scheme is designed to improve rural economies by trade in skins from hatchlings reared in captivity from wild-collected young, and conserve wild populations by decreasing indiscriminate hunting. A monitoring programme is being developed to determine the effect of the scheme on wild populations.

DISTRIBUTION Crocodylus porosus has an extensive distribution $(13,47,54,58)$, ranging from Sri Lanka, the east coast of India, also the Andaman and Nicobar Islands, to Rangladesh, then southeast through parts of Burma, Thailand, Kampuchea, Vietnam, the Philippines, the Western Caroline Islands (Palau Group) and south through Malaysia, Indonesia and Brunei to Papua New ruinea, the Solomon Islands, Vanuatu and northern Australia. Formerly extended to the Cochin area on the west coast of India, and possibly to southern China. Extinct in Singapore. Breeding populations are highly localized within the overall range due to extreme depletion of the species in most areas and to habitat preferences (large rivers, estuaries and coastal swamps). Wandering individuals have been seen at sea and recorded from localities far outside the known breeding range, such as the Fiji Islands and Cocos-Keeling Islands. กne $3.8 \mathrm{~m}$ male was found at Ponape in the eastern Caroline Islands, some $1,360 \mathrm{~km}$ from the nearest population (2), and a specimen has been sighted at sea $480 \mathrm{~km}$ north of New 
Zealand's North Cape (72). Further details on distribution are provided in the following section.

POPULATION Severely depleted and at risk almost throughout its range (24,33,42). Adequate population levels are maintained in only a few localities, notably parts of northern Australia and parts of New Guinea (Irian Jaya and Papua New Guinea). Specific data are available for parts of the following countries (no information for Kampuchea).

Australia Present in coastal regions of the far north in western Australia, Northern Territory and Queensland. Populations declined dramatically during the 25 years following World War II due to extensive hunting for skins $(27,41)$. The species may be responding to protection (27), although slowly (90), and may not be at risk while this is maintained (59). The actual magnitude of recovery is subject to some dispute $(74,75,76,77)$ although available published dara (43, Monograph 1) appear unequivocal - comparing 1980 and 1981 survey results with those in 1975 it is evident that there has been no statistically significant increase in the number of non-hatchling crocodiles sighted on most tidal waterways (43, Monograph 1,76). It has been suggested that because of the long time to maturity, populations are still mainly sub-adult and no marked increase in nesting should be expected until 1982-1983 (59). Other authorities (74) strongly disagree with this statement, and believe present data suggests that recovery in tidal rivers of northern Australia should be viewed as a very long term process, perhaps measured in terms of decades $(75,76)$. The ability of present populations to initiate and maintain recovery depends on reproductive adults that survived the years of commercial hunting (78). Two important factors, namely, destruction of nesting habitat by feral buffaloes, and accidental catch during net fishing for barramundi, may easily hamper the overall slow recovery $(42,43)$ (see Threats to Survival). A major ten year research programme by the University of Sydney has provided much information on the status and population dynamics of $C$. porosus. In total $5168 \mathrm{~km}$ of tidal waterways have been carefully surveyed, many stretches more than once; $3998 \mathrm{~km}$ in the Northern Territory, $527 \mathrm{~km}$ in Western Australia and $643 \mathrm{~km}$ in Queensland. The current situation in northern Australia is as follows (42,43): Northern Territory - populations slowly recovering in tidal waterways of northern Arnhem Land and the Alligator Rivers Region; populations from the Adelaide River westward to the Western Australian border, steady or still falling; populations in the Gulf of Carpentaria are at extinction levels with the exception of the Roper and Towns Rivers. Western Australia - populations probably recovering very slowly in major sections of the Kimberley tidal waterways. The potential for recovery here is low (9). Queensland - with the exception of tidal waterways draining into Port Musgrave, populations are at dangerously low levels and probably still falling. The upper-limit estimates for the non-hatchling $C$. porosus populations are; Northern Territory 10,000; the Kimberley, Western Australia, 2,500; Northern Cueensland, 3000. These figures are extrapolations from estimates based on actual surveys of a major proportion of the total length of tidal waterways in the Northern Territory but only a small proportion of the tidal waterways in Western Australia and Queensland. Freshwater swamps and other freshwater habitats remain inadequately surveyed. The total of 15,500 non-hatchlings is relatively very low, possibly only a few percent of primordial levels (although this cannot be objectively established), and rigid protection must be maintained (76). A maximum of $21 \%$ of the above numbers represent adults, and there appears to be around $60 \%$ mortality among the sub-adults (43, Moncgraph 1).

Bangladesh Formerly occurred in good numbers in most rivers south of $23^{\circ} 15^{\prime} \mathrm{N}$, through the Sunderbans and much of the Chittagong area in the east. Ry the early 1950 s all populations in Chittagong, the Meghna and Balleshwar estuaries and nortnern parts or the sunderdans nad aisappearea (su). Ine current population, 
restricted to southern parts of the Sunderbans, is estimated at less than 200 individuals in an area of c $780 \mathrm{sq} . \mathrm{km}$ out of the Sunderban area of 6,000 sq km (30). Preferred rivers (based on interviews with locals, not actual sightings) appear to be the Balleshwar, Bhola, Sela, Katka, Ambaria Ghat, other tributaries of the Pusur, Bhadra and part of the Sibsa between $22^{\circ} \mathrm{N}$ and $22^{\circ} 40^{\prime} \mathrm{N}$. (30). This population is of considerable importance, it stands a good chance of surviving since it is within a protected reserve for Tiger Panthera tigris and the Sunderbans area remains relatively hazardous and difficult of access for humans (84).

Brunei No detailed information available, scattered specimens are sometimes seen in the coastal mangrove and Nipa palm swamps (33). A 1978 report indicated a trade in young crocodiles, bought mostly by operators of commercial rearing stations (33).

Burma Only small isolated populations remain (64), the main concentration, comprising c 4000 individuals of all size classes spread over the entire Irrawaddy Delta, is depleted and decreasing (14). The Delta population was reportedly (33) subject to heavy exploitation in the late 1970's following control of Karen insurgents in the area.

Caroline Islands (Western) Reported to be still relatively common in the Palau group in the late 1970 s (sources cited in ref.58). A total of 300 crocodiles were killed in a 1975 control programme, present status unknown.

China One specimen was obtained in 1912 from the Hong Kong region of southern China (54), it is uncertain if a breeding population existed at that time, there are no recent records.

India Formerly extended from the Cochin area of Kerala on the west coast, southward around the tip of the peninsula, and northward along the east coast to the Sunderbans in West Bengal. Also present in the Union Territory of the Andaman and Nicobar Islands. Previously abundant wherever suitable habitat, preferably estuarine mangrove forest, occurred (13). Now severely depleted and rare or extinct in most of its former range in India (13). Extinct in Kerala, Tamil Nadu and Andhra Pradesh (a $3.2 \mathrm{~m}$ specimen captured January 1979 in the Krishna estuary in A.P. is thought to have been a wandering individual) (13). The species persists at two localities on mainland India; in West Bengal, where a small number occur in the Sunderbans (13,29), and in Orissa, where the major mainland Indian population occurs in Bhitarkanika Wildlife Sanctuary $(13,16)$. The Sanctuary was founded on Kanika Island in the Brahmani-Baiterani delta area. The entire Phitarkanika population comprises only 35 adult $\mathrm{C}$. porosus, and at the end of 1976 there were in addition 61 crocodiles of $1-1.4 \mathrm{~m}$ length, the hatchlings of the 1974 season. The young of 1973 had virtually all disappeared by late 1975, and increased survival of the 1974 cohort is attributed to the protection afforded by declaration of the area as a Sanctuary in 1975 (13). The Rhitarkanika area is probably unique in that ten per cent of the adults in this protected population exceed $6 \mathrm{~m}$ in length (13), and the largest male exceeds $7 \mathrm{~m}\left(23^{\prime}-24^{\prime}\right)(29)$. Such a high proportion of extremely large animals is unknown elsewhere. The species was said to be abundant in the first half of the present century in several islands of the Andaman and Nicobar groups $(15,66)$, but the populations here are now depleted $(13,15,66)$. On North Andaman Island, probably the best remaining area for $\mathrm{C}$. porosus in the Andaman group, a June-July 1978 survey suggested presence of $3 \overline{6}$ nesting females (15). Other workers (66) provide the following approximate figures for breeding females, based on field surveys and interviews; North Andaman - 50, Middle Andaman - 20, South Andaman - 10. The total porosus population may be $170-330(66)$. Populations are reported to be healthy in the Nicobars (66), although no precise information is yet available. Human predation on eggs, killing of adults, and loss of habitat exert a continuing pressure on the 
Indonesia Regional information available is as follows, in approximate west to east order. Sumatra, becoming rare everywhere but still present in most large rivers of the east coast (37). Present in the Kluet area of Leuser National Park in northern Sumatra, in general survival prospects are poor due to disturbance and diminishing habitat (69). Siberut, formerly common but now depleted, due to hunting in the south at least. Presence of porosus is confirmed in part of the Ray of Tiop in the south, presence reported but as yet unconfirmed in estuaries and swamps in the uninhabited northwest (within Reserve area), including rivers Simarausau, Bolot, Tobakle, Torokatkat, Taio, Togilitte, Sinlingkle, Tamaerak, also lakes at Gobjib and Bolot (44). Java, almost extinct, a few left in Ujung Kulon (37), no confirmed reports in the last three years (up to 1981) from East Java and very few unconfirmed reports (5). Kalimantan, becoming very rare (37), a 1972 survey of 200 miles of the Mahakan River revealed only two adult porosus (33). Lesser Sunda islands, rare (37). Sulawesi, a few small surviving populations, e.g. Randangan estuary on North Peninsula (37). Formerly common at the mouths of the Sausu and Tambarana Rivers (Teluk Tomini) but no longer, following the increase in human population due to two large transmigration schemes; overall, rare in Sulawesi with poor survival prospects (87). Maluku (Moluccas), reported common in Aru (37) also reported severely depleted here (33), still occurs in Wae Apu estuary on Buru, reported from Wahai near Pasahari on the north coast of Ceram, otherwise rare (37), Irian Jaya, reported common but locally overhunted (37), a major stronghold is Pulau Dolok, half of which is a Reserve (36). The population along the Mamberamo, once heavily exploited, has declined (33), several other populations have declined with widespread and persistant hunting pressure (86). It appears that adequate numbers still remain in Irian Jaya to allow recovery of the $\underline{C}$. porosus population if conservation action is taken $(33,86)$. Timor, status unknown, breeding reported a decade ago on south coast (source in 33).

Malaysia West Malaysia, uncommon and declining, considered essentially extinct $(8,33,52,88)$, a few porosus may remain in Tasek Bera Lake and the Pahang River (33). Sarawak, endangered status, occurs scattered along coastal regions and up some larger rivers, e.g. the Rejang (49). The few large individuals in this river have been trapped due to man-eating habits, the local authority at Sibu offered a bounty for each specimen killed (49). Nests are occasionally found but the young are taken to rearing farms (49). Sabah, becoming rare, reported extinct in much of the former range (source in 33), a June-October 1981 survey is planned to clarify distribution and density of porosus and Tomistoma schlegelii (3). Breeding still occurs since hatchlings from the Kinabatangan, Segama and Labuk rivers , e used (1979) to stock at least one rearing farm in Sabah; however, hatchlings are difficult to obtain (45).

Papua New Guinea The species remains widespread, but is depleted throughout its accessible range due to heavy exploitation for hides in the 1950 s and early 1960 s $(6,33)$. Although exploitation is less in remote areas, it is never negligible, and there is at present almost no locality that is not subject to some kind of hunting (95). While formerly common in the mangrove areas at the mouths of the Sepik and Fly, and around the Gulf of Papua, it is now scarce and occurs more frequently in inland swamp habitat (68). Main centres are the swamps along the Sepik and Ramu rivers in the north, and swamps of the Fly River and other rivers draining into the Gulf of Papua in the south (6). On the Sepik River, the species occurs inland to the Irian Jaya border, although numbers decrease in relation to $\mathrm{C}$. novaeguineae, and on the Fly porosus has been recorded $500 \mathrm{~km}$ from the sea (68). The species has been reported from all of Papua New Guinea's 9 lowland provinces, also the island provinces of Manus, New Ireland, West and East New Britain, North Solomons, and Milne Ray (includes portion of mainland) (68). In the 
islands, C. porosus is extremely depleted on Manus, New Ireland, somewhat depleted in North Solomons, sparse in East New Britain but more widespread and in greater numbers in West New Britain (65). An active rearing programme, aided until 1982 by FAO/UNDP, is in operation in Papua New Guinea. Wild-caught young are reared for their hides. A major aim is to expand rural economies while conserving wild crocodile populations. This scheme confirms that substantial populations still exist, since an average of 7,000 C. porosus have been harvested annually since 1972 (70\% of these were under $12 \overline{5} \mathrm{~cm}$ length). There is a trade ban on skins under $18 \mathrm{~cm}$ belly width and over $51 \mathrm{~cm}$ belly width, with the intention of protecting a significant segment of the breeding stock. However, adequate census techniques have yet to be widely implemented, and the status of wild populations is unknown in detail (42). This scheme is discussed further under Remarks. A trial release of $43 \mathrm{C}$. porosus took place in Gulf Province in 1980 (7), these individuals will be closely monitored to assess the possibility of re-stocking depleted areas.

Philippines Threatened status, surveys in 1980 indicate that $C$. porosus is still present in depleted isolated populations on Luzon, Mindanao, Mindoro, Negros, Palawan and Samar (50). Local populations were reported healthy in 1978 in Lake Danau, Camotes Island, along the north shore of Moro Gulf in Minadanao, perhaps in the Sulu Archipelago and Leyte (33). However, more recent information (1981) indicates a marked decline; no crocodiles are now known to survive on Camotes Island or in Lake Danau (94).

\section{Singapore Extinct as resident breeder for over 30 years (33).}

Solomon Islands Declined in numbers since World War II, largely due to hide-hunting. Only an occasional individual is now encountered on the larger islands. A relatively large population, perhaps up to 300 individuals, occurs on one small island where nesting occurs regularly. The persistance of this population is attributed to the fact that crocodiles are sacred totemic animals to the local people (40).

Sri Lanka The species appears to have been abundant around much of the coast until the early part of the 20 th century, but is now severely depleted (67). A recent estimate suggests around 250 individuals (excluding first year hatchlings), with 25 breeding females, along the southwest coast, and 125 individuals, with 15 breeding females, in the rest of the island (67). The main breeding population is in the heavily populated southwest wet zone and is concentrated in remnants of formerly more extensive swampland, extending from Puttalam on the west coast, southward to the southern tip of the island (67). The best areas are centred around the main rivers draining into this coast, the Maha Oya, Kelani Ganga, Bentota Ganga, Gin Ganga and Nilwali Ganga (67). Breeding unconfirmed elsewhere (33). Still present at some east coast sites where formerly more common e.g. Batticaloa lagoon (67). Also reported in the Mahaweli Ganga up to Mahiyangana ( about $125 \mathrm{~km}$ inland) in the east (23), and within the Yala National Reserve (23). Population in Sri Lanka continues to decline, chiefly due to habitat loss. The Mutharajavela swampland between Negombo and Colombo, a former main breeding site, is being cleared as it lies within a 'Free-Trade Zone' $(21,33,67)$. A suitable reserve area will be necessary to ensure survival of $\ldots$. porosus $(23,67)$.

Thailand Probably extinct (4), no more than ten adults may remain (33), the last confirmed specimen came from the area of Ko Tarutao in Changwat Satun in 1971 with no confirmed sighting since (4).

Vanuatu Single individuals have been reported during 1980-1981 from south Espiritu Santo and west Malo, but the main population appears to be located in 
Silver River on Vanua Lava in the Banks Islands group (82). Local tradition is that this population is descended from a single colonizing female (82). Breeding appears to be occurring since individuals of all sizes can be seen, the total number may be around 50 (82). Hunting does occur sporadically, in 1973 a group of Solomon Islanders shot seven crocodiles for hides and a $4.8 \mathrm{~m}$ individual (maximum recorded length for Vanuatu) was shot by an Australian in $1980(19,82)$.

Vietnam Status and distribution little-known. Reported to persist in the lower Mekong River and Rung Sat Swamp (48). Not recorded north of Ho Chi-Minh (Saigon) (54).

HABITAT AND ECOLOGY The largest extant crocodilian, C. porosus is dubiously reported to have attained around $9 \mathrm{~m} \mathrm{(30} \mathrm{feet)} \mathrm{in} \mathrm{length} \mathrm{(54)} \mathrm{(based} \mathrm{on} \mathrm{a} \mathrm{probably}$ erroneous extrapolation from length of a preserved skull (80)). The greatest

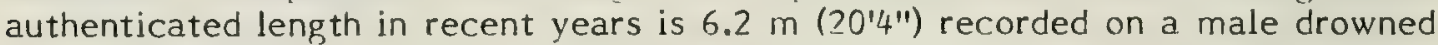
in a barramundi net in the Fly River near Obo, Papua New Guinea (68); however, a very large skull preserved by the Raja of Kanika, Orissa, belonged to an individual estimated to have been around $7 \mathrm{~m}\left(23^{\prime}\right)$ in length $(16,17)$, and it is reported that the largest male in the Bhitarkanika area at present exceeds $7 \mathrm{~m}$ in length (29).

The species typically occurs in brackish waters, inhabiting large river estuaries and deltas with associated coastal mangrove swamp-forest, but also extends into deep rivers far above tidal influence, also freshwater pools and swamps $(13,54,56)$. Through much of its range C. porosus is now mainly restricted to the mangrove system, in India for example, the remaining porosus populations occur only in this habitat $(13,16)$. The same applies to populations in southeast Asia and Indonesia. In the Andamans $\mathrm{C}$. porosus occurs in coastal streams, with mangroves, notably Rhizophora mucronata and R. apiculata, and Brugviera, giving way inland to cane brakes with Calamus and creeping cane, and semi-evergreen or evergreen riverine forest, with bamboo and scattered trees of Dipterocarpus, Planchoria and Pinsonia (15). However, while in Papua New Guinea the species has been typically associated with coastal mangrove, nipa and sago swamp, in some areas it is now more common in inland grass-swamp, and in the island provinces is most often found in inland lakes (even upland crater lakes and hill streams) (68). In Australia many $C$. porosus occur in tidal reaches with mangrove vegetation, and also occur in adjacent floodplain billabongs and spring-fed swamps which tend to be dominated by Paperbark Melaleuca and Pandanus palm, with a variety of sedges, grasses and vines. They may also extend $150 \mathrm{~km}$ upstream into freshwater non-tidal areas, and are well established in coastal freshwater swamps with floating mats of vegetation (including Phragmites, Typha and Cyclasaurus fern) $(56,77)$. As in Papua New Guinea, the present distribution of porosus and nesting activity through these habitats partly reflects differential hunting pressure before protective legislation (38), as well as location of optimum nest sites. Hunting is easiest when crocodiles are exposed on mudflats of coastal mangrove. In Sarawak, the Estuarine Crocodile was noted to spend much time basking on river banks with the jaws wide open, this latter was attributed a thermoregulatory function (local inhabitants also reported that sandpipers pick objects off the crocodile's teeth - an interesting parallel to behaviour also recorded for Nile Crocodile C. niloticus (22)) (53).

A carnivorous species, as are all crocodilians, $C$. porosus appears to be a largely opportunistic feeder, and the nature and size of the prey taken varies with age and habitat $(55,57)$. Feeding occurs during the day and night, when food is available, and on both ebb and flood tides in tidal regions. They are mainly shallow water or edge feeders. The stomach content of juveniles up to $180 \mathrm{~cm}$ length has been studied extensively in north Australia. Small fish are taken but crustaceans and insects comprise most of the diet of hatchlings and juveniles, mainiy grapsia craps or the suoramily sesarminae and ralaemonia snrimps of the 
genus Macrobrachium (55). Crustacea and insects are also the main diet of subadults in the India-Burma region (54), the stomach of a $2.5 \mathrm{~m}$ individual from the Irrawaddy was packed with crabs (54). It appears that the species may sometimes dig for crabs in sand above the high water line (39). Juveniles feed mainly along the water's edge and among mangroves at high tides, typical behaviour is for the young crocodiles to snap sideways at small disturbances or to lunge forward at them (57). Larger juveniles, over $1.2 \mathrm{~m}$ length, take an increasing proportion of vertebrate prey $(55,57)$. One feeding tactic, commonly seen in porosus $3-6$ feet $(.9-1.8 \mathrm{~m})$ in length, is to swim close to the bank so that the passage of fish between the crocodile and the bank can be blocked by curling the tail inwards and the fish can be captured with a sideways snap of the jaws (43, Monograph 1) - the same behaviour has been observed with Nile Crocodile Crocodylus niloticus (89). Food items recorded include sharks, archer fish, barramundi, pop-eye mullet, mullet, mudskippers, white-bellied mangrove snakes, cormorants and magpie geese $(42,43)$. Such prey must often be specifically hunted. When hunting riverine birds or mammals, an individual moves on the surface toward a disturbance or an intended prey item after seeing or hearing it at a distance. It then orientates its head toward the prey, dives and swims underwater to surface just in front of the prey, which may then be captured by a forward lunge with the jaws agape. Splashing in the water, perhaps indicating a trapped or wounded fish, is thought to initiate a feeding response (63). As size increases an individual becomes able to deal with progressively larger prey, including sharks, turtles, cattle, horses and humans. Virtually any mammal at the water's edge may be attacked (56), for example, in Sarawak a Macaque (presumably crab-eating monkey Macaca fasicularis) is often taken when it is seeking crabs near the water line, sometimes being knocked into the water by a blow of the crocodile's tail (53). It has been suggested (54) that a large porosus may acquire a preference for human prey because of the ease with which it may be obtained. An account of an attack on humans is given by Webb et al (63). Flying foxes Pteropus spp. are a favoured prey and porosus are of ten found among the mangroves beneath flying fox colonies (56). On one of the Solomon Islands a large colony inhabits the trees around a $C$. porosus pool, during heavy rain the bats move low in the trees and the crocodiles wait in the water below to seize any bat coming within reach (39). In Australia C. porosus appears to favour Magpie Geese Anseranas semipalmata. Large crocodiles may be cannibalistic and will take porosus hatchlings and small juveniles (42,43). Animals of up to $80 \mathrm{~cm}$ snout-vent length (approximately $1.6 \mathrm{~cm}$ total length), and those larger in size grow at different rates (data from north Australia (60)). Young C. porosus appear to show a distinct change in behaviour at $70-80 \mathrm{~cm}$ snout-vent length, coincident with a shift in growth pattern. Larger animals take larger prey and observed changes in morphology, for example the more rapid increase of head width relative to head length, may enable more efficient feeding behaviour, resulting overall in net energy gains (60).

Sexual maturity appears to be attained at around $3.2 \mathrm{~m}$, 16 years, in males and 2.2 $\mathrm{m}, 10$ years in females (60). Territoriality was very marked in a group of captive animals ( $8 \mathrm{I}$ ), the grouping behaviour shown by hatchlings is lost at about 8 months and territorial behaviour begins at about 2.5 years, several years before first breeding. The time of nesting varies between localities through the extensive range of the species, but often coincides to some extent with the annual wet season $(35,56,61)$. Nesting may be spread over a 3-5 month period and females at a given locality nest asynchronously (35). In Papua New Guinea (65), nesting occurs in September-January (or into March), and begins with or before the rains. This timing may indicate hatchling requirements for shelter, food, and fresh water (in tidal areas), all of which are enhanced by the first rains $(35,6 j)$. Nesting is in April-September in northeast India and the Andamans (here coincident with the onset of the southwest monsoon (15)). In Australia nesting occurs mainly in the wet season. The first nests are made in Cctober/November and the majority of 
nests are made in January/February. However, sporadic nesting occurs at least until August, and may occur throughout the year in suitable habitat (92). Minor peaks in nesting may correspond with falling flood levels in tidal areas, but in freshwater swamps such late nests are often next to (and in one case on top of) an earlier nest strongly suggesting multiple nesting from the one female (77). On the west coast of Sri Lanka nesting takes place in July-August (18), the height of the monsoon season (84).

A mound nesting species, the nest may be constructed from a variety of vegetable debris, including leaf litter, rushes, reeds, grasses, of ten living green materials as well as dead, and sometimes an appreciable volume of mud. In north Australian floodplain nests, broad-leaved grasses (e.g. Ischaemum villosum) appear to be a preferred nest material $(56,61)$, while in Sri Lanka the plant Lagenandra toxicaria is similarly preferred (18). Along the tidal rivers of northern Australia nests are sited in adjacent freshwater swamps in downstream areas, and at the riverside or the edge of flood plain billabongs further upstream (56). This may indicate a requirement of hatchlings or of breeding females for freshwater, or that females require a freshwater environment during the dry season and then nest in the same area (61), there is some dispute over this matter (74). In some coastal swamps almost all nests are constructed on floating mats of vegetation (77). In the Andamans while most nests were found in a zone of creeping cane and evergreens, on dry land beyond tidal reach, some were made in the shallow-waters tidal cane fringes, on raised areas such as old cane clumps (15). It was once reported in Sarawak (53) that the eggs are laid in a depression made in mud among Nipa palms near the river bank, it is not clear if this in fact represents a departure from the typical mound type of nest. A captive female in Papua New Guinea was observed to take several hours to form a nest mound, scraping backwards simultaneously with the left front and right rear feet, then the right front and left rear, in turn (68). In Australia, mean height of 27 nests with eggs was about $56 \mathrm{~cm}$ (range $33-80)$, mean long axis of base $178 \mathrm{~cm}(130-250 \mathrm{~cm})$, short axis $157(120-225)(61)$. The completed nest often has a deep groove along the top made by the female's tail as she crawls over it $(56,68)$, this is almost always an indication that the nest contains eggs (61). The clutch comprises 25-90 eggs (61), but samples of nests in north Australia (61) and in the Andamans (15) showed remarkably similar mean clutch sizes of 50 and 51 respectively, range 40-62 (18 nests) and 42-67 (6 nests). Eggs are white, hard-shelled, and develop an opaque band around the centre (61) if the embryo is alive, this results from attachment of extraembryonic membranes to the shell (77). E.gg size is rather variable between nests but remarkably constant in a given clutch, mean length (22 nests) $7.2-8.1 \mathrm{~cm}$, mean width 4.7-5.4cm, mean weight $91-132 \mathrm{gm}(61)$. The egg chamber is usually around $20 \mathrm{~cm}$ below the top of the nest $(56)$. Incubation period is $80-90$ days $(56,65)$ although this can be greatly extended in low temperatures (77).

The female apparently remains near the nest for much of the incubation period, and on bank nests is often in one of the one to four wallows typically found immediately adjacent to the nest. These wallows usually contain water or mud, and may be formed during collection of material for nest construction, or excavated separately $(18,56)$. Males appear to take no part in the nesting processs (61). The female in captivity, and apparently in some areas in the wild $(53,73)$, becomes aggressive during this phase and actively deters intruders, including other female $\mathrm{C}$. porosus (35). One female nesting in captivity would react to the slightest disturbance and would "reach the nest-site in one leap with open mouth" (1). This behaviour means that nest-guarding females are highly vulnerable to numan hunters, and it has been suggested that the trait is now less frequently shown in wild populations (12). Males in captivity also defend territories throughout the year (35). The female does not attend the nest continually for the entire incubation period, but frequently leaves it for short intervals (12). She assists the hatchlings by opening the nest, probing with the snout and digging with 
fore and hind limbs, in response to their calling within $(35,61)$. Females are also reliably recorded (12) to gather hatchlings in the throat pouch in times of danger, and probably to carry them in this way from the nest to water. At least some adult $C$. porosus remain in the water with grouped hatchlings for around two months $(61)$, in Arnhem Land rivers (Australia) for example, but creche formation appears not to be universal in Australia and may vary with river type and parental age (43, Monograph 1).

A high proportion of nests are lost due to various factors. In north Australia egg predation, mainly by Monitor lizards Varanus spp. and humans, is minimal but losses due to flooding are extremely high. It is estimated that in the four year period up to 1977 over $90 \%$ of nests in areas studied were destroyed by flooding $(56,61)$. By contrast in the Andamans of 30 nests found, 28 were destroyed by predators (human predation - 22 nests, Monitor lizard - 2, wild pigs - 2) and only 1 was flooded (15). There is a possibility that some $C$. porosus females nest more than once in a year (42). In a captive breeding colony in Papua New Guinea (35) only one clutch was laid per season.

A model has been developed, of possible great significance to management plans, to describe the general dynamics of $\mathrm{C}$. porosus populations in tidal waterways (but not in freshwater swamps) of north Australia $(42,43)$. It should be noted that certain aspects of this attempted synthesis are not universally accepted (77). However, it has been pointed out (90) that the model and the published data (43) are in conformity, and that no alternative published data are available. These tidal waterways may be classified into essentially three types, depending upon their salinity profiles. Type 1 Tidal river systems meandering through coast floodplains and having a heavy freshwater input during the wet season. The freshwater inflow decreases but remains sufficient, as the dry season progresses, to prevent the salinity upstream from rising above the sea water values measured at the mouth of the system (although the salinity front progresses upstream gradually). Such systems usually have good to excellent nesting habitat and could be expected to have good recruitment potential. Type 3 Tidal waterways which have a heavy freshwater input during the height of the wet season, but in which the freshwater input drops rapidly with the onset of the dry season. These waterways, which usually have short surveyable lengths and of ten direct openings to the sea, are typified by salinities which during the dry season are above those ineasured at their mouths and which increase with increasing distance upstream they are hypersaline and becorne increasingly so as the dry season progresses. Nesting habitat in such systems is minimal or non-existent. Recruitment potential is also usually low or non-existent. Type 2 Tidal systems which fall somewhere between Type 1 and Type 3 and which tend to show hypersaline characteristics as the dry season progresses. Such systems usually have good to poor nesting habitat and equivalent recruitment potential depending upon how close they are to Type 1 or 3 above. Each of these three types has it own characteristic pattern of salinity variation, both in respect of time of year and distance upstream, and the salinity characteristics largely determine the nature of the system $(42,43)$. The size structure of the crocodiles populating Type I systems is very different from those populating the non-type 1 systems. It is the Type I systems that account for the major recruitment of $\mathrm{C}$. porosus, other systems contribute to a lesser degree and they must -depend largely upon Type 1 systems for the provision of their crocodiles. It has also been suggested (77) that nesting habitat is the key factor, and this is not necessarily closely related to river salinity profiles. Some Type 3 tidal waterways have freshwater swamps adjacent to them which provide suitable nesting habitat; where this occurs, hatchlings from the swamp may immigrate to the Type 3 system (93). It appears that the populating of the non-Type 1 systems is triggered by the exclusion of a large fraction of the sub-adult crocodiles from Type I systems. Observations in tidal waterways in northern Australia indicate that there is over $90 \%$ mortality between the egg stage and arrival of hatchlings 
in the water, but contrary to common assumptions, mortality is considerably lower once hatchlings reach the river and most losses then appear to occur among subadults of 3 foot $(.93 \mathrm{~m})$ and over in length $(43$, Monograph 1 ). A low frequency of observation of subadult crocodiles has also been noted for Crocodylus niloticus and $\mathrm{C}$. acutus (sources in 43). These findings may relate to the fact that adult crocodiles appear to tolerate hatchlings, 2-3' (.62-.93 $\mathrm{m})$, and sometimes even 3-4' $(.93-1.24 \mathrm{~m})$ sized crocodiles in their vicinity, but not larger crocodiles in the same size class as themselves or the next smaller size class. It is stated (43) that this single factor is of critical significance, and alone largely determines the dynamics of $\mathrm{C}$. porosus populations. Once a crocodile reaches the 3-4' $(.93-1.24 \mathrm{~m})$ and $4-5^{\prime}$ $(1 . \overline{24}-\overline{1.55 \mathrm{~m})}$ size classes, it is likely to be challenged increasingly by crocodiles near its own size and in the larger size classes and be excluded from the area it was able to occupy when it was smaller. A substantial fraction ( $80 \%$ ) of the 3-6' $(.95-1.86 \mathrm{~m})$ sized crocodiles may thus be excluded from the river or be predated upon by larger crocodiles. Of those that leave, some may travel along the coast until by chance they find a non-Type 1 waterway, others go out to sea and possibly perish (perhaps because of lack of food as they are largely shallow water or edge feeders, or they may be taken by sharks) and others may take refuge in swamp areas. Those finding these non-Type 1 systems frequent the areas which act as rearing stockyards, for varying periods until they reach sexual maturity, at which time they endeavour to return to a Type 1 breeding system. Both sub-adults and recently mature adults might attempt to return and be forced out of the system many times before finally being successful in establishing a territory in a type 1 system (74). The crocodiles appear to have a homing instinct and even though a fraction of crocodiles return to a Type 1 system the overall numbers missing, presumed dead, remain high and appear to be some $60-70 \%$. The loss factor may be lower for movements in swamp areas than for movements in coastal non-type 1 systems. Since a large fraction of crocodiles sighted in non-Type 1 systems are derived from Type 1 systems, they are predominantly sub-adults or young mature adults and they probably constitute the major fraction of the long distance moving crocodiles $(42,43)$. On the other hand, it has been noted that although intraspecific interactions certainly do occur, there is no direct evidence for the relationship between this behaviour and the dispersal of small and medium sized crocodiles, nor for the patterns of movement postulated above for these individuals $(43,77,80)$. Radio telemetry of individuals in these populations appears to be the only way in which the numerous problems may be fully resolved and it is intended to develop this approach in the future $(43,77)$.

This model of the dynamics of a population of $\mathrm{C}$. porosus is able to account in a consistent fashion for the survey results and observations made in the tidal waterways of northern Australia (43). There are no data regarding the extent to which this model may apply to other areas and habitats. The ramifications of the picture, for structuring a strategy for management and eventual utilization of the valuable $\mathrm{C}$. porosus resource are potentially of great importance. An adult C. porosus is a most valuable asset in terms of reproductive potential, whereas sub-adults are of less value as a component of the population - but probably more valuable as a skin resource. It is suggested (43, Monograph 1, 'Stop Press' Section) that a strictly-controlled field experiment should be performed to test the effect of removing some fraction of the 3-6 foot $(.93-1.86 \mathrm{~m})$ subadults from the downstream section of a Type 1 river; it may be that such animals would constitute an economically significant harvestable resource since a high proportion appear not to reach reproductive age. Pending results of 4-5 years monitoring of such an experiment, strict full protection must be maintained (43). The release of hatchlings into Type 1 river systems should be questioned and it would appear that if sub-adults are to be released for the restocking of rivers then the non-Type 1 system, especially permanent freshwater swamps and billabongs with an adequate food supply (74), might be chosen. However, whether such an animal would then be able to locate a Type I system when it reaches sexual 
THREATS TO SUR.VIVAL The drastic depletion of $\mathrm{C}$. porosus throughout its range is attributed to commercial hide hunting $(12,33,4[, 47,58,67)$, a second factor is widespread loss of habitat. Hide-hunting, carried out both by local people and by expatriates armed with high-velocity rifles and often with motor boats, was on a particularly large scale in the 1950s and 1960s. In this period there was a rapid worldwide increase in the price of reptile leather and it is estimated that hundreds of thousands of $\mathrm{C}$. porosus were killed annually (47). In Papua New Guinea the estuarine and délta zones were mainly exhausted by the early 1950s (65). In Irian Jaya, and elsewhere, C. porosus occurred mainly in these. readily-accessible areas and was thus the first crocodilian species to be over-exploited (86). Selective hunting for large crocodiles has resulted in a severe reduction in the breeding population and continued hunting has resulted in minimal recruitment into the population (86). When today, in Thailand for example, a single crocodile skin can earn as much as the equivalent of half a year's wages (4), it is clear that hunting pressure will persist in many areas despite nominal legislative protection. The hide of porosus yields the finest quality leather due to the small scute size and lack of bony osteoderms in the belly skin, resulting in a relatively large area of attractive, flexible, and commercially useable hide from any given skin $(13,32,65,83,84)$. Preferred skin size, in New Guinea at least, is $15-16$ inches $(38-40.6 \mathrm{~cm})$, representing an animal of $.75-1.5 \mathrm{~m}$ length (84), or $15-20$ inches $(38-50.8 \mathrm{~cm})(83)$. Thus the larger crocodiles are not at present the most valuable commercially $(33,84)$. Irian Jaya hides are much in demand in the trade, and are mainly exported to a buyer in Singapore (not a party to CITES) (86). Collection of eggs and young for 'farm' rearing to marketable size poses a further threat to the species. Several rearing farms operate in Indonesia (in Irian Jaya, Kalimantan and Java), dependant on eggs and young taken from wild populations (33). In Kalimantan, for example, as the subadult and adult population became depleted to commercial exhaustion by hide hunting, pressure switched to eggs and young to be sold to rearing farms: most farms were closed by the mid-1970s as eggs and young could no longer be readily obtained (33). See Remarks for outline of Papua New Guinea scheme. Habitat loss appears to reduce the recovery prospects of populations already depleted by hunting, and has been more severe in India than most other areas of the range (13). The coastal mangrove habitat, with which $\mathrm{C}$. porosus is particularly associated, is a highly vulnerable system for several reasons. The ecological importance of mangroves as a spawning and feeding ground for marine fishes, prawns and crabs has not been widely appreciated; the alluvial soil of the nangrove system has very high fertility when reclaimed; in India for example, mangrove forests are not considered economically valuable and thus have low management priority (13). Similarly coastal swamps, including mangrove, in Sri Lanka have been widely cleared and drained for use as agricultural or building land; this habitat loss is continuing $(21,67)$. Habitat loss is the primary current threat in the Philippines, caused by expanding agriculture and aquaculture schemes (50).

In Australia the overall $(42,43)$ recovery of $\underline{C}$. porosus could easily be halted or reversed by two main factors. Firstly, C. porosus nesting habitat on Northern Territory waterways is being destroyed by trampling by feral water buffaloes Bubalis bubalus. The destruction of riverine and swamp habitat by these animals is extreme and on rivers such as the South Alligator it is already almost complete. The anchorage of floating mats of vegetation is broken down so that the whole mat drifts away in the wet season (77). On Adelaide and Daly Rivers, Murgenella Creek, the East Alligator, West Alligator and Wildman Rivers the habitat is now also being rapidly destroyed and unless this destruction is halted by extensive culling of the buffaloes it can be predicted that any recovery of the C. porosus populations on these excellent breeding systems will be halted. The second important factor is the toleration of net fishing for barramundi $(43,78)$ 
well upstream of tidal river mouths and often right up into the breeding areas. This is done legally and of ten illegally $(43)$. It has been suggested $(42,43)$ that this is leading to marked depletion of stocks of barramundi and of $\underline{C}$. porosus. The legal netting is reportedly (42) being carried out with the encouragement of the Fisheries Division of the Northern Territory. In one river 23 large C. porosus were found drowned in barramundi fishermen's nets within a two week period and several hundred large specimens are probably drowned annually (75). It is alleged (75) that no effective action is being taken to counter this. It is often observed that rivers with large $\underline{C}$. . porosus populations also produce good commercial catches of barramundi, and it may be that the crocodile is beneficial to barramundi populations, perhaps by eating large numbers of predatory fishes (such as catfish) that would otherwise consume small barramundi (78).

Another factor is that general animosity toward crocodiles is often directed against $\mathrm{C}$. porosus due to its large size, of ten aggressive behaviour if encountered near a nest, and tendancy to eat humans on occasion. This factor is likely to assume critical importance where recovery of $\mathrm{C}$. porosus populations is occuring $(77,78)$. In Australia there have been human fatalities due to $\mathrm{C}$ - porosus in 1980 and 1981 (77), and it may be speculated that there will be substantial hardening of attitudes if significant further predation of humans occurs. It has also been suggested (93) that multiple news releases relating an alleged population explosion of large crocodiles in northern Australia, coupled with exaggerated reports of the danger $C$. porosus poses to humans, must be viewed as a threat to attempted conservation and management programmes. The species is sometimes used for food, for example eggs are heavily-collected in the Andamans (15), or its parts used medicinally (13). Eggs and meat are consumed in Papua New Guinea (83).

CONSERVATION MEASURES TAKEN Nominally protected by legislation in Australia, Rangladesh (25), India, Indonesia (37), parts of Malaysia (Sabah not Sarawak), Sri Lanka; export of animals and products is prohibited in Australia, India and Sri Lanka. Not protected in Burma (58), Palau Islands (Western Carolines), Philippines, Thailand, Vanuatu. No information from elsewhere.

The species occurs in reserve areas in Australia, such as the Ord River Vature Reserve in Western Australia (10) and a sizeable freshwater population exists in Kakadu National Park in Northern Territory (28). Important reserves exist in India and in Indonesia $C$. porosus cccurs in reserves on Siberut, Sumatra (Leuser Nat. Park) and Irian Jaya. Pulau Dolok Game Reserve is probably the most important crocodile area in Irian Jaya in that it provides good habitat for $\mathrm{C}$. porosus, the rarer of the two Irian Jaya crocodiles (86). Much former habitat near Ko Turutao in Thailand is within Turutao Marine National Park (4). Small populations may occur in Klias N.P. and in Crocker Range N.P. in Sabah (33).

Protection in Australia is generally effective and dates from 1971 in vestern Austalia, 1972 in Northern Territory and 1974 in Queensland. The national ban on import-export was imposed in 1972. These measures, coupled with an extensive research programme (now in its tenth year) run by the University of Sydney and the Nepartment of Northern Territory $(42,43)$, allow some degree $(74,77)$ of optimism for the continued recovery of $\mathrm{C}$. porosus in Australia (providing protection is maintained). Similarly the Government of India/FAO/UNDP Crocodile Breeding and Management Project has resulted in important conservation action. This scheme was initiated in 1975 with the dual aim of rehabilitating, depleted wild populations of India's three crocodilian species, and allowing the possibility of sustained utilization of wild or farmed crocodiles $(20,26,51)$. The State Government of Orissa declared the entire remaining mangrove forest of the Brahmini-Baitarani delta (Bhitarkanika), comprising 176 sq. $\mathrm{km}$, a sanctuary in May 1975. Fishing (a cover for crocodile poaching) was banned in the area in the same month, and felling of man roves ceased in 1976 
(12). Eggs are collected from natural nests, incubated in captivity and the hatchlings reared to a size of 1 metre. Fifteen young were released into the sanctuary in 1977, and 80 in 1978. There was at least $80 \%$ survival of the 1977 cohort and, with continued protection of the sanctuary, it appears likely that there will be significant recruitment into the breeding population within several years (12). A further 30 released in January 1980 brings the total released in Bhitarkanika to 125 by January 1980 . The overall total within India is 168 , including 40 released in the Project Tiger Reserve in the Sunderbans of 'est Bengal, and 3 in the Coringa Wildlife Sanctuary in the Godavari delta of Andhra Pradesh (51). The species was extinct in the latter state but the sanctuary was declared in July 1978 with the aim of re-establishing $\underline{C}$. porosus, using hatchlings captive reared at Hyderabad from eggs from the Andaman Islands (12).

In Papua New Guinea the two indigenous crocodilians, C. porosus and C. novaeguineae, are utilized in a FAO/UNDP-aided scheme (FAO involvement ended 1982) whereby hatchlings are taken from the wild, reared in village pens or larger commercial establishments, and killed for their skins after about three years when belly width approaches $51 \mathrm{~cm}$ (20"), the maximum width permitted for sale and export $(6,34,46)$. A minimum width of $18 \mathrm{~cm}$ for skins in trade was imposed early in 1981 (7). It is claimed that the scheme not only maintains rural economies and counters urban drift, but also conserves wild crocodile populations since the hatchlings collected are considered a harvestable surplus and recruitment into the breeding segment, itself untouched, is able to continue. This project is discussed further under the Remarks section. It is officially intended to develop similar projects in Irian Jaya, when effective protection, research, and development of appropriate management and marketing techniques will be of high priority (86).

Listed on Appendix I of the Convention on International Trade in Endangered Species of Wild Fauna and Flora (CITES), with the exception of the Panua New Guinea population which is listed on Appendix II to allow trade in skins from the national rearing scheme. Appendix I listing requires that trade in the taxon and its products is subject to strict regulation by ratifying states and international trade for primarily commercial purposes is prohibited. Appendix II listing implies that commercial trade is allowed providing an export permit from the country of export is obtained, this may provide a method of monitoring trade levels. Reservations with regard to Appendix I listing have been entered by the following, party states: Austria, Federal Republic of Germany, France, Italy, Japan, Switzerland. A recent report by members of the IUCN/SSC Crocodile Specialist Group (33) urges that all populations should be listed on Appendix I until wild populations have recovered and national management plans are implemented. An effort is at present being made by the Northern Territory government in Australia to downgrade C. porosus from Appendix I to Appendix II even though, according to some authorities (74), detailed scientific evidence $(43,75,76)$ provides no support for the move and indicates that rigid protection must be maintained. It is reported (96) that there is some likelihood that commercial crocodile farming will be initiated in Australia, where there are already at least three establishments with captive porosus.

CONSERVATION MEASURES PROPOSED The protective legislation covering C. porosus through much of the range appears to be poorly enforced in most countries and with a continued demand for porosus hides, long-term survival of the species may depend on provision of strictly protected reserves, coupled with evolution of adequate management strategies where utilization is to continue. States party to CITES with reservations entered regarding $\underline{C}$. porosus should be encouraged to withdraw these reservations. Several measures to extend and improve the Crocodile Project in India are noted by Bustard and Choudhury (13). A reserve is required to ensure the species survival in Sri Lanka $(23,67)$. It has 
been proposed that a protected area should be established for the main population in Vanuatu, on Vanua Levu (Banks Islands group) (82). In Australia, because of poaching and drowning of crocodiles during legal and illegal netting for fish (prevalent in certain of the waterways inhabited by C. porosus (43)), the establishment of a number of specialist parks and/or closed areas, wherein aquatic resources are accorded protection and all netting totally prohibited, appears to provide the best chance for complete recovery of a number of geographically spread populations $(42,75,77)$. Recommendations have been made by IUCN/SSC for the establishment of such areas in Western Australia, Northern Territory and Queensland (42). The species is present in the proposed Aru Tenggara Marine Reserve in the Aru islands, Indonesia (81). Extensive crocodile habitat exists in the Gunung Lorentz Nature Reserve in Irian Jaya, although stocks are seriously depleted, re-seeding and effective protection would make this a suitable reserve (86).

It has been recommended $(43,74,75,76)$ that populations in Australia continue to require rigid protection, and there is no evidence to justify downgrading these populations from CITES Appendix I to II.

CAPTIVE BREEDING Breeds in captivity in suitable conditions, but few zoos keep adult pairs (24). The species is currently being bred at the Samut Prakan commercial crocodile farm near Bangkok, Thailand, where about 2,500 C. porosus are reportedly held (70,71). Animals are killed for their skin at around three years of age, and the meat is also sold. In 1979 it appeared (80) that most Crocodylus breeding at Samut Prakan involved $\mathrm{C}$. siamensis, and there was little or no $\mathrm{C}$. porosus breeding. Small-scale breeding is occurring on commercial crocodile farms in Australia (28) and at the Moitaka Government Experimental Farm in Papua New Guinea $(35,68)$. About 900 individuals are held in a State farm in Rangoon, Burma (14) where captive breeding on a commercial scale is intended. Breeding is also intended at Silliman University on Negros, Philippines (50). Based on research At Moitaka it appears that $C$. porosus should be managed in low density enclosures for optimal breeding success (35). Pair and group compatibility is more difficult to achieve than with $\underline{C}$. palustris or $\underline{C}$. novaeguineae for example (84). Freedom from interaction with conspecifics is probably more important than space and male-female compatibility is critical, females should be smaller than males and introduced gradually to minimize aggression between potential mates (35). Large scale captive breeding of C. porosus faces several difficulties such as these, and none of the present 'farms' are fully self-sustaining (80).

REMARKS There has been a steep decline in total world trade volume of C. porosus skins during the 1970s, from 100,000 per year to 20,000 per year, with prices rising at the same time (33). However, demand for porosus hide continues and several commercial operations attempt to meet this, either through large-scale captive breeding (as at Samut Prakan) or through captive rearing, whereby hatchlings are taken from the wild and reared in captivity to a suitable size. There are several such rearing 'farms', in Irian Jaya, Sabah, and Sarawak for example, and there are plans for similar establishments in Australia, but the government-organized scheme in Papua New Guinea is the largest existing at present. In Papua New Guinea plans to simultaneously develop the crocodile skin industry and manage wild crocodile populations were supported by FAO-UNDP, and the Project 'Assistance to the Crocodile Skin Industrv' became operational in January 1977 (6). FAO involvement has now (1982) ended and the project is now run by the national government assisted by two UN volunteers (85). It was argued that since there is a very high mortality of hatchling crocodiles in the wild, a harvestable surplus existed that could be taken and reared to commercial size in captivity, without affecting the status of wild populations. Rearing stations are mainly village-based and owned by the local people and it was intended that rational management instead of indiscriminate hunting would be of long-term 
economic benefit. By the end of 1979 over 200 village crocodile-rearing stations were established (34). However only about $15 \%$ of the 'farms' have been rearing crocodiles satisfactorily, due to lack of expertise in animal husbandry, seasonal fluctuations in water, difficulty in obtaining crocodile food, and other factors (34). The PNG Government has attempted to avoid loss of interest at the village level, and reduce dealing in small skins, by buying and redistributing young crocodiles when farm stock was to be disposed of; between June-December 1979 about 5000 young were handled in this scheme, with villagers receiving more than double the price than for sale of equivalent skins (34). Thus for the first time it is now possible for villagers to earn more from a reduced harvest (79). The young are sold to the three large-scale commercial farms. It has been suggested that this buying scheme has increased hunting pressure on wild populations (11). It has also been argued (11) that the basic assumption, that there is a very high density-dependent hatchling mortality, may only apply to populations at the carrying capacity of the environment. Density-dependent mortality would be expected to be lower in populations already depleted by exploitation. On the Blyth River in northern Australia hatchling mortality is only $50 \%$ during one June-July twelve month period and greater losses appear to occur at the sub-adult stage (74). A further problem is that since most mortality in farm animals occurs at less than $10 \mathrm{~cm}$ (4") belly width, villagers are encouraged to collect larger stock, which are those that have already survived the phase of maximum natural mortality. The effect of the rearing programme on wild populations is as yet unknown, as is the maximum sustained yield (11). However, although the practical difficulties are irnmense, a monitoring scheme is now being developed. It should be noted that in PNG the land, including crocodiles, is owned by local people under traditional tenure (79). The relative success of the project may be considered not in terms of what might theoretically be done, but in relation to what can in practice be done and what was being done before the Project started (79).

This account is based partly on comments, criticisms, and other information received through the courtesy of M. Bolton, H.P.Bustard, D. nickinson, S.Kar, Md.A.R.Khan, J.Lang, J.Mackinnon, M.McCoy, H.Messel, G.J.W.W/ebb, R. Whitaker and others, including extensive material relating to $r$-porosus in Australia kindly supplied by 4 .Messel. The Compiler is most grateful to all these persons for their valuable assistance.

RE.FERENCES 1. Acharjyo, L.N. and Mishra, C.G. (in press). F.gg-laying and nest-guarding behaviour of Estuarine Crocodile (Crocodylus porosus) in captivity. To appear in, Indian Crocodiles conservation and research. Occasional Publications No.1. Central Crocodile Breeding and Management Training Institute, Hyderabad, India.

2. Allen, G.R. (1974). The marine crocodile, Crocodylus porosus from Ponape, Eastern Caroline Islands with notes on the food habits of crocodiles from the Palau Achipelago. Copeia 1974: 553.

3. Andau, P.M. (Office of Chief Game Warden, Sabah) (1981). In litt., 12 February.

4. Bain, J.R. and Humphrey, S.R. (1980). A profile of the endangered species of Thailand. Report No.4, Office of Ecological Services, Florida State Museum, Gainesville.

5. Blouch, R. (WWF Project-Meru Betiri (1981). In litt., 11 March, via J. Mackinnon.

6. Bolton, M. (1978). Crocodile farming in Papua New Guinea. Oryx 14(4): 365-369.

7. Bolton, M. (1981). In litt., 6 February.

8. Bullock, (President Malayan Nature Soc.) (Undated). In litt., 
to $F$. Wayne King, cited in ref. 31 .

9. Burbidge, A.A. and Messel, H. (1979). The status of the Salt-water Crocodile in the Glenelg, Prince Regent and Crd River Systems, Kimberley, Western Australia. Report No.34. Dept. of Fisheries and Wildlife, Western Australia.

10. Burbidge, A.A. (1981). In litt., 5 February.

11. Burgin, S. (1980). Crocodiles and crocodile conservation in Panua New Guinea. Background paper given 30 October at Conference on Traditional Conservation in Papua New Guinea: Implication for Today. Port Moresby, 27-31 October.

12. Bustard, H.R. and Choudhury, B.C. (1980). Parental care in the Saltwater Crocodile (Crocodylus porosus Schneider) and management implications. J. Bombay Nat. Hist. Soc. 77(1): 64-69.

13. Bustard, H.R. and Choudhury, B.C. (In press, 1981). Conservation future of the Saltwater Crocodile (Crocodylus porosus, Schneider) in India. J. Nat. Hist. Soc. Bombay (to appear in August 1980 issue).

14. Caughley, G. (1981). In litt., 8th January.

15. Choudhury, B.C. and Bustard, H.R. (1979). Predation on natural nests of the Saltwater Crocodile (Crocodylus porosus Schneider) on North Andaman Island with notes on the crocodile population. J. Bombay Nat. Hist. Soc. 76(2): $311-323$.

16. Daniel, J.C. (1980). For crocodiles ... an island of hope in a sea of extinction. Animal Kingdom Oct/Nov: 26-27.

17. Daniel, J.C., and Hussain, S.A. (1974). The record (?) Saltwater Crocodile (Crocodylus porosus, Schneider). J. Bombay Nat. Hist. Soc. 7I(2): 309-312.

18. Deranigyagala, P.F.P. (1939). The tetrapod reptiles of Ceylon. Vol. 1. Testudinates and Crocodilians. Colombo Museum, Ceylon.

19. Dickinson, D. $(1980,1981)$. In litt. 24 June (1980), 28 February (1981).

20. FAO (1974). India. A preliminary survey of the prospects of crocodile farming (based on the work of H.R. Bustard). FAO, Rome (FO: IND/71/033). Oct. 1974.

21. Farook, S.M.S. (1980). Proposed study on the crocodiles of Sri Lanka. Unpublished report.

22. Guggisberg, C.A.W. (1972). Crocodiles, their natural history, folklore and conservation. David and Charles, Newton Abbott. Pp. 1-104.

23. Hoffman, T.W. (1981). In litt., 5 March.

24. Honegger, R. (1979). Red Data Book, Vol.3: Amphibia and Reptilia. IUCN, Gland (third edition revised).

25. Honegger, R. (1981). In litt.

26. Jayal, N.D. (1980). Crocodile Conservation in India. Tigerpaper $7(4): 1-3$.

27. Jenkins, R.W.G. (1979). The status of endangered Australian reptiles. Chapter 16, pp. 169-176, in Tyler, M.J. (Ed.). The status of Endangered Australasian IVildlife. Royal zool. Soc. South Australia, Adelaide.

28. Jenkins, R.W.G. (1981). In litt., 11 March.

29. Kar, S. (1981). In litt., 1 April (draft Red Data Book account relating to $C$. porosus in India).

30. Khan, lid. A.R. $(1 \overline{980})$. Present status and distribution of Crocodiles and Gavial in Bangladesh. Paper presented at 5 th meeting of the IUCN/SSC Crocodile Specialist Group; 
August 1980, Gainesville, U.S.A.

31. King, F.W. (1973). External trade statistics for undressed crocodile skins from Malaysia-Singapore - a correction. Crocodiles, IUCN Publ. New Ser. Suppl. Pap. No.41. (Proceedings of the second working meeting of Crocodile Specialists, Zululand, 1973).

32. King, F.W., and Brazaitis, P. (1971). Species identification of commercial crocodilian skins. Zoologica (N.Y.). 56(2): 15-70.

33. King, F.W., Campbell, H.W., Messel, H. and Whitaker, R. (1979). Review of the status of the estuarine or saltwater crocodile, Crocodylus porosus. Unpublished report, $33 \mathrm{pp}$.

34. Kwapena, N., and Rolton, M. (1980). The National Crocodile Project in Papua New Guinea. Unpublished report pp. $1-7$.

35. Lang, J.W. (1980). Reproductive behaviors of New Guinea and Saltwater Crocodiles. Unpublished paper given at SSAR (Soc. for Study of Amphibians and Reptiles) symposium on reproductive biology and conservation of crocodilians; 7-9 August, Milwaukee, Wisconsin, U.S.A.

36. Lever, J. (1980). In litt., 10 June, to H.W. Campbell.

37. Mackinnon, J. (Project Ecologist, FAO Nat. Parks Development Project - Indonesia) (1981). In litt., 7 May.

38. Magnusson, W.E., Grigg, G.C. and Taylor, J.A. (1978). An aerial survey of potential nesting areas of the Saltwater Crocodile, Crocodylus porosus Schneider, on the nor th coast of Arnhem Land, Northern Australia. Aust. Wildl. Res. 5: 401-415.

39. McCoy, M. (1980). Reptiles of the Solomon Islands. Handbook No.7., Wau Ecology Institute, Papua New Guinea. Pp. 1-82.

40. McCoy, M. (1981). In litt., 25 March.

41. Messel, H. (1977). The crocodile programme in Northern Australia. Population surveys and numbers. Chapter 13, pp 207-236, in Messel, H., and Butler, S.T. (Eds), Australian Animais and their Environment. Shakespeare Head Press, Sydney.

42. Messel, H. (1981). In litt., 20 February. Revised Red Data Book account (based on C. porosus in Australia).

43. Messel, H., Vorlicek, G.C., Wells, A.S., and Green, W.J. $(1979,1980,1981)$. Surveys of tidal river systems in the Northern Territory of Australia and their crocodile populations. Pergamon Press Ltd., Oxford, England and Sydney, Australia. (A series of 17 Monographs).

44. Mitchell, A. (WWF Project - Siberut Nature Reserve) (1981). In litt., 3 March, via J. Mackinnon.

45. Mittermeier, R.A. (1979). In litt., 24 May, to F. Wayne King.

46. Montague, J.J. (1981). His "crop" is crocodiles. International Wildlife 11(2) (March/April): 21-28.

47. Neill, W.T. (197I). The last of the ruling reptiles. Colombia Univ. Press, New York. 486 pp.

48. Nowak, R.M. (1976). Wildlife of Indochina: tragedy or opportunity? Nat. Park \& Conserv. Mag. 50(6): 13-18.

49. Proud, K. (WWF Asst. Representative) (1981). In litt., 12 May.

50. Ross, C.A. (1981). Report on Smithsonian Institute/WWF Philippine Crocodile Project. WWF Project 1489.

51. Saharia, V.N.(Ed.). (1981). Crocodile Breeding Project. In 
Wildlife in India. Dept of Agriculture and Cooperation, Ministry of Agriculture, Crovernment of India. Pp. 146-164. (Chapter based on a report by Dr. H.R. Rustard).

52. Scriven, K. (1972). Conservation in West Malaysia. WWF Yearbook 1971-72: 275-281.

53. Shelford, R.W.C. (1916). A naturalist in Borneo. Fisher Unwin Ltd., London.

54. Smith M.A. (1931). The Fauna of British India including Ceylon and Burma. Reptilia and Amphibia. Vol. I. Loricata, Testudines. Taylor and Francis Ltd., London. (Reprinted 1973 by Ralph Curtis Books, Hollywood, Florida).

55. Taylor, J.A. (1979). The foods and feeding habits of subadult Crocodylus porosus Schneider in Northern Australia. Aust. Wildl. Res. 6: 347-359.

56. Webb, G.J.W. (1977). Habitat and nesting. Chapter 14, pp 239-284, in Messel, H., and Butler, S.T.(Eds). Australian Animals and their Environment. Shakespeare Head Press, Sydney.

57. Webb, G.J.W. (1977). Growth, movement, river distributions and general comments. Chapter 15, pp. 285-312 in Messel, H. and Butler, S.T. (Eds), Australian animals and their environment. Shakespeare Head Press, Sydney.

58. Webb, G.J.W. (1978). The status, conservation and management of world crocodilians, and an assessment of the potential for commercial exploitation of crocodiles in Australia. Unpublished report to the Aust. Nat. Parks and Wild. Service.

59. Webb, G.J.W. (1981). In litt., 5 January.

60. Webb, G.J.W., Messel, H., Crawford, J., and Yerbury, M.J. (1978). Growth rates of Crocodylus porosus (Reptilia: Crccodilia) from Arnhem Land, Northern Australia. Aust. iVildl. Res. 5: 385-399.

61. Webb, G.J.W., Messel, H. and Magnusson W. (1977). The nesting of Crocodylus porosus in Arhem Land, Northern Australia. Copeia (1977(2): 238-249.

62. Webb, G.J.W., and Messel, H. (1978). Movement and dispersal patterns of Crocodylus porosus in some rivers of Arnhem Land, Northern Australia. Aust. Wildl. Res. 5: 263-283.

63. Webb, G.J.W., Yerbury M. and Onions, V. (1978). A record of a Crocodylus porosus (Reptilia, Crocodylidae) attack. J. Herpetol. 12(2): 267-268.

64. Whitaker, R. and Daniel, J.C. (1978). The status of Asian crocodilians. Tigerpaper 5(4): 12-17.

65. Whitaker, R. (1979). A preliminary survey of the crocodile resource in the island provinces of P.N.G. Report under FAO Project PNG/74/029, Assistance to the Crocodile Skin Industry.

66. Whitaker, R. and Whitaker, Z. (1978). A preliminary survey of the Saltwater Crocodile (Crocodylus porosus) in the Andaman Islands. J. Bombay Nat. Hist. Soc. 75(1): 43-49.

67. Whitaker, R., and Whitaker, Z. (1979). Preliminary crocodile survey - Sri Lanka. J. Bombay Nat. Hist. Soc. $76(1): 66-85$.

68. Whitaker, R. (1980). Interim report on the status and biology of crocodiles in Papua New Guinea. Field Document No.1, FAO Project PNG/74/029, Assistance to the Crocodile Skin Industry. Wildlife Division (Dept. of Lands 
and Environment) and FAO, Port Moresby.

69. Wind, J. (Project Leader, WWF Project -Gn. Leuser) (1981). In litt., 5 March, via J. Mackinnon.

7D. Youngprapakorn, U., McNeeley, J.A., and Cronin, E.W. (1971). Captive breeding of crocodiles in Thailand. Pp. 98-101, in Crocodiles: Proceedings of the First Working meeting of crocodile specialists. IUCN Publications, New Series, Supplementary Paper No.32.

71. Youngprapakorn, U. (undated). Illustrated publicity brochure. Samut Prakan Crocodile Farm. Pp. 1-14.

72. Robb, R. (1980). New Zealand Amphibians and Reptiles in colour. Collins, Aukland.

73. Bustard, H.R. and Kar, S.K. (1980). Defence of the nest against man by Saltwater Crocodile (Crocodylus porosus Schnieder). J. Rombay. Nat. Hist. Soc. 77(3): 514-515.

74. Messel, H. (1981) In litt., 5 August. (Comments on first Ped Data Book draft on C. porosus).

75. Nessel, H., Vorlicek, G.C., Wells A.C., and Green, W.J. (1981). The status and dynamics of Crocodylus porosus populations in the tidal waterways of Northern Australia. Chapter 18, pp. 78-103, in Banks, C.B., and Martin, A.A. (Eds) Proceedings of the Melbourne Herpetological Symposium Zoological Roard of Australia, The Royal Melbourne Zoological Gardens.

76. Messel, H., et al (1981). Addendum to monograph 1 of reference 43.

77. Webb, G.J.W. (1981). In litt., 13 August (Comments on a first Red Data Book Draft on C. porosus).

78. Jenkins, R.W.G. (1980). Crocodile comeback: problem or profit? Australian Fisheries reprint No. 70, (Australian Fisheries $39(4))$.

79. Bolton, M. (1981). In litt., 26 August (Comments on a first revised Red Data Book draft on C. porosus ).

80. Lang, J.W. (1981). In litt., 8 September (Comments on a first revised RDB draft on C. porosus).

81. Proud, K. (1982). In litt., 6 February.

82. Dickinson, D. (1981). Marine crocodiles (Crocodylus porosus) in Vanuatu. Naika (Journal of the Vanuatu Natural Science Society), No. $\overline{3, p .5}$.

83. Lever, J. (1982). In litt., 16 February (Comments on a first revised RDB draft on $C$. porosus).

84. Whitaker, R. (1981). In litt., 10 August (Comments on a first revised RDB draft on C. porosus).

85. Rolton, M. (1982). In litt., $\overline{25}$ February.

86. Lever, J. (1980). Crocodile conservation and industry development in Irian Jaya. Report on a FAO-sponsored consultancy prepared for Directorate of Nature Conservation, Directorate General of Forestry; Bogor, Indonesia.

87. Watling, П. (1981). In litt., via J.MacKinnon.

88. Wycherley, P. (1971). External trade statistics of West Malaysia for undressed crocodile skins. Pp.51-53 in Crocodiles: Proceedings of the first working meeting of crocodile specialists. IUCN Publications, New Series, Supplementary Paper No. 32.

89. Pooley, A.C. and Gans, C. (1976). The Nile Crocodile. Scientific American 234(4): 114-124.

90. Messel, H. (1982). In litt., 15 January (Comments on second 
revised RDB draft on C. porosus).

91. Bustard, H.R. and Kar, S.K. (1980). Territoriality in immature captive Saltwater Crocodiles (Crocodylus porosus Schneider). J.Bombay Nat.Hist.Soc. 77(1): $148-149$.

92. Jenkins, R.W.G. (1981). In litt., 26 August (Comments on first revised RDB draft on C. porosus).

93. Messel, $H$. and King, F.W. (1982). In litt., 18 March (comments on preliminary draft of RDB account for $\underline{C}$. porosus).

94. Ross, C.A. (1982). Final Report on S.I./WWF Project No. 1489. Philippine Crocodile.

95. Pernetta, J.C. (1982). In litt., 24 March (comments on preliminary draft of RDB account for C. porosus).

96. Bolton, M. (1982). In litt., April. 
SUMMARY A small to moderate size species, endemic to Cuba, where it has an extremely restricted distribution in Zapata and Lanier Swamps. A mainly freshwater species, nesting in holes or mounds, few ecological data available. Most individuals are now held in large enclosures, where the species is mixed with Crocodylus acutus, and rhombifer is strongly threatened by hybridization with acutus. The Lanier Swamp population may be threatened by establishment of the introduced Caiman crocodilus fuscus. Pure-bred rhombifer are now out-numbered by hybrids. Most of the remaining pure rhombifer have now been transferred to a separate enclosure. Management of this enclosure should be improved and the possibility of rehabilitating the species in the wild investigated. Protected by law in Cuba. Listed on CITES Appendix I. Captive breeding has occurred.

DISTRIBUTION Endemic to Cuba. Extremely restricted in distribution, now occurring only in the Zapata Swamp in Matanzas Province on mainland Cuba, and Lanier Swamp on Isla de Pinos. Formerly more widespread on Cuba.

POPULATION About 20 years ago, when threatened by agricultural development, most individuals of $C$. rhombifer were translocated (following Government decree) to enclosed 'corrales' at the Laguna del Tesoro in Zapata Swamp (6). A second species, the more widespread Central American C. acutus, was mixed indiscriminately with rhombifer in the same enclosures. These enclosures now hold the largest rhombifer population; there is no current estimate of total numbers in the enclosures but there are not more than 1000 adult males (7). The remnant Lanier Swamp population is small, no numerical estimates available (7).

HABITAT AND ECOLOGY A small to moderate size species, mean adult length is $2-2.5 \mathrm{~m}$, rarely to $3.5 \mathrm{~m}$, former maximum probably $5 \mathrm{~m}$ (1). Inhabits freshwater swamps $(1,5)$, extending to brackish water in places $(7)$. Feeds largely on fish, turtles and small mammals (1). Eggs, around $78 \mathrm{~mm} \times 52 \mathrm{~mm}$, may be laid in a hole-nest or in sand or soil mounds $(1,2)$. Little further information available (5).

THREATS TO SURVIVAL Formerly threatened by hide-hunting. Plans to drain Zapata Swamp, that led to the translocation operation (see above), were abandoned. The primary current threat is extensive hybridization, within the Zapata enclosures, with the related species $\mathrm{C}$. acutus. The genetic integrity of rhombifer is severely threatened since there are now many more hybrids ('mixturados') than pure rhombifer (7). The Lanier Swamp population around Siguanea Bay is threatened by the establishment of the introduced Caiman crocodilus fuscus (7). The latter may not out-compete adult rhombifer, but it poses a threat to immatures, and young rhombifer have been found in the gut of adult Caiman crocodilus (7). A further threat arises from artificial incubation of eggs, with over $85 \%$ mortality (7). No further details on incubation programme. Animals have still been killed within the enclosures $(6,7)$.

CONSERVATION MEASURES TAKEN By Resolution No.21-79, the Government has forbidden hunting at any time in certain areas (5), including the Zapata and Lanier Swamps (6). 
Most remaining pure rhombifer were recently transferred to another enclosure, at Tasajera in the southwest of Zapata, in Habana Province $(6,7)$. This could be a marked improvement but the new site has no scientific management (6), and general conditions are very bad (7).

Listed on Appendix 1 of the Convention on International Trade in Endangered Species of Wild Fauna and Flora (CITES). Appendix I listing requires that trade in the taxon and its products is subject to strict regulation by ratifying states and international trade for primarily commercial purposes is prohibited. Listed as Endangered under the U.S. Endangered Species Act, 1973.

CONSERVATION MEASURES PROPOSED Conditions at the new Tasajera enclosure for pure bred rhombifer should be improved. The feasibility of re-establishing adequate wild populations of pure rhombifer in the Zapata Swamp, with strict enforcement of existing protective legislation, should be investigated. More data are required on the Lanier Swamp population, this population appears to offer the only opportunity to investigate the ecology of rhombifer in natural conditions.

CAPTIVE BREEDING Three animals were bred in 1978 at Buena Park Zoo, U.S.A., at least one of these was bred in the second captive generation (no further details) (4). In 1975 there were a known total of 52 individuals held between 22 different zoos (3). A breeding project is being established at the National Zoological Park, Washington D.C., and breeding has just begun in a group of one male and three females at the New York Zoological Park (8).

REMARKS A little-known species, endemic to Cuba, one of only four Crocodylus species in the New World.

This account is based primarily on information received through the courtesy of Dr. L.S. Varona (member IUCN/SSC Crocodile Specialist Group).

REFERENCES 1. Brazaitis,, P. (1973). The identification of living crocodilians. Zoologica (N.Y.) 58(4): 59-101.

2. Campbell, H.W. (1972). Ecological or phylogenetic interpretations of crocodilian nesting habits. Nature. 238(5364): 404-405.

3. Honegger, R.E. (1978). Stock and captive breeding, 1972 (1973) - 1975 (1977). Report to fourth IUCN/SSC Crocodile Specialist Group Meeting, Madras, 1978.

4. Olney, P.J.S. (Ed.) (1980). International Zoo Yearbook. Vol.20. Zoological Society of London.

5. Varona, L.S. (1966). Notas sobre los Crocodilidos de Cuba y descripcion de une nueva especie del Pleistoceno. Poeyana Ser A., No. 16. Pp. 1-34.

6. Varona, L.S. (1980). Protection in Cuba. Oryx 15(3): 282-284.

7. Varona, L.S. (1981). In litt., 2 March.

8. Brazaitis, P. (1981). In litt., 29 June. 
SUMMARY An endangered species, inhabiting lowland freshwater lakes and swamps, formerly present in Vietnam, Kampuchea, Laos (?) and Thailand, also Kalimantan, Java and possibly Sumatra. Now apparently extinct through much of the range, although many areas require investigation. The last significant known population comprised less than 200 animals at Bung Boraphet (Thailand), but there have been no recent sightings. Depleted by intensive hide-hunting and habitat loss. In captivity, maturity is attained at 10-12 years, 20-48 eggs are laid in a mound nest. Nominally protected by legislation in Indonesia. Hunting is not allowed at Bung Boraphet. Listed on CITES Appendix 1. Status requires clarification. Captive breeding, primarily for skins, occurs regularly on a large scale at Samut Prakan crocodile farm, near Bangkok. Hybridization is encouraged here between $C$. siamensis and $C$. porosus. Hybrid offspring are commercially superior, but this practice threatens the genetic integrity of the vital siamensis stock, maintainence of a pure-bred population should be encouraged.

DISTRIBUTION A southeast Asian species, the range formerly extended from Vietnam, Kampuchea, Thailand, possibly southern Laos, and southward through parts of the Malay Peninsula (although apparently not to West Malaysia) $(2,6)$; also recorded in Indonesia from Java (3) and Kalimantan (6).

POPULATION The species appears extinct in the wild almost throughout its range (I). The former extent of its distribution is not known in detail, particularly in Indonesia, where siamensis has always been rare $(3,4)$. There is no recent information from several parts of the former range, Kampuchea and Vietnam, for example.

Kampuchea No recent information. Reported plentiful during the early 1900 s in several large swamps in southern parts (10).

Thailand The range in the recent past has been centred on Thailand, where populations were depleted by hide-hunting in the 1940s (4). Only one population has been known recently, comprising less than 200 individuals at Bung Boraphet. This population is declining and there have been no recent sightings (1). Some animals may survive in Changwat Loei (northeast Thailand) (1). As far back as 1919 the species was reported to have been heavily hunted by Europeans, although then still fairly common in central Thailand (10), at this time also reported (in the peninsula) as not uncommon in swamps near Chumporn, also found at the north end of Talé Sap near Singgora (Songkhla), and common in the Patani River. Although on the verge of total extinction in the wild, a very large captive population, numbering around 16,000 individuals in the late 1970's, is held at the Samut Prakan crocodile farm in Thailand (9) (see Captive Breeding section below).

Indonesia C. siamensis may still occur in Kalimantan (or Sumatra ? (5)) as occasional specimens are found in zoos or farms in Indonesia (5), probably extinct in Java (5).

HABITAT AND ECOLOGY A moderate size species, reaching $3 \mathrm{~m}$ or rarely $4 \mathrm{~m}$ in length (2), inhabiting lowland freshwater lakes, swamps and rivers. Few data 
available on ecology of wild populations. Said to feed mainly on fishes $(2,10)$. In Thailand the species was said to prefer swamps off the main river course, and slow-moving streams with muddy banks (10). One group of crocodiles inhabited a number of pits excavated during construction of a railway embankment (where they became accustomed to the passing daily train services) (10). Difficult to observe during floods after the rainy season, when the crocodiles appeared to disperse widely (10). Reported unaggressive, and to present no danger to man, at least when an ample supply of fish was available (10). In the Samut Prakan captive population (9), mating occurs in December-March, most females lay their eggs in April-May. A mound nest is formed from vegetable debris provided, the clutch of $20-48$ eggs, $75-80 \mathrm{~mm} \times 50 \mathrm{~mm}$ (10), hatches in 67-68 days. Hatching in this period is probably at high temperature, near the upper tolerable limit of around $35^{\circ} \mathrm{C}$, incuiation at $31-32^{\circ} \mathrm{C}$ is $80-90$ days $(11)$. The female guards the nest during incubation, and when the young vocalize within the egg immediately prior to hatching, the female aids emergence by uncovering the eggs and placing them atop the nest. Temperature and humidity are critical to hatching success. In captive conditions, sexual maturity is reached at $10-12$ years (8).

THREATS TO SURVIVAL Critical depletion of C. siamensis is attributed to unrestricted hide-hunting, aggravated in some cases by habitat destruction $(1,4)$. The species has always been rare in the Indonesian portion of the range $(3,4)$. The central siamensis populations, in Thailand, were depleted by hunting in the 1940's (4) and wetlands at the last known locality (Bung Boraphet) have been reduced by encroachment of rice cultivation (1). The original 25,000 ha area is now reduced to 5,000 ha (1).

CONSERVATION MEASURES TAKEN Nominally protected by legislation in Indonesia (5). In Thailand, Bung Boraphet is a non-hunting area (1).

Listed on Appendix 1 of the Convention on International Trade in Endangered Species of Wild Fauna and Flora (CITES). Appendix I listing requires that trade in the taxon and its products is subject to strict regulation by ratifying states, and international trade for primarily commercial purposes is prohibited.

CONSERVATION MEASURES PROPOSED The Bung Boraphet site should be thoroughly surveyed to determine the current status of $C$. siamensis there. If a viable population remains, the species and the site shouid be strictly protected (this is also the only known locality of the endangered White-eyed River Martin Pseudochelidon sirintarae (1)). Further habitat loss should be curtailed. The status and distribution in Indonesia, Kampuchea, Laos and Vietnam requires clarification. Hybridization between $\mathrm{C}$. siamensis and $\mathrm{C}$. porosus at the Samut Prakan Crocodile farm (see below) should be reduced, añd an adequate stock of pure-bred siamensis maintained.

CAPTIVE BREEDING The Samut Prakan crocodile farm, near Bangkok, Thailand, holds about 16,000 individuals of $\mathrm{C}$. siamensis, mostly hatchlings and immatures (9). This species forms the main breeding stock at the farm, and breeding occurs regularly on a significant scale. Nesting occurs in $4 \times 4 \mathrm{~m}$ walled nesting stalls adjacent to the breeding ponds. Humidity and temperature of the nest are regularly monitored and artificially adjusted as appropriate. Hatching success is up to $60 \%$. Individuals of a given age class are kept together. The farm was started primarily as a commercial project, and crocodiles other than the breeding stock are killed for their skin at around three years of age. Hybridization between $\underline{C}$. siamensis and $C$. porosus (so-called 'Crocodylus siamenrosus' (9)) is encouragè since hybrid individuals grow faster, survive better, produce larger clutches and their skin is tougher (9). This hybridization is threatening the genetic integrity of what constitutes by far the largest existing siamensis population, and measures are desirable to ensure survival of an adequate nucleus 
of pure siamensis. Hybrid offspring of ten show highly irregular belly scutellation, all true C. siamensis hides are readily identifiable on the basis of cloacal-subcaudal scalation (11). One offspring survived from a 1978 breeding at Miami C.P. (7). Approximately 24 individuals are held in U.S. zoos and aquaria, around half this number in Europe (sources in ref. 1).

REMARKS This species, while existing in good numbers in captivity, had become critically depleted in the wild before a significant body of ecological data had been gathered.

REFERENCES 1. Bain, J.R. and Humphrey, S.R. (1980). A profile of the endangered species of Thailand. Report No. 4, Office of Ecological Services. Florida State Museum, Gainesville.

2. Brazaitis, P. (1973). The identification of living crocodilians. Zoologica (N.Y.) 58(4): 59-101.

3. De Rooij, N. (1915). The reptiles of the Indo-Australian archipelago. I. Lacertilia, Chelonia, Emydosauria. E.J. Brill, Leiden. (Reprinted 1970, A. Asher \& Co. N.V., Vaals).

4. King, F.W. and Brazaitis, P. (1971). Species identification of commercial crocodilian skins. Zoologica (N.Y.) 56(2): 15-70.

5. Mackinnon, J. (Project Ecologist, F.A.O. National Parks Development Project - Indonesia) (1981). In litt., 7 May.

6. Neill, W.T. (1971). Last of the ruling reptiles. Colombia University Press, New York.

7. Olney, P.J.S. (Ed.) (1980). International Zoo Yearbook. Vol.20. Zoological Society of London.

8. Youngprapakorn, U., McNeely, J.A., and Cronin, E.W. (1971). Captive breeding of crocodiles in Thailand. Pp. 98-101, in Crocodiles: Proceedings of the First Working meeting of crocodile specialists. IUCN Publications, New Series, Supplementary Paper No.32.

9. Youngprapakorn, U. (undated). Illustrated publicity brochure. Samut Prakan Crocodile Farm. Pp.1-14.

10. Smith, M.A. (1919). Crocodilus siamensis. J. Nat. Hist. Soc. Siam. 3(3): 217-221.

11. Brazaitis, P. (1981). In litt., 29 June.

12. Brazaitis, P. (1973). The identification of Crocodylus siamensis Schneider. Zoologica N.Y. Spring, $\overline{1973 . ~ P p . ~}$ 43-45. 

Osteolaemus tetraspis

Order CROCODYLIA

Family CROCODYLIDAE

SUMMARY A very small species occurring in swamps and slow-moving streams in the tropical rain forest zone of West and Central Africa, extends in places into more arid savanna regions. Timid, slow-moving and rather nocturnal. Appears to have declined over much of the range but adequate populations may remain locally. Few recent data. Does not bask for long periods, excavates burrows near water. A mound-nesting species, clutch size (11-17 eggs) is small. Threatened by hide-hunting and habitat destruction. Used locally as a food source. Has been exploited by the live animal trade. Nominally protected in parts of the range, generally ineffectively. Listed on CITES Appendix 1. A little-known species, basic data on distribution, population status and biology are urgently required. Has bred in captivity. Populations in northern Zaire are sometimes regarded as a full species.

DISTRIBUTION See taxonomic note under Remarks, below. Fairly widespread in forest regions of west and central Africa from Senegal in the west to Zaire in the east. Present in Angola (Cabinda enclave only), Benin, Cameroon, Central African Republic, Congo, Gabon, Gambia, Ghana, Guinea, Ivory Coast, Liberia, Nigeria, Senegal, Sierra Leone, Togo, Upper Volta and Zaire $(2,10,14,21)$. A single individual has been recorded in Uganda near the Hoindagi River southeast of Lake George $(12,19)$.

POPULATION Status poorly known. Appears to have declined generally and is regarded as rare in many countries in the range, adequate populations may persist in some localities. The species has been reported as nearing extinction $(13,14)$. Much of the available information has been gathered by Pooley (14): Angola, rare or indeterminate; Benin, considered common in higher regions in $195 \overline{9, \text { no recent }}$ data; Cameroon, population status unknown, exploited for food (3); Central African Republic, severely reduced but apparently still plentiful in the arid Birao region in the extreme north near the border with Chad and Sudan; Congo, probably secure in the remote northern tropical forests near the Central African Republic border; Gabon, rare, supposedly present in mangrove swamp behind Libreville airport (I), considered plentiful a decade ago in swamps at Woleu N'tem and Ogooué Ividno but no recent data from these sites; Gambia, endangered, restricted to the western division; Ghana, few recent data, may be moderately plentiful in high forest streams, has occurred in Lake Volta, sometimes found in polluted gutters on the outskirts of towns; Guinea, no data; Ivory Coast, rare; Liberia, status uncertain, considered endangered but said to be common in mangroves near Monrovia; Nigeria, few recent data, a decade ago reported rare in Western State, commoner in mid-West and River areas, in the Calabar region the species is still quite readily found where the habitat remains intact (23); Senegal, common in the Parc National du Niokolo Koba on the River Gambia, scarce or status uncertain elsewhere; Sierra Leone, rarely seen; Togo, Upper Volta and Zaire, no data.

It is clear that there is very little information available on the detailed distribution or population status of Osteolaemus tetraspis, furthermore, although the species appears to have declined through much of the range this decline is not adequately documented in any country. Base-line surveys are required, particularly in areas now reported to hold secure or adequate populations, in order 
HABITAT AND ECOLOGY A very small crocodilian, adults rarely reach $2 \mathrm{~m}$ in length, average size is $1 \mathrm{~m}$ to $1.5 \mathrm{~m}$ (2). Generally nocturnal and thus seldom seen $(5,22)$. Rather solitary and timid $(9,20)$ and extremely docile (22). Typically associated with the tropical rain forest zone of West and Central Africa, where it inhabits small slow-moving forest streams, ponds, swamps and sometimes river shallows $(5,9,16,20)$, but in Senegal extends in gallery forest into more arid savanna regions (20), and similarly is found in arid parts of the northern Central African Empire (18). A population in Calabar (southeast Nigeria) occurs in Oil Palm Elaeis swamp in riverine lowlands (23). Major watercourses are avoided (20). Not a strictly aquatic species (20), although in some areas all individuals seen were in water (24). Said to inhabit holes excavated in stream banks $(5,16,20)$. When pursued may taken refuge in holes or crevices among submerged tree roots (24). Unlike many crocodilians, including the other two African species, Osteolaemus does not bask exposed to the sun for long periods (20), and during the hottest hours of the day may be found among the lower branches of trees, in the shade, with the mouth open (16). Food consists of small animals, especially anurans and fishes, also crabs $(9,12,16,20)$. The nest is a mound of vegetable debris, about $1.5 \mathrm{~m}$ across $(9,20)$. Captive specimens have laid clutches of 11-17 eggs in May and June, eggs c $70 \mathrm{~mm} \times 45 \mathrm{~mm}(7,10)$. Clutch size is markedly smaller than in most other crocodilians. Reproductive biology in the wild appears to be little known, as are most aspects of the biology of this species. It is suggested that the hatchlings group together after emergence and may be guarded by the mother (25).

THREATS TO SURVIVAL Hide hunting is cited as a cause of decline in most parts of the range $(8,14)$. Reports indicate that the hide industry in Africa is concentrating on Osteolaemus and Crocodylus cataphractus following the severe decline of $\mathrm{C}$. niloticus (15). The species is also used locally as food (in Benin, Cameroon, Ghana and Nigeria for example) and is affected by habitat destruction (in Gambia, Ghana, Liberia and Nigeria) (14). In Nigeria, including the southeast, habitat modification is seen as the major potential threat (23). There appears to be little evidence here of large-scale hide trade, although stuffed crocodiles, apparently including this species, can still be seen among luggage at Lagos airport (24). Has also been exploited for the live animal trade $(8,10)$. Probably the most inoffensive and slow-moving of all crocodilians, and thus easily killed or captured (22).

CONSERVATION MEASURES TAKEN Skin export and hunting are prohibited since 1969 in Angola by Decree No.14539; protected within National Parks in Cameroon and Congo; nominally protected in Gabon but apparently with poor enforcement; protected in Gambia since February 1977; protected in Ghana; in Ivory Coast since 1970; not protected in Liberia; protected within National Parks in Upper Volta; export prohibited in Zaire. No information from other countries in the range. Present in National Parks or reserves in Cameroon, Congo, Gabon, Senegal (notably the Parc National du Niokolo Koba on the River Gambia), Sierra Leone and Upper Volta (14).

Listed on Appendix 1 of the Convention on International Trade in Endangered Species of Wild Fauna and Flora (CITES). Appendix I listing requires that trade in the taxon and its products is subject to strict regulation by ratifying states and international trade for primarily commercial purposes is prohibited. France has entered a reservation to Appendix I listing.

CONSERVATION MEASURES PROPOSED Existing populations, especially those where adequate numbers are maintained, should be more effectively protected and managed where feasible. Base-line data on population levels are required to 
allow monitoring of future changes. This species has been widely exploited by the hide and live animal trade before any substantial biological data have been gathered on wild populations. Such information is urgently required to assist in design of mangement plans, the tropical forest in northern Congo may provide suitable study sites.

CAPTIVE BREEDING Has bred in zoos at Kuala Lumpur, Tel Aviv University, Tokyo, and Fort Worth, Memphis and Seattle in USA (11). Breeding has occurred at Memphis Zoo each year from 1975 to 1978,11 eggs in the first year, then 17, $16,17(7,11)$. There are plans to transfer Osteolaemus captive bred at Fort Worth back to protected areas in the areas of origin (7). In $1969(6)$ there were 10 males, 8 females and 122 of unknown sex distributed among 59 zoos.

REMARKS The form occurring in northern streams of the River Congo system of northeast Zaire was originally described as a new genus and species Osteoblepharon osborni (17), and differs from the form in West Africa in lacking the highly elevated nasal region, in nuchal scalation, in colouration of the palatal region (2), and in certain features of cranial osteology. The genus Osteoblepharon is no longer recognised and these eastern populations are usually regarded as differing only at subspecific level (Osteolaemus t. osborni) from the western populations (Osteolaemus t. tetraspis) $(2,4,21)$. However, the two population groups are sometimes treāted as full species. It is necessary to study more material from intermediate areas, for example, Congo and the Central African Republic.

It appears that Osteolaemus, because of its small size, nocturnal habits and relatively inaccessible habitat, has not suffered the intensity of exploitation that has affected Crocodylus niloticus. There are large osteoderms in both dorsal and ventral scales (8), and thus Osteolaemus skins do not yield the highest quality leather. Because of the small size of animals utilized in Cameroon and Gabon hides included both dorsal and ventral skin (and had been skinned with a mid-ventral slit instead of mid-dorsal) (1).

REFERENCES 1. Abercrombie, C.L. (1978). Notes on West African crocodilians (Reptilia, Crocodilia). J. Herpetol. 12(2): 260-262.

2. Brazaitis, P. (1973). The identification of living crocodilians Zoologica (NY) 58(4): 59-101.

3. Brazaitis, P. (1981). In litt., 25 May.

4. Fuchs, K., Mertens, R. and Wermuth, H. (1974). Zum status von Crocodylus cataphractus und Osteolaemus tetraspis. Stuttgarter Beitr. Z. Naturk. Ser. A. No.266: 1-8.

5. Guggisberg, C.A.W. (1972). Crocodiles, their natural history, folklore and conservation. David and Charles, Newton Abbot.

6. Honegger, R. (1971). Zoo breeding and crocodile bank. In, Crocodiles (Proc. First Working Meeting of Crocodile Specialists). IUCN Publ. New Ser. Suppl. Paper. No. 32: 86-97.

7. Honegger, R. (1978). Stocks and captive breeding, 1972 (1973)-1975(1977). Unpublished paper presented at fourth working meeting of Crocodile Specialists, Madras, Feb. 1978.

8. King, F.W. and Brazaitis, P. (1971). Species identification of commercial crocodilian skins. Zoologica (NY) 56(2): $115-70$.

9. Lang, H. (1919). Notes published in ref. 17.

10. Neill, W.T. (1971). The last of the ruling reptiles. Colombia Univ. Press, New York. 486 pp. 
11. Olney, P.J.S. (Ed.) (1980). International Zoo Yearbook Vol. 20. Zoological Society of London.

12. Pitman, C.R.S. (1952). Pigmy crocodiles in Uganda. The Uganda Journal 16(2): 121-124.

13. Pooley, A.C. (1971). Pers. comm., cited in ref. 8.

14. Pooley, A.C. (1980). The status of crocodiles in Africa 1980. Unpublished paper presented at Fifth Working Meeting of IUCN/SSC Crocodile Specialists Group, Gainesville, 12-16 Aug. 1980.

15. Pooley, A.C. (1980). The decline of crocodiles in Africa. Traffic (Int.) Bull. 11 (9\&10): 93-94.

16. Rodhain, J. (1926). Les petits crocodiles du District des Bangala. Rev, Zool. Africaine (Tervueren). 14(2): 21-22.

17. Schmidt, K.P. (1919). Contributions to the herpetology of the Belgian Congo based on the collection of the American Congo Expedition, 1909-1915. Bull. Am. Mus. Nat. Hist. 39(20): 385-624.

18. Spinage, C.A. (1980). In litt., cited in ref. 14.

19. Temple Perkins, E.A. (1951). The first finding of a live pigmy crocodile in Uganda. The Uganda Journal 15(2): 182-186.

20. Villiers, A. (1958). Tortues et crocodiles de l'Afrique noire française. Initiations Africaines 15: 1-354. Inst. Français D'Afrique Noire, Dakar.

21. Wermuth, $H$. and Mertens, R. (1977). Testudines, Crocodylia, Rhynchocephalia. Das Tierreich 100: 1-174. Berlin, Walter de Gruyter.

22. Pooley, T. (1981). In litt., 10 August.

23. Reid, J.C. (Univ. of Calabar). (1981). Pers. comm., 21 August.

24. Reid, J.C. (1981). In litt., 30 August.

25. Cansdale, G.S. (1955). Reptiles of West Africa. (not seen, cited in ref. 5, p. 128). 
Tomistoma schlegelii (S. Müller 1838)

SUMMARY A unique, distinctive, and little-known species, occurring in the Malay Peninsula (possibly still extending into southern Thailand) and the islands of Sumatra and Borneo. No precise status data available, but apparently severely depleted in much of its range, moderate populations may remain in parts of Sumatra and Kalimantan. A moderately large, slender-snouted, fish-eating species inhabiting freshwater rivers, swamps and lakes. Threatened primarily by over-exploitation for hides, also habitat modification. Nominally protected by legislation in much of Malaysia and in Indonesia. Present in reserves in Indonesia and Malaysia. Listed on CITES Appendix I. Numerous individuals occur in captivity. Further data are required on ecology, status and distribution.

DISTRIBUTION Restricted to the Sundaland region; the known former range extends from extreme south Thailand, through peninsular Malaysia to the islands of Borneo (Sabah and Sarawak in East Malaysia, Kalimantan in Indonesia) and Sumatra $(3,4)$.

POPULATION Little precise information available, but populations appear to be extremely depleted through much of the range $(3,5,6,9,10,16,19,20)$. Moderate populations may remain only in a few rivers of east Sumatra and south Kalimantan (7).

Indonesia Said in 1915 (4) to be "not rare" in rivers of Sumatra, and reported in $\overline{1981(7)}$ as still "locally common" in some rivers of east Sumatra and south Kalimantan. Also reported to have a limited distribution and to be decreasing in numbers $(16,19)$. In Indonesia $T$. schlegelii is reported from Leuser National Park and the Sei Lepan River in northwest Sumatra, also in the Berbak Reserve (Jambi Province) and perhaps the Way Kambas Reserve (Lampung Prov.), in eastern Sumatra (12). Populations recently confirmed $(16,19)$ in south Sumatra, in the Lalan, Kuran, and Bahar Rivers, and in swampy areas of the Medak and Merang Rivers. Reported from Tanjung Puting Reserve (7) and the Beran River near Tanjung Redeb (10), as well as several other localities $(4,10)$ in Kalimantan. Recently reported from the Marisa River in northern Sulawesi (Celebes) (10), occurrence here is also said to be possible but unconfirmed (7).

Malaysia Very rare in Malaysia $(9,20)$. Said to be never abundant in peninsular Malaysia, and no longer seen on the Tasek Bera where once readily encountered (14). Main distribution in peninsular Malaysia is reputed to be the Pahang River system, draining to the east coast (20). The Tasek Bera swamps are confluent with this system $(20)$. One specimen of $5-6$ feet in length $(1.5-1.8 \mathrm{~m})$ was caught in the late 1970 s by fishermen in the Sungai Dusun Game Reserve (on the Selangor-Perak border), in a canal connected to the Bernam River draining to the west coast (20). Individual records exist throughout Sarawak, but the species exists in extremely low numbers and is considered endangered (8). The only surviving population may be in Loagan Bunut (Sarawak's only lake) (8). At the turn of the century reported to be very rare in Sarawak, except in the Sadong River (15). Distribution poorly-known in Sabah, becoming rare (1). 
Thailand Possibly recently extinct $(2,9)$. If still surviving the Thai population probably numbers fewer than 20 individuals (2).

HABITAT AND ECOLOGY A moderately large, extremely slender-snouted crocodilian, reaching $5 \mathrm{~m}$ in length, average length $3.5-4 \mathrm{~m}$ (3). Inhabits freshwater rivers, swamps and lakes. In Tomistoma habitat along the Lalan River in Sumatra, dominant vegetation includes Susum malayanum, Pandanus helicopus, Baring tomia racemosa and Gluta rengas (16). Feeds on a variety of prey, chiefly vertebrates (16), mainly fish (4,19).

Sexual maturity in females is attained at 4.5-6 years, length $2.5-3 \mathrm{~m}$ (16). A mound-nesting species. Nests are typically located in the shade of large trees, close to a river. Nest temperature c $28-33^{\circ} \mathrm{C}(16)$. One nest reported in peninsular Malaysia (13) was on a small bank of high ground by a narrow stream, one mile from the Selangor River, surrounded by swamp. The nest comprised a heap of dead leaves about $60 \mathrm{~cm}$ high. Eggs are elliptical, approximately $64 \mathrm{~mm}$ by $97-120 \mathrm{~mm}(3,13)$. Clutch size is $20-60$ eggs $(16)$. Civets, lizards and wild pigs are common nest predators (19). Incubation period 2.5-3 months, eggs are laid in the dry season to hatch in the rainy season (16), this may assist hatchlings to reach the water (19). The hatchlings emerge by themselves (ie. apparently without the parental assistance seen in many other crocodilians) and immediately make their way to water (19). There is said to be an extremely high mortality among hatchlings (16). In captivity, known to excavate tunnels in which much time is spent (10).

THREATS TO SURVIVAL Threatened primarily by over-exploitation for hides $(5,6)$. The belly skin is said to lack osteoderms $(6)$ and be in demand for leather production. However, it has been reported (11) that personnel in the skin industry in Kuala Lumpur and Singapore suggest that Tomistoma hide does have osteoderms in the belly skin and is not favoured by the industry; this requires confirmation. Capture of young for rearing, increased motorized water transport, timber extraction, extension of rice cultivation and human settlement are also reported to have caused decline in Tomistoma populations (16). Timber extraction, along the Lalan River for example, leads to water pollution by wood preserving material and destruction of waterside plants by logs floating downstream, as well as direct habitat modification (19). In Indonesia, capture of young for rearing to commercial size has caused severe depletion (19). This practice is very prevalent (19) at Palembang, Medan, Pontianak, Balikpapan and Samarinda. At Palembang the young are captured in the Lalan River (19). Hides used in trade must reach 12 inches $(30.5 \mathrm{~cm}$ ) belly width, this corresponds to $1.5 \mathrm{~m}$ body length (19). The species is sometimes found in crocodile-rearing pens at Kuching, Sibu and Miri in Sarawak (17).

CONSERVATION MEASURES TAKEN Nominally protected by legislation in Indonesia (Decree 327/Kpts/Um/5/1978) and parts of Malaysia, including Selangor, Negri Sembilan and Malacca (5) in West Malaysia, also Sabah (1) but not Sarawak, in East Malaysia. Exists in certain Reserves in Indonesia (see Population), and is said to persist in Taman Negara National Park in West Malaysia (5).

Listed on Appendix I of the Convention on International Trade in Endangered Species of Wild Fauna and Flora (CITES). Appendix I listing requires that trade in the taxon and its products is subject to strict regulation by ratifying states and international trade for primarily commercial purposes is prohibited.

CONSERVATION MEASURES PROPOSED An investigation into the status and distribution of $\mathrm{T}$. schlegelii throughout its range, as a preliminary to effective conservation action, is planned by personnel of the Madras Snake Park (10) although funds are currently lacking. A rearing-release programme, analogous to 
those operating in India and Nepal for Gharial Gavialis gangeticus, may be feasible in Indonesia (19). Further details are required on the status of populations in Reserves in Sumatra and Kalimantan. The Lalan River floodplain in south Sumatra and the upper Mahakam River in Kalimantan have been recommended as suitable reserve sites (16). It is hoped that a major crocodile survey will be undertaken between June - October 1981 in Sabah, to determine the status of $T$. schlegelii (and Crocodylus porosus) (1). Should be added to the list of protected species in Sarawak (8). Hunting regulations should be effectively implemented in Indonesia (19).

CAPTIVE BREEDING The Samut Prakan crocodile farm in Thailand has over 170 Tomistoma of all size classes, the three adult females (housed with one large male) have been laying annually for several years. Twenty-five to 30 are held in other zoos around the world (10). The species is commonly held in Indonesian zoos (7). About 10 Tomistoma are held by crocodile rearing projects in Sarawak, the skins from which will probably eventually be sent to Singapore (8), and about 120 of various sizes are held at a Djakarta crocodile farm (11). A large breeding group is being established at New York Zoological Park, their extensive quarters will be ready in 1983 (18).

REMARKS Tomistoma schlegelii remains one of the least known crocodilians, a clearer concept of the species' ecology, status and distribution is a prerequisite for any comprehensive management plan. Fossil material assigned to this genus is reported from the Pleistocene of Taiwan and Japan.

REFERENCES 1. Andau, P.M. (Office of Chief Game Warden, Sabah) (1981). In litt., 12 February.

2. Bain, J.R. and Humphrey, S.R. (1980). A profile of the endangered species of Thailand. Report No.4, Office of Ecological Services. Florida State Museum, Gainesville.

3. Brazaitis, P. (1973). The identification of living crocodilians. Zoologica (N.Y.) 58(4): 59-101.

4. De Rooij, N. (1915). The reptiles of the Indo-Australian archipelago. I. Lacertilia, Chelonia, Emydosauria. E.J. Brill, Leiden. (Reprinted 1970, A.Asher \& Co. N.V., Vaals).

5. Honegger, R.E. (1979). Red Data Book, Vol 3: Amphibia and Reptilia. IUCN, Gland (third edition, revised).

6. King, F.W. and Brazaitis, P. (1971). Species identification of commercial crocodilian skins. Zoologica (N.Y.) 56(2): $15-70$.

7. Mackinnon, J. (Project Ecologist, F.A.O. National Parks Development Project - Indonesia) (1981). In litt., 7 May.

8. Proud, K. (WWF Asst. Representative) (1981). In litt., 12 May.

9. Whitaker, R., and Daniel, J.C. (1978). The status of Asian crocodilians. Tigerpaper 5(4): 12-17.

10. Whitaker, R. and Whitaker, Z. (1981). In litt., 10 April (outline of proposed status-distribution investigation).

11. Whitaker, R. (1981). In litt., 10 August.

12. Wind, J. (Project Leader, WWF project - Gn. Leuser) (1981). In litt., 5 March, via J. MacKinnon (ref.7).

13. Butler, A.L. (1905). The eggs and embryos of Schlegel's Gavial (Tomistoma schlegelii, S.Müller). J. Federated Malay States I(1):1-2.

14. King, F.W. (citing letter from Mr Bullock, then President of the Malayan Nature Society) (1973). External trade statistics for undressed crocodile skins from Malaysia-Singapore - a correction. In Crocodiles. IUCN 
Publ. New. Ser. Suppl. Pap. No.41: 55-57.

15. Shelford, R.W.C. (1916). A naturalist in Borneo. London, T.Fisher Unwin.

16. Sudharma, D. (1976). Beberapa aspek kehidupan buaya julung (Tomistoma schlegelii) dan kemungkinan pembinaan pengamanannya. (Some aspects of the life history of the Bowsprit Crocodile (T. schlegelii) and the possible building up of population). Departemen Biologi Perairan, Fakultas Perikanan, Inst. Pertanian, Bogor.

17. Proud, K. (1982). In litt., 6 February.

18. Brazaitis, P. (1981). In litt., 29 June.

19. Suwelu, I.S. (1982). In litt., 29 March (translation of article on $T$. schlegelii entitled Buleu Pengelolaan Saswa Langha Jilid II, published by Directorate Perlindugun Penjawetan Alam, Bogor, 1978).

20. Marsh, C. (Wildlife Officer, Sabah Foundation) (1982). In litt., 30 April. 
Gavialis gangeticus (Gmelin 1789)

SUMMARY A distinctive, large and extremely slender-snouted, fish-eating crocodilian, of great zoological interest. Largely restricted to the powerful Himalaya-fed rivers in the north of the Indian sub-continent, in the Indus, Ganges and Brahmaputra drainages. Also present in the Mahanadi (Orissa). Currently known to occur in Bangladesh, India, Nepal and Pakistan, formerly occurred in Bhutan. Reported in the nineteenth and early twentieth centuries to be abundant in many areas, but now extinct or extremely depleted throughout its former range. Almost extinct in Bangladesh and Pakistan, fewer than 20 individuals may be present in each country. On the verge of extinction in the mid-1970s in India. Population in Nepal estimated at 65-70 adults. Favoured habitat is deep fast-flowing sinuous rivers, with relatively clear water, high banks, deep pools, and sandbanks for basking and nesting. Carnivorous, feeding primarily on fish. The nesting season, within March-April, is very regular and discrete in each area. A hole-nesting species, the nest is excavated in mid-river sandbars or sandbanks at the river edge. Eggs are elliptical, $85-90 \mathrm{~mm}$ long by $65-70 \mathrm{~mm}$. Clutch size is rather variable between years and between females; on the Narayani in 1977 mean size was 36.9, range 16-61. Incubation period 83-94 days. Breeding females guard the nest site and closely attend the young for several months. Decline of Gharial is attributed to habitat loss and disturbance, also killing for skins and in the course of fishery operations, mainly by drowning in nylon set-nets. The vestigial wild population in India has been significantly augmented by release of young reared in captivity from wild-collected eggs. Young Gharial are released only into strictly protected sanctuaries established in the remaining good Gharial habitat. Gharial was a priority species for the Government of India/FAO/UNDP Crocodile Breeding and Management Project initiated in 1975, the first young Gharial were released in 1977. A similar project in Nepal has been operating in the Royal Chitwan National Park since 1978, a first batch of 50 young, 10 of which were fitted with radio telemetry collars, was released in early 1981. Nominally protected by legislation in all countries in which it occurs. A management scheme is under consideration in Pakistan. There is currently some optimism for the survival of the species; this will depend largely on continuing management of the release sanctuaries, and occurrence of breeding among released individuals when they attain sexual maturity. The recently reported nesting site in Bangladesh is currently being investigated. Efforts should be made to re-establish Gharial in the Manas River of Bhutan. Captive breeding occurred at Nandankanan Biological Park (Orissa) in 1980. Listed on CITES Appendix I.

DISTRIBUTION Present in Bangladesh, India, Nepal and Pakistan. Largely restricted to the Himalaya-fed river systems in the north of the Indian sub-continent, namely the Indus, Ganges, and Brahmaputra Rivers and certain (mainly south-flowing) tributaries, and further south in the Mahanadi River (Orissa) (27). Formerly present in the Manas River (a tributary of the Brahmaputra) in Bhutan (15). Recorded in Burma from the Kaladan River (Arakan), and the Maingtha River (part of the Irrawaddy system) (27), the validity of these records has been questioned (32) but the latter appears well-substantiated (7). There are no recent records from Burma. See next section for further details of distribution. 
POPULATION Travel accounts of the nineteenth and early twentieth centuries cited in refs. $16,26,30,32$ ) indicate that Gharial were locally common, for example it was said in 1867 that the species "abounds in all the great rivers of Northern India" (3). The Gharial is now extinct or extremely depleted throughout its former range $(12,30,32)$

Bangladesh Endangered, until very recently thought to be extinct. Present information suggests that fewer than 20 individuals may still occur in the lower courses of the Ganges (Padma) and Brahmaputra (Jamuna) Rivers (22), mostly in the Padma around Rajshahi and only one or two in Jamuna (36). Furthermore, nesting (reportedly of this species) has recently occurred near a village on a newly-accreting island (Char Mukhterpur) in the Padma near the border with India (5). These areas have recently been investigated (37). No precise estimate of the number of Gharial that may remain in Bangladesh is available.

Bhutan Probably extinct, no Gharial were seen in a recent survey of suitable habitat in Bhutan, but a single individual introduced into the Manas River was seen regularly in 1977-1978 and occasionally in 1979 (15).

Burma Extinct, if old records from this country are authentic, or may never have occurred regularly. A few years ago a survey party spent 26 days on the Kaladan River and was told by villagers that Gharial had long been extinct (41). However, the Maingtha River locality has not been investigated recently. Gharial were reported to have been held in the 1970s in the pens of a Burmese animal dealer (42), but the origin of these animals is unknown.

India Extremely depleted, reported critically endangered and on the verge of extinction in the mid 1970s $(16,17)$, but recent conservation measures (see below) allow some optimism for the continued survival of the Gharial in India. A 1975 survey of most of the former major Gharial rivers in India, in the states of Uttar Pradesh, Rajasthan and Madhya Pradesh, suggested a total of 141 animals (26), including many juveniles of low survival potential. Of this total 84 were young or sub-adults, and 24 were isolated adults, leaving a potential breeding population of only 33 adults spread over three rivers. In other parts of India it has been estimated $(32,33)$ that fewer than 10 occur in Orissa, fewer than 10 in Bihar, and around 10 in Assam. While a very few isolated Gharial still exist in some Indian rivers that formerly supported large populations, such as the Ramganga in Corbett National Park (U.P.) (31), the Ghagra (U.P.); the Gandak (U.P./Bihar) and the Kosi (Bihar), more or less regular breeding has been known in recent years in only three areas, in the Girwa, Chambal and Mahanadi Rivers. The Girwa River (U.P.) is called the Karnali in Nepal, and in India is known as the Ghagra after its confluence with the Kauriala near the Nepalese border. Gharial were formerly widespread along the Girwa, but are now largely restricted to a 3-5 km stretch within the Katerniaghat sanctuary adjoining the border with Ner-1. In 1975 two males, seven females, two near-adults, four sub-adults, 11 juveniles and two young, were counted, giving a total population of 28 (26). Much of the upper course of the Chambal River (rising in the Vindhya Range, M.P.) forms part of the Rajasthan-Madhya Pradesh state boundary, the river then forms part of the Uttar Pradesh-Madhya Pradesh boundary before flowing into the Jamuna (Jumna). In 1975 (26) the latter portion contained about 10 adult Gharial and a "fair number" of sub-adults and juveniles, the more upstream portion contained 18 adults (six males, twelve females), 15 sub-adults, 16 juveniles, and 34 young (up to two years). The population in the Mahanadi (Orissa, flowing eastward into the Bay of Bengal) has been severely depleted and is now concentrated in the Satkoshia Gorge, a $22 \mathrm{~km}$ stretch from Tikerpada downstream to Barmul. A very few isolated Gharial exist upstream of Satkoshia (10). In 1974 four or five adults were observed in Satkoshia Gorge $(16,17)$, the last hatchlings had been seen in 1974 (34). One female laid eggs in 1975 and 1976, but all proved infertile. No eggs 
The vestigial wild Gharial population in India of the mid-1970's has since been augmented by release of young Gharial from wild-laid eggs hatched and reared in captivity under the Government of India/FAO/UNDP Crocodile Breeding and Management Project. Starting in April 1977, a total of 324 young, about $1.2 \mathrm{~m}$ in length and 18 months in age, have been released into strictly protected sanctuaries up to March $1980(20,24)$. This total comprised 107 released into the Satkoshia Gorge Sanctuary on the Mahanadi (Orissa), 203 released into the tri-state National Chambal Sanctuary (U.P./M.P./Rajasthan), and 14 into the Katerniaghat Wildlife Sanctuary on the Girwa (U.P.) (24). Although India now holds many more individuals of this species than other countries within the range, and there are now considerable grounds for optimism about the continued survival of the Gharial, the species must still be regarded as Endangered until significant breeding of released individuals has occurred. See section on Conservation Measures Taken for further details of the project.

Nepal The total wild Gharial population has been estimated at about 50 individuals $(32,33)$, a more recent estimate suggests a total of 65-70 adult Gharial, comprising 50-55 adults in the Narayani (plus 50 young) and 10-15 adults in the Karnali (40). Small numbers occur in each of several rivers that rise in the Himalayas and run through lowland south Nepal before joining the Indian portion of the Ganges system. These include the Karnali (Girwa in India), Babai, Rapti, Narayani (Gandak in India), Rapti Doon, Makali, and Kosi Rivers. The major surveyed population is in the Narayani River $(12,32)$ within the Royal Chitwan National Park (in December 1980 a total of 15 adults were seen here in one day (28)), but better populations may occur in the Karnali, particularly the Chisa Pani Gorge (40). A rearing project, patterned on the India scheme, is underway in the Royal Chitwan N.P. (12).

Pakistan Critically endangered, on the verge of extinction $(4,12)$. No precise survey figures are available (4), but the total population has been estimated at fewer than $20(6,33)$. Gharial are restricted to the Indus River, around the Guddu Barrage (Sind) and two adults were recently observed during a wildfowl survey at Taunsa Barrage (Punjab) (21). There is an unconfirmed report (44) that up to 20 Gharial may occur in the $160 \mathrm{~km}$ Nara Canal (100 $\mathrm{m}$ wide, $6 \mathrm{~m}$ deep), part of the Indus River Dolphin Sanctuary (it is not clear whether these animals are included in the total population estimate; second sentence, this paragraph).

HABITAT AND ECOLOGY A large crocodilian, adults males may reach around $6.5 \mathrm{~m}$ and females about $4.5 \mathrm{~m}$ (27). Optimum habitat for Gharial would include deep fast-flowing sinuous rivers, with relatively clear water, high banks, deep pools, and undisturbed sandbanks at the river edge or in mid-river for nesting and basking. For example, the Chambal River in India has high banks and there are numerous bends where water depth exceeds $30 \mathrm{~m} \mathrm{(26),} \mathrm{while} \mathrm{the} \mathrm{remnant}$ population in the Mahanadi is concentrated in the Satkoshia Gorge (25). The river here is very slow-flowing for much of the year but contains deep pools (34). These sites, and the powerful Himalaya-fed rivers running through Nepal to the Ganges, have provided the last significant refuges for Gharial. Individuals bask on sandbanks for long periods during the winter, when water temperatures are very low and water levels are low. Dispersal, especially of juveniles, often occurs during monsoon flooding when animals may move out of the mainstream into side creeks. Like other crocodilians, Gharial will float at the water surface with only the eyes and tip of the snout exposed.

The Gharial is notable for its long and very slender parallel-sided snout and the large number of slender teeth. Fish appear to form a large proportion of the diet in slender-snouted crocodilians (19), and the Gharial feeds almost exclusively on 
fish. A swimming fish is typically first seized across the middle, then the snout is raised out of the water and with two or three snaps of the jaws the prey is turned and swallowed head first $(2,30)$. They have been known to consume birds and occasionally to seize goats and dogs, attacks on humans are exceptional and Gharial are not feared in this respect (27).

The nesting season, generally from late March to mid-April $(2,15,34)$, is very regular and discrete in each area. For example, nesting by 12 females along a 200 $\mathrm{km}$ stretch of the Chambal all occurred within seven days (25), and along the Narayani in Nepal eight nests were all laid between 2-7 April (15). Several trial nests are excavated within the month before laying takes place in the true nest, in the same vicinity. Nesting occurs only in sandbanks on the river-edge, or in mid-river. Substrate selection is critical to give the appropriate balance of sand grain and moisture content. Depth of the nest is such that temperature remains relatively constant, between 32 and $34^{\circ} \mathrm{C}$ optimum (maximum range $25-37^{\circ} \mathrm{C}$ ). Humidity also remains relatively constant despite periods of rainfall. Mean clutch size recorded on the Chambal was 43 (12). There is significant variation in this feature; on the Narayani mean clutch size in 1976 was 28.6 (range 18-40), in 1977 the mean was 36.9 (range 16-61) (15). Eggs are elliptical, 85-90 mm long by 65-70 $\mathrm{mm}$ broad (27). Young, hatching after an incubation period of 83-94 days (data from Nepal, 15) are c $375 \mathrm{~mm}$ long (27). Observations in India suggest a high rate of hatching success (26), but data from Nepal suggest marked variation in egg fertility and percentage hatch (15). The female usually guards the nest site, and also closely attends the hatchlings for several months $(13,16)$. For example, on the Chambal River a $4.5 \mathrm{~m}$ female was observed lying in the shallows with hatchlings on her head and body, and others swimming or basking on the bank immediately beside her; this female had been with the young ( 34 in number, c 40 $\mathrm{mm}$ long) for the past three months $(13,16)$. As now established with several other crocodilians, the female appears to excavate the nest at hatching time and circumstantial evidence suggests that she may carry the hatchlings to water (45). Sexual maturity is attained at between $8-12$ years, at a leng th of about 3 metres (38). Both eggs and hatchlings are heavily predated by fish, jackals, monitor lizards, birds of prey, or larger Gharial, and eggs are also eagerly sought by some tribal communities $(16,26)$. A significant number of nests are destroyed by flooding.

THREATS TO SURVIVAL The present critically depleted status of the Gharial is largely attributed to habitat modification and disturbance and to killing of animals for skins or in the course of fishing operations, a secondary factor is collection of eggs for food by some tribal peoples $(12,16,17,26,30)$.

The preferred habitats of Gharial, namely, deep fast-flowing rivers with high banks, are also the preferred sites for construction of dams, barrages and reservoirs associated with hydroelectric or irrigation schemes (26). Construction of a dam removes Gharial habitat, notably the deep pools and the sandbanks required for nesting and basking, both upstream and downstream of the dam. For example, the Ramganga River (U.P.) supported a large Gharial population until 1960, but construction of a dam (completed 1974) at Kalagarh (where the river enters the plains) has resulted in submergence of the best Gharial pools upstream of the dam $(26,31)$ and below the dam the Ramganga is now almost dry (26). Heavy dynamiting of the river banks during dam construction also caused direct damage to the Gharial population. There are now only five adult Gharial left in the Ramganga, in remaining pools along a stretch nearly $25 \mathrm{~km}$ in extent (26). These pools are also the best areas for Mahseer Tor sp. and the Gharial are much disturbed by sport fishermen (31). No breeding is now known in the river. The failure of breeding in 1976 in a group of seven Gharial on the Karnali River (Nepal) is attributed to disturbance arising from a dam feasibility project (32), several animals are thought to have moved downstream into the Indian portion of 
the river (Girwa River) as a population increase was recorded here in 1976 surveys within the Katerniaghat sanctuary (26). Canalization of waterways, including training of rivers between embankments (9) and replacement of natural sandbanks by concrete embankments, constitute another aspect of habitat modification (24). For example, diversion of the waters of the Narayani (rising in Nepal, called the Gandak in India) into the East and West Gandak canals has greatly reduced the erosive power of the Gandak so that the deep pools (kunds) required by Gharial are becoming silted-up. While groups of over 20 Gharial could be seen here at the turn of the century, basking on mid-river sandbars (29), now only two or three isolated or migrant animals are seen, and breeding is unknown (26). Construction of barrages across the Indus appears to be a factor, with hide-hunting, in the drastic decline of Gharial in Pakistan.

Another primary cause of decline is indiscriminate hide-hunting and killing of Gharial, this factor alone has decimated populations over much of the range, and elsewhere has made the effects of habitat loss even more deleterious. Large-scale hunting has now ceased following legislative protection and decline in Gharial populations, and poaching is not widespread in India (34). The most extensive good Gharial habitats remaining in India are the Jawaharlal Sagar portion of the Chambal River, and the Satkoshia Gorge portion of the Mahanadi (16), and in both these areas persecution of Gharial appears to be the major factor in decline. In 1974 about half the population of 10-15 Gharial in Jawaharlal Sagar were killed when the water was let to a commercial fishery contractor (16). Gharial were common in the the Satkoshia Gorge until quite recently, but the population was brought to the verge of extinction by 1975 following widespread use of nylon set-nets starting around $1970(16,17)$. Gharial are caught in the nets, which are usually put out overnight, and either drowned or killed to avoid damage to the expensive nylon net. The use of these nets has also caused the fishery to decline to a critical level by over-exploitation of fish stocks (in contrast to traditional line or throw-net methods). It has also been reported that the formerly abundant (fish-eating) Gharial population exerted a significant control over predatory 'coarse' fish that feed on commercially more important fishes, so that depletion of Gharial has indirectly contributed to fishery decline (25).

A secondary cause of decline is predation of Gharial eggs, mainly by certain tribal groups, for example the Matia in the Satkoshia Gorge area (16), this factor probably assumes significance only when populations are already depleted. However tribal peoples are extremely efficient egg collectors, and they will collect eggs surplus to immediate food requirements for use in barter (34). Crocodile eggs are believed to have medicinal value in parts of India (34). In the Narayani population of 50-55 adults only seven are males, this is thought to be due to selective hunting for the males whose 'ghara' at the tip of the snout (see Remarks) is reputed to have aphrodisiac properties (38). In Bangladesh eggs from the recently discovered nesting area have been taken locally for food, and three individuals from the remnant population were caught by fishermen (one on a fishing hook, one in a net left on a sandbank to dry, and one in a drag net in the Jamuna ) (36).

CONSERVATION MEASURES TAKEN Nominally protected by legislation in all countries in which it is known to occur (Bangladesh, India, Nepal, Pakistan) $(12,32)$. No information for Burma. Gharial occur in several protected areas in India, also in the Royal Chitwan National Park of Nepal, and there is a reserve including the species in Pakistan (4).

The Government of India initiated a Crocodile Breeding and Management Project in 1975, with preliminary surveys being undertaken in 1974. This project operates on advice from a U.N. Food and Agriculture Organization (FAO) Chief Technical Advisor, with finance from the U.N. Developmental Programme (UNDP). The 
Government of Nepal co-operated in the early stages of the Project and provided India with 500 eggs in the first year and over 100 hatchlings in the second year (40). The Gharial was a priority concern for this comprehensive project. Under this scheme $(20,24,26)$, Gharial eggs are collected from the wild and transported to one of several hatcheries where the young are reared for release into the wild at a length of $1.2 \mathrm{~m}$, aged about 18 months. An essential aspect of the scheme is that young are released into protected areas, established in the last remaining areas of extensive Gharial habitat, where breeding had occurred in recent years $(16,17,20,24,26)$. The first captive hatching occurred at the Gharial Research and Conservation Unit at Tikerpada on the Mahanadi (Orissa) in June 1975, another major hatchery is located at Kukrail near Lucknow (U.P.), and others have since started $(20,24,26)$. Commencing in April 1977 a total of 324 young have been released into the wild up to March 1980; 107 in the Satkoshia Gorge Sanctuary (Orissa), 203 in the tri-state National Chambal River Sanctuary (U.P., M.P., Rajasthan), and 14 in Katerniaghat Sanctuary on the Girwa River (U.P.). Others were planned for release in the winter of 1980/1981. Commercial net-fishing is banned in Gharial sanctuaries on the Mahanadi and the Girwa (20). There is currently considerable optimism for the continued survival of the Gharial in India as a result of this scheme, but its success cannot be fully confirmed until released young have been observed to grow and breed in the wild, and this will be dependent on suitable management of the Gharial sanctuaries $(16,17)$. It has been noted (46) that there is a possibility that strongly biased sex ratios are being produced by rearing projects involving artificial incubation. Recent work with chelonians (eg. ref 48) has demonstrated that incubation temperatures of only a few degrees difference can result in egg clutches developing into all males or all females; a similar effect has now been demonstrated in American Alligator Alligator mississippiensis (46). If this also occurs in other crocodilians, and if incubation procedures in the rearing projects are producing sex ratios strongly biased toward one sex (especially if toward all males), then the projects will be having a largely negative effect (46). This matter requires investigation. There is a hatchery scheme in Nepal, centred on the Narayani River population within the Royal Chitwan National Park. The rearing station at Kasara Park headquarters was established in 1978 with financial aid from Frankfurt Zoological Society. In early 1981 the project held 107 young of 34 months, 148 young of 22 months, and 119 hatchlings of 11 months (38). The first release of young Gharial took place in March 1981. An important facet of the Narayani operation is that all of the 50 Gharial released are tagged and 10 are fitted with radio telemetry collars (provided by the Smithsonian Institute) to allow individual Gharial to be monitored. Further releases are planned after the 1981 monsoon season (40).

Listed on Appendix 1 of the Convention on International Trade in Endangered Species of Wild Fauna and Flora (CITES). Appendix I listing requires that trade in the taxon and its products is subject to strict regulation by ratifying states and international trade for primarily commercial purposes is prohibited.

CONSERVATION MEASURES PROPOSED The recently reported nesting area for Gharial in Bangladesh is currently being investigated, and measures to protect the site will be taken if appropriate (5). Efforts should be made to re-establish Gharial in the good habitat provided by the Manas River in Bhutan, especially in view of the protection afforded by the Manas Sanctuary (15). In Pakistan a detailed survey of status and distribution is required, and there are plans to initiate a rearing scheme (details unsettled) (6). The rearing projects in India and in Nepal should be sufficient to ensure the survival of Gharial in these countries, provided that adequate management plans and protective legislation continue to be rigidly implemented within release areas. Rearing procedures, where operating (see previous section), should be investigated to ensure that the sex ratio among hatchlings produced is not unduly biased. 
CAPTIVE BREEDING Breeding in captivity occurred for the first time at the Nandankanan Biological Park in Orissa (India), where a female mated with a male on loan from the Frankfurt Zoo, and laid 25 eggs in March 1980, from which 24 hatchlings emerged on 7 May 1980 (1). This Park has held several Gharial since 1963, in a pool specificially constructed to provide suitable breeding habitat $(2,23)$. Madras Crocodile Bank has four subadults and one adult female Gharial in a $50 \mathrm{~m} \times 20 \mathrm{~m}$ pool with sand banks, built with the intention of breeding the species (43). The Reptile Breeding Foundation (Ontario, Canada) is sending its two male Gharial on breeding loan to Atlanta Zoo (Georgia, USA) which has two females (47). Two males are held at Karachi Zoo in Pakistan (4) and a very few other specimens occur in other collections, in conditions generally unsuitable for breeding (18).

REMARKS Adult male Gharial are remarkable in possessing a tough bulbous excrescence at the tip of the snout $(8,11)$. This structure is formed by growth of tissues adjacent to the nostrils, its complex morphology results from a combination of folding and cavitation during growth (8). The name 'Gharial' is said to be derived from the resemblance of the knob to an earthen pot, known as a 'ghara' in north India. When the male emerges from water the obstruction of exhaled air caused by the ghara usually results in a hissing sound (11). The function of the ghara is uncertain, but it may be associated with courtship vocalisation or sex recognition (8).

Fossil gavialids are known from South America, Africa and Asia, the late Tertiary Gavialis pachyrhynchus from north India attained a remarkable length of 13-17 metres (35).

REFERENCES 1. Acharjyo, L.N. (1981). In litt., 28 March.

2. Acharjyo, L.N., Biswas, S., and Misra, R. (1975). Some notes on Gharial (Gavialis gangeticus (Gmelin)) in captivity. Journal Bombay Nat. Hist. Soc. 72(2): 558-560.

3. Adams, A.L. (1867). Wanderings of a Naturalist in India. Edmonston and Douglas, Edinburgh. (not seen, cited in refs. 32,33).

4. Ahmed, Md.F. (Director, Zoological Survey of Pakistan) (1981). In litt, 18 March. (Information from Zoological Survey of Pakistan).

5. Akonda, A.W. (1981). In litt., 25 April (translation and comments on an article published 10 April in a daily Bengali newspaper, the Dainik Barta).

6. Aleem, A. (Wildlife Management Specialist, Pakistan Forest Inst.) (1981). In litt., 16 February.

7. Barton, C.G. (1929). The occurrence of the Gharial (Gavialis gangeticus) in Burma. J. Bombay Nat. His. Soc. 33: 450-451. (See Editor's note confirming identification of skull).

8. Martin, B.G.H., and Bellairs, A. d'A. (1977). The narial excrescence and pterygoid bulla of the gharial Gavialis gangeticus (Crocodilia).

9. Biswas, S. (1970). A preliminary survey of Gharial in the Kosi River. Indian Forester 96: 704 (not seen, cited in ref. 24).

10. Biswas, S. (1976). The Gharial in the Mahanadi River in Orissa. Newsl. Zool. Surv. India 2(2): 44-46.

11. Biswas, S., Acharjyo, L.N., and Mohapatra, S. (1978). A note on the protruberance or knob on the snout of male Gharial (Gavialis gangeticus (Gmelin)). J. Bombay Nat. Hist. Soc. 74(3): 536-537. 
12. Bustard, H.R. (1979). In litt. to René Honegger, 15 November (draft Red Data Book account for Gavialis gangeticus).

13. Bustard, H.R. (1980). Maternal care in the Gharial, Gavialis gangeticus (Gmelin). Brit. J. Herpet. 6(2): 63-64.

14. Bustard, H.R. (1980). Clutch size, incubation and hatching success of Gharial (Gavialis gangeticus (Gmelin)) eggs from Narayani River, Nepal, 1976-1978. J. Bombay Nat. Hist. Soc. 77(1): 100-105.

15. Bustard, H.R. (1980). Status of the Gharial (Gavialis gangeticus (Gmelin)) in Bhutan. J. Bombay Nat. Hist. Soc. $77(1): 150$.

16. FAO. (1974). India. A preliminary survey of the prospects for crocodile farming (based on the work of H.R. Bustard, Consultant). FAO, Rome.

17. FAO. (1975). India. Gharial and Crocodile conservation management in Orissa (based on the work of H.R. Bustard, Consultant). FAO, Rome.

18. Honegger, R. (1979). Red Data Book, Vol. 3: Amphibia and Reptilia. IUCN, Gland (third edition, revised).

19. Iordansky, N.N. (1973). The skull of the Crocodilia. In Gans, C. and Parsons, T.S. (Eds), Biology of the Reptilia. Vol. 4. Morphology D. Academic Press, London \& NY. Pp. 201-262.

20. Jayal, N.D. (1980). Crocodile Conservation in India. Tigerpaper 7(4): 1-3.

21. Khan, A.A. (Deputy Conservator of Forests, Govt. of Punjab Wildlife Dept.) (1981). In litt., 22 April.

22. Khan, Md. A.R. (1981). In litt., 7 February.

23. Mohapatra, S., Acharjyo, L.N., and Misra, R. (1976). Catching and transferring adult Gharial (Gavialis gangeticus) Indian Forester 102(9): 636-637.

24. Saharia, V.B. (Ed.) (1981). Crocodile Breeding Project. In, Wildlife in India. Dept. of Agriculture and Cooperation, Ministry of Agriculture, Government of India. Pp. 146-164. (Chapter based on a report by Dr H.R. Bustard).

25. Singh, L.A.K. (1977). Conservation of nature and future of mankind (Man and Crocodile). Tigerpaper 4(2): 16-17.

26. Singh, V.B. (1978). The status of the Gharial (Gavialis gangeticus) in U.P. and its rehabilitation. J. Bombay Nat. Hist. Soc. 75(3): 668-683.

27. Smith, M.A. (1931). The Fauna of British India, including Ceylon and Burma. Reptilia and Amphibia. Vol. I Loricata, Testudines. Taylor \& Francis Ltd., London. (Reprinted 1973 by Ralph Curtis Books, Hollywood, Florida).

28. Taylor, I. (1981). In litt., 10 April.

29. Webber, T.S. (1902). The forests of upper India. (not seen, cited in ref. 26).

30. Whitaker, R. (1975). Status and conservation of the Gharial (Gavialis gangeticus). Herp. Review 6(1): 2-3.

31. Whitaker, R. (1979). The crocodilians of Corbett National Park. Indian J. Forestry 2(1): 38-40.

32. Whitaker, R., and Daniel J.C. (1978). The status of Asian crocodilians. Tigerpaper 5(4): 12-17.

33. Whitaker, R., and Daniel, J.C. (1980). The status of Indian crocodilians. J. Bombay Nat. Hist. Soc. 75 (suppl.): 1238-1245.

34. Bustard, H.R. (1981). In litt., 20 June. 
35. Hecht, M.K. and Malone, B. (1972). On the early history of the gavialid crocodilians. Herpetologica 28 (3): 281-284.

36. Khan, Md. A.R. (1980). Present status and distribution of Crocodiles and Gavial in Bangladesh. Paper presented at 5 th meeting of the IUCN/SSC Crocodile Specialist Group; August 1980, Gainesville, U.S.A.

37. Khan, Md. A.R. (1981). Article on Gharial and other crocodilians of Bangladesh. Bichitra (a Bengali weekly journal) 10(2): 33-42. May 29.

38. Maskey, T.M. (1981). Report on Gharial in Nepal. In litt., received 9 June.

39. Maskey, T.M., and Mishra, H.R. (1980). Conservation of Gharial (Gavialis gangeticus) in Nepal. In Majpuria, T.C. (Ed), Wild is beautiful

40. Mishra, H.R. (1981). In litt., 21 July (comments on first draft of RDB Gharial account).

41. U Tun Yin (1982). In litt., 27 February.

42. Fuchs, K. (1978). Pers. comm. at SSC Crocodile Specialist Group meeting, Madras, reported by W.F. King, in litt., 1981.

43. Whitaker, R. (1981). In litt., 10 August.

44. Latif Rao, A. (undated, pers. comm. noted in ref. 43).

45. Basu, D., and Bustard, H.R. (1981). Maternal behaviour in the Gharial (Gavialis gangeticus (Gmelin)). J. Bombay Nat. Hist. Soc. 28(2): 390-392.

46. King, F.W. (1981). In litt.

47. Anon, (Z. Whitaker). (1982). Editor's Notes, in Hamadryad $7(1): 2$.

48. Mrosovsky, N., and Yntema, C.L. (1980). Temperature dependence of sexual differentiation in sea turtles: implications for conservation practices. Biol. Consv. 18: $271-280$. 

Sphenodon punctatus (Gray 1842)

Order RHYNCHOCEPHALIA

Family SPHENODONTIDAE

SUMMARY A unique lizard-like reptile, the sole living representative of a widespread and archaic group known from fossils dating back to around 200 million years before present. Occurs on at least 30 islands in two areas off the coast of New Zealand. Present population probably exceeds 100,000, about one third of these on Stephens Island. On all islands supporting self-maintaining populations of Tuataras, breeding populations of petrels and shearwaters are present. Tuataras often use these birds' burrows, and occasionally eat the the smaller species. Feeds mainly on suitable-sized land invertebrates, especially beetles and orthopterans. Clutch size ranges from 8-15 eggs, taking 12-15 months to hatch. Growth rate is exceptionally slow, Tuataras may live for longer than 100 years, sexual maturity is reached at around 20. Active at much lower body temperatures than other reptiles. Appears unable to persist on islands were rats are present, these constitute a potential threat. Protected by law in New Zealand. All Tuatara islands are designated as Wildlife Sanctuaries or Flora and Fauna Reserves. Listed on Appendix I of CITES.

DISTRIBUTION Present: Tuataras now occur on at least 30 islands off the coast of New Zealand. The islands fall into two groups, one between North Cape and East Cape of the North Island, and the other in Cook Strait between the North and South Islands (2). Sixteen of the 30 islands have an area of 10 ha or less. Former: Throughout both the North and South Islands of New Zealand. Sub-fossil records have been mapped by Crook (2).

POPULATION Probably exceeds 100,000. Stephens Island (150 ha) supports at least 30,000 Tuataras and possibly more than 50,000 (5). On this island, as many as 30 Tuataras have been recorded in an area of $625 \mathrm{sq} \mathrm{m}$ - a density equivalent to 480 per hectare, although average densities may be considerably lower than this (2). A typical Tuatara island habitat of 10 ha is not likely to support more than 5,000 Tuataras (2).

HABITAT AND ECOLOGY A rather large, to $\mathrm{c} 70 \mathrm{~cm}$ length, lizard-like reptile. Occurs on offshore islands, mostly forested, from $0-300 \mathrm{~m}$ above sea level.

On all islands supporting self-maintaining populations of Tuataras, breeding populations of petrels and shearwaters are present. The birds provide Tuataras with many benefits, principally in the form of housing and food. Tuataras often live in the birds' burrows, though the reptiles can and frequently do construct their own. Tuataras may use several burrows, which are often separated by distances as great as 50 or even $100 \mathrm{~m}$; the time spent in any one burrow varies, as does the number of burrows any individual may use. Not only do Tuataras use several burrows, but several Tuataras may use the same burrow, although at different times. Resident animals aggressively defend their burrow and on several occasions have been observed to forcibly expel an intruder (6).

Tuataras take almost any suitable-sized land invertebrate as food, especially beetles, beetle larvae and large orthopterous insects. Occasionally they eat the adults, chicks and eggs of smaller petrel species, lizards and rarely, frogs $(2,3,6,7)$. 
Mating has been observed in late summer and early autumn (January, February, March) and egg-laying in spring and early summer (October, November, December). The eggs take 12-15 months to hatch. Egg clutches, which vary from 8-15, are deposited in small, specially constructed chambers or blind tunnels which are then filled with soil and abandoned $(2,3,6)$.

Can be active at much lower body temperatures than other reptiles. Growth rate is exceptionally slow. The growing period of the Tuatara is approximately 60 years and sexual maturity is attained at about 20 years. The life expectancy of Tuataras is likely to exceed 100 years $(3,4)$.

THREATS TO SURVIVAL Collected evidence strongly suggests that Tuataras cannot persist on islands where rats are present. Polynesian rats Rattus exulans at present occur on 7 Tuatara islands. Tuataras co-existing with rats are almost all greater than $200 \mathrm{~mm}$ snout-vent length which suggests that the reptile's decline is the result of recruitment failure (1). Although every precaution has been taken it seems likely that rodents might gain access to further Tuatara islands in the future (9).

CONSERVATION MEASURES TAKEN The Tuatara is rigidly protected under the Wildlife Act 1953 administered by the New Zealand Wildlife Service, Department of Internal Affairs. All Tuatara islands are designated either Wildlife Sanctuaries or Flora and Fauna Reserves so that permits are required to visit them.

Currently (1981) a long-term research programme aimed at investigating Tuatara Polynesian rat relationships and how they may be modified by other factors is being undertaken by Wildlife Service Staff.

Listed on Appendix I of the Convention on International Trade in Fndangered Species of wild Fauna and Flora (CITES). Appendix I listing requires that trade in the taxon and its products is subject to strict regulation by ratifying states and international trade for primarily commercial purposes is prohibited.

CONSERVATION MEASURES PROPOSED Present protective measures are considered adequate, and should be maintained.

CAPTIVE BREEDING Tuataras held in captivity as at January 1981 total 43,27 in New Zealand (10 males, 11 females, 6 juveniles) and 16 overseas ( 8 males, 7 females, 1 juvenile). Mating and egg-laying have occurred in captivity, but only at three institutions have eggs been successfully hatched: the Iniversity of Sydney (10), the Australian Reptile Park, Gosford (11), and the Auckland Zoo (8).

REMARKS This account was kindly provided by D.G. Newman (New Zealand Wildlife Service) in March, 1981.

Although superficially resembling a large lizard, the Tuatara is not in fact a lizard but the sole living representative of the rhynchocephalians - a widespread group of reptiles that arose some 200 million years ago, flourished before the dinosaurs, and declined in diversity from the later Mesozoic onward, possibly in the face of competition from the true lizards.

The Tuatara is thus of extraordinary zoological interest in illustrating some aspects of the anatomy of an archaic group of reptiles, otherwise known only as fossils. While lacking the various specializations of snakes and lizards, the Tuatara shows several features that would be expected in the group ancestral to snakes, lizards, amphisbaenians and others. For example, it possesses a diapsid 
skull (i.e. with two complete arcades of bone in the temporal region), also shown by a variety of archaic reptiles, including forms ancestral to the crocodiles and dinosaurs, but considerably modified in snakes and lizards. A brief discussion of the many interesting anatomical features of the Tuatara is given in reference 12 .

REFERENCES 1. Crook, I.G. (1973). The Tuatara, Sphenodon punctatus Gray, on islands with and without populations of the Polynesian rat, Rattus exulans (Peale). Proceedings of the New Zealand Ecological Society 10: $115-120$.

2. Crook, I.G. (1975). The Tuatara. In Kuschel, G. (Ed.). Biogeography and Ecology in New Zealand, pp. 331-352. Junk, The Hague.

3. Dawbin, W.H. (1962). The Tuatara in its natural habitat. Endeavour 21: 16-24.

4. Dawbin, W.H. (in press). The Tuatara-aspects of life history, growth and longevity. In Newman, D.G. (Ed.). New Zealand Herpetology: Proceedings of a symposiu $n$ held 29-31 January 1980.

5. Newman, D.G. (in press). Tuataras, Sphenodon punctatus, and burrows, Stephens Island. In Newman, D.G. (Ed.), New Zealand Herpetology: Proceedings of a symposium held $29-31$ January 1980.

6. Newman, D.G., Crook, I.G., Moran, L.R. (1979). Some recommendations on the captive maintenance of Tuataras Sphenodon punctatus based on obsrvations in the field. International Zoo Yearbook 19: 68-74.

7. Walls, G.Y. (in press). Feeding interactions of the Tuatara, Sphenodon punctatus, on Stephens Island. In Newman, D.G. (Ed.), New Zealand Herpetology: Proceedings of a symposium held 29-31 January 1980.

8. Wood, D. (1967). Breeding Tuataras Sphenodon punctatus at Auckland Zoo. International Zoo Yearbook 7: 178-179.

9. Newman, D.G. (1981). In litt., 17 March.

10. Dawbin, W.H. (1981). pers. comm. to D.G. Newman.

11. Worrell, E. (1981). pers. comm. to D.G. Newman:

12. Bellairs, A.d'A., and Attridge, J. (1975). Reptiles, Hutchinson University Library; London. (Fourth edition, revised).

General references, not cited in the text, include:

a. Robb, J. (1980). New Zealand Amphibians and Reptiles in Colour. Collins, Auckland. 128 pp.

b. Robb, J. (1977). The tuatara. Patterns of Progress. Meadowfield, England. 64 pp.

c. Sharell, R. (1966). The Tuatara, Lizards and Frogs of New Zealand (reprinted, with addendum, 1975). Collins, London. $95 \mathrm{pp}$. 



\section{INDEX}

Scientific synonyms are enclosed in brackets.

(Acinixys planicauda) 121

African Dwarf Crocodile 397

African Long-snouted Crocodile 325

African Slender-snouted Crocodile 325

Alabama Red-bellied Turtle 37

Aldabra Giant Tortoise 77

(Aldabrachelys gigantea) 77

ALLIGATORID AE 283

Alligator, American — xliii

Alligator, Chinese — 283

Alligator mississippiensis xliii

Alligator sinensis 283

Alligator, Yangzi - 283

Amazon Sideneck Turtle, Red-headed — 251

American Crocodile 319

Angonoka 91

Atlantic Ridley 201

Aquatic Box Turtle 57

Arrau 253

(Asterochelys radiata) 85

(Asterochelys yniphora) 91

Australian Freshwater Crocodile 333

Batagur 21

Batagur baska 21

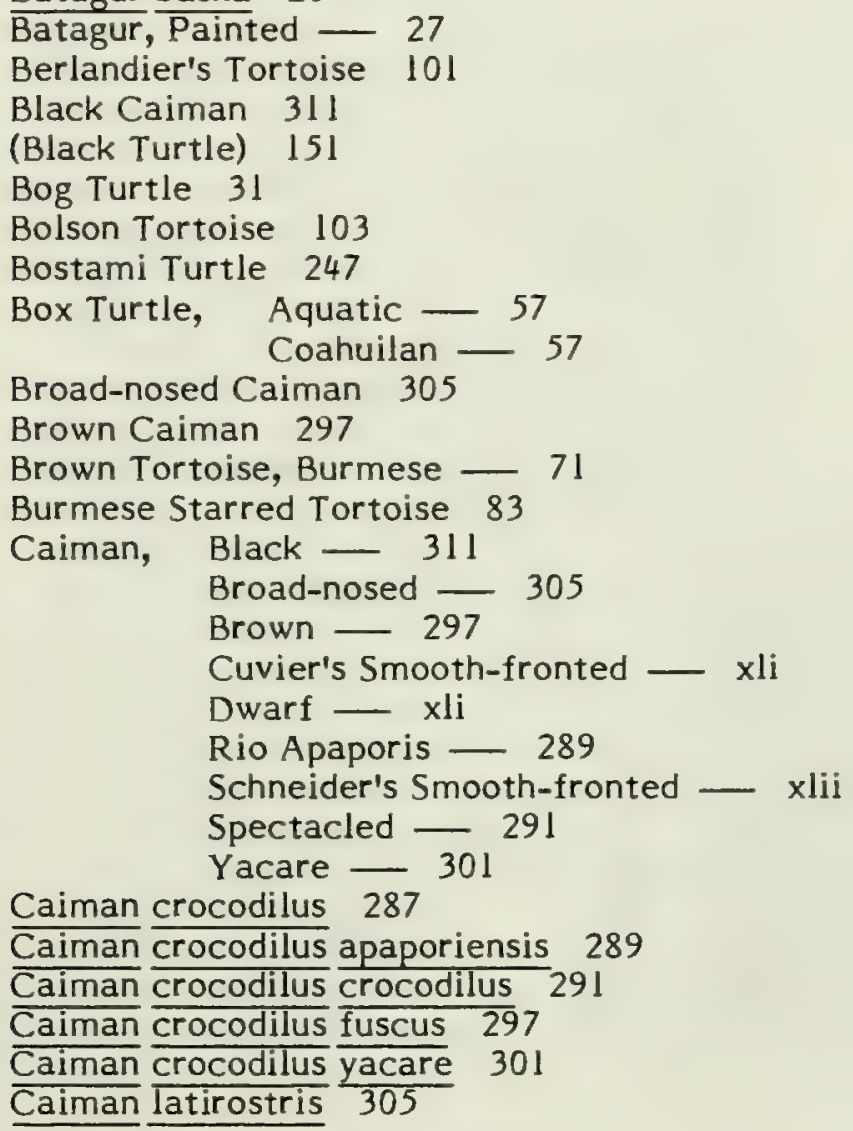


Caiman yacare 301

Callagur borneoensis 27

Caretta caretta 137

CARETTOCHELYIDAE 243

Carettochelys insculpta 243

Cat Island Turtle 39

Celebes Tortoise 75

Central American River Turtle 17

Chaco Sideneck Turtle 275

Chaco Tortoise 63

Charapa 253

CHELIDAE 269

CHELONIIDAE 137

(Chelonia agassizii) 151

Chelonia depressa xli

Chelonia mydas 151

(Chelonoidis carbonaria) 61

(Chelonoidis chilensis) 63

Chinese Alligator 283

(Chrysemys felis) 39

(Chrysemys malonei) 43

(Chrysemys rubiventris bangsi) 47

(Chrysemys scripta callirostris) 51

Clemmys muhlenbergii 31

Coahuilan Box Turtle 57

Creaser's Mud Turtle 3

Crocodile, African

Dwarf - 397

Long-snouted - 325

Slender-snouted — 325

American — 319

Australian Freshwater — 333

Cuban - 391

Estuarine - 371

Marsh — 363

Morelet's — 341

New Guinea — 355

Nile - 345

Orinoco -329

Philippines — 337

Saltwater - 371

Siamese - 393

CROCODYLIA 283

CROCODYLIDAE 319

Crocodylus acutus 319

Crocodylus cataphractus 325

Crocodylus intermedius 329

Crocodylus johnsoni 333

Crocodylus mindorensis 337

Crocodylus moreletii 341

Crocodylus niloticus 345

Crocodylus novaeguineae 355

Crocodylus palustris 363

Crocodylus porosus 371

Crocodylus rhombifer 391

Crocodylus siamensis 393

Cuban Crocodile 391

Cupiso 261 
Dahl's Toad-headed Turtle 269

Dark Soft-shell Turtle 247

DERMATEMYDIDAE 17

Dermatemys mawii 17

DERMOCHEL YIDAE 225

Dermochelys coriacea 225

Desert Tortoise 97

Dunn's Mud Turtle 5

Dwarf Caiman xli

Dwarf Crocodile, African

East Pacific Turtle 151

Egyptian Tortoise 133

EMYDIDAE 21

Eretmochelys imbricata 181

Erymnochelys madagascariensis 249

Estuarine Crocodile 371

False Gharial 401

Flatback Turtle xli

Flat-tailed Tortoise, Madagascar _ 121

Flattened Musk Turtle 13

Fly River Turtle 243

Freshwater Crocodile, Australian — 333

Furrowed Wood Turtle 53

Galapagos Giant Tortoise 65

GAVIALIDAE 405

Gavialis gangeticus 405

Gazari 247

Geochelone carbonaria 61

Geochelone chilensis 63

(Geochelone donosobarrosi) 63

Geochelone elephantopus abingdoni

Geochelone elephantopus becki 65

Geochelone elephantopus chathamensis 65

Geochelone elephantopus darwini 65

Geochelone elephantopus elephantopus 66

Geochelone elephantopus ephippium 66

Geochelone elephantopus galapagoensis 66

Geochelone elephantopus guentheri 66

Geochelone elephantopus hoodensis 66

Geochelone elephantopus microphyes 66

(Geochelone elephantopus nigrita) 66

Geochelone elephantopus phantastica 66

Geochelone elephantopus porteri 66

Geochelone elephantopus vandenburghi 67

Geochelone emys 71

Geochelone forsteni 75

Geochelone gigantea 77

Geochelone impressa 81

Geochelone petersi) 63

Geochelone platynota 83

Geochelone travancorica

Geochelone radiata 85

Geochelone yniphora 91

(Geoemyda silvatica) 35

Geometric Tortoise 115

Gharial 405

Gharial, False — 401 
Malayan - 401

Giant Tortoise, Aldabra - 77

Gopher Tortoise 109

Galapagos — 65

Gopherus agassizii 97

Gopherus berlandieri 101

Gopherus flavomarginatus 103

Gopherus polyphemus 109

(Gopherus polyphemus flavomarginatus) 103

Green Turtle 151

Hawksbill Turtle 181

Heosemys silvatica 35

Hermann's Tortoise 127

Hoge's Sideneck Turtle 271

Iaca 261

Illinois Mud Turtle 7

Impressed Tortoise 81

Inagua Island Turtle 43

(Indotestudo forsteni) 75

(Indotestudo travancorica) 89

Irapuca 251

Jacare-acu 311

Jacare de Papo Amerelo 305

Kapidolo 121

Kapila 119

Kavalai Forest Turtle 35

Kemp's Ridley 201

KINOSTERNIDAE I

Kinosternon angustipons 1

Kinosternon creaseri I

Kinosternon dunni 5

Kinosternon flavescens spooneri 7

Largarto Negro 311

Leatherback 225

Leathery Turtle 225

Lepidochelys kempii 201

Lepidochelys olivacea 209

Loggerhead Turtle 137

Long-snouted Crocodile, African - 325

Luth 225

Madagascar, Flat-tailed Tortoise 121

Sideneck Turtle 249

Spider Tortoise 119

Madari 247

Magdalena River Turtle 259

Malacochersus tornieri $\quad 113$

Malayan Gharial 401

(Manouria emys) 71

(Manouria impressa) 81

Marsh Crocodile 363

Melanosuchus niger 311

Mexican Spotted Wood Turtle 55

Morelet's Crocodile 341

Mud Turtle, Creaser's — 3

Dunn's - 5 
Mugger 363

Illinois - 7

Musk Turtle, Flattened

Narrow-bridged _ 1

- 13

Narrow-bridged Mud Turtle 1

New Guinea Crocodile 355

New Guinea Plateless Turtle 243

Nile Crocodile 245

Olive Ridley 209

Orinoco Crocodile 329

Osteolaemus tetraspis 397

Pacific Ridley 209

Painted Batagur 27

Painted Terrapin 27

Paleosuchus palpebrosus xli

Paleosuchus trigonatus xlii

Pancake Tortoise 113

PELOMEDUSIDAE 249

Philippines Crocodile 337

Phrynops dahli 269

Phrynops hogei 271

Phrynops rufipes 273

Pig-nosed Turtle 243

Pitiu 261

Pitted Shell Turtle 243

Plateless Turtle, New Guinea

Platemys pallidipectoris 275

Platemys spixii 277

Plymouth Red-bellied Turtle 47

Podocnemis erythrocephala 251

Podecnemis expansa 253

Podocnemis lewyana 259

(Podocnemis madagascariensis) 249

Podocnemis sextuberculata 261

Podocnemis unifilis 263

Psammobates geometricus 115

Pseudemydura umbrina 273

Pseudemys alabamensis 37

Pseudemys felis 39

Pseudemys malonei 43

(Pseudemys ornata callirostris) 51

Pseudemys rubriventris bangsi 47

Pseudemys scripta callirostris 51

Pyxis arachnoides 119

Pyxis planicauda 121

Radiated Tortoise 85

Red-bellied Turtle, Alabama — 37

Red-bellied Turtle, Plymouth — 47

Red-foot Tortoise 61

Red-headed Amazon Sideneck Turtle 25I

Red-lined Turtle, South American _ 51

Rere 249

Rhinoclemmys areolata 53

Rhinoclemmys rubida 55

RHYNCHOCEPHALIA 415 
Ridley, Atlantic 201

Ridley, Kemp's 201

Ridley, Olive 209

Ridley, Pacific 209

Rio Apaporis Caiman 289

River Terrapin 21

River Turtle, Central American - 17

Saltwater Crocodile 371

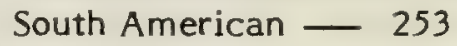

Schneider's Smooth-fronted Caiman xlii

Sea Turtle, see families CHELONIIDAE, DERMOCHELYIDAE

Siamese Crocodile — 393

Sideneck Turtle, Chaco 275

Hoge's - 271

Madagascar — 249

Spix's — 277

Yellow-spotted - 263

Slender-snouted Crocodile, African — 325

Smooth-fronted Caiman, Cuvier's _ xli

Sokake 85

Schneider's — xlii

South American Red-lined Turtle 51

South American River Turtle 253

Spectacled Caiman 291

Sphenodon punctatus 415

SPHENODONTIDAE 415

Spider Tortoise, Madagascar — 119

Spotted Wood Turtle, Mexican — 55

Spur-thighed Tortoise 123

Starred Tortoise, Burmese 83

Sternotherus minor depressus 13

Swamp Turtle, Western — 279

Tao Lai Teen Bet 27

Taricaya 263

Tartaruga 253

Terecay 263

Terrapene coahuila 57

Terrapin, Painted 27

Terrapin, River $\ldots 21$

TESTUDINES 1

TESTUDINIDAE 61

(Testudo carbonaria) 61

(Testudo chilenesis) 63

(Testudo emys) 71

(Testudo forsteni) 75

(Testudo gigantea) 77

Testudo graeca graeca 123

Testudo hermanni 127

(Testudo impressa) 81

Testudo kleinmanni 133

(Testudo nutapundi) 71

(Testudo platynota) 83

(Testudo travancorica) 89

(Testudo radiata) 85

(Testudo yniphora) 91 
Texas Tortoise 101

Toad-headed Turtle, Dahl's — 269

Tomistoma schlegelii 401

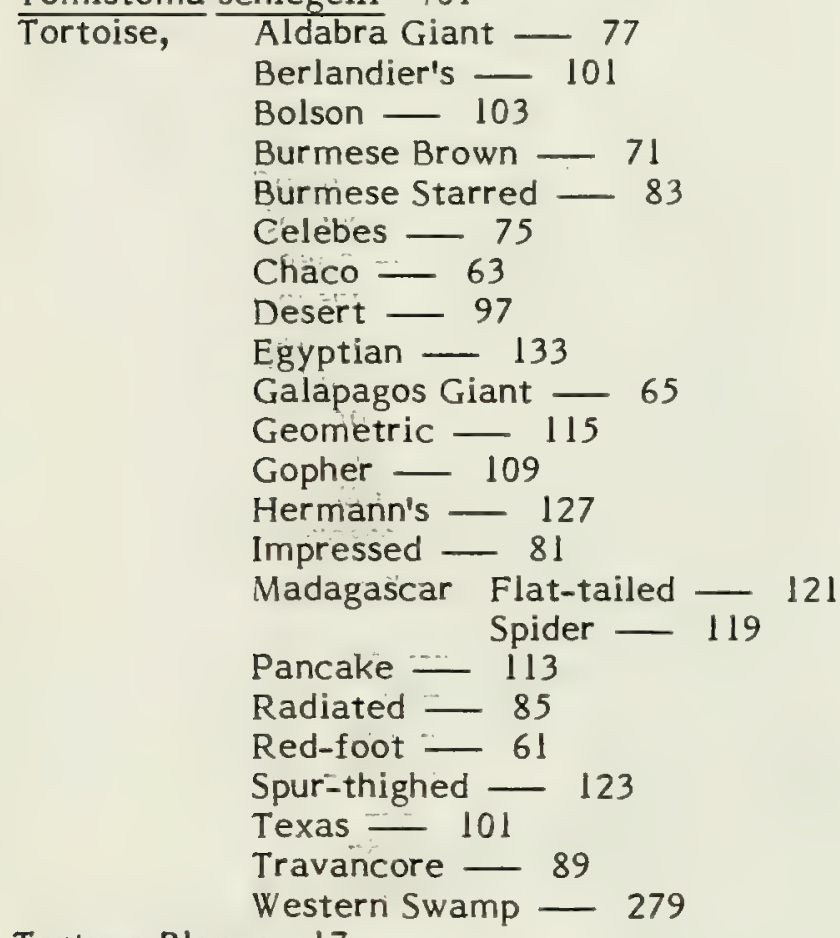

Tortuga Blanca 17

Tortuga Canaleta 277

Tracaja 263

TRIONYCHIDAE 247

Trionyx nigricans 247

Tsakafy 119

Tuatara 415

Tuntong Laut 27

Sungei 21

Tuo-long 283

Turtle, Alabama Red-bellied - 37

Aquatic Box - 57

Black - 151

Bog - 31

Bostami - 247

Cat Island — 39

Central American River - 17

Chaco Sideneck — 275

Coahuilan Box — 57

Creaser's Mud - 3

Dahl's Toad-headed - 269

Dark Soft-shell — 247

Dunn's Mud — 5

East Pàcific - 151

Flàtback … xli

Flattened Musk _- 13

Fly River … 243

Furrowed Wood — 63

Green - 151 


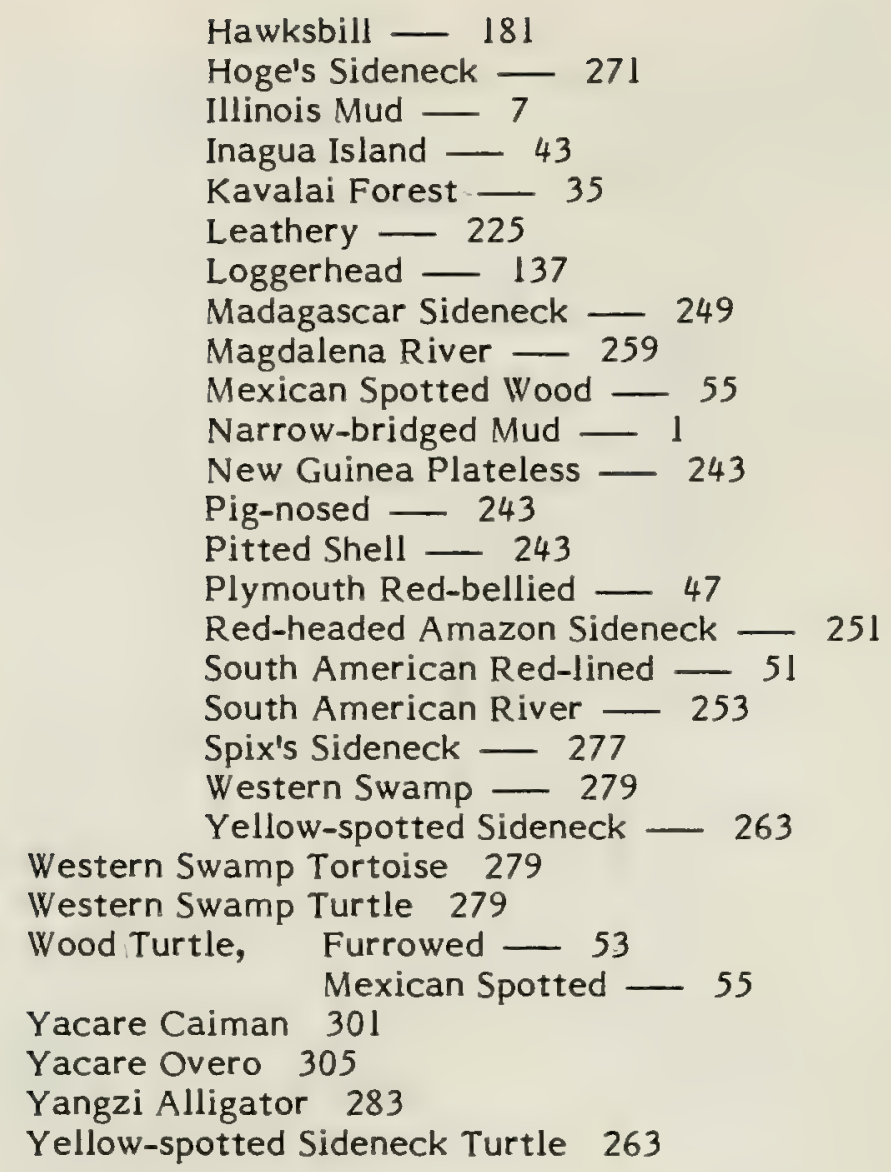





